\title{
Principales problemas de salud pública en México
}
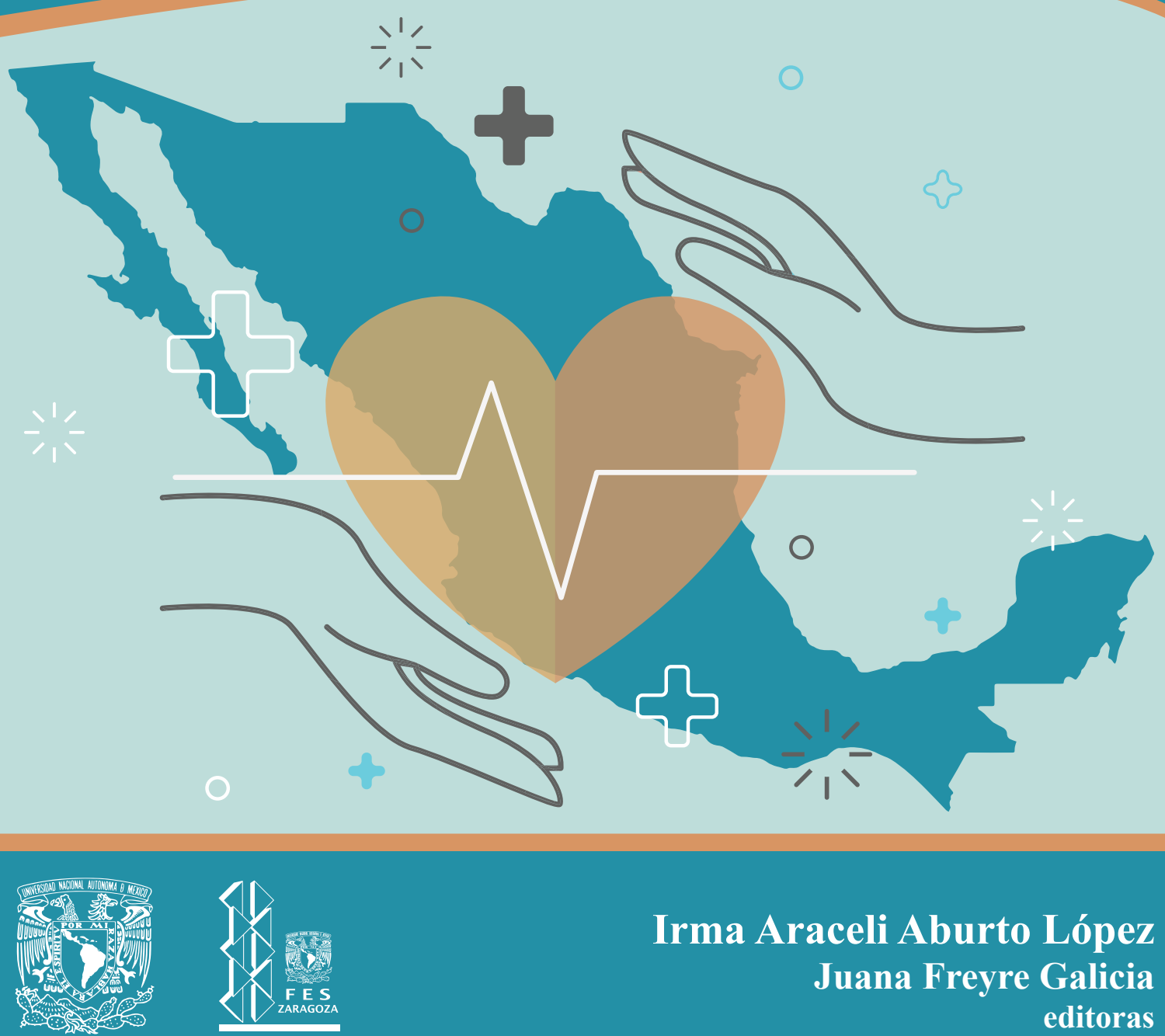

Irma Araceli Aburto López Juana Freyre Galicia editoras 


\section{Principales problemas de Salud Pública en México}

Irma Araceli Aburto López Juana Freyre Galicia editoras 
Universidad Nacional Autónoma de México

Facultad de Estudios Superiores Zaragoza

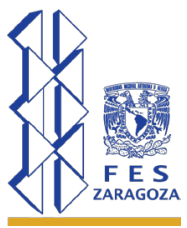

\section{Datos para catalogación bibliográfica}

Editoras: Irma Araceli Aburto López y Juana Freyre Galicia.

\section{Principales problemas de Salud Pública en México.}

UNAM, FES Zaragoza, enero de 2018.

Peso: $7.9 \mathrm{MB}$

ISBN: 978-607-30-0105-2

Diseño de portada: Carlos Raziel Leaños.

Diseño y formación de interiores: Claudia Ahumada Ballesteros.

Proyecto PAPIME 213712.

\section{DERECHOS RESERVADOS}

Queda prohibida la reproducción o transmisión total o parcial del texto o las ilustraciones de la presente obra bajo cualesquiera formas, electrónicas o mecánicas, incluyendo fotocopiado, almacenamiento en algún sistema de recuperación de información, dispositivo de memoria digital o grabado sin el consentimiento previo y por escrito del editor.

\section{Principales problemas de salud pública en México}

D.R. ( ) Universidad Nacional Autónoma de México

Av. Universidad \# 3000, Col. Universidad Nacional Autónoma de México, C.U., Delegación Coyoacán, C.P. 04510, México, D.F.

Facultad de Estudios Superiores Zaragoza Av. Guelatao \# 66, Col. Ejército de Oriente, Delegación Iztapalapa, C.P. 09230, México, D.F. 


\section{Autores}

\section{Irma Araceli Aburto López}

Maestra en Ciencias de la Salud Pública en el Área de Concentración de Salud Pública, Médica Cirujana y Diplomada en Prospectiva Universitaria de la Ciencia y la Tecnología. Profesorainvestigadora de la FES Zaragoza, UNAM, en la carrera de Medicina. Tutora y profesora de Epidemiología y Salud Pública. Cargos académico-administrativos en la FES Zaragoza, UNAM. Publicaciones varias.

\section{Juana Freyre Galicia}

Socióloga con 30 años de experiencia en investigación médica, adscrita al Hospital Psiquiátrico Fray Bernardino Álvarez, profesora de asignatura en la FES Zaragoza, UNAM, desde hace 24 años, con 38 publicaciones, asesora de tesis de licenciatura y de especialidad; maestrante en psicología.

\section{Noé Contreras González}

Es Médico Cirujano por la UNAM; Especialista en Docencia por la UNAM; Maestro en Neuropsicología por la UNAM. Doctor en Neuropsicología por la Universidad Autónoma del Estado de Morelos. Docente de la carrera de Médico Cirujano de la FES Zaragoza, UNAM, con 36 años de antigüedad; Ex Jefe de la carrera de Médico Cirujano; Profesor Titular en la carrera de Médico Cirujano de la FES Zaragoza, UNAM.

\section{María Luisa Ponce López}

Doctora en Ciencias en Salud Colectiva, especialidad en Medicina Familiar, maestra en Enseñanza Superior, Medica Cirujana y Diplomada en investigación clínica epidemiológica y en sobrepeso y obesidad. Profesora-investigadora en la carrera de licenciado en Medicina de la FES Zaragoza, UNAM. Expresidenta y vicepresidenta de la Academia Mexicana para el Estudio de la Obesidad y de la Sociedad Mexicana de Obesidad. Cargos académico-administrativos en la FES Zaragoza, UNAM. Coordinadora de diplomados. Publicaciones diversas. 


\section{Marco Antonio Cardoso Gómez}

Doctor en antropología, maestro en enseñanza superior y licenciado en psicología. Profesorinvestigador en la carrera de Psicología de la FES Zaragoza, UNAM. Tutor y profesor en posgrado. Miembro del Sistema Nacional de Investigadores. Ha recibido reconocimientos, tanto en el ámbito local, nacional e internacional. Cargos académico-administrativos en la FES Zaragoza, UNAM.

\section{Mercedes Esmirna Ríos Bustos}

Médica Cirujana, acreditación de la especialidad en Psiquiatría y de Psicoanálisis. Acreditación de la Maestría en Educación. Círculo de Psicoterapia Analítica de México. Doctorante del Doctorado en Pensamiento Complejo. Multidiversidad Mundo Real. Edgar Morín. Profesora-investigadora en la carrera de Medicina de la FES Zaragoza, UNAM.

\section{Marisela Torres Vaca}

Maestra en ciencias de la salud pública, especialista en anestesiología y Médica cirujana. Profesora de tiempo completo en el área de Ciencias clínicas de la FES Zaragoza, UNAM. Labor profesional en hospitales públicos de México. Autora de capítulos en libros y de artículos científicos. Asesora de tesis en licenciatura y maestría. Profesora de cursos de actualización profesional y docente. Actividades académicas y de acreditación de planes de estudio.

\section{Concepción de la Torre}

Médico Cirujano Egresado de la Facultad de Medicina de la UNAM, maestrante en Educación, Diplomados en obesidad, Diplomado en Tutoría en la Educación Superior, FES Zaragoza, UNAM. Profesor de carrera Tiempo Completo Asociado "C" Definitivo, desde hace 36 años. Cargos académico-administrativos en la FES Zaragoza, UNAM. Miembro de la Academia Mexicana para el Estudio de la Obesidad y de la Sociedad Mexicana de Obesidad.

\section{Alejandro Zarco Villavicencio}

Maestría en Citopatología, Especialidad en Medicina Familiar y Médico Cirujano. Profesor de tiempo completo en el Área de Ciencias Clínicas, carrera de Médico Cirujano, FES Zaragoza, UNAM. Dirección y asesoría de tesis de licenciatura e informes de servicio social. Participación en proyectos de investigación, con y sin financiamiento. Autor y coautor de varios artículos científicos. 


\section{Determinantes en la salud de los mexicanos}

\section{Irma Cortés Escárcega}

Irma Cortés Escárcega, profesor de carrera T.C. Asociado "C", docente de la carrera de Enfermería FES Zaragoza, en los Módulos: Introducción a la Enfermería Profesional, Enfermería Comunitaria y Salud Pública. Licenciada en Enfermería y Obstetricia, ENEO UNAM. Master of Science in Nursing, College of Nursing, University of New México, U.S.A. Doctorado en Ciencias de Enfermería, Universidad Nacional de Trujillo, Perú.

\section{María del Carmen Aguilar Espíndola}

Medica cirujana, egresada de la FES Zaragoza, UNAM. Profesora de asignatura B definitiva en el área de clínicas médicas desde hace 27 años. Ex coordinadora del área de clínicas médicas. Participación en la actualización del programa académico de primero y segundo años. Participación en varios proyectos de investigación. Sinodal de exámenes de oposición. Expositora de varios cursos y diplomados.

\section{María Guadalupe Contreras García}

Médica Cirujana por la UNAM; Profesora de Asignatura A en el Área de Clínicas Médicas de la carrera de Médico Cirujano y colaboradora en la Unidad de Investigación en Gerontología de la FES Zaragoza, UNAM. Cursa estudios de Maestría en Salud Pública con Área de Concentración en Envejecimiento en el Instituto Nacional de Salud Pública y en el Instituto Nacional de Geriatría.

\section{Malinali Alvarado Orozco}

Médico Cirujano por la FES Zaragoza, UNAM, Maestra en Salud Pública con área de concentración en Epidemiología por el Instituto Nacional de Salud Pública, Médico Epidemiólogo adscrito en el Instituto Mexicano del Seguro Social, Profesora de la asignatura Epidemiología Clínica y Medicina Basada en Evidencias, carrera de Médico Cirujano, Facultad de Medicina, UNAM.

\section{José Damián Carrillo Ruíz}

Médico cirujano egresado de la Universidad La Salle, con Especialidad en Neurocirugía por el Hospital General de México y Supraespecialidad en Neurocirugía Funcional y Estereotaxia, por la Universidad de París, Francia. Es Investigador Nacional Nivel II. Es Médico de Base en el Servicio de Neurocirugía del Hospital General de México. Presidente de la Sociedad Latinoamericana de Neurocirugía Funcional y Estereotaxia. 


\section{Dolores Patricia Delgado Jacobo}

Especialista en Medicina del Deporte y Rehabilitación IPN, docente e investigadora en la FES Zaragoza, UNAM, en la carrera de Médico Cirujano. Docente en Morfofisiología. Coordinadora en el programa universitario de servicio social en Psicología Tratamiento integral de la Obesidad desde una perspectiva cognitivo conductual, autora de libros y capítulos de libro, Certificadora en la Universidad La Salle.

\section{Juan Miguel Espinosa Ortiz}

Maestro en educación sexual, Licenciaturas de Médico Cirujano y Psicólogo, Diplomados en medicina forense, educación humanista en la sexualidad, psicoterapia sexual, sexualidad humana y psicoterapia sexual. Médico de MEXFAM, responsable del área de sexología en INATSS. Profesor de Epidemiología en la carrera de Médico Cirujano y de investigación de la carrera de Psicología en la FES Zaragoza, UNAM.

\section{Leticia Ferro Flores}

Maestría en Enseñanza Superior, maestrante en Salud Pública y Médica Cirujana. Médica Familiar en el IMSS, profesora de Epidemiología en la FES Zaragoza, UNAM, profesora del postécnico de enfermería en medicina familiar del IMSS y del Diplomado de Salud Pública en la FES Zaragoza, UNAM. Publicación de manuales para la carrera de Médico Cirujano, sobre metodología de la investigación, Diagnóstico de Salud, Servicio Social y Sociomedicina.

\section{María del Carmen García Ríos}

Egresada de la carrera de Médico Cirujano, en Universidad Nacional Autónoma de México, Especialista en Medicina Familiar, con formación docente. Profesora de asignatura "A" en laboratorio de Anatomía disección y en laboratorio de fisiología, coordinadora de área terminal de la carrera de Médico Cirujano en la FES Zaragoza, UNAM, por 3 años.

\section{Román T. A. Vargas Basurto}

Médico Cirujano, programador analítico, diplomado en tecnología de punta. Profesor de Epidemiología en la carrera de Medicina y Enfermería y Profesor de Estudio Médico Integral de la Familia, en la carrera de Médico Cirujano en la FES Zaragoza, UNAM. Médico de la Secretaría de Salud. 


\section{Patricia Dorotea Acevedo Ballinas}

Médica Cirujana egresada de la FES Zaragoza, UNAM, diplomado en Epidemiología aplicada. Profesora de Epidemiología en la FES Zaragoza, UNAM. Participante en la elaboración del programa académico de epidemiología en la FES Zaragoza, UNAM.

\section{Eva Leticia Acevedo Ballinas}

Medica cirujana, diplomada en medicina general y medicina familiar. Docente en el área de epidemiología en la FES Zaragoza, UNAM. Participante en diplomados con temas como síndrome metabólico, obesidad y nutrición. Participante en la elaboración de los programas de epidemiología de la carrera de Médico Cirujano en la FES Zaragoza, UNAM.

\section{Rocío Paniagua Hernández}

Médica cirujana, maestra en Salud Pública, Diplomada en Gerontología, Diplomada en Diabetes, Obesidad e Hipertensión Arterial, Diplomada en sexualidad, Diplomada en investigación clínica, cursos de docencia y de TIC. Profesora de Epidemiología y clínicas Médicas en la FES Zaragoza, UNAM. Asesora de tesis en licenciatura. Ex coordinadora del Área de Ciencias clínicas de la carrera de Médico Cirujano en la FES Zaragoza, UNAM.

\section{Yolanda Orozco Pérez}

Médica Cirujana egresada de la FES Zaragoza, UNAM. Profesora de Epidemiología en la FES Zaragoza, UNAM. Participante en la elaboración del programa académico de epidemiología en la FES, Zaragoza UNAM.

\section{Xochitl Ponce Martínez}

Maestría en ciencias egresada de la Universidad de Quebec, Licenciada en nutrición egresada de la Universidad Iberoamericana y Educadora en diabetes mellitus. Investigadora categoría $\mathrm{C}$ en el Instituto Nacional de Salud Pública. Miembro del consejo nacional de nutrición.

\section{Gloria Marina Moreno Baena}

Maestra en Antropología y Licenciada en Psicología. Profesora definitiva en la carrera de Licenciado en Psicología de la FES Zaragoza, UNAM. Ha sido colaboradora en varios proyectos INFOCAB, PAPIME, PAPIIT y Conacyt. 


\section{Alumnos}

Pasante de la carrera de Médico Cirujano de la FES Zaragoza, UNAM:

Darío Sebastián Posadas Estrada

Estudiantes de la carrera de Médico Cirujano de la FES Zaragoza, UNAM:

Abraham Sebastián García Zamorano

Diana Stefany Mares Martín

Diana Alejandra Marín Sánchez

Erick Ramírez Cruz

Paola Ozcebely Mata Rodríguez

Marisol Eranderi Rocha Salinas

Andrés Bello Munguía

Jorge Macázar Rodríguez

Laura Angélica Nava Ávila

Magda Mara Torres Isidoro

Alma Rosa Silva Barrios

José Luis Espinoza Herrera 


\section{Prefacio}

La carrera de Médico Cirujano que se imparte en la Facultad de Estudios Superiores Zaragoza (FES Zaragoza), de la Universidad Nacional Autónoma de México (UNAM), cuenta con profesionales interesados en participar de actividades colegiadas que permitan generar apoyos educativos adecuados a la formación de Médicos Generales que sepan utilizar los recursos que brinda la Salud Pública, en la prevención, atención y rehabilitación de las principales enfermedades que padece nuestra población.

Con este texto, profesores y alumnos destacados, hemos pretendido otorgar una guía útil, que de manera sintética pueda brindar información necesaria para la toma de decisiones médicas, frente a enfermedades frecuentes en nuestro medio.

Todos y cada uno de los tópicos tratados aquí, son temas elementales que han de aprenderse durante el segundo año de la Licenciatura de Médico Cirujano y por tanto el objetivo del texto es servir de material de apoyo en el estudio que realizan los alumnos de la carrera, mostrando en todo momento, la manera adecuada de integrar los conocimientos clínicos, epidemiológicos y farmacológicos y de tratamiento en general, para el abordaje de los padecimientos que se seleccionaron.

Se espera que este sea el primero de diversos textos de apoyo, que sirvan a los alumnos con datos actualizados, confiables y reinterpretados, para beneficio de la elección de los mejores tratamientos disponibles para las enfermedades, así como de las estrategias más eficientes y eficaces para la prevención de las mismas. Con ello, los autores de cada tema esperamos contribuir a una mejor y cada vez más útil, formación de Médicos Generales egresados de la FES Zaragoza, UNAM. 



\section{Índice}

15 PRÓLOGO

19 1. DETERMINANTES EN LA SALUD DE LOS MEXICANOS

Juana Freyre Galicia

31 2. ACCIDENTES Y LESIONES

Irma Araceli Aburto López, Juana Freyre Galicia, Román T. A. Vargas Basurto, Abraham Sebastián García Zamorano, Diana Stefany Mares Martin, Diana Alejandra Marín Sánchez y Erick Ramírez Cruz

67 3. ESCABIOSIS

María del Carmen Aguilar Espíndola

85 4. INFECCIONES RESPIRATORIAS AGUDAS

Irma Araceli Aburto López

101 5. TUBERCULOSIS

Leticia Ferro Flores

121 6. CIRROSIS HEPÁTICA

Marisela Torres Vaca

139 7. CÓLERA

Malinali Alvarado Orozco

159 8. ENFERMEDAD DIARRÉICA

Irma Araceli Aburto López 


\section{Principales problemas de Salud Pública en México}

179 9. HEPATITIS

María del Carmen Aguilar Espíndola

197 10. CARDIOPATÍA ISQUÉMICA

María del Carmen García Ríos

223 11. HIPERTENSIÓN ARTERIAL SISTÉMICA

Dolores Patricia Delgado Jacobo, Yolanda Orozco Pérez, Paola Ozcebely Mata Rodríguez y Marisol Eranderi Rocha Salinas

\section{12. CÁNCER}

Irma Araceli Aburto López, Concepción de la Torre, Román T. A. Vargas Basurto, Andrés Bello Munguía, Jorge Macázar Rodríguez, Laura Angélica Nava Ávila, Magda Mara Torres Isidoro y Georgina Zavala Vargas

269 13. INFECCIONES DE TRANSMISIÓN SEXUAL Juan Miguel Espinosa Ortiz

293 14. INFECCIÓN DE VÍAS URINARIAS

Eva Leticia Acevedo Ballinas y Patricia Dorotea Acevedo Ballinas

307 15. DEPRESIÓN

Mercedes Esmirna Ríos Bustos

319 16. DIABETES MELLITUS

Darío Sebastián Posadas Estrada

333 17. ENFERMEDAD VASCULAR CEREBRAL

Darío Sebastián Posadas Estrada

343 18. EPILEPSIA

Noé Contreras González y María Guadalupe Contreras García

369 19. NEOPLASIAS DEL SISTEMA NERVIOSO

Noé Contreras González y José Damián Carrillo Ruíz 


\section{Índice}

393 20. RABIA

Rocío Paniagua Hernández

421 21. TRASTORNO POR DÉFICIT DE ATENCIÓN

Noé Contreras González y José Luis Espinoza Herrera

443 22. OBESIDAD Y LOS PROBLEMAS DE MAL NUTRICIÓN

María Luisa Ponce López, Xochitl Ponce Martínez y Alma Rosa Silva Barrios

479 23. ATENDER AL PADECIENTE: UNA PROPUESTA CONCEPTUAL PARA LA CONFORMACIÓN DE UN MODELO DE ATENCIÓN MÉDICA A ENFERMEDADES CRÓNICAS

Marco Antonio Cardoso Gómez, Alejandro Zarco Villavicencio, Irma Araceli Aburto López, Gloria Marina Moreno Baena e Irma Cortés Escárcega 



\section{Prólogo}

El presente libro es una labor colectiva de docentes, pensado y escrito con la finalidad de apoyar los estudios de licenciatura en las disciplinas del área de la salud. Destaca que las editoras, a diferencia de la mayoría de textos médicos, incluyeron la participación de estudiantes, misma que aporta a generar un diálogo más cercano con quienes serán sus principales lectores. Se trata de un texto de apoyo académico acorde a la avanzada visión educativa de la FES Zaragoza, UNAM, que rompe con una educación disciplinaria propia del modelo flexneriano y que es hoy un referente de la educación médica en nuestro país. En correspondencia con esta visión, el libro integra distintas disciplinas alrededor de problemas de salud pública en nuestro país facilitando el aprendizaje del estudiante.

Su estructura tiene como eje algunos de los principales problemas de Salud Pública en México, mismos que van siendo abordados uno a uno, desde los accidentes y lesiones hasta la obesidad y problemas de mal nutrición, pasando por grandes problemas como el cáncer, la escabiosis, la cirrosis, la epilepsia y otros tantos que tienen todos ellos como común denominador: ser problemas frecuentes y trascendentes a los que se enfrentarán el médico, la enfermera, el psicólogo y otros profesionales de la salud. La obra inicia y termina con sendos capítulos que no tratan de problemas específicos de salud pública pero que son fundamentales para la formación del estudiante, el primero dedicado a la determinación general de los problemas de salud que se expondrán tras éste, y el último dirigido a hacer una propuesta sobre el enfoque y modelo de atención a seguir por el profesional de la salud en especial ante los problemas crónicos.

Estos capítulos, inicial y final, proponen reflexiones aplicables al conjunto de problemas de salud que se revisan capítulo a capítulo. En el primero se abordan los determinantes sociales de la salud enfermedad. Iniciar el libro con esta problemática permitirá al lector situar los problemas que se van abordando de manera específica dentro de un marco más general: los procesos de determinación y articulación de lo social y lo biopsíquico. No es común que libros de medicina inicien con esta temática, que la mayoría de las veces queda 


\section{Principales problemas de Salud Pública en México}

relegada o minimizada en la literatura especializada. Un acierto de las editoras reside en inicialmente enfrentar al estudiante al estudio de la determinación de la economía y la cultura sobre la salud. La autora de este capítulo sitúa al estudiante dentro de un México en el que los procesos de producción generan grandes desigualdades sociales y pobreza que son la base sobre la que germinan infinidad de problemas de salud. En esta parte se abona a que el estudiante vea los problemas de salud resultando de procesos sociales inequitativos e injustos, esto es como desórdenes biológicos generados por el orden social. Se abordan también los determinantes culturales abonando al entendimiento de que los problemas de salud se dan y se enfrentan dentro de culturas específicas y se hace también una crítica a la cultura del individualismo que se ha fortalecido en tiempos recientes. Finalmente en el primer capítulo se analiza el papel de recursos y políticas de salud como un tercer determinante de la salud, destacándose los avances logrados así como los problemas derivados de centrarse en la curación y las tendencias privatizadoras en la atención a la salud.

El capítulo final, al igual que el inicial nos propone una reflexión fundamental para el futuro profesional de la salud referida al objeto de su práctica: tratamos enfermedades (o sujetos enfermos) o bien tratamos, además de ello, personas que padecen, es decir, viven y sufren de manera especial. Se hace aquí la propuesta de denominar padeciente al sujeto que enfrenta la enfermedad (en especial la crónica) recuperando el carácter subjetivo de la misma y su inclusión dentro de la dinámica de la vida familiar y social. Al hacer esta diferenciación se hace una (auto)crítica al trabajo médico que hace de lado la subjetividad del padeciente, desde una postura autoritaria y a veces hasta soberbia, y que exige obediencia incondicional. A su vez, contra una relación en donde el padeciente es pasivo y el médico activo, se busca recuperar la idea de que el padeciente es también activo dentro de un contexto no siempre fácil que tiene que ser comprendido y tomado en cuenta por el médico.

Los capítulos referidos a problemas de Salud Pública en México tienen toda una estructura que permite articular saberes de diversas áreas. Resalta que, en comparación con textos disciplinarios donde se trata exclusivamente un área (fisiopatología, clínica, epidemiología, etc.) en cada capítulo se integran dichos saberes en el análisis en un solo relato. Los problemas de salud además son claramente abordados desde una perspectiva colectiva y también individual de forma que el estudiante puede construir un saber que incluye la acción en ambos niveles sin que, como en otros textos, quede desplazada o minimizada la 


\title{
Prólogo
}

acción a nivel colectivo. De esta forma se promueve un estudio útil para un médico que será responsable de la salud de individuos, familias y comunidades. Por lo mismo, en este texto se pueden encontrar respuestas desde los niveles subcelulares hasta el nivel poblacional y se pueden encontrar también recomendaciones tanto curativas como preventivas.

Estudiar con programas y textos así articulados, facilita al estudiante la integración de saberes, tarea muy poco cumplida por los modelos flexnerianos predominantes en nuestro país. Y permite también situar al futuro médico como alguien dispuesto y capaz de enfrentar los problemas prioritarios de salud desde la medicina general.

Finalmente podemos afirmar que este libro es un reto para el estudiante, pues de su lectura se desprende la necesidad de profundizar en diversas áreas en las que cada capítulo ofrece una generosa y actualizada bibliografía. Enhorabuena contaremos con este valioso trabajo.

\author{
Rafael González Guzmán \\ Profesor del Departamento de Salud Pública \\ Facultad de Medicina, UNAM
}





\section{Determinantes en la salud de los mexicanos}

Juana Freyre Galicia

\section{Introducción}

En este espacio abordaremos aquellas condiciones que determinan las posibilidades de las personas para obtener salud. En el caso específico de los mexicanos, dicha situación adquiere características especiales, toda vez que su circunstancia histórica les hace aparecer como miembros de una economía emergente, que para lograr estabilidad ha tenido que renunciar a una gran cantidad de bienes, incluidas la paz social, la equidad y el acceso a la justicia en la primera década y media del nuevo milenio.

Los aspectos que influyen en la aparición de los problemas de salud de nuestra población exceden por tanto: a la voluntad de las personas, el conocimiento que tengan sobre las cosas que les hacen enfermar o su interés por permanecer sanas, ya que una gran variedad de sucesos y fenómenos quedan fuera de su control y por ende solo tienen como recurso el ajustarse a las circunstancias en que viven.

El avance tecnológico y médico no basta para detener el avance y propagación de una gran cantidad de males que aquejan a la salud. Incluso se puede sostener que una importante proporción de dichos avances han generado mayores males que bienestar a la población mundial $^{1}$. Se sabe, por ejemplo, que la modernidad globalizada, aceleró el calentamiento global que ha dado lugar a la aparición de nuevas enfermedades, mientras algunas que se pensaba estaban controladas han venido a desquiciar los magros recursos que se emplean en la recuperación de la salud².

De este modo, buscaremos explicar cómo los determinantes socioeconómicos y culturales se expresan en los problemas de salud que agobian a los mexicanos y cuáles son los retos que debemos enfrentar en un futuro cercano, mismo que será parte del quehacer médico del presente siglo. 


\section{Principales problemas de Salud Pública en México}

\section{Concepto}

Según la Organización Mundial de la Salud los determinantes sociales son las circunstancias en que las personas nacen, crecen, viven, trabajan y envejecen, incluido el Sistema de Salud. Esas circunstancias son el resultado de la distribución del dinero, el poder y los recursos a nivel mundial, nacional y local, que depende a su vez de las políticas adoptadas ${ }^{3}$. En este sentido los conceptos de Sistema Económico y equidad en la distribución de la riqueza adquieren singular importancia de ahí que debamos comenzar por explicar algunas de sus características y repercusiones en la vida cotidiana de las personas.

\section{Determinantes socioeconómicos}

Son todos aquellos derivados de la manera en que las sociedades locales, nacionales y mundiales se engarzan para producir y distribuir riqueza entre los habitantes. Para producir las personas trabajan y lo hacen organizando no solo los procedimientos que les permiten producir una mercancía; pues al momento en que acuerdan o idean como realizar un trabajo conjunto, también modifican la manera en que las personas se relacionan entre sí, con la propia mercancía y hasta con el medio ambiente.

El trabajo distribuye roles a realizar para cada uno de los que intervienen en él. Así, uno de ellos será el dueño, otros los jefes y una multitud más serán empleados. Los intereses que tiene cada uno de ellos son diferentes, el dueño quiere ganar dinero para gastarlo o hacer crecer sus propiedades, los jefes, buscarán hacer que los trabajadores produzcan más a menor tiempo y el menor costo pues de ello depende que sigan siendo jefes y ganando más que los otros empleados, los trabajadores buscarán producir cansándose menos por el mejor salario posible. Como puede notarse los intereses que cada uno tiene del trabajo es diferente y también distintas posibilidades de influir para que las cosas sean como ellos quieren.

Entre más opuestas sean las necesidades o intereses de quienes están implicados en el trabajo menos oportunidades tienen de que el ambiente o las relaciones que establecen entre ellos sean cómodas, cordiales y productivas. Cuando las situaciones o condiciones de trabajo no son adecuadas, las relaciones entre las personas se vuelven desagradables y producen distracciones que pueden generar problemas graves como los accidentes o bien generar a la larga, deterioro a la salud de quienes participan en la producción ${ }^{4}$. 


\section{Determinantes en la salud de los mexicanos}

El estrés laboral no solo es resultado de la responsabilidad y afecta todos los ámbitos de la vida del trabajador, al grado de apresurar la aparición de disfunciones fisiológicas o favorecer la violencia tanto dentro como fuera del trabajo, de ahí que la higiene laboral incluya no solo las condiciones de trabajo (con que se hace la labor) sino también el ambiente laboral.

Por su parte, los dueños de las empresas tienen dificultades para hacer que sus empresas sobrevivan y crezcan porque como ellos, hay otros que han pensado que generar cierta mercancía es redituable, por tanto han de competir entre ellos para adueñarse del mercado de esas mercancías ofreciendo el mejor precio y la mejor calidad posible. Así, eventualmente el empresario debe invertir en desarrollo tecnológico que haga más eficiente, rápida y barata su producción, o bien buscar un área de mercado que no tenga acceso a mercancías económicas, sea por su distancia o sus dificultades para allegarse lo moderno. La finalidad última será conseguir un mercado cautivo incapaz de elegir por algo mejor a lo que ya se le ofrece.

Dueños de empresas hay muchos en distintos países y cada uno de ellos tiene preferencia por generar mercancías usando recursos propios de su lugar, pero conforme el comercio y los mercados se vuelven más reñidos, todos terminan comprando mercancías subsidiarias en otras partes del mundo, con tal de hacer más atractiva la mercancía que ellos venden. Conforme se usan cada vez más recursos de distintos lugares del mundo para generar una mercancía vemos más plenamente que existe la globalización, es decir el intercambio mundial de mercancías. Como es de suponerse, los países poseedores de cierto tipo de recursos suelen hacerse especialistas en ciertas áreas productivas, lo que al final genera un fenómeno denominado división internacional del trabajo, donde ciertas naciones se dedican a producir materias primas, manufacturas o bienes de capital, es decir máquinas y tecnología en general. Estas últimas serán las mejor pagadas ${ }^{5}$.

Las empresas que más tecnologías usan más rápida y eficazmente producen cosas y tienen menos pérdidas, ello hace que las empresas busquen usar la tecnología para eficientar su trabajo, pero con ello a los trabajadores no les va muy bien, pues se necesitan menos jefes y menos obreros para producir, lo que hace que las personas no encuentren empleo o sean despedidas.

Las personas que son adultas o están, según la ley en edad de incorporarse al empleo a veces tienen que ceder y aceptar aquellos que tienen muy baja remuneración o les ofrecen 


\section{Principales problemas de Salud Pública en México}

tiempos parciales de empleo, pues lo que necesitan es dinero para intercambiar por otras mercancías que les son indispensables para vivir, tales como alimento, ropa, medicinas, casa y transporte, entre otros muchos, así termina siendo menos importante para ellos tener que conseguir varios empleos para conseguir, finalmente un salario que si les alcance para sufragar todos o casi todos los gastos ${ }^{6}$. Cuando no existe la posibilidad de encontrar un empleo denominado formal (porque está basado en un contrato de empleo que debe cumplir con prestaciones de ley), las personas suelen autoemplearse o trabajar para empresas que no están legalmente establecidas y que por ende no les ofrecen las garantías de ley, entre las que se incluyen prestaciones de servicio médico para ellos y sus familiares ${ }^{4}$.

Mientras las personas se mantienen sanas, o funcionales para desempeñar trabajos de distinta índole, la ausencia de un seguro médico puede parecer adecuado, el problema surge cuando las condiciones de trabajo resultan inconvenientes y aparecen males o disfunciones que impiden seguir laborando; porque entonces surge un fenómeno denominado gasto catastrófico en salud, que ocasiona entre otras cosas la depauperización de la economía familiar y el riesgo de mayores problemas de salud y seguridad personal para todos los miembros de la familia.

Los miembros de la familia que más se ven en riesgo cuando acontece un gasto catastrófico son aquellos que se encuentran en las edades extremas de la vida, es decir, los infantes y los ancianos. De ahí que la llamada economía informal pueda generar momentáneamente satisfactores para quienes se desempeñan en ella, pero a la larga, produce el empobrecimiento de quienes ganando salarios magros, no pueden invertir en salud ${ }^{7}$.

Las condiciones de trabajo en las empresas establecidas es frecuentemente mejor que para quienes se desempeñan en la calle o en establecimientos sin ninguna vigilancia de seguridad. Pongamos un ejemplo, un comerciante de vía pública eventualmente no podrá ir al baño durante toda su jornada, se encuentra a la intemperie y si lo que vende u oferta se echa a perder por las inclemencias del tiempo, será responsabilidad suya el reponer su costo, no recibir paga y ser despedido. Mientras que en el caso de un asalariado de empresa formal, tendrá asignado un tiempo para hacer esas necesidades, contará con instalaciones en su lugar de trabajo para ello y el proceso asegura que las mercancías no sufran desperfectos o pérdidas mientras él o ella se ausentan por momentos del proceso de producción. 


\section{Determinantes en la salud de los mexicanos}

Por otra parte, el puesto o lugar que se ocupa en el establecimiento productivo también parece justificar el salario que se recibe, pues algunas actividades productivas son mejor pagadas que otras, en ocasiones ello se debe a la complejidad de la actividad, su riesgo o responsabilidad o por la oferta de mano de obra especializada en dicha actividad.

El salario es el pago que las personas reciben por realizar un trabajo remunerado (recordemos que existen trabajos que no se remuneran como el doméstico realizado por la mujer que desempeña el rol de ama de casa), y entre menor sea este, menos capacidad tiene para adquirir bienes o servicios que favorezcan una adecuada calidad de la vida. Así resulta que quienes menores ingresos tienen, padecen más dificultades para adquirir bienes o servicios, y cuando acceden a ellos, obtienen solo los de peor calidad.

Los alimentos no son la excepción, por ende entre peor trabajo y salario se tengan menos acceso a alimentos de calidad se tiene, de tal forma que las personas dejan de comer para alimentarse, lo hacen solo para menguar su sensación de hambre y continuar siendo potencialmente trabajadores, pues como sabemos, a peor calidad alimentaria mayores riesgos a la salud tienen las personas, y si comen cosas que no les nutren, pronto dejarán de ser suficientemente productivos para ser contratados.

Generalmente las personas con perores recursos alimentarios provienen de familias en las que la condición de pobreza alimentaria ha estado presente durante generaciones por ello tienden a ser de menor estatura, más endebles en términos de la salud y físicos y padecen además de pobreza alimentaria, de pobreza educativa, inmobiliaria y de recursos de salud.

La falta de una alimentación adecuada para la edad y actividad, hace que las personas se pongan en riesgo de padecer enfermedades tanto infecciosas como crónicas degenerativas. Las primeras porque se diseminan fácilmente en lugares donde se carece de adecuada higiene (y quienes padecen de pobreza inmobiliaria, generalmente ocupan espacios de vivienda que carecen de servicios como agua potable, alcantarillado, drenaje, alumbrado público y pavimentación), y las segundas porque dado el desgaste de las capacidades del cuerpo humano sin un proceso de reposición adecuado, produce envejecimiento acelerado, desgaste sistémico y aparición de enfermedades endocrinas como la diabetes, hipertensión y cáncer. 


\section{Principales problemas de Salud Pública en México}

México tiene aproximadamente 121 millones de habitantes de los cuales más de 50, viven en pobreza y 11.5 de ellos sobreviven a la pobreza extrema, casi siempre habitan zonas rurales e indígenas donde lo que se produce son mercancías de muy bajo valor comercial y por ello obtienen muy bajas o nulas ganancias por el trabajo realizado ${ }^{8}$.

Si las personas no tienen para comer, o lo que comen no es de calidad sus habilidades para aprender se disminuyen con el paso del tiempo y es factible además que las personas con menos recursos se encuentren alejados de los centros educativos, por lo que ir a la escuela resulta para los niños un mayor problema que permanecer en casa coadyuvando a los quehaceres domésticos y productivos en zonas agrícolas.

La educación que es una de las herramientas más eficientes para gestionar mejores condiciones de vida, se ofrecen más frecuentemente a población urbana de estrato social medio y alto. Lo que deja fuera a la mayor parte de proporción de jóvenes mexicanos del proceso de preparación para el empleo, de modo que hoy ello ha dado lugar a la generación de personas menores de 25 años que ni estudian ni trabajan, por lo que se encuentran en mayores riesgos de tomar decisiones peligrosas para su vida tales como consumir y distribuir drogas o buscar recursos económicos de otras maneras ilegales, así como de convertirse en padres y madres sin contar con los recursos financieros, psicológicos y materiales para hacer frente a esa importante tarea.

Finalmente este círculo vicioso se cierra de esta manera: sin educación o preparación para el desempeño de un empleo calificado, difícilmente se accede a salarios que permitan adquirir satisfactores de vida que incluyan medidas protectoras a la salud, tales como la atención temprana de padecimientos, acceso a medicamentos o el goce de vacaciones y otras actividades lúdicas que beneficien el desarrollo humano.

\section{Determinantes socioculturales}

La forma de comprender el mundo y de adecuarnos a él, esta mediado por nuestros recursos socioculturales, ellos son una serie de patrones de saberes y habilidades que nos permiten interactuar con otros miembros de nuestro entorno cultural, de modo que cada que hacemos uso de esos recursos no solo resolvemos nuestro problema de adecuación e interacción, sino que la reproducirnos. 


\section{Determinantes en la salud de los mexicanos}

La cultura en ese sentido no es un hecho consumado e inamovible, sino que continuamente se amplia y se hace cada vez más complejo, pues debe dar cuenta de las novedades que se presentan así como ser útil en su aplicación. Se constituye de valores y prácticas que fomentan un determinado modo de ser y que se conoce también como estilo de vida.

Como ya habíamos comentado anteriormente, el intercambio mundial de mercancías modifica no solo nuestro entorno sino nuestros valores y la manera en que concebimos el mundo. Es decir, cada nuevo producto que llega a nuestras manos modifica la manera en que contemplamos nuestro entorno. Se nos muestras a través de la publicidad lo que está de moda y lo que las sociedades moderas dicen que es lo mejor para nosotros, al grado que incluso llegamos a considerar natural tener ciertas aspiraciones y rápidamente adoptamos costumbres y gustos que no son oriundos de nuestros pueblos y cultura.

Estas modificaciones culturales pueden crear grandes abismos generacionales si algunos grupos de edad o étnicos no se adaptan a ellos con éxito. A su vez dan lugar a nuevas tribus culturales que imprimen de manera especial significado a las cosas y las palabras con que se representan, pues la identidad de grupo son elementos esenciales del proceso de culturización que no se pierde, solo cambia en la manera en que se manifiesta.

Los valores se adoptan porque provienen de sociedades a las que consideramos superiores y de las que suponemos tienen el saber que las legitima para imponer sus perspectivas de vida. Dichos valores tienden a homogenizar las aspiraciones de todo mundo al grado que personas de procedencias tan disimiles como China, México y Portugal pueden coincidir en formas de vestir, gustos por la comida, conceptos básicos sobre la política y hasta preferencias en la lectura9 .

La simple llegada de cadenas de tiendas de alimentos ha dado un vuelco a la manera en que los mexicanos comemos, y del mismo modo se puede apreciar la influencia que la gastronomía mexicana ha tenido en el resto del mundo. La convergencia de varios tipos de alimentos preparados de manera rápida en lugares donde se vive con prisa, como suelen serlo las ciudades, ha tenido nefastas pero importantes consecuencias a la salud ${ }^{10}$.

A la forma de comer del mexicano, que mexicaniza cualquier cosa que adopte como alimento y que provenga de otras culturas (agregar picante, cebolla, tomate rojo, etc), 


\section{Principales problemas de Salud Pública en México}

debe sumársele la necesidad de que las mujeres abandonen de manera total o parcial las labores domésticas para sumarse a la fuerza productiva ha generado que los infantes tengan pocas alternativas de proveerse de alimentos no procesados industrialmente. Muy por el contrario, adultos e infantes consumimos cada vez con mayor frecuencia, alimentos procesados y adicionados de manera infinitamente mayor a las necesidades nutrimentales que tenemos, pues la mayor parte de nosotros tenemos actividades de poca movilidad y nos hemos destacado por permanecer sedentarios. Esta situación explica en gran medida que seamos el primer país en obesidad infantil y el segundo en obesidad en adultos ${ }^{11}$.

Dentro de los factores que han promovido el sedentarismo en los mexicanos debe mencionarse el fenómeno de la migración a los centros urbanos, el uso cada vez más común de tecnologías que permiten el control a distancia, la ausencia de las madres de la crianza de sus hijos, las largas jornadas que impiden que los padres y madres jueguen con sus hijos, la construcción de vivienda de reducido espacio o que carece de lugares de esparcimiento y la inseguridad.

La violencia como manera de relación con el medio ambiente parece ser un fenómeno que se ha fomentado con la segregación de los jóvenes que ahora no tienen una imagen masculina a la que adherirse y que no obstante, se ven retados por sus pares para demostrar una hombría que hoy por hoy solo parece ser comprobada a través de los golpes y el sometimiento del más débil, pues carecen de medios para destacar en otros ámbitos de la vida social como son: la escuela, el trabajo, los negocios, el deporte y las artes ${ }^{12}$.

Esta violencia muchas veces emana de sus propios hogares que se destruyen a causa de costumbres machistas, paternidad y maternidad irresponsable o en muy tempranas, adicciones y eventualmente adopción de valores morales que justifican el abuso, robo y cualquier otra actividad que suministre recursos monetarios sin la necesidad de trabajar. La descomposición social, atraviesa por supuesto la salud mental, haciéndola endeble y dando pie al desarrollo de trastornos como la ansiedad, la depresión y las psicosis por consumo abusivo o adicciones.

El individualismo, la competencia, la falta de consideración para con los demás destruye o mina la protección que con anterioridad brindaba la pertenencia a una comunidad. Estas ahora parecen no existir y la solidaridad comienza a transformarse en una conducta rara o solo verificable en grupos más bien alejados de las grandes ciudades. De este modo el 


\section{Determinantes en la salud de los mexicanos}

individuo y las familias se encuentran más expuestos a sufrir a causa de las enfermedades o a enfermar pues no existe la protección de un grupo más amplio.

Para muchas personas la única manera de allegarse de recursos de la comunidad o de personas que no sean sus familiares es exclusivamente mediante la posesión del dinero, pues ese parece ser el único que es capaz de comprarlo todo, compañía, afecto, aceptación. Esa es la razón por la que todos desean obtener dinero.

Las mujeres, los niños y los ancianos, alejados socialmente como están de la obtención del dinero, se convierten fácilmente en mercancías que se intercambian por ese dinero o que son excluidos de la sociedad por no poseerlo. Frente a esas injusticias y delitos, solo se cuenta con una magra esperanza de que el estado encargado de dar seguridad a la población, tal vez decida hacer algo a favor de aquellos que parecen no tener ningún valor social. Sin duda la corrupción generalizada ha diezmado la calidad de vida de todos los mexicanos, contribuye enormemente a la aparición de trastornos mentales y disminuye la esperanza de vida en enormes grupos sociales que por sus edades y lugares de residencia están condenados a vivir en violencia ${ }^{13}$.

\section{Recursos de salud y políticas en salud}

México es un país que se distingue por haber consolidado un Sistema de Salud eficaz en varios aspectos sanitarios, como las estrategias de vacunación. Sin embargo padece como la mayor parte de las naciones centroamericanas de una inadecuada distribución de recursos, personal e independencia de suministros, pues la mayor parte de estos, así como los medicamentos los obtiene por importación. Ello de entrada encarece y dificulta su acceso a todos los mexicanos.

El avance en la esperanza de vida de los mexicanos ha implicado graves consecuencias para el sistema financiero y médico nacional. Por un lado las personas que trabajan al llegar a la edad de jubilación, no pueden aspirar a una pensión vitalicia, pues los recursos que se tienen para ello decrece al aumentar la cantidad de jubilados, además, el empleo no crece los suficiente como para que la carga económica se distribuya con menor peso entre quienes laboran y son jóvenes.

En México esto obligó a la modificación de la correspondientes Leyes de IMSS e ISSSTE, sin embargo ello no es garantía de que podrá mantenerse tanto la pensión como la atención 


\section{Principales problemas de Salud Pública en México}

gratuita a los Servicios de Salud. Más aún, el bono poblacional con que se contaba (el mayor número de jóvenes en la historia del país) está literalmente siendo desperdiciado pues no se otorgan oportunidades de desarrollo y trabajo para ellos. Así pues, en un intento por hacer algunas correcciones a estos problemas, el gobierno federal ha instrumentado algunas políticas que lo colocan a la vanguardia respecto de otras naciones.

México es un país de ingreso medio, que ha logrado abatir las tasas de mortalidad materna e infantil, ha sido pionero en el proceso de la universalidad de acceso a los servicios médicos a través del Seguro Popular ${ }^{14}$ y fue primer país en el mundo en aprobar un impuesto a las bebidas endulzadas con azúcar. No obstante, México recibió recomendaciones asentadas en el informe Salud global 2035 entre las que se incluyen alcanzar cifras similares a las de los países desarrollados en cuanto salud materna e infantil y realizar acciones encaminadas a disminuir la inequidad al interior del país, es decir que los recursos sanitarios ni se concentren en las grandes urbes, ni se distinga la calidad que se brinda a los diferentes sectores sociales

Para México el reto de los próximos 20 años está en reducir las tasas de enfermedades no trasmisibles y las lesiones que causan a través de intervenciones tempranas, dado que la población tiende a envejecer de manera acelerada y no existe ni capacidad ni capacitación para atender las enfermedades de la vejez, menos aún de prevenirlas. Por ello es indispensable que se integre conocimiento que beneficie el estado de salud de esta población creciente ${ }^{15}$.

La racionalidad de los gastos en salud debe contemplar la independencia económica del sector salud, así como la capacidad de brindar atención adecuada a las necesidades de toda la población, para ello debe evitarse que la salud siga siendo concebida como un negocio rentable, tanto para servidores públicos que aprovechan los puestos para dilapidar el patrimonio del sector salud, como para las empresas privadas que abusan de los precios a sabiendas que la persona enferma está dispuesta a desprenderse de todo cuanto posea con tal de recuperar la salud.

La perspectiva de curar en lugar de prevenir encarece el gasto en salud para todos, favorece la emergencia de nuevas patologías y permite que se realicen actividades contrarias a la salud, como el uso indiscriminado de antibióticos en la producción de carne para consumo humano o para conservar alimentos industrializados. 


\section{Determinantes en la salud de los mexicanos}

La subvención del Seguro Popular y la reforma al sector salud son asuntos que permanecen en la opacidad, pues siguen siendo los mismos trabajadores de siempre quienes corren con los gastos de la atención de aquellos que por su condición económica no pueden pagar los gastos de su servicio médico. Mientras, el sector hacendario sigue siendo incapaz de ensanchar la base tributaria, minando aún más las expectativas de vida de los trabajadores asalariados, creando de modo paradójico, incentivos para la permanencia en la informalidad de la mayor parte de los trabajadores en México.

Sin duda la privatización de los Servicios de Salud ha llegado para quedarse, el problema es que estos no sean verdaderamente resolutivos de los problemas de salud o generen mayor inequidad en alternativas de curación. Más aún, pese a las recomendaciones de la OMS, continúa la tendencia a la súper-especialización médica y la depauperización de la práctica pública de esta profesión. Tal parece que el estado no está en condiciones de invertir más en salud ni en educación, ambos rubros han sido fuertemente castigados con los recortes presupuestarios devenidos de la baja del precio del petróleo, no así por ejemplo la partida destinada a mantener con vida múltiples partidos políticos que más bien se delinean como modo de vida de grandes familias que han encontrado en la política un negocio más.

Así más médicos que se necesitan, egresan cada año, pero no tienen acceso al empleo, de modo que se alquilan para trabajar en farmacias que no les garantizan seguridad en el empleo ni a su salud. Miles de jóvenes concursan para realizar una especialidad médica y solo uno de cada cuatro, tendrá acceso a ella, no importa si también de ese tipo de médicos se requiere también. Lo importante para los administradores de la salud es únicamente que las cuentas cuadren, aunque no queda claro a favor de quién ${ }^{16}$.

\section{Referencias}

1. 1. Leff E. La geopolítica de la biodiversidad y el desarrollo sustentable. Economización del mundo, racionalidad ambiental y reapropiación social de la naturaleza. Cuaderno Interdisciplinar de Desarrollo. 2013; 10:185-209.

2. 2. Llambias Wolff J. Los desafíos inconclusos de la salud y las reflexiones para el futuro en un mundo globalizado. Rev Cubaba Salud Pública. 2003; 29(3):236-245.

3. 3. OMS. Determinantes sociales de la salud. Disponible en: http://www.who.int/ social_determinants/es/ 


\section{Principales problemas de Salud Pública en México}

4. Tomasina F. Los problemas en el mundo del trabajo y su impacto en la salud. Crisis Financiera actual. Uruguay Rev Salud Pública. 2012; 14sup(1):56-67.

5. Romero A. Globalización y pobreza. Colombia: Ediciones Uraniño; 2002.

6. Arancibia Fernández F. Flexibilidad laboral: elementos teórico conceptuales para su análisis. UAPI Revista Ciencias Sociales. 2011; 26:39-55.

7. Luna Ruiz GA. Los gastos catastróficos por motivos de salud en México. Los factores socioeconómicos relacionados y la política en Salud [Tesis de Doctorado]. Madrid: Universidad Autónoma de Madrid; 2013.

8. INEGI. México en Cifras (2015). Disponible en: http://www3.inegi.org.mx/sistemas/ Méxicocifras/default.aspx

9. Palmer GT. Globalización y cultura. Homogeneidad, diversidad, identidad, libertad. México: FFN; 2006.

10. González García CJ, Villa Montes de Oca D. Herencia alimentaria: Promoción de hábitos alimentarios saludables desde la infancia, una estrategia pedagógica durante la crianza para la prevención de la obesidad en niños. Reidocrea. 2015; 4:35-47.

11. UNICEF México (s.f.). Salud y Nutrición-infancia y salud [Página web; consultado 7 febrero 2016]. Disponible en: http://www.unicef.org/México/spanish/17047.htm

12. Briseño-León R. La nueva violencia urbana en América Latina. Sociologías Porto Alegre. 2002; 4(8):34-51.

13. Sandoval Ballesteros IE. Enfoque de la corrupción estructural: poder, impunidad y voz ciudadana. Revista Mexicana de Sociología. 2016; 78(1):119-152.

14. Ávila-Burgos L, Serván-Mori E, Wirtz VJ, Sosa-Rubí SG, Salinas-Rodríguez A. Efectos del Seguro Popular sobre el gasto en salud en hogares mexicanos a diez años de su implementación. Salud Pública Mex. 2013; 55(Supl. 2):S91-S99.

15. Beyeler N, González P, Alleyne G, Barraza LM, Frenk J, Pablos Mendez A, Pérez Cuevas R, Regalia F, Sepúlveda J, Jamison D, Yamey G. Salud global 2035: implicaciones para México. Salud Pública Méx. 2015; 57(5):441-443.

16. Barba Solano C. Claroscuros de la Reforma social en México y América Latina. Espiral UDG. 2015; 13(39):35-76. 


\title{
2. Accidentes y lesiones
}

\author{
Mtra. Irma Araceli Aburto López \\ Mtra. Juana Freyre Galicia \\ M. C. Román T. A. Vargas Basurto \\ Alumnos (as) de la carrera de Médico Cirujano: \\ Abraham Sebastián García Zamorano \\ Diana Stefany Mares Martín \\ Diana Alejandra Marín Sánchez \\ Erick Ramírez Cruz
}

\section{Introducción}

La Clasificación Internacional de las Enfermedades en su décima revisión (CIE-10) establece en el capítulo XX, para abordar las lesiones derivadas de causas externas, de manera que los traumatismos, envenenamientos corresponden al capítulo XIX, aunque aparecen frecuentemente como parte de las estadísticas de la morbilidad y mortalidad de causas externas. Ambos capítulos abarcan un extraordinario abanico de posibles lesiones, que incluyen las no intencionales como los accidentes, además de otras como las que se adquieren por el contacto incidental con animales ponzoñosos; las intencionales que incluyen las agresiones infligidas por otras personas (homicidios) y las autoinfligidas (suicidios) y aquellas en las que la intencionalidad no puede ser determinada, es decir, se desconoce si existía la voluntad y el saber de querer dañar o lastimar a alguien de manera específica ${ }^{1,2}$.

La gama de problemas de salud que se derivan de las lesiones requieren la puesta en marcha tanto de estrategias médicas (preventivas, de rehabilitación y tratamiento), como otras de carácter legal y social para su control. No obstante, algunas formas de lesión como los accidentes y el intento suicida y el suicido consumado se encuentran en constante crecimiento y muestran no solo alta letalidad, sino una fuerte eficacia para procurar discapacidad en los sobrevivientes. El costo económico de todas estas no puede compararse con las problemáticas que causan a las familias y a las personas que deben recuperarse de dichas lesiones, pues emocional, económica y efectivamente su mundo se modifica, se vuelve más hostil y eventualmente les precipita al empobrecimiento y la vulnerabilidad ${ }^{3}$. 


\section{Principales problemas de Salud Pública en México}

Pese a la magnitud de las repercusiones que puedan adjudicarse a los accidentes, debe subrayarse que estos son siempre prevenibles y evitables y que su ocurrencia hace suponer que alguien o muchos dejaron de hacer cosas indispensables, de modo que frente a estos problemas de salud debe asumirse siempre responsabilidad sobre los hechos de una o varias personas que se han involucrado en el daño a la salud. Así pues, estos capítulos de clasificación médica tienen especial interés en el área legal de la medicina, pues sus guías específicas permiten deslindar las responsabilidades antes dichas ${ }^{4}$.

\section{Concepto}

Las lesiones causadas por causas externas se definen como "cualquier daño o impedimento corporal específico e identificable, resultado de una exposición aguda a energía térmica, mecánica, eléctrica o química o de la ausencia de elementos esenciales como el calor y el oxígeno" $^{5,6}$.

La Ley General de Salud, capítulo IV, artículo 162, conceptúa a los accidentes, como un "hecho súbito que puede ocasionar daños a la salud y que se produce por la concurrencia de condiciones que son potencialmente prevenibles". Y la Organización Panamericana para la Salud (OPS), los considera, como "una cadena de eventos y circunstancias que llevan a la ocurrencia de una lesión no intencional (con perjuicio a las personas) y con consecuencias de daños de tipo material" 2,7,8.

\section{Clasificación}

De acuerdo a la intencionalidad con la que se presentan, las lesiones de causa externa pueden clasificarse en intencionales o no intencionales. Las primeras son aquellas en las que hay una acción humana realizada de forma premeditada y estimada a causar un daño, ya sea auto-infligido (suicidio) o provocados a otras personas (agresión o violencia). En las lesiones no intencionales no hay una intencionalidad, implícita o explícita, de causar un daño por lo que tradicionalmente han sido denominadas "lesiones accidentales" 5 .

El capítulo XIX utiliza los numerales S00 a T98 y el XX del V01 al Y98. Debido a que principalmente estaremos refiriéndonos a las enfermedades contempladas en el capítulo XX, ofrecemos en el Cuadro 1 su agrupación ${ }^{1}$. 


\section{Accidentes y lesiones}

Cuadro 1. Clasificación de las lesiones accidentales de acuerdo a la Clasificación Internacional de Enfermedades (CIE-10). ${ }^{1}$

\begin{tabular}{|l|c|}
\hline \multicolumn{1}{|c|}{ Causa externa } & Código CIE-10 \\
\hline Caídas & W00-W19 \\
\hline Ahogamiento y sumersión & W65-W74 \\
\hline Obstrucción de la respiración & W75-W84 \\
\hline Envenenamiento por sustancias & X40-X49 \\
\hline Quemaduras & X00-X09 \\
\hline Exposición al fuego humo y llamas & X10-X19 \\
\hline Contacto con calor y sustancias calientes & W85-W99 \\
\hline $\begin{array}{l}\text { Corriente eléctrica, radiación y temperatura y presión del aire } \\
\text { ambientales externos }\end{array}$ & Y40-X89 \\
\hline Efectos adversos de tratamientos médicos & V01-V99X \\
\hline Transporte & W20-W52, W64 \\
\hline Exposición a fuerzas mecánicas & X20-X29 \\
\hline Contacto animal / plantas & W53-W63 \\
\hline Animales y plantas venenosos & \\
\hline Mordedura de animal o lesión con plantas & X30-X39 \\
\hline Otros accidentes & X50-X57 \\
\hline Exposición a fuerzas de la naturaleza & X58-X59 \\
\hline Exceso de esfuerzo viajes y privación & \\
\hline Exposición accidental a otros factores y a los no especificados & \\
\hline
\end{tabular}

También es importante considerar que existe la clasificación para los accidentes, de acuerdo al lugar en donde acontecen, y son: en el hogar, en la escuela, en el trabajo, en el transporte (o de tránsito), en la vía pública y en centros de recreación ${ }^{8}$.

\section{Epidemiología}

Desde el punto de vista de la Vigilancia Epidemiológica, como observatorio de las lesiones producidas a consecuencia de los accidentes, éstos se pueden registrar y estudiar desde diferentes perspectivas, tales como el agente productor, lugar donde ocurre, consecuencias que provoca, tipo de lesión producida y localización de la lesión ${ }^{8}$. 


\section{Principales problemas de Salud Pública en México}

A causa de accidentes en el mundo ocurren, cada año, un millón 240 mil muertes, principalmente de tránsito. Nuestro continente colabora con 150 mil defunciones y más de 5 millones de lesionados que equivale a 33 personas con lesión por cada fallecido. Cabe subrayar que $10 \%$ de los lesionados desarrollan una discapacidad motriz o sensorial para toda la vida. En nuestro país, en el año de 2012, la tasa de lesiones por accidentes viales fue de 14.6 defunciones por cada 100000 habitantes; y la de letalidad es de 41.2 muertos por cada mil lesiones acontecidas. En México, para ese mismo año, los accidentes de tráfico son la primera causa de muerte en niños entre los 5 y 9 años de edad; la segunda causa de muerte en personas de 10 a 19 años y de 20 a 29 años de edad; y la principal causa de discapacidad motriz en jóvenes de 17 a 24 años ${ }^{4,9}$.

Si bien cualquiera está en posibilidad de sufrir las consecuencias de las lesiones externas, debe subrayarse que las edades de las personas pueden influir en el tipo de lesión que se adquiere, el lugar donde ocurre la lesión y por supuesto, la consecuencia para la vida de padecerla. Son así los extremos de la vida aquellos que pueden obtener mayor discapacidad, sin embargo, son los jóvenes quienes con mayor frecuencia los padecen.

Los accidentes en niños de uno a cuatro años, se encuentran entre las primeras causas de muerte para este sector poblacional y se ha calculado que la cantidad de eventos aumentan después de que los infantes cumplen un año de edad y se incrementan notablemente en los grupos de preescolares y escolares. En los casos donde los accidentes no causan la muerte los lesionados, pierden actividades escolares y de la vida cotidiana muy importantes para su sano desarrollo, pues deben acudir a rehabilitación o permanecer hospitalizados y/o en convalecencia durante periodos prolongados, además de que muchos de ellos tendrán secuelas, a veces incapacitantes que incrementan el costo de su rehabilitación. La Encuesta Nacional de Salud y Nutrición 2012 (ENSANUT 2012) reportó que 4.4\% de los menores de 10 años han sufrido algún accidente presentando una prevalencia mayor en hombres que en mujeres $5.3 \%$ para ellos y $3.4 \%$ para ellas ${ }^{10}$. La misma encuesta, incluyó población de seis años o más, en los que se midió la discapacidad, resaltando dos tipos de ellas con mayor prevalencia tales como: dificultad para caminar, moverse, subir o bajar $(4.9 \%$ en hombres y $5.8 \%$ en mujeres), dificultad para ver aun usando lentes (3.3\%).

En México anualmente, de 2000 al 2013 ocurrieron 4500 muertes de menores de 15 años, por causa de accidentes, lo que suma aproximadamente 64 mil muertes debidas 


\section{Accidentes y lesiones}

a accidentes en el hogar, automovilísticos, caídas y envenenamientos, aunque debe subrayarse que la tasa de mortalidad se encuentra a la baja desde 2011. Los accidentes son los que mayor cantidad de muertos generan en este grupo de edad, destacándose los ocurridos por tráfico en vehículo de motor, al generar cerca de la tercera parte de las muertes (31.3\%), después los relacionados con el ahogamiento y la sumersión (13.8\%), las caídas accidentales (3.7\%) y los envenenamientos y accidentes relacionados con fuego, humo y llamas, con porcentajes muy similares (2.4\%). El 46.5\% restante de las muertes corresponden a la categoría residual "otros accidentes" que agrupan múltiples causas con diferente desagregación ${ }^{11}$.

En ese mismo sentido los accidentes siguen siendo un problema de salud que atenta contra el pleno desarrollo de los adolescentes, pues la prevalencia de los accidentes ocurridos en población de 10 a 19 años se ha estado incrementando desde 2006, alcanzando una prevalencia de $10.7 \%$ para hombres y $5.8 \%$ para mujeres en 2012. El grupo con mayor reporte de accidentes fue el de 10 a 12 años de edad. En este mismo grupo la violencia produce daños importantes a la salud, siendo los hombres más expuestos a sufrir estos daños (4.4\%) que las mujeres (3.4\%); la violencia la sufren principalmente en sus propias casas e incluye el recibir golpes, patadas y puñetazos. Los daños a la salud de estos jóvenes incluyen la violencia verbal y la agresión sexual; la primera similar en ambos sexos, y la segunda solo reportada en mujeres para la ENSANUT 2012. Las agresiones ocurren en vía pública, en la escuela o en el hogar, pero los hombres sufren dicha violencia preferentemente en la vía pública (54\%).

En México, en 2013 se registraron 5909 suicidios, que representan 1\% del total de muertes registradas, colocándose como la décima cuarta causa de muerte y presentando una tasa de cerca de cinco por cada 100 mil habitantes. Las entidades con mayor tasa de suicidio son Aguascalientes (9.2), Quintana Roo (8.8) y Campeche (8.5). El 40.8\% de los suicidios ocurren en jóvenes de 15 a 29 años. Entre ellos, la tasa alcanza 7.5 suicidios por cada 100 mil jóvenes.

Del total de suicidios ocurridos en 2013 el 81.7\% fueron consumados por hombres y el $18.2 \%$ por mujeres. El ahorcamiento, estrangulamiento o sofocación es el principal método de suicidio (77.3\%). El principal lugar donde ocurren los decesos es dentro de la vivienda particular (74\%). 


\section{Principales problemas de Salud Pública en México}

Otra forma de lesiones que aquejan a estos adolescentes es el intento suicida, mismo que se encuentra en aumento desde 2006, alcanzando una prevalencia para este grupo etario en el año 2012 de 1,7\% para hombres y 4.6\% para mujeres. Preocupa que la conducta suicida comienza a presentarse en personas de cada vez menores edades presentándose en personas de entre 13 y 15 años de edad, más frecuente en las mujeres que se encuentran casadas y en hombres que consumen alcohol o que sufrieron algún tipo de violencia en el último año ${ }^{12}$.

Más de 800000 personas se suicidan cada año, lo que representa una muerte cada 40 segundos. El suicidio es la segunda causa principal de defunción en el grupo etario de 15 a 29 años. El 75\% de todos los suicidios se produce en países de ingresos bajos y medianos. La ingestión de plaguicidas, el ahorcamiento y las armas de fuego son algunos de los métodos más comunes de suicidio en todo el mundo ${ }^{13}$.

En adultos los accidentes han aumentado para el año 2012, reportándose una incidencia mayor en hombres que en mujeres de hasta $5.8 \%$; ellos los accidentes fueron más frecuentes en los rangos de edad de 20 a 29 años y en mayores de 80 . En el caso de las mujeres la frecuencia de accidentes se incrementa conforme aumenta la edad, siendo mayor en aquellas que superan los 80 años ${ }^{9}$.

En cuanto a la violencia reportada en el año 2012, el 3.0\% de los adultos de 20 años o más sufrió algún robo, agresión o violencia, presentándose con mayor frecuencia en hombres, siendo los de 20 a 29 años quienes son víctimas de estos delitos (60\%). Por el tipo de agresión y el sexo de las víctimas, se sabe que 51.7\% de los hombres sufrió golpes, patadas y puñetazos, mientras que $25.7 \%$ de las mujeres fue agredida de esta forma. Las mujeres sufrieron más agresiones verbales (55.1\%) que los hombres; además ellas recibieron más agresiones sexuales (5.6\%) a diferencia de los hombres, en quienes solo se reportaron $0.6 \%$ de casos de víctimas por este tipo de violencia. A los hombres los agreden preferentemente en la calle y a las mujeres en el hogar.

Como se sabe, el proceso de envejecimiento condiciona limitaciones físicas y de los sentidos que predisponen la ocurrencia de accidentes que pueden producir lesiones de distinta 


\section{Accidentes y lesiones}

magnitud que afecten la calidad de vida o precipiten la muerte del anciano. En México para el año 2012, más de una cuarta parte de los adultos mayores (26.9\%) presentó algún grado de dificultad para realizar al menos una actividad de la vida diaria como caminar, bañarse, acostarse o levantarse de la cama y vestirse. En una proporción similar (24.6\%) presentó dificultad para realizar al menos una de las cuatro actividades instrumentales estudiadas: preparación de alimentos, compra de alimentos, administración de medicamentos y manejo de dinero. Estos problemas aumentan conforme aumenta la edad de las personas y su prevalencia es mayor en mujeres.

Uno de los síndromes geriátricos más importantes y contribuyen significativamente a la morbilidad y mortalidad de los ancianos son las caídas, estas tienen repercusiones que trascienden la esfera social, psicológica y física, y contribuyen a disminuir la independencia del adulto mayor. Debido a que las mujeres son más longevas son ellas quienes se ven más afectadas por las caídas, aunque en general se estima que los adultos mayores sufran estos accidentes en promedio 2.5 veces por año, de los cuales $40 \%$ requirieron atención médica por esa razón ${ }^{14}$.

Como puede notarse, el incremento de discapacidad, invalidez y muerte a causa de lesiones tenderá a subir puesto que la población envejece y pierde capacidades, al mismo tiempo que se incrementa la población de riesgo para sufrir accidentes y que corresponde a los menores de 30 años. De este modo en el año 2012 se estimaron los siguientes agregados de discapacidad y de mortalidad por entidad federativa y por países de América Latina, por causas externas (Gráficas 1, 2 y 3); las que muestran cómo, a pesar de los incrementos en estas problemáticas, los mexicanos no superamos las tasas promedio de mortalidad del continente para este tipo de lesiones. Sin embargo es necesario efectuar medidas encaminadas a la prevención de las mismas, para abatir tales tasas, ya que representan consecuencias sociales, gastos a la nación, así como discapacidad o muerte y sufrimiento para los individuos y las familias ${ }^{9,15}$. 
Gráfica 1. Población mexicana con discapacidad a consecuencia de causas externas, por entidad federativa, 2012.

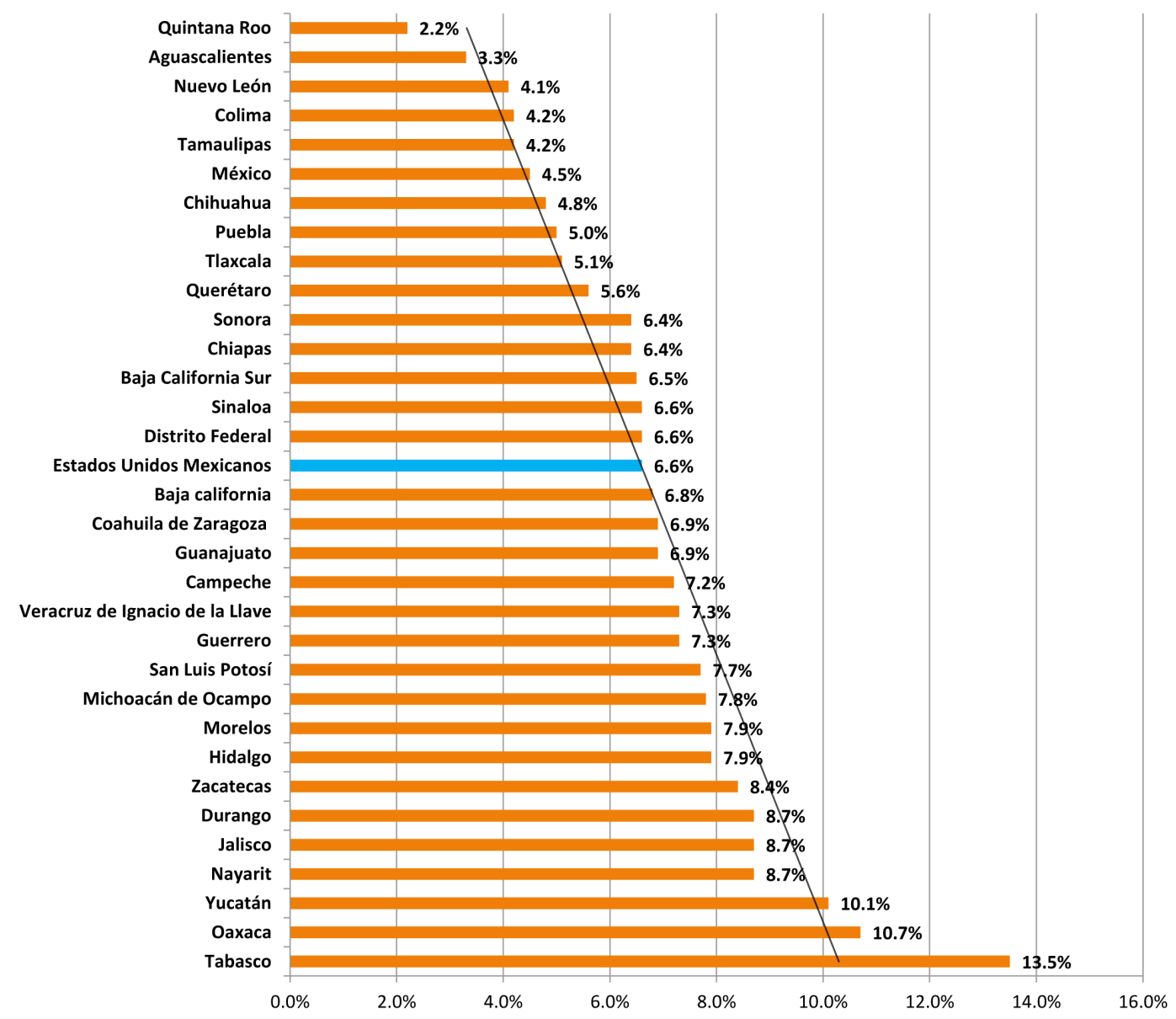




\section{Accidentes y lesiones}

Gráfica 2. Tasa de mortalidad de la población mexicana a consecuencia de causas externas, por entidad federativa 2012.

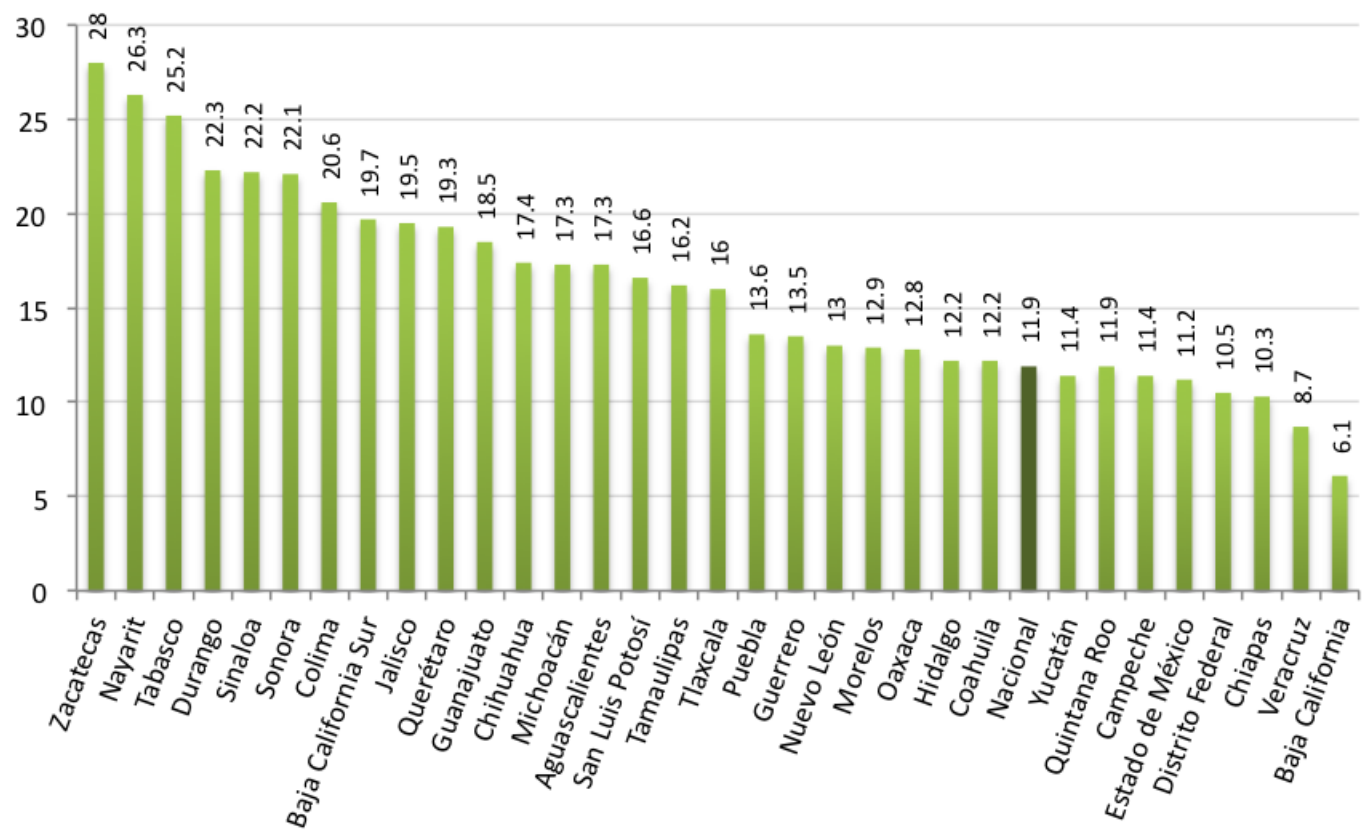

Retomado de: INEGI, defunciones 2012.

Tasas por 100000 habitantes. 
Gráfica 3. Mortalidad por causas externas en diferentes países de América, 2009.

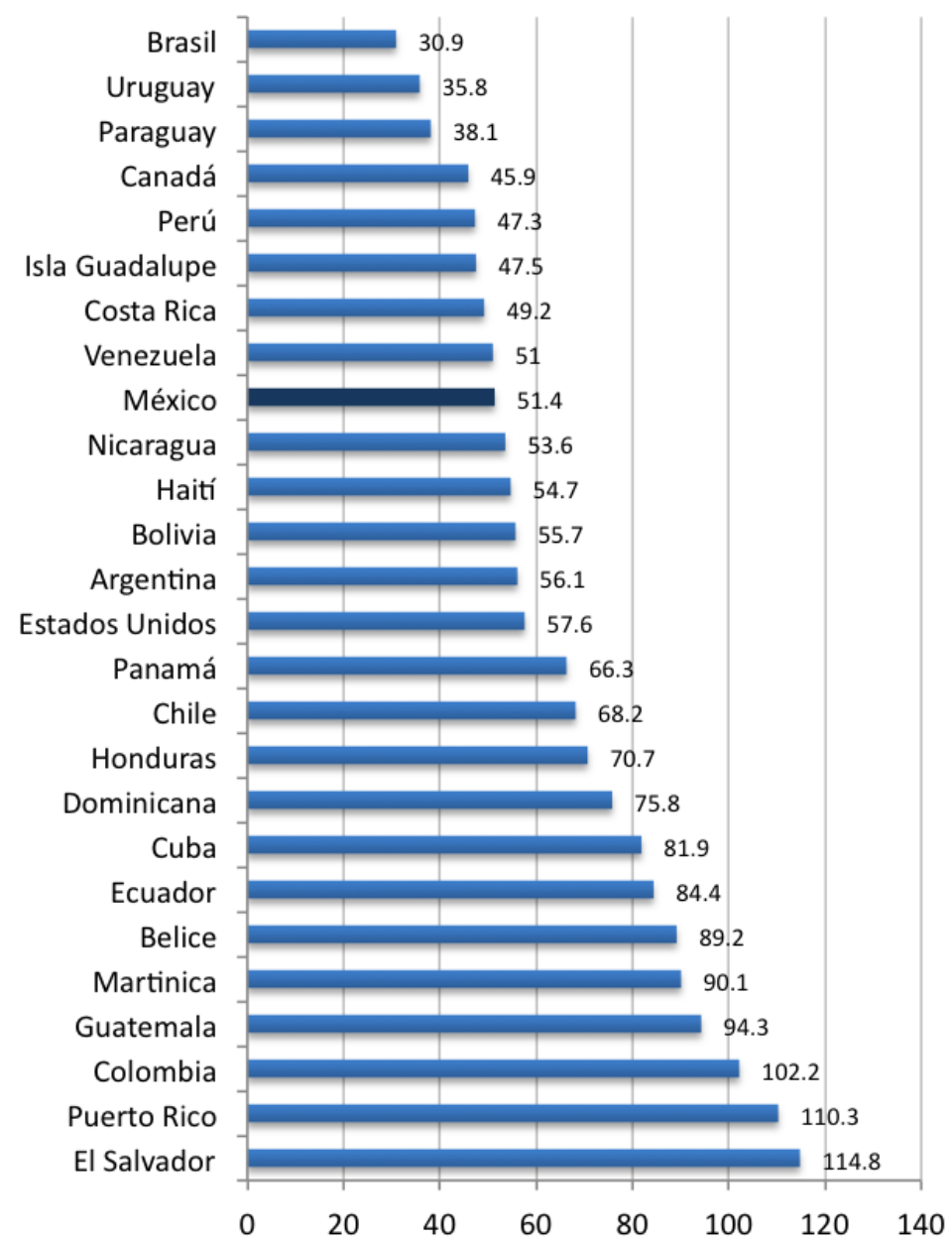

Retomado de: INEGI, defunciones 2012.

Tasas por 100000 habitantes. 


\section{Accidentes y lesiones}

\section{Causalidad}

Los factores causales que se consideran para la producción de lesiones y accidentes son múltiples, independientemente del lugar en donde acontecen, llámese en el hogar, en la escuela, en el trabajo, en el transporte (o de tránsito), en la vía pública o en centros de recreación. En donde tienen que ver el ambiente en donde ocurren, las personas que sufren los accidentes y/o lesiones; además de la manera de cómo interactúan los individuos y lo que les rodea.

Entre los elementos del ambiente, que los favorecen, en el caso de los debidos a los del sistema vial, tienen que ver las condiciones de carreteras y calles (condiciones del suelo, de la red vial, peralte, señalamientos, curvas), los vehículos y su tránsito, llámense autobuses, automóviles o motocicletas, así como las condiciones de los mismos, como calidad de las llantas y frenos, entre otros; cabe mencionar que toman gran relevancia otras características, como las condiciones del clima (presencia de neblina, nieve, lluvia, agua), horas pico en donde circula gran número de vehículos, carencia de un sistema de transporte público seguro y eficaz; velocidad inapropiada de los vehículos ${ }^{16}$. Para los acontecidos en el hogar, las condiciones de la vivienda son determinantes, como la presencia de cisternas sin tapar, ollas con agua caliente, instalaciones eléctricas deficientes, escaleras inadecuadas (ángulo de las mismas, no barandal, escalones inadecuados), falta de iluminación, presencia de objetos punzocortantes y sustancias tóxicas o nocivas, al alcance de los niños o mal etiquetadas y pisos resbalosos. Para los laborales, resaltan mencionar las condiciones de la maquinaria, espacios pequeños, con poca iluminación y ventilación.

Entre los factores que intervienen en la producción de los accidentes se encuentran las características de los individuos, como es el grupo de edad que determina la capacidad física y de percepción de cada persona, aspectos conductuales, inexperiencia, género (por los roles que desempeñan), ignorancia, negligencia, falta de capacitación, no usar equipo de protección para el trabajo o casco, para el caso de motociclistas o ciclistas, falta de uso de cinturón de seguridad, no respetar las reglas de manejo de la maquinaria o de tránsito ${ }^{17}$.

En el caso de accidentes por vehículos de motor la persona es el conductor, pasajero o peatón, el que porta cualquiera de las características ya mencionadas. Al respecto, el 20\% de los conductores, que tuvieron lesiones mortales, tenían alto consumo de alcohol; de 
tal manera que para 2012, en México, el 7.3 de las lesiones a consecuencia de accidentes automovilísticos, estuvieron relacionados con presencia de aliento alcohólico; de ellos el $45.5 \%$ de los conductores lesionados se encuentran entre la edad de 18 y 30 años de edad, y en su mayoría son hombres ${ }^{9}$. En el caso de existir una colisión, se reduce en un $60 \%$ la probabilidad de muerte, al usar correctamente el cinturón de seguridad. ${ }^{18}$ Otro factor de riesgo que interviene para éste tipo de accidentes es el exceso de velocidad ${ }^{19}$. También pueden favorecer la presentación de accidentes, el hacer otra cosa aparte de manejar, ya que representan distracciones al conducir. En éste sentido cabe resaltar que el uso de los teléfonos celulares, incluyendo los de manos libres, por parte de los conductores, tienen la probabilidad de presentar cuatro veces más accidentes, en comparación con quien no lo usa; tales efectos se deben a que al utilizarlos, ya sea para hablar o enviar mensajes, cursan con reacciones más lentas para frenar y al leer las señales de tránsito, además de que tienen una capacidad limitada para mantenerse en el carril que les corresponde y no les permite guardar una distancia adecuada con el vehículo que va delante ${ }^{20}$.

En cuanto al género, los hombres tienden a sufrir más casos de lesiones y accidentes, y con mayor gravedad, que las mujeres. Tales situaciones se deben a que los hombres, en general en el mundo, los niños y los adolescentes, poseen mayor grado de actividad y tienen un comportamiento más compulsivo y arriesgado, además de que se socializan de diferente manera, lo que comienza desde la niñez, ya que los padres tienen una expectativa de desempeño hacia los varones, limitándoles menos para explorar, les dejan solos y con más permisividad para alejarse y jugar más rudo. También los adolescentes tienden a buscar activamente el riesgo (sensaciones intensas o al extremo), para que se sientan que poseen el control de las situaciones y en ocasiones por su característica contradictoria hacia la autoridad; además de que se dejan influenciar con mayor medida por otros jóvenes para cometer infracciones, como elevar la velocidad, manejar bajo intoxicación alcohólica, no utilizar el cinturón de seguridad, usar el teléfono celular, conducir cansados o no respetar la circulación ${ }^{16}$.

Los niños y las niñas tienen más propensión a los accidentes, en relación con los adultos, debido a la falta de desarrollo físico y cognoscitivo, además de la carencia de conciencia del riesgo o la capacidad para evitarlo. Dichos elementos pueden limitar en ésta edad, su capacidad de equilibrio, de ver, o dejarse ver, o ver más allá de un vehículo, no pueden calcular la velocidad de los vehículos, ni mucho menos el discernimiento para calcular la distancia a la que se encuentra un vehículo, además de que carecen de conocimientos y 


\section{Accidentes y lesiones}

aptitudes para desplazarse solos. En edad infantil (menores de un año de e ad), la piel es más delgada que la de los adultos, por lo que se pueden quemar más fácilm :nte y cuando sucede son más profundas y a temperaturas menores que la de los adultos. Ln cuanto a las sustancias tóxicas requieren menor dosis para provocar dicho daño. Los niños pequeños al explorar el mundo que les rodea pueden quedar atrapados de diversas partes del cuerpo (como ejemplos: cabeza, mano), por su menor tamaño; además al ir creciendo tienen curiosidad por el fuego por lo que pueden quemarse; también es frecuente en esa edad, que se descubran así mismos los orificios naturales de su cuerpo, por lo que se pueden introducirse objetos extraños en ellos ${ }^{16}$.

Se considera que a nivel de todo el mundo existen actividades riesgosas, que producen del 80 al 95\% de los traumatismos, intoxicaciones y quemaduras, entre dichos factores se encuentran la pobreza (ya que limita para mejorar las condiciones del ambiente), la falta de cultura para la prevención de los accidentes, la carencia de normatividad o el no aplicarla (para actividades de riesgo: ejemplo el utilizar pólvora) y la carencia de control para evitar la violencia entre los individuos ${ }^{21}$.

La pobreza es un factor determinante, ya que al existir escasos recursos económicos limitan la educación de los padres, se coarta la crianza, se tiene escasa tasa de alfabetización de la familia; monoparentalidad; se vive en hacinamiento y/o en espacios desordenados; existe escasa vigilancia de los niños; se puede contar con antecedentes de quemaduras en los hermanos; el número de hijos que se tienen; falta de supervisión de los niños (los preescolares deben ser vigilados de manera constante); la edad en que se embarazan las mujeres; a menor edad de la madre; las ocupaciones a las que se dedicar o desempleo; el número de personas que viven en el hogar; el tipo de vivienda; ı. ıantenimiento inadecuado de la vivienda; iluminación deficiente; falta de protección en las ventanas; cuartos de usos múltiples o redondos (donde la familia realiza todas sus actividades) lo que puede provocar la falta de espacio y de las instalaciones seguras para el juego y para satisfacer las demás necesidades de la familia; con escaleras sin barandal; sin cocina adecuada, con la posibilidad de hacer fuego con leña para la preparación de sus alimentos o jugar dentro de ese espacio, provocando quemaduras en los niños. También la escasez de recursos económicos favorece la ausencia de leyes que regulen la construcción de edificios y viviendas; propicia la falta de detectores de humo dentro de las edificaciones; provoca un difícil acceso adecuado de suministro de agua (grifo o rociador) para sofocar el fuego o evitar a que se propague. Al respecto, se ha demostrado que la probabilidad de 


\section{Principales problemas de Salud Pública en México}

fallecer en un incendio doméstico es 2,4 veces mayor en personas con in ̨ esos bajos con respecto a los que poseen mayores ingresos. Cabe referir que las situaci nes culturales, también juegan un papel importante, ya que en algunos lugares sueler ı hacer fogatas, utilizar veladoras o parafina, pueden usar cohetes con pólvora para festejar, lo que puede provocar quemaduras ${ }^{16}$.

\section{Fisiopatología}

\section{- Síndrome de latigazo}

El síndrome de latigazo cervical es comúnmente causado por un accidente automovilístico. El vehículo que se conduce lleva una aceleración hacia adelante y por ir dentro del vehículo, todo el cuerpo de la persona (incluyendo la cabeza) viaja en la misma dirección que el automóvil. Después del impacto el carro seguirá acelerándose hacia enfrente, ocasionando que todo el tórax del pasajero y sus hombros sean llevados para adelante. Esto ocasiona que por un instante la cabeza se quede atrás, con lo que se hiper extiende. Seguido de este instante de hiperextensión, la cabeza con violencia sigue la trayectoria del cuerpo originando una flexión. Después de este violento acontecimiento, tanto por la extensión como por la flexión se origina una lesión en las estructuras articulares de la columna espinal. Este daño puede ser superior y abarcar de C1 a C2 o bien inferior y abarcar de C3 a $\mathrm{C}^{22}$.

\section{- Heridas}

Las heridas son la pérdida de la continuidad tisular producidas por agєııtes externos o internos. Estas se clasificaran de acuerdo al tiempo de reparación del tejido dañado en: agudas, donde su evolución es en tiempo corto y cursan sin complicaciones; crónicas, se presenta retraso en el tiempo de cicatrización (mayor a 3 meses), generalmente con complicaciones las cuales pueden ser causadas por diversos factores como edad avanzada, falta de perfusión sanguínea, enfermedades metabólicas (diabetes mellitus), inmunodeficiencias, etc. La etiología por agentes externos es múltiple, se pueden clasificar en: incisas o cortantes (producidas por objetos afilados como navajas, cuchillos y se caracterizan por ser lineales y sin bordes tortuosos, la hemorragia dependerá de la zona y los vasos lesionados), punzantes (por encajamiento de objetos puntiagudos como clavos, cuchillos; dejando un orificio pequeño exterior pero su profundidad puede ser 


\section{Accidentes y lesiones}

mayor llegando a vísceras y generar hemorragias internas), contusas (generalmente producidas por traumatismos, la lesión es en tejidos blandos, generando hematomas sin perder la integridad de la piel), avulsivas ( presentan pérdida parcial o completa de tejido y abundante sangrado, ej. mordedura de perro), por abrasión (producida por fricción de la piel con objetos duros, perdiendo capa más superficial, la epidermis) y quemaduras (causadas por contacto con agentes térmicos, físicos o químicos). El proceso de reparación del tejido, cursa por 3 fases. La fase de inflamación: inmediato a la lesión, inicia la adherencia plaquetaria para la formación de un coagulo de fibrina sobre la herida con el fin de evitar la pérdida de flujo sanguíneo, la fibrina activa células inflamatorias como leucocitos polimorfonucleares y monocitos con el fin de destruir agentes que representen peligro para el tejido dañado. Puede durar hasta 6 días. La fase proliferativa: va después de la fase anterior. Abarca de los días 3 a 12; para la formación de tejido de granulación, fibroblastos (principal función es la síntesis y modelación de matriz extracelular) y células endoteliales proliferan durante las primeras $72 \mathrm{hrs}$. La zona suele ser edematosa por la presencia de neovasos (angiogénesis) que permiten la salida de proteínas plasmáticas y liquido al espacio extravascular. Durante esta fase la continuidad de tejido se restablece. Y la tercera fase de maduración y remodelación: durante esta fase el tejido de granulación restante desaparece convirtiéndose al final del 1 mes en una cicatriz pálida y avascular constituida de fibroblastos fusiformes, colágeno denso y tejido elástico; elementos dérmicos como folículos pilosos no se logran regenerar ${ }^{23,24}$.

\section{- Lesiones musculares (heridas que afectan a músculo)}

Se basa en tres fases principales: destrucción e inflamación (1-3 días), reparación (3-4 semanas) y remodelación (3-6 meses). En la primera fase, al ocurrir la lesión las miofibrillas se rompen involucrando a las microvasculaturas del músculo generando así una necrosis inducida por la pérdida del riego sanguíneo, debido a la extravasación del líquido se formara un hematoma alrededor de la lesión. Subsecuentemente se genera un proceso inflamatorio y se reclutan leucocitos polimorfonucleares (monocitos) que se diferencian en macrófagos mediante quimiocinas (CC,C,CXC,CX3C), estos fagocitan los restos necróticos y junto con los fibroblastos envían señales químicas para la aparición de factores tales como FGF, IGF1, IGF-2, TNF- $\alpha$, TGF- $\beta$, citosinas IL-6 y quimiocinas desde la matriz extracelular para permitir el paso de componentes celulares desde el espacio intravascular y que estimulan la actividad miogénica precursora de proliferación y diferenciación de las células satélite especialmente mediante IGF-1 y IGF-2. En la segunda fase las células satélite se diferencian 


\section{Principales problemas de Salud Pública en México}

en mioblastos están se unen a las miofibrillas dañadas comenzando la for ración tejido cicatricial generando así una unión miotendinosa por la fibrina y fibronecti ıa, derivadas de la sangre del hematoma producido después de la lesión. Este tejido cicatricial brinda la fuerza del músculo y resiste a las contracciones, los fibroblastos invaden el sito de la lesión y generan más tejido conjuntivo. En la última fase las miofibrillas maduran y comienzan la remodelación del tejido cicatricial, por células productoras de colágeno tipo 3 que lentamente se remodelaran a tipo 1. Y junto con esto hay una asociación de neovascularización en el sitio de la lesión ayudando así al proceso reparativo ${ }^{25,26}$.

\section{- Esguince}

Son lesiones de los ligamentos. Existen de primer grado (estiramiento de las fibras ligamentosas sin que exista el incremento de la longitud del ligamento, pero las fibras están intactas), segundo (se puede observar la interrupción incompleta del ligamento, lo que provoca incremento de su longitud, que se traduce clínicamente con una cierta inestabilidad articular) y tercer grado (solución de la continuidad del ligamento es completa y la inestabilidad que ocasiona es mayor). Dichas lesiones son producidas por mecanismos que se relacionan con posiciones en inversión o eversión, por lo que es común después de realizar deportes. Su regeneración se asocia con las tres fases de las lesiones musculares, requiriendo 52 semanas para semejar las características del ligamento normal ${ }^{27,28,29}$.

\section{- Luxación}

Es la pérdida de relación entre dos superficies articulares (separación de iss huesos de su articulación), produciendo el desplazamiento de los extremos óseos. Puede observarse además desgarros de ligamentos, músculos periarticulares, vasos sanguíneos y nervios. Si la pérdida de relación es completa se denomina luxación; si esta es parcial, subluxación. Las luxaciones pueden ser ocasionadas por diversos mecanismos entre ellos se encuentran los traumáticos, que generalmente son producidos de manera indirecta, donde la fuerza del traumatismo es transmitida a lo largo del hueso y vence la resistencia de las estructuras de contención (cápsula articular, ligamentos, músculos), generando la pérdida de continuidad de las articulaciones lesionadas; muy pocas veces la fuerza es directa sobre esta. Se pueden clasificar en recidivantes (la articulación ya fue lesionada con anterioridad y esto facilita su daño), y habituales, donde el paciente la produce y la reduce sin dificultad. Entre otras 


\section{Accidentes y lesiones}

causas se encuentran las patológicas, las cuáles se presentan espontáneamente sin trauma alguno, en ellas puede haber destrucción o daño de alguna de las dos articulaciones generado por procesos patológicos como ejemplo, los tumores y artritis. Y las originadas de manera congénita, cuando hay alguna alteración de las superficies articulares que faciliten la luxación ${ }^{30,31}$.

\section{- Fractura}

Inmediatamente después de la fractura (ruptura de hueso) sigue un proceso de inflamación, este se da por que la lesión ósea repercute en los músculos y vasos adyacentes, cuando se segmentan estos últimos se interfiere con el riego sanguíneo, las células que no reciben nutrientes por este medio terminan necrosándose y liberando componentes estructurales de la membrana celular, estos son detectados por el linfocito $\mathrm{T} \gamma$ que a través de la IL-6 y el TNF le darán comienzo al proceso de inflamación, otras citosinas importantes son IL-1 $\beta$, IL23 y la IL-17F, durante este proceso aumenta la permeabilidad de los vasos que aunados a su segmentación conduce a la salida de la sangre al espacio extravascular, constituyendo el hematoma y más importante aún, se da el reclutamiento de grandes poblaciones celulares, entre los más importantes, los macrófagos que removerán el tejido necrótico y las células mesenquimatosas indiferenciadas del periostio responsables de la reparación ósea, una vez que esto ocurre estas células mesenquimatosas invadirán el hematoma mientras se están diferenciando en condrocitos, osteoblastos y células vasculares para producir nuevos vasos y cartílago que se osificara, durante este proceso de diferenciación que obedece a factores como BMP-2, TGF- $\beta$ y FGF-2 (moléculas cuya expresión es vital durante el desarrollo embrionario), las células mesenquimatosas intervienen en la regulación de la inflamación activando a los linfocitos Tregs inducidos, con el fin de evitar una respuesta autoinmune con las nuevas células en desarrollo. Una vez diferenciadas se produce la matriz cartilaginosa que constituye el callo primario, simultáneamente los osteoclasto degradan el componente óseo lesionado con el fin de liberar espacio para el nuevo que se producirá, el callo primario posteriormente se verá reforzado por el proceso de mineralización formando hueso laminar y por ende el callo secundario aquí también hay actividad osteoclástica, que elimina la primera matriz ósea producida también es importante remarca el hecho de que es aquí cuando se considera la unión clínica entre los dos segmentos del hueso lesionado, finalmente el callo secundario sufre los procesos de remodelación y alineamiento con base en las líneas de tensión (Figura 1) ${ }^{24,32}$. 
Figura 1. Evolución de las fracturas en días.

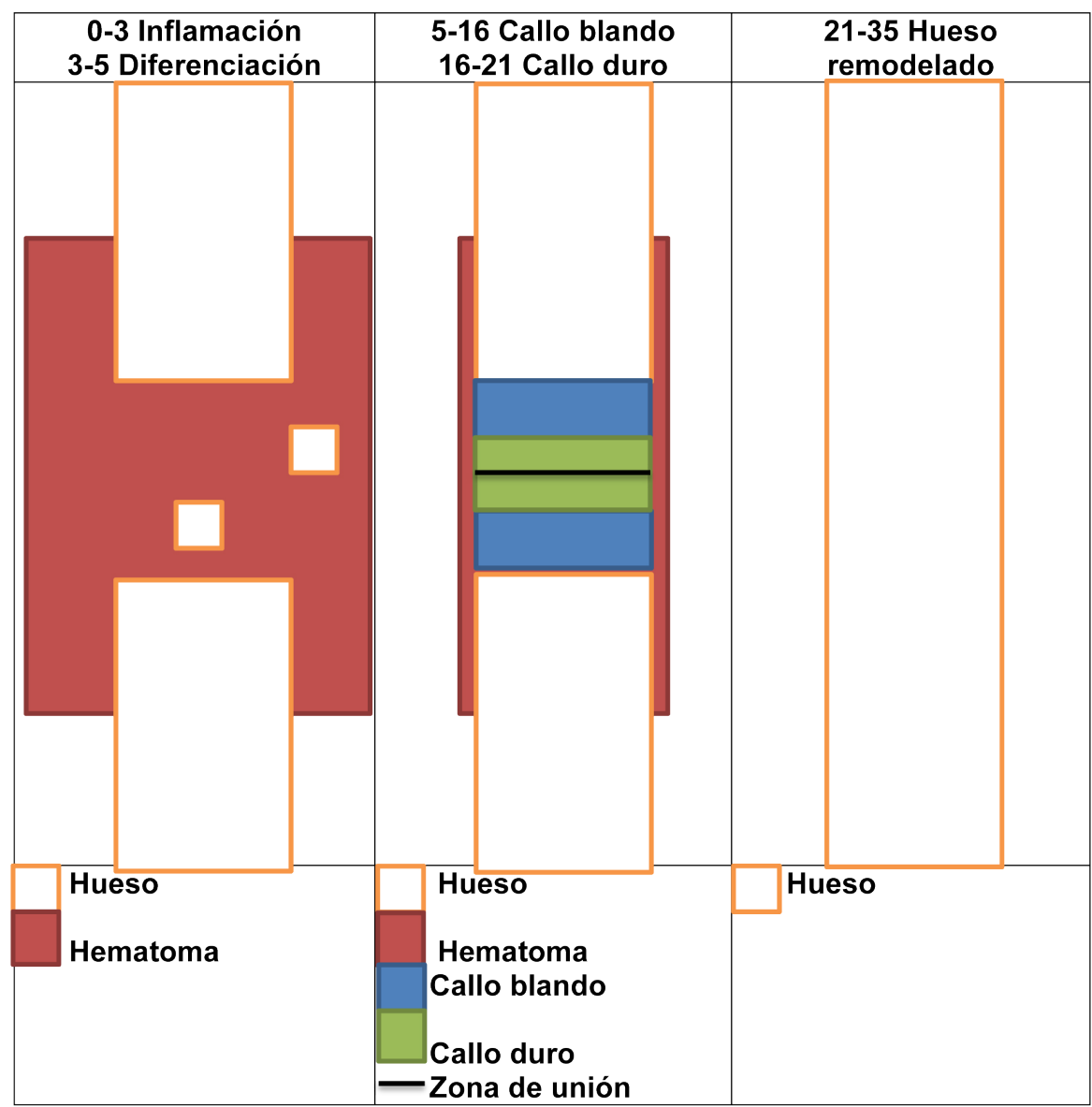

\section{- Quemadura}

El cuerpo, responde de la misma forma a una quemadura, sin importar si el agente es seco (fuego, electricidad o hielo) o húmedo (agua o vapor). Se reconocen, al igual que en otro tipo de heridas tres fases. Una primera fase inflamatoria; una segunda fase de proliferación; y una tercera de remodelación y cicatrización. Se debe hacer énfasis sobretodo en la primera fase (inflamatoria), ya que es de vital importancia entender los 


\section{Accidentes y lesiones}

sucesos que pueden ocurrir para entender el manejo terapéutico de un paciente quemado. La fase inflamatoria comienza después del daño al tejido por medio de tres tipos de células: neutrófilos, monocitos y mastocitos. La principal función de esta fase es evitar una infección oportunista en esta zona, pero como veremos más adelante esta función por lo regular falla. Tanto neutrófilos como monocitos, en especial este último, se encargan de sintetizar citocinas proinflamatorias tales como Interleucina $1 \beta$ (IL-1 $\beta$ ), interleucina 6 (IL6) y factor de necrosis tumoral $\alpha$ (TNF- $\alpha$ ). El mastocito se desgranula y libera histamina. Estos agentes, entre otras funciones, ocasionan un aumento de la permeabilidad de la microvasculatura. Este aumento de la en la permeabilidad tiene como consecuencia la extravasación del plasma hacia líquido intersticial generando edema. De ser una quemadura que comprometa una gran extensión del cuerpo (mayor al 30\% de la superficie corporal), este edema no solamente aparece en el tejido periférico a la quemadura, también puede ser sistémico e involucrar el pulmón, generando edema pulmonar, que ocasiona en el paciente insuficiencia respiratoria. Además la extravasación del líquido del plasma al tejido intersticial genera hipovolemia. De ser una quemadura como de la que se habló con anterioridad, esta hipovolemia es severa y es reconocida por la mácula densa en el riñón, el cual comienza la producción de renina en las células yuxtaglomerulares y activa el sistema renina-angiotensina-aldosterona. La angiotensina II que se produce tanto en el pulmón como en el riñón mismo y en este tendrá un efecto vasoconstrictor, preferentemente en la arteriola eferente lo que ocasionará un descenso en la tasa de filtración glomerular ocasionando insuficiencia renal aguda. Otra característica de esta fase de inflamación es que, la quemadura al ser un estímulo estresante para el cuerpo, este liberara principalmente dos hormonas, cortisol y noradrenalina. La noradrenalina se libera después de un estímulo estresante, (además el cortisol que también se libera en estas situaciones, favorece la síntesis de más noradrenalina) la que tiene efectos sobre los receptores adrenérgicos generando un aumento de las resistencias periféricas, y una disfunción cardiaca por aumento del gasto cardiaco a causa de la taquicardia por acción de la adrenalina en el corazón. El cortisol, se libera, ocasiona hiperglucemia, y además disminuye la función inmunológica. Esta disminución de la respuesta inmune, hace que el organismo sea susceptible a infecciones oportunistas, sobre todo por Pseudomona aureuginosa. Esta infección no se limita al sitio de la lesión y de ser una quemadura grado dos o tres, ocasiona una septicemia. La última característica de este proceso, es que hay aumento del metabolismo basal que puede llegar a ser del doble del normal, lo que aumenta las necesidades nutricionales del paciente. La fase proliferativa comienza al final de la fase inflamatoria y es llevada a cabo por queratinocitos y fibroblastos. Por 


\section{Principales problemas de Salud Pública en México}

último la fase de cicatrización está a cargo de fibroblastos y queratinocitos y tiene como finalidad la resolución de la herida (Figura 2) ${ }^{33,34}$.

Figura 2. Mecanismos fisiopatológicos en la respuesta inflamatoria ante una quemadura.

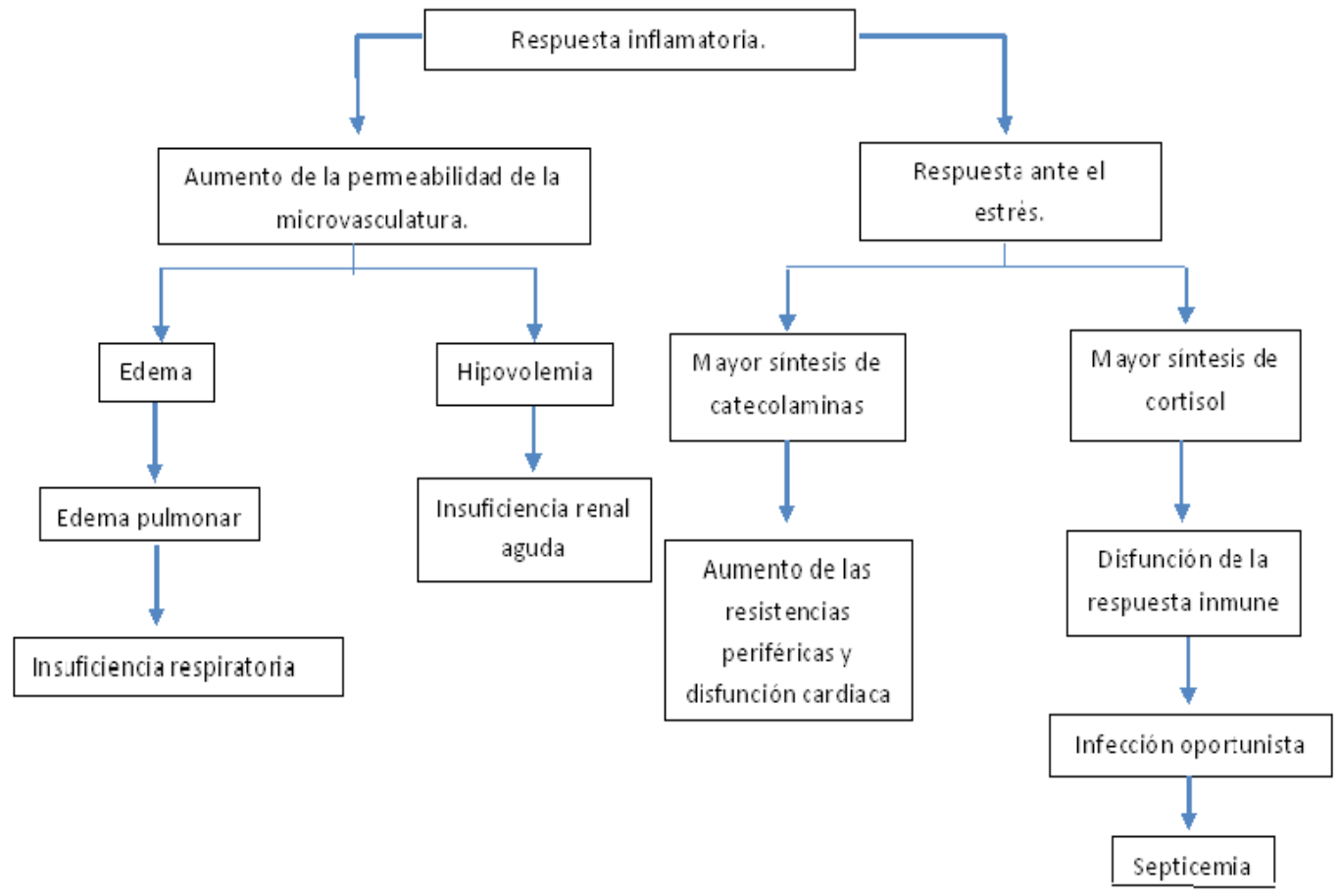

\section{Cuadro clínico}

Entre las consecuencias que tienen importancia para la salud, producidas por los accidentes, son traumatismo, quemadura, mordedura, picadura, ahogamiento e intoxicación. Y los tipos de lesión a consecuencia de los mismos incluyen entre otros: fractura, luxación, esguince, herida, laceración, amputación y contusión. Es por ello que a continuación se desarrollan los aspectos clínicos de las lesiones más frecuentes (Cuadro 2). 


\section{Accidentes y lesiones}

Cuadro 2. Cuadro clínico de las lesiones producidas por accidentes.

\begin{tabular}{|c|c|}
\hline $\begin{array}{l}\text { Tipo de } \\
\text { lesión }\end{array}$ & Datos clínicos \\
\hline Fractura & $\begin{array}{l}\text { Dolor, impotencia funcional, deformación, movilidad anormal, aumento } \\
\text { de volumen, equimosis y crépito óseo, que obligan al paciente a consultar } \\
\text { a la brevedad }{ }^{35,36}\end{array}$ \\
\hline Luxación & $\begin{array}{l}\text { Dolor, impotencia funcional, deformación, movilidad anormal, aumento } \\
\text { de volumen, equimosis y crepito óseo, que obligan al paciente a consultar } \\
\text { a la brevedad }{ }^{35}\end{array}$ \\
\hline Esguince & $\begin{array}{l}\text { Dolor, tumefacción articular y de partes blandas, pudiendo aparecer } \\
\text { después equimosis, limitación de movimientos }{ }^{37}\end{array}$ \\
\hline Heridas & Presencia de solución de continuidad, sangrado, hemorragia ${ }^{36}$ \\
\hline $\begin{array}{l}\text { Síndrome } \\
\text { de latigazo }\end{array}$ & $\begin{array}{l}\text { Dolor en la región del cuello, cefalea, pueden existir alteraciones visuales, } \\
\text { vértigo, alteraciones de memoria y concentración, parestesias en manos, } \\
\text { puede haber debilidad, pesadez o fatiga de las extremidades superiores }{ }^{22}\end{array}$ \\
\hline $\begin{array}{l}\text { Contusión } \\
\text { (daño por } \\
\text { golpe sin } \\
\text { ocasionar } \\
\text { herida) }\end{array}$ & $\begin{array}{l}\text { Pueden existir a consecuencia de traumatismos en diferentes partes de la } \\
\text { economía: } \\
\text { Cuando se localiza en tejido muscular existe edema, dolor leve o moderado } \\
\text { y en ocasiones equimosis. } \\
\text { En área pulmonar: Datos de neumonía, taquipnea, cianosis y en cuello } \\
\text { puede haber petequias. } \\
\text { En el abdomen: Dolor abdominal, distención abdominal, signos de } \\
\text { irritación peritoneal. Debe ser considerado como traumatismo grave. } \\
\text { Craneal: Cuando se localiza en ésta zona puede ser conmoción cerebral o } \\
\text { en su defecto contusión cerebral. } \\
\text { Y también existen por: } \\
\text { Conmoción: Es a consecuencia de un golpe o traumatismo leve, que } \\
\text { provoca confusión o en algunas ocasiones con pérdida de la conciencia } \\
\text { menor a un minuto, cefalea, pérdida de memoria, sueño, puede haber } \\
\text { náusea, vómito, problemas de concentración, mareos, pérdida del } \\
\text { equilibrio, tinitus y debilidad. } \\
\text { Contusión: Por fuerzas de contacto externo y también a consecuencia del } \\
\text { fenómeno de latigazo }{ }^{36,37,38}\end{array}$ \\
\hline Quemadura & $\begin{array}{l}\text { Zona de hiperemia, estasis, necroptosis y puede haber una respuesta } \\
\text { inflamatoria sistémica. Existen } 3 \text { grados: } \\
1^{\circ} \text { Capa externa de la piel: enrojecimiento, dolor e hinchazón. } \\
2^{\underline{0}} \text { Capa externa y subyacente de la piel: enrojecimiento, dolor, hinchazón } \\
\text { y ampollas. } \\
3^{\underline{0}} \text { Capas profundas de la piel: piel blanquecina, quemada u oscura, piel } \\
{\text { adormecida }{ }^{21}}\end{array}$ \\
\hline
\end{tabular}




\section{Principales problemas de Salud Pública en México}

\section{Complicaciones}

Las complicaciones son diversas, entre ellas se encuentran hemorragias, shock hipovolémico, choque por dolor, insuficiencia renal aguda, procesos infecciosos que incluyen sepsis, epilepsia, desequilibrio hidroelectrolítico, limitación de movimientos, tétanos, sección vascular (Cuadro 3) ${ }^{29,38}$.

Cuadro 3. Complicaciones de las lesiones producidas por accidentes.

\begin{tabular}{|c|c|}
\hline Tipo de lesión & Complicaciones \\
\hline Fractura & $\begin{array}{l}\text { Locorregionales: Lesiones vasculares, nerviosas y } \\
\text { musculotendinosas; infección de partes blandas, osteomielitis y } \\
\text { artritis sépticas; artrosis postraumática; alteraciones en el proceso } \\
\text { de consolidación; alteraciones de longitud del crecimiento de los } \\
\text { huesos; necrosis avascular; rigidez articular; y miosistis osificante. } \\
\text { Generales: Choque traumático (hipovolémico, cardiogénico, } \\
\text { neurogénico o séptico), trombosis venosa, coagulación } \\
\text { intravascular diseminada, síndrome de embolia grasa, síndrome } \\
\text { de dificultad respiratoria del adulto, tétanos, complicaciones } \\
\text { psiquiátricas }^{36} \text {. }\end{array}$ \\
\hline Luxación & $\begin{array}{l}\text { Lesiones vasculares, nerviosas, ligamentarias, de tejidos blandos } \\
\text { y fracturas }{ }^{39} \text {. }\end{array}$ \\
\hline Esguince & $\begin{array}{l}\text { Lesiones recidivantes, compromiso neurovascular, parálisis de } \\
\text { los músculos, ruptura tendinosa, heridas penetrantes a nivel de } \\
\text { las articulaciones }{ }^{27,40} \text {. }\end{array}$ \\
\hline Heridas & $\begin{array}{l}\text { Hemorragias, hematomas, infección (la que aparecehabitualmente } \\
\text { de } 3 \text { a } 5 \text { días después de una curación: piel roja, fluctúa y duele), } \\
\text { tétanos, dehiscencia de la herida }{ }^{41} \text {. }\end{array}$ \\
\hline Síndrome de latigazo & $\begin{array}{l}\text { Puede desencadenar alteraciones cognitivas, emocionales, estrés } \\
\text { postraumático, depresión, ansiedad, miedo al movimiento y } \\
\text { disminución de la concentración }{ }^{42} \text {. }\end{array}$ \\
\hline Quemadura & $\begin{array}{l}\text { Sepsis, choque, daño pulmonar agudo, daño cerebral, } \\
\text { hipermetabolismo, fallo } \\
\text { gastrointestinales, cardiacas, insuficiencia renal aguda, } \\
\text { tromboflebitis, alteraciones musculares esqueléticas y } \\
\text { articulares }{ }^{21,46} \text {. }\end{array}$ \\
\hline
\end{tabular}




\section{Accidentes y lesiones}

Cuadro 3. Complicaciones de las lesiones producidas por accidentes (continuación).

\begin{tabular}{|l|l|}
\hline \multicolumn{1}{|c|}{ Tipo de lesión } & \multicolumn{1}{|c|}{ Complicaciones } \\
\hline Contusión & $\begin{array}{l}\text { Pulmonar: atelectasia, neumonía, infección pulmonar, fallo } \\
\text { respiratorio y muerte. } \\
\text { Abdominal: son de dos tipos, las que afectan de manera } \\
\text { generalizada a todo el cuerpo y las localizadas en el abdomen. } \\
\text { Entre ellas se pueden presentar infecciones, peritonitis, sepsis, } \\
\text { choque hemorrágico, alteraciones metabólicas, endócrinas } \\
\text { e inmunológicas, síndrome de inflamación generalizada, } \\
\text { alteraciones hepáticas y renales, que pueden ser causa de } \\
\text { mortalidad. } \\
\text { Craneal: Edema cerebral, hipertensión intracraneana, lesiones } \\
\text { secundarias de causa sistémica (hipoxia, hipotensión arterial, } \\
\text { hipercapnia, hipertermia, alteraciones de la glucemia, lesión } \\
\text { pulmonar aguda, hiponatremia y síndrome cerebral perdedor de } \\
\text { sal }{ }^{36,43,44,45} \text {. }\end{array}$ \\
\hline
\end{tabular}

\section{Diagnóstico}

El diagnóstico se conforma tomando en consideración, lugar en donde aconteció el accidente (ciudad, campo), el mecanismo por el cuál fue adquirida la lesión, tiempo de evolución de la lesión, partes estructurales y anatómicas del cuerpo que están afectados, tamaño de las lesiones. Además es crucial utilizar los signos y síntomas, exploración física (inspección, palpación, auscultación). Para la inspección es necesario efectuar comparación bilateral, así como maniobras específicas, para efectuar diagnósticos concretos. Con el afán de completar la diagnosis, se deberán usar estudios de gabinete en casos necesarios, como es el uso de rayos $X$, tomografía axial computarizada, ecografía. Así como indagar patologías previas del paciente, como diabetes mellitus, entre otras. Es por ello que para valorar adecuadamente, en algunos pacientes se deberán realizar otros estudios de laboratorio, como biometría hemática (Cuadro 4) ${ }^{29,38}$. 
Cuadro 4. Diagnóstico de las lesiones producidas por accidentes.

\begin{tabular}{|c|c|}
\hline Tipo de lesión & Diagnóstico \\
\hline Fractura & $\begin{array}{l}\text { Datos clínicos como impotencia funcional, dolor; crepitación de los } \\
\text { fragmentos y hemorragias. Considerar antecedentes del paciente, } \\
\text { además del traumático, cómo ha sido el accidente (mecanismo de } \\
\text { producción), cuanto tiempo hace del mismo. Inspección y palpación } \\
\text { de la zona lesionada, evaluación de la movilidad y del estado neuro- } \\
\text { vascular. Efectuar radiografías, en algunos casos se requieren TAC, } \\
\text { gamagrafías o tomografías. } \\
\text { Determinar el tipo de fractura y su ubicación. El tipo de fractura se } \\
\text { determina con su Clasificación. } \\
\text { La clasificación de las fracturas según su estabilidad: Estable (no } \\
\text { tienen tendencia a desplazarse después de la reducción, son de } \\
\text { trazo transversal u oblicuo, menor de } 45^{\circ} \text { ) e inestable (tienden a } \\
\text { desplazarse después de la reducción), tienen trazo oblicuo mayor de } \\
45^{\circ} \text { ). Cabe aclarar que la estabilidad depende de las partes blandas. } \\
\text { La clasificación de las fracturas según su patrón de interrupción: } \\
\text { Incompletas: Fisuras (solo una parte del espesor), en tallo verde } \\
\text { (fracturas por flexión), en caña de bambú o en torus (en zonas de } \\
\text { unión metafiso - diafisiarias). } \\
\text { Completas: } \\
\text { - Simples (un trazo único sin desplazamiento), } \\
\text { - Con desplazamiento (pierden la alineación de los fragmentos) } \\
\text { Y dependiendo de su localización pueden ser en el eje: } \\
\text { a) Longitudinal: acabalgamiento, diástasis, rotación o decalaje. } \\
\text { b) Transversal: desviación lateral, desviación angular } \\
\text { - Conminuta (más de un trozo) }\end{array}$ \\
\hline Luxación & $\begin{array}{l}\text { Considerar el cuadro clínico que consiste en dolor, tumefacción } \\
\text { articular y de partes blandas, pudiendo aparecer después equimosis, } \\
\text { limitación de movimientos. } \\
\text { Considerar antecedentes del paciente, además del traumático, cómo } \\
\text { ha sido el accidente (mecanismo de producción), cuanto tiempo hace } \\
\text { del mismo. Inspección y palpación de la zona lesionada, evaluación } \\
\text { de la movilidad y del estado neuro-vascular. Efectuar radiografías, } \\
\text { en caso necesario }{ }^{35,36} \text {. }\end{array}$ \\
\hline
\end{tabular}




\section{Accidentes y lesiones}

Cuadro 4. Diagnóstico de las lesiones producidas por accidentes (continuación).

\begin{tabular}{|c|c|}
\hline Tipo de lesión & Diagnóstico \\
\hline Esguince & $\begin{array}{l}\text { Considerar el mecanismo de la lesión, tiempo de evolución, } \\
\text { antecedentes (diabetes mellitus, insuficiencia vascular periférica, } \\
\text { alteraciones de la coagulación), estado neurovascular, localización y } \\
\text { grado de esguince: } \\
\text { Grado I. El ligamento está dañado parcialmente, sin pérdida } \\
\text { funcional o con limitación leve. Edema e inflamación leve, no existe } \\
\text { inestabilidad mecánica al examen clínico. Recuperación de } 1 \text { a } 7 \text { días. } \\
\text { Grado II. Lesión incompleta del ligamento. Dolor cuando apoya, } \\
\text { edema moderado sobre las estructuras que están afectadas, } \\
\text { discapacidad parcial de los movimientos y función, al examen clínico } \\
\text { con presencia de inestabilidad de leve a moderada. Recuperación de } \\
3 \text { a } 28 \text { días. } \\
\text { Grado III. Pérdida completa de la integridad del ligamento. Presencia } \\
\text { de edema severo (por arriba de } 4 \text { centímetros del peroné), equimosis } \\
\text { severa, el paciente no puede apoyar, por lo que existe pérdida de la } \\
\text { función y movimiento, con inestabilidad mecánica de moderada a } \\
\text { severa). Canalizar para valoración con el especialista. } \\
\text { Además realizar serie radiográfica para descartar que no exista } \\
\text { luxación o fractura }{ }^{27}\end{array}$ \\
\hline Heridas & $\begin{array}{l}\text { Valorar la presencia de hemorragia; localización, forma, longitud, } \\
\text { profundidad de la herida y estructuras afectadas (vasos, hueso, } \\
\text { tendones). Así como valorar las características de los bordes de la } \\
\text { herida (limpios o contusos), presencia de cuerpos extraños, tiempo } \\
\text { transcurrido desde que ocurrió la lesión. Además clasificar al tipo de } \\
\text { herida. } \\
\text { Las heridas se clasifican de acuerdo a su profundidad y gravedad en: } \\
\text { a) Superficiales: no afectan a vasos, nervios ni tendones. } \\
\text { b) Profundas o complicadas, localizadas en tejidos, piel, músculo } \\
\text { o hueso. } \\
\text { c) Penetrantes, graves, las que aquejan a cavidades, sin existir } \\
\text { lesión a órganos o vísceras. } \\
\text { d) Perforantes, graves, lesionan vísceras y órganos. } \\
\text { También se clasifican en limpias o sucias (son aquellas que fueron } \\
\text { producidas por mordedura, o en un ambiente que las contaminó, así } \\
\text { como las que tienen más de } 6 \text { horas de evolución) }{ }^{41} \text {. }\end{array}$ \\
\hline
\end{tabular}


Principales problemas de Salud Pública en México

Cuadro 4. Diagnóstico de las lesiones producidas por accidentes (continuación).

\begin{tabular}{|c|c|}
\hline Tipo de lesión & Diagnóstico \\
\hline Contusión & 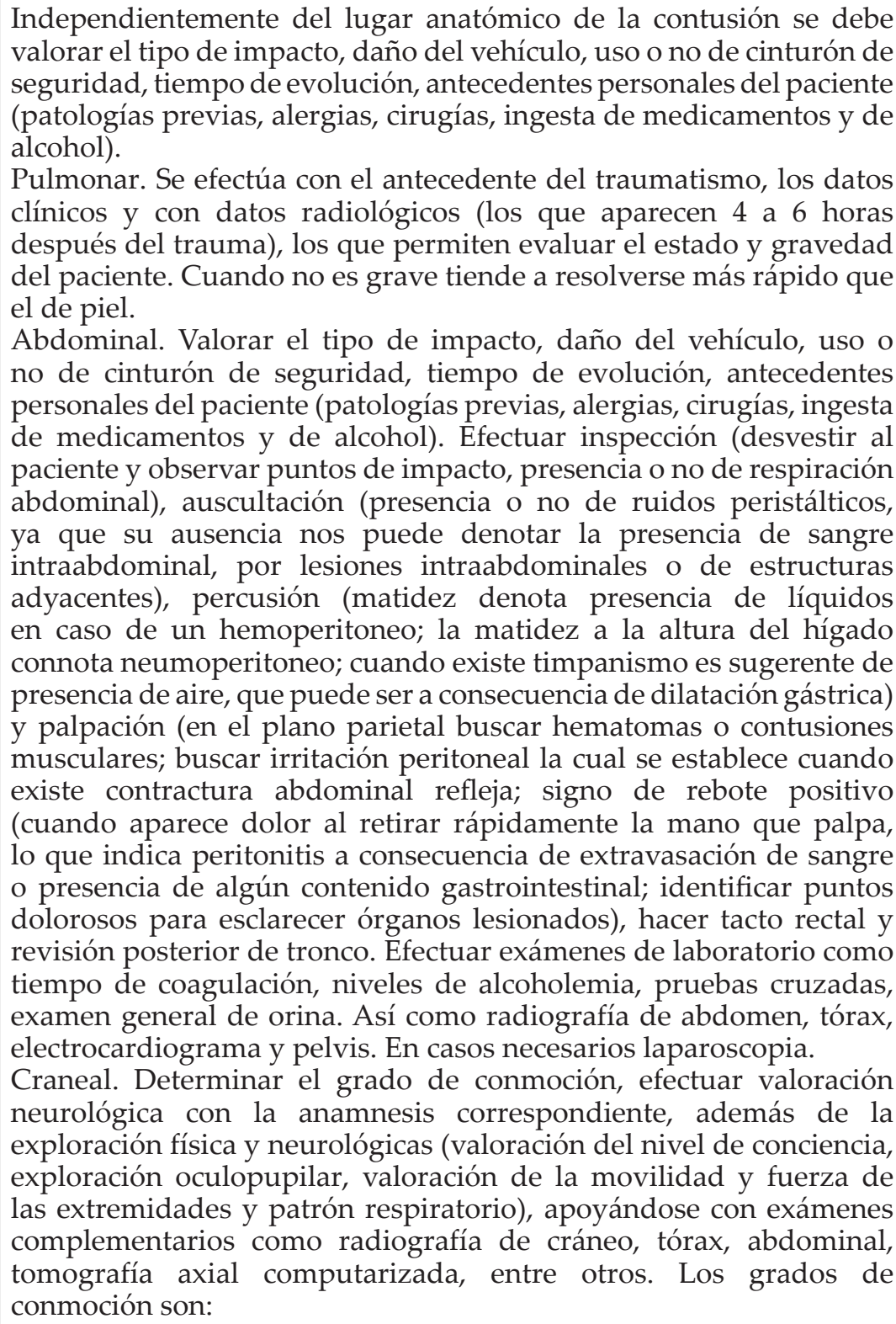 \\
\hline
\end{tabular}




\section{Accidentes y lesiones}

Cuadro 4. Diagnóstico de las lesiones producidas por accidentes (continuación).

\begin{tabular}{|c|c|}
\hline Tipo de lesión & Diagnóstico \\
\hline Contusión & $\begin{array}{l}1^{\text {o }} \text { No existe pérdida del conocimiento, pueden existir datos clínicos } \\
\text { durante } 30 \text { minutos. Son consideradas leves. } \\
2^{\circ} \text {. Existe pérdida del conocimiento con duración menor de un } \\
\text { minuto, con signos que duran más de un minuto. Consideradas } \\
\text { moderadas. } \\
3^{\circ} \text {. Tienen pérdida de la memoria que dura más de } 1 \text { minuto, o con } \\
\text { amnesia postraumática con duración de } 24 \text { horas. Los datos clínicos } \\
\text { de éste grado duran más de } 7 \text { días. Es considerada grave }{ }^{36,37,44,48} \text {. }\end{array}$ \\
\hline $\begin{array}{l}\text { Síndrome de } \\
\text { latigazo }\end{array}$ & $\begin{array}{l}\text { Además de los datos clínicos que incluyen Dolor en la región } \\
\text { del cuello, cefalea, pueden existir alteraciones visuales, vértigo, } \\
\text { alteraciones de memoria y concentración, parestesias en manos, } \\
\text { puede haber debilidad y pesadez o fatiga de las extremidades } \\
\text { superiores, se deben efectuar exploración física (palpando las } \\
\text { estructuras y puntos dolorosos, balance articular de la columna } \\
\text { cervical, examen neurológico, (incluye sensibilidad, fuerza y reflejos } \\
\text { osteotendinosos), así como estudios radiológicos, para descartar otro } \\
\text { tipo de lesiones }{ }^{22,47} \text {. }\end{array}$ \\
\hline Quemadura & $\begin{array}{l}\text { Para establecer el diagnóstico se debe determinar la extensión y la } \\
\text { profundidad de las mismas, además de decidir si son quemaduras } \\
\text { menores o mayores. } \\
\text { Menores. Incluyen las de primer grado en cualquier parte de la } \\
\text { economía; o en su defecto de segundo grado con extensión menor de } \\
5 \text { a } 7 \text { centímetros de ancho. } \\
\text { Mayores. Se encuentran las de tercer grado; o de segundo con más } \\
\text { de } 5 \text { a } 7 \text { centímetros de ancho; o de segundo que se encuentren } \\
\text { localizadas en la cara, manos, ingle, nalgas o sobre articulaciones } \\
\text { importantes. } \\
\text { Además, se debe establecer la superficie corporal quemada, por } \\
\text { medio del esquema de Kirschbaum o regla de los } 3: \text { Cabeza } 9 \% \text { (cuero } \\
\text { cabelludo } 3 \% \text {, cara } 6 \% \text { y Cuello } 1 \% \text { ), tronco anterior } 18 \% \text { (tórax } 9 \% \\
\text { y abdomen } 9 \% \text { ), tronco posterior } 18 \% \text { (dorso } 9 \% \text { y lumboglúteo } \\
9 \% \text { ), miembro superior } 9 \% \text { (brazo } 3 \% \text {, antebrazo } 3 \% \text { y mano } 3 \% \text { y y } \\
\text { miembro inferior } 18 \% \text { (muslo } 9 \%, \text { pierna } 6 \% \text { y pie } 3 \% \text { ). Con el que se } \\
\text { clasifica al paciente de acuerdo al porcentaje de la superficie corporal } \\
\text { quemada, que presenta el paciente, en quemado: } \\
\text { Leve: Quemaduras de hasta el } 9 \% \text {. } \\
\text { Moderado: Quemaduras hasta el } 18 \% \text { de la superficie corporal. } \\
\text { Grave: Quemaduras mayores del } 18 \% \text { hasta un } 50 \% \text { de superficie } \\
\text { corporal. } \\
\text { Crítico: Quemaduras mayores del } 50 \% \text { de la superficie corporal }{ }^{49} \text {. }\end{array}$ \\
\hline
\end{tabular}




\section{Principales problemas de Salud Pública en México}

\section{Terapéutica}

La terapéutica puede ser intrahospitalaria o deambulatoria, dependiendo de la gravedad y/o tipo de lesión o lesiones y tamaño de las mismas, que comprometen al paciente. Y después de efectuar la valoración lesional, se pueden realizar compresión de la zona afectada, crioterapia (frío), calor local, vendaje compresivo, elevación del miembro afectado, limitación de movimiento, inmovilización, reducción, debridación, curación de heridas; tratamiento medicamentoso para el dolor y procesos infecciosos, así como manejo quirúrgico en casos necesarios. Cabe mencionar que el tratamiento, también incluye la rehabilitación del paciente basados en movimientos, uso de esteroides, ultrasonido, ondas de choque, acupuntura. Además se debe incluir, en casos necesarios, la aplicación de vacunas para la prevención de tétanos (Cuadro 5) $)^{29,38}$.

Cuadro 5. Tratamiento de las lesiones producidas por accidentes.

\begin{tabular}{|l|l|}
\hline Tipo de lesión & \multicolumn{1}{c|}{ Datos clínicos } \\
\hline Fractura & $\begin{array}{l}\text { Reducción (alineación anatómica del hueso), mantenimiento de la } \\
\text { reducción (inmovilización y contención) y rehabilitación }\end{array}$ \\
\hline Luxación & $\begin{array}{l}\text { Incluye el no quirúrgico (reducción) la cual generalmente se confirma } \\
\text { con un chasquido audible, una posición y longitud normal de la } \\
\text { extremidad y la recuperación de los arcos de movimientos, hay que } \\
\text { confirmar el éxito logrado con una radiografía; incluye el uso de } \\
\text { analgésicos, evitando en lo sucesivo movimientos riesgosos. Quirúrgico } \\
\text { para colocar prótesis }{ }^{50}\end{array}$ \\
\hline Esguince & $\begin{array}{l}\text { Va encaminado a reducir el edema y el dolor, con el afán de lograr } \\
\text { la movilización. Reposo, crioterapia, vendaje elástico, elevación de la } \\
\text { extremidad, antiinflamatorios y analgésicos. Revisión del paciente a los } \\
\text { tres días para valorar evolución }{ }^{27} .\end{array}$ \\
\hline Heridas & $\begin{array}{l}\text { Controlar la hemorragia, limpieza de la herida con suero salino } \\
\text { fisiológico (curación), en caso necesario efectuar sutura (no en casos de } \\
\text { heridas potencialmente tetanígenas, ni aquellas producto de animales } \\
\text { con posibilidad de rabia) colocar un apósito estéril, elevar e inmovilizar } \\
\text { la zona afectada, iniciar antibioterapia (en heridas con más de tres } \\
\text { horas, heridas contaminadas con heces o saliva, y aquellas con signos } \\
\text { de infección o por enfermedades previas del paciente como diabetes o } \\
\text { inmunosupresión) }\end{array}$ \\
\hline $\begin{array}{l}\text { Síndrome de } \\
\text { latigazo }\end{array}$ & \begin{tabular}{l} 
Reposo, inmovilización con collar o fisioterapia y analgésicos ${ }^{22}$. \\
\hline
\end{tabular} \\
\hline
\end{tabular}




\section{Accidentes y lesiones}

Cuadro 5. Tratamiento de las lesiones producidas por accidentes (continuación).

\begin{tabular}{|l|l|}
\hline Tipo de lesión & \multicolumn{1}{|c|}{ Datos clínicos } \\
\hline Contusión & $\begin{array}{l}\text { Pulmonar: La mayoría de las veces solo requieren monitoreo; cuando } \\
\text { existe un compromiso respiratorio moderado a severo y se presenta } \\
\text { insuficiencia respiratoria, es necesario dar ventilación mecánica. } \\
\text { Medir el intercambio gaseoso a través de gasometría en sangre } \\
\text { arterial. Administrar y controlar líquidos y electrolitos. En caso de } \\
\text { complicaciones, tratarlas tempranamente. }\end{array}$ \\
$\begin{array}{l}\text { Abdominal: Mantener la tensión arterial sistémica, control de } \\
\text { hemorragia, restablecimiento de la hemodinámica, en caso necesario } \\
\text { efectuar laparoscopia, ecografía abdominal y cirugía para la reparación } \\
\text { de daños encontrados. }\end{array}$ \\
\hline $\begin{array}{l}\text { Cerebral: Reposo y tratamiento sintomático } \\
\text { Cuemadura }\end{array}$ \\
$\begin{array}{l}\text { Eliminar la ropa y cualquier material caliente, poner suero fisiológico a } \\
\text { chorro a temperatura de 12o C (agua templada) y cubrir con un lienzo } \\
\text { estéril. Valorar función respiratoria. Determinar si se requiere o no } \\
\text { tratamiento hospitalario. Los pacientes con más del 15\% al 20\% de la } \\
\text { superficie corporal dañada por quemaduras, requiere de soluciones } \\
\text { intravenosas. Las quemaduras graves, las pequeñas de grosor parcial } \\
\text { profundas y las que se encuentran localizadas en cara, ojos, oídos o } \\
\text { cuello, o en otras zonas de función crítica como manos, codos, fosas } \\
\text { poplíteas o pies, necesitan la valoración de un experto. No requieren } \\
\text { hospitalización las quemaduras menores. }\end{array}$ \\
$\begin{array}{l}\text { El tratamiento de las quemaduras menores incluye la curación de } \\
\text { las mismas; y quimioprofilaxis tópica para evitar infecciones, con } \\
\text { sulfadazina de plata o nitrofurazona o rifampicina o gentamicina } \\
\text { (excepto en las de primer grado). El personal de salud deberá vigilar el } \\
\text { proceso de recuperación del paciente, con el afán de identificar vendajes } \\
\text { apretados o presencia de infección }{ }^{51,52} \text {. }\end{array}$ \\
\hline
\end{tabular}

\section{Medidas de prevención}

Son múltiples, entre ellas están las encaminadas a la reducción a la exposición de riesgos (tratados en la causalidad) y mejoría de las condiciones ambientales que rodean a los individuos, llámese en la escuela, trabajo, la calle o en el hogar. Y en cuanto a las personas, 


\section{Principales problemas de Salud Pública en México}

que pueden sufrir accidentes y lesiones, promover la capacitación de las madres y padres, conductores, peatones y de los trabajadores, para el uso adecuado de maquinaria e instrumentos, utilización de equipo de seguridad, respeto a las leyes y reglamentos, así como crear en ellos la cultura de la prevención.

Es por ello que la Organización Mundial de la Salud ha propuesto que exista planificación y diseño de vías públicas para mejorar la seguridad; acciones de corrección en lugares en donde existe alto riesgo de choques; ofertar vehículos de motor con características que permitan mejorar la resistencia al impacto, que permitan tener mayor visibilidad, además de que exista mantenimiento de los vehículos; establecimiento de normas de seguridad en las calles y carreteras; hacer que se cumplan los límites de velocidad (la supervivencia de los peatones y ciclistas es mayor cuando la velocidad de la colisión es menor a 30 $\mathrm{Km} / \mathrm{h}$ ); respetar el reglamento de tránsito; evitar la ingesta de alcohol, fármacos y drogas, cuando se maneja; no manejar cuando el conductor posea fatiga; utilización obligatoria del cinturón de seguridad y sillas infantiles; uso obligatorio de casco en bicicletas y motocicletas; uso de dispositivos de protección; prohibir el uso de teléfono celular cuando se maneja; educación vial.

En cuanto a la prevención de los accidentes en el hogar y del trabajo, es necesario tratar de mejorar las condiciones de la vivienda y del espacio donde se labora, drenando las acumulaciones innecesarias de agua en los baños o estanques, poner cisternas con tapa, mejorar las escaleras, las instalaciones eléctricas y tener iluminación adecuada, entre otros.

Dentro de las medidas para evitar daños a consecuencia de los accidentes, es muy importante efectuar investigación sobre las causas, consecuencias y prevención de los mismos. Y sobre todo lo más significativo es la cultura de la prevención ${ }^{53}$.

\section{Referencias}

1. Organización Panamericana de la Salud. Clasificación Estadística Internacional de Enfermedades y Problemas Relacionados con la Salud, décima revisión. 10a ed. Washington, DC: OPS; 1995.

2. Secretaría de Salud. Programa de acción específico: accidentes. México: Dirección General del Centro Nacional para la prevención de accidentes; 2002. 


\section{Accidentes y lesiones}

3. Lozano RG, Garrido LF, Jiménez CA, Campuzano RJ, Franco F. La carga de enfermedad, lesiones, factores de riesgo y desafíos para el Sistema de Salud en México. Salud Púb Méx. 2013; 55(6):580-94.

4. Hijar MM. Los accidentes como problema de Salud Pública en México. Retos y oportunidades. ANM/CONACYT; 2004.

5. Merson MH, Black RE, Mills A. International public health: diseases, programs, systems, and policies. 2nd ed. Sudbury, Mass.: Jones and Bartlett; 2006.

6. World Health Organization. Health statistics and information systems. Global summary estimates 2000-2015. Department of Information, Evidence and Research WHO, Genova 2017. Disponible en: http://www.who.int/healthinfo/global_burden_ disease/GlobalDALYmethods_2000_2015.pdf?ua=1

7. Secretaría de Salud. Programa de acción específico 2007-2012. Seguridad Vial. México: Subsecretaría de Prevención y Promoción de la Salud; 2008.

8. Secretaría de Salud. Norma Técnica No. 54, para la prevención, atención y control de daños a la salud en casos de accidente. Publicada en el Diario Oficial de la Federación el 20 de agosto de 1984.

9. Secretaría de Salud. Programa de acción específico. Seguridad vial 2013-2018. México: Subsecretaría de Prevención y Promoción de la Salud, 2014.

10. INSP/SS. Encuesta Nacional de Salud y nutrición. Resultados Nacionales 2012. México: INSP/SS; 2014.

11. Secretaría de Salud. Programa de acción específico. Prevención de accidentes en grupos vulnerables 2013-2018. México: Secretaría de Salud; 2014.

12. INEGI. Estadísticas a propósito del día mundial para la prevención del suicidio (10 de septiembre 2015). Disponible en: http://www.inegi.org.mx/saladeprensa/ aproposito/2015/suicidio0.pdf).

13. Organización Mundial de la Salud. Suicidio. Nota descriptiva abril 2016. Disponible en: http://www.who.int/mediacentre/factsheets/fs398/es/

14. Manrique EB, Salinas RA, Moreno TK, Téllez RM. Prevalencia de dependencia funcional y su asociación con caídas en una muestra de adultos mayores pobres en México. Salud Pública Méx. 2011; 53(1):26-33.

15. INEGI. Encuesta nacional de ingresos y gastos de los hogares. México: INEGI; 2012. 


\section{Principales problemas de Salud Pública en México}

16. Organización Mundial de la Salud. Informe mundial sobre prevención de las lesiones en los niños. Washington: OPS; 2012.

17. Organización Panamericana de la Salud. Prevención de Accidentes y lesiones. No. 29, Serie PALTEX para ejecutores de Programas de Salud. Washington: OPS; 1993.

18. Foundation for the automobile and society (FIA). Cinturones de seguridad y sistemas de retención infantil: un manual de seguridad vial para decisores. Londres: FIA; 2009.

19. Centro Nacional para la Prevención de Accidentes (2012 del 4 al 10 de noviembre). Día mundial de accidentes viales 18 de noviembre. México, Boletín Epidemiológico del Sistema Nacional de Vigilancia Epidemiológica de la Secretaría de Salud. 2013; 45 (29):1-5. Disponible en: http://www.epidemiologia.salud.gob.mx/doctos/boletin/2013/ sem45.pdf.

20. Organización Mundial de la Salud. Lesiones causadas por el tránsito. Nota descriptiva mayo 2017. Disponible en: http://www.who.int/mediacentre/factsheets/ fs358/es/

21. Moctezuma PL, Páez FI, Jiménez GS, Miguel JK, Foncerrada OG, Sánchez FA, et al. Epidemiología de las quemaduras en México. Rev Esp Méd Quir. 2015; 20:78-82.

22. Combalia AA, Suso V, Segur VJ, García RS, Alemany GF. Síndrome de latigazo cervical. Med Integr. 2001; 38:95-102. Disponible en: http://www.elsevier.es/es-revistamedicina-integral-63-articulo-sindrome-del-latigazo-cervical-13016397.

23. Kumar V, Abbas A, Aster J. Robbins y Cotran. Patología estructural y funcional. Amsterdam: Elsevier; 2015.

24. Brunicardi F, Schwartz S. Principios de cirugía. México: McGraw-Hill; 2011.

25. Baoge L, Van Den Steen E, Rimbaut S, Philips N, Witvrouw E, Almqvist K, et al. Treatment of skeletal muscle injury: a review. ISRN Orthop. 2012.

26. Margheritini F, Rossi R. Orthopedic sports medicine. Milan: Springer; 2011.

27. Pérez RJ, Hernández EE, Mazadiego GM, Mora OR, Rangel VY, De la Torre SR, et al. Guía clínica para la atención del paciente con esguince de tobillo. Rev Med IMSS. 2004; 42(5):437-444.

28. Cárdenas Sandoval RP, Garzón Alvarado DA, Peinado Cortés LM. Mecanobiología de reparación del ligamento. Rev Cubana Invest Bioméd [Internet]. 2010 Mar 


\section{Accidentes y lesiones}

[citado 2017 Jul 03]; 29(1). Disponible en: http://scielo.sld.cu/scielo.php?script=sci_ arttext\&pid=S0864-03002010000100009\&lng=es

29. Santonja MF, Martínez Gonzalez-Moro I, Ferrer López V. Cap. 19. Esguince de tobillo y deporte en Ejercicio Físico. En: Arribas JM (Ed.). Manual de cirugía menor y otros procedimientos en la consulta del médico de familia. Madrid: Jarpyo Editores; 1993, p. 203-219. Disponible en: http://www.santonjatrauma.es/wp-content/uploads/2014/11/ Esguince-de-tobillo-y-deporte.-Libro-V-Ferrer.compressed-1.pdf

30. Kapandji AI. Fisiología articular. México: Editorial Médica Panamericana; 2007.

31. Universidad Complutense de Madrid. Tema 5. Traumatismos articulares. [Internet]. 2014 [cited 17 October 2016]. Disponible en: https://www.ucm.es/data/cont/docs/4202014-03-20-05\%20Traumatismos\%20articulares.pdf

32. Einhorn T, Gerstenfeld L. Fracture healing: mechanisms and interventions. Nature Reviews Rheumatology. 2014; 11(1):45-54.

33. Rowan MP. Burn wound healing and treatment: review and advancements. Critical Care. 2015; 19:243.

34. Guillory. Cardiovascular dysfunction following burn injury: what we have to learned from rat and mouse models. Int J Mol. 2016, 17:53.

35. Fortune HJ, Paulos AJ, Liendo PC. Patología ortopédica. En: Ortopedia y traumatología. Escuela de Medicina. Universidad Católica de Chile. 1995. Recuperado de: http:// dspace.utalca.cl/bitstream/1950/10295/1/Manual\%20de\%20Ortopedia\%20y\%20 Traumatologia\%20PUC.pdf.

36. Ruiz del Pino J, Hazañas RS, Conde MM, Enríquez AE, Jiménez-Peña M. Fracturas, conceptos generales y tratamiento. Disponible en: http://www.medynet.com/usuarios/ jraguilar/Manual\%20de\%20urgencias\%20y\%20Emergencias/fractgen.pdf.

37. Sulca JS. Correlación de la perfusión cerebral por tomografía computada con el estado clínico en los pacientes que presentan accidente cerebrovascular isquémico- Hospital Central Pnp "Luis N. Sáens", julio-diciembre de 2015. [Tesis de la licenciatura en Tecnología Médica], Área de Radiología. Universidad Nacional Mayor de san Marcos, Lima Perú, 2016. http://neurocirugiaendovascular.com/pdf2/TCE\%20Glasgow,\%20 conmocion $\% 20 \mathrm{y} \% 20$ fractura.pdf. 


\section{Principales problemas de Salud Pública en México}

38. Consejo de Salubridad General. Guía de práctica clínica. Diagnóstico y tratamiento de las lesiones traumáticas del codo en el adulto. Evidencias y recomendaciones, Secretaría de Salud, Catálogo maestro de guías de Práctica Clínica, IMSS-198-08. México: SSA; 2010.

39. Garnica MM, Caballero ZC, Garnica ME, Bello GA, Vives AH, Rosas CJ. Amputación como tratamiento de complicaciones de la luxación traumática de rodilla. Presentación de un caso. Acta Ortopédica Mexicana. 2008; 22(3):198-203.

40. Úbeda PI, Sobrá HG. Esguince de tobillo de primer grado como causa de paresia del nervio peroneo común. Caso clínico. Rev Andal Med Deporte. 2015; 8: 86-91. Disponible en: http://www.mgyfsemg.org/medicinageneral/abril2000/379-384.pdf.

41. McClune T, Burton AK, Waddell G. Whiplash associated disoirders: a review of the literatura to guide patient information and advice. Emerg Med J. 2002; 19:499-506.

42. González VM, García GA. Traumatismo craneoencefálico. Anestesiología en neurocirugía. Abril-Junio 2013; 36(Supl. 1):186-193.

43. Ochoa PM, Martínez LJ, Palacios QM. Contusión pulmonar. Rev Ecuatoriana de Med Crítica. (3)1:1-5. Recuperado desde http://www.medicosecuador.com/medicina_ critica/rev_vol3_num1/contusion_pulmonara.html.

44. Jover NJ, Ramos RJ, Moreno AM. Complicaciones de los traumatismos abdominales. Cir Esp. 2001; 69:318-23.

45. De los Santos C. Complicaciones de las quemaduras, en Guía básica para el tratamiento del paciente quemado. Capítulo 13 [consultado 18/07/17]. Disponible en: http://www. indexer.net/quemados/complicaciones_de_las_quemaduras.htm.

46. Baños AV. Diagnóstico, tratamiento y pronóstico del síndrome de latigazo cervical. Rev Fisioter 2009; 8(1):5-28.

47. Martínez EG. El traumatismo craneoencefálico (TCE) en urgencias. Valoración neurológica. Recepción y traslado a UCI. Enferm Intensiva 1998; 9:9005-9012.

48. Frías ME. Quemaduras. Diagnóstico y tratamiento en las primeras 72 horas. Rev. Cubana Cir. 2006; 45(2): [2 pantallas]. Disponible en: http://bvs.sld.cu/revistas/cir/ vol45_2_06/cir12206.htm.

49. Dabaghi A, Saleme J, Ochoa L. Evaluación y tratamiento de la luxación protésica de cadera. Acta Ortopédica Mexicana. 2014; 28(2):137-144. Recuperado desde http://www. 


\section{Accidentes y lesiones}

medigraphic.com/pdfs/ortope/or-2014/or1421.pdf.

50. Rangel GH. Infección en quemaduras. Cir Plast. 2005; 15(2):111-117. Recuperado de: http://www.medigraphic.com/pdfs/cplast/cp-2005/cp052h.pdf.

51. La Enciclopedia Médica. Quemaduras: tratamiento, causas, síntomas, diagnóstico y prevención 2013. Disponible en: http://sintomastratamiento.com/dolor-enfermedadtrastorno/quemaduras-tratamiento-causas-sintomas-diagnostico-y-prevencion/

52. Organización Mundial de la Salud. Informe mundial sobre prevención de los traumatismos causados por el tránsito. Suiza Ginebra: OMS; 2004. 



\section{Escabiosis}

\section{C. María del Carmen Aguilar Espíndola}

\section{Introducción}

La escabiosis es una enfermedad fácilmente transmisible y de alta frecuencia, con una incidencia aproximada de 300 millones por año en todo el mundo, sin embargo, es más común en regiones pobres y con hacinamiento, alcanzando proporciones pandémicas y constituye un problema de Salud Pública. En México esta ectoparasitosis no es de notificación obligatoria por lo que se desconoce su frecuencia real, el diagnóstico es relativamente fácil con las características clínicas y sus métodos diagnósticos son económicos. El tratamiento es sencillo, económico y de fácil acceso, como son las medidas de higiene personal y el uso de medicamentos. Por lo que es importante que el médico detecte los factores de riesgo y establezca el diagnóstico oportuno para limitar la progresión de la enfermedad ${ }^{1,2,3,4}$.

\section{Concepto}

Es una parasitosis exclusivamente cutánea y muy pruriginosa producida por Sarcoptes scabiei de la variedad hominis.

Los sinónimos con los que se conoce ésta enfermedad son: sarna, roña y rosquiña, debido al intenso prurito que provoca ${ }^{1,2,3,4}$.

\section{Clasificación}

La escabiosis podemos clasificarla en:

- Escabiosis de lactantes, niños, adultos y ancianos.

- Personas limpias.

- Escabiosis nodular e incógnita.

- Sarna noruega.

- Transmitida por animales. ${ }^{1}$ 


\section{Principales problemas de Salud Pública en México}

\section{Epidemiología}

Es una de las dermatosis más frecuentes producidas por parásitos animales. Su distribución es mundial, sin embargo es endémica en países en desarrollo, debido a que la pobreza y el hacinamiento son factores de riesgo. Se presenta cíclicamente en todo el mundo, originando epidemias, apareciendo cada 10 a 12 o 20 años. En 1960 la incidencia en Europa y América del Norte comenzó a aumentar, y en 1980 alcanzó niveles cercanos a la pandemia. Desde entonces su incidencia ha disminuido pero sigue siendo muy común. Aproximadamente 300 millones de personas pueden verse afectadas en el mundo.

En México la tendencia es descendente, según reportes de la división de epidemiología de la Secretaría de Salud. En el año 2000 se notificaron 87,155 casos y para el año 2009 se registraron 59,542, con una incidencia de 55 casos nuevos por 100,000 habitantes, los Estados más afectados se encuentran en el sur del país, con la mayor incidencia en Tabasco, 300 casos por 100,000 habitantes, Campeche, Quintana Roo, Chiapas y Oaxaca. Por institución la Secretaría de Salud concentra el 46.9\%, el IMSS régimen ordinario $30.9 \%$, el IMSS oportunidades el 13.8\%, el ISSSTE, DIF, PEMEX, SEDENA, SEMAR y otras instituciones $8.4 \%$. Del total nacional las mujeres representan $57 \%$ de los casos y el grupo etario más afectado fue el de menores de 5 años. La morbilidad por escabiosis varía entre 6 y $27 \%$ de la población general.

Es más frecuente en las áreas urbanas, predomina en mujeres y niños de cualquier edad, grupo étnico y estrato socioeconómico.

Es más frecuente en el otoño e invierno que en el verano, esto se explica de manera probable porque las personas se aglomeran y hay mayor sobrevida de los ácaros en los fómites en temperaturas más frías $3,5,6,7$.

\section{Causalidad}

El Sarcoptes scabiei variedad hominis, es el agente causal. Sarcoptes es un vocablo griego que significa cortar, mientras que la palabra escabiosis derivada del latín, significa rascar. Fue identificado como agente etiológico de esta parasitosis por Hillier y Renucci a mediados del siglo XIX. Pertenece a Phyllium Arthropoda, clase Arachnida, subclase acarina, orden Astigmatica, familia Sarcoptidae. 


\section{Escabiosis}

Es de color marrón blanquecino, de ocho patas cortas y robustas, y espículas en el dorso, de forma muy similar a una tortuga (forma hemiesférica), carecen de ojos. La hembra que es la que produce las manifestaciones clínicas, mide aproximadamente 0.4 por $0.3 \mathrm{~mm}$. El macho mide $0.20 \mathrm{~mm}$ de largo, por lo general el macho se mantiene en la piel junto con las ninfas. En ambiente frío con alta humedad, sobreviven más tiempo. La hembra puede sobrevivir fuera del hospedero durante 2 a 3 días a temperatura ambiente y tiene una longevidad de 4 a 6 semanas, los huevecillos viven por lo menos 10 días. Se calcula que para llevarse a cabo una infestación son necesarias 10 a 15 ácaros hembras. En condiciones similares los ácaros hembras, sobreviven más tiempo que los machos, ya que estos mueren después de fertilizar a la hembra. Cuando la hembra es fertilizada, rápidamente excava un túnel en la epidermis a nivel del estrato granuloso, ayudada por sus patas y su aparato bucal que posee quelícero (piezas bucales utilizadas para morder), conforme avanza en la formación de los túneles defeca y deposita 2 a 3 huevecillos diarios. Los huevecillos eclosionan en los túneles y la eclosión de las larvas se produce en tres o cuatro días y continúa el ciclo. Después pasa por la etapa de ninfa y adulto en 14 días, empiezan a perforar nuevas galerías conforme se desarrollan. Posteriormente de 72 a 84 horas, las larvas alcanzan la superficie de la piel, convirtiéndose en adultos después de varias mudas y apareándose a los 10 a 17 días. Se extiende aproximadamente 2 a $5 \mathrm{~mm}$ cada día, para formar el túnel. Al final del mismo existe una vesícula o una pápula de 2 a $3 \mathrm{~mm}$ de diámetro donde está el parásito. Pone de dos a tres huevos a la vez, hasta un total de 10 a 25, algunos autores mencionan hasta 40 o 50 huevos. Después de uno a dos meses muere.

El período de incubación dependerá del estadio del parásito, siendo en promedio de dos días para el adulto, y de dos a seis semanas, para la larva. Las personas que ya han estado infestadas manifiestan síntomas de uno a cuatro días después de la exposición. Existe cierta resistencia en las personas previamente infectadas, menos ácaros logran establecerse en comparación con quienes no han sufrido exposición previa, en tanto que las personas inmunológicamente deficientes son susceptibles a la superinfestación.

Se transmite por contacto directo o fómites, especialmente ropa, donde el parásito vive de 2 a 5 días. La transmisión es de persona a persona por contacto directo. La transmisión de padres a hijos y sobre todo de madre a hijo es lo común. En los adultos jóvenes el modo de transmisión más común es la sexual. Aunque es poco común se han reportado casos en los que el parásito se contagia por el uso o manejo de ropa muy contaminada o por dormir en una cama recientemente ocupada por una persona parasitada. La transmisión por prendas 


\section{Principales problemas de Salud Pública en México}

de vestir o ropa de cama es más común con grandes cargas de parásitos lo cual ocurre en la escabiosis costrosa, o en ancianos que viven en asilos, que son infectados por miles de parásitos ${ }^{1,2,3,4,8,9}$.

Factores de riesgo.

- Edad. Es más frecuente en población menor de 15 años, por lo que los grupos etarios más afectados, son los menores de 1 año y los de 1 a 4 años con incidencias de 176.2 y 132.5 por cada 100 mil habitantes. Aunque también son afectados los ancianos que permanecen en instituciones como asilos y los adultos jóvenes por contacto sexual.

- Pacientes inmunocomprometidos.

- Sexo. Afecta más a mujeres con un porcentaje de $57 \%$, que a hombres con un porcentaje del $43 \%$.

- Ocupación. El personal de salud del primer nivel de atención presenta un riesgo elevado de infestación. Se presenta en sitios de concentración como guarderías, asilos y orfanatos.

- Lugar de residencia. Se observa más en áreas urbanas y regiones de clima tropical.

- Deficiencia de higiene personal y de la vivienda ${ }^{1,2,3,7,8,9,10}$.

\section{Fisiopatología}

El parásito hace túneles mediante la secreción de enzimas proteolíticas que causan daño a nivel de los queratinocitos.

El prurito intenso, de predominionocturno es resultado de una reacción dehipersensibilidad. Los infiltrados de linfocitos orientan a una reacción de hipersensibilidad retardada tipo IV y el aumento de IgE, hacia la hipersensibilidad inmediata o de tipo I, a sus huevecillos, a sus heces o ácaros muertos. Esto evita la multiplicación de los parásitos, pero no los elimina. Se ha encontrado también activación de mastocitos, estimulados por alguna estructura antigénica, como son los ácaros, heces o huevecillos. La respuesta inmunitaria es compleja, por la dificultad que implica estudiar a los ácaros vivos para estudios in 


\section{Escabiosis}

vitro y los bajos niveles de infestación de pacientes con escabiosis clásica. Las células epidérmicas y dérmicas que se encuentran alrededor del ácaro son las primeras en entrar en contacto con los productos del mismo. Por ello se considera que los queratinocitos, las células de Langerhans, los fibroblastos cutáneos, las células endoteliales, los monocitos y los linfocitos interactúan con el ácaro y sus productos. Entre las sustancias liberadas por los ácaros vivos están las secreciones salivales, los materiales fecales y de excreción y las sustancias asociadas con la metamorfosis y el proceso de muda.

La forma nodular es una reacción de hipersensibilidad a los antígenos, y las lesiones no son contagiosas. En pacientes con VIH, las lesiones con atípicas, exageradas o costrosas y dependen del recuento bajo de linfocitos.

En los casos de sarna noruega, por un defecto inmunitario del huésped, se encuentran miles de ácaros, así como cifras reducidas de IgA y altas de IgE.

La difusión del parásito a diferentes zonas del cuerpo se produce cuando al rascarse el individuo afectado, transfiere los ácaros de un lugar a otro. De forma experimental la reinfección solo se logra en el $40 \%$ de los pacientes lo cual orienta hacia la inmunidad humoral. Algunos estudios revelan aumento de niveles de $\operatorname{IgA}$ e $\operatorname{IgM}$ y disminución de las IgG, las cuales regresan a niveles normales después del tratamiento correcto ${ }^{1,2,3,4,8,11,12,13,14,15}$.

\section{Cuadro clínico}

Los síntomas empiezan tres a seis semanas después de la infestación primaria, sin embargo en pacientes que han sufrido la escabiosis con anterioridad, los síntomas por lo general comienzan entre uno y tres días después de la reinfestación, presumiblemente por la previa sensibilización del sistema inmunológico.

Topografía de las lesiones. En lactantes y niños es generalizada y simétrica, predominando en la piel cabelluda, palmas, plantas y entrantes; en los adultos las lesiones son diseminadas y simétricas, se presentan entre las líneas de Hebra (dos líneas imaginarias, una que pasa por los hombros y otra por las rodillas), predominando en cara anterior de muñecas (superficies flexoras), borde interno de las manos (eminencias tenar e hipotenar), pliegues interdigitales de las manos, cara interna de antebrazos, superficies extensoras de los codos, axilas, región periumbilical y nalgas sobre todo alrededor de los pliegues subglúteos e 


\section{Principales problemas de Salud Pública en México}

interglúteos. En el hombre se localiza también en abdomen, escroto y pene; y en la mujer en pliegues submamarios, areola y pezón. En general la topografía de las lesiones respeta cabeza, cuello y pies, aunque en formas atípicas se pueden encontrar en niños y ancianos en piel cabelluda, palmas y plantas.

Morfología de las lesiones. Raras veces se pueden presentar pequeñas ronchas, ampollas o pústulas; el túnel que labra el parásito es muy difícil de ver; y en su extremidad existe una vesícula aperlada conocida con el nombre de eminencia de Bazin. De manera habitual, las lesiones tienen el aspecto polimorfo, en lactantes se puede acompañar de eccema, en el abdomen con pápulas y costras abundantes, lo que le da el aspecto de "cielo estrellado"; y en el adulto se caracteriza por pápulas pequeñas y eritematosas (pápulas acarinas), excoriadas, vesículas, costras hemáticas y liquenificación.

Síntomas acompañantes. El prurito suele ser intenso, de predominio nocturno; inicialmente es localizado y después se generaliza; en reinfección el prurito aparece de inmediato, no así en los casos de primera vez, que tarda en aparecer de 2 a 6 semanas, después de la infección; en el caso de lactantes menores de 2 o 3 meses, el prurito puede estar ausente.

Evolución. La evolución de la enfermedad puede ser sub-aguda o crónica (cuando dura el cuadro clínico más de quince días).

Existen variantes del cuadro clínico, entre ellos se encuentran la sarna de los limpios y las formas atípicas.

Sarna de los limpios. Como su nombre lo indica, lo característico es que se presenta en personas aseadas, encontrándose solamente algunas pápulas y costras hemáticas en axilas, pliegues interdigitales y en el escroto, el prurito es escaso, lo cual dificulta el diagnóstico; aunque pueden aparecer ronchas o dermografismo.

Formas atípicas o variantes clínicas:

- Escabiosis noruega o costrosa.

- Escabiosis nodular.

- Escabiosis inmunológica. 


\section{Escabiosis}

Sarna noruega (costrosa). Es una variedad de escabiosis descrita en Noruega en 1848 pacientes que presentaban lepra, aunque actualmente también se asocia con otras afecciones como el linfoma, diabetes con neuropatía, afecciones mentales con discapacidad, el síndrome de Down, individuos bajo tratamiento con inmunosupresores (metotrexato, lacrolimus o ciclosporina) y otras enfermedades que comprometen la inmunidad celular; es indicativa de infección por el virus linfotrópico humano de células T tipo 1 (HTLV1), sobre todo en zonas endémicas como el Perú; hasta el 58\% de los pacientes presentan hipereosinofilia, detectándose hiper IgE en el 96\% de esa población. Dado que el $40 \%$ de los casos de escabiosis costrosa carecen de un factor predisponente, se ha sugerido que existe predisposición genética; sin embargo se puede presentar en ancianos. Afortunadamente esta variante clínica no es común, pero al presentarse en personas inmunodeprimidas hay una reproducción masiva del parásito, por lo que la persona infestada presenta de miles a millones de parásitos, y es altamente contagiosa. En relación a la topografía no respetan las líneas de Hebra, tendiendo a ser generalizada, en cuanto a la morfología predominan las placas eritematosas mal definidas que desarrollan de manera muy rápida escamas, las escamas y verrugas se presentan sobre todo en las salientes óseas, aparecen costras y fisuras, sus lesiones son malolientes, las costras y escamas están llenas de ácaros, las costas melicéricas y la hiperqueratosis, hay distrofia ungueal, caracterizada porque son gruesas, descoloridas; cualquier área puede ser afectada pero la piel cabelluda, manos y pies son muy susceptibles. Si no se trata la enfermedad se extiende el proceso y se vuelve generalizado; y en contraste, el prurito tiende a ser mínimo, con respecto a lo aparatoso de las lesiones.

Escabiosis nodular. Se manifiesta con lesiones en forma de cúpula de 5 o $6 \mathrm{~mm}$ de diámetro, eritematosas y prurito intenso; predominan en escroto, ocasionalmente en región inguinal y axilas. La forma incógnita es por enmascaramiento debido al uso de glucocorticoides ${ }^{1,2,3,4,16,17,18,19,20}$.

Antecedentes heredo-familiares.

Es una enfermedad transmisible de persona a persona, por lo que existe el antecedente de que varios familiares tienen sintomatología similar. El antecedente del síndrome de Down y síndrome de Turner son importantes en relación a la presentación de la sarna noruega. 


\section{Principales problemas de Salud Pública en México}

Antecedentes personales patológicos.

El uso de esteroides tópicos o sistémicos por tiempo prolongado favorece la presencia de escabiosis, observándose infestaciones masivas que provocan lesiones hiperqueratósicas en manos y pies; la misma situación se presenta en pacientes inmunocomprometidos, especialmente con SIDA.

Antecedentes personales no patológicos.

Se requiere del contacto directo y prolongado para su transmisión, por lo que es importante indagar sobre diversos antecedentes; para ello es necesario interrogar sobre los hábitos higiénicos como es el baño y cambio de ropa interior y exterior, corte de uñas, y cambio de ropa de cama; las condiciones de hacinamiento incrementan su prevalencia en la población, inclusive puede ocurrir en forma epidémica en las instituciones, como los asilos; se favorece cuando existen múltiples parejas sexuales, sobre todo en adultos jóvenes. En relación a la fauna doméstica, los gatos y los perros también contraen la sarna, pero los ácaros que los infectan son diferentes a los que parasitan a los humanos, por lo que es poco probable que causen infestaciones en un huésped humano, a menos que el animal no reciba tratamiento; estos ácaros no suelen reproducirse en los seres humanos, y rara vez sobreviven más de unos cuantos días.

Inspección general.

Por lo general presenta facie de irritabilidad por el prurito, cuando la escabiosis se ha impetiginizado se presenta el "signo del cirujano", así mismo es común encontrar la vestimenta sucia.

Somatometría.

De manera común no se alteran el peso y la estatura. En los pacientes inmunocomprometidos se puede asociar a la disminución de peso.

Signos vitales.

La temperatura puede aumentar si se presentan complicaciones como la impetiginización secundaria o la sepsis s,2,3,4,6,8,9. $^{1}$. 


\section{Escabiosis}

\section{Complicaciones}

Con frecuencia el cuadro se complica, sobre todo en los meses de verano, con infección por estafilococos aureus o estreptococo del grupo A, incluyendo impétigo, ectima, paroniquia y furunculosis.

- Impetiginización. Cuando el paciente se rasca disemina la infestación y las excoriaciones que produce en la piel permite la introducción de infecciones secundarias. Se caracteriza por pústulas y costras melicéricas. Cuando esto se presenta en los espacios interdigitales, sobre todo en los niños, el paciente no puede cerrar sus manos por la presencia de pústulas, edema y dolor, colocando las manos en alto y con los dedos separados, lo que se denomina "Signo del cirujano".

- Glomerulonefritis. Esta complicación se presenta cuando la Impetiginización es extensa.

- Dermatitis de contacto. Casi siempre es provocada por tratamientos incorrectos, o medicamentos que pueden causar sensibilización.

- Sepsis. En la escabiosis costrosa se pueden presentar fisuras que son puerta de entrada para las bacterias. Esto puede provocar sepsis en pacientes ancianos e inmunocomprometidos, produciendo la muerte del paciente.

- Complicaciones psicológicas. Delirio de parasitosis, vergüenza o culpabilidad ${ }^{12,3,4}$.

\section{Diagnóstico}

El cuadro clínico es de vital importancia para realizar el diagnóstico, el que comprende una tétrada caracterizada por:

- Túneles, denominados también, surcos o galerías.

- Distribución típica de las lesiones.

- Prurito nocturno. 


\section{Principales problemas de Salud Pública en México}

- Sumamente contagiosa. Por lo que es muy útil el antecedente de contacto con otras personas afectadas, sobre todo en lo que respecta a los miembros de la familia con convivencia estrecha y datos clínicos de una dermatosis semejante.

El túnel es difícil de observar, en ocasiones se ve como una línea oscura, color gris, rojizo o marrón, de 7 a 15 mm de largo. Más visible si se coloca una gota de tinta negra, con el fin de que esta penetre en el túnel, al final de este se puede observar una vesícula y al romperse puede observarse al parásito.

Intencionadamente se deben explorar los pliegues interdigitales de las manos, cara anterior de las muñecas y pliegues antecubitales, axilas, área periumbilical, en la cintura, superficie extensora de las rodillas, la parte inferior de los glúteos y los muslos, y caras laterales y posteriores de los pies; por lo general la parte trasera del cuerpo y la cabeza están libres de lesiones. En mujeres se localiza en piel adyacente a los pezones y en el hombre escroto, pene y glande.

En el caso de la escabiosis nodular se sugiere explorar de manera intencionada la región inguinal, genitales, glúteos y axilas; estos pacientes pueden desarrollar urticaria generalizada, incluso algunos de ellos han presentado urticaria como manifestación clínica inicial de la escabiosis.

Los niños pequeños y los lactantes presentan lesiones en palmas y plantas, en toda la superficie de los dedos, e incluso pueden mostrar ácaros en las uñas; suelen ser más inflamatorias que en los adultos y tienden a predominar las vesículas y ampollas.

La identificación de los túneles en la piel es un dato específico para realizar el diagnóstico y se hace de manera definitiva identificando al parásito, las heces o sus huevecillos.

Las tomas de las muestras deben ser de los sitios de lesión o en las zonas de rascado. Los estudios paraclínicos que se pueden realizar son los siguientes:

- Raspado de piel. Las zonas más útiles para tomar las muestras son las regiones interdigitales, los lados de las manos, muñecas, codos, axilas, región inguinal, tórax y pies. Se identifica una pápula no excoriada, se pone una gota de aceite mineral, se raspa con un bisturí, para posteriormente revisarla al microscopio. En los casos de escabiosis costrosa un gran número de ácaros y huevecillos pueden observarse. 


\section{Escabiosis}

- Biopsia por rasurado. Se realiza para el diagnóstico de las formas atípicas o cuando el examen directo no es posible.

- Microscopio de bajo poder.

- Dermatoscopía.

- Prueba de fluorescencia de tetraciclina.

- Prueba de la cinta adhesiva. Se pega una cinta adhesiva a la lesión, y después se quita rápidamente, se aplica al portaobjetos, y se observa al microscopio para identificar ácaros y huevos. Esta prueba es muy recomendable aplicarla en los niños $1,2,3,5,21,22$,

Diagnóstico diferencial.

- Dermatitis atópica. Se diferencia por los antecedentes familiares de atopia y la distribución de las lesiones.

- Dermatitis herpetiforme. El prurito es episódico, y con diferentes lesiones como eczema, placas vesiculosas y pápulas urticariales.

- Dermatitis por contacto. Cuando se presenta el eczema en la aréola, descartar escabiosis, además de la enfermedad de Paget.

- Dermatitis seborreica.

- Pediculosis del pubis. Se visualiza el parásito adherido al vello, y color rojizo en la piel alrededor de los vellos.

- Liquen plano. Las lesiones son poligonales de color violáceo y afectan mucosas.

- Urticaria papular.

- Pitiriasis rosácea.

- Uremia. El prurito es intenso, y se corrobora con los exámenes paraclínicos. 


\section{Principales problemas de Salud Pública en México}

- Impétigo.

- Psoriasis. El diagnóstico diferencial se presenta con la sarna noruega, ya que esta se caracteriza por ser hiperqueratósica y costrosa, siendo mínimo el prurito.

- Sífilis. La Escabiosis se considera una enfermedad transmitida sexualmente, y enmascara completamente a la sífilis.

- Dermatitis por contacto al níquel y platino. Las lesiones son muy parecidas a las de la escabiosis, pero tiene el antecedente de contacto con estos metales. Y si se da tratamiento empeora el cuadro del paciente $e^{1,2,3,5}$.

\section{Pronóstico}

Es una enfermedad benigna, aunque muy molesta. El prurito es tan intenso que produce en los niños y en la familia, insomnio e intranquilidad, afectando el estado general del paciente, en ocasiones produce una verdadera neurosis, inclusive una acarofobia. La mayoría de los casos no presentan problemas. Se puede pensar en el diagnóstico de asociación de VIH, cuando existe mucha escama o costras, en los casos resistentes al tratamiento o muy graves ${ }^{12,3}$.

\section{Terapéutica}

Medidas generales. Deben tratarse primero las complicaciones como impétigo y dermatitis por contacto.

- Aplicar medidas preventivas educando a la población y a la comunidad médica sobre el modo de transmisión, el diagnóstico temprano y el tratamiento de los pacientes infestados de los contactos.

- Deben ser tratados todos los contactos físicos cercanos del paciente, independientemente si hay o no sintomatología.

- Desinfectar todos los objetos que están en contacto directo con el paciente. La ropa de cama con la que estuvo en contacto el paciente en las 48 a y 72 horas y un día después 


\section{Escabiosis}

de iniciado el tratamiento, debe mantenerse en agua con detergente durante una hora, luego lavarse, y exponerla al sol. La ropa debe ser planchada con bastante calor. Los objetos que no pueden ser lavados se deben colocar en una bolsa de plástico sellado por 72 horas o más, ya que el ácaro no sobrevive más tiempo fuera del ser humano. Evitar el intercambio de prendas de uso personal.

- Lavado y cepillado de uñas.

- Informar al paciente que es una enfermedad transmisible.

- Evitar el contacto sexual hasta que ambas partes hayan completado el tratamiento.

- Evitar la promiscuidad y el hacinamiento.

- Tomar en cuenta el costo, la eficacia y la tolerancia del paciente a los fármacos, para evitar el abandono o la posible resistencia.

- Los fármacos deben aplicarse los días señalados ni un día más. Con el fin de evitar la dermatitis de contacto.

La eficacia de la permetrina es superior a la del líndano y el crotamitón, incluso para reducir el prurito. La permetrina en crema al 5\%, se utiliza una vez al día por la noche, y se retira después de 8 a 14 horas. Se puede usar en pacientes embarazadas, niños y ancianos, no es recomendable su uso en pacientes asmáticos.

El lindano (hexacloruro de gammabenceno) en loción y crema al 1\%, es un insecticida de tipo órgano clorado. Se absorbe en todos los sitios y se metaboliza y se excreta a través de la orina y heces.

El benzoato de bencilo, es un éster del ácido benzoico y alcohol bencílico. Sus presentaciones comerciales son la emulsión y loción al 10 y 25\%. Actúa directamente sobre el ácaro y lo intoxica. Se absorbe en el estrato córneo de la epidermis y se excreta por vía renal. La loción debe aplicarse al menos 2 o 3 noches continuas. Está contraindicado durante el embarazo, la lactancia y en niños menores de 5 años. 


\section{Principales problemas de Salud Pública en México}

El azufre en ungüento al 2 o 10\% en base de petrolato, es el más antiguo escabicida. Mediante su oxidación a ácido pentatiónico ejerce su acción germicida, también tiene acción queratolítica, antiséptica leve y parasiticida. Es un medicamento barato, seguro, pero mancha la ropa y requiere tres días de aplicación.

El crotamitón, debido a su poca eficacia y alta toxicidad está en desuso.

Ivermectina. Se utiliza a razón de 200 microgramos/kg vía oral, dos dosis con intervalos de 2 semanas, teniendo un $100 \%$ de eficacia. Se recomienda la vía oral cuando hay dificultades para aplicar el tratamiento tópico, como cuando existen excoriaciones, lesiones eccematosas o el potencial riesgo de absorción percutánea.

En la escabiosis impetiginizada es recomendable el uso de antibióticos tópico y un macrólido por vía oral.

El uso de antihistamínicos es recomendable para disminuir el prurito, así como el uso de lubricantes o emolientes. El prurito aparece 2 a 3 semanas después del contagio y persiste por otras 2 semanas, aproximadamente después de la curación ${ }^{12,3,23,24,25,26}$.

\section{Medidas de prevención}

Un mayor conocimiento de los antígenos del ácaro, de la respuesta inmunitaria generada contra los mismos y de los mecanismos de evasión utilizados por el parásito sería fundamental para el desarrollo de una vacuna que permita prevenir la infestación, de manera análoga a lo que se ha logrado con algunas garrapatas del ganado. Esto sería de gran importancia para la Salud Pública, ya que, pese a las estrategias de uso masivo de escabicidas, no se ha logrado controlar la infestación en áreas endémicas y la resistencia a los escabicidas disponibles es cada vez mayor.

Otras medidas de prevención son:

- Detección de portadores no diagnosticados circulando entre la población.

- Adecuada higiene del medio

- Realizar pesquizaje familiar para evitar epidemias. 


\section{Escabiosis}

- Instituir tratamiento en todos los enfermos.

- Realizar el baño diariamente.

- Uso personal de las toallas de aseo ${ }^{19,20}$.

\section{Referencias}

1. Saúl A, Arellano I, Peniche A. Lecciones de Dermatología de Saúl. 15ª ed. México: Méndez editores; 2013.

2. Arenas R. Atlas, diagnóstico y tratamiento. 5ae ed. México: Mc Graw Hill; 2013.

3. Romero R. Microbiología y parasitología humana: bases etiológicas de las enfermedades infecciosas y parasitarias. 3ª̣ ed. México: Editorial Médica Panamericana; 2007.

4. Kumate J, Gutiérrez G, Muñoz O, Preciado S, Solorzano S, Miranda N. Infectología clínica. 17ª ed. México: Méndez Editores; 2008.

5. SSA. Escabiosis. Sistema Nacional de Vigilancia Epidemiológica. México: Secretaría de Salud; 2010.

6. Longo D, Fauci A, Kasper D, Hauser S, Jamenson J, Loscalzo J. Harrison. Manual de Medicina Interna. 18 ed. España: McGraw-Hill Interamericana; 2013.

7. Campillos MT, Causin S, Duro E, Agudo S, Martínez MO, Sánchez JM. Escabiosis: revisión y actualización. MEDIFAM. 2002; 12(7): 442-452.

8. Moyano L, Santos A. Ectoparasitosis. Dermatología en Medicina Interna. 3 $3^{\underline{a}}$ ed. Buenos Aires: Alfaomega; 2010.

9. Magaña G, Magaña L. Dermatología. 2ª ed. México. Editorial Médica Panamericana; 2011.

10. Ramiro M, Halabe J, Lifshitz A, López J. El internista. 2 $2^{\underline{a}}$ ed. México: McGraw-Hill; 2002.

11. Ríos JM, Mercadillo P, Ríos E. Actualización en escabiosis con insistencia en los aspectos inmunológicos de la infección. Dermatol Rev Mex. 2012; 56(6):404-413 Disponible:http://new.medigraphic.com/cgibin/resumen.cgi?idrevista=86idarticulo=3 943idpublicacion $=4144$ 


\section{Principales problemas de Salud Pública en México}

12. Rampton M, Walton S, Holt D, Pasay C, Kelly A, Currie B, et al. Antibody Responses to Sarcoptes scabiei Apolipoprotein in a Porcine Model: Relevance to Immunodiagnosis of Recent Infection. Plosone 2012; 8(6): 1-10. Disponible en: http://www.plosone.org/ article/info\%3Adoi\%2F10.1371\%2Fjournal.pone.0065354

13. Walton S, Pizzutto S, Slender A, Viberg L, Holt D, Hales B, et al. Increased Allergic Immune Response to Sarcoptes scabiei Antigens in Crusted versus Ordinary Scabie. American Society Foy Microbiology 2010; 17(9):1427-1438.Disponible en:http://cvi. asm.org/content/17/9/1428.full.pdf+html

14. Rama J, Halesc B, Viberga L, Pizzutoa S, Holta D, Rollandd J, et al. A diagnostic test for scabies: IgE specificity for a recombinant allergen of Sarcoptes scabiei. Diagnostic Microbiology and Infectious Disease 2011; 71(4): 403-407. Disponible en: http://www. sciencedirect.com/science/article/pii/S0732889311003610

15. Morgan M, Arlian L. Response of Human Skin Equivalents to Sarcoptes scabiei. National Institutes of Healt. 2010; 47(5): 877-883. Disponible en: http://www.ncbi.nlm. nih.gov/pmc/articles/PMC2955294/?report=classic

16. Vázquez J, Campos T, Duran C, Rosas M. Escabiasis en lactantes. Medisan. 2008; 12(3): 73-83. Disponible en: http://bvs.sld.cu/revistas/san/vol12_3_08/san01308.htm

17. Plascencia A, Proy H, Eljure N. Atoche C, Calderón C. Escabiosis una revisión. Dermatología CMQ. 2013; 11(3):217-223.

18. De Anda J, Ángeles A, Arispe K. Escabiosis noruega a propósito de un caso de autopsia. Patología Rev Latinoam. 2010; 48(1):32-35.

19. Pérez-Cotapos ML, Zegpi TMS. Pediculosis y escabiosis. Boletín Escuela de Medicina, Pontificia Universidad Católica de Chile. 1996; 25: 40-43.

20. Borrero TC. Incidencia de enfermedades transmisibles. La escabiosis en el círculo infantil. Rev Cubana Med Gen Integr. 1998; 14(6):595-600.

21. Cruz A, Ortega C, Parrila J, Torres G, Velasco L. Guía de práctica clínica, diagnóstico y tratamiento de Escabiosis (en línea). México: CENETEC; 2012. Disponible en: http:// www.facmed.unam.mx/deptos/microbiologia/pdf/escabiasis_SS_2012.pdf

22. Chin J. El control de las enfermedades transmisibles en el hombre. Publicación científica 581. Organización Panamericana de la Salud. 17ª ed. 2001. 


\section{Escabiosis}

23. Arenas R, Ruiz-Esmenjaud J, Morales-Chávez CE, et al. Ivermectina oral: cinco años de experiencia. Presentación de 34 parasitosis cutáneas: Escabiosis, sarna costrosa, larva migrans, gnathostomiasis, pediculosis y demodecidosis. Dermatología CMQ. 2003; 1(1):20-9. Saúl A, Arellano I, Peniche A. Lecciones de dermatología de Saúl. 15ª ed. México: Méndez editores; 2013.

24. Macotela E, Peña G. Tratamiento de la escabiosis con ivermectina por vía oral. Gac Med Mex. 1993; 129(3):201-205.

25. Morales L, Arenas R. Escabiasis tratamiento de 40 pacientes con ivermectina oral. Dermatología CMQ. 2006; 4(4):237-241.

26. Escalante E, Valdivia L. Tratamiento de escabiosis humana con ivermectina vía oral dosis única. Dermatol 2013; 13(1):17-29. Disponible en: http://sisbib.unmsm.edu.pe/ BVRevistas/dermatologia/v13_n1/trata_esca.htm 



\section{Infecciones respiratorias agudas}

Mtra. Irma Araceli Aburto López

\section{Introducción}

Las Infecciones Respiratorias Agudas (IRAS), siguen siendo un problema de Salud Pública en todo el mundo, ya ocupan los primeros lugares como causa de morbilidad y mortalidad; son la primera causa de consulta externa y provocan mortalidad por casos de neumonía, principalmente en menores de 5 años de edad, en países en vías de desarrollo ${ }^{1}$. En éste capítulo se desarrolla el cómo prevenir la enfermedad; clasificar adecuadamente los casos, para darles manejo correcto y tratamiento oportuno; se establece cuándo canalizar a medio hospitalario a los pacientes y a quién se les deben prescribir antibióticos, con el afán de evitar muertes a consecuencia de éstas infecciones. Incluye datos del Síndrome Respiratorio Agudo Severo (SRAS) y la influenza, las que representan una amenaza para la salud en el mundo.

\section{Concepto}

Las IRAS, son enfermedades infectocontagiosas que duran menos de quince días de evolución, ocasionadas principalmente por virus o bacterias, que afectan a las estructuras del sistema respiratorio y que pueden ser asintomáticas, leves, graves o fatales, dependiendo de la edad del paciente, del agente etiológico, las estructuras del sistema respiratorio afectado, la susceptibilidad individual y las características del medio ambiente. Se consideran superiores cuando se presentan por arriba de la epiglotis e inferiores por debajo de ésta estructura anatómica. Afectan a cualquier edad y sus signos y síntomas que se pueden presentar, dependiendo de la enfermedad son tos, disnea, rinorrea, disfagia, odinofagia y otalgia, entre otros. Y en algunos casos como el SRAS y la influenza aviar, acompañados de náuseas, vómito, diarrea o trastornos de conciencia; éstos últimos dos cuadros acompañados con una tasa de ataque muy elevada (gran número de casos de la enfermedad) y una letalidad grande (muchos enfermos que mueren) $)^{2,3,4}$. 


\section{Principales problemas de Salud Pública en México}

\section{Clasificación}

Desde la perspectiva de la Norma Oficial Mexicana 024, para la prevención y control de las IRAS en la Atención Primaria a la Salud y considerando la Clasificación Internacional de las Enfermedades décima revisión (CIE-10), se incluyen en este rubro enfermedad muy grave, neumonía grave, neumonía, resfriado común, mastoiditis, otitis media aguda supurada o no, otitis media crónica, absceso de garganta, faringitis probablemente bacteriana y faringitis probablemente viral ${ }^{5}$.

\section{Epidemiología}

Las IRAS, dependiendo de la que se trate, en algunos momentos a nivel internacional pueden convertirse en emergencia de Salud Pública, como el SRAS, influenza aviar o por un tipo de virus nuevo ${ }^{6}$. Según la Organización Mundial de la Salud (OMS), en todo el mundo, la gripe estacional provoca 3 a 5 millones de casos de enfermedad grave y 250 000 a 500000 muertes al año; es una infección que causa epidemias anualmente, en zonas templadas alcanza su máximo número de casos en los meses invierno; mientras que en regiones tropicales se presentan durante todo el año, provocando brotes epidémicos irregulares de la enfermedad; su tasa de ataque oscila de 5 al 10\% en los adultos y del 20 al 30\% en los menores de edad; es prevenible por vacunación; su trascendencia es a nivel individual, familiar, nacional; provocando ausentismo laboral y escolar, pérdidas de productividad; casos graves con hospitalización y muerte de los pacientes, en especial de menores de edad, ancianos y personas que padecen enfermedades crónicas; aunque se poseen antivirales, los agentes biológicos pueden convertirse en resistentes a los fármacos ${ }^{7}$.

Según la OMS, anualmente en el mundo, las muertes por neumonía se presentan en el 2\% de los neonatos ( 0 a 28 días) y en el 13\% en edad postneonatal ( 1 a 59 meses $)^{8}$.

En nuestro país, las IRAS, en los menores de 5 años de edad, ocupan el primer lugar como causa de enfermedad, provocando neumonía, muerte y afecciones en su crecimiento y desarrollo ${ }^{1}$.

En México las IRAS, incluyendo la influenza y neumonía, de 1998 a 2011, poseen una mortalidad con tendencia descendente, las tasas más altas se encuentran en los menores 


\section{Infecciones respiratorias agudas}

de un año de edad. En el año de 2008, las tasas de mortalidad por Infección Respiratoria Aguda (IRA), neumonía e influenza en los Estado Unidos Mexicanos fue de 2.2, 15.1 y 0.2, respectivamente; y para los menores de 5 años de edad, para esas mismas enfermedades 10.5, 38.9 y 0.6. Para el año 2011, la tasa de mortalidad por IRA, influenza y neumonía en la población general de México son 0.9, 13.3 y 0.1; y en menores de cinco años edad, para IRA, influenza y neumonía les corresponde en ese mismo orden las tasas de 5.7, 18.1 y 0.2, por cada 100000 habitantes. Es decir, existió una disminución del 59.9\% (IRA), 11.9\% (neumonía) y del 50\% (influenza), en la población mexicana; y en los menores de 5 años de edad disminuyeron 45.7\% (IRA), 52.4\% (neumonía) y 66.6\%(influenza). En 2011, dentro de las diez principales causas de mortalidad general, en México, la influenza y neumonía, ocupan el noveno lugar y no aparece el rubro de las IRA; en edad infantil (menores de un año de edad), representan el $4^{\circ}$ influenza y neumonía y $6^{\circ}$ las IRA; en edad preescolar (1 a 4 años de edad), la influenza y neumonía se encuentran en el $4^{\circ}$ lugar de mortalidad y no aparecen las IRA; en edad escolar (5-14 años) en 8º la influenza y neumonía; en edad productiva (15 a 64 años) no figuran dentro de las diez principales causas de mortalidad; y en adultos mayores ( 65 años y más) ocupan en $7^{\circ}$ como causa de mortalidad la influenza y la neumonía ${ }^{9,10}$.

Como parte de la transición epidemiológica en México, prevalecen dentro de las primeras causas de morbilidad, enfermedades de rezago como las enfermedades infectocontagiosas, entre ellas ocupan el primer lugar las infecciones respiratorias y además son la primer causa de egreso hospitalario, con una razón de 13 por cada 100 consultas médicas; y ocurren 2 y 4 episodios de éstas infecciones en los niños por año ${ }^{10}$.

Ya que las IRAS, son transmisibles, forman parte de la Vigilancia Epidemiológica y son de notificación obligatoria, reguladas en nuestro país, por la Dirección General de Epidemiología, México cuenta con registro de casos de enfermedad, a través del Sistema Nacional de Vigilancia Epidemiológica la incluye a las IRAS, influenza, neumonía por Haemophilus influenzae, neumonías y bronconeumonías y otitis media aguda. En población general mexicana, para dichas enfermedades, las tasas de incidencia por cada 100000 habitantes, con respecto a los años 2008 y 2014, respectivamente fueron IRAS, 22609 y 22 965; influenza, 0.16 y 56.05; neumonía por Haemophilus influenzae, no se registraron casos; neumonía y bronconeumonía 137,28 y 145,97; y otitis media aguda 624,74 y $534,30^{11,12}$. 


\section{Principales problemas de Salud Pública en México}

\section{Causalidad}

Es un padecimiento infeccioso causado por múltiples agentes biológicos, como bacterianos, virales; asociados a factores determinantes que interactúan entre sí provocando casos asintomáticos y sintomáticos.

\section{Agentes biológicos}

En México, al igual que en los países en vías de desarrollo, entre los agentes biológicos más importantes que provocan la mayoría de los cuadros clínicos de IRAS, primeramente son las de origen viral y en un segundo momento a causa de bacterias. Las bacterias más frecuentemente encontradas en menores de 5 años de edad, en países en vía de desarrollo son Streptococcus pneumoniae y Haemophilus influenzae (Hib) ${ }^{13}$.

El Haemophilus influenzae en menores de 5 años de edad, provoca múltiples enfermedades como otitis media, sinusitis, faringitis, faringoamigdalitis, neumonía, meningitis, epiglotitis empiema, infecciones intestinales, artritis séptica, pericarditis e infección de vías urinarias. Provocando secuelas neurológicas después de haber presentado meningitis ${ }^{14}$.

Los agentes causales del resfriado común son múltiples e incluyen a los rinovirus, coronavirus, parainfluenza, influenza, virus sincitial respiratorio (VSR), adenovirus y enterovirus. Los más frecuentes rinovirus y coronavirus ${ }^{3}$.

La gripe estacional es producida por los virus gripales A, B y C, los que circulan en todo el mundo; los del tipo A se clasifican en subtipos, dependiendo de las combinaciones de sus dos proteínas de superficie $\mathrm{H}$ y $\mathrm{N}$, en la actualidad circulan en el humano los subtipos $\mathrm{A}(\mathrm{H} 1 \mathrm{~N} 1)$ y A(H3N2); los más frecuentes son los virus A o B; son menos frecuentes los $\mathrm{C}$, es

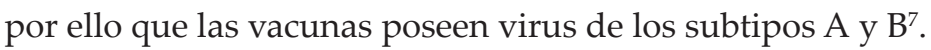

Los microorganismos que afectan con más frecuencia la faringe y amígdalas son Streptococcus pyogenes, Arcanobacterium haemolyticum, Mycoplasma pneumoniae, Chlamydophila pneumoniae, adenovirus, Epstein - Barr y Coxsackie A. La otitis media es principalmente causada por los microorganismos Streptococcus pneumoniae, Heamophilus influenzae y por Moraxella catarrhalis ${ }^{3}$. 


\section{Infecciones respiratorias agudas}

Los agentes biológicos se propagan rápidamente ya que las gotículas infectadas con los microorganismos, que son eliminadas por el paciente al estornudar o toser, pueden ser inspiradas por otras personas susceptibles de enfermar ${ }^{7}$. Es por ello que el mecanismo de transmisión, es a través de microgotas que expulsa un reservorio, que posee la enfermedad, al toser o estornudar sin cubrirse la nariz o la boca; dichas gotitas de flugüe entran por la vía respiratoria, a un huésped susceptible; también puede ser por contacto con fómites o vehículos, como las manos contaminadas con secreciones respiratorias, al comer o beber alimentos con utensilios contaminados por los microorganismos; al ser autoinoculadas (a ojos, nariz o boca) y al saludar a otras personas; y por aerosoles pequeños respiratorios infecciosos distribuidos a por una corta distancia ${ }^{1,6}$. El periodo de incubación es variable, dependiendo de los agentes biológicos y de la enfermedad. Por ejemplo para el caso de la gripe estacional de 2 días aproximadamente ${ }^{7}$.

\section{Factores de Riesgo}

Los factores de riesgo para adquirir neumonía son tener desnutrición, poseer bajo peso al nacer, no haber recibido lactancia materna durante los primeros seis meses de edad; contaminación ambiental, hacinamiento, medio ambiente en el hogar, escuela o trabajo con tabaquismo y carbón, tener madre analfabeta, joven e inexperta, cursar con comorbilidades como anemia de células falciformes, displasia broncopulmonar, Síndrome de inmunodeficiencia adquirida, asma, cardiopatías, reflujo gastroesofágico, fibrosis quística, reflujo; atención médica inadecuada; deficiencia de vitamina A y zinc. Así como carencia de inmunizaciones en contra del sarampión, tos ferina y Haemophilus influenzae, para los menores de cinco años y además la no inmunización para evitar en contra de otros neumococos y para la influenza, en personas de 6 meses a 5 años de edad, y mayores de 65 años, así como en personas que padecen enfermedades crónicas, que cursan con asma o alguna inmunosupresión ${ }^{1,3}$.

La gripe estacional, puede atacar a cualquier grupo de edad y sexo, sin embargo, los casos más graves se presentan en menores de 2 años y mayores de 65 años de edad, y en cualquier edad cuando poseen enfermedades crónicas, cardiacas, pulmonares, renales, hepáticas, sanguíneas, metabólicas, como es el caso de la diabetes mellitus y/o por inmunosupresión?.

Debido a la transmisibilidad de las IRAS, se consideran poblaciones de alto riesgo, aquellas en donde la convivencia se da con un gran número de población, tal es el caso de guarderías, salas pediátricas ${ }^{14,15}$. 


\section{Principales problemas de Salud Pública en México}

También son factores determinantes que favorecen la enfermedad y sus complicaciones, la pobreza, la mal nutrición, vivir en poblaciones dispersas y retirados de los centros de atención médica; así como el ser atendidos de manera inadecuada o por solicitud tardía de la atención. Al respecto el $40 \%$ de los menores de edad que tienen posibilidades de desarrollar neumonía, carecer de atención médica adecuada y solo el 31\% reciben antibióticos ${ }^{16}$.

Factores de mal pronóstico.

Tanto el personal de salud como los cuidadores de los menores de edad, deben conocer los factores de mal pronóstico, ya que la presencia de ellos favorece las complicaciones y muerte a causa de IRAS. Dichos aspectos a considerar incluyen ser menor de dos meses de edad; menor de un año de edad con antecedentes de bajo peso al nacer; dificultad para el traslado a los Servicios de Salud, por la distancia, horas invertidas, falta de vías de comunicación, transporte; desnutrición moderada o grave, al respecto la OMS refiere que el 35\% de las muertes en niños menores de cinco años de edad, están asociadas con la desnutrición; presencia de alguna enfermedad que provoca inmunosupresión como el cáncer, desnutrición, VIH-SIDA; antecedente de haber tenido una defunción en menor de cinco años en su núcleo familiar; y madre analfabeta o menor de 17 años de edad ${ }^{1,8}$.

\section{Factores Protectores.}

Son factores protectores para reducir la morbilidad y mortalidad a causa de las IRAS, las encaminadas al recién nacido, como la lactancia materna exclusiva, durante los primeros seis meses de edad y extender la ingesta de leche materna, en los niños hasta los dos años de edad con alimentación complementaria, además de administrar suplementos de vitamina $\mathrm{A}^{16}$.

\section{Fisiopatología}

Los agentes biológicos entras por vía respiratoria, en donde se replican en las primeras horas después del contacto y continúa esa reproducción hasta después de iniciado el cuadro clínico. Los microorganismos se fijan en las células de la mucosa nasal, faríngea, tráquea y en casos graves pueden encontrarse a nivel bronquiolar y alveolar. Los epitelios de las vías respiratorias altas y bajas pueden desencadenar los mecanismos de defensa locales, la respuesta inflamatoria y la liberación de mediadores bioquímicos. La duración de la 


\section{Infecciones respiratorias agudas}

diseminación de los patógenos en el tracto respiratorio, dependen de la patogenicidad, infectividad y virulencia de cada uno de ellos; además de la edad del paciente, su susceptibilidad y su grado de resistencia ${ }^{3}$.

\section{Cuadro clínico}

Es importante identificar tempranamente los signos de alarma de las enfermedades respiratorias, para poderlas manejar de manera oportuna y adecuada. Antes que cualquier otro signo, debemos identificar la existencia o no de polipnea, ya que predice de manera temprana los casos que desarrollarán neumonía; además del rechazo a la ingesta (ingiere menos de la mitad de lo que acostumbra o no puede beber), decaimiento, disnea, tiros intercostales, somnolencia, cianosis, vómito, sibilancias o estridor, fiebre por más de 3 días y salida anormal de líquido por el oído ${ }^{1,17}$.

Para evaluar la existencia de polipnea, el paciente no debe tener fiebre. Se considera polipnea en niños menores de 2 meses, 60 o más respiraciones por minuto; de 2 a 11 meses, 50 o más respiraciones por minuto; y de 1 a 4 años de edad, 40 o más respiraciones por minuto. Una vez detectada la presencia o no de dicho signo, se procede a clasificar la enfermedad y su posible etiología ${ }^{17}$.

Si el enfermo posee polipnea tiene neumonía. Si no cursa con polipnea puede tratarse de rinofaringitis, faringitis, faringoamigdalitis purulenta, otitis, sinusitis, laringitis, laringotraqueitis, bronquitis o bronquiolitis (Cuadro 1$)^{3}$.

Cabe aclarar que el cuadro clínico de neumonía a consecuencia de Hib, se presenta con tos, taquipnea, estertores y uno o más signos de dificultad respiratoria y uno o más signos clínicos de derrame pleural ${ }^{14}$.

\section{Complicaciones}

La complicación más grave es la neumonía, ya que es la que provoca el mayor número de muertes, pero también se pueden presentar otras complicaciones como la deshidratación o coinfecciones. En el caso de tener faringoamigdalitis puede presentarse hipertrofia amigdalina y absceso retrofaríngeo. Particularmente en la sinusitis pueden terminar con trombosis séptica del seno caversono, meningitis, ostiomielitis y absceso cerebral. Cuando 


\section{Principales problemas de Salud Pública en México}

existe otitis, sus complicaciones incluyen la meningitis, hipoacusia, sordera, parálisis facial y laberintitis ${ }^{3}$.

Cuadro 1. Cuadro clínico de las enfermedades respiratorias ${ }^{3,16}$.

\begin{tabular}{|c|c|}
\hline $\begin{array}{l}\text { Enfermedad } \\
\text { respiratoria }\end{array}$ & Datos clínicos de la enfermedad \\
\hline Gripe estacional & $\begin{array}{l}\text { Fiebre alta súbita, tos generalmente seca, cefalea, dolor de garganta, } \\
\text { malestar general intenso, secreción nasal abundantes; los que } \\
\text { suelen desaparecer en siete días. Puede causar enfermedad grave } \\
\text { o la muerte. }\end{array}$ \\
\hline Rinofaringitis & $\begin{array}{l}\text { Rinorrea, obstrucción nasal, estornudos, tos, odinofagia, cefalea o } \\
\text { irritabilidad, malestar general. }\end{array}$ \\
\hline Laringotraqueitis & Disfonía, tos traqueal, estridor laríngeo. \\
\hline Faringoamigdalitis & $\begin{array}{l}\text { Dolor faríngeo, adenopatía cervical, fiebre, exudado faríngeo } \\
\text { blanquecino en placas, vesículas o úlceras. }\end{array}$ \\
\hline $\begin{array}{l}\text { Angina } \\
\text { estreptocócica }\end{array}$ & $\begin{array}{l}\text { Ganglios linfáticos del cuello sensibles e inflamados, además de la } \\
\text { presencia de exudado y placas blanquecinas en las amígdalas. }\end{array}$ \\
\hline Faringitis viral & $\begin{array}{l}\text { Secreción u obstrucción nasal, orofaringe hiperémica con dolor o } \\
\text { ardor y puede existir fiebre. }\end{array}$ \\
\hline Sinusitis & $\begin{array}{l}\text { Fiebre, cefalea, congestión nasal, descarga nasal anterior, tos, } \\
\text { halitosis. }\end{array}$ \\
\hline Otitis & Otalgia, otorrea menor de 2 semanas, tímpano abombado, fiebre. \\
\hline $\begin{array}{l}\text { Infección aguda } \\
\text { del oído }\end{array}$ & $\begin{array}{l}\text { Otorrea menor a dos semanas, dolor de oído, tímpano rojo e } \\
\text { inmóvil. }\end{array}$ \\
\hline $\begin{array}{l}\text { Infección crónica } \\
\text { del oído }\end{array}$ & Otorrea igual o mayor a dos semanas. \\
\hline Bronquitis & Estertores bronquiales, tos productiva. \\
\hline Bronquiolitis & Sibilancias, disminución del ruido respiratorio. \\
\hline Neumonía & $\begin{array}{l}\text { Polipnea, tiros intercostales, sibilancia, disnea, no puede beber, } \\
\text { convulsiones, somnoliento o difícil de despertar, estridor en } \\
\text { reposo, fiebre. }\end{array}$ \\
\hline Mastoiditis & $\begin{array}{l}\text { Inflamación del hueso mastoideo, presencia de sensibilidad } \\
\text { aumentada con dolor detrás de la oreja y sobre la oreja en los } \\
\text { lactantes. }\end{array}$ \\
\hline
\end{tabular}




\section{Infecciones respiratorias agudas}

\section{Diagnóstico}

Los pacientes con IRA, requieren diagnóstico clínico adecuado y temprano, con el afán de dar un tratamiento oportuno, el que incluye la identificación de factores de mal pronóstico, la evaluación clínica y su clasificación exacta, la capacitación de los padres o tutores, el manejo adecuado y el seguimiento del caso, conforme a lo indicado y así abatir y / o acabar con las muertes prevenibles por esta enfermedad ${ }^{3,17}$.

Para poder efectuar la clasificación del caso clínico a tratar, primeramente debemos evaluar al paciente, para ello debemos considerar que edad tiene; saber si existe la presencia de tos o no, en caso afirmativo, desde cuando la presenta; en menores de 2 meses a 4 años de edad, saber si puede beber o no; en menor de 2 meses, indagar si ha dejado de comer; identificar la presencia de fiebre y la presencia de convulsiones. Observar y escuchar, cuando el niño este tranquilo, el número de respiraciones por minuto, tiros intercostales, estridor, sibilancia, somnolencia, fiebre o hipotermia, determinar la existencia de desnutrición. Una vez que hemos evaluado, debemos determinar bien los signos y síntomas, para poder clasificar de manera adecuada el caso, con el afán de que en un momento posterior se dé el manejo correspondiente, para tal efecto los diferentes cuadros clínicos los tipificamos en ${ }^{3,13}$ :

1) Casos graves y muy graves, corresponden a neumonía grave y muy grave. En menores de 5 años se presentan los siguientes datos clínicos: no puede beber, convulsiones, somnoliento o difícil de despertar, estridor en reposo, desnutrición grave, tiros intercostales y sibilancia.

2) Casos moderados, tiene neumonía sin tiros intercostales. Pueden cursar con tos, polipnea, fiebre y sibilancia.

3) Casos leves, los pacientes no tienen neumonía. Pueden cursar con tos o resfriado, por lo tanto no presentan tiraje, ni tampoco polipnea. Evaluar si el paciente tiene otitis (mastoiditis, infección aguda de los oídos o infección crónica de los oídos) o faringitis.

\section{Tratamiento}

Es muy importante abatir las muertes por neumonía y evitar otras complicaciones como pérdida de la audición, es por ello que la población debe tener acceso a la atención médica, 


\section{Principales problemas de Salud Pública en México}

la que incluye en casos necesarios la administración de antimicrobianos y la canalización a un medio hospitalario. Al respecto, los pacientes que tienen la oportunidad de ser atendidos, muchas de las veces se les prescriben antibióticos de manera indiscriminada e inadecuada, ya sea porque no requieren el medicamento o en su defecto les dan dosis y número de días inapropiado ${ }^{13}$.

Una vez que hemos evaluado, clasificado y diagnosticado de manera correcta, procederemos a actuar según sea el caso y tomar la decisión, si se prescriben o no antimicrobianos y si el enfermo debe tratarse en el hogar o a nivel hospitalario. Para ello se considera la clasificación utilizada para el diagnóstico general de las IRAS ${ }^{3,13}$ :

1) Casos graves y muy graves, presentan neumonía o neumonía muy grave. Requieren hospitalización. Se atienden en medio hospitalario. Referirlo al hospital de manera urgente, dando la primera dosis de antimicrobiano, manejo de la fiebre y sibilancia. Dar medidas para evitar cambios bruscos de temperatura y abrigar bien al niño.

2) Casos moderados, neumonía sin tiros intercostales. Se atienden en el primer nivel de atención en los centros de salud y unidades de medicina familiar, de manera ambulatoria con medicamentos antimicrobianos. Manejo en casa, antimicrobiano, tratar la fiebre, sibilancia y solicitar al tutor o padre responsable de cuidar al niño que regrese al servicio de salud dentro de dos días para volverlo a evaluar o antes si se requiere. Capacitar a los cuidadores sobre los signos de alarma. Mantener abrigado al paciente, limpiar la nariz.

3) Casos leves, no tienen neumonía. Los que requieren medidas generales en casa y sin antimicrobianos. Las medidas de manejo son la ingesta de líquidos, alimentación materna, antipiréticos y control de temperatura, alimentación continua, limpieza de nariz en caso necesario, en observación y consultas a tiempo si empeora el paciente (identificación temprana de signos de alarma). Se atienden en el hogar. Capacitar a los cuidadores de los niños, sobre los signos de alarma: Respira con dificultad, respira rápidamente, es difícil alimentarlo, la salud del bebe empeora.

En mastoiditis, referirlo a nivel hospitalario, prescribir la primera toma de antibiótico, tratar la fiebre y dolor. En infección aguda del oído prescribir antibiótico oral, secar el oído con mechas (no hisopos), tratar fiebre y dolor; evaluar en cinco días. En presencia de infección crónica del oído secar con mechas, tratar fiebre y dolor ${ }^{3}$. 


\section{Infecciones respiratorias agudas}

En los casos de absceso faríngeo, si el paciente no puede beber es necesario referirlo al hospital, prescribiendo penicilina benzatínica, en pacientes no alérgicos, dar tratamiento para la fiebre y dolor. Cuando existe angina estreptocócica, hay que prescribir antibióticos para la erradicación de dicho agente biológico, dar tratamiento para el dolor y fiebre. En la faringitis viral se deben dar medidas generales como ingesta de líquidos, tratar el dolor o fiebre y capacitar al cuidador del niño para que regrese a consulta en caso necesario ${ }^{3}$.

Ante casos de neumonía por H. influenzae o a causa de neumococos y en otitis, se pueden indicar penicilina procaínica, amoxicilina oral, ampicilina o cotrimoxazol. Para la gripe estacional se deben recetar antivirales como la amantadina o el oseltamivir ${ }^{3,7,13}$.

Es importante promover las consultas a tiempo, a través de la capacitación de las madres y del personal de salud, para que identifiquen tempranamente los signos de alarma y otros aspectos clínicos de importancia para evitar complicaciones, tales como la polipnea, que es el signo más sensible para identificar casos tempranos de neumonía.

El manejo incluye la mejora de atención médica y derivación de casos necesarios, por parte del Sector Salud, la identificación temprana de pacientes en el primer nivel de atención, incluyendo a la comunidad, que impida el agravamiento de los pacientes. Se debe administrar de manera correcta el suministro de recursos a los establecimientos del Sector Salud, con el afán de que se posean en el momento y lugar requerido los antibióticos y el oxígeno $^{16}$.

La población debe saber que ante un familiar enfermo con IRA, debe llevarlo al médico; mantenerlo hidratado; en menores de edad continuar con la lactancia materna, ofreciéndola con más frecuencia; alimentación habitual al paciente y en caso de tener pérdida de apetito, dar alimentación en pequeñas porciones y con mayor frecuencia, dando una porción extra en periodo de recuperación, cuando son desnutridos; mantener permeables las vías respiratorias, limpiando la nariz con perilla en los infantes; poniendo en la nariz gotas de agua tibia, previamente hervida con un poco de sal o en su defecto té de manzanilla tres o cuatro veces al día; además es muy importante recomendar que no debe usarse mentol o eucalipto, ya que favorecen más el proceso infeccioso. En caso de otitis supurativa, limpiar con mechas de gasa o un trapo limpio; no deberá usarse algodón ni aplicar gotas a los conductos auditivos. Control de la hipertermia por medios físicos como la aplicación de paños de agua tibia en la frente, evitar abrigar demasiado. Si existe producción de mucosidad 
y esputo, con el afán de favorecer su expulsión se deberá aumentar la ingesta de líquidos y dar puño-percusión en el tórax posterior, de abajo hacia arriba, durante 3 minutos, dos veces al día. Reposo en cama, cambiando de posición de manera frecuente. Evitando cambios de temperatura y corrientes de aire. Ventilación de la habitación. No dar medicamentos antitusígenos, ya que impide la expectoración. Evitar la automedicación. Y en caso de presentarse algún signo de alarma asistir de manera rápida a un medio hospitalarioº ${ }^{1}$

\section{Medidas de prevención}

Las medidas de prevención encaminadas a cortar los mecanismos de transmisión de la enfermedad, incluyen el cubrirse la boca y nariz al estornudar; en casos necesarios el uso de mascarilla médica; es recomendable tener una distancia igual o mayor de un metro entre los pacientes enfermos; higiene de las manos, lavándolas con agua y jabón o en su defecto con un desinfectante a base de alcohol; ventilación adecuada, limpieza del hogar y medios hospitalarios; la detección temprana de casos, notificación de casos de manera inmediata (influenza aviar, SARS), aislamiento de los pacientes y el control del proceso infeccioso en los pacientes; el personal de salud es importante que utilice mascarilla, guantes y bata y cambiárselos en lo posible, entre paciente y paciente $^{6}$.

Para la prevención de la gripe estacional, debe aplicarse la vacunación por orden de importancia a las mujeres embarazadas, niños de 6 meses a 5 años de edad y ancianos (en los que reduce la gravedad, complicaciones y muerte), los pacientes con enfermedades crónicas y en los trabajadores de la salud ${ }^{7}$.

Cuando se aplica la vacunación en contra de Hib, se ha observado un abatimiento de infecciones invasivas de la enfermedad, sobre todo en menores de 6 meses de edad ${ }^{14}$.

Con el afán de aumentar la respuesta inmunológica e incidir en la prevención de la desnutrición y pérdida de peso, es necesario continuar con la alimentación habitual y continua, incluyendo la lactancia materna para los menores de dos años de edad. Además aumentan la resistencia del huésped, la lactancia materna exclusiva durante los primeros 6 meses de vida y continuar con la lactancia materna, en lo posible hasta los dos años de edad, con alimentación complementaria apropiada, ya que reducen la aparición y gravedad de las IRAS. Otras acciones para tal efecto es la aplicación de las vacunas contra el sarampión, tosferina, Streptococcus pneumoniae y Haemophilus influenzae tipo b; 


\section{Infecciones respiratorias agudas}

además de la administración suplementaria de vitamina A. Se ha demostrado que el uso de las vacunas contra el sarampión y la tos ferina reducen de manera importante la morbilidad y mortalidad por casos de neumonía, en menores de 5 años de edad ${ }^{16}$.

Para evitar la aparición de la enfermedad se debe reducir los mecanismos de transmisión y aumentar la resistencia del huésped. Y con el afán de prevenir complicaciones y muerte por casos de IRAS, se debe hacer diagnóstico temprano y tratamiento oportuno de los casos; así como disminuir la contaminación del aire de los hogares, con estufas mejoradas, ya que esa acción ha demostrado reducir la neumonía grave; y la capacitación de la comunidad para la identificación temprana de los signos de alarma, como es la polipnea ${ }^{16}$.

\section{Referencias}

1. Secretaría de Salud. Guía técnica para la cartilla Nacional de Salud. Niñas y niños de 0-9 años. México: Dirección General de Promoción de la Salud; 2008.

2. Consejo de Salubridad General. Prevención, diagnóstico y manejo de la infección aguda de vías aéreas superiores en pacientes mayores de 3 meses hasta 18 años de edad. Evidencias y Recomendaciones. Guía de práctica clínica. Catálogo maestro de guías de práctica Clínica: IMSS-062-08; 2009.

3. Secretaría de Salud. Manual de enfermedades respiratorias 2012. Prevención, diagnóstico y tratamiento. México, Centro Nacional para la Salud de la Infancia y la Adolescencia (CENSIA), 2012. Disponible en: http://docplayer.es/5119976-Manual-deenfermedades-respiratorias-2012-prevencion-diagnostico-y-tratamiento.html.

4. Organización Mundial de la Salud. Medidas de control de infecciones en la atención sanitaria de pacientes con enfermedades respiratorias agudas en entornos comunitarios. Guía para el instructor. Organización Mundial de la Salud, Control de infecciones en la atención de salud, 2010.

5. Secretaría de Salud. Proyecto de Norma Oficial Mexicana NOM-024-SSA2-1994, Para la prevención y control de las Infecciones Respiratorias Agudas en la Atención Primaria a la Salud. México: Secretaría de Salud. Diario Oficial de la federación: 24/03/2004. Disponible en http://dof.gob.mx/nota_detalle.php?codigo=4871316\&fec ha $=24 / 03 / 1995$.

6. Organización Mundial de la Salud. Enfermedades respiratorias agudas con tendencia 


\section{Principales problemas de Salud Pública en México}

epidémica y pandémica. Prevención y control de infección en la atención de la salud. OMS, Ayuda Memoria. Control de infección. 2008. Disponible en http://www.who.int/ csr/resources/publications/11_EPR_AM3_E3_SPAN_LR.pdf?ua=1.

7. Organización Mundial de la Salud. Gripe (estacional). OMS, Nota informativa No. 211, marzo de 2014. Disponible en http://www.who.int/mediacentre/factsheets/fs211/es/.

8. Organización Mundial de la Salud. Causas de muerte en menores de 5 años de edad, 2013. Portal del Observatorio de la Salud de la OMS. Disponible en http://www.who. int/gho/child_health/mortality/causes/en/.

9. Secretaría de Salud. Panorama epidemiológico y estadístico de la mortalidad en México 2011. México: Subsecretaría de Prevención y Promoción de la Salud, Dirección General de Epidemiología; 2011.

10. Secretaría de Salud. Mortalidad. México, Boletín epidemiológico del Sistema Único de Información, del Sistema Nacional de Vigilancia Epidemiológica. 2013; 42(30):3 Recuperado desde file://C:/Users/Guest/AppData/Local/Temp/Rar\$DIa0.964/edit4213. pdf.

11. Secretaría de Salud. Incidencia de casos nuevos de Enfermedad por grupos de edad en los Estados Unidos Mexicanos 2008. México, anuarios de morbilidad de la Dirección General de Epidemiología. Disponible en http://www.epidemiologia.salud.gob.mx/ anuario/2008/incidencia/incidencia_casos_nuevos_enfermedad_grupo_edad.pdf.

12. Secretaría de Salud. Incidencia de casos nuevos de Enfermedad por grupos de edad en los Estados Unidos Mexicanos 2014. México, anuarios de morbilidad de la Dirección General de Epidemiología. Disponible en http://www.epidemiologia.salud.gob.mx/ anuario/2014/incidencia/incidencia_casos_nuevos_enfermedad_grupo_edad.pdf.

13. Organización Panamericana de la Salud. Infecciones respiratorias agudas: guía para la planificación de las actividades de control dentro de la atención primaria de salud. OMS, Serie PALTEX para ejecutores de programas de salud. Núm. 17; 1988.

14. Secretaría de Salud. Manual de procedimientos estandarizados para la vigilancia epidemiológica de las enfermedades prevenibles por vacunación. México, Grupo técnico interinstitucional del comité nacional para la vigilancia epidemiológica (CONAVE), Subsecretaría de prevención y promoción de la salud de la Dirección General de Epidemiología; 2012. 


\section{Infecciones respiratorias agudas}

15. Sandy Cairncross, Caroline Hunt, Sophie Boisson, Kristof Bostoen, Val Curtis, Isaac CH Fung, Wolf-Peter Schmidt. Water, sanitation and hygiene for the prevention of diarrhoea. International Journal of Epidemiology 2010; 39:i193-i205. Disponible en: https://oup. silverchaircdn.com/oup/backfile/Content_public/Journal/ije/39/suppl_1/10.1093/ije/ dyq035/2/dyq035.pdf?

16. UNICEF and WHO. Executive summary. Ending Preventable Child Deaths from Pneumonia and Diarrhoea by 2025. The integrated Global Action Plan for Pneumonia and Diarrhoea (GAPPD). United Nations Children's Fund (UNICEF) /World Health Organization (WHO); 2013.

17. Secretaría de Salud. Proyecto de Norma Oficial Mexicana PROY-NOM-NOM-031SSA2-2014, Para la atención a la salud de la infancia. México: Secretaría de Salud. Diario Oficial de la Federación: 25/11/2015; Disponible en http://dof.gob.mx/nota_ detalle_popup.php?codigo=5417151.

18. Organización Panamericana de la Salud. Curso sobre habilidades de supervisión del programa IRA. Atención del niño con Infección Respiratoria Aguda. OMS, Serie PALTEX para técnicos medios y auxiliares. Núm. 21; 1992. 



\section{Tuberculosis}

Mtra. Leticia Ferro Flores

\section{Introducción}

La tuberculosis $(\mathrm{Tb})$ probablemente fue la primera enfermedad infecciosa entre los humanos, ha sido detectada por arqueólogos en reliquias de Egipto, India y China. Su permanencia a través de los siglos continúa como un problema de Salud Pública en todo el mundo. Algunos países habían reducido sus casos, pero la pandemia de SIDA la dirige nuevamente por una tendencia ascendente, principalmente en África, Asia y en varios países de América incluyendo México. En el año 2012: 8.6 millones de personas enfermaron de Tb y 1.3 millones murieron por ésta, siendo así la segunda causa de muerte infecciosa a nivel mundial después del SIDA ${ }^{1}$.

Los casos nuevos antes se asociaban sólo a condiciones de hacinamiento y pobreza pero en los últimos años debemos considerar a otros sujetos susceptibles por ser portadores de enfermedades que se transforman en factores de mayor riesgo, tal como el síndrome de inmunodeficiencia adquirida, la desnutrición, diabetes mellitus, farmacodependencia incluyendo adicciones sociales como el tabaquismo y el alcoholismo ${ }^{2}$. La Organización Mundial de la Salud (OMS) menciona que una cuarta parte de las muertes entre personas afectadas por el VIH se debe a la tuberculosis.

En México Tb ocupa el lugar 22 como causa de mortalidad con cerca de 2,000 decesos por año ${ }^{3}$, afectando a todos los grupos de edad con mayor repercusión en la edad productiva y predominio en hombres a razón 3.8:1. Por su parte, la morbilidad está en promedio de 18,000 casos nuevos por año ${ }^{4}$. Calculando una letalidad del 11\%.

El agente causal Mycobacterium tuberculosis puede invadir cualquier órgano a partir de la afección pulmonar y presentar diversas formas clínicas, simulando síndromes que con frecuencia llevan al diagnóstico tardío de la enfermedad, a la aparición de complicaciones y muerte. Cabe resaltar que otras causas por la cuales no se ha logrado el control de la enfermedad son: el abandono de tratamiento por parte del paciente y la aparición de cepas multirresistentes a los fármacos utilizados. 
Principales problemas de Salud Pública en México

Esta situación ha llevado a las autoridades en salud a discutir y crear diferentes instrumentos que difundan las mejores prácticas y evidencias en el diagnóstico y tratamiento de esta enfermedad, siendo necesario consultar el llamado Catálogo Maestro de Guías de Atención Médica ${ }^{5}$ la Norma Oficial Mexicana NOM-006-SSA2-2013 para la prevención y control de la tuberculosis 6 . El presente material otorga solo un panorama general con el objetivo de motivar a la búsqueda de mayor información, actualización y discusión docente.

\section{Concepto}

$\mathrm{La} \mathrm{Tb}$ es una enfermedad infecciosa y contagiosa producida por el complejo de Mycobacterium (M.) tuberculosis (M. tuberculosis hominis, M. bovis, M. microti, M. canettii, y M. africanum). En México Mycobacterium tuberculosis hominis provoca el 95\% de los casos, M. tuberculosis bovis el $4 \%$ y M. africanum se comporta como oportunista afectando principalmente a pacientes inmunodeprimidos (es causante del $25 \%$ de los casos en África). La enfermedad tiene predominio pulmonar pero puede afectar o diseminarse a cualquier órgano corporal es prevenible y curable, pero de no tratarse conduce a la muerte.

\section{Clasificación}

De acuerdo al órgano afectado se describe en tuberculosis pulmonar ( $\mathrm{TbP}) 81.6 \%$, $\mathrm{Tb}$ meníngea $1.6 \%$, Tb ganglionar $4.7 \%$, Tb renal $1.5 \%$, Tb de piel $0.5 \%$, genitourinaria $0.5 \%$ y Tb otras formas $9.6 \%{ }^{2}$.

Para la Vigilancia Epidemiológica es muy importante registrar y notificar con la siguiente clasificación de los pacientes en: a) Caso nuevo de Tb es aquel paciente que se diagnostica y nunca ha recibido tratamiento antifímico; b) Caso de $\mathbf{T b}$ confirmado, es la persona en quien se identificó por laboratorio el agente causal; c) Caso previamente tratado, se refiere al enfermo que ha recibido al menos un esquema de tratamiento anti tuberculosis por lo menos durante un mes; d) Caso confirmado de $\mathbf{T b}$ multifarmacorresistente es el caso en el que se confirma que las cepas infectantes de M. tuberculosis son resistentes in vitro como mínimo a la isoniacida y a la rifampicina, simultáneamente; e) Contacto es la persona que convive o ha convivido con un enfermo de tuberculosis bacilífero de manera intra o extra domiciliaria y que tiene la posibilidad de contraer la infección; f) Tb latente o infección tuberculosa, se considera a la condición de la persona ya infectada con M. tuberculosis, 


\section{Tuberculosis}

demostrada por su reactividad al derivado protéico purificado (PPD), que no presenta signos y síntomas, ni datos radiológicos compatibles con enfermedad activa y no contagia a otras personas; g) $\mathbf{T b}$ activa personas enfermas cuyo diagnóstico de tuberculosis ha sido comprobado por baciloscopia, cultivo o histopatología reciente; y por último h) Tb extrapulmonar. Para mayor información consultar la Norma Oficial Mexicana7.

\section{Epidemiología}

La OMS, menciona que en 2013 un tercio de la población mundial estaba infectada por el Mycobacterium tuberculosis declarándola una emergencia mundial. En el 2012, cerca de 9 millones de personas en el mundo se enfermaron de tuberculosis, registrando más de 1.5 millones de muertes relacionadas con la tuberculosis. África subsahariana tuvo la mayor tasa de incidencia: más de 255 casos por 100000 habitantes $^{8}$. Con las estrategias propuestas por la OMS y las Naciones Unidas la mortalidad ha disminuido pero no así la morbilidad. En 2012, se estima que 530000 niños menores de 14 años enfermaron de tuberculosis y 74.000 de ellos murieron.

En México de acuerdo al sistema de Vigilancia Epidemiológica de tuberculosis, entre los años 2000 a 2010 el número de casos se ha incrementado con una tendencia ascendente de 16,159 casos a 20,088 ${ }^{9}$. Se presenta en todos los estados de la República Mexicana con una tasa media de incidencia de 17 × 100,000 habitantes. Pero en las entidades federativas con más casos: Veracruz, Baja California y Chiapas supera 50 casos por 100,000 habitantes. En el 2013 para el Distrito Federal se reportaron 777 casos.

De los casos reportados entre 2000-2010 (N=197,212) 52.2\% afectó al grupo de edad 15 a 44 años, $25.4 \%$ a los de 45 a 64 años, $16.4 \%$ mayores de 65 años y el $4.4 \%$ a menores de 15 años.

La tasa nacional de mortalidad es de 2.1 por cada 100,000 habitantes, sin embargo, en Veracruz y Baja California es alrededor de 6 x 100,000. La mortalidad es mayor entre la población productiva, pero la letalidad aumenta en los mayores de 65 años.

Para el año 2012 el Instituto Nacional de Estadística y Geografía (INEGI) reportó 2,253 muertes por todas las formas de Tb. De éstas 1,889 fueron desde un sitio pulmonar, 119 de sistema nervioso, 36 peritoneal, 31 de huesos y articulaciones, 11 genitourinaria y 167 otros sitios. Tan sólo 365 muertes por tuberculosis ocurrieron en hombres de 15 a 44 años y 94 


\section{Principales problemas de Salud Pública en México}

muertes en mujeres en la misma edad ${ }^{10}$. Una razón de 3.8 hombres por una mujer. Entre los hombres de 25 a 44 años ocupa el lugar 15 como causa de muerte y entre las mujeres el lugar $19^{10,11}$.

Las estadísticas muestran una disminución del 45\% en la tasa de mortalidad por tuberculosis entre 1990 y 2012, relacionada con el mayor acceso a los Servicios de Salud y la implementación del Tratamiento Acortado y Estrictamente Supervisado (TAES).

\section{Causalidad}

Descubierta en 1882 por el Dr. Robert Koch. Mycobacterium tuberculosis, es una bacteria aerobia estricta, de la familia mycobacteriacea del orden actinomicetales. El género Mycobacterium produce diversas enfermedades y en éste se distingue al complejo $\mathrm{M}$. tuberculosis con las variedades: M. tuberculosis hominis, M. bovis, M. microti, M canetii y M. africanum. Habitualmente se utiliza el término M. Tuberculosis o bacilo tuberculoso como sinónimo a todas ellas por el método de detección común, la diferenciación es con fines epidemiológicos. Se caracterizan por ser bacterias acido-alcohol resistentes debido al alto contenido de lípidos en su pared, lo que también dificulta que penetren colorantes habituales de anilina y requiere técnicas especiales de tinción (como Ziehl-Neelsen para BAAR) y diferentes cultivos.

Son capaces de sobrevivir durante semanas o meses sobre objetos inanimados, siempre que estén protegidos de la luz solar y son más resistentes a los ácidos, álcalis y desinfectantes que el resto de las bacterias no formadoras de esporas. Resisten la desecación y congelación, pero la luz ultravioleta y el calor mayor a 65 grados centígrados durante 30 minutos las inactiva $^{12}$.

Han sido siglos de lucha para destruir a Mycobacterium tuberculosis, en la década de los 40s con los avances en farmacología se creía tener el tratamiento eficaz, sin embargo por las resistencias se requirió combinar 2 antibióticos, luego 3 y actualmente son 4 los antibióticos que se requieren para tratar la enfermedad. Se calculan aproximadamente 500,000 casos nuevos de resistencia a nivel mundial, cepas resistentes principalmente a isoniazida y rifampicina (de aquí la emergencia epidemiológica). El 0.1\% están presentes en infecciones de primera vez y el $4.3 \%$ en pacientes tratados con esquemas incompletos o con abandono al tratamiento, sobre todo en países con bajos recursos y en pacientes con VIH/SIDA. El 


\section{Tuberculosis}

manejo de la multirresistencia lleva a usar medicamentos con mayores efectos secundarios, más prolongados y algunas veces sin éxito ${ }^{13}$.

Los científicos están ocupados en descubrir los factores de virulencia y resistencia de Mycobacterium tuberculosis y en generar una vacuna más efectiva que la BCG disponible. Refieren contar la secuencia de su genoma completo, pero a diferencia de otras bacterias que producen sus mutaciones a partir de toxinas o proteínas contenidas en el cromosoma bacteriano, en el caso de M. tuberculosis participan también glicolípidos de la pared celular y otros elementos estructurales responsables de las mutaciones y resistencias ${ }^{14}$.

\section{Modo de transmisión}

El mecanismo de transmisión de la Tb es directo por vía aérea a través de las gotitas de Flügge que son partículas expelidas al hablar, toser, estornudar o respirar, miden de 0.5 a 10 micras y pueden permanecer hasta 30 minutos en el aire en suspensión, lo cual les permite ingresar hasta los sacos alveolares. Se llama unidad bacilar a una gota de Flügge que contiene uno a tres bacilos tuberculosos. Como dato curioso este descubrimiento del alemán Carl G.F.W. Flügge en 1890 fundamentó el uso del cubrebocas quirúrgico ${ }^{15}$.

La OMS refiere que un paciente activo sin tratamiento puede infectar de 10 a 15 personas por año ${ }^{9}$ y la probabilidad de infección aumenta a mayor concentración de partículas suspendidas en el aire, la duración y cercanía de la exposición.

El período de incubación, es desde el momento de la infección hasta que aparece la lesión primaria, el que varía de 4 a 12 semanas.

\section{Factores de riesgo}

El riesgo surge al ser contacto cercano o en relación directa con pacientes de TbP activa o sea tuberculosis bacilífera. Como son pocas las bacterias que se expulsan y en condiciones de inmunidad normal aproximadamente el $70 \%$ de las personas pueden limitar el desarrollo del mycobacerium, $10 \%$ de los contactos tienen probabilidad de evolucionar a la enfermedad y 30 a 40\% desarrollarán TbP latente con probabilidad de reactivación futura, por lo que la investigación de contactos es un componente crítico ${ }^{16}$. 


\section{Principales problemas de Salud Pública en México}

Tienen mayor susceptibilidad:

1) Lactantes y niños menores de 4 años.

2) Contactos cercanos familiares o de congregaciones (y otros sitios de concentración).

3) Personas que se encuentran presentes durante procedimientos médicos en personas con $\mathrm{Tb}$ activa.

4) Todas las personas nombradas por el paciente como contacto cercano durante el periodo infeccioso.

Otras características de riesgo en las que se debe realizar búsqueda intencionada son:

1) Niños con bajo peso al nacer (menor a $2 \mathrm{~kg}$ ) con falta de crecimiento o desnutrición.

2) Infección de VIH independientemente de su estado.

3) Otras condiciones de inmunocompromiso.

4) Uso de corticoesteroides sistémicos (prednisona $15 \mathrm{mg}$ por un mes o más).

5) Historia de trasplante de órganos o de otra terapia inmunosupresora.

6) Cambios fibrosos en radiografía de tórax sugestivos de TbP inactiva.

7) Pacientes con neumonía adquirida en la comunidad que no mejora después de 7 días de tratamiento.

8) Comorbilidades como es nutrición, diabetes mellitus tipo 2, VIH, insuficiencia renal y adicciones como el alcoholismo.

9) Hacinamiento. 


\section{Tuberculosis}

Respecto a las comorbilidades son varias las situaciones consideradas "debilitantes" propicias para el desarrollo de la tuberculosis por ejemplo:

- La diabetes mellitus tipo 2 desde 1934 se encontró asociada en el 85\% de los nuevos casos de tuberculosis, en su mayoría por reactivación de un foco primario y explicable por la disfunción de los neutrófilos con alteraciones de la quimiotaxis y de la acción bactericida, aunada al desequilibrio por alteraciones vasculares (microangiopatía). En Jalisco se realizó una búsqueda intencionada de tuberculosis en pacientes diabéticos, ${ }^{17}$ encontrando que la mayoría de casos eran pacientes con más de 30 años de edad, sobrepeso u obesidad y descontrol glucémico, con un promedio de 7 años de enfermedad. El descontrol también aumentó las recaídas de Tb. El riesgo de tuberculosis es así 3.1 veces más veces en los diabéticos que entre los no diabéticos con un riesgo atribuible del 20\% ligeramente menor al atribuido por el virus de la inmunodeficiencia humana. Por todo lo anterior, se recomienda una búsqueda intencionada en pacientes diabéticos aún sin ser tosedores.

- $\quad$ El VIH/SIDA tiene áreas de alta prevalencia que están encontrando coincidencia con el incremento de $\mathrm{Tb}$. La OMS reporta 1.1 millones de pacientes que tienen al tiempo ambas enfermedades y el 70\% están en África. En América los países que reportan más casos son Barbados, Haití, Guatemala y Brasil con alta mortalidad, una de cada 3 personas con SIDA muere por Tb. La supresión de inmunidad celular determina el desarrollo de mycobacterium, la Organización Panamericana de la Salud (OPS) refiere que el $90 \%$ de inmunocompetentes quedarán con primoinfección y sólo el 10\% desarrollan la enfermedad tuberculosa. ${ }^{18}$ Siendo las formas extrapulmonares como la ganglionar más frecuentes en personas con VIH. Se ha encontrado que la tuberculosis no tiene que esperar una disminución de linfocitos CD4, el virus encuentra una sinergia y la carga viral se acelera hasta 30\% más rápido hacia SIDA en presencia de tuberculosis. $\mathrm{Al}$ aumentar los casos Tb/SIDA aumenta también el riesgo de transmisión de $\mathrm{Tb}$. La tos en personas VIH siempre debe ser investigada y tomar en cuenta que la prueba PPD en pacientes con SIDA puede ser negativa.

- El cáncer broncogénico y tuberculosis en el adulto mayor frecuentemente se detectan en forma simultánea cuando se sospechan en forma temprana y no se dejan pasar como sólo enfermedad pulmonar obstructiva crónica, aquí todo tosedor crónico debe contar con laboratorio intencionado. Además de baciloscopias positivas las cavernas pulmonares a la radiología tienen bordes irregulares. 


\section{Principales problemas de Salud Pública en México}

- Embarazo, aun cuando el embarazo no es un factor de riesgo para que se presente la $\mathrm{Tb}$, se debe tomar en cuenta, porque como se mencionó la tuberculosis afecta a la población en edad productiva y reproductiva en todo el mundo y la identificación de casos en mujeres embarazadas debe ser intencionada para disminuir la mortalidad de la mujer en esta etapa, donde $\mathrm{Tb}$ contribuye como causa no materna con un 14\%. En la población infantil es rara la tuberculosis congénita por transmisión hematógena vía placentaria o por diseminación de un foco endometrial; no produce malformaciones congénitas, la afección del feto está en relación con la salud materna incrementando la prematurez y el bajo peso, algunos presentarán hepatomegalia, dificultad para alimentarse, lesiones en la piel o linfadenopatías. La mortalidad del recién nacido es mayor por la transmisión aérea del bacilo ante el contacto estrecho con la madre. La leche materna no contiene bacilos y no está contraindicada en mujeres que ya reciben antifímicos porque los niveles de éstos en la leche son muy bajos ${ }^{19}$. Un tratamiento adecuado alcanza una tasa de curación para el binomio del $90 \%$.

Factores de riesgo para tuberculosis resistente:

1) Fracaso a los re-tratamientos

2) Casos crónicos

3) Exposición a un caso conocido de tuberculosis resistente

4) Fracaso a tratamiento primario

5) Fracaso de tratamiento en el sector privado

6) Pacientes que persisten con baciloscopía positiva al segundo o tercer mes de tratamiento

7) Recaída o regreso después de incumplimiento terapéutico sin fracaso a tratamiento reciente

8) Exposición en instituciones donde hay brotes o alta prevalencia de tuberculosis resistente 


\section{Tuberculosis}

9) Residencia en zonas de alta prevalencia de $\mathrm{Tb}$ multirresistente (MDR)

10) Antecedente de uso de fármacos antituberculosis de calidad deficiente o desconocida

11) Tratamiento en programas que funcionan mal

12) Algunos casos de VIH

\section{Fisiopatología}

La infección primaria ocurre a nivel pulmonar, puede ser inicialmente asintomática mientras sigue su reproducción sin impedimentos o evolucionar a una lesión granulomatosa en la que participan macrófagos, fibroblastos y linfocitos conteniendo el desarrollo de mycobacterium en el centro del granuloma. Esta llamada primoinfección o complejo primario puede mantener aislada a la bacteria por tiempo indefinido, evolucionar a fibrosis y calcificación (complejo de Ghon), o reactivarse y permitir su diseminación a ganglios y de vía hematógena hacia cualquier sitio del cuerpo.

E1 93\% de los enfermos de tuberculosis son casos nuevos y el resto se consideran recaídas ${ }^{9}$, siendo la tuberculosis pulmonar crónica es la forma más frecuente de una reinfección endógena, aquí el tejido pulmonar sufre necrosis caseosa que al desprenderse deja cavernas con lesiones capilares y se manifiesta la hemoptisis.

\section{Cuadro clínico}

La infección puede pasar inadvertida en las primeras semanas y seguir la evolución pulmonar o pasar a las formas extrapulmonares. La manifestación pulmonar inicial es la tos productiva seguida con fiebre de predominio vespertino de una a dos semanas acompañada de anorexia, astenia, ataque al estado general, sudoración nocturna, pérdida de peso, hemoptisis y disnea. La exploración física aportará datos sólo en los casos avanzados cuando las cavernas estén condicionando dolor pleurítico, estertores apicales finos seguidos de tos, obstrucción traqueobronquial por hempotisis, hasta la insuficiencia respiratoria en etapa tardía de la enfermedad. Por esto, tan sólo la tos de más de dos semanas debe generar sospecha de tuberculosis pulmonar. 


\section{Principales problemas de Salud Pública en México}

Sintomático respiratorio (SR), es toda persona con tos y expectoración o hemoptisis, sin importar el tiempo de evolución. En niñas y niños tos con o sin expectoración durante dos o más semanas.

La tuberculosis miliar o Tb diseminada por vía hematógena, por lo que es sistémica. Se presenta en el $3 \%$ de los casos y más frecuente en niños menores de 2 años. ${ }^{20}$ Es característico un infiltrado micronodular difuso que en la radiografía de tórax recuerda el milium (mijo o maicillo). En algunos casos de inmunosupresión severa, la radiografía puede parecer normal por falta de respuesta inflamatoria.

Frecuentemente un derrame pleural aislado puede ser la primera manifestación de una tuberculosis primaria.

\section{Complicaciones}

Las formas extrapulmonares a excepción de la laríngea no se contagian, pero en su mayoría conducen a complicaciones mortales las cuales aparecen principalmente durante el primer año, pero también pueden surgir al reactivarse el cuadro en la adolescencia o en el adulto joven.

Tuberculosis ganglionar es la presentación más frecuente extrapulmonar. Afecta principalmente las cadenas cervicales anteriores y posteriores (menos frecuente axilares y mediastinales) con pocos síntomas sistémicos. Es ascendente a partir de los ganglios paratraqueales e hiliares donde llegan macrófagos conteniendo bacilos que se reproducen con rapidez en su interior. Si no se genera la lesión granulomatosa y calcificación, los ganglios paratraqueales aumentan de tamaño, toman contornos irregulares, a menudo establecen conexiones lineales con el ganglio ipsilateral y en el $15 \%$ de los casos se disemina bilateralmente.

Se caracteriza así por adenopatía palpable, indolora, consistencia firme, que evoluciona a ulcera, hacia una fístula o degenera en una cicatriz característica llamada escrófula. La escrofulosis son lesiones tuberculosas típicas de la piel, mucosas y huesos. La tuberculosis ganglionar puede reactivarse aún en pleno tratamiento, pueden contener pocas bacterias por lo que su diagnóstico diferencial es por biopsia ${ }^{21}$. 


\section{Tuberculosis}

Tuberculosis meníngea afecta principalmente a lactantes y niños pequeños. La propagación a meninges es vía hematógena o por ruptura de un tuberculoma cerebral, los primeros síntomas son cefalea, malestar general fiebre y meningismo, vómito, confusión y signos neurológicos focales. La parálisis de pares craneales comúnmente afectados III, IV y VI. Los tuberculomas producen hidrocefalea, hipertensión endocraneana, déficit neurológico focal y convulsiones.

La tuberculosis miliar o diseminada vía hematógena es una complicación sistémica. Se presenta en el $3 \%$ de los casos y más frecuente en niños menores de 2 años ${ }^{20}$. Es característico un infiltrado micronodular difuso que en la radiografía de tórax recuerda el milium (mijo o maicillo). En algunos casos de inmunosupresión severa, la radiografía puede parecer normal por falta de respuesta inflamatoria.

Tuberculosis pleural y pericárdica. Frecuentemente un derrame pleural o pericárdico aislados pueden ser la primera manifestación de una tuberculosis primaria. Los signos de insuficiencia cardiaca y respiratoria agudos conducen a estudios de laboratorio y gabinete dónde tuberculosis es el principal diagnóstico diferencial.

Tuberculosis cutánea. Es poco frecuente, el bacilo puede llegar a la piel desde una lesión traumática formando el chancro o verruga (exógena) o por diseminación hematógena (endógena) y el cuadro clínico está determinado por la interacción entre la cantidad, la virulencia y resistencia de la piel a las mycobacterias. Tiene diversas variedades clínicas como escrofuloderma, abscesos tuberculosos o úlceras periorificiales. El diagnóstico es por biopsia.

La tuberculosis abdominal puede ser gastrointestinal, mesentérica, peritoneal o genitourinaria. La manifestación clínica puede ser simplemente una masa abdominal y evolucionar a un cuadro abdominal agudo, con mayor frecuencia afecta los ganglios mesentéricos y el intestino delgado que se disemina a peritoneo produciendo ascitis y hepatomegalia además de la fiebre, pérdida de peso, dolor abdominal inespecífico o diarrea. El diagnóstico puede hacerse por estudio del líquido de ascitis o durante laparatomía exploradora. La ultrasonografía puede mostrar ganglios mesentéricos y retroperitoneales aumentados de tamaño. 


\section{Principales problemas de Salud Pública en México}

\section{Diagnóstico}

Se reportan varios métodos de diagnóstico: baciloscopía, cultivo, radiológico, prueba de tuberculina, técnica de reacción de polimerasa, estudio histopatológico, búsqueda de contactos (epidemiológico y clínico-epidemiológico) y clínico. Del total de casos de 2000 a 2010 en el 73\% el diagnóstico fue por baciloscopía, seguido por radiología en el 10.9\% de los casos y $6.8 \%$ histopatológico.

1. Baciloscopía (técnica de Ziehl Neelsen) tiene una alta sensibilidad (51.8\%) y especificidad (97.5\%):

- Debe realizarse en todos aquellos pacientes con tos y expectoración por más de 2 semanas

- En todo paciente que no ha recibido fármacos antituberculosis

- Mensualmente durante el tratamiento para vigilancia(identificar a los pacientes con mayor riesgo de transmitir la enfermedad) y al término del tratamiento para evidenciar curación o fracaso

- Se realiza en serie de 3 muestras de esputo

- Si se toma en 2 días consecutivos debe refrigerarse y enviarse antes de 24 horas al laboratorio.

- Puede inducirse la expectoración por aerosol de solución salina isotónica o hipertónica durante 5 a 15 minutos.

2. Cultivo, está indicado:

- En caso de baciloscopía negativa, para identificar la cepa, para el diagnóstico cuando persiste sospecha

- Diagnóstico y seguimiento del tratamiento de pacientes previamente tratados 


\section{Tuberculosis}

- Casos nuevos en tratamiento, cuya baciloscopía persiste positiva al segundo mes de tratamiento

- En pacientes VIH positivo, en algunas circunstancias especiales

3. Diagnóstico radiológico:

- En su forma inicial no existe algún signo patognomónico específico, con frecuencia la primoinfección no está calcificada

- Lesiones radiológicas sugestivas como neumonitis con manchas, fibrosis y calcificación deben complementarse con estudios microbiológicos.

- La cavernas suelen tener una pared moderada gruesa y una superficie interior lisa sin niveles hidroaéreos, se acompaña de sombras acinares pequeñas múltiples (diseminación endobronquial).

4. Prueba de Tuberculina (PPD):

Se aplica Derivado Protéico Purificado de bacilo tuberculoso en la cara anterior del antebrazo y se considera positiva con una induración de más de $10 \mathrm{~mm}$ de diámetro. Pero también puede ser considerada positiva con $\geq 5 \mathrm{~mm}$ con alguna de las siguientes características:

- Contacto estrecho con un caso de TB activo

- Co-infección con VIH independientemente de su estado

- Otras condiciones de inmunocompromiso

- Uso de corticoesteroides sistémicos (prednisona 15 mg por un mes o más)

- Historia de trasplante de órganos o de otra terapia inmunosupresora

- Cambios fibrosos en radiografía de tórax sugestivos de TBP inactiva. 


\section{Principales problemas de Salud Pública en México}

- Radiografía o hallazgos clínicos de TB activa

Bajo las mismas características, si la prueba de la tuberculina es negativa, se puede realizar una segunda entre 1 y 3 semanas después. Si la segunda es negativa la persona se considera no infectada (según la Norma Oficial Mexicana pero el Hospital General de México reporta de 10 a 17\% de los pacientes activos de tuberculosis con PPD negativo). Si la segunda prueba es positiva, el paciente debe clasificarse como infectado para iniciar manejo antifímico.

5. La técnica de reacción de polimerasa (PCR):

Es muy rápida, se puede obtener en 10 horas el resultado. La sensibilidad es del 97\% para detectar micobacterias en esputo aún en cultivos negativos, pero no debe utilizarse para la monitorización del tratamiento.

6. Búsqueda de contactos:

- La búsqueda se debe realizar a todo paciente sin importar el motivo de demanda en poblaciones de alto riesgo y principalmente entre los contactos de un caso de tuberculosis y en grupos poblacionales de riesgo.

7. El Clínico ya se describió anteriormente.

En su mayoría los pacientes acuden a Servicios de Salud y ahí se establece el diagnóstico pero también la Secretaría de Salud ha implementado búsquedas activas en grupos cautivos como reclusorios, escuelas, asilos, casa por casa, o utilizando laboratorio móvil.

\section{Terapéutica}

La tuberculosis es una enfermedad que se puede tratar y curar si el paciente toma correctamente el tratamiento. La forma activa que es sensible solo a la combinación de antibióticos hace algunos años bastaba con 3, actualmente son cuatro medicamentos durante seis meses junto con información, supervisión y apoyo del paciente por un agente sanitario o un voluntario capacitado. Si no se proporcionan supervisión y apoyo, el cumplimiento terapéutico puede ser difícil y como consecuencia, la infección puede propagarse. Desde 


\section{Tuberculosis}

1995, gracias a ésta estrategia recomendadas por la OMS se calcula que se han salvado unos 22 millones de vidas.

Tratamiento primario Acortado, Estrictamente Supervisado (TAES). Tiene dos fases: una intensiva por 10 semanas y otra de sostén durante 15 semanas.

Un esquema calculado para un adulto de $50 \mathrm{Kg}$ de peso o más es:

\begin{tabular}{|l|l|l|}
\hline 1.- Fase intensiva & \multicolumn{2}{|l|}{$\begin{array}{l}\text { Diario de lunes a sábado } 10 \text { semanas hasta completar } 60 \text { dosis . } \\
\text { En una sola toma. }\end{array}$} \\
\hline Medicamentos: & $\begin{array}{l}\text { Separados } \\
\text { (dosis) }\end{array}$ & $\begin{array}{l}\text { Combinación fija de } 4 \text { grageas juntas } \\
\text { diarias por } 60 \text { días }\end{array}$ \\
Rifampicina & $600 \mathrm{mg}$ & $150 \mathrm{mg}$ \\
Isoniacida & $300 \mathrm{mg}$ & $75 \mathrm{mg}$ \\
Piracinamida & $1,500 \mathrm{mg}$ a 2,000 mg & $400 \mathrm{mg}$ \\
Etambutol & $1,200 \mathrm{mg}$ & $400 \mathrm{mg}$ \\
\hline 2.- Fase de sostén & $\begin{array}{l}\text { Intermitente: Una dosis 3 veces por semana, lunes, miércoles y } \\
\text { viernes, por 15 semanas hasta completar 45 dosis. Una sola toma. }\end{array}$ \\
& $\begin{array}{l}\text { Separados } \\
\text { (dosis) }\end{array}$ & $\begin{array}{l}\text { Combinación fija de } 4 \text { grageas juntas } \\
\text { diarias por 45 días }\end{array}$ \\
\hline Medicamentos: & 150 mg \\
Rifampicina & $600 \mathrm{mg}$ & $200 \mathrm{mg}$ \\
Isoniacida & $800 \mathrm{mg}$ & \multicolumn{2}{|l}{} \\
\hline
\end{tabular}

En México de los pacientes diagnosticados el 90\% inició con tratamiento primario acortado, $7.5 \%$ ya habían recibido tratamiento previo y se les indico tratamiento individualizado sólo el $0.5 \%$ fueron sospechosos de farmacorresistencia.

La tuberculosis multirresistente (tuberculosis MR) es un tipo de tuberculosis que está presente en prácticamente la totalidad de los países estudiados por la OMS. La principal causa de la multirresistencia es el uso inapropiado o incorrecto de los medicamentos antituberculosos.

En 2012 la OMS registró 450000 casos de tuberculosis MR. En algunos casos, un tratamiento incorrecto puede dar lugar a un tipo de tuberculosis ultrarresistente (tuberculosis XR) y este tipo de tuberculosis responde a un número aún menor de los medicamentos disponibles. 


\section{Medidas de prevención}

\section{Promoción a la Salud:}

- Promover el desarrollo de hábitos nutricionales saludables, de acuerdo con las posibilidades y características de las regiones donde habitan

- Proporcionar información respecto a qué es la tuberculosis, reconocer los factores de riesgo que facilitan su aparición, el modo de transmisión, las acciones para prevenirlas y tratarla. Actualmente se cuenta con revistas que proporcionan información básica para distribuir a los pacientes como en la revista JAMA ${ }^{22}$ o en Instituto para la Educación del Paciente ${ }^{23}$ así como su impacto social y económico en la salud individual, familiar y comunitaria.

- Sensibilizar al personal de salud y a la población sobre la importancia de la vacuna BCG y al enfermo de tuberculosis de la importancia del estudio de todas aquellas personas con quienes convive de manera cotidiana.

- Garantizar que el paciente comprenda la importancia de seguir su tratamiento en forma ininterrumpida hasta terminarlo

- Promover la participación de la comunidad para que colaboren en la localización de tosedores en su comunidad y asegurar la adherencia ininterrumpida al tratamiento.

Protección Específica:

- La vacuna BCG de aplica desde recién nacido y brinda protección aproximadamente de $80 \%$ contra las formas graves de tuberculosis como la miliar y en especial la meningitis tuberculosa², se aplica en la mayoría de los países.

- Puede ser de utilidad en donde hay cepas resistentes a fármacos, para evitar los casos severos.

- Descripción de la vacuna, está constituida por bacilos atenuados de Mycobacterium bovis. Siguiendo la técnica de cultivo y subcultivo de cepas desecadas de bacilos de 


\section{Tuberculosis}

Calmette-Guerin. (hay por lo menos 5 cepas disponibles en México). La vacuna se presenta en una ampolleta ámbar de $1 \mathrm{mg}$ de liofilizado (10 dosis) y una ampolleta con 1 $\mathrm{ml}$ de solución isotónica (diluyente). Existen varios tipos de frascos según el fabricante. Pero siempre debe mantenerse a una temperatura entre 2 y 8 grados centígrados en los refrigeradores y entre 4 y 8 grados en los termos para actividad de campo. Los frascos abiertos y los llevados a campo aun cuando no fueron abiertos se desechan al final de la jornada (consultar el manual de vacunación para detalles de reconstrucción y cuidados de la vacuna).

- Aplicar $0.1 \mathrm{ml}$ (una décima de mililitro) en el brazo derecho región deltoidea con el bisel de la aguja hacia arriba, en un ángulo de $15^{\circ}$, e introducirla longitudinalmente para vía intradérmica estricta (el bisel debe verse a través de la piel) introducir la vacuna lentamente. Debe formarse una pápula de aspecto parecido a la cáscara de la naranja. Retirar estirando la piel para perder la luz del orificio que dejo la aguja e impedir que salga la vacuna (No dar masaje en el sitio de la aplicación).

- Se debe explicar a la madre o familiar del niño lo siguiente: La pápula desaparecerá media hora después de la aplicación, posteriormente aparecerá una mácula (mancha roja) durante la primera semana y se endurece durante la segunda semana, entre la $4^{\mathrm{a}}$ y $6^{\mathrm{a}}$ semana aparecerá un nódulo. El nódulo en ocasiones se abre (úlcera) y deja escapar serosidad. Solo lavar con agua y jabón no presionar. La costra aparecerá entre $6^{\mathrm{a}}$ y $12^{\mathrm{a}}$ semanas, al secarse cae dejando generalmente una cicatriz que dura toda la vida. Sólo 1 a $6 \%$ de los vacunados pueden presentar linfadenitis (en el curso o hasta 6 meses posteriores a la vacunación y en los que se aplicó subcutánea y no intradérmica), por lo general se autolimita no requiriendo antifímicos ni tx quirúrgico, pero debe ser vigilado.

- La vacuna está indicada en recién nacidos con peso mayor a 2 kilogramos y hasta menores de 14 años que no hayan sido vacunados o no se les compruebe la vacunación.

- Está contraindicada en padecimiento febriles mayores de $38.5^{\circ} \mathrm{C}$, en recién nacidos con peso inferior a $2 \mathrm{Kg}$, en afecciones cutáneas en el sitio de la aplicación, en enfermos con leucemia (excepto si ya suspendieron tratamiento inmunosupresor) linfoma y quienes reciben inmunosupresores. Pacientes con cuadro clínico de SIDA (la afección 


\section{Principales problemas de Salud Pública en México}

asintomática por VIH no es contraindicación. Personas que hayan recibido transfusiones o inmunoglobulinas deben esperar por lo menos 3 semanas para ser vacunados. No aplicar durante el embarazo. (La vacuna puede aplicarse aún con catarro común o diarrea).

\section{Referencias}

1. Organización Mundial de la Salud. Estadísticas sanitarias mundiales. Informe 2013 (http://www.who.index.html). Suiza: OMS; 2014

2. Dávila LY. Tuberculosis. Panorama epidemiológico 2000-2010. En: Suplemento informativo. Año 1, núm. 10. Epidemiología en breve. Dirección General de Epidemiología. Boletín Epidemiológico. México: 2011.

3. INEGI. Estadísticas de mortalidad Estados Unidos Mexicanos. México: INEGI; 2012.

4. Dirección General de Epidemiología. Boletín Epidemiológico. México; 2014.

5. Secretaría de Salud. Catalogo Maestro de Guías de Práctica Clínica. México: SSA; 2014.

6. Norma Oficial Mexicana NOM-006-SSA2-2013, para la prevención y control de la tuberculosis. Diario Oficial de la Federación 10-09-2013. Disponible en: www.dof. gob.mx

7. Norma Oficial Mexicana NOM-006-SSA2-2013, Para la prevención y control de la tuberculosis publicada en el Diario Oficial de la Federación. www.dof.gob.mx

8. Organización Mundial de la Salud. Estadísticas sanitarias mundiales. Informe 20132014 Suiza, 2014. Disponible en http://www.who.int/gho/publications/world_health_ statistics/.pdf

9. SINAVE/DGE/Salud. Plataforma de tuberculosis y base de datos 2000-2010. Disponible en: http://www.sinave.gob.mx

10. INEGI. Estadísticas de mortalidad Estados Unidos Mexicanos. 2012. Disponible en: http://www.inegi.org.mx

11. Dirección General de Información en Salud (DGIS). Base de datos de egresos hospitalarios por morbilidad en Instituciones Públicas, 2004-2007. [en línea]: Sistema Nacional de Información en Salud (SINAIS). [México]: Secretaría de Salud. <http:// www.sinais.salud.gob.mx> 


\section{Tuberculosis}

12. Dorronsoro L. Torroba. Microbiología de la tuberculosis. An Sist Sanit Navarra España. 2007; 30 (Sup. 2):67-85.

13. Alcaide F, Santín M. Tuberculosis multirresistente. Enfermedades Infecciosas y Microbiología Clínica. 2008; 26(Sup13):54-60.

14. Borrero, Álvarez, Reyes, Sarmiento, Acosta. Mycobacterium tuberculosis: factores de virulencia. Instituto Finlay. Centro de Investigación. Producción de vacunas. VacciMonitor 2011; 20(1):34-38.

15. Murillo Godines G. Las gotitas de Flügge. Rev Med Inst Mex Seguro Social. 2009; 47(3):290.

16. Secretaría de Salud. Catálogo maestro de Guías de Práctica Clínica. Prevención Diagnóstico y Tratamiento de la Tuberculosis Pulmonar en pacientes mayores de 18 años. México, 2010. http://www.cenetec.salud.gob.mx/interior/catalogoMaestroGPC.html

17. Contreras Gómez, et al. Prevalencia de Tuberculosis en grupos vulnerables: adultos con diabetes mellitus tipo 2 en seis unidades de atención primaria en Jalisco. Dirección General de Epidemiología. Suplemento Informativo. 2011; 1(3):66-80.

18. OPS. Coinfección TB/VIH: Guía Clínica actualizada 2010.

19. Morales CD. Tuberculosis en embarazo y repercusiones neonatales. Revista Médica de Costa Rica y Centroamérica. 2013; LXX(606):319-323,

20. Guías Diagnósticas de Neumología. México: Hospital General de México; 2010.

21. Hernández S. Unidad de Neumología. México: Hospital General de México; 2010.

22. American Medical Association. Hojas para el paciente JAMA, 6 de marzo de 2013Vol. 309, núm. 9. USA, 2013

23. Instituto para la Educación del Paciente. España, 2014. Disponible en: http://www.nlm. nih.gov/medlineplus/spanish/tutorials/tuberculosisspanish

24. Secretaría de Salud. Manual de Vacunación 2008-2009. Catálogo Maestro. México: SSA; 2010. 



\section{Cirrosis hepática}

Mtra. Marisela Torres Vaca

\section{Introducción}

La cirrosis hepática $(\mathrm{CH})$ ocupa el tercer lugar de mortalidad en nuestro país primordialmente en las edades productivas, siendo las principales causas de este problema el alcoholismo, la hepatitis B y C, y la cirrosis biliar en mujeres. Implica gasto importante en el sector salud, en el ingreso familiar y que además afecta a la dinámica familiar y laboral. Esta entidad patológica es una complicación que se puede evitar por prevención relacionada con hábitos y costumbres como prescindir de la ingesta de alcohol, buena nutrición y vacuna.

\section{Concepto}

La cirrosis es una enfermedad crónica difusa e irreversible del hígado, caracterizada por la presencia de fibrosis y por la formación de nódulos de regeneración, que conducen a una alteración de la arquitectura vascular, así como de la funcionalidad hepática ${ }^{1}$. También es llamada insuficiencia hepática crónica y puede presentarse como la etapa final de enfermedades hepáticas de diferentes causas ${ }^{2,3}$.

\section{Clasificación}

La $\mathrm{CH}$, se encuentra en la Clasificación Internacional de Enfermedades (CIE-10), en el capítulo XI, denominado "Enfermedades del sistema digestivo", con la clave K.74 Fibrosis y cirrosis del hígado 4 . También se puede clasificar de acuerdo a la etiología, a la compensación del organismo y de acuerdo a sus etapas clínicas ${ }^{1,2,3}$.

a) La CH se acuerdo con la etiología, se clasifica en:

- Cirrosis alcohólica

- Cirrosis no alcohólica:

- Cirrosis posthepatits. 
- Cirrosis con esteatorrea.

- Cirrosis autoinmune.

- Otras.

Otra clasificación etiológica

- Metabólica-tóxica.

- Infecciosa.

- Autoinmune.

- Inducida por fármacos.

- Genético-hereditaria.

- Enfermedades biliares.

- Vascular.

- Criptogénica.

b) De acuerdo a la compensación del organismo:

- Cirrosis estable. El 60\% de pacientes con cirrosis estable desarrollarán ascitis en los siguientes 10 años 5 .

- Cirrosis inestable. La ascitis el signo que marca la descompensación.

c) De acuerdo con las etapas clínicas (ausencia o presencia de complicaciones) acordadas en el BAVENO IV (Consenso Metodológico sobre Diagnóstico y Tratamiento de la Hipertensión Portal $)^{6}$ :

- Etapa 1. Ausencia de várices y ascitis. 


\section{Cirrosis hepática}

- Etapa 2. Várices esofágicas sin ascitis ni sangrado.

- Etapa 3. Ascitis con o sin várices.

- Etapa 4. Hemorragia gastro-intestinal con o sin ascitis.

\section{Epidemiología}

Se estima que cada año en el mundo suceden más de un millón de muertes, a consecuencia de la CH. En México, según Kershenobich, en 2005, la mortalidad por CH, escila de 11.6 a 47.4 por 100000 habitantes, con la mayor tasa en el centro del país y que el promedio de edad de presentación es de $50.3 \pm 12.0$ años $^{7}$.

La CH en México, desde 1998 hasta el año 2015, ha ocupado el 5. lugar como causa de mortalidad general. Por sexo, en 2003 representó la tercera causa de muerte en hombres después de isquemia cardíaca y la diabetes mellitus. Para ese mismo año, en el caso de mujeres ocupó el 8. ${ }^{\circ}$ lugar y el hepatocarcinoma secundario a $\mathrm{CH}$ fue el tercer tumor maligno más frecuente precedidos del cáncer cérvico-uterino y cáncer de mama². La Mortalidad por enfermedades generales del hígado en México es mayor a partir de la tercera década de la vida ${ }^{8,9}$. En el año 2015, las enfermedades de hígado ocuparon el $5^{\circ}$ lugar como causa de mortalidad general (para hombres el $5^{\circ}$ y para las mujeres el $6^{\circ}$ ) y por grupo de edad es variable (Cuadro 1$)^{9}$.

Cuadro 1. Mortalidad por grupo de edad, sexo y lugar que ocupan las Enfermedades del Hígado, México 2015.

\begin{tabular}{|c|c|c|c|}
\hline EDAD & General & Hombres & Mujeres \\
\hline $15-24$ & $15 .^{\circ}$ & $11 .^{\circ}$ & $15 .^{\circ}$ \\
\hline $25-34$ & $7 .^{\circ}$ & $6 .^{\circ}$ & $13 .^{\circ}$ \\
\hline $35-44$ & $4 .^{\circ}$ & $3 .^{\circ}$ & $5 .^{\circ}$ \\
\hline $45-64$ & $4 .^{\circ}$ & $5 .^{\circ}$ & $4 .^{\circ}$ \\
\hline 65 Y MÁS & $6 .^{\circ}$ & $6 .^{\circ}$ & $7 .^{\circ}$ \\
\hline TOTAL & $5 .^{\circ}$ & $5 .^{\circ}$ & \\
\hline
\end{tabular}




\section{Principales problemas de Salud Pública en México}

La $\mathrm{CH}$ ha ido escalando peldaños como causa de mortalidad y ha sido la primera causa de internamiento a los servicios de gastroenterología en los principales hospitales del País?.

La prevalencia de cirrosis en el mundo varía desde tres hasta 250 por cada 100,000 habitantes y predomina en varones ${ }^{1,10,11}$. Fue la primera causa de internamiento en el servicio de gastroenterología del Hospital Juárez de México en una revisión retrospectiva en el año 2008. Y los Estados con mayor prevalencia fueron los de la parte central del País: Hidalgo, Puebla, Tlaxcala, Estado de México y Distrito Federal ${ }^{11}$.

El 60\% de pacientes con cirrosis compensada desarrollan ascitis en los siguientes 10 años ${ }^{5}$, lo que da inicio a la descompensación con deterioro gradual de la calidad de vida del individuo, afectación laboral y económica así como el desajuste en la dinámica familiar. Estos pacientes tienen un riesgo de mortalidad del $20 \%$ y del $57 \%$ en un año cuando existe hemorragia ${ }^{6}$.

\section{Causalidad}

La causa principal que origina la $\mathrm{CH}$ es el consumo de alcohol seguida por hepatitis viral y finalmente otros tipos de cirrosis no alcohólica ${ }^{1,2,7,10,11,12}$.

\section{$>$ Cirrosis alcohólica}

El alcohol causa más del $50 \%$ de las cirrosis ${ }^{11}$, generalmente en pacientes con un consumo excesivo y prolongado, no parece depender del tipo de bebida, más bien de la concentración de alcohol reportándose cifras de 50 a 80 gr/día ingeridos en forma continua por lo menos durante cinco años ${ }^{1}$, otros autores indican 40-60 gr/día por 20 años ${ }^{2,13}$. Aunque solo el 12\% al 15\% de pacientes que padecen alcoholismo desarrollarán cirrosis, el alcoholismo resultó ser la causa desencadenante de cirrosis en casi la mitad de pacientes cirróticos ${ }^{10}$.

El alcoholismo tiene una gran prevalencia no solo a nivel nacional, sino mundial, por ejemplo en Hungría en los inicios del siglo XXI la prevalencia fue de 19\% en hombres hospitalizados por alguna razón y $2 \%$ para mujeres ${ }^{14}$. En México de acuerdo a la Encuesta Nacional de Salud 2012 la prevalencia del consumo de alcohol es de aproximadamente el $25 \%$ en adolescentes, siendo mayor en el sexo masculino, sin haber cambios significativos del 2000 al 2012, por el contrario, en mayores de 20 años el consumo de alcohol se ha disparado del $40 \%$ en 2000 al $54 \%$ en $2012^{15}$, reporte similar existe en estudiantes de una 


\section{Cirrosis hepática}

preparatoria en el Estado de México ${ }^{16}$ en otro estudio el $40.8 \%$ de jóvenes refirió haber ingerido bebidas alcohólicas en el último mes $^{17}$.

$>$ Cirrosis no alcohólica

a) Secundaria a hepatitis viral

Las hepatitis B y C son las causas principales ${ }^{11}$, el $20 \%$ de estas hepatitis desarrollarán cirrosis después de aproximadamente 5 años en caso de hepatitis B y hasta 20 años en caso de la hepatitis C. En México entre 2000 y 2007 el 79\% de las hepatitis reportadas fue de tipo A, 3.3\% de tipo B, 6\% al tipo $C^{18}$. El Hospital General de México, entre 2006 y 2007 detectó cerca del 1 y $2 \%$ de nuevos casos de hepatitis $C$. Este tipo de hepatitis ha sido considerado como un problema de Salud Pública,19. Estas hepatitis evolucionan hacia la cronicidad en 65 a 85\% de los casos. Aproximadamente el 50\% de cirrosis hepáticas son secundarias a hepatitis crónicas $\mathrm{B}$ y $\mathrm{C}^{7,20}$. Por lo que las infecciones crónicas por virus de hepatitis $\mathrm{B}$ y $\mathrm{C}$ se consideran de alto riesgo, recomendándose la vigilancia estrecha en el servicio de gastroenterología en segundo y tercer nivel².

\section{b) Otras cirrosis no alcohólicas}

Después de los 50 años las causas de cirrosis son coledocolitiasis y tumores del páncreas y vías biliares ${ }^{21}$. La esteatohepatitis no alcohólica puede alcanzar el $20 \%$ de las cirrosis o más ${ }^{22}$. La prevalencia del hígado graso no alcohólico se ha duplicado en los últimos 20 años, en cambio la de otras enfermedades hepáticas crónicas se ha mantenido estable o inclusive han disminuido ${ }^{23}$. En el sexo femenino la causa más frecuente de cirrosis es la litiasis, la hepatitis crónica autoinmune y cirrosis biliar primaria, la colestasis del embarazo y anticonceptivos. En el hombre predomina la hepatitis B y la colangitis esclerosante ${ }^{1,11,21}$.

Otras causas ${ }^{1,2}$ son los trastornos hereditarios como hemocromatosis, una sobrecarga hepática de hierro en forma de hemosiderina, que ocasiona la muerte del hepatocito e incrementa la síntesis de colágeno, la enfermedad de Wilson carácter autosómico recesivo, caracterizada por afectar a la ceruloplasmina, proteína que se encarga del transporte de cobre en el plasma; este fallo en la proteína transportadora origina la acumulación del mineral en diversos órganos, entre ellos el hígado, produciendo una cirrosis macronodular, $\mathrm{y}$ menos frecuente por: 


\section{Principales problemas de Salud Pública en México}

- Colestasis prolongadas, intra o extrahepáticas.

- Obstrucción del flujo de las venas suprahepáticas.

- Toxinas y agentes terapéuticos.

- Bypass intestinales.

- Cirrosis de los niños indios.

- Infecciones.

- Afectación granulomatosa del hígado

\section{Factores de riesgo}

Los principales factores de riesgo incluyen al alcoholismo, infecciones por virus de la hepatitis B y C. En el caso de la cirrosis alcohólica el hecho de ser mujer implica un riesgo, ya que el daño es mayor y más rápido ${ }^{1}$.

Los factores de riesgo en caso específico de cirrosis por virus B son: antecedentes de drogadicción por vía parenteral, homosexuales, sexoservidoras, recién nacidos de madres positivas para el antígeno HBs (antígeno Australia), trabajadores de hospitales, inmigrantes procedentes de países mediterráneos, África o el lejano Oriente, personas que han recibido transfusiones y disminuidos psíquicos, tatuajes y uso de piercings, entre otros ${ }^{19}$.

Se encuentran los riesgos inherentes a las enfermedades hereditarias e inmunes así como antecedentes de obstrucción biliar, uso crónico de medicamentos hepatotóxicos, alteraciones vasculares². Los factores relacionados con hígado graso son: obesidad, dislipidemia, hiperglucemia Afortunadamente el sobrepeso y la obesidad han mostrado un ligero descenso en México en el 2012, no así la diabetes mellitus que ha tenido incremento particularmente en mujeres de 60 años y más ${ }^{15}$. También se ha mencionado el tratamiento con medicina alternativa y complementaria en cerca del $20 \%$ de casos en un hospital de Chiapas, México ${ }^{10}$. 


\section{Cirrosis hepática}

Es importante interrogar antecedentes familiares de enfermedades hereditarias y antecedentes de afección a otros órganos en el paciente en caso de cirrosis de origen metabólico-hereditario².

\section{Factores protectores}

Hábitos alimentarios adecuados, activación física, prácticas sexuales con protección y responsabilidad, vacunación contra hepatitis $\mathrm{B}^{24}$, práctica de protocolos de seguridad en personal de salud para manejo de residuos peligrosos biológico-infecciosos ${ }^{25} \mathrm{y}$ ausencia de automedicación.

Factores modificables

Hábitos alimentarios, alcoholismo, hábitos en prácticas sexuales, protocolos de seguridad en personal de salud para manejo de residuos peligrosos biológico-infeccioso. Consumo de medicamentos hepatotóxicos.

\section{Fisiopatología}

En términos generales, el proceso fisiopatológico de la cirrosis de cualquier etiología es la siguiente:

Cuadro patológico de base (alcoholismo, colestasis prolongadas, hepatitis) $\rightarrow$ inflamación de la íntima endotelial $\rightarrow$ estasis de venas centrales, en sinusoides y puede llegar hasta vénulas portales $\rightarrow$ isquemia acinar $\rightarrow$ apoptosis, atrofia e hiperplasia nodular $\rightarrow$ fibrosis $\rightarrow$ hipertensión portal.

La hipertensión portal, es una complicación y ocasiona otra serie de alteraciones en forma progresiva, a continuación se presenta la fisiopatología de las tres complicaciones iniciales: 1) varices esofágicas con hemorragia, 2) ascitis y 3) falla renal.

1) Fisiopatología de las varices esofágicas con hemorragia de tubo digestivo en cirrosis hepática 


\section{Principales problemas de Salud Pública en México}

Hipertensión portal $\rightarrow$ vasodilatación arteriolar en vísceras aledañas y dilatación venosa $\rightarrow$ síndrome dispépsico, diarrea, várices esofágicas y gástricas $\rightarrow$ hemorragia.

Si el gradiente de presión del flujo portal supera 10 a $12 \mathrm{~mm} \mathrm{Hg}$ aumenta el riesgo de sangrado por desarrollo de várices ${ }^{5}$.

2) Fisiopatología de ascitis en hipertensión portal

Hipertensión portal + vasoconstricción sinusoidal $\rightarrow$ mediadores vasodilatadores $\rightarrow$ vasodilatación asplácnica $\rightarrow$ aumento de presión capilar $\rightarrow$ fuga de líquido $\rightarrow$ ascitis.

3) Fisiopatología de falla renal en cirrosis hepática

Hipertensión portal + hemorragia $\rightarrow$ déficit circulación renal $\rightarrow$ activación sistema renina-angiotensina y déficit de filtrado glomerular $\rightarrow$ falla renal.

Existen varios mecanismos fisiopatológicos que ocasionan el daño hepático en la cirrosis: En caso de cirrosis por alcohol existe una hepatotoxicidad directa por acetaldehído y fibrogénesis mediado por citoquinas ${ }^{1}$.

La falla hepática en la cirrosis ocasiona también alteraciones a otros órganos extrahepáticos como sistema nervioso, pulmón y corazón.

\section{Cuadro clínico}

Las manifestaciones clínicas dependen de la causa y de las complicaciones que se van presentando por el proceso fibroso e hipertensión portal.

\section{Fase inicial}

En esta fase el $40 \%$ de la cirrosis es asintomática o subclínica con datos inespecíficos como anorexia, osteoporosis, astenia ${ }^{1,2,6}$. A veces es hallazgo casual al presentarse otras 


\section{Cirrosis hepática}

patologías concomitantes. Pacientes con enfermedad de Dupuytren y la hipertrofia paratiroidea nos indican un excesivo consumo de alcohol por parte de nuestro paciente. Si existen manifestaciones en otros órganos como corazón y articulaciones podemos pensar en hemocormatosis. El anillo de Kayser-Fleischer en ojo y alteraciones neurológicas se presentan en caso de la enfermedad de Wilson. En los cuadros autoinmunes aparecen otros datos de autoinmunidad ${ }^{1}$. Un síndrome ictérico en menores de 25 años generalmente corresponde a hepatitis viral y el prurito a procesos obstructivos. El hígado de bordes firmes y cortantes sugiere cirrosis ${ }^{21}$.

\section{Fase compensatoria}

En fases más avanzadas, cuando existe hipertensión portal y congestión visceral secundaria aparecen, astenia, síndrome ácido-péptico, síndrome dispépsico, y síndrome diarreico. Estos cuadros se hacen crónicos y avanzan en intensidad, posteriormente aparece red venosa colateral, varices esofágicas y gástricas. Dentro de la etapa compensada, los pacientes pueden

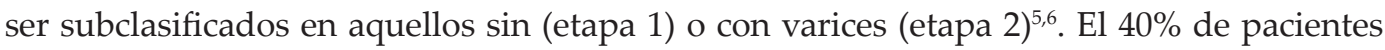
presentan varices esofágicas al inicio del diagnóstico, en etapas terminales alcanza más del $90 \%$. El déficit funcional del hígado ocasiona sintomatología y signología especialmente relacionadas con el metabolismo de sustancias tanto exógenas como endógenas, así por ejemplo, las alteraciones del metabolismo hormonal ocasiona pérdida de caracteres sexuales secundarios, atrofia testicular, dismenorrea, alteración de la libido; las alteraciones en el metabolismo de la hemoglobina y excreción de bilirrubina ocasiona ictericia. Puede haber anemia por microsangrados debido a déficit de protrombina y factor $\mathrm{V}$.

\section{Fase de descompensación ${ }^{1,2,6,12}$}

En esta etapa existe ascitis y/o hemorragia gastrointestinal (etapas 3 y 4), si es importante habrá trastornos de la respiración por compresión diafragmática y hernias de diversos tipos. El deterioro funcional hepático se acentúa de tal manera que el consumo de proteínas ocasiona exceso de amonio provocando manifestaciones psíquicas de diverso grado, desde somnolencia, excitación o coma (encefalopatía hepática), asterixis se presenta un olor desagradable característico (hedor hepático). Las hemorragias por varices esofágicas son más frecuentes, ocasionan hemorragias masivas aparece hematemesis y melena, son agravadas por el déficit de protrombina y factor $V$. Aparecen también manifestaciones de síndrome hepato-renal (10\% de los casos) por alteraciones en la circulación renal que activa 


\section{Principales problemas de Salud Pública en México}

los sistemas renina-angiotensina, que se identifica por la oliguria, cefalea e hipertensión arterial importante (datos de insuficiencia renal). También puede haber datos clínicos de derrame pleural con insuficiencia respiratoria (tórax hepático) e insuficiencia cardíaca.

\section{Complicaciones}

Las complicaciones implican a una serie de órganos y sistemas de la economía (Cuadro 2). Puede presentarse en el 10 a 30\% de los casos la peritonitis bacteriana espontánea con 50 a $70 \%$ de mortalidad ${ }^{1,27}$ y el carcinoma hepatocelular se presenta en el $20 \%$ de los casos a los 5 años. La incidencia y prevalencia del carcinoma hepatocelular se ha incrementado en los últimos años ${ }^{5}$.

Cuadro 2. Principales complicaciones de la cirrosis hepática.

\begin{tabular}{|l|l|l|l|}
\hline $\begin{array}{c}\text { Órgano, } \\
\text { aparato o } \\
\text { sistema }\end{array}$ & \multicolumn{1}{|c|}{ Alteración } & \multicolumn{1}{c|}{ Manifestación } & \multicolumn{1}{c|}{$\begin{array}{c}\text { Laboratorio } \\
\text { /gabinete }\end{array}$} \\
\hline \multirow{2}{*}{$\begin{array}{l}\text { Digestivo: } \\
\text { Hipertensión } \\
\text { Sistema porta }\end{array}$} & $\begin{array}{l}\text { Várices esofágicas } \\
\text { Dilatación venosa } \\
\text { abdominal }\end{array}$ & $\begin{array}{l}\text { Disfagia } \\
\text { Dispepsia } \\
\text { Red venosa colateral }\end{array}$ & $\begin{array}{l}\text { Diagnóstico por } \\
\text { endoscopía }\end{array}$ \\
\cline { 2 - 4 } & Ascitis & $\begin{array}{l}\text { Dispepsia, disnea, } \\
\text { hernias, signo ola, } \\
\text { charco, matidez } \\
\text { cambiante }\end{array}$ & $\begin{array}{l}\text { Radiografía de } \\
\text { abdomen } \\
\text { Composición química } \\
\text { del líquido de ascitis }\end{array}$ \\
\cline { 2 - 5 } & Ruptura de várices & $\begin{array}{l}\text { Vómito en pozos de café } \\
\text { Hematemesis } \\
\text { Melena }\end{array}$ & $\begin{array}{l}\text { Anemia hipocrómica, } \\
\text { microcítica }\end{array}$ \\
\hline Coagulación & $\begin{array}{l}\text { Déficit Protrombina } \\
\text { y Factor V }\end{array}$ & Anemia, hemorragia & $\begin{array}{l}\text { Alteraciones pruebas } \\
\text { de coagulación }\end{array}$ \\
\hline \multirow{2}{*}{ Pulmón } & Derrame pleural & $\begin{array}{l}\text { Síndrome de derrame } \\
\text { pleural }\end{array}$ & $\begin{array}{l}\text { Radiografía de tórax } \\
\text { Composición química } \\
\text { del líquido pleural }\end{array}$ \\
\hline \multirow{2}{*}{ Riñón } & $\begin{array}{l}\text { Déficit circulación } \\
\text { Activación sistema } \\
\text { renina-angiotensina }\end{array}$ & $\begin{array}{l}\text { Hipertensión arterial } \\
\text { secundaria } \\
\text { Edema }\end{array}$ & $\begin{array}{l}\text { Elevación de urea y } \\
\text { creatinina } \\
\text { Oliguria }\end{array}$ \\
\hline
\end{tabular}




\section{Cirrosis hepática}

\section{Diagnóstico ${ }^{1,2,3}$}

El Diagnóstico clínico se lleva a cabo con historia clínica completa. Generalmente el paciente presenta un síndrome ictérico y se sospechará el origen por el interrogatorio de antecedentes y exploración específica.

El diagnóstico clínico será más fácil cuanto más avanzado se encuentre el problema por la riqueza de síntomas y signos. En fases iniciales es necesario realizar diagnóstico diferencial con entidades que dan pocos síntomas: Síndromes dispépticos y ácido-pépticos, síndromes anémicos, hipertensión arterial. La buena anamnesis cobra su real importancia en estos casos para realizar un diagnóstico oportuno. En casos más avanzado o complicados el diagnóstico diferencial se realiza con cardiopatías, nefropatías, derrame pleural. Deberá hacerse la diferenciación si son afecciones primarias o secundarias a la cirrosis.

El estándar de oro para diagnóstico de cirrosis es histológico, mediante biopsia hepática (proceso invasivo). No existe otra prueba que por sí misma sea sensible y específica, sin embargo se opta por las pruebas no invasivas en un inicio, principalmente ultrasonido convencional y Doppler que alcanzan sensibilidad del 91.1 y 93.5 de especificidad. La tomografía y la resonancia se consideran de poca utilidad diagnóstica por que detectan pocos cambios estructurales. La guía de referencia rápida indica que se solicitarán pruebas de funcionamiento hepático (PFH) a los individuos que tengan datos clínicos de insuficiencia hepática crónica, si resultan alteradas se canalizará al servicio de gastroenterología para realización de ultrasonido (US) hepático convencional y US Doppler.

La determinación del índice de saturación de transferrina es básica para realizar un diagnóstico etiológico de hemocromatosis. En la cirrosis autoinmune aparece hipergammaglobulinemia y autoanticuerpos (cirrosis biliar primaria). La fosfatasa alcalina significativamente elevada en cirrosis de origen colestático o hepatocarcinoma. Existen marcadores tumorales como $\alpha$-fetoproteína. La ecografía y elastografía son usadas también en forma no invasiva. Respecto de la ecografía puede existir discordancia entre observadores lo que disminuirá la sensibilidad y especificidad. La elastografía mide el grado de rigidez del hígado.

Una vez que se tiene el diagnóstico de cirrosis el laboratorio es útil para indicarnos las complicaciones: se realizan biometría hemática (leucopenia, trombocitopenia, anemia 


\section{Principales problemas de Salud Pública en México}

microcítica, hipocrómica) pruebas de funcionamiento hepático (hiperbilirrubinemia, las transaminasas pueden estar elevadas o normales, lo mismo la fosfatasa alcalina dependiendo de la etiología), pruebas de coagulación (alargamiento de tiempo de protrombina), función renal. Estudio de líquido de ascitis.

De gabinete contamos con Radiografía ( $\mathrm{Rx}$ ) de tórax, abdomen, electrocardiograma, endoscopía, ultrasonido, punciones abdominales para descompresión y análisis.

La cirrosis compensada tiene una sobrevida del $80 \%$ a los 10 años mientras que la cirrosis descompensada alcanza solo $7 \%$ de supervivencia ${ }^{1}$. En un estudio en México se observó que los pacientes con cirrosis de origen alcohólico tenían mejor pronóstico que los secundarios a cirrosis de origen viral ${ }^{12}$ lo que contrasta con otros estudios ${ }^{26}$.

La escala de Child-Pugh-Turcotte determina el pronóstico y se basa en cinco parámetros que son: ascitis, encefalopatía, niveles de bilirrubina, de albúmina y tiempo de protombina ${ }^{2}$.

\section{Terapéutica}

La dieta adecuada con las restricciones correspondientes, los hábitos de sueño, higiene y evitar adicciones mejorará el pronóstico y la calidad de vida de los pacientes. Los grupos de autoayuda son una excelente opción. El uso de fármacos que reducen la presión portal y avances en las técnicas endoscópicas (ligador multibandas) son algunas de las opciones terapéuticas que han permitido disminuir los efectos adversos de las complicaciones y con ello mejorar el pronóstico de vida ${ }^{1}$.

En los casos de cirrosis ya diagnosticada es necesario mantener la vigilancia estrecha para la detección oportuna y manejo de las complicaciones. Se deberá evaluar clínicamente cada 2 meses, con laboratorio cada 6 meses, endoscopía cada 2 años y dependiendo la evolución o el origen del problema se puede solicitar ultrasonido hepático cada año.

El manejo multidisciplinario se hace necesario para el control y rehabilitación de estos pacientes, entre ellos son importantes la familia, médico familiar, gastroenterólogo, interconsultas a otros facultativos, psicólogo y nutriólogo ${ }^{2}$.

Se indica tratamiento específico y conservador para evitar complicaciones, sangrías en caso de hemocromatosis, descompresión abdominal mediante extracción de líquido de ascitis 


\section{Cirrosis hepática}

(paracentesis evacuadora) teniendo en cuenta que de acuerdo con el volumen extraído se tendrá que realizar reposición de volumen. En caso de insuficiencia respiratoria, ligadura de várices.

Reposo, suprimir alcohol y enviar a grupo de autoayuda, dieta hipercalórica, disminuir o suspender consumo de proteínas animales para evitar encefalopatía por amonio, restricción de sodio en la dieta, dieta líquida o blanda para evitar hemorragias de esófago pero cuidando el ingreso de líquidos (1,200 ml/día), bebidas frías para provocar vasoconstricción, transfusiones.

Se indican antivirales en caso de hepatitis, antibiótico en caso de peritonitis de preferencia antibióticos no absorbibles como neomicina y metronidazol. Penicilinas en caso de enfermedad de Wilson; complejos vitamínicos, complementos alimentarios, diuréticos, antihipertensivos, beta bloqueadores para disminuir la hipertensión porta, expansores de plasma o albúmina después de paracentesis evacuadora ${ }^{1,2,3}$.

El tratamiento definitivo es el trasplante de hígado, cuando es exitoso alcanza $80 \%$ de supervivencia a los 5 años.

\section{Medidas de prevención}

Este padecimiento afecta a la población en edad laboral y reproductiva con una alta prevalencia en la morbilidad y mortalidad por lo que es considerado un problema de Salud Pública, con base en lo anterior se crearon algunas guías de práctica clínica de diagnóstico, tratamiento y referencia y están dirigidos a profesionales de primero, segundo y tercer nivel de atención ${ }^{1,2,3}$.

Educación acerca de los riesgos que tiene sobre el organismo el consumo de alcohol y drogas principalmente por vía parenteral, orientación sobre prácticas sexuales seguras y la práctica de tatuajes y perforaciones. Fomentar hábitos saludables (alimentación, activación física, recreación). Vigilancia estrecha en caso de que el individuo tenga antecedentes heredo-familiares de riesgo. Son necesarias las estrategias informativas de orientación y de educación sobre los riesgos que tiene el alcoholismo y la drogadicción en escuelas, centros de trabajo, hogar y en general a todos los grupos con hábitos de riesgo: drogadictos, sexoservidoras y poblaciones de zonas rurales donde existe gran consumo de alcohol. También son muy adecuados en los grupos de apoyo de autoayuda. 


\section{Principales problemas de Salud Pública en México}

Realizar vacunación contra hepatitis $\mathrm{A}$ y $\mathrm{B}^{28}$ especialmente a los grupos de riesgo. La vacuna contra hepatitis A y B a personas con riesgo por su trabajo como el personal de salud y sexoservidores. Aun no hay vacuna contra hepatitis $\mathrm{C}$. La vacuna contra hepatitis A es una vacuna que se aplica a viajeros que visitan Centroamérica y/o Sudamérica, o extranjeros que visitan México, son dos dosis con un intervalo de un año ${ }^{24,28}$. La vacuna contra hepatitis B contiene una de las proteínas que cubren al virus de la hepatitis B y que es llamado antígeno de superficie, se fabrica usando ADN recombinante (son proteínas producidas mediante levaduras modificadas), sin ninguna sangre humana o productos de sangre o cualquier otra sustancia de origen humano por lo que no puede contagiar el virus de la hepatitis B o el virus de inmunodeficiencia humana (VIH), se aplica en 3 dosis a los menores de 5 años de edad, del nacimiento a los 7 días, dos meses y 6 meses. A los niños que al nacer pesan menos de $2 \mathrm{~kg}$, se les aplica 4 dosis al nacer y a los 2, 4 y 6 meses de edad. La vacuna se aplica mediante inyección, en el muslo izquierdo en los menores de 18 meses de edad y a partir de los 18 meses de edad, incluyendo adultos, se aplica en el brazo derecho.

Es importante la detección de casos en la comunidad, con estudios previos como encuestas, diagnósticos de salud comunitaria sobre hábitos, adicciones y prácticas sexuales para detectar grupos de riesgo. Realizar pruebas de funcionamiento hepático a población en riesgo: profesionales de la salud, drogadictos, sexoservidoras, zonas rurales donde existe gran consumo de alcohol y otros grupos. Realizar también campañas de ultrasonido hepático a estos grupos o como tamiz en población general. También, debe contemplarse el manejo integral a familias con problemática de alcoholismo y drogadicción, con el afán de prevenir ésta enfermedad.

\section{Referencias}

1. Gómez AAE. Cirrosis hepática actualización. Farmacia profesional. 2012; 26(4):45-51.

2. Secretaría de Salud. Guía de referencia rápida. Diagnóstico y tratamiento de la insuficiencia hepática crónica. México: 2008. Disponible en: http://www.cenetec. salud.gob.mx/descargas/gpc/CatalogoMaestro/038_GPC_InsufHepaticaCronica/ IMSS_038_08_GRR.pdf

3. Secretaría de Salud. Guía práctica clínica. Diagnóstico y tratamiento de la insuficiencia hepática crónica. México: 2009. Disponible en: http://www.cenetec.salud.gob.mx/ 


\section{Cirrosis hepática}

descargas/gpc/CatalogoMaestro/038_GPC_InsufHepaticaCronica/IMSS_038_08_ EyR.pdf

4. OPS, OMS. Clasificación Estadística Internacional de Enfermedades y Problemas Relacionados con la Salud (CIE-10). 10a revisión. Washington: OPS; 2009.

5. García BL, González MF, Moreno OR. Cirrosis hepática. Medicine. 2012, 11(11):625-33.

6. Rangel GA, Cruz RMA, Patiño LGA, Padierna J. Cirrosis. Rev Dolor. 2009; 6(VIII):4-9.

7. Kershenobich SD, Dehesa VM, Aguilar de GLM, et al. La hepatitis C como un problema de Salud Pública. Salud Pública Méx. 2011; 53(1):61-67.

8. Perdigón VG, Fernández CSB. Principales causas de muerte en la población general e infantil de México, 1922-2005. Bol Med Hosp Infant Mex. may-jun 2008: 65(3):238-40.

9. INEGI. Causas de mortalidad general 2012. México: 2012. Disponible en http://www3. inegi.org.mx/sistemas/sisept/Default.aspx?t=mdemo107\&s=est\&c=23587.

10. Meléndez GCA, Meléndez GJJ. Principales causas y factores asociados a cirrosis hepática en los pacientes del Hospital General de Zona 2 de Chiapas, México. Medwave. Revista médica revisada por pares. Medwave. 2012;12(7): e5454. Disponible en: http://www. mednet.cl/link.cgi/Medwave/Estudios/Investigacion/5454

11. Rodríguez MA, Valencia RHS, Altamirano JT. Etiología y complicaciones de la cirrosis hepática en el Hospital Juárez de México. Rev Hosp Jua Mex. 2008; 75(4):257-263.

12. Rodríguez HH, Jacobo KJS, Castañón SMC, Arámbula CHM, Martínez AG. Supervivencia de pacientes con cirrosis hepática en el Hospital regional del IMSS, Durango 2002. Gac Med Mex. 2002; 138(4):325-330.

13. Heldelbaugh JJ, Bruderly MMD. Cirrhosis and chronic liever failure: Part I. Diagnosis and evaluation. Am Fam Physcician. 2006; 74:756-762.

14. Varasovskyt Z, McKee M. Problem drinking among hospitalized patients in hungary. Alcohol and Alcoholism. 2000; 35(6):574-579.

15. Secretaría de Salud. Consumo de alcohol en México, 2000-2012: estrategias mundiales para reducir su uso nocivo. ENSANUT 2012, Evidencia para la política. México: 2012. Disponible en: http://ensanut.insp.mx/doctos/analiticos/ConsumoAlcohol.pdf

16. Morales GF, Cabrera JM, Pizeta L, et al. El consumo de alcohol y frecuencia de factores de riesgo en alumnos de una preparatoria en Ciudad Nezahualcóyotl. Vertientes 2012; 15(2):65-71. 


\section{Principales problemas de Salud Pública en México}

17. Secretaría de Salud del Estado de México. Encuesta del Estado de México sobre el consumo de alcohol, tabaco y drogas en los estudiante. Edo. de Méx.: 2009. Disponible en: http://salud.edomex.gob.mx/imca/doc/enestudiantes_2009.pdf

18. Panduro A, Escobedo MG, Fierro NA, Ruíz MB, Zepeda-Carrillo EA, Román S. Epidemiología de las hepatitis virales en México. Salud Pública de México. 2011; supl 53:s37-s45

19. Valdespino JL, Conde-González CJ, Olaiz-Fernández G, Palma O, Kershenobich D, Sepúlveda J. Seroprevalencia de la hepatitis C en adultos en México Seroprevalencia: ¿un problema de Salud Pública emergente? Salud Pública de México. 2007; supl 3(53): s394-s403

20. Lozano A, Soliz PN. Indicadores de salud para el monitoreo de políticas públicas. Dirección general de Información en Salud; 2007. Disponible en: https://es.slideshare. net/psolizsanchez/defunciones2007-México

21. Ossa G, Sierralta A, Núñez I, Gallegos BF. Ictericias y diagnóstico diferencial. Universidad de la Frontera; 2011. Disponible en: http://med.ufro.cl/clases_apuntes/ medicina-interna/gastroenterologia/docs/16-ictericias.pdf.

22. Adorna CZ. Esteatohepatitis no alcohólica. Fisiopatogenia y modelos experimentales. Rev Cubana Invest Bioméd. Mar 2007; 26(1):0-0. Disponible en: http://scielo.sld.cu/ scielo.php?script=sci_arttext\&pid=S0864-03002007000100007

23. Organización Mundial de Gastroenterología. Enfermedad del hígado graso no alcohólico y esteatohepatitis no alcohólica. Guías de la OMG 2012. Disponible en: http:// www.worldgastroenterology.org/UserFiles/file/guidelines/nafld-nash-spanish-2013. pdf

24. Halabe CHJ, Hamui SA. Vacunación en el adulto en seminario sobre medicina y salud. Marzo 2008. Disponible en http://www.facmed.unam.mx/sms/seam2k1/2008/mar_01_ ponencia.html

25. Secretaría de Salud. Guía para el manejo de los residuos peligrosos biológico infecciosos en unidades de salud. México 2003. Disponible en: http://www.promocion.salud.gob. mx/dgps/descargas1/influenza/mat/Guia_manejo_de_residuos_biologicos.pdf..

26. Niedarau C, Lange S, Heintges T, Erchardt A, Buschka- mp M, Hürter D, et al. Prognosis of chronic hepatitis C: results of a large, prospective cohort study. Hepatology. 1998; 28:1687-95. 


\section{Cirrosis hepática}

27. Sáenz de Santa María RA, Pereira GS, Sáenz de Zaitegui FJ. Sesión clínica. Mujer de 47 años con cirrosis hepática que consulta por fiebre y hematemesis, detectándose pancitopenia y acidosis metabólica. Revista andaluza de Patología Digestiva. 2010;33(4): 296-302. Disponible en: https://dialnet.unirioja.es/servlet/articulo?codigo=3275326

28. Secretaría de Salud. Vacuna contra hepatitis B, Centro Nacional Para La Salud De La Infancia y La Adolescencia. México: 2015. Disponible en http://www.censia.salud.gob. $\mathrm{mx} /$ contenidos/vacunas/antihepatitisb.html 



\section{Cólera}

Mtra. Malinali Alvarado Orozco

\section{Introducción}

Las primeras décadas del siglo XIX, dieron luz al descubrimiento de los microrganismos como causa de enfermedad, alterando de tal manera el curso de la historia médica, que el concepto de enfermedad, los métodos terapéuticos y las prácticas higiénicas de finales de siglo apenas recuerdan la existencia de la centuria anterior.

Durante esta época, la Salud Pública estuvo en gran parte condicionada por las alteraciones laborales de la Revolución industrial. Los cambios ininterrumpidos que siguieron a la construcción de fábricas y a la expansión de las ciudades implicaron grandes desplazamientos de la población y a su consiguiente hacinamiento.

Antes del descubrimiento de las bacterias como causa de enfermedad, los principales enfoques de la medicina preventiva y de la salud pública se redujeron a medidas higiénicas, como el abastecimiento de agua potable y la eliminación de los malos olores procedentes del alcantarillado y de las basuras, que se consideraban los factores etiológicos más importantes de las epidemias. Sin embargo, las epidemias continuaban devastando ciudades y países. En Londres en 1854, hubo 14,000 casos de cólera con 618 muertos. En los Estados Unidos, el cólera asoló al país con tres epidemias durante el siglo XIX. No se pudieron planear campañas hasta que se descubrió que su etiología era bacteriológica ${ }^{1}$.

El cólera, desconocido hasta cerca de 1820, excepto en la India, se difundió ampliamente en el mundo causando una serie de epidemias de efectos variables, entre las cuales, es de importancia mencionar la ocurrida a fines de agosto de 1854. Como resultado de una minuciosa observación y un razonamiento deductivo, John Snow formuló hipótesis que logró comprobar y explicar a través de su mecanismo de transmisión y formulando recomendaciones para su control, aplicando las medidas de salud pública en el control del cólera ${ }^{2}$. 


\section{Principales problemas de Salud Pública en México}

El presente capítulo, adentrará a los lectores del área de la salud, tanto clínicos como salubristas, a conocer los aspectos bacteriológicos, clínicos y de control médico y epidemiológico del cólera, debido a que es una enfermedad que se encuentra y persistirá durante la historia de la humanidad. Por ello, el personal de Médico y Paramédico de los tres niveles de atención a la salud, debe estar preparado ante las epidemias de cólera que amenazan constantemente a la población, por lo que la vigilancia epidemiológica en salud pública es la principal herramienta para identificar casos y brotes e implementar medidas de intervención que permitan identificar las fuentes de infección y romper la cadena de transmisión.

\section{Concepto}

Del griego Colades, desagües o vertederos por los que escapaba el agua que se remansaba en los techos de las antiguas viviendas. El cólera es una gastroenteritis aguda causada por la bacteria gramnegativa Vibrio cholerae, caracterizada en su forma más diagnosticada, por diarrea acuosa súbita, vómitos, signos de deshidratación y calambres musculares. Existe en forma endémica desde épocas remotas en Asia y África, y su origen se localiza en India y Bangladesh, con una propagación posterior a otros continentes; el cólera ha sido responsable de graves epidemias y pandemias en varias regiones del mundo ${ }^{3}$.

\section{Clasificación}

Se conocen 198 serogrupos de Vibrio cholerae de acuerdo con la molécula de lipopolisacárido que poseen como antígeno somático, y cada uno de ellos se identifica por un suero específico: Vibrio cholerae O1 debido a que aglutina con el suero O1, en tanto que a los grupos restantes se les denomina de manera genérica No O1.

Con base en sus características fenotípicas, propiedades metabólicas, susceptibilidad a bacteriófagos y sensibilidad a los antibióticos se divide en ${ }^{4}$ : 


\section{Cólera}

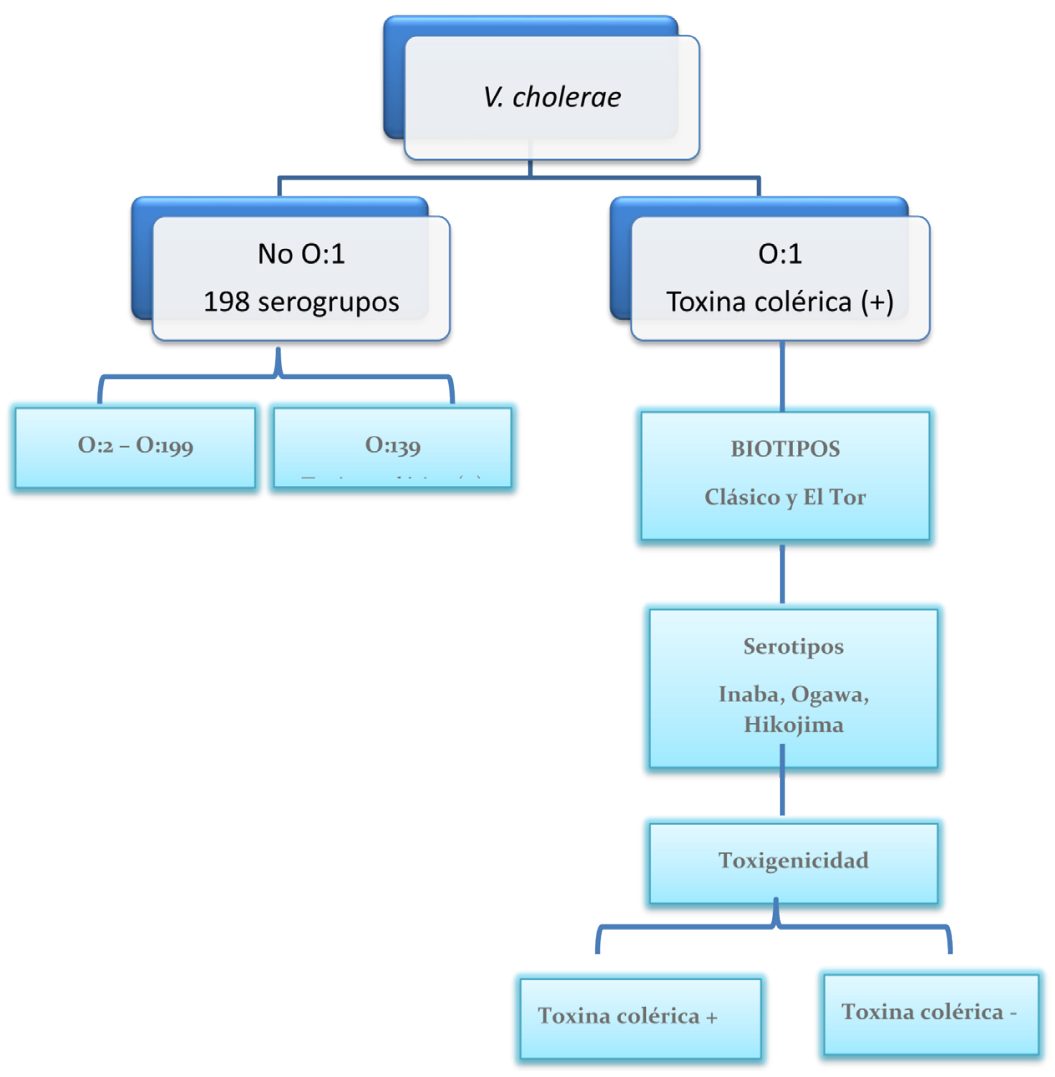

Figura 1. Clasificación del Vibrio cholerae.

Retomado de: Plan Institucional de Preparación y Respuesta ante una Epidemia de Cólera. Instituto Mexicano del Seguro Social.

\section{Epidemiología}

A nivel mundial, para el 2011 se reportaron 589, 854 casos de cólera en 58 países, incluyendo 7,816 muertes con una tasa de letalidad de $1.3 \%$ representando un incremento del $85 \%$ con respecto a años previos. Ello sucedió después del inicio de la epidemia en Haití durante 2010. De los 33 países que reportaron muertes por cólera, 23 fueron del continente Africano (53\% del global total) seguido de América, República Dominicana y Haití (41\%). 


\section{Principales problemas de Salud Pública en México}

En América y las Antillas, desde el inicio de la epidemia en Haití en octubre del 2010 hasta la semana epidemiológica número 23 del 2014, se registraron 703.510 casos de cólera, de los cuales, 393.912 fueron hospitalizados y 8.562 fallecieron. La tasa de letalidad acumulada fue de 1,2\%. En julio de 2012 se notificaron los primeros casos de un brote de cólera en Cuba 5 .

En México, durante el 2013, se registraron 187 casos de infección por $V$. cholerae O:1 Ogawa toxigénico, incluyendo una defunción. El 13 de junio del 2014, el Centro Nacional de Enlace para el RSI reportó tres casos de infección por Vibrio cholerae O:1 Ogawa toxigénico en el estado de Hidalgo. Esta es la primera transmisión local de cólera registrada en México desde la epidemia de 1991- 2001. El perfil genético de las cepas aisladas en los casos de este brote en México fue muy similar (>95\%) al de la cepa que circulaba en el Caribe (Haití, República Dominicana y Cuba) y era diferente de la cepa que circuló en México hace más de una década ${ }^{5}$.

Este tipo de vigilancia activa ante la presencia de brotes de cólera en la Región de las Américas, son determinantes para que la Organización Panamericana de la Salud/ Organización Mundial de la Salud (OPS/OMS) recomiende a los Estados Miembros que pongan en marcha sus planes de preparación y respuesta y fortalezcan sus sistemas de vigilancia del cólera. También exhorta a los países a acelerar el trabajo para mejorar la calidad y condiciones del agua y el saneamiento ${ }^{5,6}$.

\section{Causalidad}

En éste apartado revisaremos los aspectos del agente biológico (el Vibrio cholerae), el mecanismo de transmisión del microorganismo que provoca la enfermedad y los factores de riesgo que favorecen la misma.

\section{> Características del agente biológico}

El nombre Vibrionaceae fue propuesto originariamente por Veron en 1965 con la intención de agrupar algunos bacilos gramnegativos no entéricos fermentadores que eran oxidasa positivos y móviles por medio de flagelos polares. Los Vibrionaceae abarcaban en otra época cuatro géneros: Vibrio, Aeromonas, Photobacterium y Plesiomonas. Sin embargo, en las últimas décadas distintos métodos para el análisis de los ácidos nucleicos han revolucionado la taxonomía microbiana?. 


\section{Cólera}

El Vibrio cholerae es un bacilo Gram negativo pequeño de $1-3 \mu \mathrm{m}$ por 0.4 a $0.6 \mu \mathrm{m}$, tiene forma de coma, la cual se observa en materia fecal y en cultivos jóvenes, siendo más alargada y bacilar en cultivos viejos, móvil por un flagelo polar, no forma esporas ni posee cápsula.

Tiene una baja tolerancia al ácido, pero crece bajo condiciones alcalinas con un $\mathrm{pH}$ de 8.0 a 9.5 que inhiben muchas otras bacterias gramnegativas. Se distingue de los demás Vibrio por sus reacciones bioquímicas, estructura entigénica lipopolisacárida (LPS) O y por su producción de toxina del cólera $(\mathrm{TC})^{8}$.

Son bacterias aerobias o anaerobias facultativas, consideradas gérmenes frágiles, ya que no soportan condiciones ambientales desfavorables, como la desecación, la exposición a la luz solar y la competencia con otros microrganismos; pueden sin embargo, conservar su viabilidad durante varios días, en los alimentos alcalinos y húmedos ${ }^{8}$.

Consiguen sobrevivir por 2 a 5 días a una temperatura de 30 a $32^{\circ} \mathrm{C}$ en los peces y mariscos; de 1 a 7 días en los vegetales; de 7 a 14 días en la leche y sus derivados así como en el agua limpia de los depósitos y pozos. En el agua de mar sobreviven de 10 a 13 días ${ }^{3}$.

$V$. cholerae es capaz de crecer y sobrevivir en ambientes acuáticos (sobre todo estuarios, donde se pega a las algas, plancton y mariscos). Durante los periodos en los que el ambiente no es favorable para el crecimiento, el microrganismo puede tornarse a un estado latente en el que no necesita cultivarse. Las bacterias también pueden formar una "rugosa" (un agregado de bacterias rodeado de una biopelícula protectora que bloquea su eliminación por medio de cloros y otros desinfectante?

Tiene más de 140 serotipos, determinaos por el antígeno $\mathrm{O}$ de la superficie celular lipopolisacárida. Los responsables de epidemia en los humanos son del serotipo $\mathrm{O} 1$ al O139, mientras que los denominados "no O1" se encuentran asociados a gastroenteritis esporádicas no epidémicas ${ }^{10}$.

Las cepas se dividen en dos biotipos: Clásico y El Tor, ésta última fue dominante en el siglo XX, aislada por primera vez en 1905 a partir de peregrinos a La Meca en el campo de cuarentena de El Tor. La cepa sobrevive ligeramente más tiempo en la naturaleza y tiene mayor probabilidad de producir casos subclínicos de cólera. En 1992, se detectaron los primeros casos de cólera debidos a un serotipo distinto del O1 en India y Bangladesh, 


\section{Principales problemas de Salud Pública en México}

el O139 Bengala que es completamente virulento debido a la toxina colérica (TC) que posee $^{8,10}$.

Mecanismo de transmisión

El cólera inicia cuando el agente etiológico ingresa al organismo a través de la ingesta de agua y/o alimentos contaminados con heces y/o vómito de sujetos infectados con $V$. cholerae $\mathrm{O} 1$ o V. cholera O13910.

$V$. cholerae requiere una dosis de inoculo del orden de 106 microorganismos para infectar exitosamente al ser humano. Sin embargo se sabe que un sujeto enfermo de cólera puede eliminar 107 microorganismos por mililitro de evacuación y que puede evacuar hasta 20 litros en un solo día.

Esto significa que un solo enfermo de cólera puede excretar 1011 vibriones por día, lo que representa una enorme contaminación potencial tanto para las fuentes de agua como para los alimentos ${ }^{10}$.

Agua

- La contaminación del agua como consecuencia del arrastre de materias fecales hacia los mantos freáticos y aguas superficiales, no es el único mecanismo por el que $V$. cholerae $\mathrm{O} 1$ llegue a dichos cuerpos; también el mal manejo doméstico del agua para beber juega también un papel importante en la transmisión del padecimiento.

\section{Alimentos}

- La facilidad de contaminación de diversos alimentos con V. cholerae O1.

- El potencial de $V$. cholerae O1 para sobrevivir y multiplicarse en los mismos, ocasionando que la dosis de inoculo sea muy grande.

- El efecto amortiguador de los alimentos sobre la acidez gástrica que permite que el microrganismo logre rebasarla barrera gástrica. 


\section{Cólera}

Diversos mariscos, en especial los moluscos bivalvos, son alimentos de riesgo para la adquisición del padecimiento si son consumidos crudos o inadecuadamente cocidos.

Algunas especies de peces pueden contener al $V$. cholerae $\mathrm{O} 1$ en sus branquias o en el contenido intestinal pero la forma más frecuente de contaminación de estos productos es a través del manejo inadecuado de los mismos.

Se han implicado a otros alimentos en la ocurrencia del padecimiento tales como arroz, agua de coco, puerco crudo, etc. Sin embargo quizá sea oportuno recordar que el riesgo de que un alimento sea vehículo del $V$. cholerae $\mathrm{O} 1$ está dado en función de la acidez del alimento pero sobre todo por las condiciones que favorecen el crecimiento del microorganismo ${ }^{10,11}$.

Factores de riesgo

Las condiciones sanitarias y el acceso al agua potable son los determinantes principales del riesgo de cólera y otras enfermedades fecales orales. Las zonas de riesgo son las carentes de infraestructura básica donde no se cumplen los requisitos mínimos de agua limpia y saneamiento.

Las consecuencias de un desastre como la alteración de los sistemas de abastecimiento de agua y saneamiento, o la llegada de grupos humanos a campamentos deficientes y superpoblados pueden aumentar el riesgo de transmisión del cólera si el bacilo ya está presente o es introducido ${ }^{10,11}$.

El cólera sigue representando una amenaza mundial para la Salud Pública y es un indicador clave de la falta de desarrollo social. La enfermedad afecta principalmente a personas de bajo nivel socioeconómico, con higiene deficiente y que no disponen de servicios sanitarios adecuados. Los varones suelen constituir los primeros casos, ya que están más expuestos a los diversos factores de riesgo (consumo de agua de río, consumo de alimentos callejeros). Las mujeres enferman en segundo lugar y al ser manejadoras de alimentos se constituyen en fuentes de infección para el resto de los miembros de la familia. Los niños alimentados al seno materno son más resistentes a enfermar y a sufrir cuadros diarreicos graves ${ }^{10,11}$. 


\section{Principales problemas de Salud Pública en México}

\section{Fisiopatología}

La TC, es una toxina ADP-ribosilante tipo A-B. Dentro de la célula ejerce su efecto sobre el sistema adenilciclasa, el blanco de la toxina A1 es una proteína nucleótida de guanina (Gs $\alpha$ ), que regula la activación del sistema adenilciclasa con efecto neto de una acumulación excesiva de cAMP en la membrana celular, lo que ocasiona una hipersecreción de cloro, potasio, bicarbonato y moléculas de agua hacia el exterior de la célula. Esta secreción intestinal es pobre en proteínas y rica en electrolitos. La bomba de sodio está preservada, permitiendo la reabsorción del sodio, en presencia de glucosa lo cual explica la eficiencia de la rehidratación oral en su tratamiento ${ }^{3,9}$.

Cabe resaltar que las cepas de $V$. cholerae distintas a los serotipos epidémicos pueden no producir $\mathrm{TC}^{9}$.

El periodo de incubación puede ser de horas a tres y hasta 5 días mientras que su periodo de transmisibilidad es de unos pocos días después del restablecimiento. Sin embargo, en ocasiones persiste por meses ${ }^{12,13}$.

Las cepas de V. cholerae entran en el intestino delgado cuando el huésped ingiere agua, requiriendo $10^{3}$ a $10^{6}$ microrganismos para producir enfermedad, o en alimentos contaminados con $10^{2}$ a $10^{4}$ microrganismos 9 .

La capacidad del vibrión de producir infección está determinada por varios factores de virulencia: la mucinasa producida por el vibrión favorece que éste traspase la barrera representada por la capa de moco intestinal; al alcanzar la mucosa del intestino delgado (duodeno y yeyuno principalmente), el vibrión se adhiere al borde ciliado de las células epiteliales, gracias al factor de adherencia.

El espectro clínico del $V$. cholerae va desde una infección asintomática hasta un proceso diarreico severo acompañado de choque hipovolémico y muerte ${ }^{10}$.

La pérdida de líquidos se produce por la estimulación de la célula con adenilciclasa depende del equilibrio entre la cantidad de crecimiento bacteriano, producción de toxina, secreción de líquidos y absorción de los mismos en la totalidad del tracto gastrointestinal. La salida de líquidos y electrolitos es máxima en el intestino delgado, en donde la capacidad 


\section{Cólera}

de secreción es elevada y la capacidad de absorción es baja. Esta pérdida puede llegar a muchos litros por día, con un contenido de sodio aproximadamente igual al del plasma, pero con concentraciones entre dos y cinco veces mayores de potasio y bicarbonato. El resultado es la deshidratación isotónica, con hipopotasemia y acidosis metabólica por la pérdida de bicarbonato ${ }^{8}$.

El $V$. cholerae no invade ni daña al enterocito, por lo que la mucosa intestinal permanece inalterada ${ }^{8}$.

\section{Cuadro clínico}

Los pacientes comienzan con una diarrea discreta, dolor abdominal leve y malestar, puede existir una recuperación rápida, sin embargo pueden continuar excretando vibriones y ser portadores asintomáticos con importancia epidemiológica.

En pacientes con desarrollo de la enfermedad, la diarrea se inicia en forma abrupta, es de tipo acuoso, y presenta una apariencia de agua de arroz por la forma de las heces riciformes, es fétido el primer día con olor característico a "pescado" y después inodora. La pérdida de líquidos puede ser de un litro en una hora en adultos, y en niños de $300 \mathrm{~mL} / \mathrm{Kg}$ en un día, situación que lleva al estado de deshidratación severa, causa de defunción en pacientes diagnosticados y tratados tardíamente. En estos pacientes, se presenta una diarrea acuosa y los vómitos, debidos a la acidosis metabólica y a una gran pérdida hidroelectrolítica, son semejantes a las heces y con frecuencia variables. La fiebre casi siempre está ausente, los signos y síntomas por deshidratación son sed intensa, astenia, calambres musculares, pérdida acelerada de peso, disminución de la turgencia cutánea, mirada fija y vaga ${ }^{3,8}$.

Sin embargo, cabe mencionar que independientemente del agente biológico, ya sea 01 el Tor, 01 Clásico, o por el 039, el cuadro clínico puede ser asintomático, o en su defecto presenta diarrea leve, moderada o severa.

Para el biotipo O139, el 85\% de los pacientes presenta diarrea grave, mientras que para el biotipo $01 \mathrm{El}$ Tor, el 75\% de los pacientes son asintomáticos, los cuales representan un alto porcentaje de pacientes portadores que pueden diseminar el agente, a través de cualquiera de los mecanismos de transmisión descritos en el apartado de las características del agente biológico. 
Como se mencionó, no todos los pacientes presentan la misma evolución, por lo que a continuación se describe la frecuencia de cada uno de los signos y síntomas por biotipo colérico (grafica 1$)^{11}$ :

Gráfica 1. Cuadro clínico del Cólera.

\section{CUADRO CLÍNICO VIBRIO CHOLERAE O1 EL TOR CUADRO CLÍNICO}

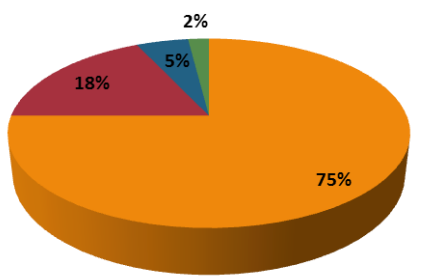

\section{CUADRO CLÍNICO VIBRIO CHOLERAE 01 CLÁSICO CUADRO CLÍNICO}

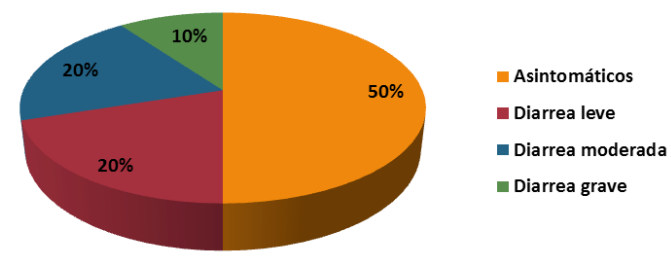

\section{CUADRO CLÍNICO VIBRIO CHOLERAE O 139 CUADRO CLÍNICO}

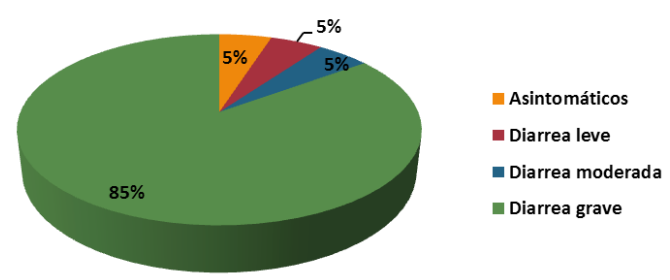

Retomado de: Secretaría de Salud. Manual de Procedimientos Estandarizados para la Vigilancia Epidemiológica de Cólera 2012.

\section{Complicaciones}

La principal complicación del Cólera es la deshidratación, motivo por el cuál si no se da terapia de hidratación de manera oportuna, los pacientes pueden morir rápidamente ${ }^{12,13}$.

\section{Diagnóstico}

El diagnóstico de cólera se realiza con la identificación del agente, hay métodos rápidos, como la visualización directa del organismo móvil en el microscopio de campo oscuro y la inmovilización de los organismos con anticuerpos contra $V$. cholerae, también se recurre a 


\section{Cólera}

las pruebas de inmunofluorescencia, de aglutinación con anticuerpos monoclonales y de coagulación; pero el cultivo microbiológico de TCBS es el estándar de oro ${ }^{10}$.

\section{Aislamiento}

La muestra de materia fecal debe ser fresca y estar en medio de transporte de Cary-Blair, deberá ser procesada lo antes posible una vez que llega al laboratorio. Para mantener viable el vibrión, es necesario enriquecer el medio de transporte con de Agua Peptonada Alcalina (APA), incubar a $36+1^{\circ} \mathrm{C}$ durante $6-8 \mathrm{~h}$. Posteriormente sembrar en una placa de agar Tiosulfato-Citrato-Bilis-Sacarosa (TCBS), durante 18 a 24 horas $^{14}$.

Las cepas de origen clínico, alimentos o ambientales para referencia o control de calidad se siembran directo en agar TCBS e incubar a $36+1^{\circ} \mathrm{C}$ durante 18 a 24 horas.

\section{Identificación}

Seleccionar del agar TCBS las colonias sacarosa positivas (colonias amarillas, planas de $2 \mathrm{~mm}$, generalmente pegajosas) y/o sacarosas negativas (colonias verdes, de $2 \mathrm{~mm}$, generalmente pegajosas), dichas colonias se siembran en los tubos para realizar las pruebas bioquímicas de identificación como la prueba de oxidasa en tira reactiva ${ }^{14}$.

\section{Serotipificación}

Si bioquímicamente se identificó Vibrio cholerae, se debe realizar la serotipificación a partir de la placa de $\mathrm{BAB}$, mediante suero polivalente Vibrio cholerae O1, suero monovalente Vibrio cholerae O1 Ogawa, suero monovalente Vibrio cholerae O1 Inaba y suero monovalente Vibrio cholerae O: $139^{15}$.

Para la colecta de aguas negras se recomienda la siembra de hisopos de Moore durante 24 horas para después recolectar el hisopo en un frasco con $500 \mathrm{ml}$ de agua peptonada alcalina pH 9.0 y enviarlo en refrigeración y a la brevedad posible al laboratorio ${ }^{11,14,15}$.

\section{Terapéutica}

La aplicación de vacunas está enfocada a personas de todas las edades que viven en zonas de alto riesgo de cólera y viajeros de los países industrializados que visitan áreas 


\section{Principales problemas de Salud Pública en México}

endémicas de cólera. Existen dos vacunas orales disponibles autorizadas, una es la vacuna de microrganismos muertos elaborada por $V$. cholerae $\mathrm{O} 1$ inactivado, administrada junto con la subunidad B de la toxina colérica. La otra vacuna es elaborada con una cepa atenuada de V. cholerae O1, CDV103-HgR, elaborada con técnicas de ingeniería genética, empleada como vacuna oral de microrganismos vivos de una sola dosis ${ }^{16}$.

El tratamiento complementario con antimicrobianos por vía oral para los casos sospechosos confirmados, contactos y portadores de Vibrio cholerae $\mathrm{O} 1$ es el siguiente ${ }^{10}$ :

- Mayores de 15 años.

Doxiciclina 300 mg vía oral en dosis única.

- Niños

De 10 a 14 años: Doxiciclina 200 mg vía oral en dosis única.

De 5 a 9 años: Doxiciclina 100 mg vía oral en dosis única.

Menores de 5 años: Eritromicina $30 \mathrm{mg} / \mathrm{kg}$ de peso por día, dividida en tres dosis durante tres días.

Sólo en caso de no contar con los antimicrobianos arriba mencionados se utilizarán los siguientes antimicrobianos:

- Adultos

Tetraciclina $500 \mathrm{mg}$ cada seis horas por tres días, o Trimetoprim-Sulfametoxazol dos tabletas de $80 \mathrm{mg}$ de trimetoprim/400 mg de sulfametoxazol cada 12 horas, por cinco días.

- Niños

Trimetoprim-Sulfametoxazol suspensión en base a una dosis de 8-10 mg/kg de peso, dividida en dos dosis durante cinco días. 


\section{Cólera}

\section{Medidas de prevención}

Es importante retomar que dentro de las funciones de la Salud Pública, las directas corresponden a la promoción y protección como medidas preventivas. En este sentido, la prevención primaria (según Leavell y Clark) ${ }^{15,22}$ está dirigida a los individuos sanos o aparentemente sanos, a través de la promoción y educación para la salud para prevenir enfermedades diarreicas, con énfasis en cólera a través del lavado de manos, lavado y desinfección de frutas y verduras, cloración de recipientes colectores a nivel intradomiciliario ${ }^{17}$.

La población infantil forma parte de la implementación de cambios educativos como un beneficio potencial a largo plazo, por ello la Organización Panamericana de la Salud diseñó un programa de salud cuyos objetivos son fomentar el comportamiento de autocuidado personal y colectivo y sugerir acciones para desarrollar actividades con la familia y la comunidad para evitar el cólera. Además, como se comentó en el apartado anterior, existen normas de saneamiento ambiental para la disposición de agua, siendo ésta, una clara actividad de prevención primaria.

La Organización Mundial de la Salud ha establecido los criterios enfocados en agua y saneamiento para la intervención en emergencias sanitarias centradas en Salud Pública. ${ }^{12}$ Asimismo, la calidad microbiológica del agua para consumo humano, incluye la búsqueda de Vibrio cholerae O1 y Vibrio cholerae O139 toxigénicos en tomas y depósitos domiciliarios, camiones cisterna, hidrantes, agua envasada, hielo y cualquier otro depósito o conducto de agua que pueda constituir una fuente potencial de infección por cólera ${ }^{18,19}$. El análisis de la calidad del agua tiene como límites permisibles de calidad del agua lo siguiente (Cuadro 1) ${ }^{19,20}$ :

Cuadro 1. Límites permisibles de la calidad del agua.

\begin{tabular}{|l|l|}
\hline \multicolumn{1}{|c|}{ Características } & \multicolumn{1}{c|}{ Límite permisible } \\
\hline Organismos coliformes totales & $2 \mathrm{NMP} / 100 \mathrm{ml}$ \\
\cline { 2 - 2 } & $2 \mathrm{UFC} / 100 \mathrm{ml}$ \\
\hline Organismos coliformes fecales & No detectable $\mathrm{NMP} / 100 \mathrm{ml}$ \\
\hline & Cero UFC/100 ml \\
\hline
\end{tabular}

Retomado de: Eugene F, Junkin MC. Agua y salud humana. México: Noriega Editores; 1988. 


\section{Principales problemas de Salud Pública en México}

Se ha adoptado por las mediciones de cloro residual para substituir a algunos de los organismos indicadores en el monitoreo de los sistemas de distribución de agua en los EE.UU. La justificación de estos se basa en parte, en la observación de que un porcentaje sustancial de los brotes de enfermedades puede atribuirse a deficiencias en la desinfección. En México, la concentración de cloro residual libre debe de ser entre los límites de 0,2 a 1,5 mg/l. ${ }^{19,20}$

La prevención secundaria tiene como objetivo principal evitar que, una vez instalada la enfermedad por cólera, ésta progrese, para ello se implementan las actividades permanentes de Vigilancia Epidemiológica de cólera aplicando las definiciones operacionales de caso y realizando el monitoreo de búsqueda intencionada con muestreo de heces fecales. El diagnóstico oportuno y el tratamiento profiláctico a base de $300 \mathrm{mg}$ de doxiciclina dosis única, son sustanciales para interrumpir la cadena de transmisión a nivel poblacional; y sobre todo, otorgar el tratamiento oportuno a pacientes con diagnóstico confirmado mediante antibióticos y terapia de rehidratación, debido a que el choque hipovolémico es la principal causa de mortalidad por cólera.

En la prevención terciaria, es importante garantizar la desinfección de los cadáveres con una solución de cloro al 0,5\%. Cuando fallece un paciente de cólera, se debe amortajar cuidadosamente su cadáver y las personas que lo transporten han de usar guantes ${ }^{15}$.

Las personas que lavan y preparan el cadáver deben usar guantes, delantal y mascarilla; rellenar la boca y el ano del cadáver con algodón hidrófilo embebido en solución de cloro, vendar la cabeza para mantener la boca cerrada y no vaciar el intestino ${ }^{24}$.

Las acciones de la Salud Pública y la Epidemiología, para el control y Vigilancia Epidemiológica de la enfermedad.

La Salud Pública, comprende un conjunto de ciencias y habilidades para promover, proteger, recuperar y rehabilitar la salud de la colectividad, mediante su participación activa y organizada, al respecto, la Epidemiología, como disciplina científica básica de ésta, permite medir la frecuencia y distribución del salud de una población a través de cuatro grandes campos ${ }^{21,22}$ :

a) El del estudio de la situación de salud de las poblaciones. 


\section{Cólera}

b) La Vigilancia Epidemiológica.

c) La evaluación epidemiológica.

d) Los estudios etiológicos de focos y cadenas epidemiológicas.

La Vigilancia Epidemiológica en Salud Pública tiene dos funciones básicas: la detección oportuna de situaciones de riesgo público en salud y la monitorización del impacto de las intervenciones de prevención y control de problemas prioritarios de salud en las poblaciones ${ }^{22}$.

En nuestro país, a través del Sistema Nacional de Vigilancia Epidemiológica (SINAVE) se realiza la recolección sistemática, continua, oportuna y confiable de información relevante y necesaria sobre las condiciones de salud de la población y sus determinantes ${ }^{23}$.

En este sentido, existen enfermedades sujetas a vigilancia por el Reglamento Sanitario Internacional como son: cólera, peste y fiebre amarilla, debido a su corto periodo de incubación y alta letalidad².

En México, el cólera pertenece al grupo de vigilancia de las enfermedades transmisibles, subgrupo enfermedades infecciosas y parasitarias del aparato digestivo, clave CIE 10 A00, cuya periodicidad de notificación es inmediata, diaria y semanal, además de pertenecer al sistema de vigilancia especial ${ }^{23}$. Para llevar a cabo una correcta Vigilancia Epidemiológica del cólera, es necesario partir de las 4 etapas de la vigilancia (recolección de datos, análisis de información, interpretación de resultados y difusión de la información) descritas a continuación y aplicadas específicamente para el caso de cólera (Cuadro 2) 2,9,10,15.

La Vigilancia Epidemiológica requiere aplicar las definiciones operacionales de caso para estandarizar el seguimiento en todas las instituciones del sector salud permitiendo realizar la investigación y confirmación de los casos para establecer las medidas de preparación y respuesta ante una situación de contingencia. 
Cuadro 2. Etapas para la Vigilancia Epidemiológica para el Cólera.

\begin{tabular}{|c|c|}
\hline Etapas & Actividades \\
\hline $\begin{array}{l}\text { 1. Recolección } \\
\text { de datos }\end{array}$ & $\begin{array}{l}\text { Definición operacional del caso } \\
\text { Caso Probable } \\
\text { Persona de } 5 \text { años o más, que presenta } 5 \text { o más evacuaciones } \\
\text { diarreicas, en un periodo de } 24 \text {, con duración menor a } 5 \text { días } \\
\text { Detección de casos } \\
\text { Toma de muestra fecal con hisopo rectal en medio de transporte Cary } \\
\text { y Blair, para su procesamiento en el laboratorio } \\
\text { Notificación de casos } \\
V \text {. Cholerae es de notificación obligatoria e inmediata dentro de las } 24 \\
\text { horas posteriores a la identificación del caso } \\
\text { Clasificación de los casos } \\
\text { a) Caso confirmado de cólera } \\
\text { Es todo caso probable en quien se aísle o se demuestre la presencia } \\
\text { de } V \text {. cholerae O1 o de } V \text {. cholerae O139 Toxigénicas en materia fecal o } \\
\text { contenido gastrointestinal } \\
\text { También se considera caso confirmado, al caso probable que por } \\
\text { cualquier razón no se le tomó muestra fecal con hisopo rectal, pero } \\
\text { en quien se demuestre seroconversión de anticuerpos vibriocidas o } \\
\text { antitoxina colérica } \\
\text { b) Caso descartado de cólera } \\
\text { Todo caso probable en el cual las pruebas de laboratorio avaladas } \\
\text { fueron negativas a cólera }\end{array}$ \\
\hline $\begin{array}{l}\text { 2. Análisis de } \\
\text { información }\end{array}$ & $\begin{array}{l}\text { Consolidación de datos } \\
\text { Análisis de variables epidemiológicas básicas }\end{array}$ \\
\hline $\begin{array}{l}\text { 3. Interpretación } \\
\text { de resultados }\end{array}$ & $\begin{array}{l}\text { Comparación con datos previos e inclusión de variables locales no } \\
\text { consideradas en la recolección de los datos. }\end{array}$ \\
\hline $\begin{array}{l}\text { 4. Difusión de la } \\
\text { información }\end{array}$ & $\begin{array}{l}\text { Elaboración de materiales de difusión para distintos niveles de } \\
\text { decisión }\end{array}$ \\
\hline
\end{tabular}

Adaptado de: Módulos de principios de epidemiología para el control de enfermedades. Organización Panamericana de la Salud.

\section{Contacto}

Es la persona que en el hogar, lugar de trabajo o sitio de reunión, haya compartido, preparado o manipulado alimentos, bebidas, agua o hielo de los casos probables o confirmados en los cinco días previos al inicio de la enfermedad. 


\section{Cólera}

\section{Portador}

Es la persona que alberga al agente infeccioso sin que presente manifestaciones clínicas y en quien se aísla o demuestra la presencia de $V$. cholerae $\mathrm{O} 1$ o $V$. cholerae $\mathrm{O} 139$ Toxigénicos en la materia fecal o en contenido gastrointestinal.

\section{Hospitalizado}

Es la persona a la que se le brinda atención médica en un establecimiento de salud, formal o improvisado y que permanezca en las mismas 12 horas o más y en quien se aísle o demuestre la presencia de $V$. cholerae $\mathrm{O} 1$ o de V. cholerae O139 Toxigénicos.

\section{Defunción}

Fallecimiento de un caso confirmado hasta dos semanas posteriores al inicio de las manifestaciones clínicas y en cuyo certificado de defunción aparezcan como causa básica o asociada: gastroenteritis o diarrea más deshidratación; gastroenteritis o diarrea más desequilibrio hidroelectrolítico.

\section{Brote}

Es la presencia de dos o más casos confirmados relacionados epidemiológicamente entre sí o la aparición de un caso en un área donde no se había demostrado la existencia previa del cólera.

\section{Fuente de infección}

Todo alimento (agua inclusive), bebida, hielo, heces, vómito, fómites o desechos en donde se aísle o demuestre la presencia de $V$. cholerae $\mathrm{O} 1$ o de $V$. cholerae O139 Toxigénicos.

\section{Área de riesgo}

Es la zona geográfica que presente condiciones que favorezcan la presencia de $V$. cholerae O1 o de $V$. cholerae O139 Toxigénicos o en la que se haya aislado dichos agentes en casos portadores o muestras ambientales (aguas blancas, aguas negras o alimentos). 


\section{Principales problemas de Salud Pública en México}

Existen dos elementos sustanciales en la Vigilancia Epidemiológica del cólera, la búsqueda intencionada de casos de cólera en todo paciente que cumpla con la definición operacional de caso y el monitoreo al 2\% de las Enfermedades Diarreicas Agudas, cuyo objetivo es identificar la circulación del Vibrio cholerae en aquellos pacientes que pueden o no reunir los criterios de la definición de caso probable de cólera.

De confirmarse un caso de cólera, se realizarán las acciones de bloqueo familiar, de cerco epidemiológico y operativos especiales. La búsqueda de casos de diarrea se mantendrá hasta 15 días posteriores a la fecha de inicio del último caso confirmado. En dichas actividades se interrogará la presencia de pacientes con diarrea, y en los casos positivos se tomará muestra con hisopo rectal con ministración de 300 mg dosis única, 10,15.

Asimismo se efectuarán determinaciones de cloro residual, se clorarán las fuentes de abastecimiento de agua de la localidad y se practicará monitoreo ambiental a través de hisopos de Moore, Spira y muestras de alimentos para búsqueda de Vibrio cholerae O1 y V. cholerae $\mathrm{O} 139^{15,23}$.

\section{Referencias}

1. Lyons SA, Petrucelli JR. Historia de la Medicina. Madrid, España: Editores Harcourt; 1994.

2. Organización Panamericana de la Salud. Oficina Sanitaria Panamericana. Módulos de principios de epidemiología para el control de enfermedades. 6 vols. Investigación epidemiológica de campo: aplicación del estudio de brotes. Washington DC: OPS; 2002.

3. Tovares W, Carneiro MLA. Diagnóstico y tratamiento en infectología y parasitología. 2a ed. México: Manual Moderno; 2009.

4. Instituto Mexicano del Seguro Social. Plan Institucional de Preparación y Respuesta ante una Epidemia de Cólera. México: Secretaría de Salud, Instituto Mexicano del Seguro Social; 2012.

5. Organización Panamericana de la Salud. Organización Mundial de la Salud. Alertas y actualizaciones epidemiológicas. Anuario 2013. Washington DC: Organización Panamericana de la Salud; 2014. 


\section{Cólera}

6. World Health Organization. Weekly epidemiological record. World Health Organization. Switzerland. Agosto 2012: 31-32.

7. Winn WC, Allen SD, Janda WM, Koneman EW, Procop GW, Schreckenberger PC, Woods GL. Koneman Diagnóstico Microbiológico. $6^{\underline{a}}$ ed. Argentina: Panamericana; 2008.

8. Kenneth JR, Ray CG. Microbiología médica. 5ª ed. México: Mc Graw Hill; 2001.

9. Southwick F. Enfermedades infecciosas. 2ª ed. México: Mc Graw Hill; 2008.

10. Ramos JJ. Infectología clínica. México: Manual Moderno; 2008.

11. Secretaría de Salud. Manual de procedimientos estandarizados para la vigilancia epidemiológica de cólera. México: Secretaría de Salud. Dirección General de Epidemiología; 2012.

12. Benesun AS. Manual para el control de las enfermedades transmisibles. $16^{\underline{a}}$ ed. Washington, DC: OPS; 1997.

13. Secretaría de Salud. Norma Oficial Mexicana NOM-016-SSA2-2012, para la vigilancia, prevención, control, manejo y tratamiento del cólera. México: Secretaría de Salud. Diario Oficial de la Federación; 2012.

14. Secretaría de Salud. Instituto de diagnóstico y referencia Epidemiológicos. Lineamientos para la vigilancia por laboratorio de la enfermedad diarreica aguda bacteriana (cólera, salmonelosis y shigelosis). México: Secretaría de Salud; 2012.

15. Organización Mundial de la Salud. Grupo especial mundial de lucha contra el cólera. Brotes de cólera. Evaluación de la respuesta a los brotes y mejora de la preparación. Suiza: Organización Mundial de la Salud; 2004.

16. Quadros CA. Vacunas. Prevención de enfermedades y protección de la salud. Washington DC: Organización Panamericana de la Salud; 2004.

17. Organización Panamericana de la Salud, Ministerio de Salud Pública, Cruz Roja Dominicana, UNICEF. [Página Principal en Internet]. Organización Panamericana de la Salud, Ministerio de Salud Pública, Cruz Roja Dominicana, UNICEF [consultado el 30 agosto 2014]. Disponible en: http://www.paho.org/dor/images/stories/archivos/6_ Guia_poblacion_escolar.pdf

18. Secretaría de Salud. Norma Oficial Mexicana NOM-127-SSA2-1994, para la salud ambiental, agua para uso y consumo humano-limites permisible de calidad y 


\section{Principales problemas de Salud Pública en México}

tratamientos a que debe someterse el agua para su potabilización. México: Secretaría de Salud. Diario Oficial de la Federación; 1994.

19. Eugene F, Junkin MC. Agua y salud humana. México: Noriega Editores; 1988.

20. Secretaría de Salud. Norma Oficial Mexicana NOM-179-SSA2-1998, vigilancia y evaluación del control de calidad del agua para uso y consumo humano, distribuida por sistemas de abastecimiento público. México: Secretaría de Salud. Diario Oficial de la Federación; 1998.

21. Sánchez RM. Elementos de Salud Pública. $3^{\underline{a}}$ ed. Texas, EU: F. Méndez Cervantes; 1983.

22. Martínez NF, Heras C, Bergonzoli G, Castellanos L. Vigilancia epidemiológica. Madrid, España: Mc Graw Hill; 2004.

23. Secretaría de Salud. Norma Oficial Mexicana NOM-017-SSA2-2012, para la vigilancia epidemiológica. México: Secretaría de Salud. Diario Oficial de la Federación; 2012. 


\section{Enfermedad diarreica}

Mtra. Irma Araceli Aburto López

\section{Introducción}

La enfermedad diarreica, actualmente sigue siendo un problema de Salud Pública en el mundo, especialmente en los países en vías de desarrollo, en donde es considerada endémica y representa la segunda causa de defunción general en menores de cinco años de edad. Las muertes producidas por ésta patología son principalmente por deshidratación y a consecuencia de la desnutrición. Es una entidad nosológica determinada por la falta de infraestructura sanitaria y malos hábitos higiénicos. Su prevención, atención temprana, oportuna y adecuada, depende de los gobiernos, de los Sistemas de Salud, del personal del primer nivel de atención y de la participación activa de la población, lo que puede impactar en los índices de morbilidad y mortalidad, abatiendo este padecimiento ${ }^{1}$.

\section{Concepto}

La palabra diarrea proviene del latín diarrhoia que significa fluir atreves de y aplicada al área de la salud, es un síntoma de patología infecciosa gastrointestinal caracterizada por un número más frecuente de deposiciones de los habitual y/o con disminución de la consistencia usual, de lo habitual para una persona por día ${ }^{2,3}$. Se considera, que por alteraciones de la absorción y de la motilidad intestinal, aumenta el número de evacuaciones intestinales ya sea blandas o acuosas al menos tres o más en 24 horas. En lactantes, no se considera enfermedad diarreica, cuando las evacuaciones son sólidas, disminuidas de consistencia, ni pastosas, en infantes que son alimentados con leche materna ${ }^{4}$.

\section{Clasificación}

Tiene gran importancia la clasificación por el tiempo de evolución de la enfermedad y también de acuerdo a sus características clínicas, ya que al aplicarlas correctamente, se permite el manejo oportuno de casos, lo que evita muertes por enfermedad diarreica. Desde estas perspectivas, existen tres tipos de presentación por ésta patología: 


\section{Principales problemas de Salud Pública en México}

1. La enfermedad diarreica aguda líquida, es la responsable del $80-90 \%$ de los episodios de gastoenteritis. Es de origen infeccioso, de inicio súbito, es aquella que tiene un promedio de duración de 7 días, aunque puede tardar en resolverse hasta menos de 14 días. Esta forma clínica provoca la mayor causa de muertes en menores de cinco años, a causa de la deshidratación. Los principales agentes causales por éste tipo son el Rotavirus, E. coli enterotoxigénica, Cryptosporidium, V. cholerae O1 o V. cholerae O139. En general, para éste tipo de diarrea, en el $85 \%$ de los casos, no requiere la prescripción de antibióticos, ya que la enfermedad se autolimita. Sin embargo, si estamos ante un caso de cólera, las evacuaciones son acuosas, que tienen la característica de olor a pescado y su apariencia física de las heces es como agua de arroz y tendremos que administrar, en éstos casos antibióticos. Por cualquier agente causal, en éste tipo de diarrea siempre es indispensable la hidratación ${ }^{4,5,6}$.

2. La diarrea disentérica, representa el 5-10\%. Caracterizada por la presencia de moco, sangre y menor cantidad de heces y líquidos. Las complicaciones producidas por éste tipo de diarrea incluyen toxemia, sepsis, úlceras, prolapso rectal, perforación intestinal e insuficiencia renal entre otras. Es producida en la mayor parte de los casos, por agentes biológicos como la Shigella, Campilobacter Jejuni, E. coli, Salmonella y por Entamoeba histolítica. Este cuadro clínico, requiere para su manejo, la prescripción de antibióticos o antiparasitarios, según sea la causa ${ }^{4,5,6}$.

3. La enfermedad diarreica persistente, su proporción menor del $10 \%$ del total de ellas. Su cuadro clínico inicia con evacuación aguda líquida o disentérica y dura más de catorce días. La mayor complicación a consecuencia de éste tipo de diarrea es la desnutrición. Los factores de riesgo que favorecen la duración prolongada son ser menor de un año de edad, la inmunosupresión y la falta de resistencia del huésped, por desnutrición, haber padecido sarampión recientemente o la no vacunación en contra de ésta enfermedad, además de carecer de inmunización en contra del rotavirus; la falta de leche materna exclusiva durante los primeros seis meses de vida, introducción reciente de leche de vaca y un episodio reciente de diarrea agua o persistente. Son factores conductuales que aumentan la probabilidad de la enfermedad diarreica, la ingesta de leche con biberón, el mal manejo de heces fecales, ingesta de alimentos y agua contaminada con heces fecales. La enfermedad diarreica persistente, no debe confundirse con la diarrea crónica, producida por otras causas diferentes a la infecciosa, como es la causada por intolerancia al gluten y a la lactosa ${ }^{2,4,5,6}$. 


\section{Enfermedad diarreica}

De acuerdo a la Clasificación Internacional de la Enfermedad (CIE-10), en México se incluyen en el rubro de Enfermedades Diarreicas Agudas (EDAS), las siguientes enfermedades absceso hepático amebiano, amebiasis intestinal, ascariasis, cólera, fiebre tifoidea, giardiasis, infecciones intestinales por otros organismos y más, intoxicación alimentaria bacteriana, otras infecciones intestinales debidas a protozoarios, paratifoidea y salmonelosis, y shigelosis?

\section{Epidemiología}

Según la Organización Mundial de la Salud (OMS), anualmente en el mundo, el número de casos y defunciones a consecuencia de la enfermedad diarreica, representan 1700 millones de casos y 760000 defunciones, respectivamente, en menores de cinco años de edad. El Observatorio de la Salud de la OMS, posee registrado para 2015, para la edad de 1 a 59 meses, que del total de muertes para éste grupo de edad, el 9\% ocurrió a causa de diarrea ${ }^{8}$. En menores de 5 años, representa la segunda causa de muerte en general, en países subdesarrollados, alcanzando el $4 \%$ del porcentaje del total de las defunciones por cualquier enfermedad, a nivel mundial, y junto con la neumonía, asciende al $29 \%$. Es en ese mismo grupo de edad en donde acontecen el $90 \%$ de las muertes ocurridas en dichos países, a consecuencia de ésta enfermedad. Los principales motivos por los que mueren éstos pacientes son a consecuencia de la deshidratación, por inmunosupresión y malnutrición $\mathbf{n}^{2,9,10}$.

En países subdesarrollados, los menores de tres años padecen en promedio tres episodios de diarrea por año y eso provoca que el infante carezca de los nutrientes necesarios para su desarrollo y crecimiento, ya que la diarrea produce disminución de la absorción de nutrientes y abatimiento del apetito, lo que favorece a su vez la desnutrición. Por lo que la diarrea es causa de malnutrición, y los niños desnutridos son a su vez más susceptibles a enfermar. También, la desnutrición y la inmunosupresión, son considerados factores de mal pronóstico para ésta patología, ya que aumentan la probabilidad de morir a consecuencia de la enfermedad diarreica ${ }^{2,3,9}$.

En nuestro país, en los menores de 5 años de edad ocupan los primeros lugares de morbilidad, provocando el $20 \%$ de las consultas en los Servicios de Salud y el $10 \%$ de los internamientos en los hospitales pediátricos. Los menores de 3 años tienen en promedio 3.3 episodios de diarrea y en algunas zonas de nuestro país asciende hasta 9, en donde el 15\% de sus vidas se la pasan con éste padecimiento ${ }^{8}$. 


\section{Principales problemas de Salud Pública en México}

Debido a la transición epidemiológica en México, antes de 1980, las principales causas de mortalidad eran infectocontagiosas. Sin embargo, a pesar de que las EDAS poseen una tendencia secular descendente, las que han disminuido en un 55.7\% de 1998 al año 2011, para éste último año aparece todavía dentro de las veinte principales causas de mortalidad general en nuestro país, ocupando el $18^{\circ}$ lugar y la mayor parte de las defunciones por éste padecimiento, siguen prevaleciendo en los menores de un año de edad, seguidos por los de edad preescolar ${ }^{11,12}$. El 80\% de las muertes ocurren en menores de dos años de edad ${ }^{8}$.

Ya que las EDAS, son transmisibles, forman parte de la Vigilancia Epidemiológica y son de notificación obligatoria, reguladas en nuestro país, por la Dirección General de Epidemiología, la incluye a las enfermedades infecciosas intestinales, al cólera, shigelosis, salmonelosis y diarrea debida a Rotavirus. Dicha información se adquiere a través de la Estrategia de Núcleos Trazadores (NuTraVE), con periodicidad de notificación (inmediata, diaria y semanal) y con sistema especial (Cuadro 1$)^{10}$ :

Cuadro 1. Periodicidad de notificación de Enfermedad Diarreica en NUTraVE ${ }^{10}$.

\begin{tabular}{|c|c|c|c|c|c|}
\hline \multirow{2}{*}{ Padecimiento } & \multirow{2}{*}{ Clave CIE } & \multicolumn{3}{|c|}{ Periodicidad de notificación } & \multirow{2}{*}{$\begin{array}{l}\text { Sistema } \\
\text { especial }\end{array}$} \\
\hline & & Inmediata & Diaria & Semanal & \\
\hline Cólera & A00 & $x$ & $X$ & $x$ & $X$ \\
\hline Fiebre tifoidea & A01.0 & & & $X$ & \\
\hline Paratifoidea & A01.1 & & & $X$ & \\
\hline Shigelosis & A03 & & & $X$ & \\
\hline Rotavirus & A08.0 & $x$ & & $X$ & $X$ \\
\hline
\end{tabular}

Es por ello que México cuenta con registro de casos de enfermedad, a través del Sistema Nacional de Vigilancia Epidemiológica, de la Dirección General de Epidemiología, para las enfermedades, causantes de enfermedad diarréica ${ }^{10-25}$ :

1. Los casos anuales de las enfermedades infecciosas intestinales, poseen una tendencia negativa de 2001 a 2007, con una disminución del 21\%, para ese periodo. Sin embargo para 2011 presentó un aumento del 10.6\%, comparativamente con $2007^{10}$. A partir de 2012, no se encuentra con ese rubro o nomenclatura para la vigilancia de la misma. 


\section{Enfermedad diarreica}

2. En cuanto al cólera, ésta enfermedad resurgió en México en junio del año de 1991, la que estuvo presente hasta 2001, de ese año a principio de 2011, no hubo notificación de $\operatorname{casos}^{10}$. En 2011, se notificó 1 caso en Sinaloa; en 2012, 2 casos reportados en San Luis Potosí; en 2013 se reportaron 106 casos, 159 en Hidalgo, 14 en Veracruz y 2 en San Luis Potosí; en 2014, 14 casos, de ellos 13 en Hidalgo y 1 en Querétaro. Con una incidencia para éste último año de 0.01 por cada 1000000 habitantes $^{13,14,15,25}$.

3. La fiebre tifoidea posee una distribución mundial, aunque ha disminuido en los países desarrollados. La tendencia en cuanto a número de casos registrados en México del año 2000 al 2011, ha sido ascendente con 107,289 y 170,400 casos, respectivamente, lo que representa un aumento del 59\% ${ }^{10}$. Los números de casos notificados para 2012, 2013 y 2014, son de 54041, 53772 y 53072, respectivamente. Con una tendencia descendente de 2011 a 2014, con un decremento del 68\%. La incidencia para éste último año es de 44.33 por cada 100000 habitantes $^{16,17,18,25}$.

4. La fiebre paratifoidea, en México para 2014 tiene un registro de casos de 15027, con una incidencia de 12.55 por cada 100000 habitantes; en donde el grupo más afectado es de 45 a 49 años de edad, con una tasa de 18.28 por cada 100000 habitantes $^{25}$.

5. La shigelosis posee una distribución mundial, endémica en clima tropical y templado, la que causa 600000 defunciones al año en el mundo; dos terceras partes de los casos y casi todas las defunciones se presentan en niños menores de 10 años de edad. La patología en general no se presenta en los menores de 6 meses. El ataque secundario en los familiares, asciende al 40\%. En México, la tendencia de casos nuevos por esta enfermedad del año 2000 al 2011, es negativa, con descenso de 36,397 a 9,975 casos. ${ }^{10}$ El número de casos registrados para 2012, 2013 y 2014, son 8066, 7125 y 5918, respectivamente; de 2011 a 2014 tiene tendencia negativa, con un descenso del 40.6\%. La incidencia para 2014 es de 4.94 por cada 100000 habitantes $^{19,20,21,25}$.

6. La Vigilancia Epidemiológica para la enteritis debida a rotavirus, en México se inició en el año 2008 y hasta 2011 posee una tendencia ascendente, en el número de casos registrados, con un aumento del $71 \% .{ }^{10}$ El número de casos para 2012, 2013 y 2014, es de 4132, 4522 y 2539, con un descenso del número de casos entre los años 2013 al 2014, del 43\%. Con una incidencia en el 2014 de 2.12 por cada 100000 habitantes ${ }^{22,23,24,25}$. 


\section{Principales problemas de Salud Pública en México}

\section{Causalidad}

Es un padecimiento infeccioso causado por múltiples agentes biológicos, como bacterianos, virales y parásitos; asociados a factores determinantes que interactúan entre sí provocando casos asintomáticos y sintomáticos.

\section{$>$ Agentes biológicos}

En México, al igual que en los países en vías de desarrollo, los dos agentes causales con más frecuencia que provocan las EDAS, son los rotavirus y la Escherichia coli enteropatógena (10-40\%). En general, en cualquier nación, los microorganismos aislados más repetidamente, causantes de la enfermedad, son los Rotavirus, Escherichia coli enteropatógena (ECEP), Campylobacter jejuni, Shigellae sp, Salmonellae sp, Crytosporidium sp y Escherichia coli enterotoxigénica (ECET). Los que menos la provocan son Escherichia coli enteroinvasora, Giardia lamblia, Entamoeba histolytica, Yersinica enterocolítica, Adenovirus entéricos y Virus Norwalk?

Entre los agentes biológicos más importantes que provocan la mayoría de los cuadros clínicos de enfermedad diarreica, en menores de cinco años:

1. Bacterias: Shigellae sp, Escherichia coli enterotoxigénica (ECET), Eschericia coli enteropatógena (ECEP), Escherichia coli enterohemorrágica (ECEH) y Campylobacter jejuni. Son causa del 10 al $20 \%$ del total de los $\operatorname{casos}^{26,27}$.

2. Virus: Rotavirus, y Adenovirus atípicos. El 70 al 80\% de los casos se deben a rotavirus, en países desarrollados ${ }^{26,27}$.

3. Protozoarios: Giardia lamblia y Cryptosporidium $\mathrm{sp}^{26}$.

En éste grupo de edad, entre los agentes biológicos que menos casos causan son: Salmonellae sp, Yersinia enterocolica, Aeromonas hydrophila, Escherichia coli enteroinvasora (ECEI), Plesiomonas shuigelloides y Vibrio cholerae ${ }^{26}$.

El periodo de incubación de la enfermedad diarreica, depende del agente causal, el que oscila de 3 a 6 horas (Cólera) hasta 10 días (Salmonella sp): Vibrio cholerae (3-6 hrs. a 5 días), 


\section{Enfermedad diarreica}

ECT (6-56hrs.), ECEP (6-48 hrs.), ECEI (1-4 días), ECEH (3-9 días), Salmonella sp (6 hrs - 10 días), Shigella (1-8 días) Campilobacter jejuni (36 horas -8 días). Yersinia enterocolítica (3-7 días), Rotavirus (48-74 hrs) 7 .

El mecanismo de transmisión es a través de alimentos y agua contaminada, o de persona a persona, como resultado de la mala higiene de las personas, que portan los microorganismos en sus manos. Los agentes etiológicos ingresan a la economía a través de la boca, al ser ingerirlos con los alimentos y agua contaminados con heces fecales y/o tierra y por las manos sucias de pacientes que los portan. Su vía de eliminación se efectúa por el tubo digestivo a través de las heces fecales, y se diseminan por vía fecal-oral (ano-mano-boca). Al respecto existe un número considerable de pacientes asintomáticos que son portadores de la enfermedad ${ }^{2,4}$.

\section{Factores de riesgo.}

Existen factores que definen la posibilidad de enfermedad o de aumentar el riesgo para morir a consecuencia de la enfermedad diarreica, entre ellos se encuentran aspectos del individuo como la deficiente higiene personal ya que favorece el mecanismo de transmisión de ésta enfermedad, a través de las manos sucias, después de defecar ${ }^{2,4}$.

La preparación insalubre de los alimentos, el almacenamiento antihigiénico de los alimentos, ya que éstos elementos favorecen que la comida que se ingiere, estén contaminados con microorganismos causales de la enfermedad, con heces fecales y tierra ${ }^{2,4,27}$.

Los alimentos se contaminan en la cosecha al regarlos con aguas negras o agua no potable. Cuando el agua de consumo para beber, cocinar e higiene personal, no es potable y está con heces fecales, provoca enfermedades intestinales. Al respecto, existen en el mundo, 750 millones de habitantes que no poseen acceso al agua potable y que 2500 millones a sistemas de saneamiento adecuados ${ }^{2,4}$.

Aspectos de saneamiento ambiental deficiente, como la carencia de la disposición de excretas en letrinas o retrete, y con inadecuado drenaje, ni disposición de agua potable $e^{2,27}$.

Características que disminuyen la respuesta inmunológica del individuo como la desnutrición, deficiencia de vitamina $\mathrm{A}^{6,27}$. 


\section{Principales problemas de Salud Pública en México}

En cuanto a los menores de edad, se anexan factores que tienen gran importancia como el bajo peso al nacer, desnutrición, incompleto esquema de vacunación, la aplicación de lactancia materna de manera inapropiada; falta de capacitación de la madre con respecto a la higiene familiar, los factores que desarrollan episodios de diarrea, así como el no conocer los signos de alarma cuando los niños poseen diarrea y que deben hacer en caso de que tengan diarrea sus hijos ${ }^{6,27}$.

La no lactancia materna en los infantes es un elemento muy importante como causa de enfermedad diarreica. La OMS, revela que el 39\% de los niños menores de 6 meses, son amamantados exclusivamente ${ }^{28}$.

Existen comorbilidades que favorecen a la enfermedad diarreica, tales como el sarampión, malaria, enfermedad intestinal no infecciosa e irritación química del intestino².

Agravan los casos de enfermedad diarreica, algunas enfermedades como la diabetes mellitus y la insuficiencia renal ${ }^{27}$.

La desigualdad social es un elemento que favorece ésta enfermedad, ya que los que menos tienen, poseen características de ser niños pobres, hambrientos y que viven en comunidades lejanas o dispersas. Estos mismos grupos sociales no tienen acceso a los Servicios de Salud o en su defecto los tienen parcialmente o tardíamente, lo que agrava los casos de enfermedad diarreica. Es por ello que en la actualidad solamente el 35\% de los niños que padecen enfermedad diarrea, reciben terapia de rehidratación oral ${ }^{28}$.

\section{Factores de mal pronóstico}

Son los factores que favorecen que la enfermedad se prolongue, agrave o que provoquen la muerte del paciente, entre ellos se encuentran los elementos que aumentan la probabilidad de deshidratación y de diarrea persistente $e^{4,27,28,30}$.

Además se incluyen entre éstos factores ser menor de 2 meses de edad, presencia de alguna inmunodeficiencia, el antecedente de haber tenido una muerte de un menor de cinco años en la familia, madre con baja escolaridad (igual o menor a tercer año de primaria, madre menor de 17 años de edad, dificultad para el traslado al médico si se agravara el niño (ya que hay familiar que hacen demasiado tiempo para llegar desde su casa a la atención 


\section{Enfermedad diarreica}

médica, desnutrición moderada o grave. $Y$ en menores de dos meses de edad, tener una madre soltera y primigesta, edad gestacional mayor de 42 semanas o menor de 37 semanas de gestación, embarazo de alto riesgo, defectos al nacimiento, atención por personal no capacitado, hipoxia neonatal, trauma obstétrico, bajo peso al nacimiento, lactancia materna ausente o inadecuada, proceso infeccioso en la edad neonatal, retraso en el diagnóstico y manejo del padecimiento ${ }^{31}$.

Factores de riesgo para deshidratación

Son factores de riesgo que favorecen deshidratación en edad infantil: ser menor de un año de edad, en especial los menores de 6 meses, bajo peso al nacimiento, niños que han presentado más de 5 evacuaciones y más de 2 vómitos en 24 horas, desnutrición, no haber recibido lactancia materna exclusiva hasta los seis meses de edad, intolerancia a la ingesta de líquidos ${ }^{27}$.

Factores de riesgo para diarrea persistente

La presencia de desnutrición, presentar cuadro clínico de enfermedad diarreica con disentería, el uso indiscriminado de antibióticos, presentar más de 10 evacuaciones en 24 horas y la persistencia de la deshidratación por más de 24 horas de evolución ${ }^{27}$.

Factores Protectores

Son factores protectores para reducir la morbilidad y mortalidad de las enfermedades diarreicas, las encaminadas al recién nacido, como la lactancia materna exclusiva, durante los primeros seis meses de edad y extender la ingesta de leche materna, en los niños hasta los dos años de edad con alimentación complementaria, además de administrar suplementos de vitamina $\mathrm{A}^{28}$.

\section{Fisiopatología}

Los agentes biológicos causantes de las EDAS, provocan a través de diferentes mecanismos, que la mucosa intestinal no absorba agua y ésta sea eliminada por las heces fecales, produciendo como consecuencia la diarrea. 


\section{Principales problemas de Salud Pública en México}

Puede ser que provoquen una lesión focal en las células y vellosidades intestinales, causando el abatimiento en la producción de disacaridasas (las que se encargan de la absorción de lactosa), tal es el caso de la diarrea provocada por rotavirus, que ocasiona por ese hecho, aumento de la osmolaridad en la luz intestinal, ocasionando pérdida de agua por las heces. Algunas bacterias se adhieren a la mucosa intestinal, produciendo enterotoxinas, las que alteran la función de absorción del agua, tal es el caso de la Salmonella sp, Campylobacter jejuni, Vibrio cholerae 01, E. coli enterotoxigénica y Shigella sp. Existen casos de agentes biológicos que provocan disolución del borde del cepillo y de la mucosa, invadiendo la misma y con proliferación intracelular de las bacterias (E. coli enteroinvasora y Shigella sp) o crecimiento bacteriano en la lámina propia con proliferación a los ganglios mesentéricos (Yersenia enterocolítica y Campylobacter jejuni) $^{31}$.

\section{Cuadro clínico}

Se considera que un paciente tiene EDA, cuando el paciente asiste a la atención médica por haber presentado cinco o más evacuaciones diarreicas en 24 horas, durante no más de cinco días con o sin datos de deshidratación. Se considerará moderada cuando no tenga datos de deshidratación. Y será grave cuando presente 2 o más de los siguientes datos, vómito (más de cinco en 24 horas), cuadro disentérico, temperatura mayor a $38^{\circ} \mathrm{C}$ o datos de deshidratación moderada a grave ${ }^{10}$. Habitualmente la diarrea se autolimita y dura entre 5 y 7 días y ocasionalmente puede presentarse hasta 14 días ${ }^{27}$. El vómito casi siempre dura de 1 a 2 días y cede como máximo en $3^{27}$. Cuando el cuadro diarreico es producto de virus casi siempre es de corta duración y se asocia con vómito y deshidratación. A diferencia de la ocasionada por bacterias las que presentan en su mayoría dolor abdominal y presencia de disentería. ${ }^{27}$ Sin embargo, la existencia del cuadro clínico de quien padece la enfermedad, dependerá del agente biológico causal (Cuadro 2).

Cuadro 2. Cuadro clínico por enfermedad diarreica de acuerdo a los diferentes agentes biológicos 5 .

\begin{tabular}{|l|l|}
\hline Agente biológico & \multicolumn{1}{|c|}{ Signos y síntomas } \\
\hline Shigella & $\begin{array}{l}\text { Pueden existir casos asintomáticos. Disentería o diarrea, dolor } \\
\text { abdominal, fiebre y tenesmo. }\end{array}$ \\
\hline ECET & $\begin{array}{l}\text { Pueden existir casos asintomáticos. Diarrea líquida, vómitos, dolor } \\
\text { abdominal, escasa fiebre. }\end{array}$ \\
\hline
\end{tabular}




\section{Enfermedad diarreica}

Cuadro 2. Cuadro clínico por enfermedad diarreica de acuerdo a los diferentes agentes biológicos ${ }^{5}$ (continuación).

\begin{tabular}{|l|l|}
\hline Agente biológico & \multicolumn{1}{c|}{ Signos y síntomas } \\
\hline ECEI & Disentería o diarrea, dolor abdominal, fiebre y tenesmo. \\
\hline ECEP & Pueden existir casos asintomáticos. Diarrea, vómitos y fiebre. \\
\hline $\begin{array}{l}\text { Salmonella } \\
\text { (no tifoidea) }\end{array}$ & $\begin{array}{l}\text { Son comunes los casos asintomáticos. Disentería o diarrea, vómito, } \\
\text { dolor abdominal y fiebre. }\end{array}$ \\
\hline Campylobacter & $\begin{array}{l}\text { Son pocos comunes los casos asintomáticos. Disentería o diarrea, } \\
\text { dolor abdominal y fiebre. }\end{array}$ \\
\hline $\begin{array}{l}\text { Yersinia } \\
\text { enterocolitica }\end{array}$ & $\begin{array}{l}\text { Son pocos comunes los casos asintomáticos. Diarrea, fiebre y dolor } \\
\text { abdominal. }\end{array}$ \\
\hline Vibrio cholerae & $\begin{array}{l}\text { Son muy comunes los casos asintomáticos. Diarrea aguda líquida } \\
\text { profusa con aspecto como agua de arroz y vómitos. No fiebre. }\end{array}$ \\
\hline Rotavirus & $\begin{array}{l}\text { Son comunes los casos asintomáticos. Diarrea líquida, vómitos y } \\
\text { fiebre. }\end{array}$ \\
\hline $\begin{array}{l}\text { Entamoeba } \\
\text { histolytica }\end{array}$ & $\begin{array}{l}\text { Son muy comunes los casos asintomáticos. Disentería o diarrea, dolor } \\
\text { abdominal y tenesmo. }\end{array}$ \\
\hline Giardia lamblia & $\begin{array}{l}\text { Es muy común que existan casos asintomáticos. Dolor abdominal, } \\
\text { diarrea, flatulencia, pérdida de peso o detención del crecimiento. }\end{array}$ \\
\hline
\end{tabular}

Es importante recordar que se debe efectuar la identificación de los datos clínicos con el afán de evitar complicaciones como la deshidratación y desnutrición.

\section{Complicaciones}

La complicación más frecuente en la mayoría de los casos es la deshidratación, la que provoca el mayor número de muertes por la pérdida importante de líquidos y electrolitos. Sin embargo, puede existir la desnutrición a consecuencia de la enfermedad diarreica.

La deshidratación, en las EDAS, se presenta por la pérdida de agua y electrolitos, como sodio, cloruro, potasio y bicarbonato, en las evacuaciones líquidas, los vómitos, el sudor, la orina y la respiración. La deshidratación puede ser grave y ocasionar la muerte si no se repone el agua y los electrolitos perdidos, es por ello que debemos conocer los grados de deshidratación, la que se mide en escala de tres ${ }^{4,27,29,30}$ : 


\section{Principales problemas de Salud Pública en México}

- Deshidratación incipiente: Sin signos ni síntomas.

- Deshidratación moderada: Con presencia de sed; decaimiento, comportamiento inquieto o irritable; reducción de la elasticidad de la piel; ojos hundidos, taquicardia, taquipnea, gasto urinario disminuido, extremidades tibias, mucosas secas, tiempo de llenado capilar normal, pulsos periféricos normales.

- Deshidratación grave: La que se caracteriza por agravamiento de los síntomas; choque, con pérdida parcial del conocimiento, disminución del nivel de conciencia (soporoso o comatoso), piel pálida, taquicardia, taquipnea, pulsos periféricos débiles, falta de diuresis, extremidades frías y húmedas, pulso rápido y débil, tensión arterial baja o no detectable, tiempo de llenado capilar prolongado, hipotensión y palidez.

Al respecto son signos de alarma para las EDAS, ojos hundidos, llanto sin lágrimas, boca seca y lengua seca, o saliva espesa, fontanela hundida, poca orina y obscura, sed intensa, poca ingesta de alimentos y líquidos, fiebre persistente por más de 3 días, evaluaciones líquidas numerosas y abundantes (más de 3 por hora), vómitos frecuentes (más de 3 por hora) y sangre en las evacuaciones ${ }^{3,29,30}$.

Otras complicaciones, además de la deshidratación son el desequilibrio hidroelectrolítico, acidosis metabólica, choque hipovolémico, intolerancia a la lactosa, enterocolitis, alteraciones hematológicas, coagulación intravascular diseminada, peritonitis, perforación intestinal, infarto intestinal, invaginación intestinal, sepsis, choque séptico, insuficiencia renal y alteraciones neurológicas ${ }^{31}$.

\section{Diagnóstico}

El diagnóstico se efectúa a través de la historia clínica, la que incluye los datos clínicos presentados por el paciente y la exploración física. Entre los que se encuentran las características de las evacuaciones, con disminución de la consistencia y aumento en la frecuencia y número de las mismas, presencia o no de moco y sangre, ocasionalmente náusea, vómito y dolor abdominal ${ }^{27}$.

En la exploración física, el clínico debe evaluar la presencia o no de deshidratación. En el niño menor de 5 años, es considerado como el estándar de oro, la pérdida de peso 


\section{Enfermedad diarreica}

(diferencia entre el peso de ingreso y la post- rehidratación). En edad infantil, la presencia de fontanela anterior deprimida y extremidades frías. Además de presentan en más del 5\% de los casos signo de lienzo húmedo, tiempo de llenado capilar lento, ausencia de lágrimas y patrón respiratorio anormal.

Es necesario hospitalizar a los pacientes que presenten choque, deshidratación grave (en niños con pérdida de peso corporal mayor al 9\%), niños con factores de riesgo para deshidratación, pacientes con anormalidades neurológicas como letargia y crisis convulsivas, y en niños en donde los padres o madres no sean diestros en el manejo de la enfermedad en el hogar.

Los estudios de gabinete en general no son recomendados para identificar el agente etiológico, ya que las EDAS, se autolimitan en la mayoría de los casos y son en gran parte provocadas por virus. Solo debe considerarse un estudio microbiológico, cuando la diarrea no presente mejoría al $7^{\circ}$ día de haberse iniciado, si se sospecha de septicemia o si el paciente está inmunocomprometido ${ }^{27}$.

\section{Terapéutica}

Los pacientes con enfermedad diarreica, requieren diagnóstico clínico adecuado y oportuno, para dar un tratamiento conforme a lo indicado y abatir las muertes por ésta enfermedad.

a) Para evitar la deshidratación se requiere dar en la edad infantil lactancia materna; proporcionar más líquidos de lo habitual, incluyendo solución oral de sales de rehidratación.

b) Con el afán de aumentar la respuesta inmunológica e incidir en la prevención de la desnutrición y pérdida de peso, es necesario continuar con la alimentación habitual y continua, incluyendo la lactancia materna para los menores de dos años de edad.

c) Además de promover las consultas a tiempo, lo que se logra a través de la capacitación de las madres y del personal de salud, para que identifiquen de manera temprana los signos de deshidratación o de alarma y otros aspectos clínicos de importancia para evitar complicaciones ${ }^{2,3,29,30}$. 


\section{Principales problemas de Salud Pública en México}

Para tratar las enfermedades diarreicas, de manera adecuada se deben realizar los siguientes aspectos ${ }^{4}$ :

- Rehidratación con Vida Suero Oral (VSO) de baja osmolaridad; si no se cuenta con VSO, se puede utilizar una solución salina de rehidratación oral (SRO), que son una mezcla de agua limpia, con sal y azúcar, las que se absorben en el intestino delgado y restituyen el agua y los electrolitos perdidos por las heces.

- Es recomendable tratarse con comprimidos de zinc (10 mg en menores de 6 meses y $20 \mathrm{mg}$ en mayores de 6 meses durante el episodio y durante 10 a 14 días más ${ }^{2,32}$. Se ha demostrado que éstos disminuyen en un $25 \%$ la duración de los episodios de diarrea y que también se asocian con un abatimiento del 30\% del volumen de las excretas ${ }^{4}$.

- En caso de deshidratación severa o de choque, dar rehidratación con líquidos intravenosos.

- Proporcionar alimentación rica en nutrientes, para romper el círculo vicioso diarrea malnutrición - diarrea. Es por ello que debe continuarse con la leche materna exclusiva, en los menores de seis meses, durante la enfermedad diarreica.

- Consultas a tiempo, para el tratamiento de la diarrea persistente o con disentería y en presencia de signos de deshidratación.

El tratamiento incluye la mejora de la atención médica y derivación de los casos necesarios a nivel hospitalario, cuando se requiera, por parte del Sector Salud; la identificación temprana de pacientes en el primer nivel de atención, incluyendo en ésta atención a la comunidad, específicamente a los padres o responsables de cuidar a los niños, que impida el agravamiento de los pacientes, para tal efecto se deben capacitar a los padres o tutores que cuidan a los niños. Además para poder efectuar el manejo adecuado, se debe administrar de manera correcta el suministro de recursos a los establecimientos del sector salud, con el afán de que se posean en el momento y lugar requerido los sobres de Vida Suero Oral de baja osmolaridad, zinc, antibióticos y oxígeno ${ }^{2,3,29}$.

Solamente se deberán prescribir antibióticos en casos muy concretos, se debe hacer el control de la fiebre y no está indicada la prescripción de antidiarreicos o anticolinérgicos, ni el uso 


\section{Enfermedad diarreica}

de antieméticos. Los antimicrobianos en general, para las EDAS no deben usarse, ya que el $90 \%$ de los cuadros clínicos son de origen viral y en la mayoría de los pacientes se autolimita la enfermedad. Además porque los antibióticos interfieren con la síntesis de vitamina $\mathrm{K}$; aumentan la resistencia bacteriana; disminuyen la flora bacteriana, prolongando la enfermedad por diarrea secundaria a los antibióticos; pueden producir reacciones alérgicas; además de que aumentan el riesgo de síndrome urémico - hemolítico. En caso de usarse los antimicrobianos tienen el objetivo de acortar la duración de la enfermedad, además de mejorar la sintomatología, erradicar a los microorganismos causantes de la misma y prevenir sus complicaciones. Están indicados cuando existe diarrea con presencia de sangre, en sospecha de cólera, en infección por Giardia lamblia, por Entamoeba histolytica, infecciones por Salmonella no typhy, en enfermos con E. coli enteropatógena, en pacientes inmunocomprometidos, con desnutrición grave, enfermedad diarreica crónica, colitis severa y cardiopatía congénita. Los antimicrobianos serán administrados de acuerdo a la sensibilidad (Cuadro 3) $)^{31}$ :

Cuadro 3. Cuadro clínico para la prescripción de antimicrobianos para la Enfermedad diarreica de acuerdo a los agentes biológicos ${ }^{31}$.

\begin{tabular}{|l|l|}
\hline \multicolumn{1}{|c|}{ Agente biológico } & \multicolumn{1}{c|}{ Antimicrobianos } \\
\hline Shigella & $\begin{array}{l}\text { Trimetroprim con sulfametoxasol. } 10 \mathrm{mg} / \mathrm{Kg} / \text { día, en } 2 \text { dosis } \\
\text { por } 5 \text { días, vía oral. } \\
\text { Ciprofloxacina. } 30 \mathrm{mg} / \mathrm{Kg} / \text { día en } 2 \text { dosis por } 2 \text { días, máximo } \\
500 \mathrm{mg} / \text { dosis, vía oral. }\end{array}$ \\
\hline $\begin{array}{l}\text { E. coli enteropatógena y E. } \\
\text { coli enteroinvasora. } \\
\text { Salmonella (no tifoidea) }\end{array}$ & $\begin{array}{l}\text { Trimetroprim con sulfametoxasol } \\
10 \mathrm{mg} / \mathrm{Kg} / \text { día, en } 2 \text { dosis por } 5 \text { días, vía oral }\end{array}$ \\
\hline Campylobacter jejuni & $\begin{array}{l}\text { Estolato de Eritromicina. } 30 \text { a } 50 \mathrm{mg} / \mathrm{Kg} / \text { día en } 3 \text { a } 4 \text { dosis } \\
\text { por } 5 \text { a } 7 \text { días, vía oral. }\end{array}$ \\
\hline Vibrio cholerae & $\begin{array}{l}\text { Doxiciclina. En mayores de } 8 \text { años de edad } 6 \mathrm{mg} / \mathrm{Kg} / \text { dosis, } \\
\text { única máxima } 300 \mathrm{mg} \text {. Vía oral. } \\
\text { Tetraciclina en mayores de } 8 \text { años de edad } 50 \mathrm{mg} / \mathrm{Kg} / \text { día, } 4 \\
\text { dosis por } 3 \text { días, máximo } 2 \mathrm{~g} \text { por día. } \\
\text { Furazolidona } 5 \mathrm{mg} / \mathrm{Kg} / \text { día en } 4 \text { dosis por } 3 \text { días, vía oral. }\end{array}$ \\
\hline Entamoeba histolytica & $\begin{array}{l}\text { Metronidazol. } 15 \mathrm{mg} / \mathrm{Kg} / \text { día, en } 3 \text { dosis por } 5 \text { a } 7 \text { días, vía } \\
\text { oral. }\end{array}$ \\
\hline Giardia lamblia & $\begin{array}{l}\text { Metronidazol. } 30-50 \mathrm{mg} / \mathrm{Kg} / \text { día máximo } 2250 \mathrm{mg} \text {, en } 3 \\
\text { dosis por } 7 \text { días en colitis leve a moderada, vía oral. Y para } \\
\text { colitis severa } 10 \text { días. }\end{array}$ \\
\hline
\end{tabular}




\section{Medidas de prevención}

Las medidas de prevención para las EDAS, van encaminadas a cortar los mecanismos de transmisión, dando educación para la salud dirigida a la población general, sobre cómo se propagan las infecciones del sistema gastrointestinal; mejorando las condiciones sanitarias como dotar a la población de agua potable a la comunidad y de un sistema de alcantarillado; brindar servicios apropiados de saneamiento del medio ambiente, reducción de la contaminación del aire con polvo y heces fecales; manejo y disposición adecuada de excretas, incluyendo los pañales de los niños pequeños; eliminación apropiada de basura; buena higiene personal, lavado de manos con jabón, que incluye a los niños que se chupan los dedos, así como después de defecar y antes de comer; correcto manejo de los alimentos, limpieza de los mismos, consumir leche sometida a algún tratamiento térmico, desinfección de verduras frescas; almacenamiento apropiado de los alimentos, para evitar su contaminación; e higiene del hogar ${ }^{2,4,31}$.

Las que aumentan la resistencia del huésped son la lactancia materna exclusiva durante los primeros 6 meses de vida y continuar con la lactancia materna con alimentación complementaria apropiada, las que reducen la aparición y gravedad de la diarrea y la neumonía; mejorar las técnicas de ablactación y destete, la aplicación de las vacunas contra el sarampión, el rotavirus; además de la administración suplementaria de vitamina $\mathrm{A}^{29,31}$.

Las medidas de prevención aplicables a los niños, con alto riesgo de enfermar por enfermedades diarreicas y neumonía, incluyen la aplicación de vacunas en contra de la tos ferina, el sarampión, Hib, PCV y el rotavirus; prevención del VIH, en los susceptibles de adquirirla, aplicación de cotrimoxazol como profilaxis de la infección por el $\mathrm{VIH}^{29}$.

Para evitar la aparición de la enfermedad se deben reducir los mecanismos de transmisión; y con el afán de prevenir complicaciones hacer diagnóstico temprano y tratamiento oportuno de los casos; así como la capacitación de la comunidad para la rehidratación oral e identificación temprana de los signos de alarma, acciones que nos permitirán abatir los casos y las muertes por EDA. 


\section{Enfermedad diarreica}

\section{Referencias}

1. UNICEF and World Health Organization. Diarrhoea why children are still dying and what can be done. United Nations Children's Fund (UNICEF)/World Health Organization (WHO); 2009. p. 2-6.

2. World Health Organization. Diarrhoea. Water-related diseases. OMS. Portal Water Sanatation Health. Disponible en: http://www.who.int/water_sanitation_health/ diseases/diarrhoea/en/

3. Secretaría de Salud. Proyecto de Norma Oficial Mexicana PROY-NOM-NOM-031SSA2-2014, para la atención a la salud de la infancia. México: Secretaría de Salud. Diario Oficial de la federación; 25/11/2015 p. 5. Disponible en http://dof.gob.mx/nota_ detalle_popup.php?codigo $=5417151$

4. Organización Mundial de la Salud. Enfermedades diarreicas. OMS, Nota informativa No. 330, abril de 2013. Disponible en: http://www.who.int/mediacentre/factsheets/ fs330/es/.

5. Organización Panamericana de la salud. Capítulo III. Patogenia de la diarrea infecciosa. Manual de tratamiento de la diarrea. OMS, Serie PALTEX para ejecutores de programas de salud. (13); 1987: 79-91.

6. Secretaría de Salud. Manual de procedimientos estandarizados para la vigilancia epidemiológica de la enfermedad diarreica aguda mediante la estrategia de núcleos trazadores (NuTraVE). México: Secretaría de Salud. Subsecretaría de Prevención y Promoción de la Salud. Dirección General de Epidemiología; 2012. p. 8-15.

7. Secretaría de Salud. Perfil epidemiológico de las enfermedades infecciosas intestinales. México: Subsecretaría de prevención y promoción de la Salud. Dirección General de Epidemiología; 2012. p. 15-19.

8. Organización Mundial de la Salud. Causas de muerte en menores de 5 años de edad, 2015. Portal del Observatorio de la Salud de la OMS. Recuperado de: http://www.who. int/gho/child_health/mortality/causes/en/

9. UNICEF and WHO. Executive summary. Ending Preventable Child Deaths from Pneumonia and Diarrhoea by 2025. The integrated Global Action Plan for Pneumonia and Diarrhoea (GAPPD). United Nations Children's Fund (UNICEF) /World Health Organization (WHO); 2013: 7. 


\section{Principales problemas de Salud Pública en México}

10. Secretaría de Salud. Manual de procedimientos estandarizados para la vigilancia epidemiológica de la enfermedad diarreica aguda mediante la estrategia de núcleos trazadores (NuTraVE). México: Secretaría de Salud. Subsecretaría de Prevención y Promoción de la Salud. Dirección General de Epidemiología; 2012. p. 16-21.

11. Secretaría de Salud. Mortalidad. México, Boletín Epidemiológico del Sistema Único de Información, del Sistema Nacional de Vigilancia Epidemiológica. 29(43), 21 al 27 de octubre de 2012: 4.

12. Secretaría de Salud. Panorama epidemiológico y estadístico de la mortalidad en México 2011. México, Subsecretaría de Prevención y promoción de la salud, Dirección General de Epidemiología, 2015; 14-25

13. Secretaría de Salud. Casos nuevos de cólera por fuentes de notificación Estados Unidos Mexicanos 2012. México: anuarios de morbilidad de la Dirección General de Epidemiología. Disponible en http://www.epidemiologia.salud.gob.mx/anuario/2012/ casos/fuente/001.pdf

14. Secretaría de Salud. Casos nuevos de cólera por fuentes de notificación Estados Unidos Mexicanos 2013. México: anuarios de morbilidad de la Dirección General de Epidemiología. Disponible en http://www.epidemiologia.salud.gob.mx/anuario/2013/ casos/fuente/001.pdf

15. Secretaría de Salud. Casos nuevos de cólera por fuentes de notificación Estados Unidos Mexicanos 2014. México: anuarios de morbilidad de la Dirección General de Epidemiología. Disponible en http://www.epidemiologia.salud.gob.mx/anuario/2014/ casos/fuente/001.pdf

16. Secretaría de Salud. Casos nuevos de fiebre tifoidea por fuentes de notificación Estados Unidos Mexicanos 2012. México: anuarios de morbilidad de la Dirección General de Epidemiología. Disponible en http://www.epidemiologia.salud.gob.mx/anuario/2012/ casos/fuente/006.pdf

17. Secretaría de Salud. Casos nuevos de fiebre tifoidea por fuentes de notificación Estados Unidos Mexicanos 2013. México: anuarios de morbilidad de la Dirección General de Epidemiología. Disponible en http://www.epidemiologia.salud.gob.mx/anuario/2013/ casos/fuente/006.pdf

18. Secretaría de Salud. Casos nuevos de fiebre tifoidea por fuentes de notificación Estados Unidos Mexicanos 2014. México: anuarios de morbilidad de la Dirección General de 


\section{Enfermedad diarreica}

Epidemiología. Disponible en http://www.epidemiologia.salud.gob.mx/anuario/2014/ casos/fuente/006.pdf

19. Secretaría de Salud. Casos nuevos de shigelosis por fuentes de notificación Estados Unidos Mexicanos 2012. México: anuarios de morbilidad de la Dirección General de Epidemiología. Disponible en http://www.epidemiologia.salud.gob.mx/anuario/2012/ casos/fuente/005.pdf

20. Secretaría de Salud. Casos nuevos de shigelosis por fuentes de notificación Estados Unidos Mexicanos 2013. México: anuarios de morbilidad de la Dirección General de Epidemiología. Disponible en http://www.epidemiologia.salud.gob.mx/anuario/2013/ casos/fuente/005.pdf

21. Secretaría de Salud. Casos nuevos de shigelosis por fuentes de notificación Estados Unidos Mexicanos 2014. México: anuarios de morbilidad de la Dirección General de Epidemiología. Disponible en http://www.epidemiologia.salud.gob.mx/anuario/2014/ casos/fuente/005.pdf

22. Secretaría de Salud. Casos nuevos de enteritis debida a rotavirus por fuentes de notificación Estados Unidos Mexicanos 2012. México: anuarios de morbilidad de la Dirección General de Epidemiología. Disponible en http://www.epidemiologia.salud. gob.mx/anuario/2012/casos/fuente/a080.pdf

23. Secretaría de Salud. Casos nuevos de enteritis debida a rotavirus por fuentes de notificación Estados Unidos Mexicanos 2013. México: anuarios de morbilidad de la Dirección General de Epidemiología. Disponible en http://www.epidemiologia.salud. gob.mx/anuario/2013/casos/fuente/a080.pdf

24. Secretaría de Salud. Casos nuevos de enteritis debida a rotavirus por fuentes de notificación Estados Unidos Mexicanos 2014. México: anuarios de morbilidad de la Dirección General de Epidemiología. Disponible en http://www.epidemiologia.salud. gob.mx/anuario/2014/casos/fuente/a080.pdf

25. Secretaría de Salud. Incidencia de casos nuevos de enfermedades por grupos de edad en loes Estados Unidos Mexicanos. México: anuarios de morbilidad de la Dirección General de Epidemiología, 2014. Disponible en http://www.epidemiologia.salud.gob. mx/anuario/2014/incidencia/incidencia_casos_nuevos_enfermedad_grupo_edad.pdf

26. Organización Panamericana de la Salud. Capítulo II. Etiología de la diarrea. Manual de tratamiento de la diarrea. OMS, Serie PALTEX para ejecutores de programas de salud. 1987; (13):35. 


\section{Principales problemas de Salud Pública en México}

27. Consejo de Salubridad General. Prevención, diagnóstico y tratamiento de la diarrea aguda en niños de dos meses a cinco años en el primero y segundo nivel de atención. Guía de referencia rápida. Catálogo maestro de guías de práctica clínica: SSA-156-08. S/N año; 2-21.

28. Secretaría de Salud. Manual de procedimientos estandarizados para la Vigilancia Epidemiológica de la enfermedad diarreica aguda mediante la estrategia de núcleos Trazadores (NuTraVE). Dirección General de Epidemiología, 2012; 13.

29. UNICEF and WHO. Executive summary. Ending preventable child deaths from pneumonia and diarrhoea by 2025. The integrated global action plan for pneumonia and diarrhoea (GAPPD). United Nations Children's Fund (UNICEF)/World Health Organization (WHO); 2013:7-9.

30. Secretaría de Salud. Guía técnica para la cartilla Nacional de Salud. Niñas y niños de 0-9 años. México: Dirección General de Promoción de la Salud; 2008. p. 63-67.

31. Secretaría de Salud. Enfermedades diarreicas agudas. Prevención, control y tratamiento. México: Centro Nacional para la Salud de la Infancia y la Adolescencia (CENSIA); 2009; 18-20, 32-47, 73 y 87. Recuperado desde: http://web.ssaver.gob.mx/ enfermedadestransmisibles/files/2015/12/Manual-Junio-29-2010.pdf

32. Secretaría de Salud. Proyecto de Norma Oficial Mexicana PROY-NOM-NOM-031SSA2-2014, para la atención a la salud de la infancia. México: Secretaría de Salud. Diario Oficial de la Federación; 25/11/2015: 11. Disponible en http://dof.gob.mx/nota_ detalle_popup.php?codigo=5417151 


\section{Hepatitis}

\section{C. María del Carmen Aguilar Espíndola}

\section{Introducción}

La hepatitis viral es un problema de Salud Pública mundial que todos los años afecta a millones de personas causando discapacidad y muerte. Es una lesión inflamatoria difusa del hígado, la cual está producida por diversos agentes etiológicos, esta puede ser asintomática o cursar con grados variables de insuficiencia hepática. También está producida por trastornos metabólicos y agentes físicos. Existe aumento de la concentración de aminotransferasas. Dentro de las diferentes causas se encuentran agentes infecciosos como los pertenecientes a la familia herpes (EBV, CMV, HSV, VZV, y HHV6), el de la rubéola, sarampión, coxsackie, la fiebre amarilla y ébola, capaces de presentar formas de hepatitis primaria o secundaria, trastornos metabólicos y agentes físicos. Existen siete tipos diferentes de virus hepatotrópicos capaces de producir hepatitis; se les designa como $\mathrm{A}, \mathrm{B}$, C, D, E, F, G, aunque hay evidencias de que existen más que pueden causar inflamación y necrosis del hígado. Todos los virus hepatotrópicos tienen la capacidad de causar infección aguda del hígado pero sólo el B, C, y D, ocasionan formas crónicas de la enfermedad. Es importante resaltar que el virus de la hepatitis B es una causa importante de hepatitis crónica, cirrosis hepática y carcinoma hepatocelular. La infección crónica por VHB se define por la presencia de antígeno de superficie de hepatitis B (HBsAg) en el suero, durante al menos seis meses. Existe otro término denominado enfermedad emergente, siendo una entidad reconocida de manera reciente, siendo causada por el virus de la hepatitis C. ${ }^{1-7}$

\section{Concepto}

Es una infección sistémica que cursa de manera primordial con lesión inflamatoria difusa del hígado. La infección es producida por variados agentes etiológicos; clínicamente puede ser asintomática o cursar con grados variables de insuficiencia hepática.

La hepatitis crónica es un síndrome clínico y patológico, secundario a diversas causas, que se caracteriza por infiltrado inflamatorio mononuclear portal y periportal con ruptura 


\section{Principales problemas de Salud Pública en México}

de la placa limitante, necrosis hepatocelular y fibrosis con diversos grados de extensión y distribución, que persisten por seis meses o más sin mejoría clínica. Se manifiesta desde el punto de vista bioquímico por elevación de las aminotransferasas, pueden aumentar 2 a 10 veces los valores normales ${ }^{2,6,8}$.

\section{Clasificación}

\section{$>$ Hepatitis A (VHA).}

Se transmite por vía fecal-oral, los factores de riesgo incluyen: vivir en la misma casa con un enfermo de hepatitis, actividad homosexual (propicia diseminación fecal-bucal del virus a través del contacto buco-anal), contacto cercano con niños que asisten a guarderías, y quienes están en asilos. Otros factores de riesgo son la drogadicción, transfusión sanguínea, así como viajes a zonas de alta endemicidad. El número de casos puede alcanzar entre los 60000 a los 140000 casos al año. Aproximadamente de 35 a 65\% de los casos se presentan en niños de 0 a 4 años de edad. En países en vías de desarrollo, más del $90 \%$ de la población se infecta con VHA en la niñez. Se presenta en el $85 \%$ de los niños menores de 2 años de manera asintomática; entre los 2 y 4 años afecta a 50\% y sólo se presenta en $20 \%$ de los niños mayores de 5 años. La mayor parte de las infecciones adquiridas en la infancia son subclínicas y anictéricas. Los anticuerpos persisten durante toda la vida y proporcionan inmunidad a la infección posterior. Las infecciones en el adulto son probablemente más sintomáticas, alrededor de los 40 años y se asocia con un índice de mortalidad de $1 \%$. En la VHA, el período de incubación es de 15 a 45 días, se puede encontrar el virus en bilis, heces y sangre.

\section{Hepatitis B (VHB).}

Se calcula que el virus de la hepatitis B (HBV), infecta de 200000 a 300000 de personas cada año, y 0.1 a $1 \%$ se convierten en portadores crónicos. Según la OMS, se infectan más de 2 millones de personas al año en el mundo. Aproximadamente 200 millones son pacientes crónicos, de los que 5 a $10 \%$ son portadores crónicos. La prevalencia de la hepatitis en la República Mexicana es del 3\%. El virus está presente en títulos elevados en la sangre y en los exudados de los pacientes con infección aguda o crónica. Se encuentran títulos moderados en semen, secreción vaginal y saliva, otros líquidos corporales que no contienen sangre o suero, como la materia fecal y la orina no son fuentes de HBV. Las 


\section{Hepatitis}

tres formas principales de transmisión son: 1. Percutánea (uso de drogas intravenosas, exposición a sangre, líquidos corporales entre los trabajadores de la salud y transfusiones sanguíneas), 2. Sexual (heterosexual, homosexual) 3. Madres infectadas (exposición a la sangre de la madre en el momento del parto). La transmisión entre hermanos y otros contactos interfamiliares puede ocurrir a través de lesiones de la piel como eccema, al compartir objetos contaminados con sangre como son cepillos de dientes y navajas de rasurar.

\section{Hepatitis C (VHC).}

El genotipo 1 es el más agresivo de los otros genotipos. Su periodo de incubación es de 6 semanas (rango de 2 a 24 semanas). Es de transmisión parenteral (plaquetas, crioprecipitados, sangre y plasma) aproximadamente en el 90\% de los casos. También están como factores de riesgo los trasplantes y el compartir agujas con pacientes infectados, drogadictos, aplicación de tatuajes, así como la transmisión sexual, la hemodiálisis, personas que se atienden con dentistas que no cuentan con una adecuada esterilización, transmisión perinatal y los accidentes con solución de continuidad entre el personal de salud. El riesgo de contagio en parejas heterosexuales es menor de $4 \%$, pero el grupo de mayor índice de contagio son los homosexuales. Con el advenimiento de la nueva tecnología especialmente en los exámenes de donación de sangre para detectar los antígenos específicos, se han diagnosticado y tratado a los portadores asintomáticos. El índice de recuperación es del 40 a 70\%, aunque existen casos en los cuales hay recaídas. Se calcula que ocurren de 28 a 32 mil casos nuevos al año. Hasta el 85\% de los casos pueden evolucionar a una etapa crónica, pudiendo provocar la muerte, cirrosis o carcinoma, pudiendo convertirse en potenciales receptores de un trasplante de hígado. Se llama infección oculta cuando el VHC ARN está presente en el hígado, pero con pruebas de anticuerpos y VHC ARN negativas. Los pacientes con infección oculta muestran niveles más elevados de colesterol y triglicéridos. El consumo de alcohol aumenta la mortalidad prematura asociada con la infección del virus de la hepatitis $C$, parece que el alcohol contribuye a la replicación viral o facilita el daño de las células hepáticas, teniendo mayor riesgo de desarrollar hepatitis fulminante. El estradiol inhibe la producción de citoquinas proinflamatorias por las células mononucleares de la sangre periférica de hombres y de las mujeres pos-menopáusicas, actividad que protege al hígado, la progesterona se opone a estos efectos favorables. La infección simultánea con VIH afecta la transmisión vertical de VHC. 


\section{Principales problemas de Salud Pública en México}

\section{Hepatitis D (VHD).}

Porsímismonoproduceenfermedad, sinoquesemanifiesta comocoinfecciónosobreinfección asociada al virus de la hepatitis B, y se adquiere también por vía parenteral. Este virus integra su genoma al del hepatocito y puede propiciar el desarrollo de hepatocarcinoma, aún en ausencia de cirrosis. Es de distribución mundial. Se han identificado gran número de casos, considerándose endémica en el Norte de África, sur de Egipto y Oriente. Es endémica en pacientes con hepatitis B con vía de transmisión de contacto sexual, siendo el mecanismo más frecuente. El grupo de drogadictos intravenosos, tiene altos índices de coinfección por hepatitis viral. En México, la VHD es la variedad más rara.

\section{Hepatitis E (VHE).}

Se presenta de forma aguda, se transmite por ingestión de agua contaminada y por vía fecal-oral. Es endémica en países en vías de desarrollo. Tiene una tasa extremadamente elevada de mortalidad, cuando la infección ocurre durante el embarazo, especialmente durante el tercer trimestre. No hay vacuna para el VHE. En México su prevalencia es intermedia, predomina en el sexo masculino, y en mayores de 50 años de edad. El nivel socioeconómico bajo se considera un factor de riesgo. Se encontró una mayor prevalencia en el Valle de Tulancingo.

\section{Hepatitis G (VHG).}

Fue descubierta en 1996, tiene gran similitud a la provocada por el virus de la hepatitis C, siendo aislado de pacientes con VHC coinfectados. La infección crónica de VHG no parece causar alteraciones hepáticas importantes. Se ha encontrado en pacientes hemofílicos, en individuos multitransfundidos y en drogadictos, al ser transmitido por sangre y sus derivados contaminados con el virus, al igual que con jeringas y agujas usadas por individuos infectados.

\section{Hepatitis F (VHF).}

Con los avances tecnológicos se han podido reconocer diversos virus de hepatitis. A pesar de ello no todos los que se han encontrado son, de modo necesario, diferentes a los ya conocidos. Los virus calificados como F, descubiertos en 1994, se consideran variantes de la VHB. 


\section{Hepatitis}

Se han descubierto otros tres virus causantes de otras formas probables de hepatitis, llamados GBV-A, GB-BV y GB-CV, estos nuevos agentes, relacionados de modo estrecho, pero diferentes entre sí, han sido incluidos entre los flavivirus. Son virus que pueden ser causantes hasta un 10 a $20 \%$ de las hepatitis que tienen aún etiología desconocida ${ }^{3-5,9-10}$.

\section{Epidemiología}

Es de distribución mundial, afectando sobre todo a países en desarrollo, la exposición con inmunidad subsiguiente, es común durante la infancia. En México es endémica, en la edad adulta, $90 \%$ a $100 \%$ de la población ha desarrollado anticuerpos de tipo IgG contra el virus de la hepatitis A. Las hepatitis producidas por los virus A y E suelen tener curso limitado, mientras que cuando el agente causal es B, C o G, tienen riesgo de cronicidad.

Se calcula que existen 300 millones de portadores crónicos de hepatitis B en el mundo. La OMS calcula que en Latinoamérica y el Caribe se presentan 400,000 nuevas infecciones por VHB cada año. México se considera un área de baja endemicidad. Desde 1980 el número de casos anuales de hepatitis aguda B informados al Center for Disease Control (CDC) de Atlanta disminuyó aproximadamente 50\%, debido básicamente a cambios en el comportamiento de los drogadictos y varones homosexuales y a la vacunación contra hepatitis B. Entre los años 1980 a 1997 se registraron 11740 defunciones por hepatitis viral, con un promedio anual de 691 muertes y tasa ajustada de mortalidad de 0.86 por cada 100000 habitantes, sin considerar el género y grupo de edad. La proporción de muertes de acuerdo con el género es de, $45 \%$ para el masculino y de $55 \%$ para el femenino con tasa de mortalidad de 0.75 y 0.87 por 100000 habitantes respectivamente. El grupo de edad más afectado es de 0 a 14 años, con 30\% de todas las defunciones y tasa de 0.76 y 0.62 por 100000 habitantes, en el grupo de 15 a 24 se registraron $8 \%$ de las defunciones con tasa de 0.25 y 0.38. En el grupo de 25 a 44 años la proporción es de $19 \%$ y tasas de 0.48 y de 0.64 . En el grupo de 45 a 64 años, la proporción es de $22.5 \%$ y tasas de 1.25 y 1.6. En el grupo de 65 años y más, la proporción es de $20.3 \%$ y tasa de 4 y 4.2 respectivamente ${ }^{4,5,9}$.

Las hepatitis virales representan un problema de Salud Pública en México. Geográficamente la mortalidad se ubica en los Estados federativos del sureste y centro del país y el tipo de hepatitis que más se registra es la del tipo A con $78 \%$. 


\section{Principales problemas de Salud Pública en México}

E1 5\% de las infecciones nosocomiales son de etiología viral, siendo más frecuente en niños, afectando a pacientes de cualquier edad, sobre todo inmunodeprimidos y con patología respiratoria, renal o cardíaca. Lo anterior propicia una estancia prolongada con aumento de la morbimortlidad y a una considerable morbilidad y mortalidad ${ }^{5,11}$.

Los virus de la hepatitis de transmisión fecal-oral (A, E) pueden causar brotes epidémicos nosocomiales. Los brotes de hepatitis $\mathrm{A}$, sobre todo a unidades pediátricas o neonatales, otros pacientes y personal sanitario. El virus de la VHA puede permanecer viable durante al menos una hora en las manos del personal sanitario y hasta 2 meses en artículos ambientales contaminados ${ }^{2-5,9-14}$.

\section{Causalidad}

Existen siete tipos de virus hepatotrópicos capaces de producir hepatitis, se les designa como A, B, C, D, E, F, y G., aunque hay evidencia de más virus que pueden causar inflamación y necrosis del hígado.

Los virus que causan la hepatitis se pueden dividir en dos grupos: virus hepatotrópicos y no hepatotrópicos. Los virus no hepatotrópicos que pueden cursar con afección hepática son entre otros: Citomegalovirus (CMV), Herpes simple (HSV), Epstein Barr (EBV), Parvovirus B y virus Varicela-Zoster (VVZ), filovirus (virus Ébola y Marburg), coxsackie A y B, influenza A, adenovirus, paramixovirus, etc.

Hepatitis A. Está causada por virus que mide de 25 a $28 \mathrm{~nm}$, pertenece a la familia de picornaviridae, contiene genoma tipo RNA, todas las cepas de este virus son indiferenciables inmunológicamente y pertenecen a un solo serotipo. La respuesta antigénica está estimulada por el polipéptido, que es el que predomina en la superficie. La replicación viral ocurre exclusivamente en el citoplasma.

Hepatitis B. Pertenece a la familia de los hepadnavirus, llamados así por ser hepatotróficos, estar formados de un genoma de DNA y compartir estructura y estrategia replicativa. Es un virus esférico de $42 \mathrm{~nm}$. Tiene dos componentes uno externo que expresa al antígeno de superficie (HBsAg) y otro interno que contiene el antígeno central (HBcAg). En la porción central se encuentra el DNA de doble cadena (HBVDNA) y la replicasa o polimerasa viral (DNAP o DNA polimerasa). El antígeno eHB (ageHB) se encuentra en la sangre de los 


\section{Hepatitis}

portadores del VHB y guarda relación con la viremia masiva. Los virus que provocan la hepatitis C y G pertenecen a la familia de los flavivirus. Los agentes causales de la hepatitis E, pertenece a la familia de los calicivirus. Con excepción del virus B que contiene DNA, los demás virus hepatotrópicos son RNA $2,4-6,13-15$.

\section{Fisiopatología}

La inflamación combinada con la necrosis y el grado de respuesta del sistema inmunológico del enfermo son responsables de los cambios clínicos y bioquímicos de la enfermedad. El virus de la hepatitis A es directamente citopático.

Existe degeneración hepatocelular con necrosis focal de las células hepáticas, infiltración de linfocitos y células plasmáticas en espacios porta y parénquima, proliferación de las células de kupffer y regeneración hepatocelular, las lesiones predominan en el parénquima y todos los lobulillos $2,5,7,16$.

\section{Cuadro clínico}

Clásicamente en el curso clínico se describen cuatro períodos de la enfermedad:

- Período de incubación. Esta etapa abarca el tiempo desde que el virus penetra en el organismo hasta que aparecen los primeros síntomas, se trata de una etapa asintomática de duración variable que depende del virus que está ocasionando la enfermedad y de su carga viral, acortándose cuando mayor sea ésta.

- Período prodrómico o preictérico. Esta etapa que por lo general tiene una duración entre 3 a 5 días, se inicia con la aparición de los síntomas, hasta la instauración de la ictericia, pudiendo durar varias semanas o incluso estar ausente.

- Período ictérico. Este período por lo habitual dura de 5 a 7 días. Se relaciona con la aparición de hipocolia, coluria e ictericia generalizada, y en ocasiones de prurito.

- Período de convalecencia. Comienza con la desaparición de la ictericia y se extiende hasta la normalización de las transaminasas y la remisión de los síntomas. 


\section{Principales problemas de Salud Pública en México}

La forma clínica tiene los cuatro períodos antes descritos, sin embargo existen diversas formas de presentación clínica en la hepatitis aguda y todas ellas pueden ser producidas por cualquiera de los virus conocidos.

La presentación anictérica, es la forma clínica más frecuente de todas y se presenta hasta en 90\% de los casos. Los síntomas sugestivos de la enfermedad se presentan con una menor intensidad y frecuencia. Pueden pasar inadvertidos o confundirse con un cuadro viral de vías respiratorias, caracterizado por cefalalgia leve, fiebre y mialgias. Las alteraciones bioquímicas y los cambios histológicos son semejantes a las que se presentan en la hepatitis viral ictérica, el hecho de que sea asintomática no indica un menor pronóstico, así, en la HVBy VHC es más frecuente el paso a la cronicidad.

La hepatitis viral aguda puede ser anictérica y benigna, con el posterior desarrollo de cirrosis e incremento del riesgo de presentar carcinoma hepatocelular. Los virus asociados con desarrollo de cronicidad son los virus de la hepatitis B (VHB) y el virus C (VHC) y D. Los virus A y B de la hepatitis cursan como infecciones autolimitadas y en general de curso benigno.

La VHA se caracteriza por insuficiencia hepática leve o moderada, menor a 6 meses de evolución, ocasionalmente tiene una duración mayor, sin que esto implique mal pronóstico o evolución hacia la cronicidad. Por lo general cursa asintomática (10\%en la infancia y 30 a $40 \%$ en adultos), la mayoría de los casos no muestran ictericia, presentando solo la fase prodrómica con astenia, adinamia, anorexia, pérdida de peso, dolor leve en hipocondrio derecho, cuadro gastrointestinal, caracterizado por diarrea, la cual es muy rara en los adultos, o bien un cuadro similar al de la influenza. Los casos de ictericia cursan con una cuadro prodrómico que dura de 3 a 4 días, en el que se presenta astenia, adinamia, náusea, vómito, fiebre, hiporexia, con desagrado por el cigarro o el alcohol, después presenta coluria, acolia e ictericia, cuando estos síntomas aparecen el resto tiende a disminuir. Hacia la tercera semana se puede presentar prurito generalizado, que desparece en unos días, la hepatomegalia es común en este período, y puede haber esplenomegalia que cede cuando el paciente se recupera de la infección. El tiempo de evolución puede oscilar de 1 a 4 semanas y tiende a ser menor en niños y adultos jóvenes. La gravedad aumenta progresivamente con la edad y el tiempo de la infección, en los adultos suele ser una enfermedad de varias semanas de duración con algunos meses de convalecencia, es fatal sobre todo en personas mayores de 50 años. Otras manifestaciones clínicas poco 


\section{Hepatitis}

frecuentes incluyen la hepatitis colestásica se caracteriza por ictericia persistente y datos de colestasis intrahepática en ausencia de lesión hepatocelular grave. Generalmente la hepatitis A no da lugar a portador crónico, cirrosis o carcinoma hepatocelular. Otra evolución clínica poco frecuente se observa en el 65 de los casos como una recaída con reaparición de los síntomas, con alteración de las pruebas bioquímicas y aparición del virus en las heces.

La infección con VHC causa aguda hepatitis aguda y hepatitis crónica. En la fase aguda la mayoría de los pacientes son asintomáticos o cursan con anorexia, náusea, vómitos fiebre y dolor en el cuadrante superior derecho, solo un 20 a 30\% presentan ictericia.

La hepatitis crónica activa autoinmune (HCA-A), es un padecimiento hepático inflamatorio poco frecuente de etiología desconocida que evoluciona durante más de seis meses. Hay presencia de disfunción hepatoceluar con destrucción tisular que puede evolucionar a cirrosis hepática.

La fiebre tifoidea, puede cursar con datos de alteración hepática y es importante decir que en México ésta enfermedad, continúa siendo un problema de Salud Pública, ya que existe un aumento gradual de multirresistencia a diferentes antibióticos a los que anteriormente eran sensibles. Los pacientes que cursan con fiebre tifoidea tienden a tener alteraciones de la función hepática, en un $2 \%$ de los casos, siendo difícil distinguir entre este cuadro y el producido por un virus, sobre todo si se presenta como hepatitis fulminante. Es característico que en los pacientes con hepatitis viral al iniciar la ictericia, la fiebre desparece junto con los síntomas gastrointestinales. En el caso de la hepatitis por salmonella la fiebre persiste durante la fase ictérica, hay bradicardia relativa, discreta elevación de las aminotransferasas hepáticas y la elevación de la fosfatasa alcalina en la segunda semana de la enfermedad, ayudan a hacer un rápido diagnóstico diferencial ${ }^{6,9,13,15-20}$.

\section{Complicaciones}

Las complicaciones principales suelen ser:

- Hepatitis crónica. Síndrome clínico y patológico, secundario a diversas causas, que se caracteriza por infiltrado inflamatorio mononuclear portal y periportal con ruptura de 


\section{Principales problemas de Salud Pública en México}

la placa limitante, necrosis hepatocelular y fibrosis con diversos grados de extensión y distribución, que persisten por seis meses o más sin mejoría clínica. Se manifiesta desde el punto de vista bioquímico por elevación de las aminotransferasas, pueden aumentar 2 a 10 veces los valores normales. Puede ser asintomática, hasta etapas muy avanzadas de la enfermedad, o bien presentarse con datos clínicos como ictericia, hipocolia o acolia, coluria. El síntoma más frecuente es la presencia de fatiga.

Existen 3 virus hepatotrópicos que pueden causar hepatitis crónica: VHB, VHC y VHD. Respecto a este último, se trata de un virión incompleto de RNA que se vale del antígeno de superficie de la hepatitis B, para poder completar su replicación, por lo tanto cuando el individuo se encuentra inmunizado contra la hepatitis B, también se encuentra protegido contra la infección por VHD.

- Cirrosis hepática. Los pacientes con cirrosis relacionada a VHC no presentan síntomas hasta que desarrollan complicaciones. La descompensación clínica se reconoce por la presencia de ascitis, sangrado de tubo digestivo alto, síndrome hepatorrenal y encefalopatía hepática.

- Hepatocarcinoma. Es la causa más común de cáncer hepático representa la tercera causa más común de muerte en el mundo. Con una incidencia anual de 3.5\%. es más común en hombres que en mujeres. En el 78\% de los casos está asociado con infecciones de virus de las hepatitis $\mathrm{B}_{\text {y }} \mathrm{C}^{3,6,7,16,20}$.

\section{Diagnóstico}

El diagnóstico incluye criterio clínico, bioquímico, serológico e histológico. Desde el punto de vista clínico, los pacientes pueden cursar asintomáticos, aunque la manifestación más frecuente es la fatiga, la presencia de hepato-esplenomegalia se puede encontrar hasta en un $50 \%$ por ciento.

La biometría hemática muestra leucopenia, linfopenia y neutropenia sobre todo en la fase preictérica. La VSG se eleva en la fase preictérica, para regresar a niveles normales. El examen general de orina detecta bilirrubinas antes que existan manifestaciones clínicas. La química sanguínea muestra las bilirrubinas elevadas a expensas de la directa, las cifras oscilan entre 5 a $6 \mathrm{mg} / \mathrm{dl}$., pero en la hepatitis colestásica la elevación de las bilirrubinas 


\section{Hepatitis}

puede alcanzar $25 \mathrm{mg} / \mathrm{dl}$. La elevación de las transaminasas alanino transferasa así como la aspartato aminotransferasa es de alrededor de 5 a 10 veces de lo normal. La fosfatasa alcalina se eleva, alcanzando tres veces su valor normal.

En el caso del virus de la hepatitis A, para realizar pruebas serológicas, es necesario considerar que el agente biológico se elimina en las heces desde una semana antes del inicio de los síntomas, hasta dos semanas después. Es por ello que el diagnóstico se realiza detectando el anticuerpo del tipo IgM contra este virus (anti VHA-IgM), positivo en el $99 \%$ de los casos, con un pico durante el primer mes y permanece en el suero durante 4 a 6 meses, y a veces declinan los valores hasta en un año; progresivamente aumentan los títulos de anticuerpo IgG, y probablemente persista durante toda la vida. En un segundo cuadro de hepatitis A se alteran de nuevo las pruebas inmunológicas, el anticuerpo IgM se presenta en títulos altos y los títulos de anticuerpos IgG aumentan después de la semana 6 de evolución.

Los métodos más sensibles para determinar los anticuerpos son el radioinmunoensayo (RIE) o el inmunoensayo enzimático (ELISA).

La biopsia hepática es de gran utilidad para confirmar el diagnóstico, excluir otras lesiones, valorar la respuesta al tratamiento y determinar el grado de actividad y el estadio de la enfermedad. Puede existir degeneración hepatocelular con necrosis focal de las células hepáticas, infiltración de linfocitos y células plasmáticas en espacios porta y parénquima, proliferación de las células de Kupffer y regeneración hepatocelular, las lesiones predominan en el parénquima y todos los lobulillos. En el caso de la hepatitis por virus C, la realización de PCR en el tejido obtenido por biopsia es muy útil, ya que la reacción puede ser negativas en suero, pero positiva en el tejido.

El tamizaje de hepatitis $B$, es adecuado para personas que residieron en áreas de alta o intermedia prevalencia, sus hijos y convivientes $2,5,6,8,9,16,18,20,21$.

\section{Diagnóstico diferencial}

- Hepatitis autoinmunitaria. Una de las principales manifestaciones de autoinmunidad generada por virus es la crioglobulinemia mixta y la disfunción renal secundaria a glomerulonefritis membranoproliferativa. 


\section{Principales problemas de Salud Pública en México}

- Hepatitis alcohólica.

- Hepatitis por drogas. La hepatitis asociada drogas también puede generar la presencia de fenómenos autoinmunes que no persisten después de suspendido el tratamiento con dicho medicamento.

- Enfermedades crónico-degenerativas. Enfermedad de Wilson.

El pronóstico tiene diversas variantes clínicas, desde episodios agudos y limitados, hasta episodios agudos fulminantes o desarrollo de cronicidad que puede dar origen a cirrosis o cáncer, el pronóstico varía de acuerdo al curso que tome la enfermedad ${ }^{6,16}$.

\section{Terapéutica}

- Reposo en cama o relativo, hasta que las pruebas de funcionamiento hepático se normalicen.

- Dieta normal, quizá baja en grasa si el paciente no lo tolera.

- Los esteroides están indicados en hepatitis colestásica prolongada.

El tratamiento de la hepatitis viral crónica se fundamenta en el uso de interferón y antivirales. Los interferones (IFN), son glucoproteínas, con actividad antiviral, inmunomoduladora y antiproliferativa. Los inconvenientes es que son de alto costo y producen reacciones secundarias como fiebre, caída del cabello, depresión, incluso alteraciones cardiacas. El IFNalfa2b utilizado para la hepatitis crónica VHB, después de 4 a 6 meses de tratamiento, 20 a $40 \%$ de los casos se vuelven negativos, con dosis de 5 a 10 millones diarios de interferón. $\mathrm{Su}$ utilidad depende de la adecuada asociación con antivirales. Los antivirales que han demostrado ser útiles son la ribavirina en hepatitis $\mathrm{C}$ y la lamivudina en hepatitis B.

En el caso de la hepatitis C, el interferón pegilado, se puede asociar a la ribavirina, durante 6 a 12 meses, dependiendo del genotipo viral (6 meses para genotipos 2 y 3 y 12 meses para genotipo 1 y 4), la excepción a la regla anterior es cuando el genotipo 3 cursa con esteatosis importante en la biopsia hepática, en ese caso el genotipo 3 deberá recibir 12 meses de tratamiento. Observándose la normalización de las aminotransferasas en un 40 a 50 \% de 


\section{Hepatitis}

los casos, pero al suspender el tratamiento se vuelve a detectar el RNA viral en $50 \%$ de los pacientes. El virus $C$ tiene gran capacidad de mutación, por lo que puede no dar respuesta al tratamiento o crear anticuerpos contra el interferón. Algunas contraindicaciones para dar tratamiento con el interferón incluyen depresión, leucopenia, plaquetopenia, hipohipertiroidismo y trasplante renal.

Silibinina oral. Es un compuesto flavonoide, la administración de $10 \mathrm{mg} / \mathrm{Kg} /$ día por vía intravenosa disminuyó el volumen viral.

Telaprevir. Es un inhibidor específico de la proteasa no estructural del virus de la hepatitis C.

La hepatitis fulminante es causada principalmente por virus o agentes químicos. Su pronóstico generalmente es fatal, alcanzando entre 70 y $90 \%$ de mortalidad. Se conoce que en esta patología juegan un papel importante el estrés oxidativo y las citoquinas proinflamatorias (TNF $\alpha$, IL-1 $\beta$ e IL-6), factores que contribuyen al mal pronóstico de la enfermedad. La pentoxifilina, aparte de sus efectos hemorreológicos, presenta actividad antioxidante y es un potente inhibidor de la secreción de las citoquinas proinflamatorias. Es posible pensar en un futuro en la posibilidad de usar pentoxifilina como tratamiento de la hepatitis fulminante.

El trasplante hepático representa una opción de tratamiento para pacientes con hepatopatía crónica. Su manejo es complejo y costoso $2,9,16,18,19,23-25$.

\section{Medidas de prevención}

La prevención más efectiva en las infecciones virales es la aplicación de vacunas. La inmunización contra los virus A y B debe incluirse en el esquema de vacunación de niños y adolescentes.

- Lavado adecuado de las manos de los pacientes y familiares. Los brotes de hepatitis en hospitales indica la absoluta necesidad de llevar a cabo medidas extremas de higiene de las manos, y de la aplicación de precauciones de contacto a los pacientes que presenten diarrea o incontinencia fecal.

- Higiene de los alimentos, sobre todo alimentos crudos. 


\section{Principales problemas de Salud Pública en México}

- Limpieza adecuada de las fuentes de agua.

- En 1993, México a través de la NOM-003-SSA-1993, determina que los bancos de sangre deben detectar los anticuerpos de la hepatitis C (la versión definitiva de esta norma se da a conocer el 18 de julio de 1994).

- La inmunoglobulina es eficaz si se administra dentro de los 10 a 14 días siguientes a la exposición. La dosis recomendada es $.02 \mathrm{ml} / \mathrm{kg}$ cerca de $2 \mathrm{ml}$, en el período previo a contraer la infección, si el período de peligro excede los tres meses, se recomienda .06 $\mathrm{ml} / \mathrm{kg}$ con un intervalo de 4 a 6 meses.

- La gamaglobulina hiperinmune para hepatitis B (HBIG), es preparada a partir del fraccionamiento del plasma de donantes con títulos altos de anticuerpos anti HBs. Es usada para la inmunización pasiva por exposición accidental, exposición sexual con una persona HBsAg positiva, exposición perinatal de un recién nacido o exposición domiciliaria de un niño menor de 12 meses a un foco primario de hepatitis B. La dosis recomendada varía por producto comercial y por la edad del individuo que se vacuna.

El uso de vacunas contra la hepatitis B ha disminuido la prevalencia de la misma. La vacuna preparada con antígeno viral inactivado, es eficaz en un $97 \%$ con tres dosis. En adultos son recomendadas dos dosis, cada una de $20 \mu \mathrm{g}$ de vacuna (en una suspensión de $1.0 \mathrm{ml}$ ). La vacuna se administra vía intramuscular en la región deltoidea. La segunda dosis se debe administrar a los 6 o 12 meses después de la primera aplicación y un refuerzo a los 10 años. Se recomienda aplicar la vacuna a los siguientes grupos: viajeros a zonas endémicas, niños que asisten a guarderías, trabajadores y residentes de instituciones para retrasados mentales, adictos a drogas intravenosas, personas que manipulan alimentos, homosexuales, pacientes con hepatopatías crónicas y trabajadores de alcantarillado. Si la mujer no tiene inmunidad, se recomienda vacunarla contra la hepatitis A y la hepatitis B antes del embarazo.

En el caso de la gripe, la vacunación del personal de salud es una importante medida de prevención de la infección nosocomial.

Existen asimismo casos bien documentados de transmisión del VHA a través de transfusiones y de la administración de factores de coagulación derivados del plasma a pacientes con hemofilia ${ }^{4,6,9,14,19}$. 


\section{Hepatitis}

\section{Referencias}

1. Halabe CJ, Angulo VF. Hepatitis viral. Rev Fac Mec [en línea] 2000 May-Jun [accesado 5 Jun 2014]; 43(3). Disponible en: www.ejournal.unam.mx/rfm/no43-3/RFM43306.pdf

2. Guías Prácticas de la Organización Mundial de Gastroenterología. Hepatitis B. Guía práctica de la OMG. 2008: 1-28.

3. Arroyo-Pérez JA, Estrada-Chávez JJ, Rojo-Medina J. Prevalencia del virus de la hepatitis B en donantes de sangre mexicanos. Rev Med Hosp Gen Mex. 2010; 73(2): 83-87. Disponible en:http://www.cnts.salud.gob.mx/descargas/hepatitisbdonantes México.pdf

4. Prevención y control de las hepatitis virales: Marco para la acción mundial. Organización Mundial de la Salud; 2012.

5. IMSS. Manual para la Vigilancia Epidemiológica de las Hepatitis Virales. 2009. Disponible en: http://salud.edoMéxico.gob.mx/html/Medica/HEPATITIS\%20 VIRAL.\%20MANUAL\%20DE\%20VIGILANCIA\%20EPIDEMIOLOGICA.PDF

6. Narro RJ, Rivero SO, López BJ. Diagnóstico y tratamiento en la práctica médica. $4^{\underline{a}}$ ed. México: Manual Moderno; 2010. p. 461-469.

7. Valdespino JL, Ruiz-Gómez J, Olaiz-Fernández G, Arias-Toledo E, Conde-González CJ, Palma Oswaldo, et al. Seroepidemiología de la hepatitis A en México: sensor de inequidad social e indicador de políticas de vacunación. Salud pública Méx. 2007; 49(Suppl 3):s377-s385. Disponible en: http://www.scielo.org.mx/scielo.php?script=sci_ arttext\&pid=S0036-36342007000900009\&lng=es.

8. Conde GC, Torres-Poveda PK, Madrid-Marina V. Hepatitis virales. Salud Pública de México. Redalyc. 2011; 53(1):4-6. Disponible en: http://www.redalyc.org/ pdf/106/10619778001.pdf

9. Organización Mundial de la Salud. Hepatitis A. Nota descriptiva No. 328, Julio 2016. Disponible en: http://www.who.int/mediacentre/factsheets/fs328/es/ 


\section{Principales problemas de Salud Pública en México}

10. Panduro A, Escobedo-Meléndez G, Fierro NA, Ruiz-Madrigal B, Zepeda-Carrillo EA, Román S. Epidemiología de las hepatitis virales en México Salud Publica Méx. 2011; 53 supl 1:S37-S45. Disponible en: https://attachment.fbsbx.com/file_download.php?id=88 7560241260591\&eid=ASuiTuKHhgzdg4zGJilXWux0JPgmVLEjE21MmcbqSXKnK0xfm KAYJZybwaAmc6gCeIg\&inline=1\&ext=1402407278\&hash=ASv7TrrNdofqfoau

11. Instituto Nacional de Estadística y Geografía. Estadísticas demográficas 2011. INEGI México: 2013. Disponible en: http://www.inegi.org.mx/prod_serv/contenidos/espanol/ bvinegi/productos/continuas/vitales/demograficas/2011/cua_est_dem2011.pdf

12. Perdigón-Villaseñor G, Fernández-Cantón SB. Evolución reciente del comportamiento de las hepatitis virales en México, 1990-2007. Bol Med Hosp Infant Méx. 2009; 66(2):204-207.

13. Hernández GHR, Espinoza ARF. Hepatitis viral aguda. Rev Cubana Med Gen Integr. 1998; 14(5):484-93.

14. Martinez JA, Pumarola T. Viriasis nosocomiales: Virus de la hepatitis, herpesvirus y virus de la gripe. Elsevier Agosto-Septiembre 2013; 31(7):471-479. Disponible en: http:// zl.elsevier.es/es/revista/enfermedades-infecciosas-microbiologia-clinica-28/articulo/ viriasis-nosocomiales-virus-hepatitis-herpesvirus-90219226

15. Valdespino JL, Conde-González CJ, Olaiz-Fernández G, Palma O, Kershenobich D, Sepúlveda J. Seroprevalencia de la hepatitis $C$ en adultos de México: ¿un problema de Salud Pública emergente? Salud Pública de México. 2007; 49(3):S395-S403.

16. Farreras-Rozman. Medicina Interna. Vol. 1. 16ª ed. España: Elsevier; 2009. p. 338-353.

17. Cardoso HG, Barrero BER, Nava FM. Hepatitis tífica y hemofagocitosis. Revista de Enfermedades Infecciosas en Pediatría. 2008; XXI(84):129-131.

18. Sotelo CN, López CG. Hepatitis crónica autoinmune en niños. Experiencia en 20 casos. Rev Méx Pediatr. 2002; 69(4):133-138. 


\section{Hepatitis}

19. Fundación Mexicana para la Salud Hepática. La hepatitis C como un problema de salud pública en México. Salud Pública Méx. 2011; 53 supl 1:S61-S67.Disponible en: http://www.scielosp.org/pdf/spm/v53s1/v53s1a11.pdf

20. Rodríguez AC. Actualización sobre hepatitis viral: etiología, patogenia, diagnóstico microbiológico y prevención. Rev Cubana Med Gen Integr. 2000; 16(6):574-85.

21. Dehesa-Violante M, Bosques-Padilla F, Kershenobich-Stalnikowitz D. Prevalence of hepatitis C virus genotypes in Mexican patients. Rev Cubana Med Gen Integr. 2008; 14(5):344-48.

22. Jiménez-Luevano MA, Cortés Nuño S, Rocha-López AN, Cervantes-Rodríguez MTG, Bravo-Cuellar A, Franco-Topete R, Abascal-Medina CG. La pentoxifilina en la hepatitis fulminante: reporte de dos casos. Rev Biomed. 2009; 20:33-39.

23. Manns MP, McHutchison JG, Gordon SC, Rustgi VK, Shiffman M, Reindollar R, Goodman ZD, Koury K, Ling Mei-Hsiu, Albrecht JK. Peginterferon alfa-2b plus ribavirin compared with interferon alfa- $2 b$ plus ribavirin for initial treatment of chronic hepatitis C: a randomised trial. The Lancet. 2001; 358:958-65.

24. Arús SE, Rivera RL, Infante VM, Pérez LM, Soto AG, Gra OB, Padrón GG, López SP. Tratamiento de la hepatitis viral aguda $C$ con interferón alfa $2 b$ recombinante. Ensayo clínico. Revista Cubana de Medicina. 2000; 39(1):21-29.

25. Zarate MF, Cervantes BR, Mata NR, Zarate MF, et al. Actualización en el diagnóstico y tratamiento de la hepatitis B y C. Revista EIP. 2008; 84(12):114-117. Disponible en: http://www.medigraphic.com/pdfs/revenfinfped/eip2008/eip082e.pdf. 



\section{Cardiopatía isquémica}

M. C. María del Carmen García Ríos

\section{Introducción}

El aumento de las enfermedades crónicas no transmisibles (ECNT), y la disminución de las enfermedades transmisibles ha provocado un viraje epidemiológico, entre las primeras encontramos a la diabetes mellitus, enfermedad cardiovascular (ECV), enfermedad vascular cerebral, síndrome metabólico mismas que afectan al Sistema Nacional de Salud, al aumentar la incidencia, prevalencia y mortalidad en así como el alto costo que representa el tratamiento y las secuelas que provocan ${ }^{1,6}$.

Las ECV, entre ellas la cardiopatía isquémica (CI), forman parte importante de este grupo, en México el incremento en la morbilidad y mortalidad a partir de 1990, la convierte en la principal causa de muerte y en un problema de Salud Pública ya que ataca a una tercera parte de la población mayor de 40 años de ambos sexos ${ }^{2}$. Es importante conocer los factores de riesgo, su fisiopatología así como la historia natural para aplicar las medidas preventivas necesarias para su control y tratamiento.

La principal causa de la CI es la ateroesclerosis que se origina varios años antes de dar manifestaciones clínicas ${ }^{3}$, ésta afecta al sistema vascular, en el corazón ataca a las arterias coronarias, y las vasa vasorum, por lo que el conocimiento de la aterogénesis es de gran importancia para incidir en los diferentes niveles de prevención, de manera multi, inter y transdisciplinaria para reducir la incidencia, prevalencia, secuelas y la mortalidad.

\section{Concepto}

La CI es definida como un conjunto de síndromes que presentan como característica un desequilibrio entre el aporte y la demanda de oxígeno miocárdico ya sea aguda o crónica, provocando una hipoxia tisular, su manifestación clínica es la angina de pecho y su grado extremo es el infarto ${ }^{4,47}$. 


\section{Principales problemas de Salud Pública en México}

\section{Clasificación}

La CI según la Clasificación Internacional de las Enfermedades (CIE-10)5; está basada en las características del dolor torácico, los cambios en el electrocardiograma con y sin elevación del segmento S_T y en la elevación de las enzimas cardiacas.

La CI tiene dos grandes grupos que incluyen diversas entidades. Los síntomas y signos pueden ser los mismos, sin embargo esta división depende de la presentación, de su magnitud, su mecanismo desencadenante y el abordaje diagnóstico y terapéutico.

El primer grupo es la CI crónica que comprende a la angina estable, la silente en reposo, reversibles al descontrol que existe entre la demanda y aporte de oxígeno provocando hipoxia y que habitualmente es desencadenado por un cuadro de estrés emocional o por el ejercicio, ambas se relacionan con un estrechamiento de la luz con predominio de la arteria coronaria izquierda menor o igual al 50\% o mayor o igual al $70 \%$ en otras arterias.

El segundo grupo, es la CI aguda y más grave, su atención debe ser inmediata. En este grupo se encuentra el infarto agudo del miocardio con y sin elevación del segmento ST, la angina inestable con sus diversas variantes como angina de reciente inicio, angina post infarto, así como la muerte súbita.

\section{Epidemiología}

Si bien es cierto que entre las principales causas de morbilidad aún se encuentran cuadros infecciosos, no lo es así para la mortalidad general donde las enfermedades del corazón comienzan a ascender desde mediados del siglo $\mathrm{XX}$, alcanzando la máxima incidencia a finales del mismo, y en la actualidad se refiere como la principal causa de mortalidad siendo la principal causa la cardiopatía isquémica ${ }^{6,7}$, mismo que reporta el Instituto Nacional de Estadística y Geografía (INEGI).

La CI afecta a ambos sexos aunque es más frecuente en hombres mayores de 40 años, igualando la incidencia en mujeres después de los 50 años, no obstante se puede presentar en personas de ambos sexos en edades más tempranas cuando estos presentan factores de riesgo como la obesidad, dislipidemias, ateroesclerosis, Hipertensión Arterial Sistémica (HAS) sobre todo mal controlada, diabetes mellitus mal controlada, tabaquismo, 


\section{Cardiopatía isquémica}

sedentarismo, dieta de mala calidad con bajo consumo de fibras y vitaminas como la C y la E, alto consumo de sodio y baja ingesta de potasio entre otras. En estudios recientes en población mexicana se encontró mayor asociación de CI en hombres con tabaquismo positivo y en las mujeres con asociación a la obesidad, y para ambos la asociación de diabetes mellitus mal controlada así como HAS H,9,10. $^{8}$.

En México, las ECV se elevan del 24.9 al $28.7 \%$ en los hombres y de 33.7 a $37.8 \%$ en mujeres siendo la principal causa de muerte en mayores de 40 a 60 años, con una prevalencia de $33 \%$, siendo la ateroesclerosis una de las principales causas. Con esto la CI junto con la diabetes mellitus pasan a ser las principales causas de muerte del país ${ }^{2}$

El último del INEGI reporta como primer causa de mortalidad a las enfermedades del corazón, entre ellas a la CI lo que confirma que la incidencia va a la alta mientras que Estados Unidos y Canadá así como otros países con mayor desarrollo hay una tendencia a la baja $^{6,7}$, por las medidas preventivas contra los factores de riesgo, sin embargo en un estudio del IMSS ${ }^{10}$, refiere que efectivamente en la última década del siglo XX, fue en incremento esta patología, pero que en los últimos años han tenido una disminución de la incidencia probablemente por una mejor atención o por las acciones preventivas con impacto social. En cuanto a la mortalidad por Estados en la República Mexicana se reporta en el Distrito Federal una tasa de 67.6 para mujeres y de 111.6 para hombres (tasa por 100000 habitantes estandarizada), el Estado donde se reporta menor incidencia es Tlaxcala con 27.8 para mujeres y de 53.2 para hombres, el Estado con la tasa más alta es Sonora con 79.7 para mujeres y 156.4 para hombres. En los registros del Sistema Nacional de Información de la Secretaría de Salud, la mortalidad del 2000 al 2007 fue mayor en jubilados, y pensionados (58\%), seguidos de los trabajadores agropecuarios (15.7\%), operadores de transporte $(1.7 \%)$ y trabajadores de fuerzas armadas, protección y vigilancia $(0.9 \%)$. En cuanto a la escolaridad los sujetos fallecidos en su mayoría no concluyó la primaria (42.2\%), con primaria terminada $(26.6 \%)$ quienes presentaron menor mortalidad fueron los que tenían licenciatura $(6 \%)$ y con preparatoria o equivalente $(4.3 \%)^{11}$.

\section{Causalidad}

Desde las descripciones de Whilhelm Raab en 1932, relacionaban el tipo de dieta con enfermedad coronaria sobre todo por la alta ingesta de grasas. En 1953 se describió una asociación entre las concentraciones de colesterol y la mortalidad por enfermedad 


\section{Principales problemas de Salud Pública en México}

coronaria en diferentes poblaciones. Fue en los años cincuenta con las investigaciones del Framingham Heart Study en el Servicio de Salud Pública de Estados Unidos en donde se identificó que el colesterol elevado y la presión arterial alta eran factores primordiales para la aparición de la enfermedad cardiovascular (ECV), se observa también la asociación con el tabaquismo, la obesidad, así como la d factores de riesgo para CI. Los cuatro primeros explican tan solo un $50 \%$ del total de las ECV.

En la actualidad se sabe que la principal causa de la CI es la ruptura de la placa ateroesclerótica localizada en la capa intima de la pared arteriolar independientemente de que obstruya o no su luz, al romperse altera los mecanismos de coagulación provocando una trombosis secundaria con la subsecuente obstrucción de la luz arterial y la hipoxia tisular que dependiendo de su extensión puede llegar a causar necrosis del tejido cardiaco y la muerte, Por lo que es importante conocer ampliamente el desarrollo de la aterogénesis. Otras causas son la vasoconstricción coronaria, la estenosis coronaria, alteraciones congénitas, genéticas y drogadicción. Por lo anterior es importante conocer la causa principal y todos los factores de riesgo, reconocer los cambios en los estilos de vida como el sedentarismo, el incremento del estrés, cambios en los patrones de alimentación etc., que favorecen e incrementan la incidencia y prevalencia. De la CI, lo más importante es que varios de estos son modificables y su control ayuda a disminuir esta y otras patologías.

En relación a otras causas de $\mathrm{CI}$, se han detectado pacientes con dolor torácico tipo angor sobre todo en mujeres en un $10 \%$ y hombres con un $6 \%$ que presentan un electrocardiograma con elevación del segmento ST, y con angiografía coronaria normal, donde la causa probable es la vasoconstricción coronaria no benigna ya que dependiendo del tiempo de exposición puede causar la muerte en un $2 \%$ de los $\operatorname{casos}^{12,13}$ sin embargo la presencia de una angiografía normal no indica que no haya lesión endotelial ya que en algunos casos la placa de ateroma crece hacia el exterior sin cerrar la luz arterial, por lo que estaría indicado realizar un estudio eco cardiográfico y que el cuadro remita con vasodilatadores únicamente para pensar en una vasoconstricción.

La asociación de la cardiopatía isquémica con familiares directos como padres y hermanos ha hecho pensar que la CI tenga una base genética sin embargo en estudios de ligamiento y de asociación se han encontrado en el primer caso alteraciones en el gen MEF2A que participa en la producción de leucotrienos y que a su vez interviene en la aterogénesis, en 


\section{Cardiopatía isquémica}

el segundo caso se asocia a la CI con el gen APOE ambos sin ser concluyentes. En otros estudios parece haber una alteración en el cromosoma 9 el cual se asocia con problemas de inflamación y que participan en la formación de la placa de ateroma ${ }^{14}$.

Las alteraciones genéticas asociadas a estenosis coronarias no relacionadas con la disminución de la luz arterial por ateromas.

En el caso de la CI desencadenada por drogadicción específicamente por cocaína, ésta provoca aumento del consumo de oxígeno, alteraciones en la agregación plaquetaria con la consiguiente formación de trombos, vasoespasmo por alteración en los canales de calcio o vasoconstricción por estimulación alfaadrenérgica ${ }^{15}$.

\section{$>$ FACTORES DE RIESGO}

En el estudio de la cardiopatía isquémica es importante reconocer los factores de riesgo que en muchas ocasiones pueden ser modificados para mejorar la incidencia y prevalencia, mejorar la calidad de vida y disminuir la mortalidad, entre los factores de riesgo tenemos:

Personas con obesidad mórbida con índice de masa corporal (IMC) mayor a 30 y circunferencia abdominal mayor de $103 \mathrm{~cm}$, personas con sobrepeso con IMC entre >25 y < de 29 son más factibles desarrollar $\mathrm{CI}$, diabetes e HAS, síndrome metabólico etc. Considerando que lo ideal es tener un perímetro abdominal de $80 \mathrm{~cm}$ para las mujeres y $90 \mathrm{~cm}$ para los hombres, y un índice de masa corporal menor a 24, de acuerdo a la Norma Oficial Mexicana NOM-008-SSA3-2010, para el manejo de la obesidad y la NOM-037SSA2-2012 para la prevención, control y tratamiento de las dislipidemias ${ }^{16,17}$.

En el caso de la CI la asociación con la obesidad es del $26.6 \%$ y obesidad central 49. 7 $\%{ }^{25}$. Esta asociación entre obesidad y ECV ha sido descrita desde hace ya 40 años por el estudio Framingham ${ }^{8}$. En México el sobrepeso y la obesidad identificada como obesidad central se presentan en el 88\% de las mujeres y en el $74 \%$ de los hombres según la Encuesta Nacional de Salud 2012 (ENSA-12), considerando al sobrepeso con un IMC mayor de 27 y obesidad con IMC mayor de 30 y obesidad mórbida con un IMC mayor o igual a $40^{1}$, tener un IMC más alto durante la infancia se asocia con un aumento del riesgo cardiovascular en la edad adulta, por tanto se debe considerar la progresión de la ateroesclerosis como un proceso continuo que se inicia en la infancia. México ocupa el primer lugar en obesidad 


\section{Principales problemas de Salud Pública en México}

infantil, y en pocos años serán adultos jóvenes con enfermedades crónicas no transmisibles como enfermedad cardiovascular, diabetes mellitus tipo 2, HAS, determinados cánceres como el de mama, alteraciones ortopédicas y apneas del sueño, entre otras a edades más tempranas ${ }^{26}$.

Si consideramos que la obesidad puede ser modificado ya que está asociada a una mala alimentación, con exceso en el consumo de grasas, un bajo consumo de fibra, bajo consumo de vitamina $\mathrm{C}$ y $\mathrm{E}$, alto consumo de hidratos de carbono (principalmente azucares refinados), mismos que se transforman en lípidos.

Otro factor de riesgo importante es la presencia de dislipidemias, que pueden ser por hipercolesterolemia, hipertrigliceridemia, hipoalfalipoproteinemia e hiperlipidemia mixta ${ }^{23}$, en cualquiera de los casos puede ser de origen genético, primaria o secundaria esta última es cuando acompaña otras patologías como la diabetes, obesidad, hipotiroidismo, síndrome nefrótico, alcoholismo, o ingerir exceso de azucares refinadas, así como el uso de beta bloqueadores y diuréticos etc., es importante tener presentes las cifras normales de colesterol < de $200 \mathrm{mg} / \mathrm{dL}$, triglicéridos < $150 \mathrm{mg} / \mathrm{dL}$ y C_HDL > $40 \mathrm{mg} / \mathrm{dL}^{16}$.

Ya en los resultados del estudio del Cooperative Lipoproteína Study y del Framingham Heart Study ${ }^{8}$, demuestran que las lipoproteínas de alta (HDL) >de $40 \mathrm{mg} / \mathrm{dl}$ nos protegen y las lipoproteínas de baja densidad (LDL) mayor de $50 \mathrm{mg} / \mathrm{dl}$ favorecen el desarrollo de ateroesclerosis.

En estudios observacionales y experimentales se describe que la reducción del colesterol sérico de $10 \%$ produce una disminución del riesgo cardiovascular en un $50 \%$ a la edad de 40 años, del $40 \%$ a los 50 años, del $30 \%$ a los 60 años y del $20 \%$ a los 70 años. Demuestran que con un aumento de HDL de 1mg/dl en la concentración se asocia con una disminución del riesgo coronario de un $2 \%$ en los varones y un $3 \%$ en las mujeres por tanto un aumento en las HDL es una estrategia para reducir la tasa de incidencia de CI.

En la ENSA-12 se detectó cifras de colesterol elevado en los grupos de edad de 20 a 29 años y de 60 a 69 años de edad.

Por lo anterior es importante para prevenir la CI solicitar a los adultos jóvenes e incluso a niños control de lípidos ya que sigue siendo un indicador útil para prevenir ECV. 


\section{Cardiopatía isquémica}

En cuanto a la asociación de CI con HAS, Framingham encontró una asociación directa entre la presión arterial alta con un porcentaje de $29.7 \%$ en hombres y el $28.8 \%$ en mujeres. En México se encontraron cifras similares en la Encuesta Nacional de Salud del 2006 (ENS06), con una prevalencia para HAS de 30.8\% ${ }^{1}$. También se observó que la prevalencia de Hipertensión Sistólica Aislada (HSA) es un factor importante de predicción de ECV, en donde se encontró en el 25,9\% de los casos, y la HSA aumenta a 67.7\% cuando hay un mal control de la HAS o está asociada a diabetes mellitus, y ambas asociadas a la cardiopatía isquémica. En la NOM-030-SSA2-2009 ${ }^{18}$, la clasificación de la presión arterial fronteriza con presión arterial sistólica entre 130 a 139 con otros factores de riesgo, refiere que se debe mantener vigilancia, ya que estos pacientes presentan mayor riesgo de progresión a HAS y con ello un aumento en ECV. En personas de 40 a 70 años de edad, por cada aumento de $20 \mathrm{~mm} \mathrm{Hg}$ de incremento en la Presión Arterial Sistólica (PAS) o 10 mm Hg en la diastólica se duplica el riesgo de ECV con intervalo de valores de presión arterial que va de 115/75 hasta 185/115 mm Hg Contrariamente el buen control de la HAS se ha asociado a una disminución del 35 hasta el 40\% de la incidencia de ictus y una reducción del 20 al $25 \%$ de la incidencia de infarto agudo al miocardio y una reducción de más del $50 \%$ de la insuficiencia cardiaca; sin embargo las personas hipertensas aun controladas conservan un riesgo de desarrollar una CI mayor que personas no hipertensas aún con cifras tensiónales normales ${ }^{8,19.20,22}$.

En la ENSA-12 indican que el factor de riesgo más importante en las mujeres es el antecedente de HAS, mientras que en los hombres es el tabaquismo, aunque en este estudio hubo muchas mujeres con cardiopatía isquémica sin lesiones ateroescleróticas ${ }^{12}$. Además se reporta que la lesión previa de las coronarias es del $81 \%$ en hombres y $56 \%$ en las mujeres.

Otro factor de riesgo muy importante para desarrollar una CI es el hábito del tabaquismo, adicción que inicia generalmente en la adolescencia a una edad promedio de 16 años en ambos sexos manteniéndose positivo hasta la edad adulta, esta adicción se ha relacionado con la acción de la nicotina y el riesgo de desarrollar una ECV y que depende del número de cigarrillos al día y los años de su consumo. En México para el año 2000 existía una prevalencia general de tabaquismo del $27 . \%^{1,21}$. Se destaca que el $31 \%$ de los pacientes con CI tiene antecedentes de tabaquismo de por lo menos 15 años de evolución. Un estudio del Instituto Mexicano del Seguro Social (IMSS) en el Estado de Morelos en el año 2000, clasifica al tabaquismo de la siguiente manera: a) no fumadores, b) fumadores 


\section{Principales problemas de Salud Pública en México}

de bajo consumo (66 570 cigarrillos), c) fumadores de mediano consumo (66 571 a 165600 cigarrillos) y d) fumadores de alto consumo (>165 600) y estos últimos son los de mayor riesgo de ECV. La edad promedio para la ECV fue de 45 años promedio en los fumadores, y de 55 años en los no fumadores. El Framingham Stydy y el Albany Cardiovascular Healt Center study demostró que los fumadores presentan un 31\% de riesgo de infarto de miocardio o muerte súbita.

Los tóxicos del tabaco entre ellos la nicotina, el monóxido de carbono el cadmio, el óxido nítrico y el disulfuro de carbón son los responsables de desarrollar la arterioesclerosis, formación de trombos por alteración en las plaquetas, espasmo arterial coronario, arritmia cardiaca y sobre todo reducción de la capacidad sanguínea para transportar oxígeno, participa en la ruptura de la placa ateroesclerótica, aumento en la concentración de fibrinógeno y disminución en la concentración de plasminógeno etc., aunque no se conocen bien los mecanismos de acción, están fuertemente asociados la CI y a otras enfermedades graves ya mencionadas. Actualmente se reporta que existen 1100 millones de fumadores a nivel mundial y se espera que para el año 2020 fallezcan aproximadamente 10 millones por consecuencia del tabaquismo. La fuerte adicción al tabaco requiere de tratamiento especializado farmacológico y psicológico ya que afecta tanto a los fumadores activos como a los fumadores pasivos ${ }^{21}$.

Según la Dirección General de Información en Salud, en México para el año 2007, la diabetes mellitus (DM) ocupó el primer lugar como causa de mortalidad, con una tasa de mortalidad de 69.2 y 64 por 100000 habitantes en mujeres y hombres respectivamente ${ }^{22}$. En relación a la cardiopatía isquémica aislada tiene una mortalidad del $20 \%$ en pacientes diabéticos y no diabéticos, pero cuando se asociación la DM con cardiopatía isquémica incrementa la mortalidad hasta $65 \%$ por lo que la Asociación Americana del Corazón (AHA) considera a la DM como el principal factor de riesgo para el desarrollo de la CI y la muerte súbita. En diferentes estudios se ha observado que la mortalidad aumenta cuando el evento cardiovascular ocurre en edades mayores, sobre todo en mujeres postmenopáusicas mayores de 75 años que ya no tienen la protección hormonal y/o cursan con mayor grado de obesidad ${ }^{24,31}$.

Otro elemento que favorece el desarrollo de la CI, es la inactividad física, al respecto la OMS estima que en la actualidad el $60 \%$ de la población mundial no es lo suficientemente activa físicamente. En diversos estudios se ha encontrado una mayor relación entre la 


\section{Cardiopatía isquémica}

poca actividad física y las enfermedades cardiovasculares; el riesgo relativo de muerte por enfermedad cardiaca en un individuo sedentario en comparación con uno activo es de 1.9. Las recomendaciones para realizar ejercicio forman parte de una gran campaña de salud para disminuir el riesgo de ECV realizar ejercicio, mejora la sensibilidad a la insulina sobre todo si es de tipo aeróbico ${ }^{27,28}$.

Quizás el factor más importante para desarrollar una CI, es la presencia del síndrome metabólico, llamado anteriormente síndrome $\mathrm{X}$ o en su defecto síndrome plurimetabólico, donde se asocian varios factores de riesgo que comparten una misma fisiopatología, como son la presencia de dislipidemia aterogénica de predominio hipertrigliceridemia, colesterol de alta densidad con cifras bajas y de baja densidad con cifras altas con aumento de la apolipoproteina B (ApoB) y disminución de la Apolipoproteína A1 (ApoA1), intolerancia a disacáridos, o DM tipo 2 (DM2), HAS, obesidad central, trastornos de la coagulación, resistencia a la insulina, estado proinflamatorio, esteatosis hepática no alcohólica, hiperferritinemia, hiperhomocistinemia etc., que asociados al tabaquismo favorecen e incrementan la mortalidad por cardiopatía isquémica ${ }^{27,28}$.

Para diagnosticar un síndrome se deben de tener por lo menos la reunión d tres factores de riesgo, los más importantes, son la obesidad central o visceral, DM2 y la hipertriglicedidemia, donde probablemente la resistencia a la insulina y el hiperinsulinismo sean el factor desencadenante.

Otros factores de riesgo detectados son la baja escolaridad que favorecen el desarrollo de ECNT, la edad mayor, el sedentarismo, antecedentes familiares de dislipidemia y ECV, y cuando varios de estos factores se reúnen la probabilidad de tener CI se incrementa ${ }^{28,29}$.

\section{Fisiopatología}

La CI puede darse por diversas alteraciones a nivel de las coronarias, la más importante en la actualidad es la ruptura de la placa ateroesclerótica hacia la luz arterial desencadenando la cascada de coagulación, donde los macrófagos son los responsables de romper la placa ateromatosa ${ }^{31}$; otras causas son la obstrucción arterial por crecimiento de las placas ateroescleróticas hacia la luz obstruyendo hasta un $70 \%$ su luz, otra causa es la vasoconstricción coronaria provocada por HAS o uso de drogas; embolias, arteritis coronaria, aumento de la demanda de oxígeno por el miocardio, o una disminución de 


\section{Principales problemas de Salud Pública en México}

aporte de oxígeno como una anemia severa, la hipotensión arterial en que disminuye la sangre retrograda que nutre a las paredes ventriculares o un aumento de la frecuencia cardiaca acortando la diástole con la disminución del aporte de oxígeno y nutrientes al miocardio.

La hipoperfusión territorial por más de 20 minutos, puede llegar hasta la muerte del tejido miocárdico por tres razones diferentes, por la falta de oxígeno, por el exceso de dióxido de carbono y por falta de nutrientes, esta última provoca una falta de polarización en la zona isquémica.

La lesión endotelial de las arterías coronarias izquierda y derecha por ateroesclerosis ocurre al inicio de ambas arterias, sin embargo la presentación de las lesiones cardiacas son más frecuentes en el lado izquierdo del corazón, fisiológicamente esto se explica porque el consumo de oxígeno del lado izquierdo es mayor al ser más gruesa la pared, más grande el ventrículo izquierdo, requiere de mayor fuerza de contracción, para vencer la resistencia de la gran circulación, por otra parte el corazón se nutre escasamente por la sangre que maneja dentro de las cavidades cardiacas, su principal fuente de nutrición es a través de estas dos arterias coronarias que son extracardiacas y que viajan por los surcos del corazón las cuales van emitiendo pequeñas ramificaciones hacia el interior del músculo cardiaco, de tal manera que cuando se lleva a cabo la contracción miocárdica la sangre circulante se exprime y como hay mayor presión en el endocardio que en el epicardio y esto nos explica que ya en condiciones normales hay menos irrigación en el endocardio durante la sistole ${ }^{34}$, Lo anterior nos explica entonces que las zonas isquémicas son más frecuentes en el territorio de la arteria descendente anterior izquierda en su parte proximal, y en segundo lugar la arteria posterior derecha, ECV, la localización más frecuente de la isquemia fue la arteria coronaria inferior izquierda(32.5\%), seguida de la antero-septal (17.5\%), la ínfero-septal $(16.3 \%)$, ambas ramas de la coronaria izquierda, la postero-inferior y la anterior extensa (6.2\% cada una); y la diafragmática ( $5 \%$ cada una), la antero-inferior ( $3.8 \%$ ) ramas de la coronaria derecha y la septal sin onda Q (2.5\%). a pesar de la localización más frecuente en la coronaria izquierda, las lesiones de la coronaria derecha son muy importantes ya que esta irriga al nodo auricular, al auriculoventricular, la irrigación del Haz de His está dado por la descendente anterior ${ }^{32,41}$.

Anteriormente se pensaba que la ateroesclerosis solo ocurría en adultos mayores en la actualidad se han demostrado placas de ateroma en jóvenes entre 15 y 19 en más del 50\% 


\section{Cardiopatía isquémica}

de la población ${ }^{26,34}$, lo que demuestra que la ateroesclerosis se inicia en etapas tempranas de la vida y se va depositando en forma paulatina en la capa intima de las arterias durante varios años, causando estenosis de la luz y cambios en las fibras musculares.

A temprana edad y dependiendo de los antecedentes heredofamiliares y la dieta, se inicia una acumulación de partículas de lipoproteínas que se unen a proteoglicanos en la capa intima para formar una estría grasa, que al desarrollarse va formando el ateroma, este material extraño provoca una acumulación de macrófagos ${ }^{32}$ y leucocitos, que al ingerir las partículas de lipoproteína da origen a la formación de células espumosas, este mismo proceso favorece la presencia de fibrosis que rodea al acumulo de lipoproteínas de baja densidad formando un casquete fibroso, y mientras más exposición a lipoproteínas de baja densidad mayor es la placa de ateroma, si esta placa de ateroma es frágil, o inestable al romperse casi siempre lo hace hacia la luz endotelial, desencadenando los mecanismos de coagulación para formar el trombo obstructivo, causante de la hipo perfusión miocárdica así como los mecanismos de la inflamación que se desencadenan se dan en los siguientes pasos.

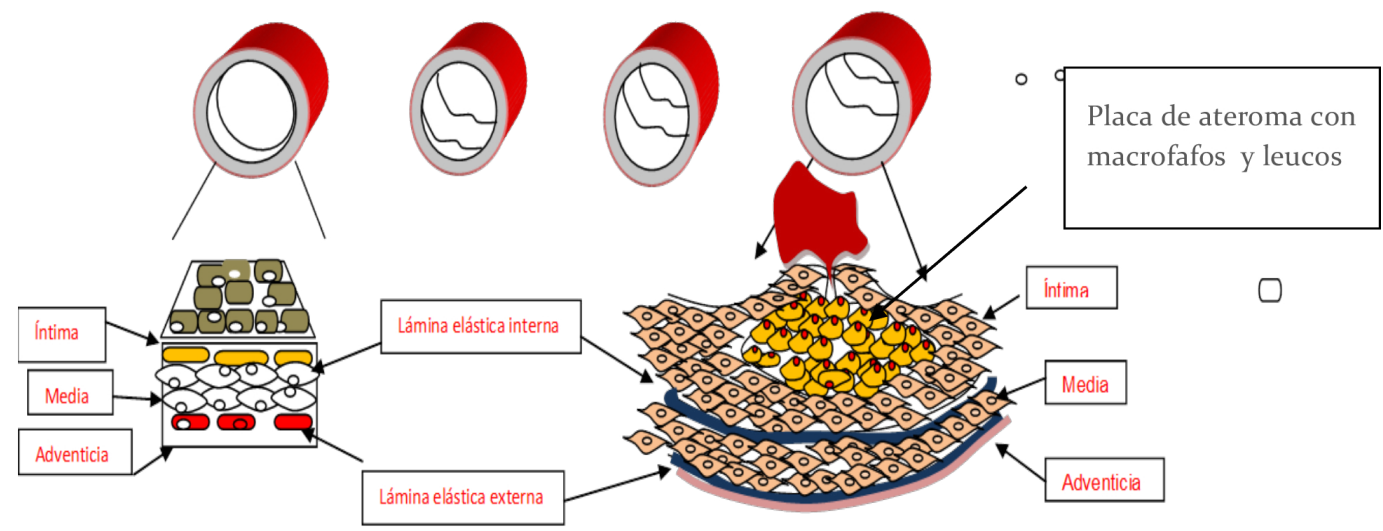

Figura elaborada por María del Carmen García Ríos.

La ruptura del casquete fibroso ocurre en casos de fragilidad (o por delgado), es favorecida por un factor tisular que puede ser la trombina que en etapa inicial, activa la cascada de la coagulación primero favoreciendo la adhesión y agregación plaquetaria por medio del factor de Von Willebrand, la producción de tromboxano A 2, Serotonina y factor activador 


\section{Principales problemas de Salud Pública en México}

de las plaquetas, una vez activadas las plaquetas aumenta la afinidad de unión a la trombina y al fibrinógeno para la formación de un trombo, en condiciones normales se activa la fibrinólisis para la reabsorción del trombo, pero esta acción está alterada, si la obstrucción es total y tarda entre 15 a $30 \mathrm{~min}$ la isquemia provoca una necrosis del tejido miocárdico que se inicia en el endocardio y progresa hacia el epicardio, en segundo lugar pero a la par de lo anterior la trombina actúa desencadenando el proceso inflamatorio. Otro fenómeno que ocurre y que contribuye a la formación de la placa es el gran infiltrado de macrófagos y la diferenciación de células musculares a tejido conjuntivo, con esto disminuye la elasticidad de las arterias y aumenta la trombogenesis ${ }^{32,33}$.

En condiciones normales en la capa intima hay algunas células musculares lisas cubiertas en su parte interna por una capa de células endoteliales y es allí donde se empieza a tener una mayor permeabilidad a las lipoproteínas transportadoras de colesterol y triglicéridos, sobre todo las lipoproteínas de baja densidad, que se van depositando en la capa intima formando la estría grasa, a esta se unen componentes de la matriz extracelular de proteoglicanos extracelulares, favorecidos por substancias como moléculas del sulfato de heparan, sulfato de queran o sulfato de condoitrín, provocando oxidación y glucosilación no enzimática, y desencadena el proceso inflamatorio, favoreciendo la aterogénesis. Al modificarse las apolipoproteínas permite la ruptura del esqueleto peptídico formando compuestos hidroperóxidos lisofosfolipidos y oxiesteroles y aldehídicos productos de la degradación de ácidos grasos, formando núcleos lipídicos si es pequeño rodeado de un casquete fibroso grueso se le considera estable o puede ser un núcleo lipídico abundante rico en colesterol y con un gran infiltrado linfocitario con disminución de células musculares y placa de calcio con casquete delgado y frágil volviéndolo un ateroma inestable, el 60\% de síndromes coronarios agudos son del tipo inestable $\mathrm{e}^{33,34,35}$.

El crecimiento de la estría o placa ateromatosa hacia la luz arteriolar puede obstruir hasta un $70-80 \%$ de su diámetro y dependiendo de la distensibilidad o la longitud afectada y requerimientos de oxígeno dará sintomatología coronaria, cuando el crecimiento de la placa es hacia afuera de la luz tarda más tiempo en dar sintomatología, incluso causar aneurismas o aumento del calibre.

En la actualidad lo más importante es la ruptura de la placa ateroesclerótica hacia la luz más que el grosor o la estenosis coronaria, en estudios recientes el 68\% de los infartos 


\section{Cardiopatía isquémica}

ocurren en arterias con estenosis menor del 50\%, 18\% con lesión del 50 al 70\% y solo el 14\% ocurre en arterias con lesión mayor al 70\%, en este último caso se considera que da menos complicaciones ya que la lenta obstrucción favorece el proceso de revascularización ${ }^{33}$.

En un segundo paso con la formación de la estría grasa se lleva a cabo una acumulación de leucocitos primeramente monocitos y linfocitos que probablemente son atraídos por moléculas de inmunoglobulinas llamadas selectinas para favorecer la adhesión celular (VCAM I). La lisofosfatidilcolina componente de la LDL oxidada aumenta la acción de la VCAM1 que promueve la quimiotaxis de los leucocitos, ya dentro de la capa intima estos se transforman en macrófagos que introducen a su interior los lípidos modificados a través de endociosis, los macrófagos finalmente se convierten en células espumosas que liberan citocinas IL1 y TNFa y factores de crecimiento quienes estimulan la proliferación de músculo liso y matriz fibroblástica que participa en la formación del casquete fibroso, y en el desarrollo de músculo liso en la íntima aunque este proceso es muy lento, se cree que favorece la ruptura desencadenando los procesos inflamatorios sobre todo a nivel del endotelio provocando una respuesta endotelial alterada como, la vasoconstricción desencadenada por frío, estrés o ejercicio y la consecuente isquemia. Por otro lado las lipoproteínas oxidadas favorecen también la producción de citocinas. Implicadas en el desarrollo del casquete fibroso $\mathrm{O}^{31,35}$.

Otro factor implicado en el desarrollo casquete fibroso y ateromas es la apoptosis de las células musculares lisas y de las células espumosas (muerte celular), que en etapas avanzadas de la ateroesclerosis ya no se aprecian y quedan como tejido fibroso, otros elementos estudiados para la formación del tejido fibroso es por acción de las plaquetas que liberan serotonina y factor de crecimiento plaquetario.

Los vasa vasorum se desarrollan más a medida que crece la placa ateromatosa y provocan sangrados dentro de la misma, desencadenando factores de coagulación con la transformación de la protrombina en trombina y formación de trombosis in situ.

En el ateroma se encuentran también calcio, osteocalcina osteoponina y otras proteínas morfo genéticas.

Cuando se fractura el casquete fibroso se desencadenan los factores de la coagulación, formando el trombo a través de cuatro estadios: 1) aumento en la adhesividad plaquetaria 


\section{Principales problemas de Salud Pública en México}

por la glicoproteína ib IX que se une al factor de Von Willebrand, 2) activación del factor de coagulación intrínseco y extrínseco activando el factor $\mathrm{X}$ con aumento de la trombina, $\mathrm{y}$ 3) propagación del coagulo, la trombina recluta más plaquetas y activa a la glicoproteína II b y III a, que une el fibrinógeno a las plaquetas haciéndolo muy resistente y organización del trombo. En condiciones normales la formación del coagulo es para evitar pérdida de sangre, una vez obstruida la lesión se activa el plasminógeno para realizar la fibrinólisis en el caso de la ateroesclerosis se libera un inhibidor del plasminógeno disminuyendo la fibrinólisis, por lo que el coagulo provoca la isquemia ${ }^{33}$.

Al obstruirse el flujo sanguíneo y provoca la isquemia hay incremento de lactatos, disminución del $\mathrm{pH}$, del ATP y de creatinin fosfatos, disminuye la fuerza de contracción de la distensibilidad, provoca disfunción de los músculos papilares y falla ventricular manifestada como insuficiencia cardiaca. En los casos de casquete inestable, los linfocitos actúan como mediadores del proceso inflamatorio.

\section{Cuadro clínico}

Los síntomas de la CI dependen del grado de la obstrucción coronaria, de la zona afectada, de la extensión, profundidad en la pared y del tiempo de isquemia así como de la demanda de oxígeno del tejido cardiaco. Los síntomas incluyen combinaciones de malestar o dolor en el tórax de tipo opresivo siendo esta la manifestación principal aunque no se presenta en todos los casos como en el caso de pacientes diabéticos, se puede acompañar de disnea, nauseas, vómito, fatiga diaforesis, hiperactividad vagal, taquicardia o datos de falla cardiaca $^{36}$. En México, el dolor torácico se presentó en el 80\% de los casos, la localización, irradiación, carácter, duración, relación con el esfuerzo y otros fenómenos acompañantes son determinantes para un diagnóstico temprano.

El dolor torácico es referido por el paciente aplicando la mano sobre la región dolorosa y flexionando los dedos en garra habitualmente sobre el esternón, se irradia habitualmente hacia el hombro izquierdo pero puede ser a ambos lados, cuando irradia al brazo sigue borde cubital del mismo lado y hasta la flexura del codo y los dos últimos dedos de la mano, el dolor se puede manifestar entre las escápulas, la mandíbula, dientes y epigastrio. Estos síntomas pueden ser transitorios ocasionados por un aumento de la demanda de oxígeno, en el caso de una angina estable o durar más de 20 minutos en presencia de Infarto agudo del miocardio. El dolor puede aparecer al estar en reposo o se pueden desencadenar 


\section{Cardiopatía isquémica}

al realizar un esfuerzo, y / o acompañarse de sensación inminente de muerte y actividad simpático adrenérgica como la palidez y la diaforesis ${ }^{37}$.

Se describe que el sitio más frecuente de irradiación del dolor es la región esternal en el $47.5 \%$ de los casos, seguido de la cara cubital de las extremidades torácicas en el $12 \%$ al $18 \%$, de predominio izquierdo, 5 a $8 \%$ de los casos se refiere hacia el epigastrio y la región izquierda del cuello y en menor porcentaje en la región dorsal (2\%).

En algunos casos el síncope es la manifestación inicial y la sensación de angustia extrema es evidente. Todo este cuadro es inespecífico y puede sub diagnosticarse o atribuirse a otras enfermedades de origen gastrointestinal cuando se acompañada de sensación de quemazón o ardor, o problemas pulmonares cuando hay sensación de falta de aire, fatiga, o a problemas neurológicos cuando se acompaña de desasosiego o metabólicos como la diabetes, entre otros.

En el caso de EI, cuando existe dolor retro esternal desencadenado por actividad física o emocional y sede con el reposo, se le denomina angina estable y de acuerdo a la clasificación funcional de la Sociedad Cardiovascular Canadiense, la divide en cuatro estadios que dependen de cómo se desencadena con el ejercicio.

En el caso de angina inestable es el paso de una angina estable a un infarto agudo al miocardio (IAM), y es el empeoramiento de la angina estable habitualmente por la ruptura parcial del casquete ateromatoso, con obstrucción parcial de la luz arteriolar por el trombo puede ocurrir en reposo.

El cuadro de dolor en reposo, matutino por vaso espasmo coronario se le denomina angina variante de Prinzmetal ${ }^{37}$.

\section{Complicaciones}

La principal complicación de la cardiopatía isquémica es el infarto al miocardio que se presenta cuando la isquemia persiste por más de 20 minutos, y del IAM cuando este afecta al ventrículo izquierdo y dependiendo de la magnitud es la falla ventricular izquierda que se traduce como insuficiencia cardiaca, en este caso se presenta hipovolemia, confusión o pérdida del estado de alerta, si la afección es sobre la coronaria derecha se 


\section{Principales problemas de Salud Pública en México}

pueden presentar arritmias, e insuficiencia cardiaca derecha con disnea severa y edema pulmonar, en cualquier caso la muerte puede presentarse como máxima complicación, otra complicación durante la fase aguda y que depende del tratamiento antitrombótico son las hemorragias en diferentes partes de la economía, en las complicaciones tardías de una cardiopatía isquémica son la angina inestable, en lesiones post infarto las arritmias, las dilataciones cardiacas o aneurismas y la ruptura cardiaca y la muerte súbita sobre todo en pacientes con diabetes mellitus y en mujeres mayores de 70 años o post menopáusicas, también puede presentarse un reinfarto ${ }^{32,33,36}$.

\section{Diagnóstico}

El avance científico del siglo XX que nos brindó más recursos para el diagnóstico, sin embargo una buena clínica la evaluación de los factores de riesgo, la presentación del cuadro siempre serán una buena arma diagnostica invaluable $\mathrm{e}^{36,37}$.

1. La historia clínica es primordial en los pacientes con alta probabilidad de presentar cardiopatía isquémica, al igual que cualquier otra patología es de suma importancia realizar un interrogatorio dirigido y una exploración física adecuada $a^{16,37,38,39,40}$.

2. El dolor precordial es un síntoma importante en la presentación de esta entidad, el dolor de etiología coronaria generalmente es definido como un dolor opresivo, transfictivo, generalmente intenso acompañado de sensación inminente de muerte que aparece en la cara anterior de tórax que se puede irradiar a ambos brazos principalmente al lado izquierdo así como a la espalda o al epigastrio de duración variable y que puede acompañarse de situaciones complicadas como la insuficiencia cardiaca, sincope o arritmias, sin embargo en pacientes con cardiopatía isquémica previa la severidad del dolor puede no guardar relación con la gravedad de la enfermedad como en el caso de pacientes diabéticos con neuropatía en que no presentan dolor, conocido como infarto silencioso Es importante descartar posibilidades de otras etiologías que causan dolor torácico como una osteocondritis, un problema esofágico e incluso problemas emocionales, se pueden encontrar estrías palmares ${ }^{38,41,42}$.

3. El electrocardiograma (ECG) se realiza de 12 derivaciones a todos aquellos pacientes que presenten dolor precordial o malestar con datos sugestivos de cardiopatía isquémica. El 


\section{Cardiopatía isquémica}

ECG es normal en más del 50\% de los pacientes que no presentan dolor. En el síndrome coronario agudo (angina inestable e IAM) se debe realizar un electrocardiograma urgente en los primeros 10 minutos de aparición de un dolor anginoso. Los hallazgos en el ECG se clasifican en síndrome coronario agudo con ascenso del ST (SCACEST) en más del 40\% y síndrome coronario agudo sin ascenso del ST (SCASEST) cerca del 60\%. El SCASEST indica una obstrucción incompleta del vaso sin llegar a producir necrosis del tejido miocárdico (angina inestable). El SCACEST o el bloqueo de rama izquierda del Haz de His (BRIHH) indica una obstrucción completa del vaso que produce necrosis transmural (IAM con onda Q). En la angina estable la alteración más frecuente es el descenso del ST que desaparece cuando lo hace el dolor. Otras alteraciones que pueden aparecer son las ondas $\mathrm{T}$ hiperagudas, ondas $\mathrm{T}$ invertidas simétricas y la pseudnormalización de la onda T. El ascenso del ST indica lesión subepicardica. El descenso del ST indica lesión subendocardica ${ }^{38,41,42,43}$.

4. Las pruebas sanguíneas incluyen a las troponinas $\mathrm{T}$, que son biomarcadores más sensibles y específicos como marcadores de lesión miocárdica comparadas con la creatinfosfokinasa CPK o con su isoenzima MB (CK-MB). Las troponinas empiezan a elevarse a las 3-4 hs posterior a un daño miocárdico con elevación máxima a las 8-12 hs. y pueden persistir elevadas de 5 a 14 días. El marcador CK-MB se eleva de 4-6 hs. y su máximo es de 12- 24 hs., tiene baja especificidad y sensibilidad en infartos menores de 6 hs. de evolución ${ }^{45,46,47,48}$.

5. Los rayos $X$ de tórax, puede aparecer sin alteraciones, aunque sirve para detectar causas de dolor no coronario u otras alteraciones cardiovasculares previas.

6. La prueba de esfuerzo está indicada en aquellos pacientes con sospecha de angina estable, con una sensibilidad media del $70 \%$ y una especificidad del $80-90 \%$, mientras más grave sea la cardiopatía más sensible será la prueba. Cuando no es concluyente o es negativo con síntomas clínicos de cardiopatía isquémica o cuando no es posible la interpretación del ECG se puede solicitar otras pruebas diagnósticas. En relación al sexo las pruebas de esfuerzo fueron positivas en un $54 \%$ para los hombres y $38 \%$ en mujeres ${ }^{41,49,50,51,52,53,54}$. 


\section{Principales problemas de Salud Pública en México}

7. Gamagrafía cardiaca.

Los estudios referidos nos apoyan para poder efectuar el diagnóstico de las EI. En México, el diagnóstico clínico más frecuente encontrado en las mujeres fue la angina de pecho en el $57 \%$ de los casos, a diferencia del grupo de hombres donde el infarto miocárdico fue más frecuente en $46 \%{ }^{54}$.

\section{Terapéutica}

En general los pacientes con CI deben ser tratados de acuerdo a las guías internacionales y en las normas oficiales para el manejo de las dislipidemias, diabetes mellitus, obesidad e hipertensión, que correspondes a los principales factores de riesgo $0^{15,16,17,18}$ Es importante reconocer el momento fisiopatológico para actuar sobre: a) La trombosis coronaria; b) Sobre la acción de la angiotensina; c) Sobre la función del sistema adrenérgico en los ventrículos, la insuficiencia cardiaca; y d) El control de las dislipidemias, evaluando el grado de Insuficiencia cardiaca de acuerdo a la American Heard Asociación ${ }^{36,38}$. Todo esto sin olvidar que el manejo depende de la urgencia con la que se presente el paciente.

En forma general el tratamiento se divide en no farmacológico y farmacológico el primero es tan importante como el segundo, ya que incide en todos los factores que son modificables como la obesidad, dieta, ejercicio etc, y no incide en las no modificables como la edad y sexo, en el tratamiento farmacológico se divide en tratamiento preventivo de urgencia y conservador, y el tratamiento quirúrgico y de las complicaciones y secuelas $^{53}$.

Desde el reconocimiento de la ruptura del endotelio y la activación inicial de la adhesión plaquetaria en la época de los 80 s, se han dado tratamiento antitrombótico y antiagregante plaquetario, el más conocido es el ácido acetil salicílico, tanto preventivo como curativo a dosis de 75 a 325 mgs diarios sobre todo en cardiopatía sin elevación del S-T y en angina estable $^{38,50,54,55}$.

El clopidogrel, es un antagonista no competitivo del receptor plaquetario e impide la activación de las glicoproteínas y la agregación plaquetaria, la dosis para un cuadro agudo es de 300 mgs. y la de sostén de 75 mgs cada 24 hrs., cuando se asocia al AAS aumentan su eficacia. 


\section{Cardiopatía isquémica}

Como inhibidores de la Glicoproteína IIb y IIIa su función es evitar la unión de las plaquetas con el fibrinógeno para evitar la formación del trombo. Una vez formado el trombo el manejo es con anticoagulantes y fibrinolíticos la más utilizada es la Heparina no fraccionada y heparinas de bajo peso molecular, que actúan sobre la antitrombina III, trombina y factor Xa, la Fondaparinox que debe aplicarse en las primeras 2 hrs cuando hay un riesgo alto de $\mathrm{CI}^{38,56}$.

Los Beta bloqueadores (BB), son muy utilizados en el cuadro agudo de la CI y como tratamiento en la prevención secundaria para evitar el re infarto, en CI por estrés, en CI sin antecedente de infarto, o cuando hay problema de disfunción ventricular izquierda o con HAS. Los BB actúan en forma selectiva en los receptores BI o cardioselectivos y B2 adrenérgicos no selectivos, bloqueando la acción de las catecolaminas, recordar que algunos BB tienen efecto agonista o simpaticomiméticos intrínsecos y son menos bradicárdicos. Otros BB provocan un bloqueo $\alpha$-adrenérgico, por lo que tienen acción vasodilatadora periférica, su acción es importante para el tratamiento de CI, y conocer su función en forma adecuada para evitar sus efectos secundarios ${ }^{36,38,55,56}$.

Los antagonistas de los canales del calcio (ACC) actúan interfiriendo en la entrada de calcio al interior de las células, al bloquear los canales de calcio. Sus principales sitios de acción son en el sistema cardiovascular, en las células del músculo liso vascular, los miocitos cardíacos y el tejido de conducción. Se clasifican en dos grupos las dihidropiridinas con acción vasodilatadora como la nifedipina y las no dihidropirimidas con acción cronotrópica e inotrópica negativa como el verapamilo y el ditiazem. Su uso en la CI se reduce al tratamiento de problemas por vaso espasmo, en algunos casos de angina o en contraindicaciones a los BB.

La acción de la trimetazidina no es bien conocida, se cree que, interviene optimizando el metabolismo energético de la célula isquémica a través de un intercambio metabólico entre la oxidación de ácidos grasos y la oxidación de glucosa. El efecto anti isquémico no es mejor BB o ACC para el control de las crisis de angina. También ha mostrado resultados favorables en asociación con diltiazem.

Los inhibidores de la enzima de conversión de la angiotensina (IECA) impiden la conversión de angiotensina I en angiotensina II y con ello disminuye la secreción de aldosterona. Actúan también en los vasos de resistencia y de capacitancia, para reducir la precarga y la pos carga 


\section{Principales problemas de Salud Pública en México}

e Inhiben la aterosclerosis, y ayuda a remodelar los vasos arteriales afectados, reducen el riesgo de muerte súbita post infarto, y previenen la nefropatía diabética, están indicados cuando hay infartos en la cara anterior y cuando está indicada la revascularización.

Los antagonistas de los receptores de la angiotensina II, bloquean de forma selectiva el receptor AT1 de la angiotensina II,. No actúan en las bradicininas, favorece un aumento del filtrado glomerular por vasodilatación, tanto de las arteriolas aferentes como de las eferentes. El losartan y el valsartan son los más conocidos y están indicados cuando hay lesión ventricular izquierda.

Las estatinas, inhiben la 3-hidroxi-3-metilglutaril coenzima A (HMG-CoA) reductasa, con lo que reducen la síntesis de colesterol y aumentan los receptores de LDL y su catabolismo. También inhiben la proliferación de fibroblastos, mejoran los factores pro inflamatorios y protrombóticos, mejoran la función endotelial y la síntesis de óxido nítrico. Están indicados para prevenir y tratar la hipercolesterolemia en forma indefinida principalmente en pacientes con cifras altas de LDL > de $100 \mathrm{mg} / \mathrm{kg}$ están contraindicados en falla renal.

Hay diversos fármacos que contribuyen al aumento de la HDL como fibratos, niacina, y con ello se pretende controlar de manera natural a las LDL solo los fibratos han demostrado una reducción de los episodios coronarios graves.

Dentro del tratamiento no farmacológico, la OMS recomienda estrategias para ser adoptadas de manera personal para disminuir el riesgo de ECV, entre ellas realizar 30 minutos diarios de ejercicio físico, dejar de fumar y evitar exponerse pasivamente al humo del tabaco, escoger una dieta rica en frutas, verduras y potasio, evitando comidas grasosas disminución de la ingesta de sodio, control de peso, reducir el estrés en la casa y el trabajo. De manera general, el aporte calórico debe de ser de 20 a $25 \mathrm{Kcal} / \mathrm{Kg}$ de peso si el paciente tiene sobrepeso y obesidad; se disminuye de 5 a $10 \mathrm{Kcal}$ es decir 15 a $20 \mathrm{Kcal} / \mathrm{Kg}$, la ingesta de proteínas de origen animal, por lo que no debe de exceder del $20 \%$ del total de acuerdo al plato del buen comer; bajo consumo de sal; aumento en el consumo de fibras; $<$ del 10\% deben ser grasas saturadas, $10 \%$ de grasas mono saturadas y $10 \%$ de grasas poli insaturadas. La dieta baja en grasas disminuye eventos cardiacos 2.5 veces, y para ser efectiva debe ir acompañada de ejercicio físico. En niños mayores de 2 años y adolescentes lo ideal es mantener el colesterol total $<170 \mathrm{mg} / \mathrm{dl}$. LDL- $<110 \mathrm{mg} / \mathrm{dl}$. HDL-col mayor de 


\section{Cardiopatía isquémica}

$40 \mathrm{mg} / \mathrm{dl}$ y triglicéridos menor de $100 \mathrm{mg} / \mathrm{dl}$. El ejercicio aeróbico básico posterior a un infarto de preferencia se debe iniciar una semana o hasta seis semanas después del alta hospitalaria de acuerdo al tipo, localización del infarto o evento isquémico.

Para efectuar el tratamiento quirúrgico, debe ser analizado de manera multidisciplinaria para realizar una angioplastia percutánea transtorácica, re perfusión y/o revascularización ${ }^{38}$, con este mismo fin de mejorar la perfusión cardiaca se están haciendo ensayos sobre el uso de células madre.

\section{Medidas de prevención}

Las medidas de prevención siguen siendo con los niveles de Leavell y Clark, primaria, secundaria y terciaria, en el primer nivel es llevando medidas de promoción de la salud incidiendo en la familia y encaminadas a una dieta saludable, efectuar ejercicio, control de peso, evitar el estrés, en la prevención secundaria se debe llevar un manejo adecuado de las enfermedades crónicas que la favorecen como la obesidad, DM, HAS, hipercolesterolemia y tabaquismo, con la finalidad de limitar daño, y en el tercer nivel de prevención la rehabilitación desde la psicológica, física y social ${ }^{56,57,58}$.

\section{Referencias}

1. Secretaría de Salud. Encuesta Nacional de Salud y Nutrición 2012. Instituto Nacional de Salud Pública México 2012. Disponible en: http://ensanut.insp.mx/informes/ ENSANUT2012ResultadosNacionales.pdf

2. Córdova-Villalobos JA, Barriguete-Meléndez JA, Lara-Esqueda A, Barquera S, RosasPeralta M, Hernández-Ávila M, et al. Las enfermedades crónicas no transmisibles en México: sinopsis epidemiológica y prevención integral. Salud Pública de México. 2008; 50(5):419-27.

3. Arias MA. Placa vulnerable: métodos de identificación actual y futuro. Rev Archivos de Cardiología de México. 2006; 76(Supl. 2):229-232.

4. Serrano VX. Valoración preoperatoria del paciente con cardiopatía isquémica. Rev Mexicana de Anestesiología. 2007; 30(Supl. 1):S338-S345.

5. Grupo de trabajo de la Sociedad Europea de Cardiología sobre diagnóstico y tratamiento de la cardiopatía isquémica estable. Guía de Práctica clínica de la ESC 2013 


\section{Principales problemas de Salud Pública en México}

sobre diagnóstico y tratamiento de la cardiopatía isquémica estable. Rev Esp Cardiol. 2014; 67(2):135.e1-e81.

6. Chávez DR. Mortalidad de las enfermedades cardiovasculares en México. Artículo Especial. Arch Inst Cardiol Méx 1979; 49:303-323.

7. González Guzmán R, Alcalá Ramírez J. Enfermedad isquémica del corazón, epidemiología y prevención. Rev Fac Med UNAM. 2010; 53(5):35-43.

8. O'Donnell CJ, Elosua R. Cardiovascular risk factors. Insights from framingham heart study. Rev Esp Cardiología. 2008; 61(3):299-310.

9. Jiménez-Corona A, López-Ridaura R, González-Villalpando C. Incidence of myocardial infarction in low-income urban residents of México City. Salud Pública Méx. 2009; 51:458-46.

10. Escobedo-De La Pena, J, Rodríguez-Abrego G, Buitrón-Granados, LV. Morbilidad y mortalidad por cardiopatía isquémica en el Instituto Mexicano del Seguro Social. Estudio ecológico de tendencias en población amparada por el Instituto Mexicano del Seguro Social entre 1990 y 2008. Arch Cardiol Méx. 2010; 80(4): 242-248. Disponible en: <http:// www.scielo.org.mx/scielo.php?script=sci_arttext\&pid=S1405-99402010000400008\&lng $=$ es\&nrm=iso $>$. ISSN 1405-9940.

11. Sánchez-Barriga JJ. Comportamiento de la mortalidad por cardiopatía isquémica en México en el periodo 2000-2007. Gac Méd Méx. 2009; 145(5):375-382. Disponible en: http://www.anmm.org.mx/GMM/2009/n5/15_vol_145_n5.pdf

12. Quyyumi AA, Cannon RO III, Panza JA, DiodatiJG, Epstein SE. Endothelial dysfunction in patients with chest pain and normal coronary arteries. Circulation. 1992; 86:1864-1871.

13. Giardini R, Bairey Merz CN. Angina with "normal" coronary arteries: a changing philosophy. JAMA. 2005; 293(4):477-484.

14. Roberto Elosua CL, Gavin L. Estudio del componente genético de la cardiopatía isquémica: de los estudios de ligamiento al genotipado integral del genoma. Rev Esp Cardiol Supl. 2009; 9(B):24-38.

15. Freire Castroseiros E, Penas Lado M, Castro Beiras A. Patología del corazón de origen extracardiaco (VIII). Cocaína y corazón. Rev Esp Cardiol. 1998; 51(5):396-401.

16. Norma Oficial Mexicana NOM-037-SSA2-2012. Para la prevención, tratamiento y control de las dislipidemias. Diario Oficial de la Federación, 13 de julio del 2012. 


\section{Cardiopatía isquémica}

17. Norma Oficial Mexicana NOM-008-SSA3-2010, para el tratamiento integral del sobrepeso y la obesidad. Diario Oficial de la Federación. 4-08-2010.

18. Norma Oficial Mexicana NOM-030-SSA2-2009, para la prevención, diagnóstico tratamiento y control de la hipertensión arterial sistémica. Diario Oficial de la Federación. 31-05-2010.

19. Rosas Peralta M, et al. Re-encuesta nacional de hipertensión arterial (RENAHTA): Consolidación mexicana de los factores de riesgo cardiovascular. Cohorte nacional de seguimiento. Arch Cardiol Méx. 2005; 75(1):96-111. Disponible en: <http://www. scielo.org.mx/scielo.php?script=sci_arttext\&pid=S1405-99402005000100016\&lng=es\& nrm=iso>

20. Rosas M, et al. Hipertensión arterial en México: guías y recomendaciones para su detección, control y tratamiento. Arch Cardiol Méx. 2004; 74(2):134-157. Disponible en: <http://www.scielo.org.mx/scielo.php?script=sci_arttext\&pid=S140599402004000200007\&lng=es\&nrm=iso>

21. Salazar ME, Sánchez ZL, López PL, Estrada NA, Lazcano PE, Hernández AM. El tabaquismo y su fracción atribuible en la enfermedad isquémica cardiaca. Salud Pública de México 2002; 44(supl 1):S34-S43 http:// www.insp.mx/salud/index.html.

22. Norma Oficial Mexicana NOM-015-SSA2-2010, para la prevención, tratamiento y control de la diabetes mellitus. Diario Oficial de la Federación. 23-11-2010.

24. Zamora A, Marrugat J. Pronóstico de los pacientes diabéticos con cardiopatía isquémica. Rev Esp Cardiol. 2002; 55(7):751-62.

25. UNICEF. México -salud y nutrición- infancia y salud. Disponible en: https://www. unicef.org/mexico/spanish/17047.htm.

26. Escudero-Lourdes G, Morales-Romero V, Valverde-Ocaña C, Velasco-Chávez J. Riesgo cardiovascular en población infantil de 6 a 15 años con obesidad exógena. Rev Med Inst Mex Seguro Soc. 2014; 52(Supl 1):S58-S63.

27. Ministerio de Sanidad. Estrategia en cardiopatía isquémica del Sistema Nacional de Salud. Madrid, España: 2011. Disponible en http://www.mspsi.es/organizacion/sns/ planCalidadSNS/docs/cardiopatia_isquemica/Estrategia_Cardiopatia_Isquemica.pdf

28. Abdullah MA. Metabolic syndrome and cardiovascular risk. J Family Community Med. 2010; 17(2):73-78. Disponible en https://www.ncbi.nlm.nih.gov/pmc/articles/PMC3045098/ 


\section{Principales problemas de Salud Pública en México}

29. Reaven G. El síndrome metabólico o síndrome de resistencia a la insulina. Los diferentes nombres, diferentes conceptos y diferentes objetivos Endocrinol Metab Clin Norte Am. 2004; 33:283-303

30. Heras M. Servicio de cardiología. Hospital Clínic. IDIBAPS. Barcelona. España Cardiopatía isquémica en la mujer: presentación clínica, pruebas diagnósticas y tratamiento de los síndromes coronarios agudos. Rev Esp Cardiol. 2006; 59(4):371-381.

31. Guyton, AC. Tratado de fisiología médica. $7^{\circ}$ ed. México: Interamericana McGraw Hill; 1990. Cap. 25. p. 294-299

32. Jadraque Martín L. Cardiopatía isquémica. Angina de pecho, infarto de miocardio. Madrid: Norma Editores; 1988. Disponible en: https://books.google.com.mx/ books?isbn=8474870445

33. Kasper D, Fauci A, Hauser S, Longo D, Jameson JL, Loscalzo J. Harrison. Principios de medicina interna. $14^{\circ}$ ed. España: McGraw Hill Interamericana; 1998. Vol. 1.

34. Arias MA. Placa vulnerable: métodos de identificación actual y futuro. Rev Archivos de Cardiología de México. 2006; 76(Supl. 2):229-232

35. Vilariñoa J, Esperb R, Badimón J. Fisiopatología de los síndromes coronarios agudos. Tres paradigmas para un nuevo dogma. Rev Esp Cardiol Supl. 2004; 4(G):13-24.

36. Serrano VX. Valoración preoperatoria del paciente con cardiopatía isquémica. Rev Mexicana de Anestesiología. 2007; 30(Supl. 1):S338-S345.

37. López de la Iglesia J, Rodríguez GA, Fernández CS. Cardiopatía isquémica. AMF. 2011; 7(6):304-315.

38. Secretaría de Salud. Guía de Práctica Clínica. Diagnóstico, Estratificación y Tratamiento de pacientes con síndrome coronario agudo sin elevación ST. México; Secretaría de Salud, 2010.

39. Instituto Mexicano del Seguro Social. Guía de Práctica Clínica. Diagnóstico y Tratamiento de la Cardiopatía Isquémica Crónica. México: IMSS; 2009.

40. Vallejo E. Enfermedad arterial coronaria o cardiopatía isquémica: dos entidades distintas con diferentes procedimientos diagnósticos. Arch Cardiol Méx. 2009; 79(4):279-285.

41. Solorio S, Hernández GM, Rangel AA, Murillo OB. Cardiopatía isquémica en mujeres mexicanas. Archivos de Cardiología en México. 2007; 77(3): 226-231. 


\section{Cardiopatía isquémica}

42. Consejo de Salubridad General. Guía de Práctica Clínica. Detección y estratificación de factores de riesgo cardiovascular. México: CENETEC; 2011.

43. Castellanos C, Pérez de Juan MA, Attie F. Electrocardigrafía. 2a ed. España: Elsevier; 2004.

44. Andrea R, Bellera N, Loma-Osorio P, Heras M. Fundamentos del tratamiento farmacológico actual de la cardiopatía isquémica. Rev Esp Cardiol. 2006; 6(supl A):31A40A.

45. Grupo de trabajo de la Sociedad Europea de Cardiología sobre diagnóstico y tratamiento de la cardiopatía isquémica estable. Guía de Práctica clínica de la ESC 2013 sobre diagnóstico y tratamiento de la cardiopatía isquémica estable. Rev. Esp Cardiol. 2014; 67(2):135.e1-e81

46. Grupo de Trabajo sobre la gestión de la enfermedad arterial coronaria estable de la Sociedad Europea de Cardiología. 2013 ESC guidelines on the management of stable coronary artery disease. European Heart Journal. 2013; 34: 2949-3003.

47. Macin S, Bono J, Ramos H, Rengel E, Suasnabar R, Zapata G, Hasbani E, Cooke R, Muntaner J, Carusso O, Luciardi H. Guías de manejo de cardiopatía isquémica crónica: angina crónica estable. Rev Fed Arg Cardiol. 2009; 38(supl 1): S1-S23.

48. Comité de Cardiopatía Isquémica de la Federación Argentina de Cardiología. Guía de síndromes coronarios agudos. Argentina: Federación Argentina de Cardiología; 2011.

49. Sancho CD, Solano RM. La cardiopatía isquémica en la mujer. Rev Latino-Am. Enfermagem. 2011; 19(5):[09 pantallas]. Disponible en http://www.scielo.br/pdf/rlae/ v19n6/es_25.pdf

50. Cáceres LF, Ramírez HR. Protocolo de tratamiento de la cardiopatía isquémica en la atención primaria de salud. Rev Cubana Farm. 2002; 36(1):69-72.

51. Fernández O, Jiménez J, Bodíc J, Barrabés J. Actualización en cardiopatía isquémica. Revista Española de Cardiología. 2012; 65(supl.1):42-9.DOI:10.1016/j.recesp.2011.10.031 TRATAMIENTO AAS CLOPIDOGREL.

52. Gobierno del Principado de Asturias. Pruebas complementarias en la cardiopatía isquémica. España: Servicio de Salud del Principado de Asturias; 2006.

53. Andrade JP, Pinto FJ, Arnett DK (eds.). Prevention of cardiovascular diseases: from current evidence to clinical practice. EUA: Springer; 2015. 


\section{Principales problemas de Salud Pública en México}

54. FDA Drug Safety Communication: FDA review finds long-term treatment with bloodthinning medicine Plavix (clopidogrel) does not change risk of deathhttp. Comunicado emitido el 16 de noviembre de 2014. Disponible en ://www.fda.gov/Drugs/DrugSafety/ ucm471286.htm

55. Antman EM, Anbe DT, Armstrong PW, et al. ACC/AHA guidelines for the management of patients with ST-elevation myocardial infarction: a report of the American College of Cardiology/American Heart Association task force on practice guidelines (Committee to Revise the 1999 Guidelines for the management of patients with acute myocardial infarction). Circulation. 2004; 110:588-636.

56. Ramos Nascimento B, Roberto de Sousa R, Nogueira Demarqui F, Luiz Pinho R. Risks and benefits of thrombolytic, antiplatelet, and anticoagulant therapies for st segment elevation myocardial infarction: systematic review. Hindawi Publishing Corporation ISRN. Cardiology. 2014, Article ID 416253, 11 pages. http://dx.doi. org $/ 10.1155 / 2014 / 416253$

57. López Mora E. Beneficios del entrenamiento físico en sujetos con cardiopatía isquémica. Arch Cardiol Mex. 2013; 83(3):174-175.

58. Kim C, Kim DY, Lee DW. The impact of early regular cardiac rehabilitation program on myocardial function after acute myocardial infarction. Ann Rehabil Med. 2011 Aug; 35(4):535-540. http://dx.doi.org/10.5535/arm.2011.35.4.535 


\title{
11. Hipertensión arterial sistémica
}

\author{
M.C. Dolores Patricia Delgado Jacobo \\ M.C. Yolanda Orozco Pérez \\ Pasante en Servicio Social: \\ Paola Ozcebely Mata Rodríguez
}

Alumna:

Marisol Eranderi Rocha Salinas

\section{Introducción}

La Hipertensión Arterial Sistémica (HAS) conocida como el "enemigo silencioso"1 por su curso clínico silencioso, actualmente es uno de los grandes problemas de Salud Pública a nivel mundial. La falta de diagnóstico y tratamiento oportuno sigue siendo una de las principales limitantes para disminuir su prevalencia. La Organización Mundial de la Salud (OMS) reporta que 140 millones de personas padecen de esta enfermedad ${ }^{2}$.

En todo el mundo en el año 2013, las enfermedades no transmisibles fueron la causa de muerte de más de 36 millones de personas, las que por orden de importancia de acuerdo a su tasa de mortalidad, se encuentran: en el primer lugar las enfermedades cardiovasculares, con cifras que ascienden a los 17.3 millones, seguidas por el cáncer con 7.6 millones, después por las enfermedades respiratorias crónicas con registro de 4.2 millones y en cuarto lugar por la diabetes mellitus con 1.3 millones $^{3}$.

Estas enfermedades crónicas se dan más en países de ingresos bajos y medios, siendo probablemente resultado de la falta de educación y apego al tratamiento de los pacientes o bien, a la falta de recursos del Sector Salud para su tratamiento. Es importante destacar que las enfermedades no transmisibles comparten cuatro factores de riesgo: consumo de tabaco, alcohol, sedentarismo y hábitos dietéticos inadecuados. Dichos factores deben ser considerados como el objetivo primario en programas de prevención y promoción a la salud. 
Si se analizan estadísticas de mortalidad, emitidas por el Sistema de Vigilancia Epidemiológica de las Enfermedades Crónicas no Transmisibles (SVEECNT), entre los años de 1995, 2000 y 2012 se pueden verificar datos alarmantes, ya que para el año 1995 la primera causa de muerte en nuestro país estaba representada por diarrea y enteritis, ocupando las enfermedades del corazón el décimo sitio; en el año 2000 las enfermedades del corazón se encuentran en la cuarta causa de mortalidad, siendo los accidentes la principal causa; diabetes mellitus (DM) en la novena causa; y finalmente en el año 2012 se reporta como primera causa de muerte, a las enfermedades del corazón seguido de la DM y de los tumores malignos.

Este impacto en la salud, obliga a mejorar la promoción de la salud, para elevar el nivel de la educación en la población a fin de concientizar la prevención, la búsqueda oportuna del diagnóstico y llevar adecuadamente las recomendaciones hechas por el médico tratante.

\section{Concepto}

La HAS (HAS) es un padecimiento multifactorial caracterizado por aumento sostenido de la presión arterial sistólica, diastólica o ambas, la OMS la define como una presión sistólica superior a $160 \mathrm{~mm} \mathrm{Hg}$, una presión diastólica superior a 90 mm Hg o ambas situaciones, pero también una Presión Arterial Sistólica (PAS) mayor o igual a $140 \mathrm{~mm} \mathrm{Hg}$ o una Presión Arterial Diastólica (PAD) mayor o igual a $90 \mathrm{~mm} \mathrm{Hg}$ en adultos, en por lo menos tres visitas consecutivas al consultorio médico, sin embargo hay que considerar que en ausencia de enfermedad cardiovascular renal o DM se considera $\geq 140 / 90 \mathrm{~mm} \mathrm{Hg}$, en caso de presentar enfermedad cardiovascular o diabetes $\geq 130 / 80 \mathrm{~mm} \mathrm{Hg}$ y en caso de tener proteinuria mayor de $1.0 \mathrm{~g}$ e insuficiencia renal $\geq 125 / 75 \mathrm{~mm} \mathrm{Hg} 5,5,7,8$

La HAS en pediatría se define siguiendo las tablas de percentiles elaboradas especialmente para ello, siendo una presión arterial normal cuando la presión arterial, según sexo, edad y peso está por debajo del percentil 90, presión alta normal cuando está encima del percentil 90, pero debajo del percentil 95, en 3 ocasiones o más9.

\section{Clasificación}

La HAS se clasifica en dos:

1) Primaria, esencial o idiopática cuando la presión arterial se mantiene constantemente mayor de lo normal sin causa subyacente, y representa de 85 al 90\%de total de casos. 


\section{Hipertensión arterial sistémica}

2) Secundaria, cuando la presión arterial es elevada como resultado de una causa subyacente identificable, frecuentemente corregible; que ocurre en un 10 a $15 \%$ de los pacientes hipertensos ${ }^{9,10}$.

La HAS se clasifica por cifras, de acuerdo a los siguientes criterios según la NOM-030SSA2-20095 (Cuadro 1):

Cuadro 1. Clasificación de HAS de acuerdo a la NOM.

\begin{tabular}{|l|c|c|}
\hline \multicolumn{1}{|c|}{ Categoría } & Sistólica $\mathbf{~ m m ~ H g}$ & Diastólica $\mathbf{~ m m ~} \mathbf{~ H g}$ \\
\hline Óptima & $<120$ & $<80$ \\
\hline Presión arterial normal & 120 a 129 & 80 a 84 \\
\hline Presión arterial fronteriza* & 130 a 139 & 85 a 89 \\
\hline Hipertensión 1 & 140 a 159 & 90 a 99 \\
\hline Hipertensión 2 & 160 a 179 & 100 a 109 \\
\hline Hipertensión 3 & $>180$ & $>110$ \\
\hline Hipertensión sistólica aislada & $>140$ & $<90$ \\
\hline
\end{tabular}

De acuerdo al el Séptimo Informe de la Junta Nacional del Comité (por sus siglas en inglés JNC7), para la prevención, detección, evaluación y tratamiento de la HAS, la clasifica de la siguiente manera ${ }^{8}$ (Cuadro 2):

Cuadro 2. Clasificación según la JNC7.

\begin{tabular}{|l|c|c|}
\hline Clasificación de presión arterial & Presión sistólica & Presión diastólica \\
\hline Normal & $<120$ & $\mathrm{Y}<80$ \\
\hline Prehipertensión & $120-139$ & $80-89$ \\
\hline Hipertensión etapa 1 & $140-159$ & $\mathrm{O} 90-99$ \\
\hline Hipertensión etapa 2 & $>160$ & $\mathrm{O}>100$ \\
\hline
\end{tabular}

\section{Epidemiología}

A nivel mundial las enfermedades no transmisibles son causa del $63 \%$ de las 57 millones de muertes de las cuales, 36 millones, son atribuidas a enfermedades cardiovasculares, 


\section{Principales problemas de Salud Pública en México}

diabetes, cáncer y enfermedades respiratorias crónicas. En 2010 la OMS reporta que más de 9 millones de muertes por estas causas ocurren antes de los 60 años de edad siendo posible su prevención. Causan la muerte prematura en países de bajos ingresos al $22 \%$ en hombres y $35 \%$ en mujeres mientras que para países con ingresos altos, las cifras consideradas son $8 \%$ para hombres y 10\% para mujeres. En México, el 78\% de las muertes en 2011 fueron atribuibles a estas enfermedades, $26 \%$ de ellas fueron causadas por enfermedades cardiovasculares ${ }^{3}$.

La HAS es considerada como uno de los más importantes factores de riesgo cardiovascular y de enfermedad renal, constituyéndose en un serio problema de Salud Pública. Uno de los grandes retos para abatir su influencia negativa, es la del diagnóstico y tratamiento precoz; ya que si no se efectúan de manera temprana, trae como consecuencia que la evolución de la historia natural de la enfermedad incluya complicaciones al paciente, el que requerirá de mayor atención y participación de todos los sectores de la sociedad a fin de aliviar su situación de vida.

La re-encuesta Nacional de HAS en 2005 estimó que 16 millones de mexicanos entre los 20 y 69 años en el año 2000 padecían de HAS ${ }^{11}$. En el año 2006, se estimó que el 47.8\% de los adultos con HAS no había sido diagnosticados como tal y solo el 39.0\% de los que habían sido diagnosticados recibía tratamiento. Según datos de la ENSANUT 2012, del 100\% de adultos hipertensos, el $47.3 \%$ desconocían que padecía HAS, lo que explica la tendencia ascendente de las tasas de crisis hipertensivas, eventos cerebrales y otras complicaciones, sobre todo cuando se compara la información de México con otros países 2,12,13.

La tasa de mortalidad por HAS en la población de 15 años o más, se incrementó de 17.67 por cada 100 mil personas a 23.06 entre los años de 2006 al 2011. Durante 2011 de cada 100 hombres que padecían hipertensión, 10 fallecieron antes de los 50 años, 10 más antes de los 60, registrándose 7 casos en la población de entre 60 y 64 años, y 40 entre los adultos mayores de 80 años. En las mujeres de cada 100 muertes por hipertensión una murió antes de los 30 años, tres entre los 40 y 49 años, 8 entre el grupo de 50 a 59 años y siendo un $50 \%$ la tasa de mortalidad en mujeres mayores de 80 años $^{14}$.

Comparando los datos de tensión arterial de la Encuestas Nacional de Salud del año 2000 (ENSA 2000), la Encuesta Nacional de Salud y Nutrición 2006 (ENSANUT 2006), y la Encuesta Nacional de Salud y Nutrición 2012 (ENSANUT 2012). La tendencia entre los 


\section{Hipertensión arterial sistémica}

años 2000, 2006 y 2012 sugiere una estabilización en los casos de HAS ${ }^{15}$. La tendencia de la HAS en los últimos seis años (2006-2012) se ha mantenido estable tanto en hombres (32.4 vs $32.3 \%$ ) como en mujeres (31.1 vs. $30.7 \%$ ) (ver Gráfica 1$)^{12}$. No obstante, la HAS afecta a $31.5 \%$ de los adultos mexicanos y se encuentra entre las más altas a nivel mundial ${ }^{15}$.

Gráfica 1. Tendencia de la hipertensión en México, 2000-2012*.

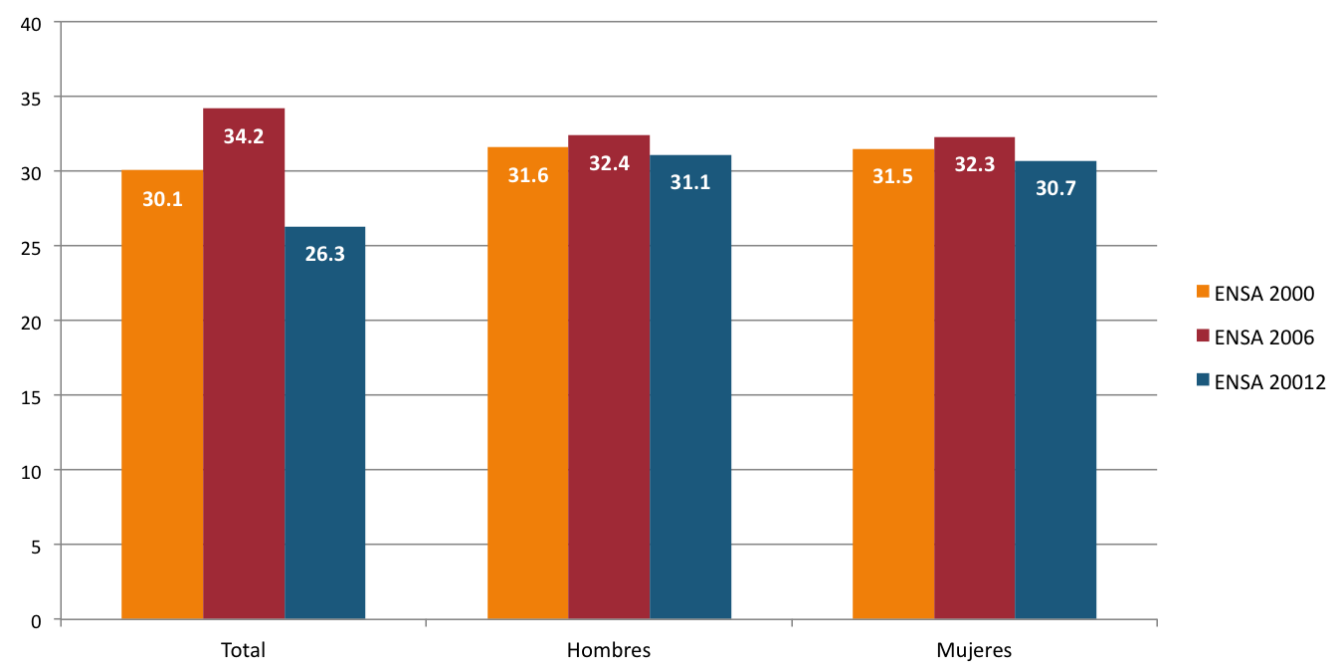

${ }^{*}$ Tendencias de las prevalencias de HAS en adultos mayores de 20 años.

Retomado de: Encuesta Nacional de Salud 2000 y la Encuesta Nacional de Salud y Nutrición 2006 y $2012^{12}$.

En los países de ingresos bajos y medios, los adultos mayores son especialmente vulnerables a las enfermedades crónicas no transmisibles (ECNT). En dichos países, las personas tienden a desarrollar enfermedades a edades más tempranas y sufrirlas por periodos más largos, a menudo con complicaciones prevenibles y con un incremento de la mortalidad prematura, respecto a la de los países de altos ingresos. Dentro de las ECNT, se calcula que las enfermedades cardiovasculares reducen en siete años la expectativa de vida. Aproximadamente entre 1.5 a 5\% de todos los hipertensos mueren cada año por causas directamente relacionadas a HAS sistémica ${ }^{16}$. Además es el segundo motivo de consulta en el primer nivel de atención ${ }^{17}$.

El impacto económico es importante, se estiman 50 mil millones de dólares anuales para el tratamiento antihipertensivo, de los cuales más del 90\% se gastan en países de altos 


\section{Principales problemas de Salud Pública en México}

ingresos y solo el 10-5 en países de bajos ingresos, aun cuando se conoce que la prevalencia es 5 veces mayor en países de medianos y bajos ingresos ${ }^{9,18}$.

Aun cuando se cuenta con medicamentos de última línea en el tratamiento, se considera que no se logran las metas en el tratamiento teniendo un escaso control sobre la evolución de la enfermedad, siendo la falta de cambios en el estilo de vida la principal limitante. Se estima que solo se alcanzan las metas del tratamiento en menos de la mitad de los pacientes, aun cuando el $73.6 \%$ del total que de ellos reciben tratamiento, incluso son tratados con tres tipos de medicamentos, causando grandes pérdidas económicas para el sector salud ${ }^{19,12}$.

En 2005, el 54.7\% de la población había acudido al servicio de urgencias al menor una vez

durante el seguimiento de la enfermedad ${ }^{13}$, lo que refleja que la falta de cumplimiento de las metas establecidas siguen siendo la causa de complicaciones incapacitantes para el paciente.

Cuando la presión arterial media está por encima del 50\% o más de lo recomendado, se estima que la expectativa de vida se disminuye en 30 a 40\% a menos que la hipertensión sea tratada adecuadamente. En Latinoamérica el 5.1\% de los años ajustados por discapacidad pueden ser atribuidos a la hipertensión?

\section{Causalidad}

Se trata de un padecimiento multifactorial en el que la interacción de factores ambientales y del huésped, alteran la homeóstasis del organismo provocando una vasoconstricción, resultante de un aumento de las resistencias vasculares, con aumento en la actividad del sistema renal que induce la liberación de diferentes hormonas reguladoras. Esta activación y la liberación hormonal desencadenan diferentes procesos que alteran el funcionamiento cardiovascular y la elevación de la presión arterial de manera crónica ${ }^{1}$.

Los factores de riesgo, que favorecen la HAS Sistémica, se presentan en los párrafos siguientes:

a) Edad: En México en el año 2005 es estableció la máxima incidencia en la población entre los 20 y 54 años de edad, así el 75\% de los hipertensos tenían menos de 54 años ${ }^{13}$. 


\section{Hipertensión arterial sistémica}

b) Sexo: La prevalencia de HAS se estima en un 33.3 en hombres y 30.8 en mujeres de cada 100 personas para el grupo de edad de 20 años o más ${ }^{14}$.

c) Genética: se considera un factor de riesgo importante, se estima que el $30 \%$ de las variaciones de la presión arterial tienen un componente genético, de esta manera una persona antes de los 55 años, la elevación de la presión arterial será de 3.8 veces más frecuente entre individuos con historia familiar, frente los individuos que no la tienen ${ }^{1}$.

d) Tabaquismo: Al consumir un cigarrillo se aumenta la presión arterial en la siguiente media hora, y mientras se continúe la exposición la presión seguirá aumentando progresivamente. Se estima que a nivel mundial el consumo es alto en países con nivel de ingreso medio y menor en países con alto o bajos ingresos, siendo más frecuente el consumo de tabaco en hombres si se compara con las mujeres ${ }^{3,10}$.

e) Influencia psicosocial: La exposición crónica a ambientes de alto estrés y tensión como la presión laboral, proceso de cambio cultural y cambios en el estilo de vida, entre otros, provocan niveles de estrés crónico que pueden generar estados hipertensivos patológicos ${ }^{20}$.

f) Condiciones socio-económicas: Factor de riesgo importante a considerar en especial en países de bajos recursos, donde la inversión económica para el tratamiento es baja ${ }^{9}$.

g) Consumo de alcohol: El consumo crónico se ha relacionado con cifras de presión arterial alta además, los pacientes con HAS tienen riesgo de sufrir complicaciones como hemorragias subaracnoideas e intracraneales ${ }^{13}$.

h) Diabetes: La prevalencia de HAS en la población diabética es 1.5 a 3 veces mayor que en los no diabéticos, la prevalencia en diabetes mellitus tipo 2 (DM2) es cercana al 30\% y en DM2 la prevalencia de HAS es aproximadamente del $60 \% 9$.

También es importante mencionar, que existen factores protectores, que permiten evitar ésta enfermedad, entre los que se incluyen los siguientes:

- Control de peso: Se ha estimado que el control de la obesidad puede eliminar el $48 \%$ de la HAS en individuos bancos ${ }^{3}$. Se debe mantener el objetivo de un IMC debajo de $25 \mathrm{mg} / \mathrm{m}^{2}$. 


\section{Principales problemas de Salud Pública en México}

- Disminución del consumo de sal: Se recomienda el consumo por debajo de 6 g de $\mathrm{NaCl} /$ día.

- Mejorar hábitos dietéticos: Se recomienda adoptar el plan con enfoque dietético para detener la hipertensión (DASH, por sus siglas en inglés Dietary Approaches to Stop Hypertension) caracterizado por una dieta con abundantes frutas, verduras y productos lácteos con poca grasa y reducir el consumo de grasas saturadas y totales.

- Limitar el consumo de alcohol: Se recomienda un consumo de menos de 2 copas al día en varones y menos de una copa al día en mujeres.

- Actividad física: Se recomienda realizar actividad aeróbica regular, como la marcha acelerada y constante durante 30 minutos/día, como se muestra en el siguiente Cuadro ${ }^{21}$.

Sin embargo es necesario mencionar que existen factores que determinan los niveles de presión arterial, entre ellos se encuentran (Cuadro 3):

Cuadro 3. Factores relacionados con el nivel de presión arterial.

\begin{tabular}{|l|c|c|c|}
\hline \multirow{2}{*}{ Factor } & \multicolumn{3}{c|}{ Porcentaje según nivel de presión arterial } \\
\cline { 2 - 4 } & Óptimo & Prehipertensión & Hipertensión $^{\mathbf{2}}$ \\
\hline IMC $<20 \mathrm{Kg} / \mathrm{m} 2$ & 90.0 & 8.7 & 1.3 \\
\hline IMC $20-24 \mathrm{Kg} / \mathrm{m} 2$ & 64.2 & 34.6 & 1.2 \\
\hline IMC $25-29 \mathrm{Kg} / \mathrm{m} 2$ & 37.2 & 58.3 & 4.5 \\
\hline IMC $<30 \mathrm{Kg} / \mathrm{m} 2$ & 10.3 & 58.6 & 31.1 \\
\hline Cintura $<90 \mathrm{~cm}$ & 71.1 & 28.0 & 0.9 \\
\hline Cintura $>90 \mathrm{~cm}$ & 29.0 & 58.0 & 13 \\
\hline $\begin{array}{l}\text { Sin antecedentes de diabetes } \\
\text { en la familia }\end{array}$ & 60.6 & 35.5 & 3.9 \\
\hline $\begin{array}{l}\text { Antecedentes de diabetes en } \\
\text { la familia }\end{array}$ & 61.7 & 34.7 & 3.6 \\
\hline $\begin{array}{l}\text { Sin antecedentes de HAS en } \\
\text { la familia }\end{array}$ & 61.1 & 36.8 & 2.1 \\
\hline
\end{tabular}




\section{Hipertensión arterial sistémica}

Cuadro 3. Factores relacionados con el nivel de presión arterial.

\begin{tabular}{|c|c|c|c|}
\hline \multirow{2}{*}{ Factor } & \multicolumn{3}{|c|}{ Porcentaje según nivel de presión arterial ${ }^{8}$} \\
\hline & Óptimo & Prehipertensión & Hipertensión \\
\hline $\begin{array}{l}\text { Antecedentes de HAS en la } \\
\text { familia }\end{array}$ & 61.4 & 33.9 & 4.7 \\
\hline Tabaquismo negativo & 61.0 & 35.1 & 3.9 \\
\hline Tabaquismo positivo & 68.8 & 31.2 & --- \\
\hline No ingesta de alcohol & 62.5 & 33.6 & 3.9 \\
\hline Ingesta de alcohol & 57.6 & 39.4 & 3.0 \\
\hline
\end{tabular}

La HAS afecta a 3 de cada 10 adultos mexicanos de las distintas regiones, localidades y nivel socio económico ${ }^{12}$. La edad eleva la prevalencia, y en México, hay un $10-20 \%$ de afectación a los 20 años y $60 \%$ en los de cincuenta años ${ }^{23}$.

\section{Fisiopatología}

La presión sistólica por lo general aumenta durante toda la vida y la diastólica se incrementa hasta los 50 o 60 años de edad, sin embargo, después de un tiempo se reduce, de modo que la presión del pulso sigue aumentando 7 .

La presión arterial es el producto del gasto cardiaco y la resistencia vascular sistémica al flujo sanguíneo. La hipótesis más aceptada sobre el desarrollo de la HAS primaria, sostiene que la hipertensión deriva de un desequilibrio de las interacciones de estos mecanismos, los cuales dependen en parte de la función renal y la homeostasis del sodio.

Sensibilidad a la sal: activa a través de dos vías que dan pie a la contracción del músculo liso vascular:

1) Estimula a las proteínas $G^{12-13}$ que se encarga de la activación de la miosina cinasa de cadena ligera, la cual fosforila a la miosina para iniciar la contracción.

2) Estimula la vía de la Rho/Rho cinasa, que inhibe la fosfatasa de cadena ligera de miosina para prevenir la relajación del músculo liso. 


\section{Principales problemas de Salud Pública en México}

Respecto a la HAS secundaria se dice que la incidencia de hipertensión se incrementa al tiempo que cae la tasa de filtración glomerular (TFG) y cuando existe disfunción renal leve. De esta manera la disminución de la TFG en la disfunción renal desencadena retención de sodio y la expansión del volumen, los cuales se compensan con la disminución de la reabsorción tubular de sodio. Ejemplo de ello lo tenemos en la nefropatía crónica secundaria a diabetes y edad avanzada.

Sin embargo, otras causas de HAS secundaria son:

1) Coartación de la aorta: Es una malformación congénita que ocurre en la parte distal del origen de la arteria subclavia izquierda.

2) Otra condición frecuente para la alteración de la tensión arterial proviene de las anormalidades renales que se caracterizan por:

- El estrechamiento de la arteria renal, el cual se debe a Glomerulonefritis aguda y crónica y otras enfermedades renales difusas.

- Síndrome de Liddle.

3) Anormalidades del sistema renina-angiotensina:

- Menor transporte de cloruro de sodio en la rama ascendente del asa de Henle (mecanismo de la mácula densa).

- Disminución de la presión o el estiramiento dentro de la arteria aferente renal (mecanismo barorreceptor).

- Estimulación por parte del sistema nervioso simpático, de las células reninógenas a través de los adrenorreceptores.

4) Trastornos de las glándulas suprarrenales:

- Exceso de mineralocorticoides: causado por el síndrome de Conn o hiperaldosteronismo primario. 


\section{Hipertensión arterial sistémica}

- Exceso de glucocorticoides: los glucocorticoides estimulan la secreción de angiotensinógeno por el hígado, por tanto incrementa a angiotensina II circulante.

5) Secreción excesiva de catecolaminas: Noradrenalina, adrenalina y dopamina ${ }^{21}$. El aumento de la secreción de adrenalina y noradrenalina por la médula suprarrenal incrementa las presiones sistólica y diastólica?

6) Afección del volumen intravascular: El sodio predominantemente es un ion extracelular y es el elemento primario que rige el volumen de líquido extracelular ${ }^{21}$.

\section{Cuadro clínico}

La HAS es un padecimiento en general asintomático, por lo que la falta de clínica es una de las principales causas que retrasan el diagnóstico y tratamiento. Síntomas como cefalea, dificultad respiratoria, mareo, dolor torácico, palpitaciones, epistaxis y cansancio entre otras, pueden orientar el diagnóstico aunque no puedan interpretarse en general como indicativos de hipertensión ${ }^{18}$.

\section{Complicaciones}

El aumento sostenido de la presión arterial, las alteraciones a los vasos sanguíneos sistémicos y al corazón propias de la fisiopatología de la hipertensión puede traer diferentes complicaciones. El incremento de las fuerzas de desgarro vascular convierte al endotelio, que normalmente tiene un efecto anticoagulante, a un estado protrombótico, por lo que un paciente hipertenso con cifras mal controladas suele presentar eventos trombóticos en lugar de hemorrágicos. El riesgo de estas complicaciones se duplica por cada $6 \mathrm{~mm} \mathrm{Hg}$ de incremento de la presión arterial diastólica.

Las principales causas de morbilidad y mortalidad del paciente con HAS esencial son las cardiovasculares, por lo que es importante dirigir el tratamiento para su prevención. Cambios estructurales, como la hipertrofia del ventrículo izquierdo se pueden encontrar hasta en un $15 \%$ de la población hipertensas, este crecimiento de cavidades facilitan la presencia de otras complicaciones incluyendo, insuficiencia cardiaca congestiva, arritmias ventriculares, isquemia miocárdica y muerte súbita. 


\section{Principales problemas de Salud Pública en México}

Paciente con hipertensión de larga evolución es frecuente que presenten disfunción diastólica del ventrículo izquierdo cuya sintomatología suele iniciar junto a los síntomas de una insuficiencia cardiaca congestiva, cuya aparición de esta se reduce hasta en un $50 \%$ con tratamiento antihipertensivo adecuado. Se recomienda el uso de diuréticos, ya que han demostrado disminución de la masa del ventrículo izquierdo igual e incluso mayor que con otros antihipertensivos.

La principal causa de apoplejía hemorrágica e isquémica es la hipertensión. Las complicaciones cerebrovasculares se relacionan más con los niveles altos de presión arterial sistólica que con niveles de presión diastólica. La incidencia de estas complicaciones se reduce considerablemente el tratamiento antihipertensivo. Se ha relacionado la presencia de HAS como un riesgo subsecuente del desarrollo de demencia de tipo vascular y Alzheimer.

El mantener presiones arteriales altas de manera crónica conduce a la aparición de nefroesclerosis, causa común de insuficiencia renal. El control de la cifras tensionales reduce esta complicaciones, teniendo como objetivos en un paciente con nefropatía hipertensiva niveles de presión arterial menores a 130/80 mm $\mathrm{Hg}$ e incluso menor si existe proteinuria. El tratamiento antihipertensivo recomendado para su prevención son los inhibidores de la enzima convertidora de angiotensina (IECA).

La prevención de estas complicaciones y otras como la disección de la aorta y las complicaciones por ateroesclerosis acompañante de la hipertensión, debe ser el principal objetivo del tratamiento antihipertensivo a fin de evitar su aparición en el paciente hipertenso ${ }^{24}$.

\section{Diagnóstico}

El diagnóstico de HAS debe incluir la identificación de la HAS secundaria, valorar la presencia de daño cardiovascular asociado o producido por la propia HAS, identificar los factores de riesgo cardiovascular de cada paciente y clasificarlo en el grupo correspondiente ${ }^{25}$.

En el paciente que se sospeche HAS en el examen de detección deberá ser confirmada; el diagnóstico se basa en el promedio de por lo menos tres mediciones realizadas en intervalos de tres a cinco minutos dos semanas después de la detección inicial, con cifras 


\section{Hipertensión arterial sistémica}

igual o superior a las consideradas en la definición de HAS Sistémica. Cuando la presión arterial sistólica y diastólica se ubican en diferentes etapas de HAS, se utilizará el valor más alto para clasificarlo ${ }^{26}$.

La anamnesis debe estar dirigida en la búsqueda de antecedentes heredofamiliares en busca de posibles causas de hipertensión secundaria, antecedente de muerte por EVC en familiar varón antes de los 65 años y femenino antes de los 55 años de edad, entre otras patologías como DM, dislipidemia. Los antecedentes personales deberán incluir hábitos de alimentación, actividad física, enfermedades crónicas, así como si conocía el diagnóstico de HAS, tratamiento previo, eficacia y tolerabilidad de estos.

La exploración física deberá incluir medidas antropométricas como la estatura, peso corporal, índice de masa corporal y circunferencia abdominal. Se deberá realizar una exploración sistematizada en busca de signos que orienten el origen de una hipertensión secundaria, la exploración cardiovascular se hará con el propósito de detectar posibles soplos, arritmias, desplazamiento del choque de punta, presencia de tercer o cuarto ruido, así como la auscultación de territorios carotideos para orientar una posible estenosis así como la palpación de pulsos periféricos. La medición de la PA mediante Doppler ayudará a estimar el índice tobillo/brazo cuando este sea menor a 0.9 nos indicará que el paciente tiene una artropatía periférica ${ }^{13,26}$.

Es importante realizar exámenes de laboratorio con el objetivo de identificar otros factores de riesgo, evaluar daños a órganos blancos, e identificar probables causas secundarias de HAS, por lo que se deberá realizar de manera indispensable en la primera visita hemoglobina y hematocrito para descartar poliglobulia o anemia secundaria a una insuficiencia renal, glicemia en ayunas, urea, creatinina, ácido úrico, perfil de lípidos, potasio y electrólitos, examen general de orina, la tasa de filtrado glomerular, además de un electrocardiograma buscando trastornos del ritmo, alteraciones de la repolarización y si hay o no hipertrofia de ventrículo izquierdo. Estudios Opcionales ecocardiograma de acuerdo a disponibilidad, pruebas de funcionalidad hepática, T3, T4 y TSH, microalbuminuria y monitoreo ambulatorio de la presión arterial91,10,26.

Se recomienda realizar radiografía PA de tórax, ultrasonido carotideo, ecografía y Doppler vascular, cardiaco y renal para evaluar el tamaño del ventrículo izquierdo e identificar ateromatosis succínica en diferentes territorios vasculares, estenosis de 


\section{Principales problemas de Salud Pública en México}

arterias renales o alteraciones renales. La medición de la velocidad de la onda de pulso es útil para evaluar la rigidez de arterias grandes. Los estudios cerebro, corazón o riñones se realizarán en pacientes que lo requieran, como en hipertensión complicada o secundaria ${ }^{9,26}$.

El objetivo de las detecciones o tamizaje en población general, es identificar a individuos de 25 años en adelante que esté en riesgo de presentar presión fronteriza o HAS. Esta medición se llevará a cabo cada tres años a la población de adultos que acuden a las instituciones e salud, tanto pública como privada. Así como en forma de campaña entre la población en general en el ámbito comunitario y en el sitio de trabajo. El valor de la presión arterial sistólica y diastólica que se registre corresponderá al promedio, de por lo menos dos mediciones hechas con un intervalo mínimo dos minutos. A los pacientes con presión arterial óptima o con presión normal y sin factores de riesgo se les recomendará adoptar estilos de vida saludables para la prevención del desarrollo de HAS. Individuos con presión arterial normal, con factores de riesgo o fronteriza, se les recomendará seguir un tratamiento conductual adecuado, a fin de reducir los niveles de presión arterial. Si en el momento de la detección se muestra una presión arterial mayor o igual a $140 \mathrm{~mm} \mathrm{Hg} \mathrm{y/o}$ mayor a $90 \mathrm{~mm} \mathrm{Hg}$ deberán recibir confirmación diagnóstica. El tamizaje para mayor de 65 años será dos veces al año ${ }^{26}$.

\section{Terapéutica}

El plan de manejo debe incluir el establecimiento de metas, tratamiento conductual, tratamiento farmacológico, la educación del paciente y la vigilancia de complicaciones.

La meta principal es lograr una PA menor a 140/90 mm $\mathrm{Hg}$, en pacientes que cuentan con comorbilidades como diabetes o enfermedad cardiovascular establecida, la meta será mantener una PA menor de 130/80 mm Hg; en presencia de proteinuria mayor de 1.0 gr., e insuficiencia renal, el objetivo será mantenerla menos a 125/75 mm Hg Entre otras metas se encuentra el mantener un IMC menor de 25, niveles de colesterol menor a $200 \mathrm{mg} / \mathrm{Dl}$, evitar o suspender el consumo de tabaco y alcohol.

A todos los pacientes se les ofrecerá iniciar un tratamiento conductual es decir, mantener el control de peso, realizar actividad física, restringir el consumo de sal y alcohol, consumir suficiente potasio, así como una adecuada alimentación ${ }^{26}$. 


\section{Hipertensión arterial sistémica}

La terapéutica farmacológica incluye el tratamiento antihipertensivo, el cual se debe iniciar antes de que se produzca daño cardiovascular significativo siendo así, el inicio inmediato en hipertensión grado 3 así como en grado 1 y 2 cuando el riego CV total es alto o muy alto. El riesgo depende de la combinación de las cifras de presión arterial, de su evolución, de la asociación con otros factores de riesgo, con la presencia de daño orgánico subclínico o establecido y la presencia de DM. El tratamiento depende del riesgo de cada paciente, de esta manera el tratamiento farmacológico debe ser individualizado, bajo la valoración directa del médico tratante.

Es importante prescribir el antihipertensivo que por sus efectos además de reducir la presión arterial, beneficie a cada paciente en particular. Se deben utilizar la dosis de los diferentes fármacos que logren el efecto óptimo, sin o mínimos efectos adversos, de manera que si no se logra la meta, pero si hay respuesta, se debe combinar con otro fármaco. Si no hay respuesta con determinado fármaco o no es bien tolerado se deberá cambiar a otro grupo farmacológico. Si con dos medicamentos no se logra el control se deberá agregar un tercer fármaco, considerando inicialmente el uso de un diurético a dosis bajas. Se debe esperar un mínimo de cuatro semanas para evaluar la respuesta terapéutica antes de modificar el tratamiento, hay que considerar siempre el tratamiento combinado, en cualquier tipo de hipertensión, preferentemente en una sola tableta, esperando lo más pronto posible el efecto antihipertensivo y favorecer de esta manera su adherencia.

Si se logra un adecuado control durante un año, el médico podrá evaluar la conveniencia de reducir paulatinamente la dosis, e incluso suspender el medicamento, si es que le tratamiento conductual es suficiente para tratar la hipertensión se deberá mantener en continua vigilancia estrecha debido al riesgo de que se vuelva a elevar la PA por arriba de niveles normales ${ }^{9,26,27}$.

Los fármacos recomendados para iniciar el tratamiento son los diuréticos, los calcio antagonistas, los inhibidores de enzima convertidora de angiotensina (IECA) y los antagonistas de los receptores de la angiotensina II (ARA-II), que también se les conoce como bloqueadores del receptor de la angiotensina (BRA).

- Diuréticos: Aumentan la excreción de sodio por lo que se disminuye la respuesta vasoconstrictora. Se dividen en cuatro subgrupo dependiendo del lugar donde actúen en el sistema tubulocolector: tiazidas, diuréticos de asa, ahorradores de potasio y la 


\section{Principales problemas de Salud Pública en México}

indapamida. En dosis pequeñas se utilizan como tratamiento de primera línea, en monoterapia o combinados con otros antihipertensivos. Generan efectos hipotensores si se combinan con bloqueadores beta, inhibidores de la enzima convertidora de angiotensina o antagonistas del receptor de angiotensina.

- Betabloqueadores beta: Disminuyen a PA por disminuir la frecuencia cardiaca y la fuerza de contracción miocárdica, por lo que disminuyen el consumo de oxígeno. Se consideran útiles en el manejo del hipertenso asociado a la angina de pecho. Otro de los mecanismos para disminuir la presión arterial está basado en la influencia sobre el sistema nervioso central y la inhibición de la libración de la renina.

- Antagonistas del calcio: Evitan principalmente la reentrada de calcio a las células, se diferencian en relación a su mayor acción y los de mayor efecto a nivel vascular periférico. Cualquier tipo ha demostrado su utilidad en el control de la hipertensión sistólica aislada, su neutralidad en diabetes y dislipidemia y el retraso o regresión de la ateroesclerosis carotidea y coronaria.

- Inhibidores de la enzima convertidora de angiotensina: Entre sus diferentes mecanismos destaca el bloqueo de la enzima dipeptidilcarboxipeptidasa que evita la transformación de la angiotensina II y la degradación de la bradicinina que tiene un efecto vasodilatador. Dentro de sus efectos beneficiosos se encuentra el reducir la hipertrofia ventricular izquierda y las complicaciones cardiovasculares del hipertenso. Evitan la remodelación del miocardio pos infartado, ofrecen nefroprotección al reducir la hiperfiltración renal y la progresión de la microalbuminuria y proteinuria, que mejoran la sensibilidad de la insulina por lo que son de elección en el paciente pre diabético o diabético.

- Antagonistas de los receptores AT1 de la angiotensina II: Bloquean los efectos de la Angiotensina III en el receptor AT1, favoreciendo con ello la vasodilatación, la disminución de la hipertrofia ventricular izquierda y del músculo liso vascular, así como protección endotelial. Retienen potasio, por lo que se debe tener precaución en el uso concomitante de ahorradores de potasio en estados de hiperkalemia ${ }^{21,27}$.

Existe terapéutica no farmacológica, en donde se recomienda que el manejo de la HAS sea multifactorial siendo las medidas higiénicas dietéticas de gran importancia. De esta manera 


\section{Hipertensión arterial sistémica}

las recomendaciones citadas por el Colegio Americano de Medicina del Deporte (ACSM por las siglas en inglés American College of Sport Medicine) en el año 2010, están dirigidas a cambios en la alimentación, mejorar la actividad física con el propósito de disminuir el peso corporal que en conjunto con fármacos controlados por personal capacitado sean el tratamiento de elección para pacientes hipertensos. Con estas intervenciones y una reducción de $3 \mathrm{~mm} \mathrm{Hg}$, en la presión sistólica se relaciona con una reducción de 5-9 \% en la morbilidad del paciente por causas cardiacas, una reducción del 8-14\% en la morbilidad por accidentes cerebro vasculares y el $4 \%$ en la mortalidad por todas las causas ${ }^{19,28}$.

La falta de concientización del paciente para realizar estos cambios es uno de los grandes problemas a los que el personal de salud se enfrenta. Se sabe que para una persona es difícil cambiar hábitos con los que ha vivido por largo tiempo, es así como el cambio de alimentación representa un estado de estrés y gran impacto para muchas personas ${ }^{29}$.

Se ha propuesto como mejora en el tratamiento realizar por parte del personal de salud, visitas a los hogares de pacientes hipertensos con el objetivo de identificar el uso excesivo de productos como azúcar, aceite, sal entre otros; los alimentos que con mayor frecuencia se compran, y crear una mayor confianza para responder dudas acerca de estos nuevas medidas. Con estas visitas podría lograrse cesar el consumo de alcohol y tabaco, una reducción importante en la ingesta de sal y grasas y aumentar el consumo de frutas y vegetales, teniendo resultados positivos y evidentes en los niveles de tensión arterial, nivel de glucosa, lípidos así como en un IMC, logrando reducir el riesgo de complicaciones. El objetivo principal de estas visitas consistiría en entender las características biológicas, psicológicas, afectivas y sociales, a nivel individual y familiar, permitiendo que la intervención tenga mayor éxito. Sin embrago esta medida presenta ciertas limitaciones que requieren de más estudios para aprobar su uso. Otra medida son los grupos de apoyo o de ayuda mutua; tienen el propósito de incorporar y crear redes de apoyo social y el autocuidado de los hipertensos, así como promover una capacitación adecuada para fomentar la adopción de estilos saludables ${ }^{2,26}$.

En el paciente con sobrepeso y obesidad se recomienda reducir del 5 al $10 \%$ del peso corporal inicial durante el tratamiento en seis meses con una pérdida semanal de $0.5 \mathrm{~kg}$ a $1 \mathrm{~kg}$ para mantener un IMC óptimo para el paciente hipertenso de estar entre 18 y $25 \mathrm{~kg} /$ $\mathrm{m}^{2}$, con una circunferencia abdominal adecuada menor de $90 \mathrm{~cm}$ en hombres y menor de $80 \mathrm{~cm}$ en mujeres. 


\section{Principales problemas de Salud Pública en México}

En el plan de alimentación se recomienda la distribución de los nutrimentos será 55-60\% de hidratos de carbono, del $20-25 \%$ de grasa (6\% de grasas saturada menos del $1 \%$ de grasas trans, $10-15 \%$ de proteínas, pacientes con daño renal $0.8 \mathrm{~g} / \mathrm{kg} /$ día), menos de $200 \mathrm{mg}$ de colesterol, $4.700 \mathrm{mg}$ de potasio, $1250 \mathrm{mg}$ de calcio, $500 \mathrm{mg}$ de magnesio y 14 gr por cada 1 $000 \mathrm{Kcal} /$ día de fibra ${ }^{9,26}$.

La dieta DASH es un régimen alimentario establecido en el que se tienen el objetivo de aumentar el consumo de frutas, vegetales y lácteos descremados, incluyendo el consumo de granos enteros, pollo, pescado, semillas y reducir la ingesta de carnes rojas, grasas y dulces teniendo como objetivo la disminución de la presión arterial. El mecanismo por el cual esta dieta puede bajar los niveles de presión arterial, al parecer se debe a sus propiedades diuréticas para la excreción renal de sodio, así como sus componentes antioxidantes que tienen efecto sobre la inflamación vascular y el estrés exudativo, lo que mejorara el balance entre los antioxidantes y el estrés oxidativo. La explicación de este mecanismo se ha ligado a que la dieta DASH induce la relajación vascular y mejora la función endotelial gracias a las propiedades antioxidantes de los prolifenoles, así como la posibles reducción de la proteína $\mathrm{C}$ reactiva por parte de los fitoquímicos presentes en la dieta DASH, que disminuye de este modo también, el riesgo cardiovascular.

Una de las limitantes para los pacientes del llevar dietas hipo sódicas es el cambio de sabor en los alimentos, pero se cree que esta preferencia por el sabor salado de los alimentos va disminuyendo con el tiempo, al proveer una dieta baja en sodio y sustituir este consumo por diferentes especies que dan sabor diferentes. De esta manera una dieta baja en sodio aumenta la respuesta beta adrenérgica vascular y de los linfocitos con lo que se baja la presión arterial. Se recomienda una ingesta no mayor de 6 gr al día ( 2.4 gr de sodio). Un estudio en Estados Unidos en el año 2013, propuso que al seguir este consumo recomendado de sal, la incidencia de enfermedades cardiovasculares, infarto cerebral, infarto agudo al miocardio (IAM) disminuyó, lográndose una reducción anual del número de muertes de 92000 a 44000 al año ${ }^{30}$.

Las dietas altas en potasio tienen un efecto protector contra el desarrollo de daño vascular inducido por el sodio, por medio de la supresión de la producción de especies reactivas de oxígeno. La recomendación dietaria de potasio es de $4.7 \mathrm{~g} /$ día $^{31,26}$.

Un incremento de la actividad física es la primer medida no farmacológica para el tratamiento de personas con pre hipertensión, presión arterial sistólica 120-139 mm Hg 


\section{Hipertensión arterial sistémica}

y/o presión diastólica 80-89, se considera una medida de intervención de bajo costo con pocos efectos secundarios si esta se realiza acorde con las guías de recomendación. Si la actividad física se considera dentro del estilo de vida desde las primeras etapas, el riesgo de desarrollar HAS disminuye, ya que individuos inactivos tienen de 30 a 50\% mayor riesgo de desarrollar HAS comparados con los que realizan actividad física.

Son múltiples los beneficios de un entrenamiento programado y sistematizado, ya que se tiene una mejora en el consumo de oxígeno máximo, disminución de la frecuencia cardiaca y de la presión arterial y se ha demostrado mejora en la función endotelial, relacionada con la capacidad de vasodilatación de las arterias especialmente en pacientes con HAS y con insuficiencia cardiaca crónica.

El ejercicio físico como tratamiento de la hipertensión debe ser supervisado por personal médico capacitado, los niveles de tensión arterial permitidos para iniciar con la actividad física del día, no debe sobrepasar el grado II, por lo que está contraindicado cuando se tenga hipertensión grave (grado III), es decir con cifras de $\geq 180 / \geq 110 \mathrm{~mm} \mathrm{Hg}$ y el ejercicio debe ser suspendido si los niveles de presión arterial, al efectuarlo llegan a 220/105 mm Hg $\mathrm{mg}^{1932}$.

Se recomienda realizar actividad física hasta alcanzar 30 minutos la mayor parte de los días de la semana e incrementar las actividades físicas diarias. La intensidad recomendada es de leve a moderada, de naturaleza rítmica, que se utilizará a lo largo de una sesión con el uso de grandes grupos musculares como son la caminata a paso vigoroso, trote, carrera, ciclismo, natación, gimnasia rítmica y baile ${ }^{26}$.

\section{Medidas de prevención}

La HAS es una enfermedad prevenible, en caso contrario es posible que se pueda retardar su aparición, siendo el cambio en los factores modificables las principales medidas para la prevención o retardo en su aparición. La educación del paciente hipertenso debe involucrarlos en su propio tratamiento, y ayudar a la formación de equipos de salud en el área de educación de paciente, ya que la HAS es una enfermedad subestimada y subtratada, para conseguir estos objetivos, la OMS cuenta con pautas de bolsillo disponibles en varios idiomas. El desarrollo de un sistema de etiquetado frontal de alimentos compresible para la población, es una alternativa para orientar en la compra de alimentos saludables, especialmente bajos en sal, puede coadyuvar para conseguir las metas en el hipertenso 9,12,26. 


\section{Principales problemas de Salud Pública en México}

En el primer nivel de atención se dará atención a los pacientes con HAS que tengan riesgo bajo o medio con el objetivo de controlar los factores de riesgo de la enfermedad y a la población en general con Medidas de prevención Importantes instituciones como la OMS, a través de la Política Nacional de Dieta y Nutrición, entre otras, están de acuerdo que la alimentación saludable es útil en el control y en la prevención de enfermedades cardiovasculares y que debe emplearse como una de las medidas principales en los Centros de Atención primaria. Es importante considerar que la adherencia a estas medidas es compleja y multidimensional donde se debe relacionar, al individuo y su medio ambiente considerando aspectos como, su estado de salud, estatus socioeconómicos, sistemas de salud disponibles, terapias ofrecidas y de manera conjunta una buena la relación con profesionales del cuidado de la salud ${ }^{2,13,26}$.

Se remitirán al segundo nivel de atención los casos de HAS con riesgo alto y muy alto, de complicaciones cardiovasculares, HAS secundaria, HAS resistente y los casos de HAS asociada al embarazo. Estos pacientes serán referidos al especialista para su atención. Los pacientes con enfermedades concomitantes que interfieran en la HAS, los que inicien la enfermedad antes de los 20, o después de los 50 años, y todos los pacientes que el médico de primer contacto así lo juzgue necesario también serán remitidos. Las medidas realizadas en este nivel buscarán evitar las complicaciones secundarias a la HAS, siendo una detección temprana y un control adecuado en la población identificada ${ }^{13.26}$.

En tercer nivel de atención se deberá dar estrecho seguimiento a los pacientes con alto riesgo a fin de evitar eventos clínicos macrovasculares recurrentes. Los objetivos terapéuticos generales deberán estar mejor establecidos administrando medicamentos para su tratamiento, se harán cambios pertinentes sobre los cambios en el estilo de vida. Se deberá considerar el tratamiento de otros fármacos en la prevención de enfermedades cardiovasculares tales como aspirina y otros antiagregantes plaquetarios, beta bloqueadores en pacientes después de haber sufrido un infarto al miocardio o con una disfunción ventricular secundaria a enfermedad coronaria, inhibidores de la ECA en pacientes con sintomatología de disfunción ventricular izquierda secundaria a enfermedad coronaria o a HAS, así como anticoagulantes en pacientes con enfermedad coronaria y riesgo alto para padecer eventos tromboembólicos ${ }^{13}$. 


\section{Hipertensión arterial sistémica}

\section{Referencias}

1. McPhee S, Ganong W. Fisiopatología médica: una introducción a la medicina clínica. 5a ed. México: El Manual Moderno; 2007.

2. Ribeiro AG, Ribeiro SM, Dias CM, Ribeiro AQ, Castro FA, Súarez-Varela MM, et al. Non-pharmacological treatment of hypertension in primary health care: A comparative clinical trial of two education strategies in health and nutrition. BMC Public Health. 2011; 11(637): 1-10.

3. Alwan A, Armstrong T, Cowan M, Riley L. Noncommunicable diseases: country profiles. Geneva: World Health Organization; 2011.

4. Revuelta Herrera A, Salcedo UM, Murguía P. Sistema de información para la vigilancia epidemiológica de los factores de riesgo en enfermedades crónicas no transmisibles (SVEECNT). Mazatlán: Dirección General Adjunta de Epidemiología; 2013.

5. Diario Oficial de la Federación. Modificación a la NOM-030-SSA2-1999, para la prevención, tratamiento y control de la hipertensión arterial, para quedar como NOM030-SSA2-2009. Para la prevención, diagnóstico, tratamiento y control de la hipertensión arterial sistémica. México: SSA; 2010.

6. Rubin R, Strayer DS. Patología: fundamentos clinicopatológicos en medicina. In. Barcelona: Wolters Kluwer Lippincott Williams \& Wolkins; 2012.

7. McPhee S, Hammer GD. Fisiopatología de la enfermedad: una introducción a la medicina clínica. México: McGraw-Hill Educación; 2010.

8. The seven report of the Join National Commite on prevention, detection, evaluation, and treatment of high blood pressure. National Institutes of Health. National heart, lung, and blood Institute, U.S. Departament of Health and Human Services National; 2004.

9. Sánchez RA, Ayala M, Baglivo H, Velázquez C, Burlando G, Kohlmann O, et al. Guías latinoamericanas de hipertensión arterial. Revista Chilena de Cardiología. 2010; 29(1): 117-144.

10. Román L, Aller R, Bustamante Bustamante J. Aspectos terapéuticos de la dieta en la hipertensión arterial. Nefro Plus. 2008; 1(1):39-46.

11. Rosas Peralta M, Lara Esqueda A, Pastelín Hernández G, Velázquez Monroy O, Martínez Reing J, Méndez Ortiz A, et al. Re-encuensta Nacional de Hipertensión Arterial 


\section{Principales problemas de Salud Pública en México}

(RENAHTA): consolidación mexicana de los factores de riesgo cardiovascular. Cohorte nacional de seguimiento. Archivos de Cardiología de México. 2005; 75(1): 96-111.

12. Instituto Nacional de Salud Pública. Hipertensión arterial en adultos mexicanos: Importancia de mejorar el diagnóstico oportuno y el control. Encuesta Nacional de Salud y Nutrición (ENSANUT) 2012. México: INSP; 2012.

13. Molina Díaz R, Guija Villa E, Ortega Marlasca MM, García Matarín L, González Delgado A, Algualcil Cubero P, et al. Manual de Hipertensión Arterial en la práctica clínica de atención primaria. España: Sociedad Andaluza de Medicina de Familia; 2006.

14. Instituto Nacional de Estadística y Geografía. Estadísticas a propósito del día Mundial de la Salud. México: INEGI; 2013.

15. Campos-Nonato I, Hernández-Barrera L, Rojas Martínez R, Pedroza A, Medina-García C, Barquera-Cervera S. Hipertención arterial: prevalencia, diagnóstico oportuno, control y tendencias en adultos mexicanos. Salud Pública de México. 2013; 55(2): S144-S150.

16. Secretaría de Salud. Programa de acción específico 2007-2012. Riesgo cardiovascular México: SSA; 2008.

17. Mejía-Rodríguez O, Paniagua-Sierra R, Valencia-Ortíz M, Ruíz-García J, FigueroaNúñez B, Roa Sánchez V. Factors associated with uncontrolled hypertension. Salud Pública de México. 2009; 51(4): 291-297.

18. Organización Mundial de la Salud. Información general sobre la Hipertensión en el mundo: una enfermedad que mata en silencio, una crisis de Salud Pública mundial; 2013. Disponible en http://apps.who.int/iris/bitstream/10665/87679/1/WHO_DCO_ WHD_2013.2_spa.pdf

19. Rodríguez Hernández M. La actividad física en la prevención y tratamiento de la hipertensión arterial. Revista de las Sedes Regionales. 2012; 13(26):142-156.

20. Tierney L, McPhee S, Papadakis M. Diagnóstico Clínico y Tratamiento. 41st ed. México: El Manual Moderno; 2006.

21. Kotchen TA. Valvulopatía hipertensiva. In Kotchen TA. Harrison. Principios de medicina interna. 18 ed. China: Mc Graw-Hill Educación; 2012.

22. Suárez Fernández C. Protocolos riesgo vascular. 2a ed. España: Sociedad Española de Medicina Interna; 2004. 


\section{Hipertensión arterial sistémica}

23. Salcedo-Rocha AL, García de Alba A, Contreras-Marmolejo M. Presión arterial en adolescentes mexicanos: Clasificación, factores de riesgo e importancia. Revista de Salud Pública. 2010; 12(4): 612-622.

24. Sutters M. Hipertensión sistémica. En: McPhee SJ, Papadakis MA. Diagnóstico clínico y tratamiento 2007. 46th ed. México: McGraw Hill; 2007.

25. Calvo Vargas CG, Parra Rodríguez L, Pérez Cortés G. La atención del paciente con hipertensión arteril: un enfoque para el consultorio. 1a ed. México: JGH Editores; 1999.

26. Secretaría de Salud. Resumen integrado: NOM-030-SSA-2009 y Guía de tratamiento farmacológico y control de la HAS. Revista Mexicana de Cardiología. 2012; 23(1): 4A-38A.

27. Hernández y Hernández H, Díaz y Díaz E, Meaney Mendiolea E, Meaney Martínez A. Guía de tratamiento farmacológico y control de la hipertensión arterial sistémica. Revista Mexicana de Cardiología. 2011; 22(1):1A-21A.

28. Whaley MH, Brubraker PH, Otto RM. Guidelines for exercise testing and prescription. 7a ed. Baltimore: Lippincott Williams \& Wilkins; 2005.

29. Oliveira T, de Sousa Fernandez P, de Paula Miranda L, Prates Caldeira A. Effectiveness of education in health in the nonmedication treatment of arterial hypertension. Acta Paul Enferm. 2013; 26(2):179-184.

30. Bibbins-Domingo K, Chertow GM, Coxson PG, Moran A, Lightwood JM, Pletcher MJ, et al. Protected effect of dietary salt reductions on future cardiovascular disease. The New England Journal of Medicine. 2010; 362(7): 590-599.

31. Esquivel Solis V, Jiménez Fernández M. Aspectos nutricionales en la prevención y tratamiento de la hipertensión arterial. Revista Costarricense Salud Pública. 2010; 19(1):42-47.

32. Rosales W. Entrenamiento aeróbico y de fuerza en rehabilitación cardiovascular. Revista de Sobreentrenamiento. 2001; 10(8):pid 2. Disponible en www.Sobreentrenamiento. com 



\section{Cáncer}

Mtra. Irma Araceli Aburto López M. C. Concepción de la Torre M. C. Román T. A. Vargas Basurto Alumnos (as) Andrés Bello Munguía Jorge Macázar Rodríguez Laura Angélica Nava Avila Magda Mara Torres Isidoro Georgina Zavala Vargas

\section{Introducción}

En la actualidad, el cáncer es una enfermedad muy frecuente, causado por múltiples factores. Ésta patología puede provocar la muerte en los pacientes que la padecen, si no se da tratamiento de manera oportuna. Muchos de éstos enfermos pueden ser curados a través de cirugía, radioterapia y en particular si son detectados en fases tempranas. Y en la mayoría de los casos por los diferentes tipos de cáncer, estos pueden ser prevenibles. Es por ello que en éste capítulo resaltaremos los factores de riesgo que los favorecen, además de su detección oportuna y medidas de prevención de los principales cánceres que se presentan en México.

\section{Concepto}

El cáncer, son neoplasias (tejido nuevo) malignas o tumores malignos, que se pueden localizar en distintas partes de la economía. Este padecimiento se caracteriza por el crecimiento rápido e incontrolado de células indiferenciadas, es decir con características diferentes, morfológicamente a sus precursoras, como consecuencia de mutaciones del DNA; y dichas células cancerosas, tienen la capacidad de invadir de manera local ("cáncer in situ"), en el órgano que se origina (tumor primario); después puede afectar al tejido contiguo o estructuras vecinas (invasión local) o en su defecto pueden producir metástasis 


\section{Principales problemas de Salud Pública en México}

(invasión a distancia a otros tejidos). Dicho desarrollo de éstas células, persisten aún si desaparece el estímulo que las desencadenó ${ }^{1,2}$.

\section{Clasificación}

La Clasificación Internacional de Enfermedades décima revisión (CIE-10) incluye a éste grupo de patologías, en el Capítulo II "Tumores (neoplasias) malignos", y que para su registro, están incluidos en los códigos C00 a C97), e incluye a los siguientes cánceres (Cuadro 1$)^{3}$ :

Cuadro 1. Clasificación de los tumores malignos.

\begin{tabular}{|l|l|}
\hline \multicolumn{2}{|c|}{ Clasificación de los Tumores malignos } \\
\hline $\begin{array}{l}\text { Del labio, de la cavidad bucal y de la } \\
\text { faringe (C00-C14). }\end{array}$ & De órganos genitales femeninos (C51-C58) \\
\hline De los órganos digestivos (C15-C26) & $\begin{array}{l}\text { De los órganos genitales masculinos } \\
\text { (C60-C63) }\end{array}$ \\
\hline $\begin{array}{l}\text { De los órganos respiratorios e } \\
\text { intratorácicos (C30-C39) }\end{array}$ & De las vías urinarias (C64-C68) \\
\hline $\begin{array}{l}\text { De los huesos y de los cartílagos } \\
\text { articulares (C40-C41) }\end{array}$ & $\begin{array}{l}\text { Del ojo, del encéfalo y de otras partes del } \\
\text { sistema nervioso central (C69-C72) }\end{array}$ \\
\hline $\begin{array}{l}\text { Melanoma y otros tumores malignos de } \\
\text { la piel (C43-C44) }\end{array}$ & $\begin{array}{l}\text { De la glándula tiroides y de otras glándulas } \\
\text { endocrinas (C73-C75) }\end{array}$ \\
\hline $\begin{array}{l}\text { De los tejidos mesoteliales y de los } \\
\text { tejidos blandos (C45-C49) }\end{array}$ & $\begin{array}{l}\text { Del tejido linfático, de los órganos } \\
\text { hematopoyéticos y de tejidos afines (C81-C96) }\end{array}$ \\
\hline De la mama (C50) & $\begin{array}{l}\text { Tumores malignos (primarios) de sitios } \\
\text { múltiples independientes (C97) }\end{array}$ \\
\hline
\end{tabular}

Los tumores malignos también se pueden clasificar de acuerdo a su extensión, en diferentes estadios, de acuerdo al Sistema TNM, en donde la T significa tumor primario, in situ, es decir que no ha invadido; la N, especifica la extensión a ganglios linfáticos regionales del tumor primario; y por último la $\mathrm{M}$, que se refiere a la presencia o no de metástasis

Estos estadios de enumeran de la siguiente manera:

Estadio 0: Tumores in situ. 


\section{Cáncer}

Estadio I: Pequeños y localizados.

Estadio II y III: Localizados avanzados que pueden tener o no afección a ganglios linfáticos locales.

Estadio IV: Con metástasis ${ }^{4}$.

\section{Epidemiología}

En todo el mundo en la actualidad, el cáncer es una de las principales causas de morbilidad y mortalidad. Para el año 2012, 14 millones de casos de enfermedad y 8.2 millones de defunciones ${ }^{1,5}$.

Según cálculos de proyección, se espera que aumenten los casos nuevos en un 70\% en los próximos 20 años (a 22 millones). ${ }^{1}$ De los años 2007 a 2030, aumenten las defunciones en un $45 \%$, las que pasarán en ese periodo de 7.9 millones a 11.5 millones, a causa del envejecimiento de la población y por el crecimiento demográfico ${ }^{6}$.

En los países desarrollados el cáncer ocupa la segunda causa de defunción, después de las enfermedades cardiovasculares, sin embargo en las naciones en vías de desarrollo, que se encuentran en transición epidemiológica, éste panorama de mortalidad ya se comenzó a dar6.

Cabe referir que en cuanto a la incidencia, más del 60\% de todos los casos de todo el mundo se registran en África, Asia, América Central y América del Sur, y en dichas regiones se dan el 70\% de las defunciones por cáncer a nivel mundial, ya que carecen de mecanismos de detección precoz y de acceso a los servicios médicos para su tratamiento ${ }^{5}$.

Los tipos de cáncer más frecuentemente encontrados a nivel mundial, para el año 2012, de mayor a menor, son pulmonar, hepático, gástrico, colorrectal, mamario y de esófago. En los hombres de pulmón, próstata, colon y recto, estómago e hígado; y en las mujeres de mama, colon, recto, pulmón, cuello uterino y estómago. ${ }^{7}$ Por lo tanto el tipo de cáncer que provoca mayor número de defunciones a nivel internacional es el de pulmón. Sin embargo en países desarrollados se presentan más comúnmente los de próstata, mama y colon. Y en las naciones en vías de desarrollo los de hígado, estómago y cuello uterino ${ }^{6}$. 
En México, la tasa de mortalidad por cáncer cérvico uterino ha ido descendiendo a partir de 1990, gracias a la detección temprana y tratamiento oportuno ${ }^{5}$. Al respecto, en 1980 el riesgo de fallecer a consecuencia del cáncer cérvico uterino era dos veces mayor que por cáncer mamario. Hoy en día el cáncer de mama en mujeres es un grave problema de Salud Pública en América Latina y el Caribe ya que aproximadamente 40000 mujeres mueren cada año a consecuencia de ésta enfermedad. El 55\% de los nuevos casos provienen de países en vías de desarrollo donde la letalidad por la enfermedad es mayor, pues representa alrededor del 68\% de las muertes por esta enfermedad. En México a partir del 2005 la tasa de mortalidad de cáncer de mama es superior a la de cáncer cérvico uterino. Por lo que a partir del 2006 el cáncer de mama ha sido la primera causa de mortalidad por tumores malignos entre las mujeres. Y posee una mortalidad con tendencia ascendente, ya que en 1950 existía una tasa de 2 por cada 100000 mujeres; y para 2008, 9 por 100000 mujeres; la tasa se incrementó 2.5 veces de 1992 al 2008. Actualmente en nuestro país existe un fallecimiento de mujeres, cada 2 horas por éste padecimiento 9 .

En cuanto al cáncer infantil, que es aquel que se presenta antes de los 15 años de edad, en el mundo, es la segunda causa de muerte solo precedido por accidentes y cada 3 minutos se diagnostica un niño con cáncer ${ }^{9}$. A nivel internacional, figura entre el $0.5 \%$ y el $4.6 \%$ de la carga total de morbilidad. Sus incidencias van de 50 a 200 por cada millón de niños en el mundo ${ }^{7,10}$. En toda la orbe, el 33\% de los cánceres en edad infantil son por leucemia, es resto, que son también comunes, son los linfomas y los tumores del Sistema Nervioso Central. Existen otros tipos que casi son exclusivos en niños, como los neuroblastomas, los nefroblastomas, los meduloblastomas y los retinoblastomas. Y son raros en encontrar en ésta edad a los de mama, el cáncer de pulmón, el cáncer de colon y el cáncer anorrectal ${ }^{11}$. En México, el 5\% de los tumores malignos son la principal causa de muerte entre los 5 y 14 años de edad, provocando 2 mil defunciones y 23 mil casos anualmente. Se considera que la razón de incidencia de casos, para población no derechohabiente, es de 9 casos de cáncer infantil por cada 100 mil menores de 18 años $^{12}$; y posee un promedio anual de 2,150 defunciones, en la última década. Los tipos más comúnmente notificados como casos de enfermedad por cáncer, son las leucemias (52\%), linfomas (10\%), tumores del sistema nervioso central (10\%) y los tumores sólidos de otros órganos ${ }^{9,12}$.

Existen retos muy importantes para la resolución de éstas enfermedades, ya que existe falta de concienciación para su prevención, acceso limitado a los Servicios de Salud, para su detección y manejo. Además de que agravan éste problema, la desigualdad social, la que 


\section{Cáncer}

incluye a niños y niñas, y a las mujeres y hombres más pobres, que viven en zonas rurales, la discriminación a causa del género, la falta de recursos económicos, la pobreza, la falta de educación, religión y etnia ${ }^{13}$.

\section{Causalidad}

Son muy diversos los factores que pueden originar cáncer, e incluso muchos individuos que están en contacto con ellos no siempre desarrollan la enfermedad, entre algunos de éstas causas se encuentran la herencia, los productos tóxicos, químicos (asbestos, amianto, humo del tabaco, dioxinas, aflatoxinas de los alimentos y arsénico contaminante del agua de bebida), las radiaciones ultravioleta e ionizantes y por infecciones causadas por virus, bacteria o parásitos. Sin embargo ninguno de estos es realmente determinante en desencadenar el cáncer. Hoy en día los investigadores estudian cómo estos elementos pueden interactuar de una manera multifactorial y secuencial para producir los tumores malignos. El cáncer es en esencia un proceso que inicia con aspectos genéticos. Dichas alteraciones genéticas pueden ser heredadas o adquiridas en el transcurso de la vida de un individuo, producidas en alguna célula al estar en contacto con un virus o por una lesión provocada de manera externa. Se considera que el envejecimiento es otro factor, ya que a mayor edad aumenta la probabilidad de cáncer, tal vez porque se van sumando múltiples factores de riesgo y a la pérdida de la capacidad de reparar las células ${ }^{1,6,14}$.

Además, se ha determinado que un 30\% de las muertes a causa del cáncer son provocadas por cinco factores dietéticos y conductuales, los que a su vez son considerados evitables; entre ellos se incluyen el Índice de Masa Corporal (IMC) elevado, sedentarismo, ingesta pobre de frutas y verduras, consumo de alcohol y de tabaco ${ }^{1,6}$.

El sobrepeso, obesidad y el sedentarismo en general, provocan 274,000 defunciones al año, en todo el mundo, a consecuencia del cáncer, como el de colon y recto, mama, esófago, endometrio y riñón ${ }^{6,15}$.

En cuanto a la dieta, las personas que tienen un consumo excesivo de alimentos en conserva, así como el de carnes rojas (res, ternera, cerdo, cordero, caballo y cabra) y procesadas (salazón, el curado, la fermentación, el ahumado, u otros procesos para mejorar su conservación o sabor), tienen mayor riesgo a desarrollar cáncer colorectal, de páncreas y de próstata. A nivel mundial, cada año, existen 34.000 muertes y 50.000 defunciones, 


\section{Principales problemas de Salud Pública en México}

por cáncer atribuibles a dietas ricas en carne procesada y dietas ricas en carnes rojas, respectivamente. Además, se dice que por cada porción de 50 gramos de carne procesada consumida diariamente, se eleva el riesgo de cáncer colorectal en un $18 \%$; sugieren que por una ración de 100 gramos de carne roja ingerida diariamente, podría aumentar el riesgo de cáncer de colon en un $17 \%$ 15,16 .

La ingesta nociva de alcohol provoca 351000 defunciones anuales en todo el mundo, a consecuencia del cáncer, ya que provoca los de boca, faringe, laringe, esófago, hígado, colon y recto, y mama. El riesgo para padecer cáncer a consecuencia del alcohol, aumenta de manera proporcional a la cantidad consumida; y aumenta si el individuo es fumador. El $22 \%$ de los casos de cáncer de boca y orofaringe en los hombres son atribuibles al alcohol y en las mujeres es del $9 \%$.

Se considera que el tabaco es la causa más importante, provocando el 70\% de las muertes en ambos sexos, a consecuencia del cáncer de pulmón y del 20\% del total de todos los tipos de cáncer en general, ya que el humo del tabaco provoca diferentes tipos de cáncer entre los que se encuentran los del pulmón, esófago, laringe, boca, riñón, vejiga, páncreas, estómago y cuello del útero (en el sexo femenino); y el tabaco de mascar o en polvo favorece el cáncer de boca, esófago y páncreas. Quien provoca alrededor de 1.8 millones de defunciones cada año. Cabe decir que el $60 \%$ de dichas muertes acontecen en los países en vías de desarrollo $0^{1,6,15}$.

Otras causas importantes son las infecciones producidas por el papilomavirus humanos $(\mathrm{PVH})$ y además por el virus de las hepatitis $\mathrm{B}$ (VHB) y $\mathrm{C}(\mathrm{VHC})$, que aumentan el riesgo de cáncer de hígado; los que pueden ser responsables de un $20 \%$ de las muertes por cáncer en países con ingresos bajos y medios. El PVH, transmitido sexualmente, causa 235000 defunciones cada año en el mundo, a consecuencia de cáncer. Además de la infección del VIH, que provoca el riesgo de algunos cánceres, tal como lo hace con el de cuello uterino ${ }^{7}$. Y las provocadas por la bacteria Helicobacter pylori aumenta el riesgo de cáncer de estómago; la esquistosomiasis parasitaria se asocia con la causalidad del cáncer de vejiga; el trematodo del hígado favorece el riesgo de colangiocarcinoma de las vías biliares ${ }^{15}$.

También existen más de 40 agentes y mezclas que actúan como carcinogénicos en el ambiente laboral, los que causan a nivel mundial 152000 defunciones por cáncer de pulmón, vejiga, laringe, piel, leucemia, nasofaríngeo y por mesotelioma. Al respecto, del 20\% al 30\% de 


\section{Cáncer}

los hombres y entre el 5\% al 20\% de las mujeres en edad productiva, pueden haber estado expuestos a sustancias carcinógenas en su trabajo, ocasionando alrededor del 10\% de los casos de cáncer de pulmón y del $2 \%$ de los casos de leucemia en todo el mundo ${ }^{6,15}$.

Cabe señalar que los fuegos de carbón domésticos, provocan la contaminación del aire en los interiores, causando aproximadamente el 1,5\% de todas las muertes por cáncer y quienes a su vez duplica el riesgo de cáncer de pulmón, especialmente entre el género femenino de las no fumadoras ${ }^{15}$.

Con respecto al cáncer infantil, la causalidad tiene que ver con la constitución genética, las radiaciones ionizantes y la toma de dietilestilbestrol, durante el embarazo; también pueden estar inmiscuidos ciertos tipos de virus como el EBV, el virus de la hepatitis B, el virus del herpes humano o el $\mathrm{VIH}^{11}$.

Los factores de riesgo asociados al cáncer son producto de un modo de vida que puede considerarse, poco sano, en donde se incluye el consume de alcohol, tabaco, falta de actividad física y una dieta inadecuada (Cuadro 2).

Cuadro 2. Factores de riesgo por tipo de cáncer.

\begin{tabular}{|c|l|}
\hline $\begin{array}{c}\text { Tipo de } \\
\text { cáncer }\end{array}$ & \multicolumn{1}{c|}{ Factores de riesgo } \\
\hline Próstata & $\begin{array}{l}\text { Edad avanzada (alrededor de } 6 \text { de } 10 \text { casos se detectan en hombres mayores } \\
\text { de } 65 \text { años), ser de raza negra, que el padre o un hermano lo padezca, } \\
\text { sobrepeso u obesidad, talla (entre más alto es un hombre, más riesgo tiene de } \\
\text { padecer cáncer de próstata }{ }^{17,18} .\end{array}$ \\
\hline Mamario & $\begin{array}{l}\text { Para ambos sexos: Predominio después de los } 40 \text { años, no realización } \\
\text { de ejercicio físico, hábito de fumar, obesidad o sobrepeso, antecedentes } \\
\text { familiares de la enfermedad, uso frecuente de antitranspirantes que contienen } \\
\text { aluminio, así como ser nuligesta; ser portador conocido de los genes BRCA1 } \\
\text { o BRCA2; tener una dieta alta en hidratos de carbono, grasas y baja en fibra; } \\
\text { y consumo de alcohol mayor a 15 g/día. En mujeres: No ofrecimiento de la } \\
\text { lactancia materna o lactar menos de 4 meses, terapia de reemplazo hormonal, } \\
\text { primer embarazo a término después de los 30 años de edad, ser del sexo } \\
\text { femenino, menarca antes de los 12 años y menopausia después de los 52 } \\
\text { años. En varones: Síndrome de Klinefelter, administración de estrógenos, y } \\
\text { radiación ionizanted }\end{array}$ \\
\hline
\end{tabular}


Principales problemas de Salud Pública en México

Cuadro 2. Factores de riesgo por tipo de cáncer (continuación).

\begin{tabular}{|c|c|}
\hline $\begin{array}{l}\text { Tipo de } \\
\text { cáncer }\end{array}$ & Factores de riesgo \\
\hline $\begin{array}{l}\text { Cérvico- } \\
\text { uterino }\end{array}$ & $\begin{array}{l}\text { Mujeres: Menores de } 30 \text { años sin antecedente de control citológico, } \\
\text { inmunocomprometidas, con virus del papiloma humano, con pareja sexual } \\
\text { que tenga antecedente de estar infectada por el virus del papiloma humano, } \\
\text { con antecedentes de infección de transmisión sexual, con múltiples parejas } \\
\text { sexuales, que iniciaron vida sexual a temprana edad (antes de } 18 \text { años), con } \\
\text { inmunodeficiencia adquirida, con deficiencia de ácido fólico, tabaquismo }{ }^{21} \text {. En } \\
\text { la pubertad o embarazo hay transformación del exocérvix lo que incrementa } \\
\text { la exposición al VPH y facilitar la infección, paridad, y que hayan tenido un } \\
\text { primer parto a edad muy temprana, uso de anticonceptivos orales durante } \\
\text { más de } 5 \text { años }^{22} \text {. }\end{array}$ \\
\hline Piel & $\begin{array}{l}\text { Exposición solar en los primeros años de vida porque el mayor porcentaje } \\
\text { de luz ultravioleta (UV) es recibida antes de los } 20 \text { años. Luz solar (piel } \\
\text { fotoexpuesta más frecuente como cabeza y cuello). Las personas jóvenes por } \\
\text { estilos de vida:incrementala exposición solary eluso de cámaras debronceado. } \\
\text { Por sexo: Hombres - razones socioculturales, principalmente la ocupación; } \\
\text { mujeres - costumbres y estilos de vida (estética). Radioterapia, exposición a } \\
\text { arsénico, personas con cabello rubio, ojos azules y piel blanca y que viven más } \\
\text { cerca al Ecuador; poca educación vinculada al uso de protectores solares }{ }^{23} \text {. } \\
\text { Pacientes post trasplantadas con tratamiento inmunosupresor; antecedente } \\
\text { en la infancia de recibir radioterapia contra cáncer. }{ }^{24} \text { Dos o más familiares de } \\
\text { primer grado con melanoma: }>5 \text { nevos displásicos y con presencia de }>100 \\
\text { lunares comunes. }\end{array}$ \\
\hline Gástrico & $\begin{array}{l}\text { Los factores de riesgo demográficos son edad avanzada, predominio en } \\
\text { el género masculino, una alimentación pobre en frutas y verduras, con un } \\
\text { alto contenido en sal, además de una ingesta alta de comidas ahumadas o } \\
\text { en conserva; también el tabaquismo y alcoholismo. Los factores biológicos } \\
\text { son la infección por Helicobacter pylori, gastritis crónica, anemia perniciosa } \\
\text { y pólipos adenomatosos gástricos. Y los factores hereditarios son los } \\
\text { antecedentes familiares de cáncer gástrico, esófago de Barret, úlcera Gástrica, } \\
\text { enfermedad de Ménetrier y mutación CDH } 1^{25,26} \text {. }\end{array}$ \\
\hline $\begin{array}{l}\text { Pulmonar } \\
\text { o bronco- } \\
\text { génico }\end{array}$ & $\begin{array}{l}\text { Los factores demográficos son edad mayor de } 70 \text { años, predomina en el género } \\
\text { masculino, el tabaquismo, la exposición ocupacional (arsénico, asbesto, } \\
\text { cromo y níquel) y la contaminación. Los factores biológicos son la diabetes } \\
\text { Mellitus tipo 2, la obesidad, EPOC, y fibrosis pulmonares. Y por último los } \\
\text { factores hereditarios son la agregación familiar. Los factores dietéticos que } \\
\text { influyen con ácidos grasos saturados y baja ingesta de antioxidantes }{ }^{27.28} \text {. }\end{array}$ \\
\hline
\end{tabular}




\section{Fisiopatología}

El rol de las alteraciones genéticas en la carcinogénesis (mecanismo por el cual se origina el cáncer), fue puesto de manifiesto al descubrir en el genoma humano, genes homólogos a genes retrovirales relacionados previamente con el desarrollo de tumores. En células humanas normales estos genes se denominan protooncogenes y se relacionan con el crecimiento y proliferación de las células normales. Cuando se encuentran mutados se denominan oncogenes y su mutación es de tipo dominante, es decir, sólo es necesario que un alelo sufra una mutación para que la proteína que codifica, gane funcionalidad. Esto generalmente se traduce en aumento de sobrevida y proliferación ${ }^{29}$.

Posteriormente, las células hijas de éstas células alteradas acumulan diversas mutaciones que permite generar distintos clones. Estos presentan mayores capacidades de sobrevida, crecimiento y ventajas proliferativas con respecto de su contraparte normal que permite generar un clon neoplásico persistente. Normalmente, las células del sistema inmune son capaces de eliminar a estas células tumorales, en un proceso denominado inmunovigilancia tumoral. Sin embargo, algunos de estos clones pueden adquirir nuevas capacidades que les permiten evadir estos mecanismos de control y se desarrolla una neoplasia. En la parte final del entendimiento del mecanismo patológico del cáncer cabe aclarar que las neoplasias suelen afectar las tareas estructurales y funcionales de los distintos tejidos y órganos, causando así diferentes tipos de afecciones, dependiendo del sitio donde se hayan alojado, ${ }^{9,29}$.

\section{Cuadro clínico}

Los cuadros clínicos son múltiples, los que dependen del tipo de cáncer presentado por el paciente, por lo que a continuación se refieren los datos clínicos característicos para los cánceres más frecuentes (Cuadro 3).

\section{Complicaciones}

Las complicaciones más comunes en los pacientes que padecen cáncer, se pueden agrupar en cuatro tipos: metastásicas, metabólicas, quirúrgicas y las derivadas por la quimioterapia. Las metástasis suelen ocurrir en cualquier parte de la economía. Con respecto a las implicaciones metabólicas habitualmente la padecen los pacientes con 


\section{Principales problemas de Salud Pública en México}

enfermedad avanzada, en quienes el tratamiento citotóxico ha fallado; quienes pueden cursar con hipercalcemia, (la que esta mediada por factores liberados por las células tumorales), Síndrome de lisis tumoral (liberación concentrada y abrupta de contenidos celulares) o Enfermedad tromboembólica. Las quirúrgicas incluyen la perforación, lesiones o laceraciones de tejidos al efectuar las intervenciones e incluso obstrucción abdominal, en el caso de haber maniobrado en ésta zona anatómica. Y las derivadas por la quimioterapia, debido a que los fármacos, no actúan tan solo en las células tumorales, por lo que son tóxicos que afectan al organismo, provocando a los pacientes anemia, toxicidad renal, cardiaca o pulmonar ${ }^{35}$.

Cuadro 3. Cuadro clínico.

\begin{tabular}{|c|c|}
\hline $\begin{array}{l}\text { Tipo de } \\
\text { cáncer }\end{array}$ & Cuadro clínico \\
\hline Próstata & $\begin{array}{l}\text { En etapa inicial no causa síntomas, sin embargo, los más avanzados } \\
\text { pueden cursar con: flujo urinario lento o debilitado, dificultad en } \\
\text { iniciar la micción, disuria, sensación de no haber vaciado la vejiga al } \\
\text { terminar la micción, urgencia miccional, nictámero invertido, hematuria, } \\
\text { hematospermia, disfunción eréctil, lumbalgia, dolor torácico, paresia o } \\
\text { parestesia de miembros pélvicos }{ }^{30,31} \text {. }\end{array}$ \\
\hline Mamario & $\begin{array}{l}\text { Nódulo sólido, irregular de consistencia dura, fijo a planos profundos; } \\
\text { cambios cutáneos evidentes como piel de naranja, retracción de la } \\
\text { piel, lesión areolar que no cicatriza a pesar de tratamiento, zona de } \\
\text { sistematización en el tejido glandular focalizado a una sola mama y } \\
\text { región, secreción serosanguinolenta, crecimiento ganglionar axilar o } \\
\text { supraclavicular; así como dolor en el seno o en el pezón, hinchazón de } \\
\text { una parte o todo el seno y enrojecimiento, descamación o engrosamiento } \\
\text { de la piel del seno o del pezón }{ }^{20,32} \text {. }\end{array}$ \\
\hline $\begin{array}{l}\text { Cérvico- } \\
\text { uterino }\end{array}$ & $\begin{array}{l}\text { Algunos signos y síntomas: sangrado intermenstrual, postcoital, } \\
\text { posmenopáusico; apariencia anormal del cérvix, descarga vaginal, dolor } \\
\text { pélvico; hinchazón de una sola pierna; dolor de espalda; cansancio; } \\
\text { pérdida de peso y apetito }{ }^{21,22} \text {. Es importante recordar que en estadios } \\
\text { iniciales con afectación únicamente microscópica, las pacientes suelen } \\
\text { estar asintomáticas. }\end{array}$ \\
\hline
\end{tabular}




\section{Cáncer}

Cuadro 3. Cuadro clínico (continuación).

\begin{tabular}{|l|l|}
\hline \multicolumn{1}{|c|}{$\begin{array}{c}\text { Tipo de } \\
\text { cáncer }\end{array}$} & \multicolumn{1}{c|}{ Cuadro clínico } \\
\hline Piel & $\begin{array}{l}\text { Las lesiones cutáneas comienzan principalmente en áreas expuestas a } \\
\text { rayos UV, como la cara y por orden de frecuencia afecta nariz, párpados } \\
\text { inferiores, mejillas y frente. Puede presentarse en el tronco pero es menos } \\
\text { frecuente. La forma más frecuente en la que se presenta es en forma de } \\
\text { pápula perlada con telangiectasias en su superficie, al evolucionar puede } \\
\text { ulcerarse en el centro de la lesión }{ }^{24} \text {. Algunas otras lesiones en el caso de } \\
\text { melanoma pueden ir desde una mancha atípica que tiene cambios de } \\
\text { color como café claro o rosado, forma o tamaño hasta lesiones que se } \\
\text { ulceran y sangran o neoformaciones exofíticas de aspecto nodular que } \\
\text { son firmes, simétricas y de color uniforme }{ }^{33} \text {. }\end{array}$ \\
\hline Gástrico & $\begin{array}{l}\text { Se caracteriza por síntomas inespecíficos por lo que se llega a diagnosticas } \\
\text { en etapas avanzadas. La duración de los síntomas es <3 meses en } 40 \% \\
\text { de los pacientes y }>1 \text { años en solo 20\%. Los síntomas más comunes } \\
\text { son pérdida de peso, anorexia, dolor abdominal y distensión; plenitud } \\
\text { prandial temprana, fatiga, nausea/vómito, melena, disfagia, diarrea, } \\
\text { esteatorrea y en menor frecuencia sangrado de tubo digestivo alto y } \\
\text { anemia. Los tumores localizados en los tractos de entrada o salida del } \\
\text { estómago se relacionan con síntomas dispépticos leves antes de provocar } \\
\text { los de obstrucción }{ }^{26} \text {. }\end{array}$ \\
\hline $\begin{array}{l}\text { Pulmonar o } \\
\text { broncogénico }\end{array}$ & $\begin{array}{l}\text { Las manifestaciones de la enfermedad localizada son tos, hemoptisis, } \\
\text { dolor mediastínico, disnea; en la enfermedad localmente avanzada se } \\
\text { observa disfonía parálisis del nervio frénico, disfagia, estridor, derrame } \\
\text { pleural y pericárdico. Los principales sitios de metástasis son cerebro, } \\
\text { ósea, hígado y glándula suprarrenal27,34. }\end{array}$ \\
\hline
\end{tabular}

\section{Diagnóstico}

El diagnóstico debe ir encaminado a detectar la enfermedad de manera temprana, con el afán de dar tratamiento oportuno y evitar que la enfermedad desencadene la muerte. Para poder realizar la detección temprana es importante conocer en primer lugar los signos y síntomas iniciales, como es el caso de los cánceres de mama, piel, cuello uterino, boca, colon y recto, en especial cuando se carece de métodos de o de pruebas de detección dirigidos a toda la población; ya que de no ser así se pueden diagnosticar los cánceres en fases avanzadas de la enfermedad y de esa manera no existen tratamientos curativos. Las 


\section{Principales problemas de Salud Pública en México}

detecciones efectuadas a toda la comunidad o cribado o tamizaje, van dirigidas a descubrir a los portadores de algún tipo de cáncer o para identificar alguna lesión precancerosa, son eficaces y de bajo costo, además de ser accesibles a poblaciones en riesgo. Entre ellos podemos encontrar el Papanicolaou, detección de PVH e inspección visual con ácido acético en el cuello uterino ${ }^{1,5}$. Para detectar los cánceres infantiles es muy complejo, ya que en etapas iniciales los signos y síntomas son inespecíficos, lo que provoca que en la mayoría de los casos, se identifiquen en etapas avanzadas. Es por ello que se debe tener una estrecha vigilancia médica y por parte de los padres, para identificar lo más tempranamente posible algún cambio que pueda ser señal de cáncer en un niño ${ }^{12}$.

A continuación se desarrollan las formas de detección para identificar los cánceres más frecuentes en nuestro país (Cuadro 4):

Cuadro 4. Formas de detección para identificar los cánceres más frecuentes en nuestro país.

\begin{tabular}{|c|c|}
\hline $\begin{array}{l}\text { Tipo de } \\
\text { cáncer }\end{array}$ & Formas de detección \\
\hline Próstata & $\begin{array}{l}\text { Tacto rectal, medición sérica del antígeno prostático específico (APE), } \\
\text { mismo que es un mejor predictor de cáncer que el primero. La biopsia } \\
\text { de próstata debe determinarse en las bases del APE, o en un tacto rectal } \\
\text { sospechoso. }{ }^{36} \text { Los niveles normales del antígeno prostático específico son } \\
\text { de } 0 \text { a } 4 \mathrm{ng} / \mathrm{mL} \text {. La combinación de tacto rectal y APE en suero es la } \\
\text { prueba de primera línea para evaluar el riesgo de que se presente un } \\
\text { cáncer de próstata en un individuo, y La tríada de tacto rectal-antígeno } \\
\text { prostático específico-biopsia de próstata dirigida por ecografía se utiliza } \\
\text { en la detección temprana del cáncer de próstata }{ }^{37} \text {. }\end{array}$ \\
\hline Mamario & $\begin{array}{l}\text { Autoexploración, exploración clínica y mastografía }{ }^{20} \text {. La autoexploración } \\
\text { debe hacerse a partir de la menarca; la exploración clínica a partir de } \\
\text { los } 25 \text { años; la mastografía anual a partir de los } 40 \text { años. El ultrasonido } \\
\text { mamario se debe realizar a < de } 35 \text { años con afección mamaria o mama } \\
\text { densa. La biopsia es la técnica estándar para las lesiones palpables y no } \\
\text { palpables }{ }^{38} \text {. }\end{array}$ \\
\hline $\begin{array}{l}\text { Cérvico- } \\
\text { uterino }\end{array}$ & $\begin{array}{l}\text { La prueba de elección para cáncer cérvico-uterino es la citología cervical } \\
\text { convencional que se recomienda para: mujeres con vida sexual activa, } \\
\text { dentro de los tres años después de la primera relación sexual o hasta los } \\
21 \text { años y mujeres que lo soliciten }{ }^{21} \text {. }\end{array}$ \\
\hline
\end{tabular}




\section{Cáncer}

Cuadro 4. Formas de detección para identificar los cánceres más frecuentes en nuestro país (continuación).

\begin{tabular}{|c|c|}
\hline $\begin{array}{l}\text { Tipo de } \\
\text { cáncer }\end{array}$ & Formas de detección \\
\hline $\begin{array}{l}\text { Cérvico- } \\
\text { uterino }\end{array}$ & $\begin{array}{l}\text { La detección precoz, mediante el tamizaje de todas las mujeres del grupo } \\
\text { etario previsto, seguida del tratamiento de las lesiones precancerosas } \\
\text { detectadas, permiten prevenir la mayoría de los cánceres cervicouterinos. } \\
\text { El tamizaje de cáncer cervico-uterino se debe realizar por lo menos una } \\
\text { vez a cada mujer del grupo etario previsto (de } 30 \text { a } 49 \text { años de edad), que } \\
\text { puede obtener los mayores beneficios. Las decisiones sobre el método } \\
\text { de tamizaje y tratamiento por adoptar en un país o un establecimiento } \\
\text { de asistencia sanitaria deben basarse en una variedad de factores, entre } \\
\text { ellos las ventajas e inconvenientes, la posibilidad de que las mujeres no } \\
\text { regresen para el seguimiento, los costos y la disponibilidad del equipo } \\
\text { y los recursos humanos necesarios. En las mujeres con resultados } \\
\text { negativos en la prueba de tamizaje de VPH, se debe proceder a un } \\
\text { nuevo tamizaje tras un intervalo mínimo de cinco años. Los métodos } \\
\text { moleculares de detección del VPH se basan en la detección de ADN de } \\
\text { los tipos de VPH de alto riesgo en muestras vaginales o cervicouterinas. } \\
\text { No se recomienda aplicar estos métodos a mujeres menores de } 30 \text { años } \\
\text { de edad porque muchas jóvenes están infectadas por esos tipos de VPH, } \\
\text { pero la mayoría de esas infecciones remitirán espontáneamente antes de } \\
\text { que ellas lleguen a los } 30 \text { años de edad }{ }^{39} \text {. }\end{array}$ \\
\hline Piel & $\begin{array}{l}\text { El abordaje clínico que compete una historia clínica completa y un } \\
\text { examen clínico completo mediante la observación a simple vista, además } \\
\text { palpando la superficie cutánea con la intención de identificar lesiones. } \\
\text { Interrogar de forma dirigida a los pacientes sobre lesiones en piel que } \\
\text { no cicatrizan en aproximadamente de } 4 \text { a } 6 \text { meses, que sangran con } \\
\text { facilidad, que no duelen y que se localizan en la cara principalmente, } \\
\text { pero sin olvidar el tronco. Especialmente en personas que cuenten con } \\
\text { factores de riesgo. Es recomendable en caso de contar con recursos y } \\
\text { personal capacitado, tomar biopsia para confirmación histológica }{ }^{23} \text {. } \\
\text { Algunos especialistas utilizan la nemotecnia acunada como "ABCDE" } \\
\text { de los lunares con el fin de identificar rápidamente lesiones sospechosas; } \\
\text { A de asimetría, B de bordes, C de color, D de diámetro y E de elevación } \\
\text { o evolución a fin de que el especialista discrimine estas lesiones con base } \\
\text { en su morfología }{ }^{40} \text {. También se puede utilizar el sistema de } 7 \text { puntos para } \\
\text { las lesiones en piel (criterio o característica mayor): Cambio en el tamaño } \\
\text { de la lesión; pigmentación irregular; bordes irregulares; inflamación; } \\
\text { prurito; lesión de mayor tamaño comparada con otras; y exudado/ } \\
\text { presencia de costras }{ }^{38} \text {. }\end{array}$ \\
\hline
\end{tabular}


Cuadro 4. Formas de detección para identificar los cánceres más frecuentes en nuestro país (continuación).

\begin{tabular}{|l|l|}
\hline \multicolumn{1}{|c|}{$\begin{array}{c}\text { Tipo de } \\
\text { cáncer }\end{array}$} & \multicolumn{1}{c|}{ Formas de detección } \\
\hline Gástrico & $\begin{array}{l}\text { La endoscopia con toma de biopsia es el estándar de oro, y tiene una } \\
\text { eficacia del 95\%. La serie esófago-gastro-duodenal con doble contraste } \\
\text { es el método idóneo para estudiar el estómago en el nivel primario de } \\
\text { la salud. La tomografía axial computarizada tiene una exactitud global } \\
\text { del 90\%. El ultrasonido endoscópico evalúa la profundidad de invasión } \\
\text { y metástasis a ganglios regionales }\end{array}$ \\
\hline $\begin{array}{l}\text { Pul,42. } \\
\text { broncogénico }\end{array}$ & $\begin{array}{l}\text { Análisis citohistológico del esputo, también la broncoscopía con } \\
\text { punción aspiración transparietal con aguja fina y control radiológico. La } \\
\text { radiografía de tórax puede mostrar masas ocupantes o extensión; y la } \\
\text { TAC es de utilidad para la estatificación del cáncer }\end{array}$ \\
\hline
\end{tabular}

Para poder efectuar un diagnóstico adecuado, se debe de clasificar a cada paciente en su estadio correcto que le corresponde, es decir si es un cáncer "in situ", tumor primario, invasión local o en su defecto con metástasis, ya que ello permitirá determinar el manejo así como el pronóstico de la enfermedad. Para ello es muy importante apoyarse del método clínico, el que incluye la Historia Clínica completa y detallada, exploraciones complementarias, pruebas de imagenología, de laboratorio, incluyendo los estudios de patología. Dichos estudios permitirán establecer el tipo de cáncer (de acuerdo al tipo de células del que se deriva), grado histológico (diferenciación celular), localización, tamaño del tumor maligno, extensión a nivel local o invasión a órganos vecinos, afección a ganglios linfáticos, existencia o no de metástasis ${ }^{45}$.

\section{Terapéutica}

Para realizar un manejo adecuado de los pacientes es indispensable hacer un diagnóstico correcto, ya que cada tipo de cáncer y según su etapa de desarrollo del mismo, será su tratamiento, el que puede incluir cirugía, trasplante de células progenitoras hematopoyéticas radioterapia o en su defecto quimioterapia. En tales casos lo que se persigue es curar al 100\% el problema o en su defecto si el cáncer se identifica muy avanzado, cuando el enfermo posee bajas probabilidades de curarse, lo que se pretende es mejorar la calidad de vida del paciente, a través de cuidados paliativos, para disminuir el dolor físico y psicológico (individual y familiar) $)^{1,9}$. 


\section{Cáncer}

En la actualidad se pueden curar el cáncer cervicouterino, mamario, colorrectal y bucal si se detectan tempranamente. Y en el caso de leucemias y linfomas en los niños, así como el seminoma testicular, tienen un porcentaje elevado de curación si los procedimientos del tratamiento son adecuados ${ }^{1}$.

En los Estados Unidos de Norteamérica y en México, la tasa de sobrevida por cáncer mamario a los cinco años es del $98 \%$ y cuando se detecta tempranamente en $66 \%{ }^{8}$.

Las posibilidades de curación en los casos de cáncer infantil son cambiantes a nivel internacional. Son más halagadores los resultados en países desarrollados, en donde el $80 \%$ de los pacientes sobreviven por cinco años o más, después de haber diagnosticado la enfermedad. En nuestro país esa cifra disminuye al 56\%. En los países en vías de desarrollo, disminuye la eficacia de los tratamientos a consecuencia de las carencias dentro de los hospitales, falta de medicamentos, las comorbilidades de los enfermos, la falta de capacitación del equipo de salud y la falta de recursos económicos de los padres. ${ }^{15}$ Tal es el caso de nuestro país, en donde, el 75\% de los casos se diagnostican en etapas avanzadas de la enfermedad, lo que aumenta el tiempo y el costo del tratamiento, y disminución de la probabilidad de curación?.

\section{Medidas de prevención}

Las medidas de prevención van encaminadas a evitar los factores de riesgo. Al respecto, se sabe que más del 30\% de las muertes a casusa de cáncer se podrían impedir modificando el consumo del tabaco, controlando el peso para que no exista obesidad, dieta sana con el consumo adecuado de frutas y verduras; actividad física; no consumir bebidas alcohólicas, ni tabaco; evadir infecciones por PVH y VHB, a través de la vacunación; no exponerse a radiaciones ionizantes (ocupacional o rayos $\mathrm{X}$ ) y no ionizantes (ultravioleta); controlando la calidad del aire en las grandes ciudades, así como el humo de la quema de combustibles dentro de los domicilios; y controlar riesgos ocupacionales. Al efectuar la prevención del cáncer, impidiendo éstos elementos causales, estamos realizando una estrategia más costo eficaz, para el control del cáncer ${ }^{1,15}$.

Las medidas de prevención, para cada uno de los principales tipos de cáncer se resumen en el cuadro siguiente (Cuadro 5): 
Cuadro 5. Medidas de prevención.

\begin{tabular}{|c|c|}
\hline Tipo de cáncer & Medidas de prevención \\
\hline Próstata & $\begin{array}{l}\text { Medición del antígeno prostático específico, mismo que debe ser } \\
\text { solicitado a los varones mayores de } 45 \text { años. La periodicidad del estudio } \\
\text { debe ser anual si el nivel del antígeno está dentro de los parámetros } \\
\text { normales ( } 0 \text { a } 4 \mathrm{ng} / \mathrm{mL} \text { ). Los pacientes con antecedentes familiares de } \\
\text { cáncer de próstata deben ser estudiados a partir de los } 40 \text { años de edad. } \\
\text { Un nivel por debajo de } 4 \text { no garantiza que un hombre no tenga cáncer de } \\
\text { próstata. Alrededor de un } 15 \% \text { de los hombres que tienen un antígeno } \\
\text { prostático específico menor de } 4 \text { presentará cáncer en una biopsia }{ }^{32,37} \text {. }\end{array}$ \\
\hline Mamario & $\begin{array}{l}\text { Autoexploración, exploración clínica y mastografía, así como } \\
\text { amamantart,20. }\end{array}$ \\
\hline $\begin{array}{l}\text { Cérvico- } \\
\text { uterino }\end{array}$ & $\begin{array}{l}\text { Informar a la población acerca de la enfermedad, factores de riesgo, } \\
\text { posibilidades de prevención, diagnóstico y tratamiento oportuno. } \\
\text { Promover la participación de grupos que hagan promoción para la } \\
\text { detección oportuna y tratamiento. Orientara las mujeres sobreeducación } \\
\text { sexual }{ }^{12} \text {. Educación deniños varones y niñas sobre sexualidad saludable, } \\
\text { adaptada según corresponda a la edad y la cultura, con la intención de } \\
\text { reducir el riesgo de transmisión de VPH (junto con otras infecciones } \\
\text { de transmisión sexual, incluido el VIH). Promoción o suministro de } \\
\text { condones a los que sean sexualmente activos. Circuncisión masculina } \\
\text { donde sea pertinente y apropiado. Reducir infecciones por VPH, ya } \\
\text { que si estas son persistentes, pueden causar cáncer cervicouterino. } \\
\text { Vacunación a las niñas de } 9 \text { a } 13 \text { años de edad (o de las edades previstas } \\
\text { en las directrices nacionales), antes de que inicien su actividad sexual. } \\
\text { Tamizaje de todas las mujeres de } 30 \text { a } 49 \text { años de edad (o edades } \\
\text { determinadas por las normas nacionales) para identificar las lesiones } \\
\text { precancerosas, generalmente asintomáticas. A partir de los } 30 \text { años, } \\
\text { inspección visual del cuello del útero tras la aplicación de ácido acético. } \\
\text { Pruebas de detección de PVH como método de cribado. Tratamiento de } \\
\text { las lesiones precancerosas identificadas antes de que progresen hacia } \\
\text { un cáncer invasor }{ }^{39} \text {. }\end{array}$ \\
\hline
\end{tabular}




\section{Cáncer}

Cuadro 5. Medidas de prevención (continuación).

\begin{tabular}{|c|c|}
\hline Tipo de cáncer & Medidas de prevención \\
\hline Piel & $\begin{array}{l}\text { Insistir a la población; evitar la exposición solar entre las } 11 \text { y } 15 \mathrm{hrs} \\
\text { (mayor riesgo), desde la infancia, al igual que las cámaras de bronceado, } \\
\text { especialmente aquellas personas en riesgo como piel blanca, cabello } \\
\text { rubio, ojos azules, con presencia de efélides (pecas). Evitar cualquier } \\
\text { tipo de autobronceadores y otras mezclas, como aceites de coco, de } \\
\text { tortuga, entre otros. En personas identificadas con riesgo: estimular la } \\
\text { autoexploración de toda la superficie cutánea (apoyados de un espejo } \\
\text { para áreas como el cuello, espalda, glúteos y piernas). Utilizar ropa } \\
\text { que cubra áreas fotoexpuestas, como mangas largas, sombreros con } \\
\text { ala ancha y lentes oscuros. Promover la aplicación de bloqueadores } \\
\text { que se deben aplicar sobre la piel seca y bajo la sombra. Usar películas } \\
\text { protectoras en las ventanas, utilizar lentes y bloqueadores solares para } \\
\text { la piel }{ }^{23,24,47} \text {. }\end{array}$ \\
\hline Gástrico & $\begin{array}{l}\text { Mejorar las instalaciones sanitarias y el acceso a agua potable para } \\
\text { reducir la infección por Helicobacter pylori; exámenes periódicos a } \\
\text { pacientes con gastritis atrófica, metaplasia intestinal, úlcera gástrica } \\
\text { especialmente por las condiciones poco favorables en educación, } \\
\text { ocupación, salud, vivienda y condiciones de empleo. Tratamiento } \\
\text { adecuado para la erradicación del Helicobacter pylori. Se recomienda } \\
\text { una dieta rica en frutas y verduras no feculentas; y evitar comidas } \\
\text { picantes e irritantes. Ingesta adecuada de ácido ascórbico que inhibe la } \\
\text { formación de N- nitroso }{ }^{25,48} \text {. }\end{array}$ \\
\hline $\begin{array}{l}\text { Pulmonar o } \\
\text { broncogénico }\end{array}$ & $\begin{array}{l}\text { Evitar el uso de tabaco, no tener contacto con materiales cancerígenos } \\
\text { como es el asbesto, utilizar medidas de protección en contingencia } \\
\text { ambiental; recomendar una dieta baja en grasas saturadas y aumento } \\
\text { en la ingesta de antioxidantes }{ }^{34,44} \text {. }\end{array}$ \\
\hline
\end{tabular}

Ya expuestas las medidas de prevención para cada uno de los tipos de cáncer más frecuentes que se presentan en nuestro país, podemos decir que las acciones generales para evitar la enfermedad incluyen: la realización de actividades físicas de manera regular; el mantenimiento del peso ideal para cada una de las personas; dieta sana, ricas en frutas y hortalizas, con limitación del consumo de carnes rojas y procesadas; impedir el consumo de alcohol, tabaco y la exposición a agentes químicos que se saben cancerígenos; vacunación; evitar infecciones e infestaciones ${ }^{5,13,15}$. 


\section{Principales problemas de Salud Pública en México}

A pesar de que conozcamos teóricamente las acciones encaminadas a impedir que aparezca la enfermedad, también hay que recordar que para que exista prevención, se debe tener acceso a los Servicios de Salud, así como los recursos necesarios para efectuarla, en cualquier nivel de prevención.

\section{Referencias}

1. Organización Mundial de la Salud. Datos y cifras sobre el cáncer [Internet]. 2016. Disponible en: http://www.who.int/cancer/about/facts/es/

2. Organización Mundial de la Salud. Cáncer [Internet]. 2016. Disponible en: http://www. who.int/topics/cancer/es/

3. Organización Mundial de la Salud. Clasificación estadística internacional de enfermedades y problemas relacionados a la salud. Décima Revisión. Ginebra, Volumen 1, Publicación científica No. 554. p. 36-39.

4. Fundación para la Excelencia y la Calidad de la Oncología. Generalidades en oncología. Recuperado de: http://www.fundacioneco.es/wp-content/uploads/2014/04/1. Generalidades.pdf.

5. Organización Mundial de la Salud. La batalla mundial contra el cáncer no se ganará únicamente con tratamiento [Internet]. 2016. Disponible en: http://www.who.int/ mediacentre/news/releases/2014/cancer-report-20140203/es/

6. Organización Mundial de la Salud. [Internet]. 2016. Disponible en: http://www.who. int/features/qa/15/es/

7. Stewart BW, Wild CW (eds.). World cancer report 2014. Francia: Organización Mundial de la Salud; 2014. ISBN (PDF) 978-92-832-0443-5.

8. Knaul FM, Arreola OH, Lozano R, Gómez DH. Numeralia de cáncer de mama. (2013 semana 23 del 23 al 29 de junio). Boletín Epidemiológico del Sistema Nacional de Vigilancia Epidemiológica de la Secretaría de Salud. 2013; 30(26):1-5. Recuperado de: http://www.epidemiologia.salud.gob.mx/doctos/boletin/2013/sem23.pdf

9. Secretaría de Salud. Cáncer infantil [Internet]. 2016. Disponible en: http://www.censia. salud.gob.mx/contenidos/vinculacion/campanas/campana_cancerinfantil2015.html 


\section{Cáncer}

10. Organización Mundial de la Salud. IARC Publications [Internet]. Disponible en: http:// www.iarc.fr/en/publications/books/wcr/index.php

11. Organización Mundial de la Salud. Preguntas frecuentes sobre el cáncer infantil [Internet]. 2016. Disponible en: http://www.who.int/cancer/media/news/Childhood_ cancer_day/es/

12. Secretaría de Salud. [Internet]. 2016. Disponible en: http://censia.salud.gob.mx/ contenidos/cancer/cancer_infantil.html

13. Organización Mundial de la Salud. Nueva guía de la OMS para la prevención y el control del cáncer cervicouterino [Internet]. 2016. Disponible en: http://www.who.int/ mediacentre/news/releases/2014/preventing-cervical-cancer/es/

14. Instituto Nacional de Cáncer. Manual de enfermería oncológica. Argentina: Editorial INC; 2012. p. 10.

15. Organización Mundial de la Salud. Prevención del cáncer [Internet]. 2016. Disponible en: http://www.who.int/cancer/prevention/es/

16. Organización Mundial de la Salud. Carcinogenicidad del consumo de carne roja y de la carne procesada [Internet]. 2016. Disponible en: http://www.who.int/features/qa/ cancer-red-meat/es/

17. American Cancer Society. Cáncer de próstata [Internet]. 2017. Disponible en: http:// www.cancer.org/acs/groups/cid/documents/webcontent/002319-pdf.pdf

18. wcrf.org. [Internet]. Reino Unido; World Cancer Research Fund International/American Institute for Cancer Research Continuous Update project report: diet, nutrition, physical activity, and prostate cancer [Internet]. 2 p. 4, 2014. [Consultado 12 oct 2016]. Recuperado de: www.wcrf.org/sites/default/files/Prostate-Cancer-2014-Report.pdf

19. Cuenca C, Despaigne A, Beltrán Y. Factores de riesgo de cáncer de mama en mujeres pertenecientes a un consultorio médico del Centro Urbano "José Martí". MEDISAN 2013; 17(9):4090. [Consultado 12 oct 2016]. Recuperado de: http://bvs.sld.cu/revistas/ san/vol17_9_13/san05179.pdf.

20. Secretaría de Salud. NOM-041-SSA2-2011, para la prevención, tratamiento, control y vigilancia epidemiológica del cáncer de mama. Diario Oficial de la Federación de 0609-11. [Consultado 12 oct 2016]. Recuperado de: http://dof.gob.mx/nota_detalle.php?c odigo $=5194157 \&$ fecha $=09 / 06 / 2011$. 


\section{Principales problemas de Salud Pública en México}

21. Secretaría de Salud. Guía de práctica clínica. Prevención y detección oportuna del cáncer cérvico uterino en el primer nivel de atención. México [Internet]. 2011. [citado 13 Oct 2016]:2. Recuperado de: http://www.cenetec.salud.gob.mx/descargas/gpc/ CatalogoMaestro/146_GPC_CACU/SS_146_08_GRR_CaCU.pdf

22. Organización Mundial de la Salud. Human papillomavirus (HPV) and cervical cancer [Internet]. 2016. http://www.who.int/mediacentre/factsheets/fs380

23. Secretaría de Salud. Guía de práctica clínica prevención diagnóstico y tratamiento del carcinoma basocelular. México [Internet]. 2013. [citado 13 Oct 2016]: 7-15. Recuperado de: http://www.cenetec.salud.gob.mx/descargas/gpc/CatalogoMaestro/IMSS_360_13_ CA_BASOCELULAR/360GER.pdf/es/

24. Secretaría de Salud. Guía de práctica clínica prevención primaria y detección oportuna del melanoma cutáneo en adultos en el primer nivel de atención. México, [Internet]. 2009. [citado 13 Oct 2016]: 20. Recuperado de: http://www.cenetec.salud.gob.mx/descargas/ gpc/CatalogoMaestro/099_GPC_Melanoma/MELANOMA_EVR_CENETEC.pdf

25. Hernández RR, López CL. Dieta y cáncer gástrico en México [Internet]. Rev Salud Pública Méx. 2014; 56(5):555-558 [citado el 12 oct 16]. Recuperado de: http://www. scielo.org.mx/pdf/spm/v56n5/v56n5a23.pdf

26. Acuña TM, Román BE. Cáncer de estómago. Guías diagnósticas. Hospital General de México [Internet]. 2013 [citado 12 Oct 2016]: 1-2. Recuperado de: http://www.hgm. salud.gob.mx/descargas/pdf/area_medica/onco/guias/cancer_Estomago.pdf

27. Secretaría de Salud. Guías diagnósticas. Cáncer de pulmón. Hospital General de México [Internet]. 2013[citado el 12 oct 16];1. Recuperado de: http://www.hgm.salud. gob.mx/descargas/pdf/area_medica/onco/guias/cancer_Pulmon.pdf

28. Cuervo MF, Carrillo BJ. Neoplasias pulmonares broncogénicas [internet]. Rev Neumo Colombia 2003; 16(1):51. Recuperado de: http://www.scielo.org.co/pdf/rcneum/v16n1/ v16n1a8

29. Sánchez C. Conociendo y comprendiendo la célula cancerosa: fisiopatología del cáncer. Rev Med Clin Condes. Ago 2013; 24(4):553-562.

30. prostatecanceruk.org. [Internet]. Reino Unido; Prostate Cancer UK.Enlarged prostate. A guide to diagnosis and treatment. p. 10-11, 2015. [Consultado 12 oct 2016]. Recuperado de: http://prostatecanceruk.org/media/41599/enlarged_prostate_booklet.pdf 


\section{Cáncer}

31. Cancer.org. [Internet]. EUA: American Cancer Society; Cáncer de próstata [Actualizado 20 oct 2016; consultado 12 oct 2016]. Recuperado de: http://www.cancer.org/acs/ groups/cid/documents/webcontent/002319-pdf.pdf

32. Cancer.org. [Internet]. EUA: American Cancer Society; Cáncer de mama; [Actualizado 24 may 2016; consultado 12 oct 2016]. Recuperado de: http://www.cancer.org/acs/ groups/cid/documents/webcontent/002284-pdf.pdf

33. Secretaría de Salud. Guía de práctica clínica abordaje diagnóstico de melanoma maligno. México [Internet]. 2010. [citado 13 Oct 2016]: 39-40. Recuperado de: http://www. cenetec.salud.gob.mx/descargas/gpc/CatalogoMaestro/547_GPC_Melanomamaligno/ GER_MelanomaMaligno.pdf

34. Río RT, Jiménez H. Actualización en el carcinoma broncogénico. Monografías NEUMOMADRID [Internet]. 2012; 19:63,69. Recuperado de: http://neumomadrid.org/ descargas/monog_neumomadrid_xix.pdf

35. Clase de residentes 2009. Manejo de complicaciones graves en la paciente oncológica. Recuperado de: http://www.hvn.es/servicios_asistenciales/ginecologia_y_obstetricia/ ficheros/cr.complicaciones_oncologicas.pdf

36. uroweb.org [Internet]. Países Bajos; European Association of Urology. Guidelines on Prostate Cancer. 2014 [Consultado 12 oct 2016]. p. 18-19. Recuperado de: https:// uroweb.org/wp-content/uploads/1607-Prostate-Cancer_LRV3.pdf

37. Sánchez L., Paredes C., Hernández O., Sánchez I. El antígeno prostático específico Su papel en el diagnóstico del cáncer de próstata. Rev Med Inst Mex Seguro Soc. 2013;51(2):124-6. [Consultado 12 oct 2016]. Recuperado desde http://www.medigraphic. com/pdfs/imss/im-2013/im132a.pdf

38. Secretaría de Salud. Oncología 111. Guías diagnósticas 2013. Cáncer de mama. Hospital General de México. [Consultado 12 oct 2016]. Recuperado de: http://www.hgm.salud. gob.mx/descargas/pdf/area_medica/onco/guias/cancer_Mamario.pdf

39. OMS, Organización Panamericana de la Salud. Control integral del cáncer cervicouterino: guía de prácticas esenciales. 2 ed. Washington, DC [Internet]. 2016. [citado 13 Oct 2016]: 55 y 139. Recuperado de: http://iris.paho.org/xmlui/bitstream/ handle/123456789/28512/9789275318799_spa.pdf?sequence=1\&isAllowed=y\&ua=1

40. Gutiérrez C, Sordo C. Cáncer de piel y radiación solar: experiencia peruana en la prevención y detección temprana del cáncer de piel y melanoma. Revista Peruana de 


\section{Principales problemas de Salud Pública en México}

Medicina Experimental y Salud Pública [Internet] 2013: 30 [Citado 13 de Oct 2016] Recuperado de: http://www.redalyc.org/articulo.oa?id=36326085021

41. Medina FH. Cáncer gástrico. Rev Gastroenterol Mex. [Internet]. 2012; [citado el 12 oct 16]; 76(supl1):88-91. Recuperado de: http://www.revistagastroenterologiaMéxico.org/ es/cancer-gastrico/articulo/X0375090611252746/

42. Rollán A. Diagnóstico precoz de cáncer gástrico. Propuesta de detección y segumiento de lesiones premalignas gástricas: protocolo ACHED. Rev Méd Chile [Internet]. 2014 [citado el 12 oct 16]; 142(9):1185-1187. Recuperado de: http://www.scielo.cl/pdf/rmc/ v142n9/art13.pdf

43. García LR. Carcinoma broncógenico [internet]. Grupo Cooperativo Médico Quirúrgico de Carcinoma Broncogénico del Hospital Universitario 12 de Octubre; 2010 [actualizado feb 14]: 8. Recuperado de: http://www.mbeneumologia.org/mbe/actividadcientifica/ shtml/pdf/pautacb2013_abreviada.pdf

44. Rodríguez CA, Martín RA, Hernández CK. Concordancia clínica, tomográfica y anatomopatológica en el cáncer de pulmón. Rev MEDISAN [Internet]. 2011; 15(5):650. Recuperado de: http://scielo.sld.cu/pdf/san/v15n5/san12511.pdf

45. Fundación para la Excelencia y la Calidad de la Oncología. Generalidades en oncología. Recuperado de: http://www.fundacioneco.es/wp-content/uploads/2014/04/1. Generalidades.pdf

46. Martel C, Ferlay J, Franceschi S. Global burden of cancers attributable to infections in 2008: a review and synthetic analysis. The Lancet Oncology. 2012;13: 607-615.

47. Secretaría de Salud. La piel es susceptible de padecer enfermedades por la radiación solar. Rev MéxicoSano [Internet] 2015. 3; marzo (20): 9. Recuperado de: http://portal. salud.gob.mx/contenidos/sala_prensa/México_sano/pdf/MS20.pdf

48. Meza J, Montano L. El cáncer gástrico en México: mejoría, pero aún con mucho por hacerse. Rev Gatroenterol Mex [Internet]. 2016 [citado el 12 oct 16]; 81(2):63-64. Recuperado de: http://www.revistagastroenterologiaMéxico.org/es/el-cancer-gastricoMéxico-mejoria/articulo/S0375090616000197/. 


\section{Infecciones de transmisión sexual}

\section{Mtro. Juan Miguel Espinosa Ortiz}

\section{Introducción}

A lo largo de la historia, las Infecciones de Transmisión Sexual (ITS), han sido conocidas con distintos nombres: Enfermedades de Transmisión Sexual, Enfermedades Venéreas y actualmente ITS. A pesar de que en la actualidad se consideran un problema de Salud Pública, aún hay muchas creencias erróneas del propio personal de salud en torno a ellas, desde el cómo identificarlas, diagnosticarlas y tratarlas, el inapropiado manejo y conocimiento de las medidas preventivas o de los factores de riesgo en las poblaciones vulnerables. Las causas de estas ideas son más sociales que médicas, y van desde el prejuicio, el mito y la idea popular, entre ellas encontramos hacia los hombres que tienen sexo con hombres, mujeres que tienen sexo con mujeres, personas transexuales y transgénero, o para aquellos individuos que tienen múltiples parejas sexuales.

La Organización Mundial de la Salud (OMS), en el año 2013, refiere que diariamente más de un millón de personas contraen una ITS, y que anualmente, más de 500 millones de personas, adquieren una de las cuatro infecciones siguientes: clamidiasis, gonorrea, sífilis o tricomoniasis, y dos de ellas, la gonorrea y la sífilis, se consideran de las menos frecuentes ${ }^{1}$. Los informes reportan que existen más de 530 millones de nuevas infecciones anuales por Virus del Herpes tipo 2 (HSV2) o herpes genital; y 290 millones de mujeres infectadas por el Virus del Papiloma Humano (VPH). La Infección por el Virus de la Inmunodeficiencia Humana (VIH), sigue siendo un gran problema de Salud Pública ${ }^{1,2}$.

A lo largo de este capítulo abordaremos las generalidades más importantes desde el punto de vista epidemiológico, su contexto social y en relación a su presentación clínica. 


\section{Principales problemas de Salud Pública en México}

\section{Concepto}

Las ITS, son un grupo de entidades clínicas fisiopatológicas, adquiridas en su mayoría por vía Sexual, ya sea por vía genital, anal u oral que son causados por diferentes agentes biológicos. Algunas de ellas se pueden adquirir por vía cutánea, mientras que otras pueden depender de otras vías como la transplacentaria, la sanguínea, durante el embarazo y el parto. Existen pacientes que pueden portar una infección sin manifestar ninguna sintomatología (asintomáticos). Los datos clínicos más comunes de las ITS pueden incluir flujos vaginales, ulceras genitales y dolor. Hay más de 30 agentes etiológicos relacionados con éstas infecciones, de las cuales, según la OMS ocho poseen mayor frecuencia, de las cuales cuatro son curables (sífilis, gonorrea, clamidiasis y tricomoniasis); en cuanto a las otras cuatro, son virales y a pesar de ser incurables, se pueden disminuir o tratar para mejorar la calidad de vida de los pacientes, mediante medicamentos y tratamientos integrales, estas patologías son herpes tipo 2, hepatitis B, VIH y VPH. En los últimos años, tal vez debido a los estilos de vida, como los nuevos hábitos sexuales, ha habido un aumento en la incidencia de las vulvovaginitis producida por Cándida albicans, molusco contagioso y vaginosis bacteriana ${ }^{2}$.

\section{Clasificación}

La clasificación según la OMS, incluye ITS virales y no virales, aunque también se pueden subdividir, por ejemplo, en el caso de los virus, podemos sub-clasificarlos en los que se replican en la piel y mucosas, por ejemplo, el virus del herpes tipo 1, VPH y virus del molusco contagioso.

Se utiliza la Clasificación Internacional de Enfermedades décima edición (CIE-10), para fines de registro y vigilancia epidemiológica y le competen a las ITS los siguientes números 3 :

A50 Sífilis congénita.

A51 Sífilis precoz.

A52 Sífilis tardía.

A53 Otras sífilis y las no especificadas. 


\section{Infecciones de transmisión sexual}

A54 Infección gonocócica.

A55 Linfogranuloma (venéreo) por clamidias.

A56 Otras enfermedades de transmisión sexual debidas a clamidias.

A57 Chancro blando.

A58 Granuloma inguinal.

A59 Tricomoniasis.

A60 Infección anogenital debida a virus del herpes [herpes simple].

A63 Otras enfermedades de transmisión predominantemente sexual, no clasificadas en otra parte.

A64 Enfermedad de transmisión sexual no especificada.

B37.3 Candidiasis de la vulva y de la vagina

B37.4 Candidiasis de otras localizaciones urogenitales

Desde el punto de vista clínico, se utiliza la clasificación de los CDC (Centros para el Control y la Prevención de Enfermedades de los Estados Unidos de Norteamérica), conforme a lo siguiente ${ }^{3}$ :

a) Enfermedades caracterizadas inicialmente por úlceras genitales: Chancroide, infección genital por Virus de Herpes simplex, granuloma inguinal y sífilis.

b) Enfermedades caracterizadas por uretritis y cervicitis: Linfogranuloma venéreo, uretritis gonocócica, uretritis no gonocócica, cervicitis mucopurulenta e infección por Ureaplasma urealyticum y Mycoplasma hominis.

c) Enfermedades caracterizadas por flujo vaginal: La vaginosis bacteriana y la candidiasis urogenital no están consideradas como ITS; sin embargo, por ser las causas más 


\section{Principales problemas de Salud Pública en México}

frecuentes de flujo vaginal que requieren de tratamiento médico, se incluyen en este apartado. Pueden ser indicadoras de otros problemas de salud y sólo en algunos casos de vaginosis bacteriana se establece la transmisión sexual; 2) la Tricomoniasis; 3) Enfermedad pélvica inflamatoria (EPI), y la 4) infección por el virus del papiloma humano (VPH).

d) ITS prevenibles por vacunación: Virus de la hepatitis A (VHA) y por el virus de la hepatitis B (VHB).

e) Ectoparásitos: Escabiasis y por pediculosis pubis.

\section{Epidemiología}

Según las cifras de la OMS, a nivel mundial, en el año 2013, las ITS son una de las 5 principales causas por las cuales los adultos acuden a la consulta médica; cada día más de un millón de personas contrae una infección de éste tipo; al año 500 millones de personas adquieren una de las cuatro ITS curables más frecuentes (Sífilis, Gonorrea, Clamidiasis y Tricomoniasis) y otros tantos son portadoras del Virus del Herpes tipo 2; además 290 millones de mujeres están infectadas por el VPH, provocando más de 530000 casos de cáncer cérvico uterino y 275000 defunciones; la sífilis durante el embarazo provoca 305 mil muertes fetales y neonatales; y en el año 2008, existían 33 millones de personas viviendo con HIV-SIDA ${ }^{3,4}$. De acuerdo a la OMS, el número de casos de ITS curables en el mundo para el año 2012 fueron 357 millones (América 64 millones, África 63 millones, Región del mediterráneo 31 millones, Europa 18 millones, Asia suboriental 39 millones y Región del Pacífico Occidental 142 millones) ${ }^{1,4}$.

En México, el Instituto Nacional de Estadística y Geografía (INEGI) en 2015, en un trabajo hecho a propósito del día internacional de la juventud, refiere que los jóvenes de 15 a 24 años representan el 25.7\% de la población de México; y que el 61.8\% de las jóvenes de 15 a 19 años sexualmente activos, no uso un método anticonceptivo en su primera relación sexual. Y tres de cada 10 jóvenes de 15 a 29 años han consumido bebidas alcohólicas ${ }^{5,6}$. Según la Encuesta Nacional de Salud y Nutrición 2012 (ENSANUT-2012), del total de la población general de 15 a 49 años, el $84.6 \%$ de los hombres y el 81.6\% de las mujeres eran sexualmente activos. ${ }^{5,6,7,8}$ De acuerdo con la Dirección General de Epidemiología, de la Secretaría de Salud en el 2012, reporta9: 


\section{Infecciones de transmisión sexual}

- 112 casos de sífilis congénita, $49.1 \%$ en hombres y 50.9\% en mujeres

- 3038 casos de sífilis adquirida, 54.9\% hombres y $45.1 \%$ mujeres

- 1389 casos de sífilis genitourinaria, 39 \% hombres y 61 \% mujeres

Estas cifras de la Secretaría de Salud, contradicen la idea de algunos médicos sobre la sífilis, los que consideran que ya no es representativa, como parte de las ITS.

En los anuarios de morbilidad de la Dirección General de Epidemiología en el año 2015, refiere 336,427 casos nuevos de infecciones por el VPH, de ellos el 98\% se presentaron en las mujeres; con una incidencia para ambos sexos de 27.6 por cada 100 mil habitantes, para los hombres de 1.91 y 52,13 en mujeres ${ }^{10}$.

El VIH-SIDA, aún sigue siendo un problema de Salud Pública en México, ya que en el periodo de 1983 a 2012, cuenta con una cifra acumulada de 160,860 casos de SIDA, 82.1\% en hombres y $17.9 \%$ en las mujeres. Para el año 2011, la incidencia de hombres contra la de las mujeres fue de 5.36 y 1.5 respectivamente, con una razón hombre-mujer de 3.5:1. En cuanto a la distribución geográfica, la mayoría de los casos se presentan en el Distrito Federal (15.6\%), Estado de México (10.8\%), Veracruz (9.2\%) y en Jalisco $(7.6 \%)^{3}$.

Según CENSIDA, en el periodo de 1986 al 2004, las demás ITS poseen una tendencia descendente, con las incidencias siguientes: Sífilis adquirida de $6.3 \%$ a $1.4 \%$, la sífilis congénita de $0.2 \%$ a $0.1 \%$, el linfogranuloma venéreo de $0.5 \%$ a $0.2 \%$, chancro blando de $1.2 \%$ a $0.6 \%$, gonorrea de 19.1 a 12 , hepatitis B de $0.6 \%$ a $0.5 \%$; con un incremento en la tricomoniasis de 31.6 a 95.3 y de Herpes Genital de 1.1 a $2.7 \%$, por cada 10 mil habitantes ${ }^{11}$.

Además de la magnitud de las ITS, éstas provocan estigma social, problemas legales y de pareja que pueden dificultar el diagnóstico y manejo adecuado y oportuno de los pacientes y de las personas inmersas en el caso índice.

El modo de transmisión de las ITS se efectúa a través de las relaciones heterosexuales (41\%), homosexuales (32\%), bisexuales (22\%); por drogas inyectables, por el uso de agujas infectadas (2\%); vía materno-fetal (1\%); y por transfusión sanguínea, que en la actualidad en nuestro país es poco probable por el control de donadores de sangre, ya que se verifica 


\section{Principales problemas de Salud Pública en México}

que no estén enfermos ni sean portadores de éstas enfermedades transmisibles. A pesar de estos registros epidemiológicos, existe la idea social (errónea) de que los homosexuales, solo por serlo, están en un mayor riesgo de contraer una infección por VIH. La vía de entrada y salida la constituyen la genital, anal y oral ${ }^{12,13}$.

\section{Causalidad}

Las ITS son causadas por bacterias, protozoarios, virus, hongos y parásitos y los agentes etiológicos dependen de la enfermedad (Cuadro 1$)^{6,13,14}$ :

Cuadro 1. Agentes biológicos de las ITS.

\begin{tabular}{|l|l|}
\hline \multicolumn{1}{|c|}{ Enfermedad } & \multicolumn{1}{c|}{ Agente biológico } \\
\hline Sífilis & Treponema pallidum \\
\hline Gonorrea & Neisseria gonorrhoeae \\
\hline $\begin{array}{l}\text { Clamidiasis y } \\
\text { linfogranuloma } \\
\text { venéreo }\end{array}$ & Chlamydia trachomatis \\
\hline Tricomoniasis & Trichomonas vaginalis \\
\hline Candidiasis & Cándida albicans \\
\hline Vaginosis bacteriana & Gardnerella vaginalis \\
\hline Herpes genital & Virus Herpes simplex tipo II \\
\hline Hepatitis B & Virus de la hepatitis B (VHB) \\
\hline Papiloma & Virus del Papiloma Humano (VPH) \\
\hline VIH-SIDA & Virus de inmunodeficiencia humana (VIH), el VIH-1 y el VIH-2 \\
\hline
\end{tabular}

La sífilis, es producida por el Treponema pallidum, esta espiroqueta tiene un genoma pequeño y carece de genes que codifican las funciones metabólicas y factores de virulencia clásicos; posee un metabolismo lento para poder sobrevivir en los tejidos; puede permanecer latente y asintomática por tiempos prolongados.

La gonorrea, también conocida como blenorrea o blenorragia, es causada por la bacteria Neisseria gonorrhoeae o Gonococo; es un diplococo gram negativo aerobio, con un diámetro de 0.8 micrómetros y cuyo único hospedero natural es el ser humano, que afecta los 


\section{Infecciones de transmisión sexual}

epitelios cilíndricos y de transición, uniéndose a las células por unas fimbrias llamadas Pili; son microrganismos termolábiles, mueren con la desecación, luz, sol, calor humedad y a la exposición de diferentes desinfectantes; posee en algunos acasos resistencia a los antimicrobianos.

La clamidiasis y linfogranuloma venéreo, son originados por Chlamydia Trachomatis. Chlamydiaceae, es una familia de parásitos intracelulares obligados relacionados con bacterias gram negativas. El linfogranuloma venéreo es originada por $\mathrm{C}$. trachomatis de los tipos L1 a L3.

La tricomoniasis es causada por Trichomonas vaginalis, que es un protozoario patógeno flagelado perteneciente al orden Trichomonadida, es cosmopolita y tiene una única forma de vida en su ciclo vital, el trofozoíto, ya que no forma quistes. El trofozoito tiene un tamaño aproximado de 10-20 $\mu \mathrm{m}$ de longitud y una morfología piriforme; posee 5 flagelos, cuatro son anteriores y libres, y el quinto se dirige hacia la parte posterior del cuerpo celular que no tiene porción libre del flagelo.

La candidiasis, es originada por la Cándida albicans, que son levaduras de hongos de desarrollo unicelular, que se adaptan a una temperatura de $37^{\circ} \mathrm{C}$ y pueden ocasionalmente ser patógenas para el humano.

La vaginosis bacteriana, es producto de la Gardnerella vaginalis, la cual es una bacteria que produce succinato, necesario para la proliferación de anaerobios, los cuales producen aminopeptidasas que liberan aminoácidos que a su vez son descarboxilados para producir diaminas. Es un bacilo inmóvil no encapsulado de 0.5 por 1.5 a $3 \mathrm{~mm}$, anaerobio facultativo, catalasa y oxidasa negativa con una toxina citotóxica que rompe las células.

El herpes genital aparece a consecuencia del Virus herpes simplex tipo II (VHS-2), pertenece a la familia Her-pesviridae, son virus con ADN, icosaédricos y envueltos, de $150 \mathrm{~nm}$ de diámetro; persisten de manera latente y pueden reactivarse; el virus no sobrevive en el exterior del cuerpo a temperatura ambiente. Cabe aclarar que existen dos tipos de Virus Herpes simplex, el uno y el dos. El VHS-2 es el causante del herpes genital y el VHS-1 produce el herpes labial ${ }^{15}$. 


\section{Principales problemas de Salud Pública en México}

La hepatitis B, es producto del VHB, que es un virus ADN hepatotrópico, quien puede transmitirse sexualmente; pertenece a la familia Hepadnaviridae.

El papiloma, es a consecuencia del $V P H$, los cuales son virus ADN de gran peso molecular; incluido entre los papovavirus (PApiloma-POlioma-VAcuolizantes); existen más de 100 tipos diferentes para cualquier infección y con respecto a las infecciones genitales, son 40 tipos diferentes de VPH, que infectan a la piel y a las mucosas ano-genitales.

El VIH/SIDA, es producido por el VIH, el cual es un Retrovirus, de la Familia de los Lentiviridae, en este grupo los que provocan ésta enfermedad en humanos, son el VIH-I y el VIH-2 $2^{4,11,12,16,17,18,19}$.

- Factores de riesgo

Los factores de riesgo que aumentan la posibilidad de ITS son múltiples y pueden ser biológicos, conductuales y sociales ${ }^{11,17,18,20,21}$ :

Los factores biológicos más representativos son:

a) La edad: Las características de la mucosa vaginal y cervical hacen más vulnerables a las mujeres adolescentes y entre más jóvenes sean, el riesgo aumenta en la misma proporción.

b) Estado inmunológico: El estado Inmunológico del hospedero y la virulencia del agente infeccioso aumenta la posibilidad de adquirir una ITS.

c) Tipo de relación sexual: Es más fácil el contagio a través de las mucosas de vagina, boca y recto que a través de la piel, y en personas que no se protegen con condón.

d) Relaciones coitales sin protección, la falta de lubricación, la cantidad o duración de la exposición y una mayor vascularización en la zona pueden aumentar el riesgo de transmisión, así como infecciones previas, los cambios hormonales en el ciclo menstrual y la presencia de hemorroides y otras patologías ano-rectales.

e) La circuncisión es un factor protector hasta en un $68 \%$. 


\section{Infecciones de transmisión sexual}

Los factores conductuales más sobresalientes son:

a) Tener relaciones sexuales bajo el efecto del alcohol $u$ otra droga.

b) Tener varias parejas sexuales de manera simultánea sin protección.

c) Cambiar frecuentemente de pareja sexual.

d) Relaciones sexuales "casuales" o adquisición de sexo servicio sin protección.

e) Compartir juguetes sexuales sin la limpieza ni la protección necesaria, utilizados en vagina, ano-recto y boca.

f) Relaciones sexuales con penetración y sin protección.

g) Haber tenido una ITS en el último año.

h) Tener relaciones sexuales bajo coerción o violencia

Entre los factores sociales encontramos:

a) Diferencia de poder: Cuando en la relación sexual existen jerarquías; abuso de poder económico; diferencia significativa de edad; aspectos culturales que favorecen la discriminación, limitación cultural para el uso de condones; una mujer u hombre que es penetrado mediante el uso de la violencia, es vulnerable socialmente y queda en desventaja para ser infectado.

b) Contextos de mayor riesgo: Grupos en situación de vulnerabilidad, por estar en una situación que dificulta la prevención de las mismas, tales como quienes viven en privación de la libertad, violencia social, estigma, discriminación o situación de calle. Los usos y costumbres o el orden social dominante dificultan la protección en las prácticas sociales.

c) Hombres que tienen relaciones sexuales con hombres (HSH). 


\section{Principales problemas de Salud Pública en México}

d) Personas que venden servicios sexuales y sus clientes sin protección.

e) Personas con varias parejas sexuales simultaneas sin protección.

f) Personas con alejamiento momentáneo de sus parejas sexuales, tales como azafatas, camioneros, vendedores foráneos, soldados, etc.

g) Personas privadas de su libertad.

h) Personas que viven violencia sexual, principalmente adolescentes.

i) Jóvenes sin información o sin facilidades para conseguir condones.

j) Poblaciones indígenas y marginadas.

k) Población migrante.

1) Mujeres embarazadas.

\section{Fisiopatología}

A continuación se desarrolla la fisiopatología de algunas de las ITS22:

- Sífilis

Es una infección sistémica y crónica, causada por Treponema pallidum, trasmitida por relaciones sexuales y vía placentaria; es curable si se trata a tiempo; se caracteriza por presentar períodos de actividad interrumpidos por periodos de latencia. Debido a esta característica de intermitencia y evolución a estadios cada vez más severos, es necesario hacer los diagnósticos diferenciales pertinentes.

Tras un periodo de incubación promedio de tres semanas a partir de la transmisión, aparece un chancro (lesión primaria), con crecimiento linfático regional inguinal o bubón, seguido, por una fase de bacteriemia secundaria que cursa con lesiones mucocutáneas y adenitis linfática generalizada. A esta fase sigue un periodo de latencia subclínica prolongado, que 


\section{Infecciones de transmisión sexual}

puede durar años si la infección no es detectada y curada. Posterior a esta se desarrolla la fase tardía (sífilis terciaria) caracterizada por lesiones destructivas a nivel mucocutáneo, osteoarticular, y en distintos parénquimas llamadas "gomas"; se pueden presentar también aortitis, carditis, formación de aneurismas y afección sintomática del sistema nervioso central.

Las manifestaciones mucocutáneas, constitucionales y parenquimatosas ${ }^{22}$, de la sífilis secundaria pueden aparecer entre las 6 y 8 semanas después de la aparente curación del chancro primario, incluso, puede aparecer varios meses después de la curación del mismo, en algunos casos pueden alcanzar la fase de latencia sin haber presentado lesiones secundarias. Las lesiones sueles ser hiperqueratosis de la epidermis, proliferación capilar con tumefacción endotelial en la dermis papilar y una gran presencia de polimorfonucleares en la dermis e infiltración perivascular por monocitos. Las alteraciones del líquido cefalorraquídeo se observan hasta en el $40 \%$ de los infectados. Las alteraciones de la función hepática se presentan hasta en un 25\%, el $85 \%$ de los pacientes presentan linfadenopatías generalizadas. Las lesiones secundarias remiten en un promedio de 2 a 6 semanas para entrar a fase de latencia ${ }^{22}$.

Las lesiones secundarias suelen ser difusas y simétricas. Las pápulas secundarias pueden ser más evidentes en zonas calientes y húmedas tales como ano, vulva, escroto, pliegues cutáneos hasta en el $10 \%$ de los pacientes.

Durante el periodo de Latencia el organismo infectado pasa por un proceso que dista mucho de ser de inactividad, el treponema continúa con un proceso invasivo que precede a las manifestaciones de la sífilis terciaria, el treponema en esta etapa puede provocar malformaciones en caso de embarazo.

En la Sífilis Terciaria, que puede expresarse desde pocos meses hasta más de 40 años del primocontacto con el Treponema, se caracteriza por lesiones destructivas sistémicas, tales como neurolúes y meningitis en el sistema nervioso, en el corazón puede expresarse como aortitis, insuficiencia aortica, aneurisma sacular y estenosis de arterias coronarias ${ }^{23}$.

\section{- Gonorrea}

Esta infección, es adquirida por Neisseria a través de la vía genital, genital oral y genital anal, la que puede ser sintomática y asintomática; afecta a distintos órganos del cuerpo, 


\section{Principales problemas de Salud Pública en México}

principalmente a aquellos en donde hubo contacto con la persona infectante, como son los órganos sexuales, ano-recto, faringe y cavidad oral ${ }^{24,25}$.

- Clamidiasis

Chlamydia trachomatis es una bacteria intracelular, es caracterizada por su modo único de multiplicación, esta característica hace que tenga su propio orden, las Chlamidiales, cuyos serotipos $\mathrm{D}$ a $\mathrm{K}$ se relacionan con infecciones neonatales y genitales tales como uretritis y cervicitis; los serotipos LGV (L1, L2 y L3) están relacionados con linfogranuloma venéreo; y los serotipos A, B, Ba y C están relacionados con tracoma y la queratoconjuntivitis de inclusión.

Esta bacteria se identifica en el 23 a $55 \%$ de los casos de uretritis no gonocócica, además de que se asocia a infecciones por Neisseria gonorrhoeae en 60 a 80 \%. Su periodo de incubación es de 21 días a partir del contacto de contagio. Es una de las infecciones consideradas por estricto contacto físico, ya sea por contacto genital, anal u oral. Las personas infectadas por la bacteria Chlamydia trachomatis, puede dar lugar a uretritis en más del $60 \%$ de los casos.

La cervicitis purulenta es asintomática en la mayoría de las mujeres, en ocasiones, principalmente cuando se asocia con otro gonococo o con algún hongo, puede causar disuria.

Algunos estudios (25) realizados en México mencionan una prevalencia de mujeres asintomáticas que asistieron como usuarias de métodos anticonceptivos de entre 3 y 5\%, estas cifras aumentan a más de $20 \%$ en las clínicas de ITS's. La prevalencia en embarazadas varía de 2 hasta 37\% y en mujeres que toman anticonceptivos orales y que no acuden al servicio médico a revisión, las posibilidades de esta infección asociada a un ectropión cervical son más altas. En el caso de los hombres asintomáticos detectados con Clamidia solo se relaciona con $7 \%$.

La prevalencia de la enfermedad también varía por la edad, hábitos sexuales, y estrato económico. Se calcula que el $28 \%$ de las mujeres que tienen cervicitis por Clamidia, desarrollarán Enfermedad Pélvica Inflamatoria (EPI), infertilidad por salpingitis entre el 13 y el $75 \%$ dependiendo de los episodios de recurrencia de la mujer. Además del incremento, en las mujeres que tienen salpingitis del riesgo de embarazos ectópicos. 


\section{Infecciones de transmisión sexual}

En el hombre la manifestación más común, relacionada hasta con $40 \%$ de los infectados es la uretritis, la cual suele ser dolorosa (muy dolorosa), con secreción de pus a través de la uretra, aunque al inicio de esta manifestación puede haber solo disuria con la orina más concentrada por la mañana. Puede haber orquitis dolorosa uní o bilateral antes o después de la descarga purulenta uretral.

La faringitis por Clamidia también es un cuadro presente en hombre y mujeres que han presentado Clamidia a nivel genital $1^{24,25,26}$.

- Herpes Genital

Es una Infección de Transmisión Sexual que no solo se manifiesta como genital, también puede ser el causante de lesiones en la boca.

Es producida por el Virus del Herpes Simple del tipo 1 y 2, el cual presenta lesiones parecidas, independientemente si es 1 o 2. De 80 especies identificadas, el ser humano es afectado solo por 5, y de estos el ser humano es el único reservorio natural. Puede adquirirse y provocar lesiones en boca, ano o genitales. Su periodo de incubación es de 4 a 8 días. Podemos dividir su patogenia en 5 fases, Infección Primaria, Mucocutánea, Infección Ganglionar aguda, Latencia, Reactivación e Infección Recurrente.

La primoinfección es generalmente asintomática, aunque se puede presentar con lesiones vesiculares. El inicio de la lesión es en el sitio del contacto, en las membranas de las mucosas, en las cuales provoca una lisis del tejido, diseminándose a tejidos adyacentes y neuronas que inervan el sitio de la infección inicial o donde se dio el contacto. Aparentemente no hay lesión en el nervio afectado, pero puede haber dolor crónico aun cuando la lesión mucocutánea aparentemente haya curado y se puede reactivar con diferentes estímulos como irritación por la ropa, otras ITS, enfermedades sistémicas o inmunosupresión ${ }^{3,8,12,20}$.

- Infección por Virus del Papiloma Humano IVPH

Por su trascendencia, es una ITS de las que más atención se presta y significa una gran preocupación, también por su amplio espectro clínico, la capacidad oncogénica de algunos genotipos virales y las frecuentes recidivas que pueden seguir a la infección. 


\section{Principales problemas de Salud Pública en México}

Es un DNA virus de doble cadena, sin envoltura, perteneciente a la Familia Papovaviridae, y dependiendo del tipo específico es el tejido o tejidos que afecta, En los adultos la transmisión sexual es predominante, adquiriendo esta infección más de 5 millones de personas al año, y de estos, un 75 \% en el rango de edad de 15 a 24 años, en niños puede ser un dato de abuso sexual.

En relación a su presentación clínica, se puede clasificar de la siguiente manera:

1. Verruga común o verruga vulgar, que es causada por los tipos 2 y 4 .

2. Verruga plana, que es causada por los tipos 2,3 y 5 .

3. Verruga plantar, que es causada por los tipos $1,2,4$ y 10 .

4. Verruga genital, a la cual pertenecen los virus que provocan verrugas acuminadas o condiloma acuminado y son usualmente los tipos 6 y 11.

5. Lesión o mancha cervical, que son los que más se relacionan con el cáncer cervical son los tipos 16, 18, 31, 33, 35, 45, 51, 52, 56, 58 y 66.

Regularmente, aunque aparatosas y extensas, las lesiones o verrugas producidas por estos virus son benignas, pero algunas variedades clínicas o subclínicas pueden progresar a un cáncer invasivo en distintos lugares, el más común es en el epitelio de transición cérvico uterino, pero puede ser también en vulva, vagina, pene y ano, así como en casos aislados se puede encontrar en faringe o cualquier sitio de la cavidad oral secundario a prácticas orogenitales sin protección.

Una situación facilitadora para que el virus infecte, es que haya una solución de continuidad, ya sea en la piel o en la mucosa, esta pérdida de continuidad puede ser por las relaciones sexuales, por infecciones frecuentes, o por partos cercanos. Las adolescentes, al presentar una zona de transición de epitelios cérvico vaginales más amplia y una cantidad de glucógeno, son más vulnerables a esta infección, es más fácil que tengan una transformación metaplásica a células escamosas y una evolución a cáncer cérvico uterino $8,20,27,28$. 


\section{Infecciones de transmisión sexual}

- Hepatitis B (Infección por Virus de la Hepatitis B) (VHB)

Es una Infección viral del hígado, ocasionado por un RNA virus, perteneciente a la familia Flaviviridae, género Hepacivirus, que si bien se replica en los hepatocitos, no tiene una acción directamente citopática, por lo que se relaciona con una infección crónica y persistente. Existen más de 6 genotipos y 50 subtipos.

Tiende a ser una infección asintomática y presentar una evolución lenta desde la fase infectante hasta la degeneración de las células hepáticas, provocando cirrosis hepática y fibrosis avanzada. Si bien la vía sexual no es la vía más frecuente del contagio, si ocupa un lugar en cuanto al riesgo de estas infecciones.

Podemos decir que hay dos presentaciones clínicas:

1. Hepatitis aguda. Se caracteriza principalmente por ser asintomática, lo que la hace tendiente a la cronicidad y al aumento de los síntomas. Solo el 25\% es sintomática, y aunque las cifras de transaminasas se eleven hasta 10 veces su valor normal, es muy raro que evolucione hasta una hepatitis fulminante. $Y$ además tiene una probabilidad de 20 a 30\% de que se resuelva espontáneamente.

2. La variedad crónica se caracteriza por tener de manera permanentemente elevadas las cifras de transaminasas y persistencia del RNA del VHC. Aunque también hasta el $25 \%$ de los pacientes puede presentar niveles de transaminasas normales en periodos largos de tiempo, lo que dificulta el diagnóstico y puede provocar que no se detecte la evolución maligna de la enfermedad. Hay una fibrosis hepática progresiva, pueden estar asintomáticos por años. Incluso en la fase de cirrosis hepática, la mayoría de los pacientes se mantendrá compensados, de ellos solo el $25 \%$ aproximadamente desarrollaran hepatitis o hepatocarcinoma $a^{4,3,29,30}$.

- Infección por Virus de la Inmunodeficiencia Humana (VIH) /Síndrome de Inmunodeficiencia Adquirida (SIDA)

La infección-enfermedad VIH/SIDA es un complejo, una afección clínica crónica, progresiva, de transmisión en la mayoría de los casos sexual, aunque existen otros mecanismos como la 


\section{Principales problemas de Salud Pública en México}

vía materno-fetal, transfusional y personas que usan drogas inyectables por uso inmediato de jeringas contaminadas de persona a persona.

Es uno de los virus de más reciente descubrimiento (década de los 80's), se trata de un retrovirus, de la familia de los Lentiviridae, cuyo mecanismo de acción es la inmunodeficiencia y la destrucción lenta y progresiva de las células que infecta. En este grupo los que provocan la enfermedad en humanos, son el VIH I y el VIH 2, los que comparten características como el mismo tropismo celular, el mismo modo de transmisión, mecanismo de replicación similares, producen inmunodeficiencia, y tienen una cantidad alta de genes y proteínas reguladoras de la interacción virus-célula, lo que define la patogenia de esta enfermedad.

El VIH 1 tiene mayor trascendencia epidemiológica que el VIH 2, es el causante de la mayoría de las infecciones, sin embargo, para este capítulo, tomaremos indistintamente los datos de ambos.

La entrada del virus al cuerpo, independientemente de la vía, va a provocar la destrucción progresiva del sistema inmune mediado por linfocitos CD4, y los monocitos macrófagos. El Virus se replica constantemente y se pueden producir entre 100 y 1000 billones de virus por día. La disminución de los linfocitos CD4 afecta toda la respuesta inmune del hospedero y aumenta la susceptibilidad del mismo a tener infecciones oportunistas o cánceres.

El período de tiempo entre la entrada del agente infectante al organismo y la expresión de la enfermedad oscila entre 6 meses hasta más de 15 años, y se calcula en promedio de 12 años. Y para comprender mejor la enfermedad, la dividimos en las siguientes etapas:

- Periodo de Seroconversión: Con una sensación física parecida a un cuadro gripal, se presenta entre una a seis semanas del contacto infectante.

- Periodo asintomático: con niveles de virus bajos, replicación constante, los linfocitos CD4 y CD8 normales, este periodo puede durar desde seis meses hasta más de quince años.

- Linfadenopatía persistente generalizada: Crecimiento ganglionar generalizado, sin otro cuadro clínico y sin relaciones con alguna patología aparente. 


\section{Infecciones de transmisión sexual}

- Infección Sintomática: Se caracteriza por la aparición de sintomatología diversa, Infecciones oportunistas, y se puede considerar como precursora de SIDA.

- SIDA: Es la fase de inmunodeficiencia grave, con la aparición de infecciones severas con baja respuesta a antibióticos, aparición de tumores cancerosos considerados como raros como el sarcoma de Kaposi, una baja severa de linfocitos CD4 por debajo de 200 células por $\mathrm{mm}^{2,4,11,17,18,31}$.

\section{Cuadro clínico}

Una de las formas para hacer más comprensibles los diversos cuadros clínicos de las ITS es el sindromático $23,4,6,10,11,14,20$ :

1) Síndrome de secreción uretral. Cuando hay secreción de la uretra anterior como pus, sangre o moco que puede ir acompañada o no de disuria, tenesmo vesical, irritación y eritema del glande o prepucio, prurito y/o dolor, son datos clínicos de los agentes etiológicos como Gonococos, Clamidia y Ureaplasma.

2) Síndrome de flujo vaginal. En éste caso se presentan secreciones distintas a las normales a través de la vagina, que son desde leves hasta abundantes, las cuales pueden ser fétidas, o estar acompañadas de prurito, edema, inflamación, disuria, dispareunia de leve a intensa, y/o con dolor abdominal bajo, también pueden presentarse otros datos urinarios como urgencia urinaria, nicturia, tenesmo vesical, y dolor lumbar. Algunos agentes etiológicos inmiscuidos en éstos datos clínicos son Neisseria gonorreae, Clamidia, Cándida albicans, Gardnerella y Tricomonas.

3) Síndrome de dolor abdominal bajo. Se presenta como una EPI. Aunque se tiene que hacer diagnóstico diferencial con otras patologías no infecciosas como ovarios poliquísticos y embarazo ectópico. Puede presentarse en caso de infección por Neisseria Gonorrae o Clamidia.

4) Síndrome genital ulcerativo. La infección se acompaña con pérdida de continuidad de la piel o mucosas en las zonas de contacto, en los órganos sexuales, boca y/o ano; estas lesiones pueden ser secas o húmedas, dolorosas o indoloras, y acompañadas de crecimiento ganglionar regional, difuso o generalizado. Algunos de los agentes 


\section{Principales problemas de Salud Pública en México}

etiológicos que las producen son Treponema pallidum, Haemophillus dukreyi y Clamidia.

5) Síndrome Tumoral. Son tumoraciones condilomatosas o no, dependientes de la primera capa de la piel, las que pueden aparecer en distintas partes del cuerpo, principalmente en región genital, perianal, peri-genital y boca. Se manifiestan específicamente con los condilomas acuminados, verrugas y molusco contagioso.

\section{Complicaciones}

Las complicaciones dependen del agente etiológico y su cronicidad:

Las bacterianas tienden a ser agudas, sintomáticas, provocar lesiones muy localizadas, con daño a los tejidos, los que son evidentes (menores a los de las virales), acompañados de secreciones, con malestar general y fiebre; y que generalmente son tratadas de manera más eficiente. Aunque hay bacterias como el treponema sifilítico que causa complicaciones multi sistémicas (a distancia), provocando daños cardiacos, al sistema nervioso, a los huesos e incluso malformaciones en el producto de mujeres infectadas o muerte de la persona infectada. Otras bacterianas tienen que ver con esterilidad y lesiones severas en las vías urinarias y genitales como la Clamidia y la Gonorrea.

Las ITS de origen viral se pueden presentar tanto de manera localizada como sistémica, con daño o destrucción tisular localizada como en el caso del herpes genital, cuyas recurrencias se asocian con la extensión de las lesiones o dolor crónico, dispaurenia de leve a severa, que en ocasiones es muy difícil de tratar. En el caso del Papiloma puede ocasionar lesiones racimosas deformantes, con daño genital extenso, asociación con otros agentes etiológicos, y limitación severa de la vida sexual, o si se presenta en lesión plana está relacionado con cáncer cérvico uterino. También pueden deprimir el sistema inmune y favorecer la aparición de cáncer, enfermedades sistémicas y otro tipo de infecciones atípicas o raras como en el caso del VIH, que pueden formar complejos tan severos que pueden provocar la muerte $\mathrm{e}^{20,23,26,27,28,29}$. 


\section{Infecciones de transmisión sexual}

\section{Diagnóstico}

De inicio, el diagnóstico tiende a ser clínico, sindromático y basado en evidencias, siendo la historia clínica detallada, una herramienta fundamental para la sospecha diagnóstica inicial, con énfasis en el interrogatorio de relaciones de riesgo, higiene, uso de drogas intravenosas y alcoholismo. La presencia de síndromes característicos de este tipo de infecciones, tales como asociaciones de infecciones atípicas relacionadas con inmunosupresión, nos pueden aproximar de manera segura al diagnóstico etiológico. También podemos auxiliarnos con la detección de antígenos específicos, principalmente en las virales, aunque también en algunas bacterianas. Las pruebas diagnósticas de laboratorio siguen siendo muy útiles, dependiendo del agente etiológico. En el caso de las bacterianas, los cultivos de los tejidos o secreciones tienden a darnos diagnósticos certeros, además de que el antibiograma tiende a orientarnos al tratamiento más efectivo. Las pruebas clásicas como VDRL, ELISA, inmunofluorescencia, cultivos específicos, tipificaciones virales, búsqueda de antígenos específicos o asociados a inmunoglobulinas, e incluso toma de biopsias de tejidos afectados, siguen siendo útiles para la sospecha inicial y posterior certeza diagnóstica ${ }^{23,28,29,30}$.

\section{Terapéutica}

Este se decide tomando en cuenta la presentación clínica y el agente etiológico.

En cuanto a la presentación clínica, dependiendo de ésta se usarán medicamentos dirigidos a la curación del síntoma, como analgésicos, antiinflamatorios, antihistamínicos para el prurito y cremas cicatrizantes.

De acuerdo al agente etiológico, depende del microorganismo causal o su asociación a otros agentes indirectamente relacionados pero influyentes en la presentación clínica. En caso de bacterias lo más frecuente, es el uso de antibióticos, por ejemplo para Clamidia se usan las tetraciclinas, doxiciclina; y aún es efectivo el uso de penicilina benzatinica, para Neisseria y Treponema. En el caso de algunos protozoarios como Tricomonas, el metronidazol es la primera elección. Para Gardnerella, la azitromicina. En cuanto a la Cándida Albicans, que es una micosis, el medicamento sugerido es la nistatina. 


\section{Principales problemas de Salud Pública en México}

La mayoría de las infecciones virales se pueden manejar de manera sintomática. Deberá prescribirse en el caso del herpes, el aciclovir. Y en otros complejos virales como en el caso de VIH-SIDA, se da manejo sintomático y preventivo, aparte del manejo antiviral $2,9,10,11,12,20,21$.

\section{Medidas de prevención}

Las medidas de prevención, las desarrollamos como sigue $2,3,10,11,16,15,33$ :

Prevención primaria: Dado que la modalidad primaria y más frecuente de transmisión es la relación sexual se recomiendan las medidas que sean dirigidas a un ejercicio del erotismo más seguro, que evite en lo posible el intercambio de fluidos y la exposición directa a lesiones como el sexo seguro y el sexo protegido. Evitar el contacto sin protección con distintas parejas sexuales. En el caso de las virales, es el único medio de evitar propagación.

Prevención secundaria: Esta comprende el suministro de alimentos y medidas de rescate, a personas infectadas, asistencia social y prevención de complicaciones. Estas medidas comprenden la promoción de comportamientos encaminados a que la persona se cuide y evite también propagar la enfermedad. La prestación de servicios médicos y de laboratorio accesibles, y servicios de apoyo social y consejería. Educación sexual dirigida al autocuidado, reconocimiento del cuerpo y ejercicio de una sexualidad libre, informada e incluyente, sin prejuicios ni discriminaciones.

La NOM-0393, establece la necesidad de brindar un servicio integral de protección a poblaciones vulnerables para el contagio de VIH/SIDA, lo que incluye prestar servicios de atención integral de calidad:

- Manejo de riesgos personales;

- Desarrollo de capacidad y competencia en salud;

- Participación social para la acción comunitaria;

- Desarrollo de acciones que combatan el estigma y la discriminación relacionada al VIH/ SIDA; 


\section{Infecciones de transmisión sexual}

- Abogacía intra e intersectorial, y

- Mercadotecnia social en salud

\section{Referencias}

1. Organización Mundial de la Salud. Infecciones de Transmisión Sexual. OMS, Nota informativa No. 110, Agosto de 2016. Disponible en: http://www.who.int/mediacentre/ factsheets/fs110/es/

2. ONUSIDA. Enfermedades de transmisión sexual: políticas y principios de prevención y asistencia. Programa Conjunto de las Naciones Unidas sobre el VIH/SIDA (ONUSIDA) /OMS. Disponible en: http://data.unaids.org/publications/irc-pub04/una97-6_es.pdf

3. Secretaría de Salud. Proyecto de Norma Oficial Mexicana PROY-NOM-039-SSA2-2002, para la prevención y control de las ITS, México 2014. Diario Oficial de la Federación: 14/07/2014. Disponible en: http://www.dof.gob.mx/nota_detalle.php?codigo=5352227 \&fecha $=14 / 07 / 2014$

4. Dirección General de Epidemiología. Manual de procedimientos estandarizados para la vigilancia epidemiológica del VIH SIDA. México: SSA; 2012.

5. INEGI. Estadísticas a propósito del día internacional de la juventud (15 a 29 años), 2016. Disponible en: http://www.inegi.org.mx/saladeprensa/aproposito/2016/ juventud2016_0.pdf

6. Martínez TA. Diagnóstico microbiológico de las ITS (ITS). Parte 1. ITS no virales. Rev Chil Infect. 2009; 26(6):529-539.

7. OMS. Informe sobre la salud en el mundo 2002. Ginebra: OMS; 2003.

8. Martínez MJ. Diagnóstico microbiológico de infecciones de transmisión sexual. Parte II. ITS virales. Rev Chil Infect. 2010; 27(1):60-64.

9. Secretaría de Salud. Casos nuevos de sífilis por fuentes de notificación. Estados Unidos Mexicanos 2012. México, anuarios de morbilidad de la Dirección General de Epidemiología. Disponible en: http://www.epidemiologia.salud.gob.mx/anuario/2012/ casos/fuente/001.pdf 


\section{Principales problemas de Salud Pública en México}

10. Cruz Palacios C, Ramos Alamillo U, González Rodríguez A. Guía de prevención, diagnóstico y tratamiento de las ITS. Dirigida a personal de Servicios de Salud. México: Fundación Mexicana para la Salud; 2011.

11. Secretaría de Salud. Norma Oficial Mexicana NOM-010-SSA2-2010, para la prevención y el control de la infección por virus de la inmunodeficiencia humana. México: SSA; 2010.

12. Domínguez Soto L, Díaz González JM. Enfermedades de transmisión sexual, seminario. El ejercicio actual de la medicina. México: Facultad de Medicina, UNAM; 2010.

13. OMS. Enfoque estratégico de la OMS para fortalecer políticas y programas de salud sexual y reproductiva Ginebra, Suiza: OMS; 2008.

14. OMS. ITS y otras infecciones del tracto reproductivo una guía para la práctica básica Ginebra, Suiza: OMS; 2005.

15. Valdez G JA, Abad Camacho MT. Prevalencia y características clínicas de enfermedades de transmisión sexual en mujeres atendidas en el Hospital Universitario de Puebla. 2008. Puebla: Universidad de Puebla; 2009.

16. OMS. Estrategia mundial de prevención y control de las ITS 2006-2015. Ginebra: SSA; 2007.

17. ONU. Salud sexual y reproductiva y VIH SIDA Afiche. Ginebra, Suiza: SSA; 2004.

18. OMS. Eliminación mundial de la sífilis congénita: fundamentos y estrategia para la acción. Ginebra, Suiza: SSA; 2008.

19. OMS. Year's report on HIV/AIDS interventions in the health sector. Ginebra, Suiza: OMS; 2010.

20. CENSIDA. Manual para capacitadores en el manejo sindromático de las ITS (ITS). $2^{\underline{a}}$ ed. México: CENSIDA; 2004.

21. Gallegos EC, Villareal AM. Intervención para reducir riesgo en conductas sexuales de adolescentes: un ensayo aleatorizado y controlado. Salud Pública Méx. 2008; 50:59-66.

22. Mandal A. Fisiopatología del SIDA. 2010. Disponible en: https://www.news-medical. net/health/AIDS-Pathophysiology-(Spanish).aspx

23. Carrada Bravo T. Sífilis: actualidad, diagnóstico y tratamiento. Rev Fac Med UNAM. 2003; 46(6)noviembre-diciembre:236-242. 


\section{Infecciones de transmisión sexual}

24. OMS. Enfoques de Salud Pública para el control de las ETS. Ginebra, Suiza: OMS; 1998.

25. Fariñas Álvarez MC. Enfermedades infecciosas. España: Universidad de Cantabria; 2007.

26. Canto-de Cetina T, Polanco RL, Cupul YDG, Fernándes GV, Piña CR, Ballote ZM. Prevalencia de infección por Chlamydia Trachomatis en usuarias de una clínica de planificación familiar en Mérida, Yucatán. Inf Infecy Micro 2000:21(3);102-105.

27. Lizano Soberón M. Infección por virus del papiloma humano: epidemiología, historia natural y carcinogénesis. Cancerología. 2009; 4:205-216.

28. López Navarrete GE. Infección por virus de papiloma humano. Rev Fac Med UNAM. 51(6)noviembre-diciembre:243-244.

29. Secretaría de Salud. Guía de práctica clínica, diagnóstico y tratamiento de hepatitis C. México: SSA; 2010.

30. Comisión Científica de la Real Fundación Victoria Eugenia. Recomendaciones para el diagnóstico y el tratamiento de la infección por el virus de la hepatitis C. Madrid, España: Real Fundación Victoria Eugenia; 2008.

31. INMUJERES. Enfermedades de transmisión sexual y VIH/SIDA. México; 2012 Disponible en: http://estadistica.inmujeres.gob.mx

32. OMS. El uso de las pruebas rápidas para sífilis. Ginebra, Suiza: OMS; 2007.

33. OMS. Preparación de la introducción de las vacunas contra el virus del papiloma humano. Orientaciones normativas y programáticas para los países. Ginebra, Suiza: OMS; 2006. 



\title{
14. Infección de vías urinarias
}

\author{
M. C. Eva Leticia Acevedo Ballinas \\ M. C. Patricia Acevedo Ballinas
}

\section{Introducción}

La Infección de Vías Urinarias (IVU), se encuentran dentro de las patologías que se ven con mayor frecuencia en la consulta médica, ocupan el tercer lugar, como causa de morbilidad infectocontagiosa. El agente causal, más frecuente que las provoca en los casos agudos es la E. coli y en la crónica se ven inmiscuidos varios agentes patógenos. Es más frecuente en las mujeres que en los hombres, debido a las características anatómicas y a los cambios hormonales. Debe hacerse énfasis en la promoción y prevención de reinfecciones, en grupos de población susceptible, con el afán de evitar complicaciones. La terapéutica antibiótica es simple y puede utilizarse como profiláctica, para prevenir recurrencias.

\section{Concepto}

La IVU, se define como la presencia y reproducción de microorganismos, generalmente de tipo bacterianos, en la orina; y se puede presentar en el riñón, vejiga, próstata o uretra. Además es conocida como una infección persistente ${ }^{1,2,3}$.

\section{Clasificación}

La IVU se puede clasificar de tres maneras, las que incluyen la anatómica, epidemiológica y la clínica.

1. Anatómica, es la que considera las estructuras que conforman el sistema urinario:

a) Infección del tracto urinario inferior: Uretritis, cistitis. 


\section{Principales problemas de Salud Pública en México}

b) Infección del tracto urinario superior: Pielonefritis aguda, prostatitis y absceso renal o peri nefrítico (indican invasión tisular).

2. Epidemiológica, la que considera el lugar intra o extra hospitalario, donde fue adquirida:

a) Nosocomiales o asociadas a cateterización, adquirida en medio hospitalario, por intervenciones médicas.

b) Comunitarias no asociadas a cateterización, es decir no adquirida en medio hospitalario ${ }^{1}$.

3. Clínica, en ésta clasificación se considera la existencia o no de complicaciones:

a) Simple se caracteriza por no presentar alteración intrínseca o extrínseca de las estructuras de las vías urinarias, las que son de pronóstico benigno y se origina por los estilos de vida inadecuados, con presencia de hábitos higiénicos que facilitan la presencia de la infección.

b) Complicada, en donde se encuentran alteraciones en cualquier parte del sistema urinario y/o también pueden existir anomalías extrínsecas, que comprimen las estructuras urológicas, como tumoraciones abdominales y hematomas ${ }^{1}$.

\section{Epidemiología}

Se estima que globalmente en el mundo ocurren 150 millones de casos de infección de vías urinarias por año. En Estados Unidos de Norteamérica son solicitadas cada año 7 millones de consulta por esta enfermedad.

La cistitis y uretritis, son un problema de Salud Pública por ocupar el tercer lugar como causa de morbilidad infectocontagiosa, la cual se presenta con mayor frecuencia en mujeres con una razón de 3:1 en relación con los hombres ${ }^{1,2,3}$.

En el boletín epidemiológico de la Secretaría de Salud se reportó en el año 2007 un total de 3, 076,468 casos de infecciones del tracto urinario, de los cuales 2, 294,451(74.5\%) fueron mujeres y $749,755(23 \%)$ se presentaron en hombres. La proporción entre mujeres y 


\section{Infección de vías urinarias}

hombres jóvenes es de 30:1, sin embargo como se vaya envejeciendo esta proporción tiende a igualarse. La prevalencia en ancianos es de 10 a $50 \%$ y el $26 \%$ de ellos al menos ha tenido una recurrencia.

En México, el Sistema Nacional de Vigilancia Epidemiológica reporto que en el año 2010, las IVU ocuparon el tercer lugar dentro de las principales causas de morbilidad infectocontagiosa y se reportaron 1, 204,032 casos en adultos de 25 a 44 años de edad.

Las IVU en México en el año 2011 son la tercera causa de morbilidad por padecimientos de carácter transmisible. Para éste mismo año en México se notificaron 3671249 casos, equivalentes a una incidencia de 3.6 por cada 100 habitantes. Con respecto al sexo femenino ocupan el primer lugar con una incidencia de 5.4 por cada 100 mujeres. Y para los hombres, el segundo lugar con una incidencia de 1.7 por cada 100 habitantes.

La incidencia de las IVU varía dependiendo de la edad y sexo. La infección de vías urinarias es un problema frecuente en la población pediátrica. En los niños, las IVU son la causa más común de consulta y hospitalización; la infección sintomática ocurre en uno de cada 1000 recién nacidos y menores de un mes de edad y es más común en los varones. La Organización Mundial de la Salud (OMS) ha estimado que la enfermedad se ha diagnosticado en el 1\% en los niños. Con una tasa reportada de recurrencias del 12 al 30\% con mayor probabilidad en menores de seis meses en caso de reflujo vésico-uretral grave.

En mayores de 60 años, la incidencia en México para el año 2011, fue de 6 por cada 100 habitantes con predominio en el sexo masculino por la presencia de prostatitis. ${ }^{4}$.

Los Estados de la República Mexicana, que más registros de casos nuevos poseen para el año 2011, del primero al décimo lugar, por orden de mayor a menor número de casos, son Estado de México (464 904), Distrito Federal (372 021), Jalisco (245 750), Veracruz (230 876), Puebla (149 765), Nuevo León (148 409), Sinaloa (146 042), Chihuahua (143 946), Oaxaca (130 877) e Hidalgo (130 744). El número de casos fueron más frecuentes en las mujeres con una razón de 3:1; y el grupo de edad más afectado para ambos géneros fue el de 25 a 44 años. La institución con mayor número de casos reportados fue el IMSS (1 625 458) seguido de la Secretaría de Salud (1 405491 ). Cabe señalar que el crecimiento porcentual de la incidencia del 2011 con respecto al año 2000 fue de $22.5 \%$. La tendencia de la enfermedad desde 2006 a 2013, es ligeramente ascendente ${ }^{2,5}$. 


\section{Principales problemas de Salud Pública en México}

En el año 2013, las IVU se mantienen como una de las primeras causas de morbilidad en adultos $2,3,5$.

Las IVU representan la primera causa de consulta médica en mujeres en edad reproductiva. Durante el embarazo es la causa más frecuente de complicaciones perinatales serias; y la tercera causa de sepsis neonatal; con una prevalencia de 8 al 35\% en los niños con desnutrición ${ }^{2,3,5}$.

\section{Causalidad}

- Factores de riesgo

En cualquier edad y sexo es susceptible de contraerse las Infecciones de Vías Urinarias. En los hombres son frecuentes las infecciones de vías urinarias, por contacto sexual y por la falta de higiene. Sin embargo, en las mujeres se presentan con mayor frecuencia, por razones anatómicas; y porque durante el embarazo existen factores de riesgo que incrementan la susceptibilidad al desarrollo de IVU, ya que la progesterona induce la disminución del tono muscular liso, lo que a su vez disminuye la parálisis uretral. A partir de los 7 años de edad el $8 \%$ de las niñas y el 2\% de los varones han tenido un episodio de IVU. Del 10 al $20 \%$ de las mujeres, durante su vida han sufrido un episodio de IVU. .Aproximadamente la mitad de todas las mujeres han tenido una infección de vías urinarias antes de los 30 años de edad, su presentación más común es durante el embarazo. ${ }^{6}$ El riesgo de IVU durante la primera década de la vida es de $1 \%$ para los varones y de $3 \%$ para mujeres. Después de la segunda década de la vida sigue predominando en las mujeres con proporción de 4:1. Las mujeres menores de 10 años y las de 18 a 40 años con vida sexual activa, son las que más frecuentemente adquieren estas infecciones. En los hombres se presenta muy frecuentemente después de los 50 años, debido a la obstrucción uretral secundaria al crecimiento prostático ${ }^{2,3}$.

Además, son factores predisponentes para ésta enfermedad, la falta de higiene personal así como los recursos con los que se cuenta para evitarlas.

La dificultad del vaciado vesical, puede alterar la expresión del factor acelerador de la degradación (DAF/CD55), que es un regulador del complemento y sirve como receptor muchos patógenos, entre ellos la E. coli $7,8,9,10,11,12,13,14,15$. 


\section{Infección de vías urinarias}

- Factores de riesgo modificables

Existen factores de riesgo modificables en las mujeres con recidivas, los que se relacionan con el coito, estilos de vida, inadecuados hábitos higiénicos como la limpieza de atrás hacia adelante, que se practica después de defecar, trauma por masturbación o introducción de objetos por el meato urinario y la constipación, en estos casos la infección urinaria puede ser recurrente y únicamente cede después de la corrección dichos factores.

En los hombres existen varios factores modificables entre ellos son la fimosis, coito anal, la ausencia de circuncisión, y parejas sexuales cuya vagina este colonizada por uropatógenos. En los varones la IVU son debido a obstrucción uretral, secundaria a prostatitis. La infección recurrente de vías urinarias, puede deberse a prácticas sexuales de alto riesgo.

Los factores modificables nosocomiales constituyen del $35 \%$ al $41 \%$ de los pacientes hospitalizados. Los cuales son producto de procedimientos invasivos, en vías urinarias como la endoscopia, cateterismo, sondeo vesical y cirugía de las vías urinarias ${ }^{4,7,8}$.

- Factores de riesgo no modificables

Las alteraciones anatómicas son factores de riesgo no modificables que favorecen el desarrollo de la IVU, estas por lo general producen una obstrucción urinaria por presencia de valvas ureterales posteriores y puede ser funcional como en las alteraciones fisiologías del cuello vesical, estenosis de la unión uretero-vesical o ureteropielicas, hidronefrosis o litiasis. Otras alteraciones anatómicas que también contribuyen a la presentación de la enfermedad son la vejiga neurogénica, ureterocele funcional, trastornos congénitos de vías urinarias, reflujo vésico-ureteral y dilatación vesical ${ }^{5,7}$.

La presencia de reflujo vésico-ureteral en niños, es a consecuencia de cicatrización renal congénita; y en las niñas producto de infección recurrente, misma que mejora con el tiempo, a medida que la vejiga crece y aumenta de longitud del túnel mucoso por el que pasa el uretero.

La cistitis recidivante, es un factor de riesgo no modificable, debido a anomalía anatómica o funcional del aparato urinario, principalmente en las mujeres, ya que en ellas la distancia 


\section{Principales problemas de Salud Pública en México}

del recto a la abertura uretral, es más corta que en el hombre, lo que favorece la infección de vías urinarias; además aumenta el riesgo de enfermar en dicho género, cuando existe una deficiencia en la técnica de limpieza genital, ya que lo efectúan de atrás hacia delante, llevando fecalitos al meato urinario.

- Factores protectores

La alimentación con leche materna tiene efecto protector contra la IVU; es 2 a 3 veces más elevado en niños no alimentados con leche materna que aquellos que si la recibieron.

Son factores protectores el tracto urinario, ya que es estéril y algunos factores como el flujo de la orina y sustancias antimicrobianas secretadas, protegen al tracto urinario de la infección de microorganismos patógenos.

Las vías urinarias en condiciones normales se encuentran protegidas por diferentes mecanismos anatómico fisiológicos, como el tamaño de la uretra en niños, que es un factor protector; no así en las niñas, que es un factor de riesgo para el desarrollo de infección de vías urinarias.

La urea, los ácidos orgánicos, el pH ácido y los mucopolisácaridos de la pared vesical son mecanismos protectores para inhibir la multiplicación bacteriana. La IgA secretoria protege al huésped.

La colonización bacteriana es limitada por las células fagocitadas, las que a su vez pueden prevenir la diseminación de la infección, sin embargo no existe evidencia de que los pacientes con neutropenia tengan mayor incidencia de infección $n^{9,10,11,12}$.

- Agentes biológicos

Los agentes biológicos causales de las IVU son múltiples, sin embargo lo produce con más frecuencia, en el $80-90 \%$ de los casos E. coli; otros microorganismos que la provocan son Klebsiella, Proteus, Estafilococo coagulasa positivo o negativo, Estreptococo, Pseudomonas, Enterobacter, Serratia mercescens, Clamiydia, Micoplasma y hongos; la Klebsiella ocupa el segundo lugar en lactantes menores. 


\section{Infección de vías urinarias}

En el 71 \% de los aislamientos de E. coli, las vías urinarias poseen fimbrias que facilitan la adherencia al epitelio, que es el primer paso para la colonización y para el desarrollo de la infección de las vías urinarias ${ }^{4,5,6,6,8,9,11,12,13,14,15}$.

Los uropatógenos poseen diversos factores virulentos que facilitan la adherencia e invasión de las vías urinarias, de este modo evaden las defensas del huésped e incluso resistiendo la acción de los antimicrobianos, el huésped a su vez dispone de mecanismos especiales de defensa, como son el recambio de las células epiteliales y los efectos de arrastre de la micción, los lactobacilos que son parte de la flora vaginal normal, que se adhieren a las células uro epiteliales e inhiben la fijación de E.Coli, klebsiella y Pseudomona ${ }^{7,8,9,10,11,12,13,14,15}$.

- Mecanismo de transmisión

La manera de cómo se transmiten más frecuentemente, las IVU es a través de los mecanismos de transmisión directa, indirecta y por vía ascendente.

a) El mecanismo de transmisión directa más común, es por el ascenso retrogrado de las bacterias.

- En las mujeres pueden acceder y ascender fácilmente al tracto urinario, debido a la relativa cercanía del orificio uretral con el ano, el cuál es una fuente de infección por poseer bacterias gran negativas; y es favorecida por la menor longitud de la uretra.

- Las relaciones sexuales.

- Por la presencia del prepucio integro en neonatos, en quienes la frecuencia de IVU es diez veces mayor a la de los circuncidados.

b) El mecanismo de transmisión indirecto es a través de fómites, en donde tiene importancia el cateterismo y sondeo vesical. La bacteriemia asociada a la sonda vesical constituye el foco habitual de bacterias por gran negativos ${ }^{1}$.

c) El mecanismo de infección de vías urinarias ascendente, se da por la cercanía del sistema urinario y el digestivo, es por ello que la mayor parte de las IVU son causadas por la colonización de gérmenes Gram negativos ${ }^{7,8,12}$. 


\section{Principales problemas de Salud Pública en México}

\section{Fisiopatología}

El tracto urinario humano es estéril y algunos factores como flujo de la orina y sustancias antibacterianas secretadas protegen al tracto urinario de la infección de microorganismos patógenos, empiezan con la colonización de la uretra por cepas de E. coli provenientes de la micro biota rectal. El establecimiento prolongado de cepas uropatógenas en el colon provee de una fuente constante de bacterias y así aumentan las posibilidades de colonizar la uretra. El hecho de que el colon contamine continuamente con bacterias a la uretra, explica, porque son tan comunes las infecciones recurrentes en el tracto urinario. La colonización de la vejiga, especialmente en el área alrededor del meato urinario, incrementa la posibilidad de que las bacterias entren por dicho orificio.

La bacterias uropatógenas tienen la capacidad para adherirse a las células uro epiteliales; para llevar a cabo esta tarea las cepas UPEC tienen diferentes apéndices adhesivos en superficie, la adherencia de las bacterias induce apoptosis y desprendimiento celular y en algunos casos las bacterias pueden internalizarse en las células uro epiteliales; para invadir y replicarse dentro de ellas.

Las vías para la adquisición de IVU en la edad pediátrica son la hematógena y la ascendente; la primera se presenta más frecuentemente en recién nacidos y menores de tres meses de vida y la segunda es la más frecuente en otros grupos etarios.

La IVU se asocia con mayor frecuencia a E. coli, esta coloniza el intestino del huésped de la piel perianal al área peri uretral y de allí asciende a la uretra y vejiga.

El coito favorece la colonización de vías urinarias por microorganismos vulvo-perianales también llamada cistitis de la luna de miel.

El termino pielonefritis se utiliza para la invasión bacteriana de los tejidos del sistema pielocalicial y del parénquima renal, con presencia de exudado inflamatorio con leucocitos polimorfo nucleares con la presencia demostrada de bacterias.

La adquisición de la infección en el parénquima renal puede ser por vía ascendente, cuando la infección se origina en la uretra, la vejiga o por vía hematógena. Cuando la infección se origina por vía ascendente los síntomas que se poseen corresponden a los de 


\section{Infección de vías urinarias}

vías urinarias bajas, como disuria y tenesmo vesical, mientras que por la vía hematógena los datos clínicos son de septicemia $7,8,9,10,11,12,13,14,15,16$.

\section{Cuadro clínico}

La IVU puede presentarse de dos maneras: asintomática y con síntomas referidos al aparato urogenital. A su vez, cuando existen las IVU, pueden ser del tracto urinario inferior (uretritis, cistitis) y del tracto urinario superior (pielonefritis aguda, prostatitis y absceso renal o peri nefrítico $)^{4,5,6,8,11,12,13}$.

a) Asintomática. Ocurre en el $60 \%$ de los casos aproximadamente y su frecuencia varía en cada grupo de edad. Es más frecuente en mayores de 5 años, en recidivas y en infección de parénquima renal antes de la fase final de la enfermedad. La bacteriuria asintomática puede detectarse en forma fortuita cuando se realiza un examen general de orina. En el $50 \%$ de los pacientes cuando se les efectúa un buen interrogatorio, bien dirigido y cuidadoso, refieren manifestaciones clínicas previas (Cuadro 1).

Cuadro 1. Porcentaje de bacteriuria asintomática por grupo de edad y sexo.

\begin{tabular}{|l|c|c|}
\hline \multirow{2}{*}{\multicolumn{1}{c|}{ Grupo de edad }} & \multicolumn{2}{c|}{ Sexo } \\
\cline { 2 - 3 } & Masculino & Femenino \\
\hline Recién nacidos & 14 & 0.3 a 2.1 \\
\hline Lactantes & 0.5 & 2 a 8 \\
\hline Preescolares & 0.5 & 1 a 4 \\
\hline Escolares & 0.03 a 1.4 & 2 a 5 \\
\hline Adolescentes & --- & 5 \\
\hline Adultos & & 5 \\
\hline
\end{tabular}

b) Sintomática. En neonatos y lactantes y menores de 2 años, los síntomas son inespecíficos tales como fiebre, vómito, irritabilidad y falta de desarrollo. Los niños mayores de 2 años van más frecuente a orinar y presentan disuria, palidez, cambios en calibre y fuerza del chorro urinario, goteo urinario, constante humedad del pañal y orina fétida, a la exploración se encuentra edema y dolor abdominal. En los preescolares y escolares, las manifestaciones clínicas son más evidentes y presentan datos como disuria, 


\section{Principales problemas de Salud Pública en México}

polaquiuria, urgencia urinaria enuresis, dolor lumbar y abdominal, nausea, vomito, fiebre y escalofrío. Las mujeres adultas con cistitis y uretritis aguda tienen inicio súbito de disuria, urgencia y frecuencia urinaria; a la exploración se encuentra dolor a la palpación de región supra púbica. Los adultos con pielonefritis aguda presentan fiebre, escalofríos, dolor lumbar o en flancos, a la exploración se encuentra dolor del flanco afectado. Los varones con prostatitis aguda se quejan de fiebre, escalofríos, dolor perineal o lumbar bajo, además hay disuria y aumento en la frecuencia urinaria; los hombres con prostatitis crónica, tienen episodios intermitentes de disuria y frecuencia urinaria (Cuadro 2) $4,5,6,8,11,12,13,14,15$.

Cuadro 2. Características Clínicas de las IVU4,5,5,8,11,12,13,14,15.

\begin{tabular}{|l|l|}
\hline \multicolumn{1}{|c|}{ Patología } & \multicolumn{1}{c|}{ Características clínicas } \\
\hline $\begin{array}{l}\text { Infección de } \\
\text { vías urinarias } \\
\text { asintomática }\end{array}$ & Bacteriuria significativa (>10 ala 5 UFC/ml de orina). \\
\hline Uretritis & $\begin{array}{l}\text { Ardor a la micción, exudado uretral muco-purulento abundante, } \\
\text { hematuria escasa o nula, presencia o no de dolor-supra púbico, } \\
\text { puño percusión de los costo vertebrales no dolorosa. }\end{array}$ \\
\hline Cistitis & $\begin{array}{l}\text { Nicturia, no existe exudado ureteral, tenesmo vesical, hematuria, } \\
\text { poliaquiuria, disuria, puño percusión de los ángulos costos } \\
\text { vertebrales no dolorosos. }\end{array}$ \\
\hline $\begin{array}{l}\text { Infección de vías } \\
\text { urinarias altas } \\
\text { (pielonefritis) }\end{array}$ & $\begin{array}{l}\text { Con o sin síntomas de disuria, urgencia y poliaquiuria, hipertermia } \\
\text { (38.5 C), escalofríos, cefalea, dolor en región costo vertebral con } \\
\text { irradiación a fosas iliacas y dorso ipsilateral, nauseas, vómito, } \\
\text { evacuaciones disminuidas en consistencia, malestar general, dolor } \\
\text { al realizar puño percusión del ángulo costo vertebral del lado } \\
\text { afectado. }\end{array}$ \\
\hline $\begin{array}{l}\text { Infecciones de } \\
\text { vías urinarias no } \\
\text { complicadas }\end{array}$ & $\begin{array}{l}\text { Disuria, ardor con la micción, polaquiuria (aumento en la } \\
\text { frecuencia de la micción), tenesmo vesical, dolor supra púbico, } \\
\text { nicturia y hematuria. Los síntomas corresponden a habitualmente a } \\
\text { infecciones del tracto urinario bajo. } \\
\text { Se presentan en pacientes que tienen un tracto urinario normal } \\
\text { (anatómicamente y funcionalmente), que no presentan datos } \\
\text { de afección sistémica como fiebre toxicidad, vomito persistente, } \\
\text { deshidratación y no tienen antecedentes de enfermedad renal o } \\
\text { comorbilidad como diabetes e inmunocomprometidos. }\end{array}$ \\
\hline
\end{tabular}




\section{Infección de vías urinarias}

Cuadro 2. Características Clínicas de las IVU (continuación).4,5,6,8,11,12,13,14,15

\begin{tabular}{|l|l|}
\hline \multicolumn{1}{|c|}{ Patología } & \multicolumn{1}{c|}{ Características clínicas } \\
\hline $\begin{array}{l}\text { Infección de } \\
\text { vías urinarias } \\
\text { complicadas }\end{array}$ & $\begin{array}{l}\text { Involucran a la vías urinarias altas presentan fiebre, nausea, vomito, } \\
\text { dolor lumbar y ataque al estado general. Presenta alteraciones } \\
\text { anatómicas. }\end{array}$ \\
\hline $\begin{array}{l}\text { Infección de las } \\
\text { vías urinarias } \\
\text { nosocomial }\end{array}$ & $\begin{array}{l}\text { Aparición de infección urinaria a partir de las 48 hrs de la } \\
\text { hospitalización de un paciente sin evidencia de infección, asociada } \\
\text { a algún procedimiento invasivo como la colocación de un catéter } \\
\text { urinario. }\end{array}$ \\
\hline $\begin{array}{l}\text { Reinfección } \\
\text { o infección } \\
\text { recurrente }\end{array}$ & $\begin{array}{l}\text { Presencia de 2 cuadros de IVU ocasionados por diferentes } \\
\text { microorganismos en un lapso menor de 6 meses; o más de } \\
3 \text { cuadros de IVU en un lapso de 12 meses; con la evidencia } \\
\text { microbiológica de crecimiento bacteriano a pesar del tratamiento } \\
\text { apropiado1. }\end{array}$ \\
\hline
\end{tabular}

\section{Complicaciones}

Generalmente las cistitis se resuelven sin dejar secuelas, la pielonefritis puede causar serias complicaciones y también puede ser fatal. Existe probabilidad de desarrollar septicemia, sobre todo en pacientes inmunosuprimidos $7,11,12,13,14,15$.

La guía de práctica clínica del Instituto Nacional para la Excelencia en Salud y Atención (por sus siglas en inglés NICE) 2007 sobre IVU, refiere que un 8 y 40\% de los menores de seis años con IVU, cursan con reflujo vésico-ureteral, otras anormalidades comunes incluyen hidronefrosis, uropatía obstructiva y doble sistema recolector (10 a 65\%).

Los menores de dos años presentan cicatriz renal. Estas últimas se asocian al desarrollo de Hipertensión Arterial Sistémica y enfermedad terminal. La cicatriz renal se presenta en 10 al $30 \%$ de los niños después de una infección urinaria; los factores de riesgo para desarrollarla incluyen la existencia de reflujo vésico-ureteral y uropatía obstructiva. Estas complicaciones a consecuencia de IVU, son frecuentes por organismos diferentes a E. coli y a menor edad la probabilidad de presentar cicatriz renal es mayor ${ }^{4,5,10,12}$. 


\section{Principales problemas de Salud Pública en México}

\section{Terapéutica}

Los antibióticos son casi siempre efectivos para eliminar la infección de la vejiga, sin embargo las infecciones renales son difíciles de tratar.

La terapia profiláctica con antibióticos es utilizada para prevenir recurrencias en mujeres con infecciones del tracto urinario.

La elección del fármaco debe ser de acuerdo con el agente causal. Sin embargo, sabemos que por probabilidad, el microorganismo etiológico más frecuente es E. coli. Por lo que el tratamiento más utilizado para tratar a la cistitis aguda, es la Nitrofurantoina por vía oral o una combinación con Trimetropim con sulfametoxazol. A continuación se presenta un cuadro con la posología de administración (Cuadro 3).

Cuadro 3. Posología de los medicamentos utilizados para el tratamiento de las Infecciones de Vías Urinarias $3,4,13,14,15,16$.

\begin{tabular}{|l|l|}
\hline \multicolumn{1}{|c|}{ Medicamento } & \multicolumn{1}{c|}{ Posología } \\
\hline Nitrofurantoina & $100 \mathrm{mg}$, vía oral, cada 8 horas durante 3 días \\
\hline Trimetropin con sulfametoxazol & $\begin{array}{l}160 \mathrm{y} 800 \mathrm{mg} \text {, vía oral, cada } 12 \text { horas durante } 3 \text { a } 7 \\
\text { días }\end{array}$ \\
\hline Ciprofloxacina & $500 \mathrm{mg}$, vía oral, cada 12 horas durante 3 a 7 días \\
\hline Norfloxacina & $400 \mathrm{mg}$, vía oral, cada 12 horas durante 7 días \\
\hline Cefalosporinas (3 ${ }^{a}$ generación) & $1 \mathrm{~g} \mathrm{IM} \mathrm{o} 500 \mathrm{mg}$, cada 6 horas de 3 a 10 días \\
\hline Amoxicilina & $500 \mathrm{mg}$, vía oral, cada 6 horas durante 3 a 10 días \\
\hline Amikacina & $1 \mathrm{~g} \mathrm{IM}$, cada 24 horas durante 3 a 10 días \\
\hline Gentamicina & $160 \mathrm{mg}$ IM cada 24 horas durante 3 a 10 días \\
\hline
\end{tabular}

\section{Medidas de prevención}

La prevención de infección vías urinarias se realiza mediante la promoción de la salud, fomentando estilos de vida saludables, la alimentación con leche materna durante el primer año de vida. Es prioritario promover la ingesta de agua en abundante cantidad, 


\section{Infección de vías urinarias}

para ayudar a limpiar el tracto urinario. Así como diversas medidas higiénicas, como la educación en técnicas de higiene perianal en mujeres.

Las medidas de prevención una vez que se ha tenido la enfermedad, incluyen la prevención de secuelas a largo plazo, entre ellas se deben evitar las recurrencias. Cuando se presentan éstos casos clínicos, se puede proporcionar terapia profiláctica, con antibióticos, con el afán de evitar las reinfecciones.

También existen otras medidas de prevención, que son importantes considerarlas:

- Es recomendable el vaciamiento y control de vejiga neurogénica.

- Evitar el uso prolongado de catéter urinario puesto que aumenta en mucho la probabilidad de una infección del tracto urinario.

- Diagnosticar y tratar oportunamente las infecciones de vías urinarias en menores de 18 años para evitar complicaciones y secuelas.

- Los grados más severos de reflujo a menudo requieren corrección quirúrgica.

- El tratamiento del estreñimiento crónico disminuye la recurrencia de las Infecciones de vías urinarias, al igual que lo hace la corrección del vaciamiento incompleto de la vejiga.

- Es importante la corrección de las anomalías estructurales .El control prenatal es importante y el estudio de ultrasonido prenatal permite identificar a los lactantes las válvulas uretrales posteriores y la obstrucción ureterovesical, también necesitan intervención quirúrgica cuando existe hidronefrosis intrauterina.

\section{Referencias}

1. Secretaría de Salud. Guías diagnósticas de consulta externa. Disponible en: www. salud.gob.mx/descargaspdfarea...guías-urinarias

2. Secretaría de Salud. Estados Unidos Mexicanos 2011 SUIVE Versión ejecutiva. 


\section{Principales problemas de Salud Pública en México}

3. Secretaría de Salud. Estados Unidos Mexicanos. Sistema de vigilancia epidemiológica de las infecciones de vías urinarias 2003, 20082009.

4. Calderón-Jaimes $\mathrm{E}$, et al. Diagnóstico y tratamiento en vías urinarias un enfoque multidisciplinario para casos no complicados. Bol Med Hosp Infant Mex 2010, 70(1):3-10.

5. Consejo de Salubridad General, IMSS, ISSSTE, PEMEX, DIF, Academia Nacional de Medicina. Guía de Referencia Rápida. Prevención, diagnóstico y tratamiento de las infecciones de vías urinarias no complicada en menores de 18 años en el primero y segundo nivel de atención. Octubre 2009.

6. Chavarría Zárate J, Sarmiento Aguilar E, Osores Plenge F. Infección del tracto urinario y manejo antibiótico. Acta Med Per. 2006; 23(1):26-31.

7. Secretaría de Salud. Abordaje diagnóstico de las malformaciones de vías urinarias en el niño. México: SSA; 2013.

8. Molina L, Manjarres H. Infecciones de vías urinarias. Recursos en bacteriología, UNAM. 2014. Disponible en: http://www.facmed.unam.mx/deptos/microbiologia/ bacteriologia/enfermedades-vias-urinarias.html

9. García-Morúa A, Hernández-Torres A, Salazar- de Hoyos JL, Jaime-Dávila R, GómezGuerra LS. Etiología y resistencia antibiótica de las infecciones de vías urinarias adquiridas en la comunidad en Monterrey, N.L. Rev Mex Urol. 2009; 69:45-48.

10. Gallardo Luna MG, Magaña Aquino M, Andrade Rodríguez HJ. Resistencia a fármacos empleados en infección de vías urinarias en pacientes de primer contacto en una unidad de medicina familiar del IMSS. Enf Inf Microbiol. 2008;28 (1):1318.

11. Tierney, LM Jr. Diagnóstico clínico y tratamiento. 30a ed. México: Manual Moderno; 1995.

12. Berkow, R. El manual Merk. 9a ed. España: Océano/Centrum; 1994.

13. Chávez-Valencia V, Gallegos-Nava S, Arce-Salinas CA. Patrones de resistencia antimicrobiana y etiología de infecciones urinarias no complicadas. Gac Med Mex. 2010; 146(4):269-273.

14. Secretaría de Salud. CIE10N39.0 Vías urinarias.

15. Resistencia antimicrobiana en la infección urinaria por E. coli adquirida en la comunidad. Salud Pública Mex. 2009; 51:155-159.

16. South Paul JE, Mutheny SC. Diagnóstico y tratamiento en medicina familiar. México: Manual Moderno; 2005. 


\section{Depresión}

\section{Mtra. Mercedes Esmirna Ríos Bustos}

\section{Introducción}

El término depresión se utiliza para sintetizar un trastorno del estado de ánimo que se caracteriza por el abatimiento, que indica la situación de hundimiento personal de quien la presenta. En estas personas, el estado de ánimo se encuentra decaído, con insuficiente energía, con disminución de su actividad, su capacidad de disfrute, así como disminución de la concentración y motivación ${ }^{1}$.

En estos pacientes los trastornos del sueño son frecuentes, y del mismo modo, presentan alteraciones del apetito; pueden presentar cansancio, incluso ante esfuerzos físicos pequeños. La baja autoestima es habitual, así como la culpabilidad; en un grado más severo no son extrañas las ideas ni las conductas suicidas.

Por otra parte, autores como Riveros, Hernández y Rivera ${ }^{2}$, mencionan que: “ La depresión se incluye en el grupo de los "trastornos afectivos", dado que una característica de la misma es la alteración de la capacidad afectiva, siendo no sólo la tristeza sino también la incapacidad de dar afecto o recibirlo de quienes nos rodean".

Desafortunadamente cada vez se identifican más casos de este trastorno emocional en los niños, adolescentes y jóvenes. La presencia tanto de la depresión, como de su complicación más grave, el suicidio, resultan ser cada vez más alarmantes, tanto por su frecuencia, como por el impacto que tienen tanto en la productividad laboral, como en la vida social y personal de quienes la presentan.

No obstante, la valoración social del suicidio, ha sido distinta a los largo de la historia, Kaplan y Sadock ${ }^{3}$ mencionan que en algunas sociedades guerreras de la antigüedad, cuyos dioses eran los de la violencia y cuyo ideal era el valor, a menudo se contemplaba al suicidio como una bendición, como es el caso de los normandos y druidas que exaltaban a este acto como un principio religioso. 


\section{Principales problemas de Salud Pública en México}

En Grecia, Homero registra el suicidio sin comentarios, como algo natural y generalmente heroico; y hasta donde llegan los testimonios, los griegos solamente se quitaban la vida por las mejores razones imaginables: dolor, elevados principios patrióticos o para evitar la deshonra.

Para los estoicos, el ideal era más vago y más digno, era el de vivir de acuerdo con la naturaleza. Cuando la vida parecía no estar de acuerdo con ello, la muerte aparecía como una elección racional ${ }^{4}$.

Para los romanos, el suicidio era contemplado como una forma cuidadosamente considerada y escogida de morir, que correspondiera a la forma en que habían vivido. Vivir noblemente significaba también morir noblemente y en el momento preciso, y esta gran racionalidad tuvo tal alcance que la multitud para entretenerse no se satisfacía con nada menos que la muerte.

Esto presenta una paradoja, mientras que en el politeísmo, intelectualmente absurdo de la Época Antigua, constituye un obstáculo efectivo para la comprensión científica, produce también en forma contraria, tolerancia, respeto por la libertad individual y un espacio vital civilizado.

El monoteísmo en contrapartida, trata al mundo como un todo sistemático, único e inteligible, sin embargo sus consecuencias son: el dogmatismo, el fanatismo y la persecución.

En un inicio, los primeros cristianos mostraron la misma indiferencia hacia la muerte, que los romanos, para ellos, el suicidio era un tema tan neutral que Tertuliano, uno de los más fervorosos Padre de la Iglesia, consideraba la propia muerte de Cristo como una especie de suicidio, llegando a sentir que cuanto más abundante era la vida, mayor tentación al pecado. La muerte, por lo tanto, era una liberación que se esperaba o se buscaba con impaciencia siendo incontables los mártires de la época ${ }^{3,4}$.

Es en el siglo XI en que este acto es considerado pecado mortal contra Dios que nos ha dado la vida, utilizándose el Sexto Mandamiento "no matarás" como única autoridad bíblica para frenar el fanatismo por suicidio y por el martirio. Por tanto, lo que comenzó como una medida preventiva terminó como un cambio de carácter universal ${ }^{3,4}$. 


\section{Depresión}

Un acto, que durante el primer florecimiento de la civilización occidental había sido tolerado, luego admirado y más tarde incluso buscado como supremo signo de fanatismo, se convirtió finalmente en objeto de profunda repulsión para la moral cristiana.

Para cambiar eso, hizo falta la intervención científica, para la cual el suicidio se transforma en asunto de estudio, por considerarlo parte de las manifestaciones de las enfermedades mentales y no como elemento esencial del ámbito de lo moral ${ }^{5}$. Por lo que, aunque la depresión fue reconocida clínicamente, desde los antiguos griegos ${ }^{6}$, no fue hasta mediados del siglo XX que se iniciaron estudios bioquímicos que demostraron no solamente que este trastorno tiene relación con la cantidad y tipo de neurotransmisores disponibles en el cerebro, sino que esta condición está también relacionada con la conducta suicida. Dichos estudios aportaron una valiosa comprensión del trastorno, abriendo alternativas para el desarrollo del tratamiento eficaz para la depresión.

\section{Concepto}

La depresión es una de las expresiones más comunes de trastorno mental entre la población general, es un desorden global de la afectividad, en donde hay una baja del estado de ánimo, que implica un cambio en la manera de percibir la vida?

Los signos y síntomas de este cuadro pueden presentarse en forma aguda, pero lo más común es que se presenten en forma episódica y recurrente. Abarca las esferas psíquica, somática y de la conducta.

\section{Clasificación}

La clasificación de este trastorno emocional, de acuerdo a la Asociación Psiquiátrica Americana8, DSM IV con códigos según la CIE-10, está conformada por trastornos depresivos:

F32.x Trastorno depresivo mayor único (345).

F33.x Trastorno depresivo mayor recidivante (345).

F34.2 Trastorno distímico (352). 


\section{Principales problemas de Salud Pública en México}

Especificar si: De inicio temprano (antes de los 21 años)/de inicio tardío (21 años o después).

Especificar: Con síntomas atípicos.

F32.9 Trastorno depresivo no especificado (357).

En donde, de acuerdo a la Asociación Psiquiátrica Americana ${ }^{8}$, el trastorno distímico o depresivo y el trastorno depresivo mayor se distinguen en base a la gravedad, la cronicidad y la persistencia. Para que un cuadro de abatimiento o tristeza, pase a ser considerado como un cuadro depresivo mayor, el estado de ánimo depresivo debe estar presente la mayor parte del día, casi cada día, durante un período de al menos 2 semanas.

Para que a un cuadro de tristeza se le considere no como a un cuadro depresivo mayor, sino como a un trastorno distímico, el abatimiento debe estar presente la mayoría de los días durante por lo menos un período de 2 años.

\section{Epidemiología}

A nivel planetario, la Organización Mundial de la Salud (OMS) ${ }^{9}$ señala que la depresión es el trastorno emocional más frecuente, lo que lo hace uno de los padecimientos mentales más relevantes de este siglo; afecta más a mujeres y su complicación, el suicidio, es la causa de aproximadamente un millón de muertes anuales.

Por su frecuencia, datos recientes reportan que la depresión se encuentra en el $5^{\circ}$ lugar dentro de las causas de discapacidad en el mundo, y comprende el $4 \%$ de la carga total de padecimientos a nivel mundial ${ }^{10}$.

A nivel nacional, el Instituto Nacional de Estadística, Geografía e Informática (INEGI) ${ }^{11}$, señala que el suicidio ha aumentado entre la población en los últimos años: en 2000 se reportaron a nivel nacional 3475 casos, con un incremento en 2007 de 4394 casos reportados y otro incremento en 2008 con 4681 casos, lo que habla de un problema del campo psiquiátrico que está tomando una magnitud cada vez más importante.

En cuanto al sexo, la depresión afecta a por lo menos el $20 \%$ de las mujeres y al $12 \%$ de los hombres, en algún momento durante su vida, donde son las mujeres la población 


\section{Depresión}

más susceptible a presentar este trastorno, con un incremento en la intensidad de la sintomatología conforme avanza la edad ${ }^{10}$. No obstante, lo anterior, son más los hombres, en relación a las mujeres los que más fallecen por suicidio ${ }^{12}$.

\section{Causalidad}

Es una enfermedad multicausal, no hay predilección por la edad ni por el sexo, aunque hay una mayor frecuencia del suicidio en hombres ${ }^{3,4}$.

Sin embargo, su origen puede ser por dos vías: ya sea por causas externas (o exógenas) o por bioquímicas (o endógenas). Se considera que la herencia juega un papel más decisivo en las formas bipolares que en las mono polares?.

También se encuentran dentro de la causalidad, factores químicos, con la presencia de alteraciones en los neurotransmisores, así como factores psicosociales entre los que se mencionan: experiencias adversas en la infancia, etapa del ciclo vital donde se forma el "troquelado" de los principales rasgos del carácter, dificultades cotidianas y crónicas, eventos indeseables durante la vida, baja autoestima y entorno social limitado ${ }^{7}$.

Dos tipos de rasgos de carácter se vinculan con la propensión a la depresión: rasgos obsesivos, rígidos, perfeccionistas, rasgos de pasividad aunada a una necesidad excesiva de depender de los demás ${ }^{8}$.

En pacientes con formas graves de depresión principalmente de tipo endógeno, se encuentra la presencia de una influencia de tipo genético, con un riesgo mayor en la morbilidad en los familiares en primer grado (padres, hermanos, hijos). En donde está incrementada la independencia de los factores ambientales, marcadores genéticos que se encontraron potenciales para la depresión se localizaron en los cromosomas $x, 4,5,11$, 18, y $21^{7}$.

Más recientemente Caspi y colaboradores ${ }^{13}$, efectuaron pruebas para observar y entender más a fondo, por qué situaciones estresantes originaban depresión a ciertas personas y a otras no, con el hallazgo de un polimorfismo funcional ubicado en la región promotora del gen transportador de la serotonina (5-HTT) regulaba la influencia de los sucesos estresantes cotidianos en la depresión. 


\section{Principales problemas de Salud Pública en México}

También se percataron, que quienes presentaban una o dos copias del alelo corto del 5-HTT mostraron más síntomas depresivos, depresión diagnosticable y tendencias suicidas con relación a eventos estresantes, en comparación con las personas que presentaban un solo alelo ${ }^{13}$.

Con este estudio los autores lograron mostrar la interacción genético-ambiental, con la obtención de evidencias de cómo una persona responde a través de su contenido genético ante los estímulos ambientales.

Por otra parte, la presencia de violencia intrafamiliar, los divorcios, el desempleo, el rechazo social, la enfermedad ya sea en un ser querido o en uno mismo, la muerte, etc. son causas que frecuentemente pueden originar la depresión de tipo exógeno, la cual es auto limitante, pero en una autoestima frágil o en una personalidad susceptible a la depresión, ésta puede hacerse crónica, o llegar a complicarse hasta terminar en una forma trágica.

Frecuentemente, la pérdida de un objeto de amor, o dicho de otra manera: la ruptura de "ligas de apego", precede a la iniciación de estados depresivos, particularmente de forma mono polar.

Ambos sucesos, tanto el de la pérdida de un objeto psicológicamente importante, y la interrupción de una liga importante, son equivalentes. En ocasiones es sumamente difícil distinguir entre una depresión endógena y una reactiva sin tomar en cuenta la biografía y los antecedentes personales y familiares ${ }^{4}$.

\section{Fisiopatología}

En el plano bioquímico, existen estudios que muestran que la existencia de niveles anormales de la serotonina, norepinefrina y dopamina, neurotransmisores cerebrales, tienen un papel importante en la fisiopatología de la depresión.

El papel de la interacción de estos tres neurotransmisores ha sido de vital importancia para entender los efectos benéficos de los antidepresivos tricíclicos y de los inhibidores de la monoamino-oxidasa $(\mathrm{MAO})^{10}$.

Estas evidencias dieron lugar a la conformación de la "hipótesis de las monoaminas en la depresión", la cual, en una primer instancia planteó que la depresión era causada por un 


\section{Depresión}

déficit funcional de las monoaminas: noradrenalina y serotonina en sitios claves del cerebro, mientras que la manía era causada por un incremento excesivo en la producción de éstas; con la facilitación por parte de los agentes antidepresivos para facilitar la neurotransmisión monoaminérgica por medio del incremento de los niveles de las monoaminas en las terminales sinápticas ${ }^{15}$.

No obstante, a pesar de que hay pocas dudas sobre el importante papel de los neurotransmisores cerebrales en el origen de la depresión, no existen hasta ahora un solo sistema neurotransmisor que sea el único responsable en la etiología de este padecimiento ${ }^{16}$.

\section{Cuadro clínico}

La depresión suele tener expresiones clínicas tanto en la esfera afectiva como somática:

- En la esfera afectiva: suele manifestarse principalmente por llanto fácil, desinterés por muchas actividades cotidianas como reuniones sociales o familiares. Hay un abatimiento del humor, aflicción, pesimismo, inhibición de las motivaciones, desinterés con una sensación de vacío y soledad así como de cansancio y culpa.

También hay una baja autoestima y no es rara la presencia de violencia en cualquier manifestación en estas personas, la cual puede ser dirigida ya sea al exterior o hacía sí mismo; donde la expresión extrema y trágica está representada en el suicidio, el alcoholismo o la drogadicción; a estas últimas se les puede considerar como una forma de suicidio crónico ${ }^{4.5}$.

- En la somática: frecuentemente hay problemas en la nutrición: ya sea como falta de apetito que puede llegar a la anorexia o bulimia, o por el contrario: como una ingesta desordenada y abundante de alimentos que puede llegar hasta la obesidad alarmante. También se presenta perturbación en el sueño y diversos síntomas disfuncionales de los aparatos y sistemas ${ }^{3,4}$.

\section{Complicaciones}

La complicación de la depresión es el suicidio, el cual se entiende como toda muerte que resulta mediante o inmediatamente después de un acto realizado por la víctima misma. 


\section{Principales problemas de Salud Pública en México}

Donde psicodinámicamente Freud señala, muchos suicidios son asesinatos encubiertos, en donde el hombre se mata y mata simbólicamente al que acusa de haber envenenado su vida, implicando en esto un gran sentimiento de ira ${ }^{17}$.

La predicción clínica del riesgo suicida, requiere de una combinación de intuición y experiencia, para identificar durante la entrevista psiquiátrica variables de alto riesgo, como:

- Intentos suicidas previos.

- Antecedentes familiares suicidas.

- Impulsividad por parte del paciente.

- Ausencias de apoyo familiar o social.

- Pérdidas significativas.

- Hostilidad.

- Culpa Intensa.

- Anhedonia.

- Padecimientos afectivos bipolares con refractilidad de tratamientos previos ${ }^{17}$.

\section{Diagnóstico}

Los criterios clínicos para determinar que un estado de abatimiento, sea considerado un episodio depresivo mayor, de acuerdo a la Asociación Psiquiátrica Americana ${ }^{8}$ son:

A. Cinco (o más) de los síntomas siguientes durante el mismo período de 2 semanas y representan un cambio respecto del desempeño previo, por lo menos uno de los síntomas es el estado de ánimo depresivo y se pueden observar otros, como: 


\section{Depresión}

- Marcada disminución del interés o del placer en todas, o casi todas la actividades durante la mayor parte del día, casi todos los días.

- Pérdida significativa de peso sin estar a dieta o aumento significativo, o disminución o aumento del apetito casi todos los días.

- Insomnio o hipersomnia casi todos los días.

- Agitación o retraso psicomotores casi todos los días.

- Fatiga o pérdida de energía casi todos los días.

- Sentimientos de desvalorización o de culpa excesiva o inapropiada (que pueden ser delirantes) casi todos los días (no simplemente autor reproches o culpa por estar enfermo).

- Menor cantidad de pensar o concentrarse o indecisión casi todos los días (indicada por el relato subjetivo o por observación de otros).

- Pensamientos recurrentes de muerte (no sólo temor de morir), ideación suicida recurrente sin plan específico, o un intento de suicidio, o un plan de suicidio específico.

B. Los síntomas no cumplen los criterios de un episodio mixto.

C. Los síntomas provocan malestar clínicamente significativo o deterioro del funcionamiento social, laboral o en otras esferas importantes.

D. Los síntomas no obedecen a los efectos fisiológicos directos de una sustancia (por ejemplo: una droga de abuso, una medicación), ni a una enfermedad médica general (por ejemplo: hipotiroidismo).

E. Los síntomas no son mejor explicados por duelo, es decir, que tras la pérdida de un ser querido, los síntomas persisten por más de dos meses, o se caracterizan por visible deterioro funcional, preocupación mórbida con desvalorización, ideación suicida, síntomas psicóticos o retraso psicomotor. 


\section{Principales problemas de Salud Pública en México}

\section{Terapéutica}

El manejo correcto del enfermo se basa en la comprensión de la naturaleza del desorden, el manejo de la relación terapéutica y el uso adecuado de los medicamentos específicos.

Ciertas medidas son importantes:

a) Evitar exámenes y consultas innecesarias.

b) Ayudar al enfermo a aceptar su impotencia y pérdida de liberad como algo reversible y a mantener viva la esperanza.

c) Explicar la naturaleza de su problema poniendo acento en su carácter transitorio y en la eficacia de los recursos terapéuticos.

d) Señalar en cada entrevista acerca de los matices de su experiencia como algo individualizado

e) Lograr la cooperación de los familiares y hacer que asuman su responsabilidad en caso de que haya riesgo suicida.

f) Eliminar en lo posible cargas y tensiones innecesarias.

g) Evitar que el enfermo haga cambios radicales en su vida.

h) Verlo periódicamente hasta su total recuperación y estar accesible para que pueda consultar acerca de sus dudad e indecisiones. Mostrarle que no importa cuán sombrío vea su futuro, hay una luz al final del túnel ${ }^{17}$.

\section{Medidas de prevención}

La difusión de este padecimiento como un trastorno de la afectividad que se trata médicamente y que es curable, así como la promoción de espacios donde manejen profesionalmente este padecimiento es una medida cada vez más importante. 


\section{Depresión}

También la sensibilización y la facilitación tanto a la población en general como a la estudiantil a usar espacios que promuevan la autoestima, la creatividad y la integración familiar como los destinados a diversas actividades artísticas o deportivas, son medidas preventivas integrales prioritarias para este trastorno ${ }^{17}$.

\section{Referencias}

1. Martínez-Otero P. Sintomatología depresiva en universitarios: estudio de una muestra de alumnos de pedagogía. Revista Electrónica de Psicología Iztacala. 2010; 13(4). Recuperado el 30-XI-2011 de: http://www.iztacala.unam.mx/carreras/psicología/ps.clin

2. Riveros $Q$, Hernández V, Rivera B. Niveles de depresión y ansiedad en estudiantes universitarios de Lima Metropolitana. Revista IIPSI, Facultad de Psicología. 2007; 10(1):91-102.

3. Kaplan HI, Sadock BJ, Grebb JA. Sinopsis de psiquiatría. Argentina: Médica Panamericana; 2000.

4. Freedman A, Kaplan H, Sadock B. Tratado de psiquiatría. Tomo II. Barcelona: Salvat; 1982.

5. Bakalar J, Baldessarini R, et al. The new Harvard guide to psychiatry. Nicholi A, Jr.1988: 309-337.

6. Escobar A. Neurobiología de la depresión. En: Velázquez Moctezuma J. (ed.). Temas Selectos de Neurociencias III. México: UAM; 2004. p. 181-190.

7. Guadarrama L, Escobar A, Zhang L. Bases neuroquímicas y neuroanatómicas de la depresión. Monografía. (s.f.). Recuperado el 7-VI-2014 de: http://www.ejournal.unam. $\mathrm{mx} / \mathrm{rfm} / \mathrm{n} 49-2 / \mathrm{RFM} 49208 . p d f$

8. American Psychiatric Association. Diagnostic and statistical manual of mental disorders. DSM-IV TR. 2a ed. Washington, DC: Elsevier Masson; 2007.

9. Organización Mundial de la Salud (OMS). Salud Mental. Informes de los países y gráficos disponibles. Recuperado el 30-I-2013 de: http://www.who.int/mental_health/ prevention/suicide/country_reports/en/index.html. 2008

10. Baldwin D, Bertwistle J. An atlas of depression. Southampton, UK: The Parthenon Publishing Group; 2002. 


\section{Principales problemas de Salud Pública en México}

11. Instituto Nacional de Estadística, Geografía e Informática [INEGI]. Agenda estadística de los Estados Unidos Mexicanos. Recuperado el 29-I-2013 de: http://www.inegi.org. $\mathrm{mx} /$ prod_serv/contenidos/pais/agenda/2010/Agenda_2010.pdf

12. Sadock BJ, Sadock VA. Kaplan \& Sadock's. Comprehensive textbook of psychiatry. 7a ed. USA: Lippincott Williams \& Wilkins; 1999.

13. Caspi A, Sugden K, Mofitt TE, Taylor A, Craig JW, Harrington H, McClay J, Mell J Martin J, Braithwaite A, Poulton R. Influence of life stress on depression: moderation by a polymorphisim in the 5-HTT gene. Science. 2003; 301(5631):386-389.

14. Racagni G, Brunello N. Physiology to functionality: the brain and neurotransmitter activity. Int Clin Psychopharmacol. 1999; suppl.14(1):53-57.

15. Nemeroff B. Hallazgos recientes en la fisiopatología de la depresión. Psimonart. 2009; 2(1):25-48.

16. Ríos B. El manejo del paciente suicida. Vertientes Revista Especializada en Ciencias de la Salud. 2007; 10(1-2): 8-11. Recuperado el 7-VI-2014 de: http://www.revistas.unam.mx/ index.php/vertientes/article/download/.../30143, http://www.journals.unam.mx/index. php/vertientes/article/download/.../25021 


\section{Diabetes mellitus}

Darío Sebastián Posadas Estrada

\section{Introducción}

El conocimiento de ésta enfermedad, y las primeras descripciones históricas, inician con la cultura egipcia, reportado en el papiro de Ebers, en el cuál se describen síntomas similares a la diabetes, en el siglo XV a.C. Posteriormente en el Siglo II d.C. Areteo de Capadocia, médico griego, nombra la enfermedad como "diabetes", derivado del griego "correr a través", relacionado con la poliuria, una de las manifestaciones clínicas cardinales $^{1,2}$.

En el presente capitulo, se analizan los componentes que integran ésta enfermedad crónicodegenerativa, los diferentes tipos de diabetes que existen, la importancia epidemiológica a nivel nacional e internacional, su explicación fisiopatológica, los factores de riesgo asociados, su presentación clínica, complicaciones, manejo terapéutico y medidas de prevención.

\section{Concepto}

La diabetes mellitus (DM) es una patología compleja; que involucra a todas las células, tejidos y órganos, por lo tanto es sistémica; se clasifica en el grupo de enfermedades crónicas y degenerativas; en la que la principal alteración es de origen endócrino, por trastornos metabólicos caracterizados por un estado de hiperglucemia crónica asociado a la deficiencia en la producción o en la acción de la insulina, alterando el metabolismo intermedio de macronutrientes, como son los hidratos de carbono, las grasas y las proteínas. Presenta diversos factores de riesgo asociados, dentro de ellos, una relación hereditaria importante para su desarrollo. Se presentan diversas explicaciones fisiopatológicas vinculadas con el inicio de la patología, generando diferentes subtipos o clases ${ }^{1,2,3,4,5}$. 


\section{Principales problemas de Salud Pública en México}

\section{Clasificación}

Definir la categoría en la que se encuentra la DM, permite realizar el manejo terapéutico adecuado y la posibilidad de un mejor pronóstico. Se clasifica en cuatro categorías clínicas y fisiopatológicas, las cuales son ${ }^{1,5,6,7,8,9}$ :

$>$ Diabetes mellitus tipo 1

Se presenta una destrucción de las células beta del páncreas, generando una deficiencia absoluta de insulina. Representa del 5\% al 10\% de los pacientes diagnosticados con Diabetes, tiene una mayor prevalencia en pacientes jóvenes (niños y adolescentes). En esta categoría, se puede presentar:

- DM autoinmune tipo 1A, con evidencia de anticuerpos contra las células del islote, anticuerpos contra descarboxilasa del ácido glutámico, anticuerpos anti insulina, y anticuerpos anti tirosina fosfatasa.

- DM tipo 1, asociada al halotipo HLA DR/DQ. Con vínculo a otras enfermedades autoinmunes como la enfermedad de Addison, enfermedad de Graves Basedow, Tiroiditis de Hashimoto, entre otras.

- DM tipo 1 idiopática. Presenta una mayor incidencia en la población de África y de Asia. No se encuentra evidencia de autoinmunidad (es decir, la determinación de auto anticuerpos es negativa), además de no tener asociación a HLA.

- DM tipo 1 de inicio en el adulto. Se abrevia con el acrónimo LADA, por sus siglas en inglés (Latent Autoinmune Diabetes in Adults), por lo general, se diagnostica como DM tipo 2, sin embargo se demuestra la presencia de auto anticuerpos ${ }^{10}$.

Diabetes mellitus tipo 2

Existe una producción deficiente de insulina de forma progresiva, asociado a un estado de resistencia a ésta hormona. Representa del 90\% al 95\% de todos los pacientes con Diabetes, es de origen poligenético y multifactorial. Es más frecuente en el paciente adulto, sin embargo ha presentado un aumento en la incidencia en niños (debido a los factores de 


\section{Diabetes mellitus}

riesgo, como obesidad infantil y sedentarismo). Su principal asociación es el Síndrome Metabólico ${ }^{1}$.

$>$ Otros tipos específicos de Diabetes

Asociados a diversas causas como son: defectos genéticos en las células beta, defectos genéticos en la insulina, enfermedades del páncreas exocrino, infecciones virales, uso de fármacos, síndromes genéticos, y enfermedades endócrinas.

Los defectos genéticos de la célula beta, están relacionados a herencia autosómica dominante, de origen monogenético, produciendo una alteración en la secreción de insulina. Se abrevian con las siglas MODY (Maturity Onset Diabetes of the Young). El tipo más frecuente es el MODY 3, ya que se relaciona con el 65\% de éstas alteraciones, donde la alteración se encuentra en el cromosoma 12. El MODY 2, es la segunda presentación más frecuente con el 15\% de los casos, su alteración se encuentra en el cromosoma 7 . En el MODY 1, la mutación se encuentra en el cromosoma 20, el MODY 4 en el cromosoma 13, el MODY 5 en el cromosoma 17 y el MODY 6 en el cromosoma 2. Otro tipo de alteración genética, son alteraciones en el DNA mitocondrial de la célula beta.

Los defectos genéticos en la acción de la insulina, presentan una muy baja incidencia, se consideran alteraciones monogenéticas, de herencia autosómica recesiva. Entre ellas se encuentra el Síndrome Donohue o Lepreuchanismo y el Síndrome de Rabson Mendenhall, con mutación en el cromosoma 19, que modifica la acción del gen receptor de la insulina.

Las principales enfermedades del páncreas exocrino, asociadas al desarrollo de Diabetes, son la fibrosis quística del páncreas, la pancreatitis crónica, hemocromatosis, pancreatectomía y la Pancreatopatía fibrocalculosa.

Las infecciones virales, que presentan un vínculo con la Diabetes, son el virus de la hepatitis $\mathrm{C}$, infección por Coxsackie B, rubeola, adenovirus, citomegalovirus y virus de la parotiditis.

Los principales fármacos, que inducen el desarrollo de diabetes, son: glucocorticoides, hormonas tiroideas, tiazidas, beta adrenérgicos, ácido nicotínico, entre otros. 


\section{Principales problemas de Salud Pública en México}

Los síndromes genéticos asociados con diabetes, se encuentra el síndrome de Down, el síndrome de Turner, el síndrome de Klinefelter, síndrome de Wolfram, entre otros. Mientras que el desarrollo de endocrinopatías relacionadas con la diabetes son: la acromegalia, el feocromocitoma, el hipertiroidismo, el síndrome de Cushing, el aldosteroma, el glucagonoma, y el somatostinoma.

Diabetes mellitus gestacional. Enfermedad inducida durante el embarazo, la que se presenta con una incidencia del 7\% en México para el año $2005^{1,2,10}$.

\section{Epidemiología}

Los reportes epidemiológicos en México y a nivel mundial, presentan evidencia que ésta patología es un problema de Salud Pública, que produce importantes consecuencias a nivel individual, familiar, comunitario, nacional e internacional.

La Federación Internacional de Diabetes, en el año 2012 señala que más de 371 millones de personas, presentan DM y 4.8 millones de personas mueren por sus complicaciones, a nivel mundial. Y se estima que para el año 2030 se presenten 439 millones de personas con ésta enfermedad, y el 7.7\% de la población adulta ${ }^{3}$.

En México, durante el año 2012 el INEGI reporta que 418, 797 personas presentan DM (que representa el $0.4 \%$ de la población), con una mayor prevalencia en el sexo femenino (59\%) y con el grupo etario más afectado de 50 a 59 años de edad. Presenta una tasa de morbilidad de 1,237.9 casos por cada 100 mil habitantes. Su tendencia es positiva, y se espera que para el año 2030 exista un aumento del $37.8 \%$ en el número de casos y $23.9 \%$ en su tasa de morbilidad.

Según datos del INEGI en el año 2012, señalan a la DM como la segunda causa de muerte en la población mexicana, con una tasa de mortalidad de 75 por cada 100 mil habitantes. Además de estar relacionado con complicaciones como son la retinopatía, nefropatía, cardiopatía, infarto agudo al miocardio (IAM), enfermedad cerebral vascular, enfermedad vascular periférica, ciertos tipos de cáncer; comorbilidades que generan una mala calidad de vida, reducción de la esperanza de vida al nacer, reducción de la vida económicamente productiva, dificultando el desarrollo biológico, psicológico y social ${ }^{11}$. 


\section{Diabetes mellitus}

La Secretaría de Salud (México 2010), reportó un gasto anual en costos directos para la atención médica de pacientes con DM tipo 2 de \$452,064, 988 dólares. Con un gasto anual por paciente de $\$ 2,740.34$ dólares sin la presencia de complicaciones y de $\$ 3,550.17$ dólares para el paciente con complicaciones ${ }^{11}$.

\section{Causalidad}

Entre los principales factores de riesgo, que se encuentran relacionados a la DM, se encuentran: el sobrepeso, con un índice de masa corporal (IMC) de $25 \mathrm{mg} / \mathrm{m}^{2}$ a $29.9 \mathrm{mg} / \mathrm{m}^{2}$ o la obesidad con IMC igual o mayor a $30 \mathrm{mg} / \mathrm{m}^{2}$; sedentarismo; inactividad física; antecedentes familiares de primer grado con DM; grupo étnico con factores de riesgo, como son Africanos, Afroamericanos, Americanos, Latinos, Asiáticos y del Pacífico; mujeres con antecedente de productos macrosómicos o haber presentado diabetes gestacional; Hipertensión Arterial Sistémica (HAS), igual o mayor a $140 / 90 \mathrm{~mm} \mathrm{Hg}$, o en tratamiento para la HAS; dislipidemia con valores de colesterol HDL menor de $35 \mathrm{mg} / \mathrm{dl}$, o triglicéridos mayor de $250 \mathrm{mg} / \mathrm{dl}$; mujeres con síndrome de ovario poliquístico; y la evidencia diagnóstica de prediabetes $3,5,6,7,10,12,13$.

\section{Fisiopatología}

Para distinguir los factores fisiopatológicos relacionados con la DM, es necesario analizar por separado las características presentes en la DM tipo 1 y en la DM tipo $2^{1,2,5,6,7,12}$.

El modelo del desarrollo de la DM tipo 1, vincula la interacción de factores genéticos, ambientales e inmunológicos, que finalizan en la destrucción de las células beta del páncreas y por lo tanto la deficiencia absoluta de insulina. La predisposición genética vinculada con el halotipo HLA DR3/DR4, se encuentra presente en el 40\% de los pacientes jóvenes con DM tipo 1, posteriormente la presencia de un inmunoactivador (factor desencadenante ambiental, como es la infección por virus coxsackie, virus de la rubeola, exposición precoz a la leche de vaca y nitrosoureas) generan el desarrollo de anomalías inmunitarias, como la generación de auto anticuerpos, con la progresiva destrucción de la masa de células beta del páncreas. Cuando se presenta una destrucción del 80\% de la masa celular, se presenta la etapa clínica de la enfermedad. La presencia de inmuno marcadores, son el principal elemento que permite el Diagnóstico En el 75\% de los pacientes con DM tipo 1, presentan anticuerpos contra las células de los islotes ${ }^{1,2,14}$. 
La explicación fisiopatológica en el desarrollo de la DM tipo 2, se caracteriza por la combinación de resistencia periférica a la insulina y la inadecuada secreción de insulina por las células beta del páncreas. La resistencia a la insulina es la menor capacidad de la hormona para actuar en los tejidos periféricos (con mayor importancia en el músculo, el hígado y la grasa), en un inicio la resistencia es relativa, ya que hay un mayor aumento en la secreción de insulina (hiperinsulinemia), para normalizar los niveles de glicemia sérica. Sin embargo, con el progreso de la enfermedad, este mecanismo compensatorio es insuficiente. El hígado aumenta el catabolismo del glucógeno, para la secreción de glucosa. Estos mecanismos, explican el estado hiperglucémico del paciente diabético. Al estar presentes estos trastornos en el metabolismo de la glucosa, se aumenta el flujo de ácidos grasos libres de los adipocitos, con la consiguiente mayor generación de lipoproteínas de muy baja densidad (VLDL), en el hepatocito ${ }^{1,25,6,14,15}$.

\section{Cuadro clínico}

Los síntomas clásicos de ésta enfermedad son poliuria, polidipsia, polifagia y pérdida de peso. La poliuria, se define como el exceso de orina en las 24 horas del día y se relaciona con la presencia de glucosa en orina, generando una diuresis osmótica secundaria, aumentando de 4 a 6 litros por día. La polidipsia, se origina para compensar el exceso en la producción de orina, en relación con el estado hiperosmolar y la deshidratación. La polifagia, consiste en el aumento del apetito, con la tendencia a comer con más frecuencia, ya que se presenta un déficit de glucosa intracelular, lo que estimula el centro hipotalámico del apetito y se produce un aumento en la sensación de hambre. La pérdida de peso, se explica por las alteraciones metabólicas, que inducen un aumento en la lipolisis y en la gluconeogénesis 2,12,16. $^{2}$

Otros síntomas, frecuentemente relacionados son la astenia, fatiga, alteraciones en la agudeza visual o visión borrosa, paresias en extremidades inferiores, prurito, retraso en la cicatrización de heridas y tendencia a las infecciones.

\section{Complicaciones}

Un gran porcentaje de pacientes, son diagnosticados con DM al momento de presentarse una complicación por ésta patología, cuando ingresa a hospitalización y se evalúa que el problema principal se encuentra asociado a la DM. Las principales complicaciones, 


\section{Diabetes mellitus}

como causa de ingreso hospitalario, reportados en México, en el año 2013 son necrobiosis $(10 \%)$, estado hiperosmolar $(9.1 \%)$, cetoacidosis $(8.2 \%)$, hipoglicemia $(65 \%)$, insuficiencia renal $(6.2 \%)$, procesos infecciosos $(3.6 \%)$, enfermedad vascular cerebral $(3.1 \%)$, cardiopatía isquémica $(2.5 \%)$, neuropatía diabética $(1.2 \%)$ y retinopatía diabética $0.2 \%$. Debido a esto es necesario realizar medidas de prevención primaria, y de esta forma disminuir el porcentaje de complicaciones en el paciente que inicia con la enfermedad ${ }^{1,3,16,17,18}$.

Las complicaciones, se pueden distinguir en dos clases, las que presentan inicio agudo y las crónicas. Dentro de las complicaciones agudas se encuentran la cetoacidosis diabética, el estado hiperosmolar no cetócico, y la hipoglicemia. Las complicaciones crónicas, se relacionan con el daño generado en los vasos sanguíneos, por lo que se pueden clasificar en complicaciones microvasculares y macrovasculares. Dentro de las patologías secundarias a daño microvascular, se encuentran la nefropatía, neuropatía y retinopatía, principalmente. Mientras que el daño macrovascular genera, cardiopatía isquémica, enfermedad vascular periférica, y enfermedad vascular cerebral. A continuación se realiza una breve descripción de las complicaciones más frecuentes que se encuentran en las personas con DM.

- Cetoacidosis diabética: Proceso agudo, asociado con mayor frecuencia a la DM tipo 1, en el cuál se genera una descompensación metabólica caracterizada por hiperglucemia (mayor de $200 \mathrm{mg} / \mathrm{dl}$ ), cetonemia (ácido betahidroxibutírico mayor de $3 \mathrm{mmol} / \mathrm{L}$ ), Acidosis (pH menor de 7.3), deshidratación y pérdida de electrolitos. Se desarrolla por la deficiencia de insulina y un aumento en la cantidad de hormonas contrarreguladoras (glucagón, cortisol, adrenalina y hormona del crecimiento), aumentando la producción hepática de glucosa y una mayor liberación de ácidos grasos libres, que después de ser oxidados, se liberan cuerpos cetónicos (principalmente ácido beta hidroxibutírico y acetoacetato), ocasionando cetonemia y acidosis.

- Estado hiperosmolar: Complicación de inicio agudo, mayormente asociada a DM tipo 2. Se caracteriza por elevados niveles de glucosa sérica (mayor de $600 \mathrm{mg} / \mathrm{dl}$ ), deshidratación severa y plasma hiperosmolar (mayor de 320 mosm/L), sin la presencia de cetosis. Se manifiesta por taquicardia, hipotensión, taquipnea y alteraciones del estado mental, desde desorientación hasta estado de coma. El principal factor desencadenante, son las infecciones, cirugías, fármacos y otras complicaciones agudas. 


\section{Principales problemas de Salud Pública en México}

- Hipoglicemia: Complicación aguda de la diabetes, en la cual se encuentran valores subnormales de glucosa, menos de 60-50 mg/dl. Presenta manifestaciones asociadas a descargas adrenérgicas, como temblor, palpitaciones, ansiedad y manifestaciones que se relacionan con la pérdida de aporte de glucosa a nivel neuronal (debilidad, visión borrosa y mareos).

- Nefropatía diabética: Se desarrolla por un proceso de daño crónico, a nivel microvascular, en el que hay alteraciones en la función y estructura del glomérulo. Su clínica, se caracteriza por proteinuria persistente, hipertensión arterial y deterioro progresivo de la función renal. Presenta una prevalencia del 25 al 50\% en pacientes diabéticos tipo 1 y tipo 2.

- Retinopatía diabética: Producción crónica de lesiones microvasculares en la retina de una persona con diabetes. Es la segunda causa de ceguera en personas entre los 20 y 74 años de edad, por ello presenta consecuencias sociales y económicas, al limitar la vida productiva en las personas jóvenes; su prevalencia varía del $15 \%$ al $23 \%$. La retinopatía se puede clasificar en dos apartados, la proliferativa y la no proliferativa. En la no proliferativa, se presenta entre los 10 y 20 años después del diagnóstico de DM, se producen microaneurismas vasculares retinianos, manchas hemorrágicas y exudados algodonosos. Para la retinopatía proliferativa, se encuentra neovascularización a consecuencia de la hipoxia crónica retiniana.

- Las complicaciones crónicas macrovasculares: Se consideran la cardiopatía isquémica, la insuficiencia cardiaca, la enfermedad vascular cerebral y la insuficiencia arterial periférica. Son consideradas la primera causa de muerte en el paciente con DM. Cada una de ellas, presenta diferentes características, sin embargo el inicio etiopatogénico se asocia a la DM debido al daño arterial a consecuencia del estado hiperglucémico crónico $^{16,17,18}$.

\section{Diagnóstico}

Los criterios diagnósticos, indicados por ADA (American Diabetes Association), en el año 2014, consideran los siguientes parámetros: Hemoglobina glucosilada igual o mayor a $6.5 \%$; glucemia sérica en ayunas igual o mayor a $126 \mathrm{mg} / \mathrm{dl}(7.0 \mathrm{mmol} / \mathrm{L})$; en pacientes que presentan manifestaciones clínicas de la enfermedad se considera diagnóstico una 


\section{Diabetes mellitus}

valoración de glucosa sérica al azar igual o mayor a $200 \mathrm{mg} / \mathrm{dl}$; test de tolerancia oral a la glucosa que reporte una glicemia igual o mayor a $200 \mathrm{mg} / \mathrm{dl}$, después de dos horas de una carga de $75 \mathrm{~g}$ de glucosa disuelta en agua ${ }^{1,3,19,20}$.

Existen criterios, para el diagnóstico de prediabetes, en población que presenta factores de riego, y para ello se encuentran las siguientes pruebas: Glucemia sérica en ayudas de $100 \mathrm{mg} / \mathrm{dl}$ a $125 \mathrm{mg} / \mathrm{dl}$; test de tolerancia a la glucosa, con carga de $75 \mathrm{~g}$ de glucosa, presentando glucosa sérica 2 horas después de $140 \mathrm{mg} / \mathrm{dl}$, a $199 \mathrm{mg} / \mathrm{dl}$; o prueba de hemoglobina glucosilada de $5.7 \%$ a $6.4 \%$. Para los pacientes, con diagnóstico de prediabetes, se recomienda la vigilancia por lo menos cada 4 meses, además de iniciar con el manejo terapéutico, corregir factores de riesgo y establecer medidas preventivas ${ }^{9,21,22}$.

\section{Terapéutica}

Es necesario efectuar una evaluación inicial completa, realizando una adecuada historia clínica, haciendo énfasis en los factores de riesgo relacionados con cada individuo, así como valorar el completo estado físico del paciente, identificar la presencia de comorbilidades (su tratamiento y control); y de ésta forma poder llevar un manejo terapéutico efectivo, el cual se desarrolla en los párrafos siguientes ${ }^{1,3,21}$.

Las metas básicas del tratamiento, consisten en mantener un control efectivo de la glucosa sérica, presión arterial y lípidos. El control glucémico se establece, cuando en la hemoglobina glucosilada se reporta del 6\% al 7\%; glucemia sérica preprandial de $72 \mathrm{mg} / \mathrm{dl}$ a $108 \mathrm{mg} / \mathrm{dl}$; prueba de tolerancia a la glucosa (2 horas, postprandial), con valores de $90 \mathrm{mg} / \mathrm{dl}$ a $144 \mathrm{mg} /$ dl; colesterol total menor de $200 \mathrm{mg} / \mathrm{dl}$; colesterol LDL menor de $100 \mathrm{mg} / \mathrm{dl}$; triglicéridos en ayuno menor de $150 \mathrm{mg} / \mathrm{dl}$; colesterol HDL mayor de $40 \mathrm{mg} / \mathrm{dl}$ en hombres y mayor de $50 \mathrm{mg} / \mathrm{dl}$ en mujeres; micro albuminuria menor de $30 \mathrm{mg}$ /día; presión arterial menor de 130/80 mm Hg; IMC menor de 24.9; y circunferencia abdominal menor de $90 \mathrm{~cm}$ en hombres y menor de $80 \mathrm{~cm}$ en mujeres. Cuando se logra llegar a éstos objetivos, se puede establecer el control metabólico adecuado y óptimo de la enfermedad ${ }^{10,19,21}$.

Las medidas no farmacológicas, para el manejo terapéutico, integran el control de peso, con una pérdida ponderal del $5 \%$ al $10 \%$ de masa corporal total, como objetivo anual, por medio de la actividad física y régimen alimentario adecuado, que debe ser específico para las características individuales, sociales y culturales de cada persona; la realización de 


\section{Principales problemas de Salud Pública en México}

actividad física con la práctica de ejercicios aeróbicos por lo menos 150 minutos a la semana (30 minutos al día, por cinco días a la semana); y mantener una alimentación adecuada, en función de las necesidades y recursos de cada paciente. La educación para la salud, para la identificación de signos de alarma, el auto monitoreo de la glicemia, así como la participación social, constituyen la piedra angular para el tratamiento ${ }^{10,21}$.

A continuación, se presentan las principales familias de medicamentos antidiabéticos (hipoglucemiantes orales e insulinas), para el manejo farmacológico de la enfermedad, con las características más relevantes de cada categoría.

Las sulfonilureas, actúan aumentando la liberación de insulina, a través de un canal de potasio ATP dependiente, son metabolizadas en el hígado y excretadas a través del riñón o las heces. Los agentes de primera generación son: tolbutamida, acetohexamida, tolazamida y cloropropamida. La segunda generación está integrada por glibenclamida, glipizida y gliclazida. Mientras que la tercera generación únicamente está compuesta por Glimepirida. Este grupo farmacológico, reducen la glucosa plasmática de ayuno de 50 a $70 \mathrm{mg} / \mathrm{dl}$, y la hemoglobina glucosilada de 0.8 a 1.7\%. Su efecto adverso más común, es la hipoglicemia y el aumento de peso, sin embargo también se producen alteraciones gastrointestinales de manera frecuente. Se consideran de primera elección en DM tipo 2, y están completamente contraindicadas en DM tipo 1.

La biguanidas, grupo farmacológico antidiabético, cuyo máximo representante es la metformina. Actúa a nivel gastrointestinal, reduciendo la absorción de glucosa, inhibe la gluconeogénesis, estimula la captación celular de glucosa, incrementa la unión de insulina a su receptor, disminuye la producción hepática de glucosa, y estimula la síntesis de glucógeno. El efecto adverso más común, está relacionado a alteraciones gastrointestinales (como son anorexia, náuseas, vómito, malestar abdominal y diarrea). Se encuentra indicado en pacientes con DM tipo 2, con sobrepeso u obesidad, y en prediabetes. Contraindicado en personas con insuficiencia renal, insuficiencia hepática, embarazo, alcoholismo, o antecedentes de acidosis láctica.

Los inhibidores de la glucosidasa alfa, de uso más común son la acarbosa y el miglitol. Su mecanismo de acción, se produce por el retraso en la digestión de hidratos de carbono, lo que permite un control de los picos en los niveles de glucosa posprandial, en la DM tipo 1 y tipo 2. 


\section{Diabetes mellitus}

Las Meglitinidas, son los fármacos que pertenecen a éste grupo la repaglinida y la nateginida. Actúan restaurando la primera fase de secreción de insulina disminuyendo la hiperglicemia postprandial, evitando el pico hiperglicémico entre las comidas. Se encuentran indicadas como terapia combinada con metformina, en pacientes con DM tipo 2. Sus principales efectos adversos incluyen nauseas, diarrea, dolor abdominal, cefalea, mareo y fosfenos.

Las Tiazolidinedionas son antidiabéticos orales que actúan aumentando la sensibilidad a la insulina, sin afectar su secreción, uniéndose a los PPARs gamma, lo que promueve la captación de glucosa, en el músculo esquelético, tejido adiposo y en el hígado. Los fármacos más representativos de esta categoría, se encuentra la pioglitazona y la rosiglitazona. Se utilizan en el tratamiento para DM tipo 2.

La terapia de insulina como manejo farmacológico, principalmente ésta indicado en pacientes con DM tipo 1. Sin embargo, existen criterios para iniciar el uso de insulina en DM tipo 2, debido a la disminución crónica de la producción de insulina. Se recomienda su uso en personas con hiperglicemia marcada (mayor de $280-300 \mathrm{mg} / \mathrm{dl}$ ), cetonuria o cetonemia, que no disminuye con el uso de antidiabéticos orales (falla con la respuesta a hipoglucemiantes orales), y en mujeres con diabetes gestacional. Las insulinas que se utilizan en el manejo farmacológico, se clasifican por su tiempo de acción: las insulinas de acción ultra rápida (lispro, glulisina y aspartato; que tiene un inicio de acción de 5 a 10 minutos, con un pico a los 45-75 minutos), insulinas de acción rápida (insulina regular; su inicio de acción empieza a los 30 minutos, y el pico en la actividad se presenta de las 2.5 a 5 horas después de su administración), insulinas de acción intermedia (insulina NPH; tiene un inicio de acción a las 2 horas de ser administrado, y su pico máximo se presenta de las 4 a las 12 horas), e insulinas de acción prolongada (glargina, detemir; insulinas basales, que no presentan pico de acción farmacológica y que mantienen su efecto por periodos de 24 horas).La dosis inicial se puede calcular entre 0.5 a $0.8 \mathrm{U} / \mathrm{kg} /$ día. Los esquemas de terapia combinada con diferentes tipos de insulina, se deben establecer de forma individual con cada paciente, hasta llegar al control metabólico óptimo ${ }^{21.23,24,25}$.

\section{Medidas de prevención}

Las medidas preventivas, forman parte del manejo integral en el paciente diabético. Se establecen tres niveles de prevención, dirigidos a población con diferentes características, 


\section{Principales problemas de Salud Pública en México}

y con objetivos y acciones distintas, los cuales son prevención primaria, secundaria y terciaria. La prevención primaria, el objetivo fundamental es evitar el desarrollo de la enfermedad, en personas que presentan factores de riesgo y en la población en general; realizando medidas de Promoción de la Salud (en donde se corrigen factores asociados a los estilos de vida); prevención y corrección del sobrepeso y la obesidad; y promoción de la actividad física. La prevención secundaria, se encuentra enfocada en personas con el diagnóstico de DM y su principal meta es evitar el desarrollo de complicaciones agudas y retrasar la aparición de complicaciones crónicas, mediante el control metabólico adecuado y constante de la enfermedad. La prevención terciaria, se realiza con pacientes diabéticos con complicaciones crónicas, donde se busca evitar la discapacidad funcional 1,3,10,24.

\section{Referencias}

1. Fauci A, Braunwald E, Kasper DL, Hauser SL, Longo DL, Jameson JL, Loscalzo J. Harrison. Principios de medicina interna. 17ª Edición. México: McGraw Hill; 2012. p. 2275-2304.

2. Gomis R, Rovira A, Feliu JE, Oyarzábal M. Tratado SED de diabetes mellitus. México: Editorial Médica Panamericana; 2007. p. 225-234.

3. American Diabetes Association. Standards of medical care in diabetes 2014. Diabetes Care. 2014 enero; 37(1):1-67.

4. Flores L, Cabeza G, Calarco Z. Endocrinología. 6aa ed. México: Editorial Méndez Editores; 2012. p. 415-499.

5. Pallardo LF, Lucas T, Mazaruela M, Rovira A. Endocrinología clínica. 2ª ed. España: Editorial Díaz de Santos; 2010. p. 249-325.

6. Vilar, L. Endocrinología clínica. $4^{a}$ ed. Rio de Janeiro: Editorial GuanabaraKoogan Gen; 2012. p. 577-763.

7. Jara, A. Endocrinología. 2ª ed. México: Editorial Médica Panamericana; 2011. p. 609-839.

8. Jameson, JL. Harrison Endocrinología. Madrid: McGraw Hill; 2007. p. 283-331.

9. American Diabetes Association. Diagnosis and Classification of Diabetes Mellitus. Diabetes Care. 2010; 33(1):S62-S69.

10. Secretaría de Salud. Norma Oficial Mexicana NOM-015-SSA2-2010, para la prevención, tratamiento y control de la diabetes mellitus. México: SSA; 2010. 


\section{Diabetes mellitus}

11. Boletín Epidemiológico Diabetes Mellitus tipo 2. Primer trimestre 2013. SINAVE, Secretaría de Salud. México 2013.

12. Holt R, Cockram C, Flyvbjerg A, Goldstein B. Textbook of diabetes. $4^{\mathrm{a}}$ ed. UK: Wiley Blackwell; 2010. p. 141-439.

13. Moreno A, Limon C. Panorama general y factores asociados a la diabetes. Revista de la Facultad de Medicina de la UNAM. 2009; 52(5):219-223.

14. Hernando, R. Etiología y fisiopatología de la diabetes mellitus tipo 2. Revista Mexicana de Cardiología. 2001; 22(1):39-43.

15. Lavin N. Manual de endocrinología clínica y metabolismo. $4^{\underline{a}}$ ed. España: Lippincott Williams \& Wilkins; 2010. p. 579-697.

16. Tebar M, Escobar J. La diabetes mellitus en la práctica clínica. Madrid: Panamericana; 2009. p. 31-188.

17. García Rodríguez MJ, Antolí Royo AC, González Maroño C, García Mingo A. Complicaciones hiperglucémicas agudas de la diabetes mellitus: cetoacidosis diabética y estado hiperosmolar hiperglucémico. Medicine. 2008; 10(18):1177-1183.

18. Castro Martínez MG, Aguilar Salinas CA, Liceaga Craviotto MG, Hernández Jiménez SC. Complicaciones crónicas en la diabetes mellitus. México: Editorial Alfil; 2010.

19. Conrado AS, Calderón ER, Mello GM, Rosas BJV. Metas terapéuticas para el control metabólico de pacientes con diabetes mellitus 2, servicio de consulta externa de Medicina Interna del Hospital Regional $1^{\circ}$ de Octubre. Revista de Especialidades Médico Quirúrgicas. 2011; 16(1):18-26.

20. Alqahtani N, Khan WA, Alhumaidi MH, Ahmed YA. Use of glycated hemoglobin in the diagnosis of diabetes mellitus and pre-diabetes and role of fasting plasma glucose, oral glucose tolerance test. International journal of Preventive Medicine. 2013; 4(9);1025-1029.

21. Gil-Velázquez LE, Sil-Acosta MJ, Domínguez-Sánchez ER, Torres-Arreola LP, MedinaChávez JH. Diagnóstico y tratamiento de la diabetes mellitus tipo 2. Revista Médica del Instituto Mexicano del Seguro Social. 2013; 51(1):104-119.

22. Canadian Journal of Diabetes. Clinical practice guidelines for the prevention and management of diabetes in Canada. Can J Diabetes. 2013; 37(1): 1-227. 
23. Kuri, M. Uso de insulinas en el tratamiento de la diabetes mellitus tipo 1 y 2. Revista Mexicana de Cardiología. 2007; 18(2):57-86.

24. Secretaría de Salud. Guía práctica clínica. Diagnóstico y tratamiento de diabetes mellitus, en el adulto mayor vulnerable. México: Secretaría de Salud; 2013.

25. Saucedo R, Basurto L, Zárate A, Hernández M, Olvera D. Actualización sobre el manejo de la diabetes. Acta Médica Grupo Ángeles. 2012; 10(4):214-219. 


\section{Enfermedad vascular cerebral}

Darío Sebastián Posadas Estrada

\section{Introducción}

La Enfermedad Vascular Cerebral (EVC), es una patología asociada a un daño vascular crónico, que produce cambios súbitos en las características hemodinámicas del encéfalo. Para la mejor comprensión de este síndrome, es necesario entender cualidades anatómicas y fisiológicas de la irrigación cerebral; así como las funciones que se integran en las zonas del cerebro. En este capítulo, se analizan los componentes de este síndrome, así como la identificación de las diferencias entre el proceso isquémico y hemorrágico, en la $\mathrm{EVC}^{1,2,3}$.

\section{Concepto}

La EVC, constituye un síndrome clínico, definido por la OMS como la "perturbación o deterioro de la función cerebral, de rápido desarrollo que se presenta con signos clínicos focales o globales, durante 24 horas o posterior a ellas, sin otra causa aparente que el origen vascular".

Existen términos que pueden generar confusión en el entendimiento del concepto, ya que en diversas fuentes y referencias, son utilizados como sinónimos. El término ictus, hace referencia a la EVC aguda, e incluye al proceso de isquemia cerebral y hemorragia cerebral. La isquemia cerebral transitoria, antiguamente se definía como el proceso isquémico cerebral con signos focales, sin daño neuronal permanente, con una duración menor a 24 horas. Sin embargo, éste término fue modificado, en relación a la duración del estado isquémico, ahora se define con una presentación no mayor a 60 minutos, con recuperación espontánea y estudios de imagen (preferentemente resonancia magnética) sin evidencias de lesiones ${ }^{1,2,3,4}$. 


\section{Principales problemas de Salud Pública en México}

\section{Clasificación}

Su clasificación, establecida con base al desarrollo fisiopatológico de la enfermedad, se divide en isquemia cerebral y hemorragia. El proceso isquémico cerebral, representa la variedad más frecuente de éste síndrome, ya que representa el $80 \%$, dentro del cual en el $20 \%$ de los casos se desarrolla un ataque isquémico transitorio y el $80 \%$ cursa con un infarto cerebral establecido. La hemorragia cerebral constituye el $20 \%$ de los casos, y dentro de ella, se produce con mayor frecuencia la hemorragia intraparenquimatosa (10-15\%), y con menor frecuencia la hemorragia subaracnoidea (5-7\%).

El síndrome de EVC, también involucra otras variables patológicas, como la trombosis venosa cerebral, proceso que se relaciona con menos del $5 \%$, en la presentación de la enfermedad. 1,2,3,4

\section{Epidemiología}

A nivel mundial, la Organización Mundial de la Salud (OMS) reporta que ésta patología constituye la primera causa de invalidez en el adulto, y la tercera causa de muerte. En México, ésta enfermedad, debe ser considerada como un problema de Salud Pública de carácter prioritario. En relación a la tendencia que se ha registrado en los últimos años, en cuanto a la mortalidad, éste padecimiento muestra un incremento continuo, ya que en el año 2010, ocupó el sexto lugar en las principales causas de defunción; y del año 2004 al año 2010, ha presentado un incremento del $27.7 \%$, por lo que implica una tendencia positiva de la enfermedad.

En el año 2012, en México los anuarios de morbilidad de la Dirección General de Epidemiología reportan, una incidencia general de $39.6 \%$, afectando con mayor importancia a la población mayor de 65 años de edad, predominantemente en el sexo femenino. Los Estados de la República Mexicana, que muestran una mayor incidencia son el Distrito Federal, Jalisco, Veracruz y Estado de México ${ }^{5,6,7,8,9,10}$.

\section{Causalidad}

Se encuentra asociada a diversos factores de riesgo, los cuales pueden ser divididos en modificables y no modificables. Dentro de los factores de riesgo no modificables, se encuentra la edad, el sexo, el grupo étnico y el antecedente heredo-familiar. En función de 


\section{Enfermedad vascular cerebral}

la edad, después de los 55 años se duplica el riesgo de que se presente la patología. Es más frecuente en los africanos, latinos e hispanos. Se presenta predominantemente en el sexo femenino y con una mayor mortalidad.

Entre los factores de riesgo modificables (por la prevención y control adecuado de ellos), se encuentran la Hipertensión Arterial Sistémica (HAS), el tabaquismo, la diabetes mellitus, estenosis carotidea asintomática, fibrilación auricular como fuente cardiogénica de émbolos, hiperlipidemia, uso de anticoagulantes, obesidad, hiperhomocisteinemia, toxicomanías (abuso de drogas como cocaína, anfetamina y heroína), estados de hipercoagulación (generado por diversos estados fisiológicos y fisiopatológicos, como el uso de anticonceptivos orales). ${ }^{4,10,11,12,13}$

Las etiologías, que producen el proceso fisiopatológico de la EVC, son diversas, dentro de ellas se pueden encontrar trombosis ateroesclerótica, embolia, hemorragia hipertensiva, aneurisma sacular roto, malformaciones arteriovenosas, arteritis, tromboflebitis cerebral, trastornos hematológicos (como purpura trombocitopénica trombótica, agentes anticoagulantes, y trombocitosis), trauma y disección de arterias carótida y basilar, angiopatía amiloide, aneurisma disecante de la aorta, entre otras.

En función de grupos de edad, a continuación se clasifican las alteraciones fisiológicas y anatómicas, que se vinculan con la EVC:

- En la etapa prenatal, se pueden presentas enfermedades circulatorias generadoras de lesión hipóxica e isquémica, así como infarto cerebral unilateral, el periodo perinatal y posnatal, se encuentra la enfermedad hemorrágica del neonato, hemorragias intrauterinas y focos isquémicos en lactantes prematuros, e infartos peri ventriculares;

- En los lactantes, preescolares y escolares, se relaciona a cardiopatías congénitas, embolia paradójica, endocarditis bacteriana, homocistinuria, fiebre reumática, lupus eritematosos sistémico y moyamoya (enfermedad oclusiva progresiva de la vasculatura cerebral principalmente del círculo de Willis y de las arterias que lo alimentan);

- Para la adolescencia e inicio de la edad adulta, se presenta asociado a estrógenos, malformaciones vasculares, ateroesclerosis prematura, disecciones arteriales, angiopatía amiloide; y 
- Para la edad madura se puede encontrar, trombosis y embolia ateroesclerótica, hemorragia cerebral primario (hipertensiva), y aneurisma sacular roto.

En la forma clínica isquémica, de la EVC, la principal causa relacionada con su producción es la embolización de la placa de ateroma, produciendo una oclusión en la circulación sanguínea arterial. En el caso de la variedad hemorrágica, la principal causa de hemorragia subaracnoidea no traumática, es la ruptura de aneurisma sacular; en el caso de que sea traumática, se relaciona con disecciones arteriales. Mientras que en la hemorragia intraparenquimatosa, se relaciona con mayor frecuencia a HAS, amiloidosis, coagulopatías y malformaciones arteriovenosas ${ }^{4,12,13}$.

\section{Fisiopatología}

La fisiopatología de los eventos vasculares isquémicos y hemorrágicos, son diferentes. Por ello es importante analizar los procesos que se generan en cada uno, de manera independiente.

Para comprender dichos fenómenos es necesario el conocimiento de las características fundamentales de la irrigación cerebral, como son: el consumo de oxígeno cerebral que es de 3.5-3.8 ml/100 gr/min (lo que representa el 20\% del oxígeno sanguíneo); el flujo sanguíneo cerebral es de $55 \mathrm{ml} / 100 \mathrm{gr} / \mathrm{min}$, lo que significa que recibe el 15\% del gasto cardíaco, equivalente $800 \mathrm{ml}$ de sangre arterial por minuto, que se divide en $660 \mathrm{ml}$ de la circulación anterior (territorio carotideo) y $140 \mathrm{ml}$ de la circulación posterior (territorio vertebro-basilar) ${ }^{12,13,14}$.

El proceso isquémico, se asocia a la oclusión repentina de un vaso intracraneal, lo que genera una disminución en la irrigación de una área encefálica específica, éste mecanismo de isquemia produce hipoxia celular y diminución del ATP neuronal, generando la entrada pasiva de iones de calcio y sodio ocasionando edema celular citotóxico. La neuronas que se encuentran en el área marginal, a la zona de isquemia, donde aún se mantiene un flujo sanguíneo cerebral de $25 \mathrm{ml} / 100 \mathrm{~g}$ de masa encefálica/minuto, se denomina la zona de penumbra. Estas neuronas, pueden permanecer funcionales, con el manejo oportuno. El infarto cerebral establecido, se establece cuando el flujo sanguíneo cerebral es menor a 10$12 \mathrm{ml} / 100 \mathrm{~g} /$ minuto, que genera la falla de bomba iónica, cese de síntesis de ATP, e ingreso de calcio a la neurona, lo que destruye a la célula. 


\section{Enfermedad vascular cerebral}

En la hemorragia intraparenquimatosa (también denominada intracerebral), ocurre un sangrado directo en el parénquima, ocasionado por la ruptura de pequeños vasos sanguíneos, secundario a la HAS crónica. Los sitios que son afectados con mayor frecuencia son: el tálamo, el putamen, cerebelo y tronco encefálico. Secundario al sangrado se genera el síndrome de hipertensión intracraneal. El proceso fisiopatológico de la hemorragia subaracnoidea, inicia con la entrada de sangre al espacio subaracnoideo, generalmente segundaria a la ruptura de aneurisma sacular, lo que inicia un aumento súbito de la presión intracraneal. Posteriormente, como respuesta al aumento de presión intracraneal, la presión de perfusión cerebral desciende lo que permite la disminución de sangrado, y es seguida de la respuesta Cushing, que consiste en el aumento de la tensión arterial. Todos estos procesos tienen el objetivo de compensar y recuperar la hemodinamia cerebral $^{10,12,13,14}$.

\section{Cuadro clínico}

Las formas clínicas que se presentan, en la EVC isquémica, se agrupan por el territorio vascular comprometido, y por ello las funciones de la región encefálica dañada $a^{4,11,15,16,17,18}$.

El territorio de la carótida interna, se presenta en el 1\%, asociado a placa de ateroma y radioterapia de cabeza y cuello. Clínicamente, se manifiesta por alteraciones en la arteria cerebral anterior y media.

La obstrucción de la carótida interna, se mantiene asintomática del 30\% al 40\% de los casos, debido a la circulación colateral que ofrece el polígono de Willis. Sin embargo cuando cursa con sintomatología, compromete el territorio de la arteria cerebral anterior y la arteria cerebral media. En estos casos se presenta ceguera monocular transitoria, que generalmente representa un pródromo del proceso isquémico, posteriormente hay alteraciones en el pulso del cuello y soplo carotideo.

La arteria cerebral media, irriga la parte lateral del lóbulo frontal, lóbulo parietal y lóbulo temporal. Cuando existe un bloqueo completo de la circulación se manifiesta con hemiplejía, hemianestesia, hemianopsia homónima contralateral, desviación conjugada de cabeza y ojos, afasia global (si se presenta en el lado dominante). Si el daño únicamente se genera en la rama superior, se relaciona con hemiparesia, hemianestesia, afasia de broca (dificultades para hablar, pero si comprende el lenguaje), y desviación conjugada de la 


\section{Principales problemas de Salud Pública en México}

mirada; y si el daño es en la rama inferior se relaciona con afasia de Wernicke (dificultades para comprender el lenguaje), cuadrantopsia superior o hemianopsia homónima.

El proceso oclusivo de la arteria cerebral anterior, afecta las funciones del lóbulo frontal, lo que se manifiesta con alteraciones del estado mental, alteraciones en el juicio, reflejos primitivos, déficit sensorial contralateral, debilidad contralateral en extremidades e incontinencia urinaria.

La arteria cerebral anterior, ante un proceso isquémico, las manifestaciones que presenta son hemianopsia homónima contralateral, ceguera cortical, agnosia visual, alteraciones del estado mental y pérdida de la memoria.

Cuando el sistema vascular posterior (es decir el sistema vertebrobasilar), se encuentra ante un proceso obstructivo (isquémico), produce las manifestaciones de vértigo, nistagmus, diplopía, déficit del campo visual, disfagia, disartria, sincope y ataxia. En el daño a la circulación posterior, se genera un déficit de nervios craneales ipsilaterales y un déficit motor contralateral.

En el caso de eventos isquémicos lacunares, que se definen como la oclusión de pequeños vasos sanguíneos (arterias de bajo calibre, arterias perforantes) que generan una zona de infarto de 2 a $20 \mathrm{~mm}$ de diámetro, se manifiestan como síndrome motor puro, síndrome sensorial puro, o ataxia hemiparética.

La EVC hemorrágica, produce síntomas de presentación súbita (aguda), o con manifestaciones rápidamente progresivas. Frecuentemente, se relaciona con un déficit neurológico máximo al inicio, con síntomas relacionados al aumento de la presión intracraneal, como cefalea, náuseas, vómito y convulsiones. Comúnmente, se refiere el inicio de cefalea, referida por el paciente como "la peor de todas su vida"4,10,14,16,19.

\section{Complicaciones}

El evento vascular cerebral, se asocia con la primera causa de discapacidad, por lo que su principal complicación, se asocia a un daño neurológico irreversible, que compromete la calidad de vida del paciente a nivel individual, familiar y social. Así como la disminución 


\section{Enfermedad vascular cerebral}

de años de vida productiva para la economía nacional. El grado de incapacidad, y el daño funcional que se presente, depende directamente de la zona encefálica con lesión. Otras complicaciones frecuentemente asociadas, es la neumonía, los sangrados de tubo digestivo, la insuficiencia cardiaca congestiva, Infarto Agudo al Miocardio (IAM), trombosis venosa profunda, tromboembolia pulmonar e infecciones de vías urinarias. En muchos de los casos, dichas afecciones se encuentran asociadas al periodo prolongado de hospitalización, sin la realización de actividad física ${ }^{4,12,18,20,21}$.

\section{Diagnóstico}

La evaluación inicial del paciente, que presenta datos de síndrome de EVC, debe ser realizada en los primeros 60 minutos, a partir de la llegada al servicio de urgencias. Se debe realizar una valoración neurológica completa así como una exploración clínica integral (es de utilidad el uso de la escala de NIHSS, para cuantificar la gravedad del paciente; ABCD, escala pronóstica que señala la probabilidad de que se presente un nuevo infarto; y escala de Glasgow, para la valoración del estado neurológico $)^{4,10,16,17,18,21}$.

El estudio de primera elección, ante la sospecha clínica de un evento cerebrovascular, es la tomografía de cráneo simple no contrastada. El objetivo de éste estudio, es reportar evidencia del tipo de enfermedad vascular es, si es un evento isquémico o hemorrágico. Otro estudio de gabinete, que es de utilidad para el diagnóstico, es la resonancia magnética, ambos estudios presentan una amplia sensibilidad, a pesar que la resonancia magnética permite identificar mejor un evento isquémico. Para un evento isquémico, la tomografía sin medio de contraste presenta una sensibilidad del 16\% y una especificidad del $96 \%$, mientras que la resonancia magnética, presenta sensibilidad y especificidad, del $83 \%$ y $98 \%$ respectivamente. En comparación para un evento hemorrágico, la tomografía sin medio de contraste presenta una sensibilidad del $89 \%$ y una especificidad del $100 \%$, mientras que la resonancia magnética, presenta $81 \%$ y 100\%, de sensibilidad y especificidad respectivamente. Otros estudios que se pueden realizar, son la angiografía por TAC y angiografía por RM, principalmente. Es necesario realizar estudios de laboratorio de extensión como es la determinación de la biometría hemática, química sanguínea, tiempos de coagulación, pruebas de función hepática, gasometría, entre otros, para realizar el diagnóstico integral del paciente $e^{4,10,16,22,23}$. 


\section{Principales problemas de Salud Pública en México}

\section{Terapéutica}

El tratamiento no farmacológico, consiste en la corrección de los factores de riesgo modificables, mantener estilos de vida saludables, y controlar el proceso de comorbilidades. El tratamiento farmacológico, para la enfermedad isquémica durante la fase aguda, es el uso de activador tisular del plasminógeno humano (r-TPA ), intravenoso a dosis de $0.9 \mathrm{mg} /$ $\mathrm{kg}$, que permite una recuperación completa o casi completa, dependiendo del grado de extensión del infarto y la atención oportuna, los criterios para el inicio de éste tratamiento son contar con un diagnóstico clínico de evento vascular cerebral isquémico con déficit neurológico evidente y tiempo de inicio de síntomas menor a 4.5 horas. Se contraindica éste manejo, cuando existe evento vascular cerebral o traumatismo craneoencefálico previo en los últimos tres meses; hemorragia intracraneal previa; antecedente de malformación arteriovenosa cerebral; síntomas sugestivos a hemorragia subaracnoidea; elevación de la presión arterial persistente (sistólica mayor de 185 o distólica mayor de $110 \mathrm{~mm} \mathrm{Hg}$ ); glucosa sérica menor de $50 \mathrm{mg} / \mathrm{dl}$; datos de sangrado interno activo; recuento de plaquetas menor a 100,000 / $\mathrm{m}^{3 ;}$ uso de anticoagulantes orales, con INR mayor de 1.7, o TP mayor de 15 segundos; evidencia tomográfica de evento hemorrágico. El manejo terapéutico de la hemorragia cerebrovascular, depende de la severidad del sangrado. El soporte básico de vida, control del sangrado, las convulsiones, la tensión arterial y la presión intracraneal, son parte fundamental del manejo. El uso de diuréticos osmóticos, como tratamiento farmacológico en la hemorragia, con el objetivo de disminuir la presión intracraneal, representan la principal medida Terapéutica ${ }^{4,17,18,19,21,22,24,25}$.

\section{Medidas de prevención}

Las medidas de prevención primaria, consisten en identificar a la población en riesgo, y establecer acciones específicas para evitar que se desarrolle la enfermedad. Las personas que presentan hipertensión arterial sistémica, obesidad, diabetes mellitus, dislipidemias, tabaquismo y antecedentes previos de enfermedades cerebrovasculares, requieren atención especial, con enfoque preventivo, cambios en los estilos de vida, abandono de toxicomanías y mantener un adecuado control metabólico, para su protección específica.

La prevención secundaria consiste en reducir las probabilidades de que se produzca otro evento cerebrovascular. Mediante el reforzamiento de las medidas preventivas primarias, los cambios en los estilos de vida, y el apego al tratamiento de las comorbilidades; 


\section{Enfermedad vascular cerebral}

además del uso de antiagregantes plaquetarios y estatinas como terapia profiláctica. En la prevención terciaria, se inician estrategias como la endarterectomía, angioplastia endovascular, aplicación local de agentes trombolíticos, con el desarrollo de la terapia endovascular y neurointensivismo $0^{4,18,23,24,25}$.

\section{Referencias}

1. Biller, J. Neurología práctica. $4^{a}$ ed. Philadelphia: Lippincott Williams \& Wilkins; 2012. p. 385-400.

2. Uribe U, Arana C, Lorenzana P. Neurología. 7a ed. Colombia: Corporación para Investigaciones Biológicas; 2010. p. 413-455.

3. Brust, J. Cuarrent diagnosis and trearment in neurology. USA: McGraw Hill Lange; 2007. p. 100-145.

4. Rivera-Nava SC, Miranda-Medrano LI, Emidgio J. Guía de práctica clínica de enfermedad vascular cerebral isquémica. Revista Médica, del Instituto Mexicano del Seguro Social. 2012; 50(3):335-346.

5. Secretaría de Salud. Perfil epidemiológico de las enfermedades cerebrovasculares en México. SINAVE. México: Secretaría de Salud; 2012.

6. Arauz A, Ruiz-Franco A. Enfermedad vascular cerebral. Revista de la Facultad de Medicina, UNAM. 2012; 55(3):11-21.

7. Alcalá R, González G. Enfermedad cerebrovascular, epidemiología y prevención. Revista de la Facultad de Medicina UNAM. 2007; 50(1):36-39.

8. Nieto-de-Pascual R, Guizar B, Ortiz T. Epidemiología de la enfermedad vascular cerebral en el Hospital General de México. Revista médica del Hospital General de México. 2003; 66(1):7-12.

9. Ávila S, Ordoñez C, Ramírez F. Enfermedad vascular cerebral: incidencia y factores de riesgo en el Hospital General La Perla. Revista de Medicina Interna de México, 2012; 28(4):342-344.

10. Martínez-Vila E, Murie F, Pagola PI. Enfermedades cerebrovasculares. Departamento de neurología, Revista de Medicina Pamplona España 2011; 11(72):4871-4881.

11. Bradley WG, Daroff RB, Fenichel GM, Jankovic J Neurología clínica. 5 $5^{\mathrm{a}}$ ed. Barcelona: Elsevier; 2010. p. 1173-1279. 


\section{Principales problemas de Salud Pública en México}

12. Toro J, Yepes S, Palacios S. Neurología. 2ª ed. Bogotá: Manual Moderno; 2010. p. 159-200.

13. Ropper, A. Brown, R. Principios de neurología de Adams y Víctor. 8a ed. México: McGraw Hill. México 2007.

14. Nouh A, Remke J, Ruland S. Ischemic posterior circulation stroke: a review of anatomy, clinical presentations, diagnosis, and current management. Frontiers in Neurology. 2014; 5:30.

15. Blanco G, Arias R, Castillo S. Diagnóstico de accidente cerebrovascular isquémico. Protocolos de práctica asistencial. 2011; 10(72):4919-4923.

16. Schwartzman, R. Differential diagnosis in neurology. Amsterdam: Editorial IOS Press; 2006. p. 3-145.

17. American Heart Association. Stroke, Guidelines for the management of spontaneous intracerebral hemorrhage. USA, 2010; 41:2108-2129.

18. American Heart Association. Stroke, Guidelines for the Prevention of Stroke in Patients with TIA. USA, 2011; 42:227-276.

19. Layon A, Gabrielle A, Friedman W. Textbook of neurointensive care. Philadelphia: Editorial Saunders; 2004. p. 155-436.

20. Silva R. Semiología y fundamentos de la neurología clínica. Chile: Editorial Amolca; 2013. p. 144-151.

21. Fauci A, Braunwald E, Kasper DL, Hauser SL, Longo DL, Jameson JL, Loscalzo J. Harrison. Principios de medicina interna. 17ª Edición. México: McGraw Hill; 2012. p. 2275-2304. p. 2513-2536.

22. Robinson AA, Ikuta K, Soverow J. Anticoagulation for the acute management of ischemic stroke. The Yale Journal of Biology and Medicine. 2014; 87(2):199-206.

23. National Institude for Health and Clinical Excellence (NHS). Stroke, Diagnosis and initial management of acute stroke and transient ischaemic attack (TIA). UK: NHS; 2008.

24. Secretaría de Salud. GPC. Prevención secundaria, diagnóstico, tratamiento y vigilancia de la enfermedad vascular cerebral isquémica. México: Secretaría de Salud; 2008.

25. National Stroke Foundation. Clinical guidelines for stroke management 2010. Australia: NSF; 2010. p. 51-112. 


\section{Epilepsia}

\section{Dr. Noé Contreras González M. C. María Guadalupe Contreras García}

\section{Introducción}

Este capítulo tiene por finalidad de aportar elementos para que el estudiante de medicina y el médico general entiendan las dificultades que padecen las personas con epilepsia, para identificar dicho padecimiento y contribuir a su manejo terapéutico de acuerdo con el conocimiento científico disponible.

Existe acuerdo entre los científicos sobre cómo se origina la epilepsia, cómo se identifica, el abordaje clínico que se hace de ella y en la necesidad de tratarla tempranamente de la manera más efectiva posible para evitar la diversidad y severidad de las consecuencias clínicas y sociales que ocasiona ${ }^{1}$.

En este documento se muestran algunos casos clínicos como ejemplo de las variedades del síndrome epiléptico.

\section{Concepto}

La epilepsia se define como un síndrome crónico, recurrente y paroxístico con manifestaciones clínicas variadas que pueden ser alteraciones sensoriales, sacudidas musculares y de las funciones cerebrales superiores, originadas por descargas neuronales desordenadas y excesivas del cerebro y que tienen causas diversas ${ }^{1,2}$. El término epilepsia $o$ ataque viene del griego epilambanen que significa ser tomado por sorpresa o sacudir. Sin embargo, los términos epilepsia y convulsiones (sacudidas musculares) no tienen el mismo significado; las convulsiones pueden ser manifestaciones de epilepsia pero no siempre; es decir, existe epilepsia con convulsiones y convulsiones que no son epilépticas.

La Liga Internacional contra la Epilepsia (ILAE) y el Buró Internacional para la Epilepsia distinguen entre crisis epiléptica y epilepsia; una crisis epiléptica es un estado transitorio 


\section{Principales problemas de Salud Pública en México}

de síntomas y signos debidos a una actividad neuronal excesiva y sincrónica cerebral; estas crisis epilépticas son similares en cada paciente; mientras que la epilepsia es un desorden cerebral caracterizado por la predisposición a generar crisis epilépticas recurrentes y las consecuencias neurobiológicas, psicológicas, cognitivas y sociales de esta enfermedad ${ }^{2,3}$.

La epilepsia, a lo largo de la historia, ha provocado muchas desviaciones de la realidad, basadas en la ignorancia, la superstición y en los prejuicios. Afortunadamente, los avances en las neurociencias en las últimas décadas están ayudando a tener una comprensión más completa de este padecimiento, su explicación fisiopatológica, su diagnóstico y su tratamiento ${ }^{4}$. La epilepsia, por sus manifestaciones dramáticas, ha desencadenado reacciones de la sociedad, la familia, el entorno escolar, el entorno laboral y la relación interpersonal, un ambiente negativo hacia el paciente que la sufre; por ello, el diagnóstico y tratamiento de la epilepsia debe incluir el manejo del problema personal, familiar y social que afecta a la persona que la sufre.

\section{Clasificación}

Las crisis epilépticas o ataques, tienen manifestaciones clínicas tan variadas como las funciones del cerebro. La finalidad de una clasificación es ordenar las diversas variedades de epilepsia de acuerdo a criterios que permitan agruparlas. Para clasificar las diversas variedades de epilepsia se tomaron en cuenta sus manifestaciones clínicas y electroencefalográficas.

Las clasificaciones propuestas por los autores se basan en el sitio de donde parte la descarga paroxística y se dividen en tres grandes grupos ${ }^{2,4,5,6}$ :

a) Las crisis parciales o focales, cuyo sustrato es un grupo de neuronas de un área específica de la corteza de un lóbulo o hemisferio cerebral;

\section{b) Crisis parciales secundariamente generalizadas; $y$}

c) Las crisis generalizadas, cuyo sustrato es grupo de neuronas del centroencéfalo (tálamo, hipotálamo y parte superior del mesencéfalo) y de allí se involucran ambos hemisferios cerebrales (Figura 1). 


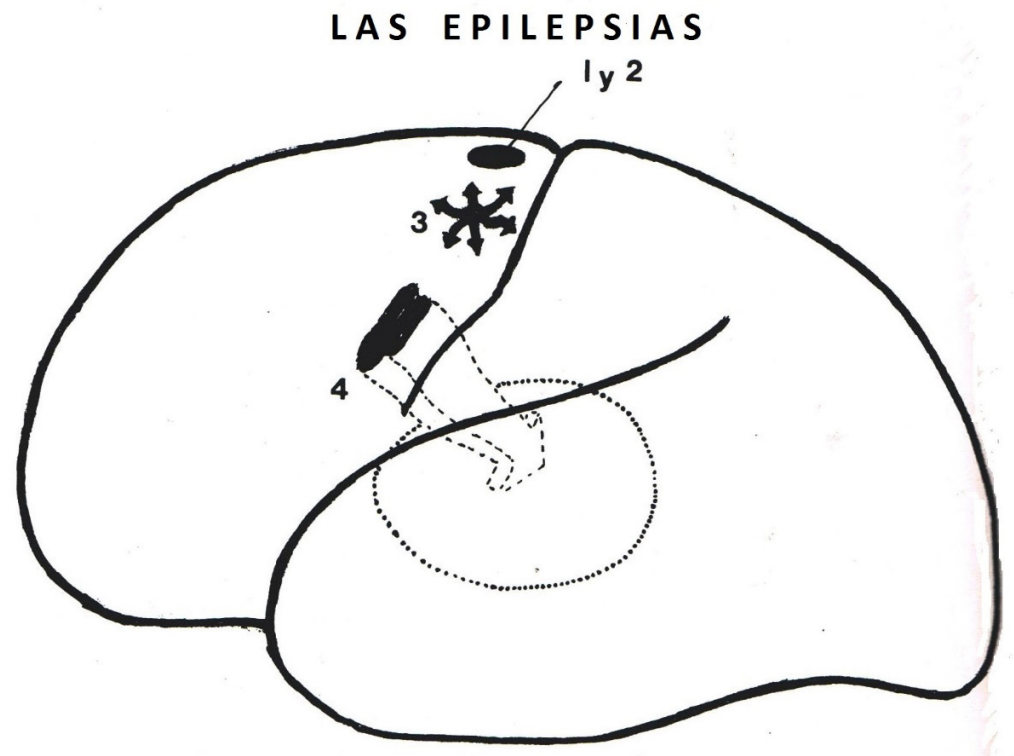

1.- Descarga localizada, se agota.

3.- Descarga que irradia a zonas corticales vecinas.

2.- Descarga localizada, persiste semanas o meses.

4.- Descarga que invade centroencéfalo y se generaliza.

Figura 1. Clasificación de la Epilepsia. Modificado con Permiso de la Referencia 2.

La clasificación más útil fue creada en 1989 por el Comité de Clasificación y Terminología de la Liga Internacional contra la Epilepsia. Esta clasificación contempla cuatro grupos (Cuadro 1$)^{5}$ :

I.- Crisis parciales o focales.

II.- Crisis generalizadas.

III.- Crisis no clasificadas.

IV.- Addendum.

Son muchas las variedades de epilepsia y se agrupan en la Clasificación Internacional de las Epilepsias y Síndromes Epilépticos de $1989^{5}$. 
Cuadro 1. Clasificación Internacional de las Crisis Epilépticas. ${ }^{5}$

I. Crisis Parciales o Focales:

A. Crisis Focales Simples:

1. De Semiología Motora
a) Sin marcha
b) Con marcha
c) Versivas
d) Posturales
e) Fonatorias

2. De Semiología Sensitiva
a) Somatosensorial
b) Visuales
c) Auditivas
d) Gustativa
e) Olfatoria
f) Vertiginosa

3. De Semiología Autonómica

4. De Semiología Psíquica
a) Disfásicas
b) Dismésicas
c) Cognitivas
d) Del talante
e) Ilusiones
f) Alucinaciones

B. Crisis Focales Complejas

1. A, seguidas de desconexión

2. Desconexión al inicio

3. 1 o 2 con automatismo

C. Crisis Focales Secundariamente Generalizadas

1. A pasa a generalizada

2. B pasa a generalizada

3. A pasa a B y luego a generalizada

II. Crisis Generalizadas
1. Ausencia
2. Mioclonias
3. Tónicas
4. Clónicas
5. Tónico-clónicas
6. Atónicas

III. Crisis No Clasificadas

IV. Addendum

1. Crisis fortuitas

2. Crisis cíclicas

3. Crisis provocadas por estímulos no sensoriales

4. Crisis reflejas

5. Estado epiléptico

El propósito de esta clasificación es complementar a la Clasificación Internacional de las Crisis Epilépticas, la cual describe los tipos individuales de crisis, pero la terminología diaria del médico más bien se refiere a síndromes o entidades por lo que se hace necesario clasificar de esta manera a las epilepsias.

Un síndrome epiléptico incluye el o los tipos de crisis, la causa, localización anatómica, factores precipitantes, edad de presentación, severidad, cronicidad, relación con el ciclo sueño-vigilia y, a veces, pronóstico.

En esta clasificación se utilizan las dos clases principales de epilepsia con crisis parciales y las crisis generalizadas, separando las de causa conocida de las de causa no conocida. Basándose en los criterios anteriores, la clasificación se encuentra en el Cuadro 25,6. 
Cuadro 2. Clasificación de las Epilepsias y Síndromes Epilépticos ${ }^{5}$.

1. Epilepsias y Síndromes Relacionados a una Localización:

\subsection{Idiopáticos:}

- Epilepsia benigna de la niñez con punta centrotemporal.

- Epilepsia de la niñez con paroxismos occipitales.

- Epilepsia primaria de la lectura.

\subsection{Sintomáticos:}

- Epilepsia parcial crónica progresiva (Síndrome de Kojewnikow).

- Síndromes con crisis precipitadas por formas específicas de activación.

- Epilepsias del lóbulo temporal.

- Epilepsias del lóbulo frontal.

- Epilepsia del lóbulo parietal.

- Epilepsias del lóbulo occipital.

\subsection{Criptogénicos.}

2. Epilepsias y Síndromes Generalizados: 2.1. Idiopáticos:

- Convulsiones familiares neonatales benignas.

- Convulsiones neonatales benignas.

- Epilepsia mioclónica benigna de la infancia.

- Ausencias de la niñez.

- Ausencias juveniles.

- Epilepsia mioclónica juvenil (Síndrome de Janz).

- Epilepsia con crisis generalizadas tónico-clónicas del despertar.

- Epilepsias con crisis precipitadas por modos de activación específicos.

\subsection{Criptogénicos o Sintomáticos:}

- Síndrome de West.

- Síndrome de Lenox-Gastaut.

- Epilepsia con crisis mioclónicasastáticas (Síndrome de Doose).

- Epilepsia con ausencias mioclónicas.

2.3. Sintomáticos:

2.3.1. Causa no específica:

- Encefalopatía mioclónica temprana.

- Encefalopatía epiléptica infantil temprana con brotes de supresión (Síndrome de Ohtahara).

2.3.2. Síndromes Específicos.

3. Epilepsias y Síndromes que no se Determina si son Localizados o Generalizados:

3.1. Con Crisis Generalizadas o Focales:

- Crisis neonatales.

- Epilepsia mioclónica severa de la infancia (Síndrome de Dravet).

- Epilepsia con punta-onda continua durante el sueño de onda lenta.

- Afasia epiléptica adquirida (Síndrome de Landau-Kleffner).

\section{Síndromes Especiales:}

4.1. Crisis relacionadas a situaciones.

4.2. Convulsiones febriles.

4.3. Crisis aisladas o estado epiléptico aislado:

- Crisis que solo ocurren por factores como alcohol, drogas, eclampsia, hiperglucemia no cetósica, etc.

Si bien, es cierto que el Comité de Clasificación y Terminología de la Liga Internacional contra la Epilepsia en 2010 propuso una nueva clasificación ${ }^{6}$, esta no ha tenido el consenso esperado, por lo que la de 1989 es la más útil para los fines de este capítulo. 


\section{Principales problemas de Salud Pública en México}

\section{Epidemiología}

La prevalencia de la epilepsia en población mexicana varía, según estudios realizados, desde 10 hasta 20 casos por mil habitantes ${ }^{7}$, por lo que se calcula que existen cerca de dos millones de enfermos actualmente.

En un estudio retrospectivo realizado durante 5 años en el Hospital Central Militar de la Ciudad de México a finales de los años noventa del siglo pasado, de 1030 pacientes de todas las edades con epilepsia, predominaron en el sexo masculino, en las edades de 21 a 30 años; las crisis generalizadas fueron las más frecuentes seguidas de las parciales complejas ${ }^{8}$.

En un estudio epidemiológico realizado en 1999 en el Hospital Civil de Guadalajara con 280 niños epilépticos, el padecimiento predominó en el sexo masculino, en el grupo de edad de 6 a 12 años; las crisis parciales fueron las más frecuentes?

En un estudio multicéntrico realizado en la primera década del presente siglo en la República Mexicana en 455 pacientes epilépticos con inicio después de los 20 años, no existió diferencia en el género, la mayor frecuencia se observó entre los 20 y 40 años, las crisis más frecuentes fueron parciales, seguidas de las generalizadas ${ }^{10}$.

En un estudio realizado en Barcelona, de los años 1974 al 2000 con 7500 casos de todas las edades, la epilepsia predominó en el sexo masculino; el 20\% de los casos inició después de los 20 años de edad; la epilepsia con crisis parciales representó el 45\% mientras que la epilepsia con crisis generalizadas representó el 41\%; la asociación de epilepsia con crisis parciales simples y crisis secundariamente generalizadas fue del $9 \%$, mientras que la asociación de crisis parciales complejas con crisis secundariamente generalizadas fue del 8\%; el síndrome de Lenox-Gastau representó el 8\%

En general, la epilepsia predomina en el sexo masculino, los grupos de edad más afectados son de 6 a 12 años y de 21 a 30 años, las crisis parciales son las más frecuentes seguidas de las crisis generalizadas $8,9,10,11$.

La trascendencia de la epilepsia como problema de Salud Pública no se debe a la invalidez ni a la mortalidad que causa, sino al deterioro de la calidad de vida del paciente, al no tener 


\section{Epilepsia}

garantizado el control médico de sus crisis, agregándose el rechazo social por tener un padecimiento crónico ${ }^{7}$. Junto con el estigma viene la discriminación, el prejuicio y el rechazo que se produce del paciente hacia sí mismo, de la familia y la sociedad hacia el paciente ${ }^{12}$.

En efecto, la epilepsia afecta la calidad de vida del paciente y su familia. En investigaciones realizadas en niños y adolescentes epilépticos en México se observó que la calidad de vida, medida en términos de conducta, control de las crisis epilépticas, asistencia a la escuela, aprendizaje escolar, relación y aceptación familiar y social, fue mala durante el primer año, tendiendo a mejorar en lo venidero ${ }^{13,14}$. En ese sentido, el fracaso escolar, los trastornos de aprendizaje y las alteraciones de conducta son más frecuentes en el niño epiléptico que en la población general. Los factores que condicionan lo anterior son muy heterogéneos e incluyen: factores propios de la epilepsia (edad de comienzo, tipo de crisis, etiología, respuesta al tratamiento y efectos adversos cognitivos y conductuales de los medicamentos) y factores psicosociales (el estigma o discriminación social, el estilo sobreprotector de los padres y educadores, el ausentismo escolar del paciente, la baja autoestima y la tendencia al aislamiento social, el acoso escolar, el abandono escolar y la falta de programas psicopedagógicos de apoyo) ${ }^{15}$.

\section{Causalidad}

Desde el punto de vista de su causalidad, la epilepsia se divide en:

a) Epilepsia primaria, idiopática, criptogénica o de etiología desconocida, o sea, la epilepsia no va precedida u ocasionada por otro padecimiento y solo existe una aparente predisposición hereditaria ${ }^{2,16}$.

b) Epilepsia secundaria a un proceso patológico del sistema nervioso de causa conocida como hipoxia-isquemia, infección y parasitosis, secuelas de traumatismos craneoencefálicos, malformaciones congénitas, alteraciones innatas del metabolismo, neoplasias e intoxicaciones, entre otras ${ }^{2,17}$.

La epilepsia es un padecimiento que tiene un componente hereditario; así lo atestiguan diversas investigaciones de agregación familiar que muestran que la epilepsia entre los parientes de pacientes epilépticos es significativamente más frecuente que en grupos controles y población general ${ }^{15,17,18}$. 


\section{Principales problemas de Salud Pública en México}

Con el avance de la biología molecular y técnicas como la clonación posicional y genes candidatos, se han identificado genes relacionados a variedades de epilepsia como la epilepsia mioclónica juvenil, la epilepsia de ausencias de la niñez y la epilepsia con crisis tónico-clónicas generalizadas ${ }^{16}$.

En el estudio del Hospital Central Militar con pacientes de todas las edades, predominó la epilepsia primaria o de causa no conocida, seguida de la secundaria a neurocisticercosis, secuelas de traumatismos craneoencefálicos y neoplasias ${ }^{8}$.

En el estudio del Hospital Civil de Guadalajara con pacientes pediátricos, predominó la epilepsia primaria o de causa no conocida, siendo las crisis febriles las más frecuentes, seguidas por el Síndrome de Lenox-Gastaut y las crisis de ausencias ${ }^{9}$.

En estudio multicéntrico realizado en México con pacientes mayores de 20 años predominó la epilepsia primaria o de causa no conocida, seguida de la epilepsia secundaria a neurocisticercosis, enfermedad vascular cerebral de predominio isquémico y neoplasias ${ }^{10}$.

De acuerdo con el estudio realizado en Barcelona por Oller en 7500 casos de todas las edades, se encontró epilepsia primaria o de causa no conocida en el $25 \%$ y en el $22 \%$ de los casos se encontró una causa adquirida, donde hubo causas perinatales $8 \%$, infecciones del sistema nervioso central $3 \%$, secuelas de traumatismos craneoencefálicos $2.5 \%$, neoplasia cerebrales $2 \%$ y procesos vasculares cerebrales $1.6 \%$, entre otras ${ }^{11}$.

En general, predomina la epilepsia primaria o de causa no conocida, seguida de la epilepsia secundaria a otros padecimientos del sistema nervioso ${ }^{8,9,10,11}$.

Existe una serie de factores precipitantes de las crisis epilépticas, entre ellos destacan el estrés afectivo, la excitación, la privación de sueño, la fiebre, la suspensión del medicamento antiepiléptico, el ciclo menstrual, desvelarse, exposición a luz intensa, ver televisión o videojuegos por tiempo prolongado, la hiperventilación, actividad física extenuante, fatiga, ingestión de bebidas estimulantes, embriaguez alcohólica, el despertar, las primeras horas de la mañana, etc., por lo que habrá que tenerlos en cuenta en las recomendaciones para el manejo terapéutico ${ }^{2,19}$. 


\section{Epilepsia}

\section{Fisiopatología}

El procesamiento de la información en el sistema nervioso se realiza a través de la transmisión sináptica entre las redes neuronales. Existen neurotransmisores excitadores en las redes neuronales cerebrales como el glutamato y el aspartato, así como neurotransmisores inhibidores como el ácido gamma-amino-butírico (GABA). Normalmente debe mantenerse un equilibrio entre excitación e inhibición en las redes neuronales cerebrales. Además, el incremento de la neurotransmisión GABAérgica es la base de la acción de varios fármacos antiepilépticos ${ }^{20}$. De tal manera que, una crisis epiléptica es el resultado clínico de una descarga brusca desordenada y sin control de un grupo de neuronas cerebrales (foco epileptógeno) y, por tanto, cualquier alteración (proceso genético, proceso isquémico, proceso inflamatorio, malformación congénita, proceso neoplásico, etc) que favorezca la hipersincronización y la excitabilidad con disminución de la inhibición en las redes neuronales cerebrales es susceptible de generar crisis epilépticas ${ }^{20,21}$.

La epilepsia es un padecimiento complejo y multifactorial, estando involucrados en su génesis varios sistemas de neurotransmisión donde todavía hace falta recorrer un amplio terreno en la investigación.

\section{Cuadro clínico}

Las crisis epilépticas constan de tres periodos, un periodo con las manifestaciones clínicas características llamado ictal o ictus, un periodo de recuperación del sujeto a su estado normal llamado postictal y un periodo interictal que es el transcurrido entre una crisis y otra. El periodo postictal consiste en un estado confusional, seguido de somnolencia, mialgias generalizadas y cefalalgia, siendo más florido después de ocurrida una crisis generalizada tónico-clónica. Una característica fundamental de las crisis epilépticas es su recurrencia con características semejantes en el paciente ${ }^{1,2}$.

En este apartado se realiza la descripción clínica de las variantes más frecuentes del síndrome epiléptico como son las crisis parciales y generalizadas a través de algunos casos clínicos con su contexto propio.

La epilepsia con crisis parciales o focales puede originarse en cualquier área de la corteza cerebral o en el núcleo amigdalino; por lo tanto, se divide en epilepsia con nacimiento en 
Principales problemas de Salud Pública en México

el lóbulo frontal que presenta manifestaciones motoras o del lenguaje; en el lóbulo parietal, con manifestaciones sensoriales; en el lóbulo occipital con manifestaciones visuales, y en el lóbulo temporal con manifestaciones de ilusiones, alucinaciones, manifestaciones de la conducta sexual, agresividad y cambios en la memoria ${ }^{2}$.

Caso Clínico No. 1.- Este caso clínico corresponde a epilepsia con crisis convulsivas focales originadas en el lóbulo frontal, a causa de un meningioma de la convexidad del hemisferio cerebral izquierdo; se aprecian manifestaciones sensitivas, motoras y de las funciones cerebrales superiores. Paciente del sexo femenino de 60 años de edad traída a la consulta de medicina general por padecimiento de 4 meses de evolución, caracterizado por la aparición progresiva de las siguientes manifestaciones clínicas: Paresia en el miembro superior derecho; crisis convulsivas clónicas en ese mismo miembro, las cuales en su inicio se presentaban una vez al mes, después una vez a la semana y cada tercer día últimamente; parestesia en los miembros derechos, y en los últimos días aparecieron cefalalgia y visión borrosa; la paciente uso anovulatorios hormonales durante algunos años. A la exploración neurológica: Nervios Craneales: Había edema papilar bilateral y veía borroso a partir de 2 metros de distancia; había hipoestesia al tacto, al dolor y a la temperatura en la mitad derecha de la cara; existía paresia facial derecha a los movimientos voluntarios. Sensibilidad: Existía hipoestesia al tacto, al dolor, a la temperatura, al sentido de posición y a la vibración, así como parestesias en el hemicuerpo derecho, llegando a la anestesia en el miembro superior del mismo lado. Movilidad Voluntaria: Paciente diestra, que presentó una crisis convulsiva clónica en el miembro superior derecho durante la exploración; paresia del 80\% en el miembro superior y del 30\% en el miembro inferior del lado derecho. Coordinación Muscular: Sin alteraciones. Reflejos, Tono, Trofismo y Ambulación: Hiperreflexia en las extremidades derechas de predominio superior, signo de Hoffmann derecho, hipertonía en el miembro superior derecho con discreta hipotrofia. Funciones Cerebrales Superiores: Paciente despierta, preocupada y colaboradora; presenta incapacidad para localizar y nombrar correctamente las partes distales del miembro superior derecho (autotopoagnosia) (Figura 2). Diagnóstico evolutivo: Padecimiento crónico. Diagnóstico anatomotopográfico: Afecta la cavidad intracraneana, supratentorial, en la convexidad el hemisferio cerebral izquierdo, los lóbulos frontal y parietal. Diagnóstico sindromático: Se integran los siguientes síndromes: Hipertensión endocraneana con cefalalgia, visión borrosa y edema papilar; Síndrome epiléptico con crisis convulsivas focales; Síndrome de afección sensitiva con hipoestesia en la hemicara y hemicuerpo derechos llegando a la anestesia en el miembro superior; Síndrome de afección motora con paresia facial y 


\section{Epilepsia}

del hemicuerpo derechos así como hiperreflexia y signo de Hoffmann del mismo lado; Síndrome de funciones cerebrales superiores con autotopoagnosia distal del miembro superior derecho Diagnóstico etiológico: Probable meningioma ${ }^{22,23}$.

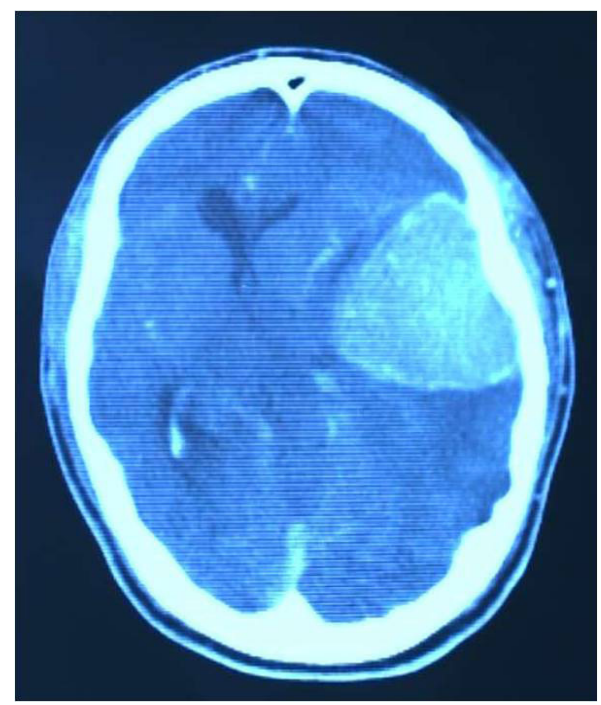

Figura 2. Meningioma. TAC contrastada. Corte axial que muestra una lesión hiperdensa en la región fronto-parietal del hemisferio cerebral izquierdo.

Caso clínico No. 2.- Este caso clínico corresponde a epilepsia focal del lóbulo temporal secundariamente generalizada, a causa de un astrocitoma de inicio en el lóbulo temporal izquierdo; se aprecian alteraciones sensoriales, manifestaciones motoras y de las funciones cerebrales superiores. Paciente del sexo masculino de 54 años de edad llevado a un hospital general por padecimiento de 4 meses de evolución, caracterizado por la aparición progresiva de las siguientes manifestaciones clínicas: Crisis epilépticas en las que agredía, se chupaba los labios o masticaba, después perdía el estado de vigilia y caía al suelo con sacudidas de las cuatro extremidades; estas crisis se presentaban una vez al día últimamente; cefalalgia y visión borrosa; falta de fuerza en las extremidades derechas y no podía expresar el lenguaje oral. A la exploración física general se encontró: Peso 60 Kg., estatura 160 cm., F. C. y pulso 76 lpm., T. A. 130/70 mm Hg y temperatura normal. A la exploración del sistema nervioso se encontró lo siguiente: Nervios Craneales: Anosmia izquierda, hemianopsia homónima derecha $\left(\begin{array}{ll}0 & 0\end{array}\right)$ y edema papilar bilateral, midriasis izquierda y esta pupila apenas respondía al estímulo luminoso, hipoestesia en la mitad derecha de la cara al tacto 
y al dolor, parálisis facial derecha a los movimientos voluntarios y afectivos, no había nistagmos optocinético a la derecha y al mostrar la lengua se desviaba hacia la derecha. Sensibilidad: No había rigidez de los músculos de la nuca, había anestesia al dolor, frío, calor, vibración y sentido de posición en las extremidades derechas. Movilidad Voluntaria: Paciente diestro, sin movimientos anormales en el momento de la exploración, con paresia del 80\% en las extremidades derechas. Coordinación Muscular: Sin alteraciones. Reflejos, Tono, Trofismo, Estación, Ambulación, Control de Esfínteres y Funciones Sexuales: Hiperreflexia, signos de Babinski y Hoffmann del mismo lado, el miembro superior derecho estaba flexionado sobre el tórax y presentaba ambulación hemiparética. Funciones Cerebrales Superiores: Paciente despierto, con afasia de expresión y amnesia para hechos recientemente ocurridos (Figura 3). Diagnóstico evolutivo: Padecimiento crónico. Diagnóstico anatomotopográfico: Afecta la cavidad intracraneana, supratentorial, dañando el hemisferio cerebral derecho, los lóbulos temporal, frontal y parietal. Diagnóstico sindromático: Se integran los siguientes síndromes: Hipertensión endocraneana con cefalalgia, visión borrosa y edema papilar; Síndrome epiléptico con crisis convulsivas focales secundariamente generalizadas; Síndrome de afección sensitiva con hipoestesia en la hemicara izquierda y anestesia en las extremidades izquierdas; Síndrome de afección motora con parálisis facial izquierda y paresia de las extremidades izquierdas así como hiperreflexia, signos de Babinski y Hoffmann y ambulación hemiparética del mismo lado; Síndrome de funciones cerebrales superiores con afasia de expresión y amnesia reciente. Diagnóstico etiológico: Glioblastoma multiforme ${ }^{22,24,25}$.

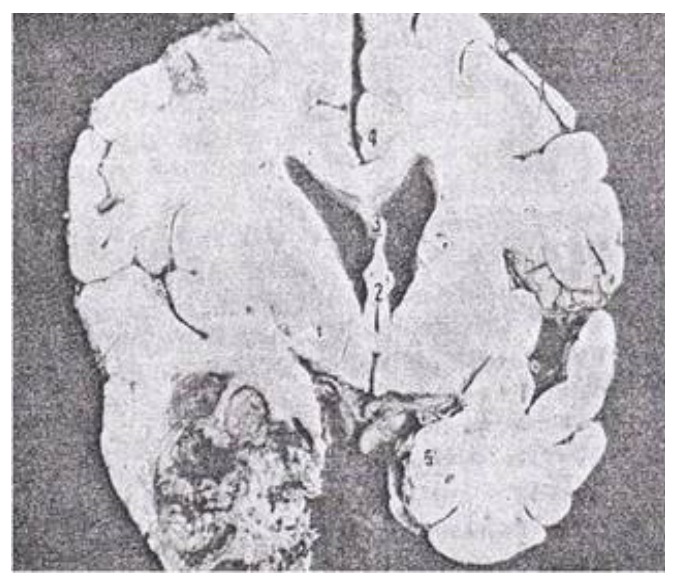

Figura 3. Corte coronal del cerebro del paciente.

Modificado con Permiso de Referencia 25. 


\section{Epilepsia}

La epilepsia generalizada tiene su sustrato morfo-fisio-patológico en el centroencéfalo y se manifiesta como crisis de ausencias de la niñez, crisis mioclónicas y crisis tónico-clónicas generalizadas. Este tipo de epilepsia se acompaña de pérdida del estado de vigilia, por lo que el paciente no graba lo acontecido y, por ello, no lo recuerda².

Caso Clínico No. 3.- Este caso clínico corresponde a crisis de ausencias de la niñez de etiología hereditaria; se aprecia que fuera de la crisis epiléptica, el paciente no presenta deterioro del sistema nervioso; además, este tipo de crisis epiléptica se pueden desencadenar con hiperventilación. Paciente del sexo masculino de 8 años de edad llevado a la consulta médica por su madre, quien refiere que, estando en la escuela la maestra notó que en forma súbita dejaba de hacer las cosas y al hablarle no respondía; dichos periodos eran de muy corta duración y cuando el niño reaccionaba no recordaba nada, cuando revisó sus cuadernos descubrió la ausencia de frases entre los dictados; por ello recomendó su atención médica. Tiene antecedente de tía materna y un primo epilépticos; existe deficiente aprovechamiento escolar. A la exploración física se encontró un paciente con somatometría y signos vitales dentro de los límites normales; sin ataque al estado general y cooperador; a la exploración del sistema nervioso no se encontraron alteraciones. Al estar sentado sobre la mesa de exploración, se le pidió realizar hiperventilación y a los pocos segundos desvió la mirada hacia arriba con ligero parpadeo de unos 15 segundos de duración, se recuperó sin cambios en la postura y sin recordar lo sucedido (Figura 4$)^{2,22,26}$.

Caso Clínico No. 4.- Este caso clínico corresponde a crisis epilépticas tónico-clónico generalizadas de etiología hereditaria; puede apreciarse que fuera de la crisis epiléptica, la paciente no presenta manifestaciones de daño neurológico y hace su vida normal. Paciente del sexo femenino de 14 años de edad que acude a la consulta médica acompañada de su madre, quien refiere que su hija presenta "ataques" una vez cada 3 meses desde hace 2 años; de acuerdo con la madre de la paciente, estos fenómenos se caracterizan por lo siguiente: durante la mañana, estando la paciente realizando cualquier actividad, presenta pérdida del estado de vigilia y la postura por lo que cae al suelo, se pone rígida por unos segundos a lo que sigue un periodo de sacudidas musculares rítmicas, simétricas y enérgicas en el cuerpo y las extremidades, presentándose, además, en esos momentos disnea, cianosis y sialorrea espumosa; después de un minuto viene un periodo de relajación, permaneciendo la paciente como en un sueño profundo del cual no se le puede despertar; una media hora más tarde recupera el estado de vigilia, no recuerda lo sucedido y permanece el resto del día con cefalalgia y somnolencia. Entre un "ataque" y otro, la paciente realiza normalmente sus 


\section{Principales problemas de Salud Pública en México}

actividades diarias. Al momento de la entrevista la paciente se refiere asintomática. Tiene antecedente de tía materna epiléptica. A la exploración física se encuentra una paciente con somatometría y signos vitales dentro de los límites normales; sin ataque al estado general y cooperadora; a la exploración del sistema nervioso no se encuentran alteraciones. Llama la atención la presencia de cicatrices en la lengua y en la piel de las extremidades (Figuras 4 y 5$)^{2,22,27}$.
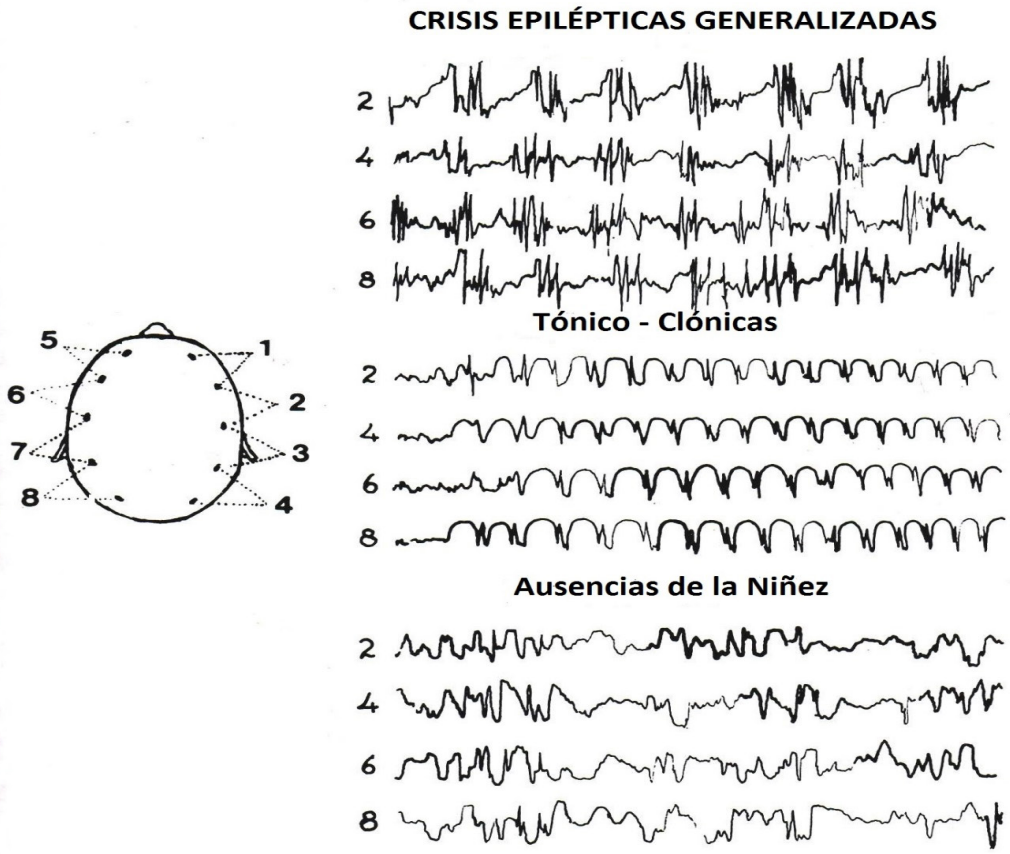

Mioclónicas Juveniles

Figura 4. Electroencefalograma mostrando grafoelementos característicos. Modificado con Permiso de Referencia 2. 


\section{Epilepsia}

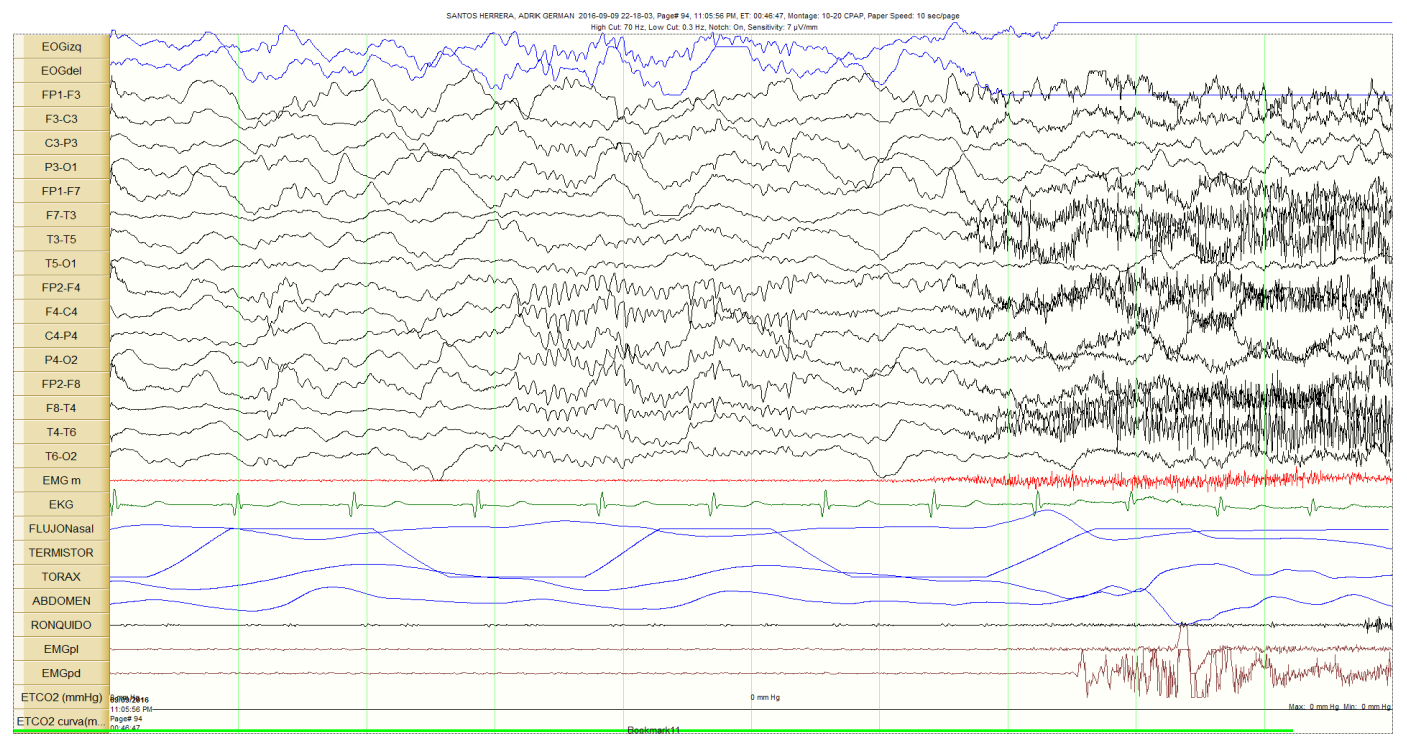

Figura 5. Electroencefalograma mostrando grafoelementos característicos en un paciente con crisis convulsiva tónico-clónico generalizada.

Cortesía: Dr. Ulises Jiménez Correa y Psic. Diego Galán Aguilar, Clínica de Trastornos del Sueño, Facultad de Medicina, UNAM.

Caso Clínico No.5.- Este caso clínico presenta epilepsia de inicio tardío con crisis convulsivas tónico-clónico generalizadas secundarias a neurocisticercosis; se aprecian manifestaciones clínicas variadas debido a las múltiples lesiones del padecimiento. Paciente del sexo femenino de 43 años de edad, originaria de Milpa Alta, Ciudad de México, inicia su padecimiento hace 4 meses, caracterizado por cefalalgia occipital, sensación vertiginosa y visión borrosa; estas manifestaciones se han intensificado en los últimos días, agregándose crisis convulsivas tónico-clónico generalizadas, motivo por el que ha sido referida a su hospital regional. A la exploración física general se encontró: Peso 72 kg., estatura 160 cm., F. C. y pulso 80 lpm., T. A. 120/80 mm Hg y temperatura normal. En la exploración neurológica se encontró lo siguiente: Nervios Craneales: había edema papilar bilateral de tres dioptrías y veía borroso a partir de 3 metros de distancia. Sensibilidad: Había rigidez de los músculos de la nuca con signo de Kernig. Movilidad Voluntaria: Paciente diestra que presentó una crisis tónicoclónico generalizada durante la exploración. Coordinación Muscular: Sin alteraciones. Reflejos: Había hiperreflexia en las cuatro extremidades con signo de Babinski bilateral. Funciones Cerebrales Superiores: Paciente despierta y poco colaboradora. Diagnóstico 
evolutivo: Padecimiento subagudo. Diagnóstico anatomotopográfico: Afecta la cavidad intracraneana, supratentorial e infratentorial. Diagnóstico sindromático: Se integran los siguientes síndromes: Hipertensión endocraneana con cefalalgia, visión borrosa y edema papilar; Síndrome epiléptico con crisis convulsivas generalizadas; Síndrome de afección motora con hiperreflexia en las cuatro extremidades y signo de Babinski bilateral; Síndrome de irritación meníngea: Cefalalgia, rigidez de los músculos de la nuca con signo de Kernig; Diagnóstico etiológico: Neurocisticercosis encefálica difusa (Figura 6) 2,22,28.

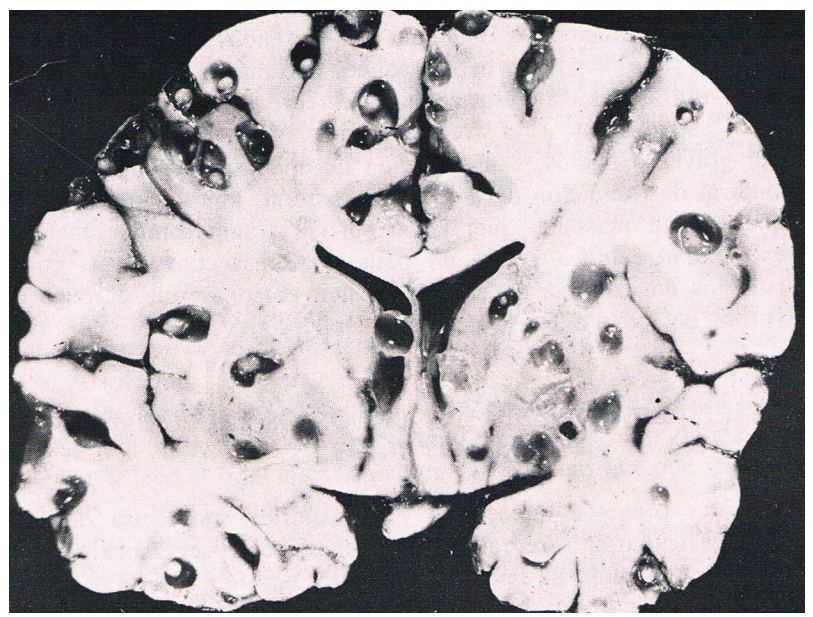

Figura 6. Corte coronal del cerebro de un paciente con Neurocisticercosis difusa. Modificado con Permiso de Referencia 2.

\section{Complicaciones}

La epilepsia es un padecimiento que presenta importante trascendencia debido a complicaciones como las siguientes:

- Epilepsia Refractaria al Tratamiento Farmacológico: Es una condición frecuente; entre el 30 y el $50 \%$ de los pacientes con epilepsia de cualquier tipo van a persistir con crisis a pesar de la terapia farmacológica. Esta condición se define como aquella en la que existe falla a dos regímenes terapéuticos (apropiados y bien tolerados) ya sea como monoterapia o en combinación ${ }^{29,30}$. 


\section{Epilepsia}

- Estado Epiléptico: Es la más frecuente emergencia médica neurológica y se asocia con una alta morbilidad y mortalidad. Se define como la persistencia de una crisis epiléptica por 30 minutos, tiempo estimado para la lesión de las neuronas del sistema nervioso. La principal causa del estado epiléptico en niños son las infecciones con fiebre y el los adultos fue la enfermedad cerebrovascular. El estado epiléptico puede manifestarse en tantas formas como crisis epilépticas existen, pero el más frecuente es el estado epiléptico convulsivo generalizado ${ }^{31}$.

- Fracaso Escolar: El fracaso escolar y los trastornos del aprendizaje son más frecuentes en niños con epilepsia que en la población general. Son condicionados por factores como los siguientes: factores propios de la epilepsia (edad de comienzo, tipo de síndrome, etiología, respuesta al tratamiento), factores de índole psicosocial (estigma social, papel sobreprotector de los padres, ausentismo escolar, ambiente escolar, baja autoestima y tendencia al aislamiento social) y factores derivados del tratamiento antiepiléptico (todos los fármacos antiepilépticos pueden producir efectos adversos cognitivos) $)^{32}$.

- Repercusión en la Calidad de Vida: Padecer epilepsia tiene consecuencias en la calidad de vida: la persona es estigmatizada, discriminada, rechazada por la familia y la sociedad; así, la persona epiléptica encontrará mayores dificultades en su calidad de vida $^{33}$.

- Depresión: Es el padecimiento psiquiátrico que más comúnmente se asocia a la epilepsia. Pueden señalarse como responsables: los psicosociales (estigma, rechazo, discriminación, riesgo de teratogénesis, restricciones), la presencia de crisis parciales complejas, entre otros factores ${ }^{34}$.

\section{Diagnóstico}

El diagnóstico de la epilepsia tiene su base fundamentalmente en la clínica, de tal manera que, la edad del paciente, la descripción y observación del tipo de crisis, la recurrencia de las mismas por lo menos en dos ocasiones, los antecedentes heredofamiliares y personales patológicos asociados constituye los elementos esenciales. 


\section{Principales problemas de Salud Pública en México}

El diagnóstico clínico de la epilepsia se complementa con los siguientes procedimientos:

- La Exploración Neurológica: Esta parte del estudio clínico del paciente no muestra cambios anormales en las epilepsias de base genética; sin embargo, muestra manifestaciones en la epilepsia secundaria a lesiones orgánicas como neurocisticercosis, traumatismos o neoplasias cerebrales.

- El Electroencefalograma: Es el registro gráfico de la actividad eléctrica cerebral y muestra grafoelementos anormales focales o generalizados que correlacionan con el suceso clínico, por lo que se considera altamente confiable (Figura 4). Este estudio también es útil para el seguimiento terapéutico de los pacientes epilépticos al mostrar la reducción o desaparición de los trazos característicos del tipo de epilepsia ${ }^{2,35}$.

- El Videoelectroencefalograma: Es la combinación del video con el electroencefalograma, es decir, registra la actividad eléctrica cerebral y el comportamiento del paciente durante la crisis epiléptica y es muy útil para realizar su semiología. Es útil en la epilepsia de difícil control y en candidatos a cirugía para epilepsia ${ }^{36}$.

- Estudios de neuroimagen: Actualmente se cuenta con varios métodos; las radiografías simples de cráneo en anteroposterior y lateral son útiles en neurocisticercosis del encéfalo y en los meningiomas por su tendencia a calcificarse; la tomografía computarizada simple y contrastada de cráneo es útil en neurocisticercosis, meningiomas (Figura 2) e infartos cerebrales; la resonancia magnética tiene su utilidad en los astrocitomas y los gliomas multiformes; la angiografía digital es útil en malformaciones arteriovenosas como causa de epilepsia ${ }^{37}$.

De tal manera que el diagnóstico de epilepsia se realiza cuando: el enfermo ha tenido al menos dos crisis recurrentes, antecedentes familiares de epilepsia, la evidencia de alguna lesión focal que origine las crisis, electroencefalograma con puntas generalizadas y la presencia de déficit en la exploración neurológica. Habrá que determinar, siempre que se pueda, el tipo de crisis que sufre el paciente.

\section{Terapéutica}

El manejo terapéutico del paciente epiléptico incluye los siguientes aspectos: 


\section{Epilepsia}

A) Medidas Generales: En este apartado es importante tomar en cuenta estilos de vida saludables, tales como una alimentación alta en grasas y baja en hidratos de carbono (dieta cetogénica $)^{38}$, medidas para el control de estrés, evitar desvelarse, dormir el tiempo suficiente, actividad física moderada, evitar las bebidas alcohólicas, los estimulantes como el café y los refrescos de cola ${ }^{39}$.

B) Medicamentos y/o Procedimientos Quirúrgicos: No existe un medicamento ideal para el tratamiento de la epilepsia. Los que más se aproximan son los que tienen identificado su mecanismo de acción, cuentan con una farmacocinética simple, eficacia comprobada y efectos secundarios limitados. La selección del tratamiento medicamentoso antiepiléptico se basa en las siguientes normas: a) empezar con un medicamento antiepiléptico e ir aumentando la dosis hasta que los efectos terapéuticos se obtengan o aparezcan signos de toxicidad; b) de no alcanzar el control adecuado con el primer medicamento se reducirá su dosis y sumar un segundo medicamento paulatinamente procurando el reemplazo para volver a la monoterapia; c) sólo usar politerapia racional en los casos en que la monoterapia fracase, (Cuadros 3) ${ }^{39,40,41}$. Entre el 50 y 70\% de los pacientes son controlados con medicamentos; el restante 30 al 50\% de los pacientes presentarán epilepsia refractaria. Una vez que el paciente ha sido tratado y seguido en forma integral y se ha llegado al diagnóstico de epilepsia refractaria, debe ser enviado a un centro donde exista un programa de cirugía en epilepsia; allí se valorará y se atenderá $29,30,42$.

Cuadro 3. Medicamentos sugeridos para la Epilepsia ${ }^{39,40,41}$.

\begin{tabular}{|l|l|l|l|}
\hline \multicolumn{4}{|c|}{ Crisis Parciales } \\
\hline $\begin{array}{l}\text { Primera } \\
\text { Línea }\end{array}$ & Ácido Valproico & Incrementa la acción del GABA & $15-60 \mathrm{mg} / \mathrm{kg}$ \\
Cearbamasepina & Bloquea canales de sodio & $10-30 \mathrm{mg} / \mathrm{kg}$ \\
\hline Línea & Vigabatrina & Aumenta niveles cerebrales de & $500-1000 \mathrm{mg} /$ día \\
& Gabapentina & GABA & $900-2400 \mathrm{mg} /$ día \\
& Lamotrigina & Incrementa la síntesis de GABA & $100-600 \mathrm{mg} /$ día \\
& Difenilhidantoina & Prolonga inactivación de canales & $5-7 \mathrm{mg} / \mathrm{kg}$ \\
& & de sodio & \\
\hline Tercera & Bloquea canales de sodio & \\
& Fenobarbital & Incrementa la acción del GABA & $3-5 \mathrm{mg} / \mathrm{kg}$ \\
& Primidona & Reduce la acción del glutamato & $10-25 \mathrm{mg} / \mathrm{kg}$ \\
& Clobazam & Incrementa la acción del GABA & $15-30 \mathrm{mg} / \mathrm{día}$ \\
\hline
\end{tabular}


Principales problemas de Salud Pública en México

Cuadro 3. Medicamentos sugeridos para la Epilepsia (continuación) $)^{39,40,41}$.

\begin{tabular}{|c|c|c|c|}
\hline \multicolumn{4}{|c|}{ Crisis Generalizadas } \\
\hline Ausencias & $\begin{array}{l}\text { Ácido Valproico } \\
\text { Etosuximida } \\
\text { Clonazepam } \\
\text { Lamotrigina }\end{array}$ & $\begin{array}{l}\text { Incrementa la acción del GABA } \\
\text { Modula los canales de calcio } \\
\text { Incrementa la acción del GABA } \\
\text { Prolonga inactivación de canales } \\
\text { de sodio }\end{array}$ & $\begin{array}{l}15-60 \mathrm{mg} / \mathrm{kg} \\
15-50 \mathrm{mg} / \mathrm{kg} \\
0.025-0.30 \mathrm{mg} / \\
\mathrm{kg} \\
100-600 \mathrm{mg} / \text { día }\end{array}$ \\
\hline $\begin{array}{l}\text { Tónico- } \\
\text { clónicas }\end{array}$ & $\begin{array}{l}\text { Ácido Valproico } \\
\text { Carbamasepina } \\
\text { Vigabatrina } \\
\text { Gabapentina } \\
\text { Lamotrigina } \\
\text { Difenilhidantoina } \\
\text { Fenobarbital }\end{array}$ & $\begin{array}{l}\text { Incrementa la acción del GABA } \\
\text { Bloquea canales de sodio } \\
\text { Aumenta niveles cerebrales de } \\
\text { GABA } \\
\text { Incrementa la síntesis de GABA } \\
\text { Prolonga inactivación de canales } \\
\text { de sodio } \\
\text { Bloquea canales de sodio } \\
\text { Incrementa la acción del GABA }\end{array}$ & $\begin{array}{l}15-60 \mathrm{mg} / \mathrm{kg} \\
10-30 \mathrm{mg} / \mathrm{kg} \\
500-1000 \mathrm{mg} / \text { día } \\
900-2400 \mathrm{mg} / \text { día } \\
100-600 \mathrm{mg} / \text { día } \\
5-7 \mathrm{mg} / \mathrm{kg} \\
3-5 \mathrm{mg} / \mathrm{kg}\end{array}$ \\
\hline $\begin{array}{l}\text { Crisis } \\
\text { atónicas }\end{array}$ & $\begin{array}{l}\text { Ácido Valproico } \\
\text { Lamotrigina }\end{array}$ & $\begin{array}{l}\text { Incrementa la acción del GABA } \\
\text { Prolonga inactivación de canales } \\
\text { de sodio }\end{array}$ & $\begin{array}{l}15-60 \mathrm{mg} / \mathrm{kg} \\
100-600 \mathrm{mg} / \text { día }\end{array}$ \\
\hline $\begin{array}{l}\text { Crisis } \\
\text { mioclónicas }\end{array}$ & $\begin{array}{l}\text { Ácido Valproico } \\
\text { Lamotrigina } \\
\text { Carbamasepina }\end{array}$ & $\begin{array}{l}\text { Incrementa la acción del GABA } \\
\text { Prolonga inactivación de canales } \\
\text { de sodio Bloquea canales de sodio }\end{array}$ & $\begin{array}{l}15-60 \mathrm{mg} / \mathrm{kg} \\
100-600 \mathrm{mg} / \text { día } \\
10-30 \mathrm{mg} / \mathrm{kg}\end{array}$ \\
\hline
\end{tabular}

C) Información sobre el Problema al Paciente y su Familia: Debe hacerse de forma accesible y clara. Debe informarse sobre la naturaleza del padecimiento y el porqué del uso de medicamentos; recomendar no suspender el medicamento sin asesoría médica.

D) Citas para Seguimiento y Control: Se realizará de acuerdo a las necesidades diagnósticas y terapéuticas de cada caso.

\section{Medidas de prevención}

La prevención de la epilepsia se justifica por la frecuencia de la enfermedad y sus drásticas consecuencias como su refractariedad al tratamiento, el estado epiléptico, el estigma social y familiar para el enfermo, mayor incidencia de desempleo y deterioro de su calidad de vida. Por otro lado, la epilepsia es una enfermedad social y su tratamiento representa una carga económica importante. 


\section{Epilepsia}

La prevención de la epilepsia incluye las siguientes medidas ${ }^{43,44}$ :

A) Prevención Primaria: Constituyen una serie de medidas aplicables antes de la aparición de la epilepsia, entre las cuales están:

- Promoción de la Salud: Con hábitos saludables, adecuada higiene personal y ambiental, nutrición adecuada, ejercicio físico, adecuadas condiciones de trabajo, desarrollo adecuado de la personalidad.

- Protección específica: Incluye consejo genético a hijos de epilépticos, atención adecuada del embarazo y el parto; detección oportuna de infecciones congénitas, disgenecia cerebral y trastornos genéticos y metabólicos pueden llevar a la interrupción del embarazo; tratamiento neuroprotector de la encefalopatía hipoxico-isquémica al nacimiento; diagnóstico precoz de encefalopatías metabólicas; vacunación contra microorganismos causantes de meningitis; higiene del sueño y evitar el uso de drogas y alcohol; evitar o tratar adecuadamente meningoencefalitis, neurocisticercosis, traumatismos craneoencefálicos, neoplasias encefálicas y padecimientos vasculares cerebrales; uso de fármacos como la carbamacepina para evitar la epileptogénesis en pacientes con traumatismo craneoencefálico. Uso de fármacos antiepilépticos y antioxidantes como neuroprotectores en estos padecimientos.

B) Prevención Secundaria: Constituyen una serie de medidas aplicables una vez que aparece la epilepsia e incluyen:

- Diagnóstico Temprano y Tratamiento Oportuno: identificación oportuna de casos mediante el estudio clínico, electroencefalograma y estudios de neuroimagen para la confirmación del diagnóstico, aplicación del tratamiento adecuado, evitando los factores desencadenantes de las crisis epilépticas.

- Limitación de la Incapacidad: Derivación al neurólogo, derivación a Centros de Atención quirúrgica de epilepsia.

C) Prevención Terciaria: Constituyen una serie de medidas aplicables para evitar las secuelas de la epilepsia e incluyen:

- Rehabilitación: Física y neuropsicológica para que el paciente se reintegre a su medio familiar, escolar, laboral y social. 


\section{Principales problemas de Salud Pública en México}

\section{Referencias}

1. Núñez OL. Introducción En: Núñez OL, Plascencia ANI, Malagón VJ (eds.). Epilepsia: una perspectiva Clínica. México: Editorial Prado; 2008. p. xxiii-xxviii.

2. Nava SJ. La epilepsia. En: Nava SJ (ed.). Neurología clínica. 5ª ed. México: Unión Gráfica; 1985. p. 311-373.

3. Fisher RS, Boas WE, Blume W, Elder C, Genton P, Lee P, Engel J. Epileptic seizures and epilepsy: depinitions proposed by the International League Against Epilepsy (ILAE) and the International Bureau for Epilepsy (IBE). Epilepsia. 2005; 46(4):470-472.

4. Rubio DF. Aspectos históricos de la epilepsia. En: Núñez OL, Plascencia ANI, Malagón VJ. Epilepsia: una perspectiva clínica. México: Editorial Prado; 2008. p. 1-6.

5. Núñez OL. Clasificación de las crisis epilépticas y de las epilepsias. En: Núñez OL, Plascencia ANI, Malagón VJ. Epilepsia: una perspectiva clínica. México: Editorial Prado; 2008. p. 53-67.

6. Berg AT, Bercovic SE, Brodie MJ, Buchhalter J, Cross JH, Van Emde Boas W, et al. Revised terminology and concepts for organization of saizures and epilepsies: report of the ILAE Commission of Classification and Terminology. Epilesia. 2010; 51(4):676-685.

7. García PF, Millán CR, Peñaloza Y. Epidemiología clínica de la epilepsia. En: Núñez OL, Plascencia ANI y Malagón VJ. Epilepsia: una perspectiva clínica. México: Editorial Prado; 2008. p. 7-51.

8. Salazar ZA, Ramos DEE, Aguilar HR, Hernández PJ. Incidencia de epilepsia en el Hospital Central Militar de 1996 a 2001. Estudio retrospectivo de revisión. Neurología, Neurocirugía y Psiquiatría. 2004; 37(1):19-24.

9. Soto-Chávez V, Ceja-Moreno H, Soto-Mancilla JL, Pérez-Rulfo D. Perfil epidemiológico de los niños con epilepsia. Archivos de Investigación Pediátrica de México. 2000; 3(11): 395-400.

10. Aveleyra OE, Castillo V, Plascencia N, Sauri S, Navarrete H, Gutiérrez J, et al. Características clínicas de la epilepsia de inicio tardío en México al principio del nuevo milenio: 455 casos. Revista de Investigación Clínica. 2009; 61(5):354-363.

11. Oller LFV. Prevalencia de los distintos tipos de epilepsia en la práctica clínica. Revista de Neurología. 2002; 34(6):526-531. 


\section{Epilepsia}

12. Núñez OL. Epilepsia y sociedad: su repercusión en la calidad de vida. En: Núñez OL, Plascencia ANI y Malagón VJ. Epilepsia: una perspectiva clínica. México: Editorial Prado; 2008. p. 645-661.

13. Rodríguez-Blanca MC. Calidad de vida en niños y adolescentes epilépticos mexicanos en consulta de neuropediatría: escala CAVE. Revista Mexicana de Neurociencias. 2014; 15(1):18-22.

14. Gutiérrez-Moctezuma J, Villegas-Peña H, Solórzano-Gómez E, Hernández-Rodríguez V. El impacto social y educacional por la epilepsia en niños de tres hospitales de seguridad social. Revista Mexicana de Pediatría. 2000; 67(3):111-116.

15. García-Peñas JJ. Fracaso escolar y epilepsia infantil. Revista de Neurología. 2015; 60(Supl 1):S63-S68.

16. Alonso VME, Delgado EA, Medina MT, Ochoa A, Jara A, Rasmussen A. Genética de las epilepsias. En: Núñez OL, Plascencia ANI, Malagón VJ. Epilepsia: una perspectiva clínica. México: Editorial Prado; 2008. p. 69-91.

17. Torres-Ferrús M, Toledo M, González-Cuevas M, Seró-Ballesteros L, Santamarina E, Raspall-Chaure M, et al. Etiología y tratamiento de la epilepsia en una serie de 1557 pacientes. Revista de Neurología. 2013; 57(7):306-312.

18. Alonso-Cerezo C, Herrera-Peco I, Fernández-Millares V, Pastor J, Palacios-Espichan J, Hernando-Requejo V, et al. Antecedentes familiares en epilepsias refractarias al tratamiento. Revista de Neurología. 2011; 52(9):522-526.

19. Ferlisi M, Shorvon S. Seizure precipitants (triggering factors) in patients with epilepsy. Epilepsy \& Behaviour. 2014; 33(4): 101-105.

20. López MML, Rocha ALL. Fisiopatología de la epilepsia. En: Núñez OL, Plascencia ANI, Malagón VJ. Epilepsia: una perspectiva clínica. México: Editorial Prado; 2008. p. 93-112.

21. Pastor J, Uzcátegui YG, Gal-Iglesias B, Ortega GJ, Sola RG, Menéndez de la Prida L. Bases fisiopatológicas de la epilepsia del lóbulo temporal: estudios en humanos y animales. Revista de Neurología. 2006; 42(11):663-673.

22. Contreras-González N, Trejo-López JA. Manual para la exploración neurológica y las funciones cerebrales superiores. México: El Manual Moderno-FES Zaragoza, UNAM. 158 páginas. 


\section{Principales problemas de Salud Pública en México}

23. Plascencia ANI. Epilepsia del lóbulo frontal y otras epilepsias focales extratemporales. En: Núñez OL, Plascencia ANI, Malagón VJ. Epilepsia: una perspectiva clínica. México: Editorial Prado; 2008. p. 357-372.

24. Irigoyen AM. Epilepsia del lóbulo temporal. En: Núñez OL, Plascencia ANI, Malagón VJ. Epilepsia: una perspectiva clínica. México: Editorial Prado; 2008. p. 339-355.

25. Nava SJ, Peláez SS, Reyes TJ. El lenguaje y las funciones cerebrales superiores. México: Impresiones Modernas; 1979. p. 311-318.

26. Malagón VJ. Ausencia epiléptica de la niñez. En: Núñez OL, Plascencia ANI y Malagón VJ. Epilepsia: una perspectiva clínica. México: Editorial Prado; 2008. p. 289-295.

27. Calderón GR. Epilepsia con crisis tónico-clónicas generalizadas del despertar. En: Núñez OL, Plascencia ANI, Malagón VJ. Epilepsia: una perspectiva clínica. México: Editorial Prado; 2008. p. 307-311.

28. Suástegui RR. Crisis de inicio tardío. En: Núñez OL, Plascencia ANI, Malagón VJ. Epilepsia: una perspectiva clínica. México: Editorial Prado; 2008. p. 413-428.

29. Reyes BG, Santiago UC. Epilepsia refractaria. Acta Neurológica Colombiana. 2010; 36(1):32-46.

30. Martínez-Juárez IE, López Zapata R, Gómez-Arias B, Bravo-Armenta E, RomeroOcampo L, Esteves-Cruz Z, et al. Epilepsia farmacorresistente: uso de la nueva definición y factores de riesgo relacionados. Estudio en población mexicana de un centro de tercer nivel. Revista de Neurología. 2012; 54(3):159-166.

31. Plascencia ANI. Estado epiléptico. En: Núñez OL, Plascencia ANI, Malagón VJ. Epilepsia: una perspectiva clínica. México: Editorial Prado; 2008. p. 429-446.

32. García-Peñas JJ. Fracaso escolar y epilepsia infantil. Revista de Neurología. 2015; 60(Supl 1):S63-S68.

33. Núñez OL. Epilepsia y sociedad: su repercusión en la calidad de vida. En: Núñez OL, Plascencia ANI, Malagón VJ. Epilepsia: una perspectiva clínica. México: Editorial Prado; 2008. p. 645-661.

34. Gutiérrez AM. Epilepsia y trastornos depresivos. Acta Neurológica Colombiana. 2005; 21(2):121-125.

35. Olmos GG. Electroencefalograma. En: Núñez OL, Plascencia ANI, Malagón VJ. Epilepsia: una perspectiva clínica. México: Editorial Prado; 2008. p. 125-136. 


\section{Epilepsia}

36. Plascencia ANI. Videoelectroencefalografía. En: Núñez OL, Plascencia ANI, Malagón VJ. Epilepsia: una perspectiva clínica. México: Editorial Prado; 2008. p. 137-147.

37. Muñoz RC, Taboada BJ, Balderrama BJ. Neuroimagen en epilepsia. En: Núñez OL, Plascencia ANI, Malagón VJ. Epilepsia: una perspectiva clínica. México: Editorial Prado; 2008. p. 149-215.

38. Vaccarezza M, Agustinho A, Alberti MJ, Argumedo L, Armeno M, Blanco V, et al. Conceso nacional de dieta Akins modificada. Revista de Neurología. 2016; 62(8):371-376.

39. Llamosa GVG. Manejo general de las crisis epilépticas. En: Núñez OL, Plascencia ANI, Malagón VJ. Epilepsia: una perspectiva clínica. México: Editorial Prado; 2008. p. 509-519.

40. Sauri SS. Fármacos tradicionales en epilepsia. En: Núñez OL, Plascencia ANI, Malagón VJ. Epilepsia: una perspectiva clínica. México: Editorial Prado; 2008. p. 521-542.

41. Quiñones AS. Nuevos fármacos antiepilépticos. En: Núñez OL, Plascencia ANI, Malagón VJ. Epilepsia: una perspectiva clínica. México: Editorial Prado; 2008. p. 543566.

42. Ávila RJ. Tratamiento quirúrgico de la epilepsia. En: Núñez OL, Plascencia ANI, Malagón VJ. Epilepsia: una perspectiva clínica. México: Editorial Prado; 2008. p. 599-621.

43. Leavell HR, Clark EG. Preventive medicine for the doctor in his community: an epidemiological aproach. New York: McGraw-Hill Boo; 1965. p. 21.

44. Legido A. Prevención de la epilepsia. Revista de Neurología. 2002; 34(2):186-195. 



\title{
19. Neoplasias del sistema nervioso
}

\author{
Dr. Noé Contreras González \\ Dr. José Damián Carrillo Ruíz
}

\section{Introducción}

El presente documento tiene por finalidad revisar, de manera breve, los datos más importantes acerca de las neoplasias del sistema nervioso, a manera de guía sencilla para el estudiante de medicina, el médico general y el médico especialista no oncólogo.

\section{Concepto}

Las neoplasias del sistema nervioso constituyen un conjunto de padecimientos dentro de los cuales destacan los meningiomas, los astrocitomas, los adenomas hipofisiarios, los meduloblastomas y los schwannomas; se manifiestan mediante diversos síndromes como hipertensión endocraneana, epilepsia y alteraciones de la función cerebral, cerebelosa o de los nervios periféricos, por lo que la clínica y los estudios de imagen son fundamentales para el diagnóstico temprano; debido a su morbilidad y mortalidad, representan un importante problema de Salud Pública en nuestro país ${ }^{1,2,3}$.

\section{Clasificación}

Dentro de la Clasificación Anatomopatológica de las Neoplasias del Sistema Nervioso, se

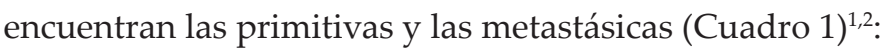


Cuadro 1. Clasificación Anatomopatológica de las Neoplasias del Sistema Nervioso ${ }^{1,2}$.
A. PRIMITIVAS
1. Células neuroepiteliales
a) Astrocitos: Astrocitoma
b) Oligodendrocitos: Oligoden- droglioma
c) Células ependimarias: Ependimoma
d) Neuronas:
- Neuroblastoma
- Meduloblastoma
e) Células Pineales: Pineoblastoma

\section{Meninges}

Meningioma

\section{Células de la vaina nerviosa}
a) Schwannoma
b) Neurofibroma

4. Vasos sanguíneos Hemangioblastoma
5. Glándula hipófisis anterior Adenoma hipofisiario

6. Anomalías del desarrollo
a) Craneofaringioma
b) Quiste epidermoide
c) Quiste coloidal

7. Tumores adyacentes
a) Cordoma
b) Tumor del glomus yugular
c) Condrosarcoma

B. METASTÁSICAS

1. Pulmón

2. Mama

3. Piel

4. Tracto urinario

5. Tracto digestivo

\section{Epidemiología}

El cáncer continúa siendo un grave problema de Salud Pública mundial debido a la discapacidad y alto riesgo de mortalidad que conlleva; en 2008 causó 7.6 millones de defunciones (13\% del total). Se prevé que las muertes por cáncer sigan aumentando en todo el mundo y alcancen la cifra de 13,1 millones en $2030^{4}$.

En México durante el año 2000, los tumores malignos ocuparon el sexto lugar dentro de las veinte principales causas de morbilidad hospitalaria ${ }^{3}$. En nuestro país, durante el 2006, los tumores malignos representaron la tercera causa de mortalidad general, con alrededor del $13 \%$ del total, afectando principalmente a la población adulta de ambos sexos. La ubicación corporal de los tumores malignos como causa de defunción, en orden decreciente durante el 2006, fueron pulmón, tracto digestivo, próstata, mama, cuello uterino, piel, sangre y encéfalo. Las defunciones por tumores del encéfalo representaron alrededor del 3\% en dicho año ${ }^{5}$. 


\section{Neoplasias del sistema nervioso}

En la población adulta de los Estados Unidos de América, de 295986 tumores intracraneales reportados entre 2004 y 2008, los meningiomas representan 36\%; predominan entre 50 y 70 años de edad y son más frecuentes en las mujeres con una relación 2:1. Le siguen los astrocitomas que representan entre el 33\% de los tumores intracraneales; el astrocitoma junto con el glioblastoma multiformes, constituyen el $20 \%$ de todos los tumores cerebrales, aproximadamente el 55\% de los tumores del grupo de los gliomas y el $90 \%$ de los gliomas supratentoriales del adulto. Los adenomas hipofisiarios con 14\% de los tumores intracraneales siendo el prolactinoma el más frecuente con predominio en la mujer. Finalmente, los schwannomas con alrededor del $8 \%$ de todos los tumores intracraneales ${ }^{1,2,6,7,8,9}$.

En la población infantil, las neoplasias del sistema nervioso representan entre el 15 y 20\% de todas las neoplasias. Los tumores más frecuentes son los astrocitomas con alrededor del $35 \%$, el meduloblastoma con el 25\% y el craneofaringioma con el 15\% de todos los tumores intracraneales $2,7,10,11$.

\section{Causalidad}

El cáncer comienza en una célula. La transformación de una célula normal en tumoral es un proceso multifásico y suele consistir en la progresión de una lesión precancerosa a un tumor maligno. Estas alteraciones son el resultado de la interacción entre los factores genéticos del paciente y los factores ambientales físicos, químicos y biológicos ${ }^{4}$.

Los factores desencadenantes más importantes son ambientales y genéticos. Los individuos están expuestos a factores cancerígenos como rayos ultravioleta, ondas electromagnéticas de teléfonos móviles y niebla tóxica, asbestos y cloruro de vinilo, dieta rica en grasas, sustancias químicas como hormonas, agentes microbianos y humo de tabaco. La incidencia creciente del cáncer con la edad puede explicarse por la acumulación de múltiples mutaciones de genes, la disminución de la competencia inmunitaria que acompaña al envejecimiento, la activación de oncogenes promotores de crecimiento, la inactivación de genes supresores de crecimiento tumoral y a la evasión de la apoptosis ${ }^{12}$.

Aproximadamente un 30\% de las muertes por cáncer son debidas a seis factores de riesgo conductuales y dietéticos: índice de masa corporal elevado, ingesta reducida de frutas y 


\section{Principales problemas de Salud Pública en México}

verduras, falta de actividad física, exposición a ondas electomagnéticas, consumo de tabaco y consumo de alcohol ${ }^{4}$. El consumo de tabaco es el factor de riesgo más importante, y es la causa del $22 \%$ de las muertes mundiales por cáncer ${ }^{4,6,13}$.

\section{Fisiopatología}

Las neoplasias del sistema nervioso se describen a menudo como "benignas" o "malignas", pero estos términos no deben compararse directamente con sus equivalentes en otros aparatos y sistemas. Un tumor "benigno" dentro del sistema nervioso (baja frecuencia mitótica, uniformidad celular y crecimiento lento) puede tener efectos devastadores si se expande dentro de los límites rígidos de la cavidad craneal o del conducto raquídeo. Un astrocitoma benigno puede infiltrar ampliamente el tejido cerebral impidiendo su extirpación completa, o puede ocupar una zona funcionalmente crítica que impida su extirpación siquiera parcial. Un tumor intracraneal "maligno" implica un crecimiento rápido, mala diferenciación, aumento de celularidad, mitosis, necrosis y proliferación vascular, pero es excepcional que de metástasis a localizaciones extra craneales.

Las neoplasias del sistema nervioso pueden ser primitivas o metastásicas. Las neoplasias primitivas del sistema nervioso central representan las dos terceras partes y derivan de componentes neuroepiteliales, meninges, células de la vaina nerviosa, vasos sanguíneos y glándula hipófisis. Las neoplasias metastásicas del sistema nervioso central representan una tercera parte y derivan de la mama, el pulmón, la piel, el tubo digestivo, el riñón, etc. (ver Cuadro 1 en el apartado de clasificación) $)^{1,2,14}$.

Las neoplasias intracraneales en el adulto son de predominio supratentorial, mientras que en los niños se ubican principalmente por debajo del tentorio ${ }^{2,10}$.

Los meningiomas se originan de las células meningoepiteliales de la membrana aracnoides y generalmente están unidos a la duramadre; son tumores benignos generalmente; son masas redondeadas, encapsuladas y de lento crecimiento, lo que permite la adaptación del parénquima cerebral a aumentos en la presión intracraneana ${ }^{6,9,15}$.

Los gliomas son neoplasias infiltrantes principalmente que se ubican en los hemisferios cerebrales predominantemente; se clasifican en cuatro grados de malignidad a partir de las 


\section{Neoplasias del sistema nervioso}

características de hipercelularidad, microquistes, pleomorfismo, proliferación vascular, actividad mitótica y presencia de focos de necrosis ${ }^{12,13,14,15}$. En el grado I, el glioma de baja malignidad solo muestra hipercelularidad. En el grado II, hay además gemistocitos. El grado de malignidad aumenta en la medida que crece la hipercelularidad y el pleomorfismo. El grado III, el glioma maligno o astrocitoma anaplásico, se caracteriza por numerosas figuras mitóticas. Por último, en el grado IV el glioblastoma es multiforme y se caracteriza por proliferación vascular, necrosis y células dispuestas en seudoempalizada. Los astrocitomas se originan a partir de los astrocitos del sistema nervioso central y durante su crecimiento pueden alcanzar grandes tamaños e infiltrar antes de producir manifestaciones clínicas.

Los adenomas hipofisiarios se clasifican en funcionantes o no según su producción de hormonas, con franco predominio de los prolactinomas; desde el punto de vista anatomoradiológico, estos tumores se clasifican en micro y macroadenomas según su tamaño sea menor o mayor de un centímetro, respectivamente. Son lesiones blandas bien delimitadas que pueden estar confinadas a la silla turca o crecer en dirección superior y comprimir el quiasma óptico ${ }^{16,17}$.

El meduloblastoma es un tumor embrionario maligno e invasivo de la línea media del cerebelo que se manifiesta preferentemente en niños ${ }^{11,15}$.

Los schwannomas se originan en las células de Schwann que derivan de las crestas neurales; son frecuentes en la rama vestibular del VIII par craneal en el ángulo pontocerebeloso; son masas encapsuladas bien circunscritas; producen manifestaciones clínicas por compresión local del nervio afectado o las estructuras adyacentes ${ }^{15,18}$.

El encéfalo y la médula espinal están protegidos por el compartimento rígido delimitado por el cráneo, los cuerpos vertebrales y la duramadre. La presión intracraneal depende del equilibrio entre el parénquima, la circulación vascular y el líquido cefalorraquídeo. De tal manera que, la presencia de una neoplasia intracraneal puede comprimir estructuras adyacentes, obstruir la circulación del líquido cefalorraquídeo, aumentar la presión intracraneal y reducir la perfusión del encéfalo, mecanismos que determinarán las manifestaciones clínicas ${ }^{15}$. 


\section{Principales problemas de Salud Pública en México}

\section{Cuadro clínico}

El estudio clínico de un enfermo con una neoplasia del sistema nervioso se realiza a través de la entrevista clínica y la exploración neurológica. Se obtienen las manifestaciones clínicas, síntomas y signos, y mediante su adecuada semiología, tendremos elementos para plantear el diagnóstico presuntivo a nivel evolutivo, anatomotopográfico, sindromático y etiológico, fundamento para la solicitud de estudios de imagen que nos permitirán mayor precisión ${ }^{19}$.

Las manifestaciones clínicas de las neoplasias del sistema nervioso dependerán de su tiempo de evolución localización, tamaño y sus repercusiones sobre el parénquima, la circulación del líquido cefalorraquídeo, así como la perfusión sanguínea y el drenaje venoso.

Las neoplasias del sistema nervioso inicialmente son asintomáticas, dado su lento crecimiento. Mediante la entrevista clínica identificaremos que se trata de una persona adulta, con un padecimiento de evolución subaguda o crónica, que se queja de hiporexia, cefalalgia olocraneal, visión borrosa, pudiendo aparecer vómito con el paso del tiempo, a veces con déficit sensitivo o motor en algún hemicuerpo y alteraciones en la ambulación, pudiendo acompañarse de crisis epilépticas focales o generalizadas, así como alteraciones en las funciones cerebrales superiores como el lenguaje, la memoria y el pensamiento correcto. Dicha persona puede ser fumadora crónica y haber usado anovulatorios hormonales por tiempo prolongado.

A la exploración neurológica de un paciente con neoplasia del sistema nervioso podemos encontrar disminución de la agudeza visual y edema papilar, así como alteraciones en la campimetría visual del tipo hemianopsia bitemporal; hipoestesia y paresia en algunas regiones corporales; dismetría, disdiadococinecia y asinergia muscular; hiperreflexia, signos de Babinski y Hoffmann, alteraciones en el tono muscular, adelgazamiento así como alteraciones en la estación de pie y la ambulación; pueden encontrarse alteraciones de las funciones cerebrales superiores tales como el lenguaje, la memoria, la percepción del esquema corporal, la agresividad y el pensamiento correcto ${ }^{20}$.

Las manifestaciones clínicas evolucionan en meses o años en el caso de los gliomas de bajo grado, los meningiomas, los adenomas hipofisiarios y los schwannomas; en pocos meses en el astrocitoma anaplásico y en pocas semanas en el glioblastoma multiforme. 


\section{Neoplasias del sistema nervioso}

Como ejemplos tenemos los siguientes casos clínicos:

Caso Clínico No. 1.- Paciente del sexo femenino de 60 años de edad traída a la consulta de medicina general por padecimiento de 4 meses de evolución, caracterizado por la aparición progresiva de las siguientes manifestaciones clínicas: Paresia en el miembro superior derecho; crisis convulsivas clónicas en ese mismo miembro, las cuales en su inicio se presentaban una vez al mes, después una vez a la semana y cada tercer día últimamente; parestesia en los miembros derechos, y en los últimos días aparecieron cefalalgia y visión borrosa; la paciente uso anovulatorios hormonales durante algunos años. A la exploración neurológica: Nervios Craneales: Había edema papilar bilateral y veía borroso a partir de 2 metros de distancia; había hipoestesia al tacto, al dolor y a la temperatura en la mitad derecha de la cara; existía paresia facial derecha a los movimientos voluntarios. Sensibilidad: Existía hipoestesia al tacto, al dolor, a la temperatura, al sentido de posición y a la vibración, así como parestesias en el hemicuerpo derecho, llegando a la anestesia en el miembro superior del mismo lado. Movilidad Voluntaria: Paciente diestra, que presentó una crisis convulsiva clónica en el miembro superior derecho durante la exploración; paresia del 80\% en el miembro superior y del 30\% en el miembro inferior del lado derecho. Coordinación Muscular: Sin alteraciones. Reflejos, Tono, Trofismo y Ambulación: Hiperreflexia en las extremidades derechas de predominio superior, signo de Hoffmann derecho, hipertonía en el miembro superior derecho con discreta hipotrofia. Funciones Cerebrales Superiores: Paciente despierta, preocupada y colaboradora; presenta incapacidad para localizar y nombrar correctamente las partes distales del miembro superior derecho (autotopoagnosia) (Figura 1). Diagnóstico evolutivo: Padecimiento crónico. Diagnóstico anatomotopográfico: Afecta la cavidad intracraneana, supratentorial, en la convexidad el hemisferio cerebral izquierdo, los lóbulos frontal y parietal. Diagnóstico sindromático: Se integran los siguientes síndromes: Hipertensión endocraneana con cefalalgia, visión borrosa y edema papilar; Síndrome epiléptico con crisis convulsivas focales; Síndrome de afección sensitiva con hipoestesia en la hemicara y hemicuerpo derechos llegando a la anestesia en el miembro superior; Síndrome de afección motora con paresia facial y del hemicuerpo derechos así como hiperreflexia y signo de Hoffmann del mismo lado; Síndrome de funciones cerebrales superiores con autotopoagnosia distal del miembro superior derecho . Diagnóstico etiológico: Probable meningioma ${ }^{15,20}$. 


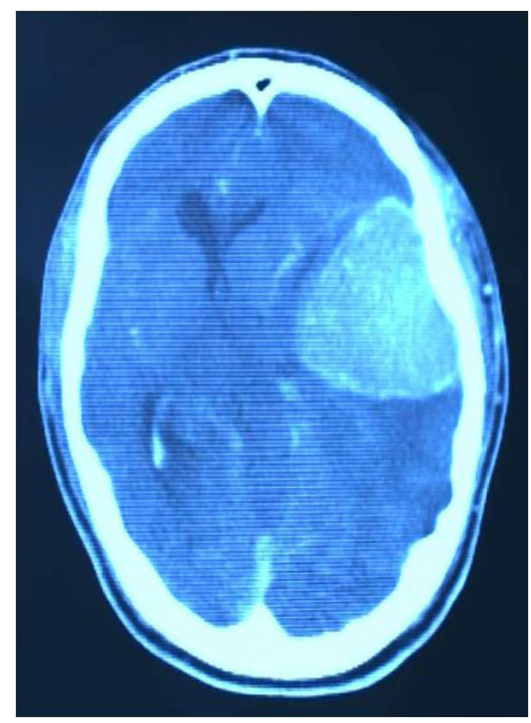

Figura 1. Meningioma. TAC contrastada. Corte axial que muestra una lesión hiperdensa en la región fronto-parietal del hemisferio cerebral izquierdo.

Caso Clínico No. 2.- Paciente del sexo masculino de 54 años de edad llevado a un hospital general por padecimiento de 6 semanas de evolución, caracterizado por la aparición progresiva de las siguientes manifestaciones clínicas: Crisis convulsivas precedidas de adormecimiento del hemicuerpo izquierdo, después perdía el estado de vigilia y caía al suelo con sacudidas de las cuatro extremidades; cefalalgia y visión borrosa; falta de fuerza en las extremidades izquierdas y dificultades para expresar el lenguaje oral; el paciente era fumador crónico. A la exploración neurológica se encontró: Nervios Craneales: Hemianopsia homónima izquierda y edema papilar bilateral, hipoestesia en la mitad izquierda de la cara al tacto y al dolor, parálisis facial izquierda a los movimientos voluntarios y afectivos, no había nistagmos optocinético a la izquierda y al mostrar la lengua se desviaba hacia la izquierda. Sensibilidad: Había anestesia al dolor, frío, calor, vibración y sentido de posición en las extremidades izquierdas. Movilidad Voluntaria: paciente diestro, sin movimientos anormales en el momento de la exploración, con paresia del $60 \%$ en las extremidades izquierdas. Coordinación Muscular: Sin alteraciones. Reflejos, Tono, Trofismo y Ambulación: Hiperreflexia izquierda, signos de Babinski y Hoffmann del mismo lado, el miembro superior izquierdo estaba flexionado sobre el tórax, paciente adelgazado que presentaba ambulación hemiparética. Funciones Cerebrales Superiores: Paciente 
despierto, con afasia de expresión y amnesia para hechos recientemente ocurridos (Figura 2). Diagnóstico evolutivo: Padecimiento subagudo. Diagnóstico anatomotopográfico: Afecta la cavidad intracraneana, supratentorial, afectando el hemisferio cerebral derecho, los lóbulos temporal, frontal y parietal. Diagnóstico sindromático: Se integran los siguientes síndromes: Hipertensión endocraneana con cefalalgia, visión borrosa y edema papilar; Síndrome epiléptico con crisis convulsivas focales secundariamente generalizadas; Síndrome de afección sensitiva con hipoestesia en la hemicara izquierda y anestesia en las extremidades izquierdas; Síndrome de afección motora con parálisis facial izquierda y paresia de las extremidades izquierdas así como hiperreflexia, signos de Babinski y Hoffmann y ambulación hemiparética del mismo lado; Síndrome de funciones cerebrales superiores con afasia de expresión y amnesia reciente. Diagnóstico etiológico: Probable glioblastoma multiforme ${ }^{15,20}$.

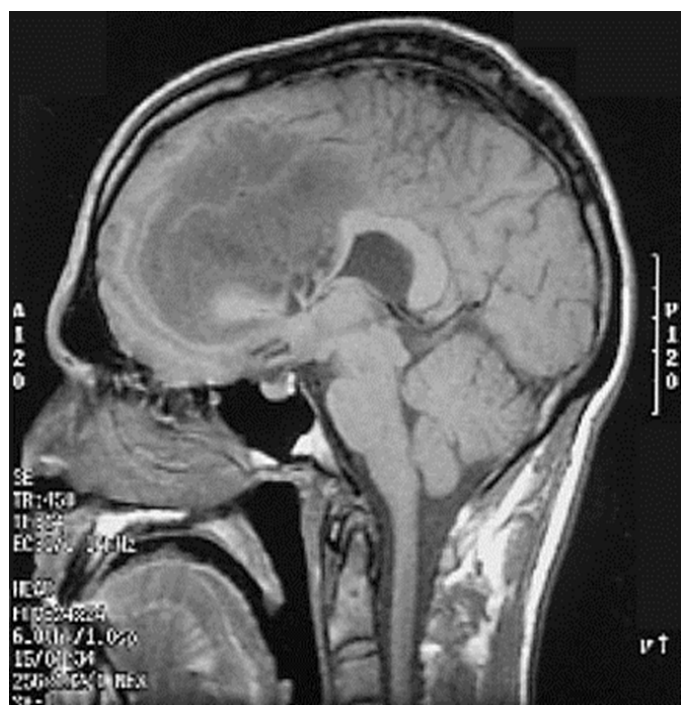

Figura 2. Astrocitoma de alto grado. IRM. Corte sagital en secuencia T1 mostrando imagen hipointensa en el lóbulo frontal derecho.

Caso Clínico No. 3.- Paciente del sexo femenino de 40 años de edad traída a la consulta de medicina general por padecimiento de un año de evolución, caracterizado por la aparición progresiva de las siguientes manifestaciones clínicas: Inició con amenorrea y galactorrea, luego aparecieron alteraciones visuales del tipo disminución de la vista a los lados y 
últimamente ceguera del ojo izquierdo, además de cefalalgia; paciente sin antecedentes de importancia. A la exploración neurológica: Nervios Craneales: Había ceguera del ojo izquierdo con atrofia de la papila óptica de ese lado, además, hemianopsia temporal del ojo derecho con edema papilar de ese lado; resto de la exploración neurológica sin alteraciones (Figura 3). Diagnóstico evolutivo: padecimiento crónico. Diagnóstico anatomotopográfico: Afecta la cavidad intracraneana, supratentorial, en el piso anterior de la base del cráneo. Diagnóstico sindromático: Se integran los siguientes síndromes: Síndrome de afección a las vías visuales con ceguera del ojo izquierdo y hemianopsia temporal del derecho; Hipertensión endocraneana con cefalalgia, visión borrosa y edema papilar. Diagnóstico etiológico: probable macroadenoma hipofisiario $8,16,17,20$.

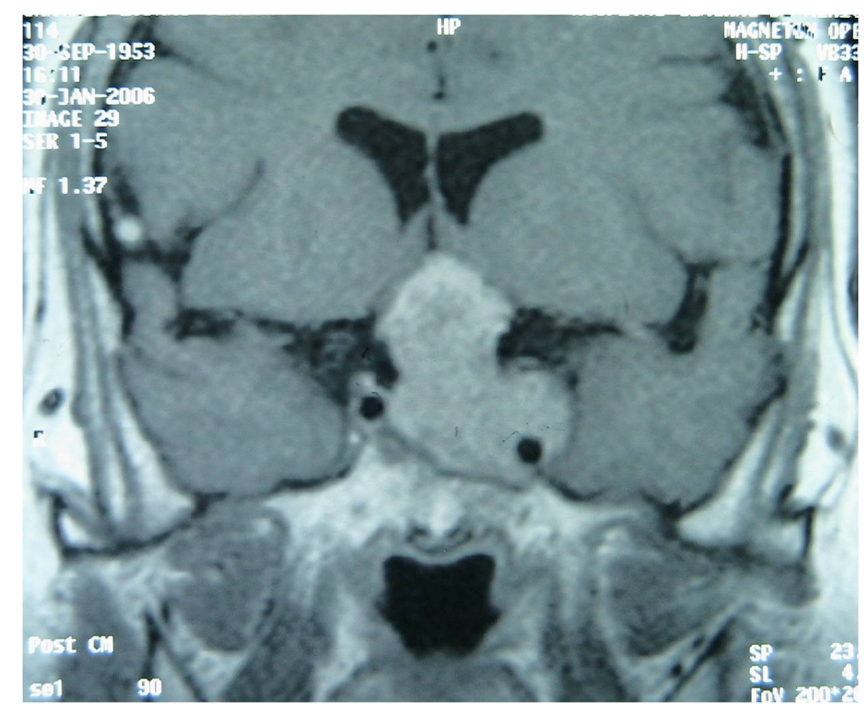

Figura 3. Macroadenoma Hipofisiario. IRM. Corte coronal que muestra una lesión hiperintensa con medio de contraste, encima de la silla turca.

Caso Clínico No. 4.- Paciente del sexo femenino de 60 años de edad traída a la consulta de medicina general por padecimiento de 4 años de evolución, caracterizado por la aparición progresiva de las siguientes manifestaciones clínicas: inició con hipoacusia derecha agregándose en los últimos meses sensación de mareo al caminar, visión borrosa y cefalalgia; paciente sin antecedentes de importancia. A la exploración neurológica: Nervios Craneales: había edema papilar bilateral y veía borroso a partir de 3 metros de 
distancia; había hipoestesia al tacto, al dolor y a la temperatura en la mitad derecha de la cara; existía hipoacusia derecha y al estar con la mirada al frente había nistagmus a la derecha. Sensibilidad del Resto del Cuerpo: Sin alteraciones. Movilidad Voluntaria: Sin alteraciones. Coordinación Muscular: Sin alteraciones. Estación de pie y Ambulación: Se desviaba a la derecha (Figura 4). Diagnóstico evolutivo: Padecimiento crónico. Diagnóstico anatomotopográfico: Afecta la cavidad intracraneana, infratentorial, en el piso posterior de la base del cráneo, en el ángulo ponto-cerebeloso derecho. Diagnóstico sindromático: Se integran los siguientes síndromes: Hipertensión endocraneana con cefalalgia, visión borrosa y edema papilar; Síndrome del ángulo pontocerebeloso derecho con hipoacusia e hipoestesia de la hemicara derecha, nistagmus y laterodesviación a la derecha. Diagnóstico etiológico: probable schwannoma del VIII $\operatorname{par}^{18,20}$.

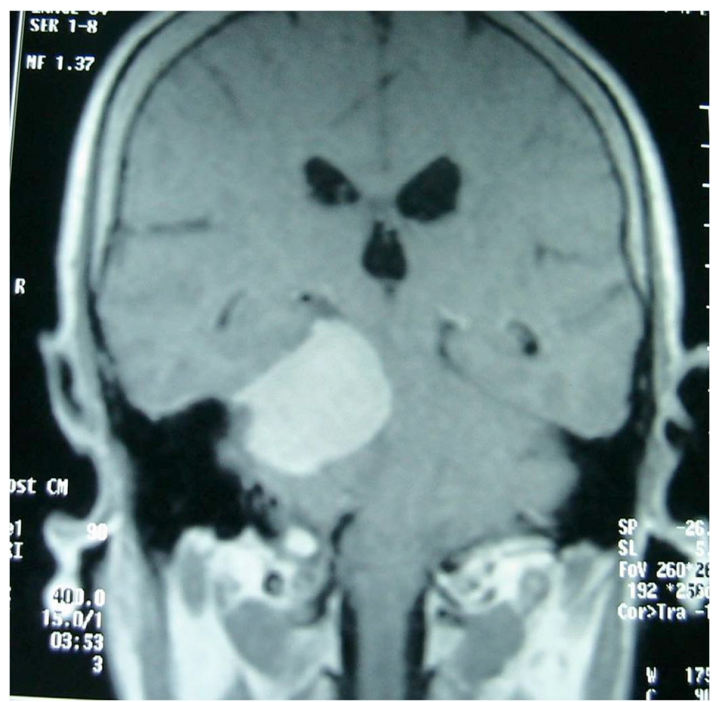

Figura 4. Schwannoma del VIII par. IRM. Corte coronal que muestra una lesión hiperintensa en T1, a nivel del ángulo ponto-cerebeloso derecho.

\section{Complicaciones}

En este rubro se quiere hacer énfasis, sobre todo, en el tratamiento, pero se pueden hacer alusión a la evolución natural de la enfermedad. Cuando un tumor ha crecido en la cavidad intracraneal, una de los principales problemas es el de una hipertensión 


\section{Principales problemas de Salud Pública en México}

endocraneana, como se ha comentado con cefalalgia intensa, vómito en proyectil, deterioro importante y súbito del estado de vigilia, puesto que la masa está ocupando un espacio que le corresponde al parénquima encefálico, los vasos o al líquido cefalorraquídeo, en lo que se conoce como ley de Monro-Kelly. El paciente puede deteriorar y morir si no se ayuda a mejorar su presión intracraneal, por lo que es muy importante saber esto. Hay que realizar una cirugía descompresiva, o resectiva dependiendo el caso. También habría que estar pendiente que el paciente no tenga hidrocefalia por acumulación del líquido cefalorraquídeo que no puede circular adecuadamente, por lo que debe realizarse una derivación ventriculoperitoneal. Las medidas antiedema deben aumentarse como ingresar a hospitalización o terapia intensiva, incrementar los esteroides, el uso de manitol, de sedación o intubación para barrer $\mathrm{CO} 2$ mediante ventilador. Los pacientes pueden morir al tener complicaciones como son las herniaciones: en el cíngulo, en el uncus o las amígdalas cerebelosas en el agujero magno ${ }^{15}$.

Con respecto a las complicaciones del tratamiento depende de la modalidad usada: las cirugías tienen el riesgo anestésico, sangrado transoperatorio, infecciones, fístulas, estancia intrahospitalaria prolongada y de muerte. En cambio, en las modalidades a cargo de radioterapia convencional, radiocirugía, radioterapia modulada y cuchillo cibernético estas complicaciones se minimizan, pero existe la posibilidad de necrosis, no solo del tumor si no de áreas aledañas, creación de nuevos tumores diferentes al tratado, y edema cerebral tardío.

Para tomar en cuenta el pronóstico, es muy importante saber el tipo de tumor del que se trata, por todas las implicaciones que con lleva en el tratamiento y en el pronóstico. Un tumor benigno tendrá siempre un pronóstico favorable, con excepción como se ha recalcado que no se encuentre en áreas de vitalidad como el tallo o el diencéfalo. La mortalidad es muy buena a 15 años, por arriba del 80\%. Los astrocitomas grado I y II pueden tener también una buena sobrevida a largo plazo, por arriba del 75\% a 10 años. En cambio los astrocitomas grados III y IV la sobrevida se ensombrece mucho a los 5 años, con un 30 a $40 \%$. Por último, en un glioblastoma multiforme la sobrevida va de seis meses a un año y medio, hacia los 5 años la sobrevida es casi nula, aunque se han reportado casos. Mientras más sea maligno el tumor la sobrevida será muy cercana a lo ya establecido para el glioblastoma como en el caso de meningiomas o schwannomas malignos ${ }^{8}$. 


\section{Diagnóstico}

La manera de realizar el diagnóstico preciso de un tumor intracraneal es a partir de:

1) El estudio clínico, ya descrito.

2) El estudio imaginológico.

3) La biopsia por estereotaxia.

4) La biopsia por trépano o craneotomía.

5) La biopsia secundaria a resección.

El estudio imaginológico ha ido refinándose en el transcurso de los últimos años, haciendo que la certeza diagnóstica sea cada vez mayor, más adelante se ampliará al respecto de este tema. Con respecto a las biopsias: se pueden hacer de tres formas: una es resecando completamente la lesión y obteniendo el resultado al tratar de quitar toda la pieza y mandarla al servicio de Patología para corroborar el diagnóstico; la segunda manera es usar una trefina o una craneotomía pequeña, puede o no ser guiada por neuronavegación, para obtener el tejido de manera muy precisa y solo tomar una parte de tumor. La tercera forma es todavía más fina en cuanto que se usan coordenadas cartesianas para tratar de extraer un pedazo de tumor, a través de un procedimiento estereotáxico, y no la resección del mismo, ya que al encontrarse en sitios inaccesibles ponen en riesgo la vida del paciente.

Uno de las áreas donde más se ha avanzado de una manera vertiginosa ha sido el estudio de imaginología en las neurociencias, siendo que actualmente se cuentan con varios métodos que se complementan unos con otros para hacer diagnósticos más oportunos y certeros. Todavía hace dos décadas la utilidad de los rayos $X$ era primordial en el protocolo de los pacientes en los cuales se pensaba en tumores, actualmentelas placas simples anteroposterior y laterales han caído en desuso para hacer diagnósticos de tumores del sistema nervioso y de sus meninges. Hay algunos detalles anatómicos que todavía pueden ser tomados en consideración: se puede decir que en las placas simples de cráneo dependiendo de algunos tumores pueden verse las calcificaciones en el caso de algunos meningiomas o en oligodendrogliomas sobretodo en la región frontal. El ensanchamiento de la silla turca en 
las placas antero-posterior y lateral puede suponer tumores de esta área como en el caso de los adenomas hipofisiarios o craneofaringiomas, Las destrucción o erosión de las tablas corticales interna o hasta la externa pueden ser debido a tumores que rebasan los límites y que degradan el hueso como en el caso nuevamente de los meningiomas. Con anterioridad se inyectaba aire o medio de contraste en las carótidas y mediante el desplazamiento de las arterias, el llenado anómalo de los vasos o bien la amputación de los mismos se podía inferir que un tumor se encontraba en el parénquima, pero hoy estos estudios francamente han caído en desuso.

Desde mediados de los 70s, con la tomografía axial computarizada (TAC) simple y contrastada de cráneo, y a partir de mediados de los 80, con la imagen de resonancia magnética (IRM) de cráneo es posible identificar con mayor oportunidad y exactitud la localización y extensión de los tumores del sistema nervioso ${ }^{14,20}$.

En la actualidad para el estudio de los tumores existen dos formas de hacerlo: uno, con los métodos anatómicos en donde la tomografía computada y la resonancia magnética; dos, con los métodos funcionales a cargo del PET y SPECT. Los estudios no solo son útiles por sí mismos, sino que son altamente complementarios. La tomografía fue inicialmente axial, es decir, pasando por una línea que pasaba por el nasión, conducto auditivo externo hasta el inion; pero hoy también se hacen cortes de manera coronal y sagital. El gran aporte de la tomografía fue que no solo se pudo observar el cráneo como se veía en las placas simples de rayos $X$, sino que por primera vez se pudo observar el parénquima cerebral con sus vasos y sus cubiertas. Así los tumores parenquimatosos como los astrocitomas por primera vez fueron captados y pudieron hacerse el diagnóstico primero en una fase simple como imágenes hipodensas, para luego ser vistas de mejor forma con medio de contraste en imágenes hiperdensas al teñirse con el medio de contraste. Evidentemente un tumor benigno se teñiría poco al tener pocos vasos y a medida que la malignidad aumentaba iba también aumentando el grado de vasos involucrados. También se pudo discernir entre tumores de la vaina como los schwannomas del ángulo ponto-cerebeloso, que no tenían mucho a diferencia de los meningiomas que independientemente de su posición en el cráneo, con el medio de contraste generalmente se observan hiperdensos ${ }^{22}$. En el estudio de TAC las neoplasias del sistema nervioso se comportan como lesiones hipodensas en relación al parénquima cerebral normal que se realzan con la administración de medio de contraste. 


\section{Neoplasias del sistema nervioso}

Cuando la resonancia magnética llegó a mediados de los ochenta, se pensó que substituiría a la tomografía, ya que la resolución de los detalles del parénquima cerebral era mucho mayor, sin embargo no fue así. En la resonancia magnética no se puede ver adecuadamente el hueso, por lo que los tumores que destruyen el hueso o que lo infiltran pueden no apreciarse de manera adecuada, aunque depende también del tamaño del tumor. En cambio las minucias que se pueden ver con la resonancia, sobre todo en las estructuras subcorticales, como los ganglios basales o bien en la fosa posterior son muy importantes. La tomografía no puede tener tanto detalle en estos sitios, y sin embargo para hacer inicialmente una planeación para hacer una biopsia por estereotaxia es más fácil hacerlo en una tomografía que en una resonancia magnética. Por lo que realmente ambos estudios son muy complementarios.

En la IRM, los meningiomas son lesiones isointensos que se vuelven hiperintensos con el medio de contraste; los astrocitomas se aprecian como lesiones iso o hipointensas en T1 y homogéneamente hiperintensas en T2; los astrocitomas anaplásicos de intensidad heterogénea en T1 y T2; el glioblastoma multiforme es una lesión de intensidad mixta con necrosis y quistes en T1, con edema intenso en T2 (Figuras 2 y 3); los adenomas hipofisiarios son isointensos o heterogéneos por necrosis y sangrado que se vuelven hiperintensos con el medio de contraste (Figura 4); el meduloblastoma se visualiza como una masa cerebelosa, vermiana o hemisférica que toma contraste y que "brilla" en la secuencia T2 y que no presenta calcificaciones; los schwannomas se presentan como lesiones hipointensas en T1 e hiperintensas en T2 (Figura 5) y captan fácilmente el medio de contraste.,11,22,23.

Los otros estudios son los funcionales, en donde antes de realizarlos debe de inicio hacerse un estudio anatómico para tener una idea del tipo de tumor. Tal es el caso del PET y del SPECT. Lo que brindan los estudio funcionales es que tanto el tumor está activo, es decir, con el uso de los radioisótopos se desea describir cuanta energía es captada por las células tumorales: evidentemente los tumores más agresivos tendrán una mayor captación que aquellos tumores que son más benignos, se pueden tener controles en el transcurso del tiempo y ver la expansión o la remisión tumoral mediante su actividad celular ${ }^{24}$.

Existe también otra modalidad que es el estudio de angio-resonancia o angio-tomografía en el que se puede ver de manera tridimensional si el tumor tiene además más componentes con la cantidad de vasos o descartar patología anexa a la tumoral como en el caso de malformaciones vasculares o aneurismas cerebrales. 


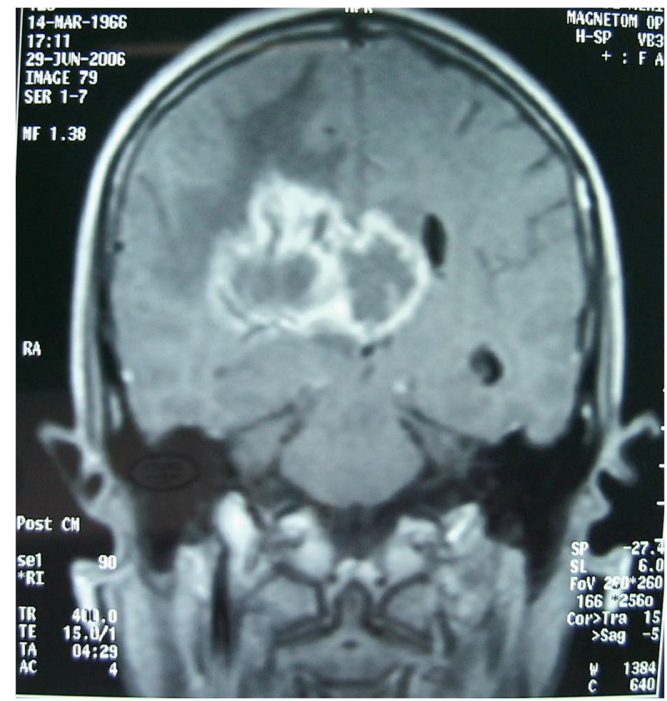

Figura 5. Glioblastoma Multiforme. IRM. Corte coronal que muestra intensidad mixta y edema en T1 situada en el lóbulo parietal derecho.

La integración de los elementos clínicos con los elementos proporcionados por los estudios de imagen permite establecer un diagnóstico correcto en la gran mayoría de los casos.

Para efectuar el diagnóstico diferencias, normalmente los diagnósticos están encaminados por dos situaciones: la estirpe histológica y el sitio en donde se encuentra el tumor. Como se comentaba previamente, se puede tener un tumor benigno histológicamente, pero que se comporta como "maligno" por el sitio donde está, ya sea en el hipotálamo o en el tallo cerebral, tal es el caso de meningiomas intraventriculares o astrocitomas del tallo cerebral. Por el contrario, se puede tener un tumor altamente agresivo que se encuentre en un sitio que sea fácilmente accesible desde el punto de vista neuroquirúrgico, como podría ser un rabdiomiosarcoma temporal con infiltración a cerebro, o un glioblastoma multiforme. Es muy importante conocer bien ambos aspectos para hacer diagnósticos diferenciales certeros.

Los estudios de neuroimagen brindan actualmente un alto grado de certeza al respecto del tipo de tumor que se puede tener, solamente mediante una biopsia "a cielo abierto" con la resección tumoral si se puede o mediante la obtención por cirugía por estereotaxia podrá establecerse con certeza el tipo de tumor de que se trate. 


\section{Neoplasias del sistema nervioso}

Otro aspecto importante a considerar es la edad del paciente: normalmente los pacientes pediátricos tienen el $80 \%$ de los tumores por debajo del tentorio y solo el $20 \%$ por arriba de éste, y viceversa en el caso de los adultos ${ }^{15}$. Si acude al consultorio un paciente pediátrico las posibilidades de pensar en un tumor son por lo tanto más enfocadas hacia el tallo cerebral y en la fosa posterior más que en los hemisferios cerebrales. Se debe pensar en un meduloblastoma, un ependimoma, o en un astrocitoma pilocítico más que un meningioma. En cambio en un adulto, lo primero que se debe pensar es en un glioblastoma multiforme o un astrocitoma en un tumor de hemisferios. Sería un absurdo pensar en un meningioma en niños, por lo menos de manera inicial, ya que también hay sus excepciones. Lo mismo sería muy difícil pensar en un meduloblastoma en un paciente anciano con una neoplasia en fosa posterior.

Por otro lado, la espectroscopía por resonancia magnética aporta datos bioquímicos importantes en el metabolismo cerebral (creatina, N-acetil-aspartato, lactato, colina, lípidos, etc.) que se correlacionan con diversas características histológicas de los astrocitomas cerebrales difusos como el grado de celularidad, la infiltración del parénquima sano, la diferenciación astrocitaria o la presencia de necrosis; por ello, este estudio es útil para el diagnóstico diferencial de los astrocitomas y procesos expansivos intracraneales como meningiomas, abscesos cerebrales y metástasis ${ }^{1,25}$.

En términos generales los tumores benignos no tienen estadificación. Es así que se habla de tumores de la vaina como los schwannomas, los quistes coloides del tercer ventrículo, los craneofaringiomas con sus diferentes componentes y los meningiomas. Realmente se clasifican como subtipos dependiendo el tumor y la estirpe, pero no se estadifican (ver tabla de la Clasificación Anatomopatológica). En cambio, los tumores del sistema nervioso central que son malignos, se puede decir que dependerá de sus características histológicas. La estadificación está más bien enfocada hacia los astrocitomas que hacia el resto de los tumores. Una estadificación baja, o también los denominados astrocitomas de bajo grado (grado I-II) son aquellos establecidos con características muy peculiares, son tumores con poca celularidad, sus núcleos se encuentran bien conformados y teñidos adecuadamente, la morfología celular está bien delimitada y sin formas irregulares y no hay vasos. Una estadificación alta, o grados (II-IV) va incrementándose el pleomorfismo, irregularidad de los bordes, núcleos picnóticos e hiperdensos, atipias celulares y se incrementa la cantidad de vasos. Por último y por desgracia el más común de los tumores, el glioblastoma multiforme contiene además de todos estos elementos, la presencia de necrosis en su interior, y como se comentaba previamente, células dispuestas en pseudo-empalizada. 


\section{Principales problemas de Salud Pública en México}

Los mismos meningiomas o los shwannomas pueden tener una contraparte maligna que también son altamente agresivos, y que dependerá por lo tanto de la cantidad de vasos que contengan en su interior con las características también ya mencionadas para el resto de los tumores malignos lo que le determinan su malignidad. Estos tumores crecen rápidamente y en la cirugía son muy sangrantes ${ }^{12,13,15}$.

\section{Terapéutica}

El tratamiento de los tumores sigue siendo hasta la actualidad un tema importante de discusión y de avance en la ciencia. Existen múltiples tratamientos para las neoplasias desde una actitud meramente conservadora y expectante hasta la resección radical del tumor, con el complemento con radioterapia o quimioterapia. ¿De qué dependen los tratamientos? De múltiples factores: la edad del paciente, de su estado y calidad de vida ligado a su Karnofsky, de los recursos económicos que tenga el paciente y los familiares, la esperanza de vida, el tipo de tumor, las opciones que sean discutidas por el médico y el paciente, por la confianza del paciente con su médico y por lo tanto de la decisión personal en cada caso.

Entonces las opciones son:

a) Actitud conservadora: De manera solo observadora debe seguirse al paciente sin hacer mayor cambio más que actuar en caso que el paciente se deteriore o que empiece a focalizar, es decir, comience con algún déficit neurológico. Los pacientes pueden recibir un tratamiento a base de medicamentos como esteroides o diuréticos para evitar edema cerebral, analgésicos en caso de que hay dolor de cabeza, anticonvulsivantes en caso de que hay crisis epilépticas o neuromoduladores para tratamiento de dolor neuropático o depresión. Este es el caso de una persona octa o nonagenaria que tiene un meningioma y que no le causa mayor problema.

b) Cirugía por estereotaxia: Como se comentaba en el apartado correspondiente, mediante un aparato que identifica con coordenadas espaciales ( $X, Y$ y Z) el tumor, se realiza una biopsia para identificar el tipo de tumor, sabiendo de antemano que no se resecará, sino que, a partir de aquí se hará otra decisión hacia la quimioterapia o radioterapia (Figura 6). Un ejemplo es la toma en paciente con un tumor en tallo cerebral en el que es imposible resecarlo ${ }^{26}$. 
c) Cirugía por craneotomía convencional: Normalmente este es el tipo de decisión en la mayoría de los casos en el que se decide tratar de quitar el tumor o de resecarlo lo más posible y luego complementar el tratamiento (Figura 7).

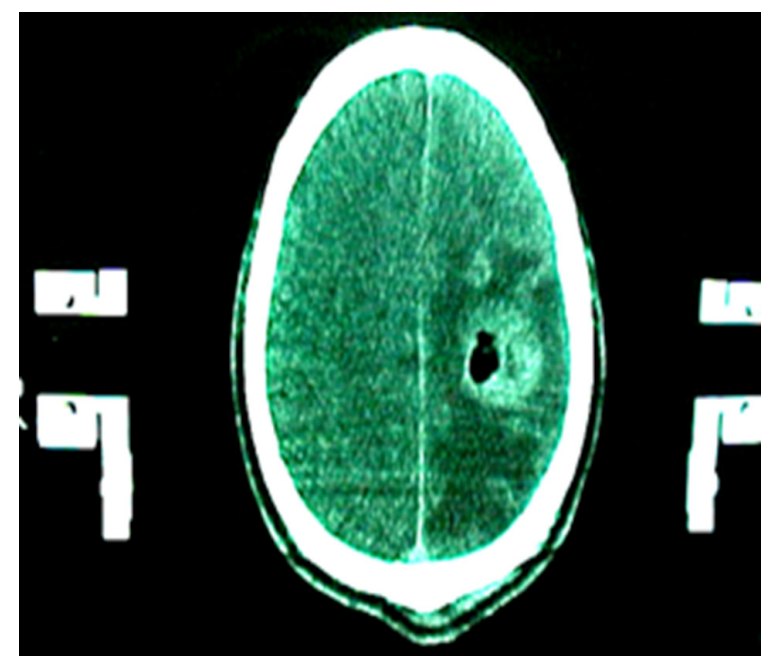

Figura 6. Cirugía por Estereotaxia. Imagen de tomografía de un paciente a quien se le ha realizado una biopsia por esteriotaxia en el área motora del lóbulo frontal izquierdo.

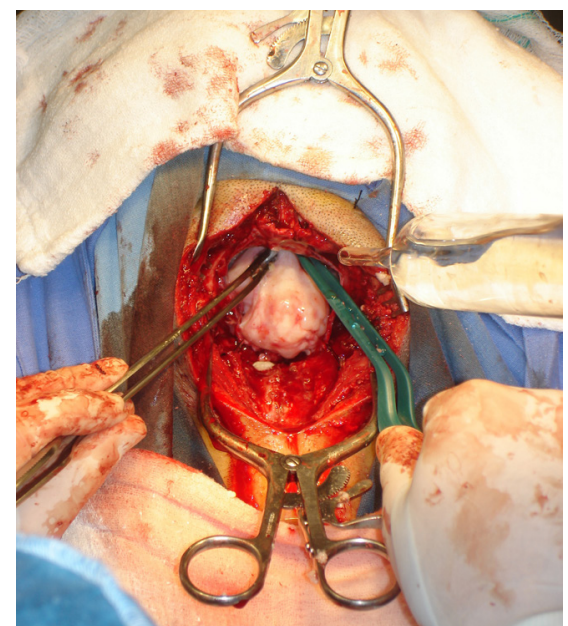

Figura 7. Cirugía por Craneotomía Convencional. Extracción de un quiste dermoide mediante abordaje quirúrgico de la fosa posterior. 
d) Cirugía por trefina o craneotomía reducida: A través de una pequeña incisión se trata de obtener el tumor sin abrir todo el cráneo. Se puede utilizar un neuronavegador o bien usar un endoscopio para tratar de resecar el tumor.

e) Radioterapia convencional. Una vez que al paciente se le haya hecho una biopsia por estereotaxia o una resección parcial o completa, se procede a irradiar el sitio del tumor para evitar que éste pueda seguir creciendo. Hay tumores que son altamente radiosensibles, otros moderados y otros que prácticamente no lo son. Los germinomas son tumores que una vez hecho el diagnóstico se les irradia y puede remitir completamente, los meningiomas pueden llegar a serlo, los glioblastomas multiformes no lo son, lo mismo que los astrocitomas de alto grado, y en medio quedarían el resto de los tumores que pueden ser medianamente sensibles a la respuesta. Normalmente se dan una serie de sesiones entre 900 y 1200 greys en 28 a 30 días y pueden posteriormente recibir un refuerzo en caso necesario, y siempre con la ayuda profesional del oncólogo.

e) Quimioterapia: Los pacientes pueden también recibir quimioterapia, es decir la aplicación de fármacos ya sea por vía tópica en el cerebro como el caso de la temozolamida, que es el único que hasta el momento ha demostrado que tiene utilidad en mejorar por lo menos un poco la sobrevida de los pacientes, sobretodo de glioblastoma multiforme. O bien aplicarse de manera sistémica como pudiera ser el caso de los linfomas, como tumor primario del sistema nervioso o secundario en el caso del SIDA.

f) Radiocirugía. Si algo ha cambiado el tratamiento de los tumores en los últimos años es el empleo de los rayos gamma o electrones a los tumores. En las últimas décadas este tratamiento ha venido a cambiar radicalmente la forma cómo se veía la cirugía tradicional, ya que a estos pacientes no se les opera, en el sentido de que se abre el cráneo. Se aplica una alta dosis de rayos o electrones al sitio del tumor: entre 15 hasta 60 greys en una sola sesión para desintegrar el tumor. El tumor se va disolviendo o en su defecto deja de crecer, pero lo hace a largo plazo, meses a años, y no de manera inmediata, actuándose sobre el DNA de células tumorales, evitando dañar el resto de las estructuras cerebrales. Esto se puede lograr mediante un cuchillo gamma (en inglés gamma knife) o un acelerador lineal (LINAC). Un caso ideal es la aplicación sobre un meningioma o un schwnnoma del ángulo pontocerebeloso ${ }^{26}$. 


\section{Neoplasias del sistema nervioso}

g) Radioterapia modulada y conformacional. En una segunda generación se ha llegado a fraccionar las dosis para tener una mejor distribución de las curvas de la radiación sobre el tumor, y se han aplicado además ciertos marcos movibles que delimitan tridimensionalmente el tumor teniendo una mejor ubicación espacial y volumétrica del mismo. En este caso pudiera ser un meningioma o un schwannoma con dimensiones más grandes (por arriba de tres $\mathrm{cm}^{2}$ ).

h) Cuchillo cibernético (ciberknife). Basados en los otros dos modelos, actualmente existe un brazo con irradiación que es mucho más dinámico que sus predecesores. Puede ir hacia tumores más basales y de más difícil acceso. La experiencia mundial al respecto está en vías de precisar si es mejor que los otros $\operatorname{dos}^{27}$.

Sin embargo, el criterio que debe prevalecer es que, cuando un tumor es resecable, la primera opción es la cirugía y luego complementar con alguna de las otras modalidades.

\section{Medidas de prevención}

Si bien, más del 30\% de las defunciones por cáncer podrían evitarse modificando o evitando los principales factores de riesgo, tales como'

- el consumo de tabaco;

- el exceso de peso o la obesidad;

- manejo inadecuado del estrés crónico;

- las dietas malsanas con un consumo frecuente de embutidos y un consumo insuficiente de frutas y hortalizas;

- la inactividad física;

- el consumo exagerado de bebidas alcohólicas;

- exposición a ondas electromagnéticas de los teléfonos móviles por tiempo prolongado;

- la contaminación del aire de las ciudades. 


\section{Principales problemas de Salud Pública en México}

Sin embargo, no existe a la fecha algún método efectivo para tratar de evitar los tumores cerebrales. El problema es multifactorial, por lo que depende de la combinación entre ambiente, genes y persona. No hay dieta que evite la producción de tumores, pero al parecer la ingesta de antioxidante puede disminuir el riesgo. Otro hecho controvertido es el uso de los teléfonos celulares que no se ha demostrado que su uso prolongado de manera directa sea la causa del tumor, y es un asunto delicado ya que es un negocio muy lucrativo en la que hay de por medio mucho dinero para establecer que se deban limitar o declinar su uso, además de que han facilitado muchas de las actividades de la vida diaria contemporánea actual. Tampoco el que las personas hagan deporte evita la aparición de tumores y no se ha ligado de manera concreta a tumores cerebrales con genes exclusivos del sistema nervioso.

\section{Referencias}

1. Santos-Franco JA, Mercado R, Ortíz-Velázquez I, Revuelta R, Luis-García J. Tumores cerebrales. Archivos de Neurociencias 2003; 8(3):139-150.

2. Lindsay KW, Bone I, Callander R. Neurología y neurocirugía ilustrada. $2^{\underline{a}}$ ed. Madrid: Edigrafos; 1993. p. 292-342.

3. Dirección General de Información y Evaluación del Desempeño de la Secretaría de Salud. Estadística de Egresos Hospitalarios de la Secretaría de Salud, 2000. Salud Pública de México 2001; 43(5):494-510.

4. Organización Mundial de la Salud. Cáncer. Nota descriptiva No. 297. Revisado el 7 de enero de 2011. Disponible en: http://www.who.int/mediacentre/factsheets/fs297/es/ index.html.

5. Sistema Nacional de Vigilancia Epidemiológica, Secretaría de Salud. Estadísticas a propósito del día mundial contra el cáncer. Epidemiología 2009; 26(5):1-3.

6. Gelabert González M, Serramito-García R. Meningiomas intracraneales: I. Epidemiología, etiología, patogénesis y factores de riesgo. Revista de Neurología 2011; 53(3):165-172.

7. Central Brain Tumor Registry of the United States. Documento que reporta los tumores registrados entre 2004 y 2008. Revisado el 23 de marzo del 2012. Disponible en: http://www.cbtrus.org 


\section{Neoplasias del sistema nervioso}

8. Pascual-Piazuelo MC, Serrano-Ponz M, Bestué-Cardiel M, Montori-Lasilla M. Estudio epidemiológico de astrocitomas en Aragón y La Rioja. Revista de Neurología 2002; 34(8):799-800.

9. Zuren-Matutes F, De Jong-Díaz LF, Izquierdo-Presmanes P. Meningiomas intracraleales. Aspectos clínico-quirúrgicos. Nuestra Experiencia. Revista Mexicana de Neurociencias 2004; 5(4):308-311.

10. Secretaría de Salud. Diagnóstico, tratamiento inicial y prevención de los tumores cerebrales infantiles en el primer y segundo nivel de atención. Guía Práctica Clínica Centro Nacional de Excelencia Tecnológica en Salud. México. 2008. 50 páginas.

11. Figols-Ladrón de Guevara J, Lafuente-Sánchez JV. El meduloblastoma. Revista de Neurología. 2006; 43(4): 213-317.

12. Stricker TP, Kumar V. Neoplasias. Cap. 7. En: Kumar V, Abbas AK, Fausto N, Aster JC (eds.). Patología estructural y funcional de Robbins y Cotran. Barcelona: Elsevier; 2010. p. 259-330.

13. Kernoham JW, Mabon RF, Svien HJ, Adson AW. A simplified classification of the gliomas. Proc Mayo Clin. 1949; 24:71-75.

14. Celis-López MA, Moreno-Jiménez S, Reyes-Moreno I. Tumores Primarios del Sistema Nervioso Central. Cap. 29. En: Granados-García M, Herrera Gómez A. Manual de Oncología. Procedimientos médico-quirúrgicos. México: INCAM-McGraw Hill; 2010. p. 355-369.

15. Frosch MP, Anthony DC, De Girolami U. Tumores del sistema nervioso central. Cap. 28. En: Kumar V, Abbas AK, Fausto N, Aster JC (eds.). Patología estructural y funcional de Robbins y Cotran. Barcelona, España: Elsevier; 2010. p. 1330-1343

16. Cásares M, Márquez M, Sánchez-Ramos M. Alteraciones neuroftalmológicas en pacientes con adenomas de hipófisis y aracnoidocele intaselar. Revista de Neurología 1998; 26:954-956.

17. Maitra A. Adenomas hipofisiarios del sistema endócrino. Cap. 24. En: Kumar V, Abbas AK, Fausto N, Aster JC (ed.). Patología estructural y funcional de Robbins y Cotran. Barcelona, España: Elsevier; 2010. p. 1100-1105.

18. López-Flores G, Cruz-García O, Fernández-Melo R, Castillo-Hernández JE, ÁlvarezRodríguez A, Bouza W, et al. Abordaje combinado de la base del cráneo en lesiones tumorales y vasculares. Revista Mexicana de Neurociencias 2003; 4(6):402-411. 


\section{Principales problemas de Salud Pública en México}

19. Contreras-González N, Medina Villaseñor EA. Propedéutica médica del enfermo con cáncer. Cap.1. En: Medina-Villaseñor EA, Martínez-Macías R. Fundamentos de Oncología. México: FES Zaragoza, UNAM y Consejo Mexicano de Oncología A.C.; 2009. p. 1-6.

20. Contreras-González N, Trejo-López JA. Manual para la exploración neurológica y las funciones cerebrales superiores. 3 ed. México: FES Zaragoza, UNAM; 2010. 231 páginas.

21. Sosa-Rivera M, Quintas-Santana M. Caracterización imaginológica por tomografía axial computarizada de las neoplasias intracraneales primarias. MediCiego. 2009; 15(2):10-19.

22. Gelabert González M, Serramito-García R. Meningiomas intracraneales: II. Diagnóstico y tratamiento. Revista de Neurología. 2011; 53(4):226-232.

23. Patel N, Wilkinson J, Gianaris N, Cohen-Gadol AA. Diagnostic and surgical challenges in resection of cerebellar angle tumors and acoustic neuromas. Surg Neurol Int 2012; $3(2): 17-34$.

24. Cornelius JF, Josef Langen K, Stoffels G, Hänggi D, Sabel M, Jakob Steiger H. Positron emission tomography imaging of meningioma in clinical practice: review of literature and future directions. Neurosurgery. 2012; 70(4):1033-1042.

25. Méndez-Cendón JC. Aplicaciones clínicas de la espectroscopía de protón por resonancia magnética in vivo en el estudio de los astrocitomas: estado actual. Neurocirugía. 2004; 15: 258-269.

26. Lefranc M, Reyns N, Blond S. Place of stereotactic techniques in the modern management of lateral ventricle tumors. Stereotactic biopsies and radiosurgery. Neurochirurgie. 2011; 57(4-6):199-205.

27. Levivier M, Gevaert T, Negretti L. Gammaknife, cyberknife, tomotherapy: gadgets or useful tools? Curr Opin Neurol. 2011; 24(6):616-625. 


\section{Introducción}

A pesar de que la rabia en México posee una tendencia descendente debido a las medidas de prevención que ha aplicado en Sector Salud y SAGARPA, sigue siendo un problema de Salud Pública, ya que es una enfermedad que afecta a los animales y a los seres humanos, por convivir con la fauna silvestre o doméstica, ya sea a nivel rural o urbano.

La finalidad de este capítulo es dar un panorama general respecto a la situación actual de la rabia, así como el de capacitar desde el punto de vista operativo los lineamientos generales, que el profesional de la salud deberá de realizar ante un caso de rabia en humanos y/o en animales; además de instruir en la toma de decisiones para evitar muertes por este padecimiento a través de medidas sanitarias de control, prevención, detección y tratamiento así como el cerco epidemiológico.

\section{Concepto}

Es una encefalitis infecciosa zoonótica aguda y mortal, que afecta al sistema nervioso, central, ocasionado por el virus del género Lyssavirus de la familia Rhabdoviridae, transmitida al hombre a través de la saliva, principalmente por perro y gato (mamíferos, incluidos los quirópteros). Infección de baja infectividad, alta patogénicidad, alta virulencia y con endémicidad moderada $a^{1,2,3,4,5}$.

\section{Clasificación}

La Clasificación Internacional de Enfermedades décima revisión (CIE-10), en el apartado A 82, y en la Norma Oficial Mexicana, la refiere de la siguiente manera:

a) Clasificación por el espécimen transmisor:

- Urbana. Perro y gato. 


\section{Principales problemas de Salud Pública en México}

- Rural. Vaca, cerdo, caballo, burro y cualquier mamífero de granja.

- Silvestre. Quiróptero, coyote, zarigüeya, zorro, etc. Mamíferos, excepto roedores por ser de tipo paralítica en estas especies.

b) Clasificación por el tipo de lesión, en:

- Exposición leve (o baja probabilidad de transmisión del virus rábico): es una mordedura única en área cubierta del cuerpo (tronco, miembro superior o inferior), y/o lamedura de piel lesionada y rasguños o arañazos ocasionados por un animal doméstico no observable, desconocido o callejero.

- Exposición grave: Exposición grave (o alta probabilidad de transmisión del virus rábico), es toda:

1) Mordedura en áreas cubiertas o descubiertas del cuerpo, lamedura de mucosas o de piel lesionada o arañazo en el cuerpo de una persona, ocasionado por un animal. Con rabia confirmada por el laboratorio con signos o síntomas compatibles con rabia al momento del accidente o durante los 10 días de observación, no vacunado, que arremete sin provocación alguna o que a juicio del médico tratante presente una alta probabilidad de trasmitir el virus rábico.

2) Mordedura, cualquiera que sea su número, extensión o profundidad, en cabeza, cara, cuello y dedos.

3) Mordeduras múltiples y lamedura de mucosa causada por un animal doméstico no observable o callejero.

4) Lesión o contacto de una persona con tejido proveniente de un espécimen sospechoso o con rabia confirmada, por razones de su oficio como fallas de la bioseguridad del personal de laboratorio, bioterios y centros de zoonosis; lesiones por esquirlas óseas o salpicaduras con material de necropsia contaminado o contacto con alta concentración de virus rábico en el ambiente (aerosoles) del laboratorio o en cavernas de murciélagos, entre otros ${ }^{6}$. 


\section{Epidemiología}

La rabia es un problema de Salud Pública debido a que es una enfermedad que aumentaría gravemente el número de casos de ella, sí la enfermedad no fuese prevenible por vacunación. Aun cuando no se encuentra dentro de las 10 principales causas de mortalidad y morbilidad, la mayor importancia radica en la prevención de dicha patología, ya que se considera que es $100 \%$ letal ${ }^{6}$.

\section{Magnitud}

La rabia es una enfermedad presente en todos los continentes, excepto en la Antártida, en donde el 95\% de los casos se presentan en Asia y África, con una endemicidad muy alta, en América latina presenta una endemicidad moderada. Según la Organización Mundial de la Salud (OMS), en el año 1992 se presentaron 36,000 casos de rabia en humanos, 97\% de ellos en Asia, particularmente en India (30,000 casos en ese año). Le siguió África con $1.4 \%$ (494 casos), Oceanía con $0.8 \%$ (317 casos), América con $0.6 \%$ (220 casos) y Europa con tan sólo $0.05 \%$ (20 casos). De acuerdo con la fuente de exposición: en América, el perro fue responsable de 805 de los casos y los animales salvajes lo fueron en 20\%; en Europa, las especies salvajes lo fueron en $80 \%$, el perro en $16 \%$ y los murciélagos en $4 \%$; en África, el perro fue la fuente más frecuente, con $96 \%$ de casos y las especies salvajes con $4 \%$; en Asia, el perro causó $80 \%$ de los casos y los animales salvajes $2 \%{ }^{12}$ La mayoría de los casos se presentaron en el grupo de edad entre los 5-14 años. En el período comprendido entre los años 1990 y 2002, los casos de rabia humana tuvieron un descenso del 97\%, los casos de rabia canina confirmada por laboratorio, disminuyeron de 3000 en el año 1990 a 105 en el año $2002^{7,8}$.

La rabia en animales silvestres, constituye una problemática particular, el SIVE (Sistema Nacional de Vigilancia Epidemiológica) reporta entre los años de 1996 a agosto de 2002, 112 casos positivos a rabia; 52 en quirópteros (46.4\%), 26 en zorrillos (23.2\%), 7 en zorros $(6.2 \%), 7$ en mapaches (6.2\%), 4 en marsupiales (3.6\%), 4 en ciervos (3.6\%), 3 en tejones $(2.7 \%), 3$ en felinos salvajes (2.7\%), 2 en coyotes (1.8\%), 2 en agutí $(1.8 \%) 1$ en coatí $(0.9 \%)$ y 1 en ardilla $(0.9 \%)^{7,9}$.

Los biotipos o variantes antigénicas, identificadas mediante anticuerpos monoclonales dirigidos contra el gen que codifica para la proteína $\mathrm{N}$ del virus rábico, identificadas con 


\section{Principales problemas de Salud Pública en México}

mayor frecuencia en México son: Vag-1 en animales domésticos, Vag-7 en zorros y felinos salvajes, Vag-8 y Vag-10 principalmente en zorrillos, Vag-3, Vag-4, Vag-9 y Vag-11 en quirópteros ${ }^{7}$. Esta técnica permite demostrar la diversidad de las variantes que circulan en el país y al mismo tiempo provee una excelente herramienta para conocer el origen y diseminación de los focos rábicos.

\section{Tendencia.}

A partir del año 1999 continuó la disminución de rabia canina y humana con casos 317 y 9 respectivamente (para ese mismo año). A pesar de que la rabia transmitida por perro ha disminuido notoriamente en las ciudades del país, y que los casos que se han presentado han ocurrido principalmente en localidades semirurales, el reto que sigue es implementar las acciones necesarias para alertar a la población (Figura 1) $)^{4,10,11}$.

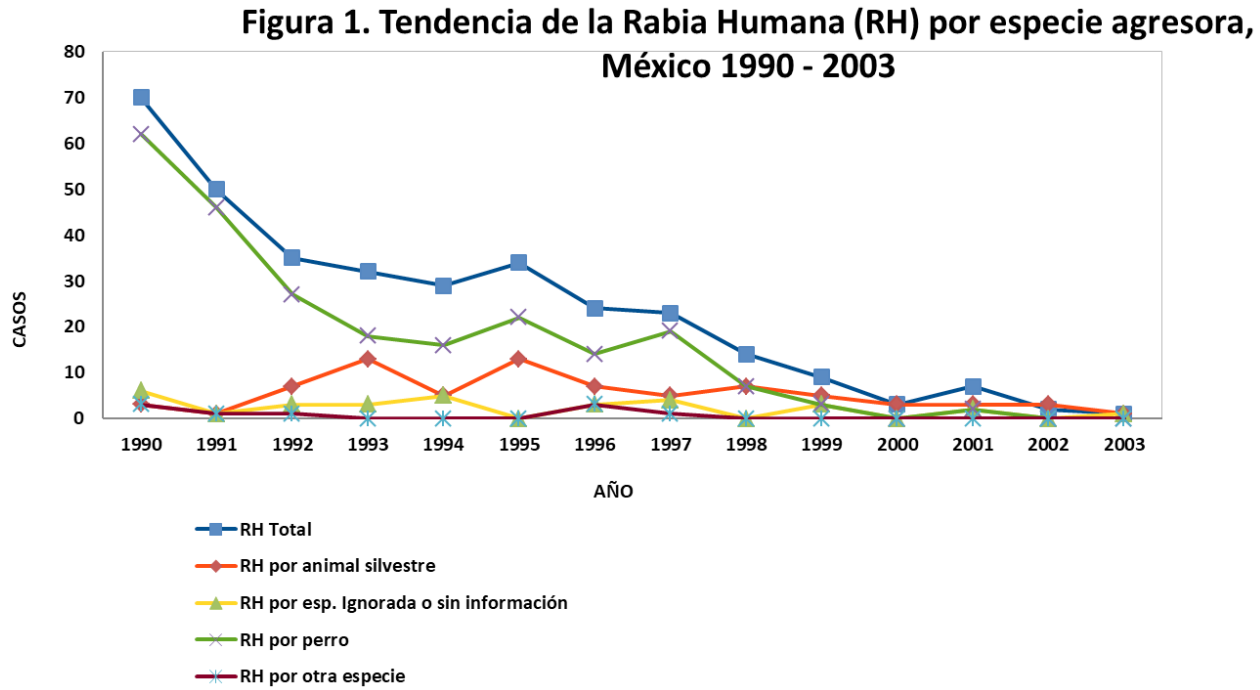

Retomado de: OPS de 1990 a 2000. Ministerio de Salud de los países de la región.

De los años 1990 al 2000, tanto la rabia en humanos como la canina, ha dado un giro en su historia en nuestro país; se registraron las cifras más bajas conocidas a la fecha. De 312 casos de rabia en humanos registrados para este período, 241 (77.3\%) fueron transmitidos 


\section{Rabia}

por perro, y de éstos, 110 (35.3\%), por perro cachorro ${ }^{6}$. La tendencia de la rabia en nuestro país al igual que en América Latina ha ido descendiendo, teniendo que de 1970 a 1997 se registraron 1,731 defunciones, por rabia y el $80.5 \%$ (1395) fueron por mordedura de perro y las reportadas por quiróptero fueron 7.27\% (126), disminuyendo aún más entre los años de 1990 y 2002 el número de casos de rabia humana en un 97\% de los casos confirmados por laboratorio, de 3000 en el año 1990 a 105 en el año 2002. En el periodo de los años de 1983 a 1988, en la República Mexicana se registraron 462 casos de rabia humana, promedio anual 71 casos, tasa $0.9 \times 106$ habitantes. El perro era el reservorio transmisor principal con 374 (87.8\%) casos los murciélagos en segundo lugar con 36 (8.5\%), seguidos por los gatos domésticos con siete (1.7\%) y los zorrillos o mofetas con seis $(1.5 \%)$; $70.22 \%$ de los casos humanos se registraron en las comunidades rurales con menos de 10,000 habitantes y sólo 65 (15\%) de los pacientes rabiosos recibieron tratamiento vacunal, incompleto o tardío. Adviértase que el número de personas mordidas en este lapso de cinco años fueron 661,527 (promedio anual de 110,255) y que los más agredidos fueron los niños de entre cuatro y 11 años de edad, 5,33 principalmente en la cara. ${ }^{7}$ Durante el año 1997, se reportaron en el país 23 casos de rabia humana, 20 de ellos transmitidos por perro $(87 \%)$, dos por vampiro (Desmodus rotundus) (9\%) y uno por zorro (4\%). Los casos de rabia canina confirmados por laboratorio fueron 523, ese año representó el último en el que la rabia humana transmitida por perro (urbana), superó a la transmitida por fauna silvestre $^{2,12}$. En el año 1998, la situación epidemiológica de la rabia humana, por primera vez en México, presenta una reducción importante de casos de rabia humana con respecto al año anterior, de 23 a 15, y por primera ocasión, ocurrieron más casos de rabia humana transmitida por fauna silvestre que por perro. Se reportaron 15 fallecimientos, de los cuáles 7 fueron causados por perro (46.7\%) y 8 (53.3\%), por animales silvestres, de estos, 5 casos fueron por vampiro (Desmodus rotundus), 1 por murciélago insectívoro (Taradira brasilensis var. mexicana) y dos por zorrillo (Spilogale putorius). En el mismo año se confirmaron por laboratorio 335 casos de rabia canina, que contrastan con los 523 casos que se registraron en el año anterior (1997). De 2000 a 2009, se reportaron 2 casos confirmados por rabia canina en dos entidades, una en Chiapas en el 2003 y 5 casos en el Estado de México 3 en el año 2001 y 2 en el año 2005, pero la rabia silvestre por agresión de murciélago fue reportada con 35 casos distribuidos de la siguiente manera: Nayarit 5 casos, Jalisco 3, Michoacán 3, Veracruz 3, tabasco 2, Guerrero 1, Oaxaca 1, San Luis Potosí 1, Sinaloa 1 y 6 por zorrillo, en Chihuahua 4, Baja California Sur 1 y Yucatán 1; por Zorro en Oaxaca 2, en Nayarit 1 y en Veracruz 1; y 1 caso por puma en Chihuahua'. En el mismo reporte se identificaron dos casos de rabia humana transmitida por gato en el Estado de Quintana 


\section{Principales problemas de Salud Pública en México}

Roo, con anticuerpos monoclonales de origen murciélago, que coincidió con zona endémica de rabia por quiróptero y otro caso confirmado por manipulación del hocico y cavidad oral de bovino confirmada como caso de rabia paralítica o derriengue. ${ }^{7}$ El número de personas agredidas en este periodo acumuló 936 mil, observando tendencia descendente, en el año 2000 fueron 110 mil y para el año 2008 a 86 mil; similar condición observó el número y porcentaje de tratamientos iniciados en estas personas, el acumulado para el período correspondió a 313 mil (33.4\%), la reducción se observó de 39 mil en el año 2000 (35.5\%) a 26 mil para el año $2008(29.8 \%)^{9}$.

Actualmente existen más casos de rabia transmitida por fauna silvestre que por fauna doméstica, debido a la implementación de campañas de vacunación permanente y a la semana nacional de vacunación antirrábica canina llevada a cabo cada año a partir del año 1990, por la Secretaría de Salud (SSA), lo que ha favorecido el cambio del tipo de agresor, que en antaño era más frecuente por el perro, como en el resto de América Latina.

En el año 1998 se integra el Instituto Mexicano del Seguro Social (IMSS) a través de su programa IMSS Oportunidades, a la lucha frontal contra la rabia en 17 entidades federativas en la República Mexicana, con acciones de educación, atención a la población agredida por perros, fauna silvestre y además con la vacunación de perros ${ }^{2}$.

A partir del año 1999 continuó la disminución de casos de rabia canina y humana con 317 y 9 respectivamente, en relación a los casos de humanos, 3 fueron ocasionados por perros y los 6 restantes por animales silvestres. En el año 2000 se reportaron 244 perros rabiosos y 5 personas fallecidas por rabia, todas con transmisión por fauna silvestre, siendo este el primer año en el que no se reportan casos de rabia humana transmitida por perros. En el año 2001, el número de casos diagnosticados en perros totalizó 117 y las defunciones humanas fueron 7 ( 1 por perro, 2 por zorrillo, 1 por puma, 2 por vampiro y 1 en que no fue posible determinar al animal agresor). En el año 2002 se reportaron 105 casos de rabia en perros y 2 en humanos, ambos debidos a agresiones por murciélagos hematófagos, disminuyendo en el año 2003 en donde se reportaron 2 casos de rabia humana, uno causado por perro y otro por zorro $3,4,9$.

En cuanto a la incidencia reportada en México, en el año, la distribución de estos casos se concentró en varones con un $64.2 \%$ contra el $35.8 \%$ para las mujeres. El grupo de edad más afectado fue el de cinco a catorce años con el 43.6\%. Dicha zoonosis, se desplazó hacia las 


\section{Rabia}

áreas suburbanas o rurales. El 60\% de los casos, se encontraba en localidades menores de 10 mil habitantes; el $88.9 \%$, no recibió atención médica antirrábica ${ }^{6,13}$.

Los primeros lugares de casos reportados en México en el periodo de años de 1990 a 1995 corresponden a los Estados de México, Puebla, el Distrito Federal, Oaxaca, Guerrero, Morelos, Michoacán, Veracruz, Jalisco, Guanajuato y Sinaloa, con el 69.8\% del total de casos .

A pesar de que la rabia transmitida por perro ha disminuido notoriamente en las ciudades del país, y que los casos que se han presentado han ocurrido principalmente en localidades semirurales, el reto que sigue es implementar las acciones necesarias para alertar a la población, utilizando los medios masivos de comunicación, sobre la necesidad de acudir a recibir tratamiento antirrábico en caso de agresión por fauna silvestre y en particular por quirópteros, zorrillos, zorros y mapaches. Es indudable que la participación de la SSA y otras instituciones como el IMSS, en las Semanas Nacionales de Vacunación Antirrábicas Caninas así como en los centros que vacunan permanentemente a los perros, continúa siendo fundamental en el control de la rabia canina y por ende humana².

La rabia paralítica bovina o derriengue se presenta actualmente en 23 entidades federativas, existiendo dos Estados más en riesgo por tener poblaciones de vampiro, aunque a la fecha no están infectadas (Querétaro y Guanajuato). Se estima que anualmente mueren entre 15 mil y 20 mil bovinos a causa de la enfermedad de la rabia, con una población de bovinos en riesgo superior a los 10 millones de cabezas.

La distribución de los brotes de derriengue coincide con el hábitat de las poblaciones de Desmodus rotundus que comprende principalmente: la vertiente del pacífico, desde Sonora y sur de Chihuahua hasta Chiapas y la costa del Golfo de México y del Caribe, desde el sur de Tamaulipas hasta la península de Yucatán. Existe también en el país el vampiro Diphylla ecaudata, en colonias aisladas, su importancia como transmisor de rabia no es significativa ${ }^{7}$.

El control de la rabia paralítica en grandes especies permite el seguimiento y control de los brotes de rabia paralítica, vacunación antirrábica en grandes especies, identificación y control de poblaciones de murciélagos hematófagos, mediante trampeo y aplicación de substancias vampiricidas tanto en quirópteros como en ganado para disminuir los riesgos de rabia transmitida por vampiros a la población humana ${ }^{7}$. Es por ello que la vacunación de ganado susceptible a la rabia paralítica se ha incrementado también año con año. Y 


\section{Principales problemas de Salud Pública en México}

los requisitos para las vacunas utilizadas en bovinos y otras especies productivas están establecidos en la NOM-035-ZOO-1996 (SAGARPA) Requisitos mínimos para las vacunas, antígenos y reactivos empleados en la prevención y control de la rabia en especies domésticas, la que estipula que los biológicos antirrábicos con virus activo modificado, deben tener un título mínimo de 103.3 DLR 50\% por cada $0.03 \mathrm{ml}$, y las inactivadas 1 U.I. $(\mathrm{NIH})$ por dosis ${ }^{2}$. Para controlar la rabia en fauna silvestre y su transmisión a otras especies y al hombre es necesario establecer programas de educación a la población, para saber qué hacer en caso de entrar en contacto con animales silvestres, e implementar nuevos sistemas que han probado ser muy exitosos para reducir la rabia en algunas especies, como la vacunación antirrábica oral ${ }^{7,14,15}$.

La rabia urbana transmitida por el perro parece haber sido finalmente abatida, sin embargo, la disminución de los perros callejeros y de dueño irresponsable y las acciones para controlar la rabia silvestre y sus vectores son los siguientes retos. Por lo tanto, constituyen un serio problema de Salud Pública, los caninos que andan en las calles, debido a las agresiones de perros a la población, que se traducen en tratamientos médicos, vacunaciones por riesgo de rabia, fecalismo ambiental y parasitosis. La tenencia responsable de mascotas, implica la necesidad de establecer campañas masivas para concientizar a la población sobre el compromiso social que implica el poseer animales y cuidar de su salud.

\section{Trascendencia}

Esta patología adquiere importancia médica al ser considerada 100\% letal, es decir al que se contagia de rabia morirá de rabia, aun cuando existe el reporte de algunos sobrevivientes.

Los sobrevivientes al padecer una encefalitis presentan secuelas tan graves que se encuentran en Estado vegetativo o con una marcada discapacidad neurológica.

Aunado a que afecta al ganado, provocando pérdidas económicas que afectan a la industria ganadera por esta enfermedad denominada derriengue.

Existen en México más de 10 millones de cabezas de ganado en áreas de riesgo, por lo que la cobertura de vacunación y programas de control deben ser incrementadas ${ }^{2,12}$. 
En forma global entre los años 1993-2002 en todo el país se reportan ventas de 143.3 MD de vacuna antirrábica canina tanto en presentación multidosis para campañas (94\%) como unidosis (6\%), dirigida al mercado privado.

En cuanto a los gastos estimados por la afección de rabia paralítica, las pérdidas económicas del ganado bovino aproximadamente están calculadas en $\$ 507,058,990.00$ millones de pesos anualmente, según la SAGARPA, 2016 y CENAPRECE, 2013¹4,15.

\section{Vulnerabilidad}

La vacunación antirrábica canina a partir del año 1990 deja de ser una acción rutinaria para convertirse en una actividad masiva intensiva y gratuita, con la instauración de la "Semana Nacional de Vacunación Antirrábica Canina", que permite vacunar a un mayor número de perros en período corto de tiempo. Esto ha favorecido que se registre un incremento sostenido del total de perros vacunados en el país, que va de 7.1 millones de dosis en año 1990 a 14 millones de dosis aplicadas en el año 2000, y que corresponde a un Incremento del 100\%.

Las acciones de captura se incrementaron año con año, de 87749 en el año 1990 a 283142 perros en el año 2000, cantidades simbólicas si se toma en cuenta que se vacuna contra la rabia a aproximadamente 14.4 millones de perros, representando el $1.2 \%$ de ese universo bajo control.

El reto a futuro es incrementar estas actividades en todo el país para lograr la estabilización de la población canina; al mismo tiempo debe reducirse el perro callejero sin dueño y el perro en la calle con dueño irresponsable.

La vigilancia de la circulación del virus rábico se llevó a cabo a través del envío de muestras al laboratorio, acumulándose 134536 especímenes estudiados con una positividad del 15\%. La dinámica que siguió la remisión de las muestras fue de 13191 para el año 1990, con $44.4 \%$ de positividad, a 16716 muestras en el año 2000, con positividad del 3.2\%.

Las acciones de control peri focales a los casos registrados, permitieron establecer en promedio las siguientes relaciones: por cada caso, se vacunaron 521 canes; se capturaron 27 y se sacrificaron 23. Sólo en el $8 \%$ de los casos estas acciones fueron inmediatamente posteriores a la confirmación por laboratorio 6 . 


\section{Principales problemas de Salud Pública en México}

Otro hecho importante fue que en año 1998 se integra el Instituto Mexicano del Seguro Social (IMSS) a través de su programa IMSS Oportunidades, a la lucha frontal contra la rabia en 17 entidades federativas de las 32 existentes en la República Mexicana².

Actualmente se cuenta con "La vacunación tipo Semple fabricada en Bélgica de cerebro de borrego cuesta \$ 5.0 en el año 2004; 4 la de cerebro de ratón lactante (tipo Fuenzalida) que se usa en México cuesta \$ 7.0; la vacuna preparada en Francia en células Vero \$ 160.0, y la de las células diploides, de importación, costaría más de $\$ 500.0$ (precios en dólares norteamericanos" ${ }^{2}$.

\section{Factibilidad}

El costo de este enorme esfuerzo se estima, para el año 2000, en 35.3 millones de pesos, que corresponde a la adquisición de los biológicos antirrábicos humanos, en los que la vacuna representa 14.1 millones y la Inmunoglobulina 21.2 millones de pesos mexicanos.

Por esta razón, en este período se ha dado un seguimiento estrecho en los Centros de Salud al total de personas agredidas que solicitaron tratamiento y que suman 1066 788, individuos con una tasa promedio nacional de 105.4 por 100000 habitantes, indicándose iniciar el tratamiento antirrábico en promedio al $35.2 \%{ }^{6}$.

El costo medio de la profilaxis tras la exposición a la rabia puede suponer gastos catastróficos para las poblaciones pobres: unos US\$ 40 en África y US\$ 49 en Asia, donde el ingreso diario medio es de US\$1-2 por persona ${ }^{16}$.

\section{Viabilidad}

La capacidad que se tiene en nuestro país para poder actuar de manera oportuna y evitar casos de rabia humana han mejorado en las últimas dos décadas gracias a la aplicación de vacunas en los perros y gatos, de igual manera se han aplicado suero hiperinmune de manera oportuna y acciones para evitar infecciones agregadas en el sitio de lesión, sin embargo es importante en este momento alertar a la población de zonas endémicas de rabia rural y silvestre en los estados de nuestro país para disminuir los casos reportados que en estos momentos son los que tienen mayor importancia epidemiológica ${ }^{4}$. 


\section{Rabia}

Existe una NOM-017-SSA- 2012 para la Vigilancia Epidemiológica de los casos de rabia una guía de atención para la atención de casos de rabia del Centro Nacional de Excelencia Tecnológica CENETEC, que favorecen el control, la detección y el manejo general de los casos reportados de rabia humana, además del programa de acción en contra de la rabia. Éste último tiene el objetivo general de eliminar el riesgo de rabia a la población ${ }^{1}$.

Actualmente se realiza en las heridas un lavado quirúrgico en el que se realiza un cierre de los tejidos de primera intención previo lavado con tercios de solución fisiológica al 9\%, isodine y agua oxigenada, en el Hospital “Lic. Adolfo López Mateos” en el periodo comprendido entre los años 2006 al 2009 con buenos resultados, lo que implica una reducción de infecciones por flora saprofita del hocico de los perros ${ }^{17}$.

\section{Causalidad}

Es provocado por un virus, lyssavirus del orden Mononegavirales, familia Rhabdoviridae, con forma de proyectil, mide $180 \mathrm{~nm}$ de longitud y $75 \mathrm{~nm}$ de diámetro, con nucleocápside helicoidal, El virus rábico no tolera el pH debajo de 3.0 ni arriba de 11.0; es inactivado también por la luz ultravioleta, la luz solar, la desecación o la exposición al formaldehído, la tripsina, la $\beta$-propionolactona y los detergentes ${ }^{5,18}$. El antígeno de la nucleocápside induce la síntesis de anticuerpos fijadores del complemento, y en el laboratorio se producen reactivos de inmunofluorescencia (IF), muy sensibles y específicos, sumamente útiles para confirmar el diagnóstico etiológico ${ }^{2,5}$. El virus es muy sensible a los disolventes de las grasas como el éter, cloroformo, acetona y solución de jabón. También lo es al etanol, a los preparados yodados y a los compuestos cuaternarios de amonio. Se inactiva a 37 C, en 24 horas y a 56 C, es parcialmente resistente a la desecación y a la congelación y descongelación repetidas y a todos los antibióticos y quimioterápicos de uso en medicina humana y animal ${ }^{19,20}$.

Mecanismo de transmisión.

- Periodo de incubación: De 2 a 8 semanas.

- Periodo de transmisibilidad: De 3 a 7 días.

- Reservorio: Mamíferos incluido el Humano 


\section{Principales problemas de Salud Pública en México}

- Modo de transmisión: Saliva de animal agresor, mordedura, lamedura, ingestión de carne cruda de animal portador de rabia.

\section{Reservorio}

En cuanto al animal agresor, debe considerarse lo siguiente:

- Presencia de rabia en la zona o región geográfica donde ocurrió la agresión, contacto o donde proviene el animal agresor.

- Especie de animal involucrado. En el medio urbano y suburbano es más común el perro y el gato y en el medio rural, los quirópteros y el zorro.

- Características del ambiente en que se ubican los agentes transmisores.

- Condiciones en que se presentó la agresión. Por ejemplo, si el animal fue provocado.

- Antecedentes inmunológicos antirrábicos del perro o gato agresor.

- Localización del anima agresor.

- Disponibilidad para la observación del perro o gato durante 10 días.

- Estado clínico del perro o gato agresor antes de la agresión, en la agresión y durante el período de observación.

- Resultados de laboratorio de especímenes del animal agresor ${ }^{21}$.

Huésped susceptible y factores de riesgo para adquirir la enfermedad

Debe considerarse:

- Edad, escolares, preescolares adultos y ancianos, generalmente en ese orden.

- Sexo masculino relación 3:1.

- Ocupación agricultor (campesino).

- Estado de salud de la persona agredida ${ }^{8,22}$. 


\section{Rabia}

\section{Fisiopatología}

La entrada del virus rábico es por la lesión, lamedura, en donde existe replicación del virus en el sitio de lesión, migración centrípeta a nervios periféricos, después se da la segunda replicación viral en ganglio espinales posteriores, invasión de medula espinal asciende al cerebro y la tercer replicación, en las neuronas distribuyéndose en todo el sistema nervioso central, pero principalmente en hipotálamo, mesencéfalo, tálamo y medula espinal, diseminación a todos los tejido por vía centrifuga especialmente saliva ${ }^{5,23,24}$.

\section{Cuadro clínico}

Aquí deben considerarse los cuadros clínicos del agresor y del humano. En el caso del perro, el cuadro clínico es el siguiente:

1) Fase prodrómica:

Fiebre, midriasis, miosis, micción frecuente, aumento de la libido, ligero cambio de comportamiento (3 días).

2) Fase furiosa (rabia negra):

Fiebre, midriasis, miosis, micción frecuente, aumento de la libido, ligero cambio de comportamiento, más agresividad, tendencia a escapar, cambio en el ladrido más agudo, estrabismo, sialorrea, apetito pervertido, incoordinación motora.

3) Fase paralítica (rabia blanca):

Caída de mandíbula, parálisis progresiva, coma y muerte ${ }^{16,17,20,21}$ :

Sintomatología en el humano

Los siguientes factores se deben de considerar para poder realizar el Diagnóstico

- Periodo de incubación (de 1 semana a 1 año) En promedio 15 a 60 días.

- El periodo es más corto si la lesión está cercana al SNC y más corto en niños que en adultos. 
Magnitud de la lesión y cantidad de inoculo

a) Periodo prodrómico 2 a 10 días

Malestar general fiebre de $38 \mathrm{C}$ anorexia, fatiga, cefalea y fiebre, angustia, parálisis, depresión nerviosa, dolor tipo neurítico, dolor radial en el sitio de agresión, parestesias y prurito en el sitio de la lesión, hidrofobia, fotofobia , aerofobia y salivación excesiva.

b) Periodo neurológico (3 días)

Fiebre de $40-42^{\circ} \mathrm{C}$.

Periodo de hiperactividad: Alucinaciones, convulsiones, comportamiento desordenado, rigidez de nuca (2 a 3 días ) taquicardia detención de la respiración odinofagía y disfagía, sialorrea, hidrofobia, aerofobia, fotofobia dada por la hiperactividad desencadenada por estímulos como estímulos táctil, auditivo, visual y olfatorio que desencadenan convulsiones o opistotonos. COMA y muerte (horas o días).

c) Periodo de estado (hasta 8 días) $)^{1,10,20,24,25}$.

Sitios de mayor frecuencia lesionadas

- 50\% afección a miembros superiores con un periodo de incubación de 1 a 2 meses.

- $15 \%$ miembros inferiores .

- $15 \%$ cara.

- $20 \%$ resto del cuerpo.

- Afección del sistema nervioso central.

\section{Complicaciones}

Encefalitis con destrucción de tejido encefálico, con severas repercusiones quedando en estado vegetativo o con secuelas incapacitantes y la muerte, considerada la enfermedad con una letalidad del $100 \%^{1,10,20,24,25}$. 


\section{Rabia}

\section{Diagnóstico}

El diagnóstico se realiza por cuadro clínico y el antecedente epidemiológico de exposición a espécimen transmisor de la rabia.

$>$ En el hombre:

Para poder establecer el diagnóstico, es importante identificar que no es lo mismo persona agredida por espécimen transmisor de rabia y caso de rabia, siendo indispensable establecer las definiciones operacionales que nos darán los elementos para el diagnóstico.

Caso sospechoso de rabia: Cualquier contacto directo o indirecto con secreciones de persona o animal transmisor del virus rábico que este infectado y que ha tenido la probabilidad de contraer la infección.

Caso probable de rabia: A la persona que sufrió alguna lesión (agresión) por animal potencialmente capaz de transmitir rabia.

Caso confirmado de rabia: Persona que presento contacto directo o indirecto con secreciones o lesión por espécimen agresor, que presenta sintomatología compatible con la enfermedad y la confirmación de laboratorio (prueba biológica, inmunohistoquímica, titulación de anticuerpos, otro), caso confirmado por clínica en zona endémica.

Caso descartado de rabia: Persona cuyos antecedentes de infección y resultados de laboratorio son negativos para virus rábico y cuando se establece otra causa de encefalitis en el paciente $\mathrm{e}^{13,24,25}$.

Diagnóstico confirmatorio posmortem en el agente agresor y en el humano:

- Degeneración y necrosis neural, con desmielinización de los cilindroejes de substancia blanca e infiltración de células mono nucleares e hiperemia perivascular.

- Cuerpos de negri: son inclusiones intracitoplásmicas que correspondan a grandes conglomerados de gran cantidad de proteína del virus rábico.

- No genera inmunidad útil que impida la infección al SNC y por tanto la muerte $12,26,27$. 


\section{Principales problemas de Salud Pública en México}

Muestras en humanos que se emplean para el diagnóstico de rabia.

De acuerdo a la experiencia en el Instituto Nacional de Diagnóstico y Referencia Epidemiológica (INDRE), las muestras pueden tomarse de diferentes partes de cuerpo, así como de las secreciones, por ejemplo de cuero cabelludo, saliva, líquido cefalorraquídeo, entre otros. Dichas muestras se desarrollan en el cuadro siguiente (Cuadro 1)9:

Cuadro 1. Tipos de muestras, conservación y la técnica de las mismas.

\begin{tabular}{|c|c|c|c|c|c|c|c|}
\hline 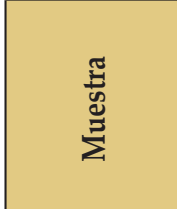 & 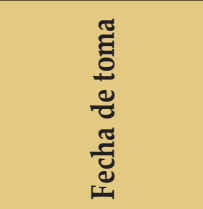 & 苞 & 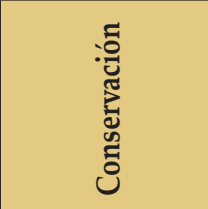 & 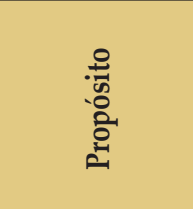 & 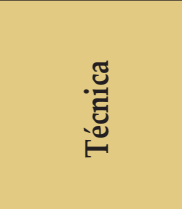 & 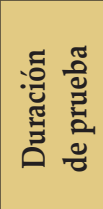 & 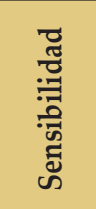 \\
\hline $\begin{array}{l}\text { Biopsia } \\
\text { de cuero } \\
\text { cabelludo }\end{array}$ & $\begin{array}{l}\text { Una semana } \\
\text { después de } \\
\text { iniciados los } \\
\text { síntomas }\end{array}$ & $\begin{array}{l}1 \mathrm{~cm} \text { de } \\
\text { diámetro de } \\
\text { piel tomada } \\
\text { entre la piel } \\
\text { y la piel } \\
\text { cabelluda } \\
\text { de la región } \\
\text { de la nuca }\end{array}$ & $\begin{array}{l}\text { Refrigeración } \\
\text { sin } \\
\text { formaldehído } \\
\text { o formalina, o } \\
\text { sol. de glicerol, } \\
\text { o sol. salina } \\
(0.85 \%) 1: 1 \text { o } \\
50 \% \text { y } 50 \% \mathrm{~V} / \mathrm{V}\end{array}$ & $\begin{array}{l}\text { Identificación } \\
\text { del virus } \\
\text { rábico } \\
\text { aislamiento } \\
\text { viral }\end{array}$ & $\begin{array}{l}\text { Inmuno- } \\
\text { fluorescencia } \\
\text { directa, } \\
\text { inoculación } \\
\text { en ratón PCR }\end{array}$ & $\begin{array}{l}2 \text { días } \\
6-21 \\
\text { días } \\
2 \text { días }\end{array}$ & $\begin{array}{l}<85 \% \\
<60 \% \\
<65 \%\end{array}$ \\
\hline $\begin{array}{l}\text { Impresiones } \\
\text { de cornea }\end{array}$ & $\begin{array}{l}\text { Una semana } \\
\text { después de } \\
\text { iniciados los } \\
\text { síntomas }\end{array}$ & $\begin{array}{l}2 \text { láminas } \\
\text { con } \\
\text { impresiones } \\
\text { corneales } \\
\text { una para } \\
\text { cada ojo }\end{array}$ & $\begin{array}{l}\text { Empacadas } \\
\text { individual- } \\
\text { mente en cada } \\
\text { papel } \\
\text { No necesitan } \\
\text { refrigeración }\end{array}$ & $\begin{array}{l}\text { Identificación } \\
\text { del virus } \\
\text { rábico }\end{array}$ & $\begin{array}{l}\text { Inmuno- } \\
\text { fluorescencia } \\
\text { directa }\end{array}$ & 2 días & $<30 \%$ \\
\hline Saliva & $\begin{array}{l}\text { Una semana } \\
\text { después de } \\
\text { iniciados los } \\
\text { síntomas }\end{array}$ & $\begin{array}{l}\text { Hisopo } \\
\text { impregnado }\end{array}$ & $\begin{array}{l}\text { Conservado en } \\
\text { tubo de ensayo } \\
\text { con solución } \\
\text { fisiológica }\end{array}$ & $\begin{array}{l}\text { Aislamiento } \\
\text { viral }\end{array}$ & $\begin{array}{l}\text { Inoculación } \\
\text { en ratón }\end{array}$ & $\begin{array}{l}\text { 6-21 } \\
\text { días }\end{array}$ & $<15 \%$ \\
\hline L.c.r & $\begin{array}{l}10 \text { a } 11 \text { días } \\
\text { de iniciada la } \\
\text { sintomatología }\end{array}$ & $3-4 \mathrm{ml}$ & Refrigeración & $\begin{array}{l}\text { Detección de } \\
\text { anticuerpos } \\
\text { neutralizantes } \\
\text { detección de } \\
\text { ARN del } \\
\text { virus } \\
\text { rábico }\end{array}$ & $\begin{array}{l}\text { Inhibición de } \\
\text { anticuerpos } \\
\text { fluorescentes } \\
\text { RT-PCR }\end{array}$ & $\begin{array}{l}2 \text { días } \\
2 \text { días }\end{array}$ & $\begin{array}{l}<10 \% \\
<40 \%\end{array}$ \\
\hline
\end{tabular}




\section{Rabia}

Cuadro 1. Tipos de muestras, conservación y la técnica de las mismas.

\begin{tabular}{|c|c|c|c|c|c|c|c|}
\hline 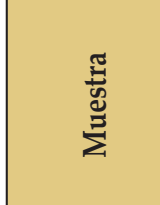 & 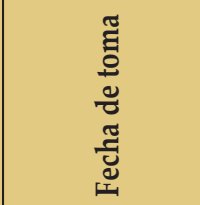 & 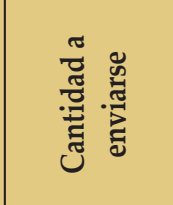 & 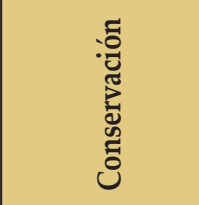 & 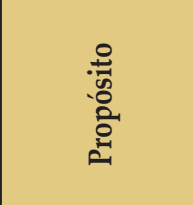 & 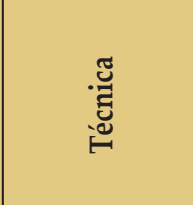 & 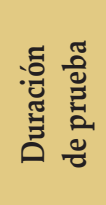 & 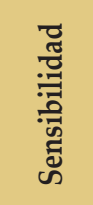 \\
\hline $\begin{array}{l}\text { Suero } \\
\text { sanguíneo }\end{array}$ & $\begin{array}{l}8 \text { a } 9 \text { días } \\
\text { después de } \\
\text { iniciados los } \\
\text { síntomas }\end{array}$ & 3-4 ml & Refrigeración & \begin{tabular}{|l|} 
Cuantifi- \\
cación de \\
anticuerpos \\
en enfermos \\
no vacunados \\
\end{tabular} & Elisa & 2 días & $<90 \%$ \\
\hline Encéfalo & $\begin{array}{l}\text { En el curso de } \\
12 \text { a } 48 \text { horas } \\
\text { después del } \\
\text { fallecimiento }\end{array}$ & $\begin{array}{l}\text { La mitad } \\
\text { del } \\
\text { cerebro, en } \\
\text { situaciones } \\
\text { particulares } \\
\text { biopsia } \\
\text { trans- } \\
\text { craneana }\end{array}$ & $\begin{array}{l}\text { Refrigeración } \\
\text { Congelación } \\
\text { puede } \\
\text { utilizarse } \\
\text { Además sol. } \\
\text { de glicerol sol. } \\
\text { salina }(0.85 \%) \\
1: 1 \text { o } 50 \% \text { y } \\
50 \% \text { v/v no } \\
\text { conservado en } \\
\text { formalina o } \\
\text { formaldehído }\end{array}$ & \begin{tabular}{|l} 
Identificación \\
viral \\
aislamiento \\
viral \\
\\
Identificación \\
de variantes \\
antigénicas \\
del virus \\
Rábico
\end{tabular} & $\begin{array}{l}\text { Inmuno- } \\
\text { fluorescencia } \\
\text { directa } \\
\text { inoculación } \\
\text { en ratón } \\
\text { PCR } \\
\text { anticuerpos } \\
\text { monoclonales }\end{array}$ & $\begin{array}{l}2 \text { días } \\
6-21 \\
\text { días } \\
2 \text { días } \\
6-21 \\
\text { días }\end{array}$ & $\begin{array}{l}<99 \% \\
<95 \% \\
<99 \% \\
<99 \%\end{array}$ \\
\hline
\end{tabular}

Nota: las muestras deben llegar al laboratorio estatal 48 hrs. después de la toma.

Retomado de: Manual para la Vigilancia Epidemiológica de la rabia (versión preliminar). www.dgepi.salud.gob.mx/infoepi/manuales/Man-Rabia/Manrab.htm \{19/08/2010.03:22.54pm\}

\section{Terapéutica}

En general entre los procedimientos médicos, ante un caso de rabia humana, se incluye la notificación inmediata, semanal con la Clave Internacional de Enfermedades (CIE-10). Además de la Vigilancia Epidemiológica de la rabia humana, la que implica acciones de detección, notificación, estudio, seguimiento de caso, defunciones y el tratamiento de caso de rabia.

Para poder realizar un manejo adecuado, se deben considerar el tipo de exposición (ejemplo lamedura o mordedura), tipo de agresor (perro vacunado o no, animal silvestre), tipo de vacuna y necesidad o no de hospitalización. En cuanto a la manera de conducirse 


\section{Principales problemas de Salud Pública en México}

de acuerdo a la exposición, es por ello que a continuación se desarrollan las acciones ante una exposición al virus rábico (Cuadro 2) 7,11,24,28,30.

Cuadro 2. Acciones procedimentales ante la exposición al virus rábico.

\begin{tabular}{|l|l|l|l|}
\hline $\begin{array}{c}\text { Condición } \\
\text { del animal al } \\
\text { agredir }\end{array}$ & \multicolumn{1}{|c|}{$\begin{array}{c}\text { Primeras } \\
\text { indicaciones }\end{array}$} & $\begin{array}{l}\text { Condiciones del } \\
\text { animal a los 10 } \\
\text { días }\end{array}$ & Indicaciones definitivas \\
\hline Sano & $\begin{array}{l}\text { Revisar y atender } \\
\text { la herida observar } \\
\text { al animal 10 días }\end{array}$ & Sano & No vacunar \\
\hline $\begin{array}{l}\text { Sospechoso } \\
\text { de rabia }\end{array}$ & $\begin{array}{l}\text { Revisar y atender } \\
\text { la herida aplicar } \\
\text { suero iniciar } \\
\text { vacunación } \\
\text { Observar al } \\
\text { animal 10 días }\end{array}$ & $\begin{array}{l}\text { Si al 5to día de la } \\
\text { exposición está } \\
\text { sano } \\
\text { Sano al 10 de } \\
\text { observación } \\
\text { Muere y positivo }\end{array}$ & $\begin{array}{l}\text { Interrumpir y continuar } \\
\text { la observación } \\
\text { Suspender el tratamiento } \\
\text { Completar el tratamiento }\end{array}$ \\
\hline Desaparecido & $\begin{array}{l}\text { Revisar y atender } \\
\text { la herida } \\
\text { Aplicar suero } \\
\text { Iniciar vacunación } \\
\text { Tratar de } \\
\text { localizarlo }\end{array}$ & $\begin{array}{l}\text { No se localiza } \\
\text { o muerto sin } \\
\text { análisis } \\
\text { Se localiza al } \\
\text { animal agresor }\end{array}$ & $\begin{array}{l}\text { Completar el esquema } \\
\text { Seguir conducta para } \\
\text { sospechoso de rabia }\end{array}$ \\
\hline Sacrificado & $\begin{array}{l}\text { Revisar y atender } \\
\text { la herida } \\
\text { Aplicar suero } \\
\text { iniciar vacunación }\end{array}$ & $\begin{array}{l}\text { Sin análisis o } \\
\text { resultado (+) Lab } \\
\text { Resultaba } \\
\text { negativo }\end{array}$ & $\begin{array}{l}\text { Completar el esquema } \\
\text { Suspender el tratamiento }\end{array}$ \\
\hline
\end{tabular}

Retomado de: Programa de Acción de Rabia 2001.

Acciones del médico de primer contacto ante un caso de rabia:

I. Obtención de datos demográficos del paciente (nombre, edad, sexo, ocupación, dirección, teléfono, municipio, delegación, Estado):
Área de procedencia
Rural Dispersa
Centro Poblado
Cabecera Municipal 


\section{Rabia}

II. Estado y características del Paciente:

$$
\left\{\begin{array}{l}
\cdot \text { Fecha de contacto } \\
- \text { Arañazo } \\
\cdot \text { Mordedura }
\end{array}\right.
$$

- Lamadura en piel sana

- Saliva en piel lesionada o mucosas

- Lesión

Tipo de agresión o contacto

a) Características de las lesiones: Número de lesiones (únicas o múltiples), Profundidad de las lesiones: superficiales y profundas, localización anatómica de las lesiones (cara, cabeza, cuello, dedos, manos, miembros superiores, tronco, abdomen, miembros inferiores) tipificando en cada una de ellas grado y profundidad.

b) Espécimen agresor: Domestico, rural y silvestre.

c) Fecha de consulta y fecha de la agresión o contacto con el transmisor biológico.

d) Fecha de inicio de la sintomatología: Síntomas, fecha de aparición, estado inmunológico del paciente, antecedentes alérgicos a la proteína de huevo.

e) Si ha recibido tratamiento antirrábico: Fecha de la última dosis, número de dosis, tipo de vacuna, aplicación de suero hiperinmune, número de frascos, tipo de suero.

f) Manejo de heridas: Lavado con agua y jabón o algún desinfectante, cual, aplicación de suero hiperinmune en la herida, tipo y cantidad, aplicación de vacuna, tipo y dosis en la que va, reacciones adversas a la vacuna.

g) Seguimiento de caso: Fecha de aplicación del suero, tipo y número de frascos y reacciones adversas, fecha aplicación de cada dosis y que tipo de vacuna y reacciones adversas, tipo de reacción adversa, localizada, generalizada y ninguna, Interrupción de tratamiento, por orden médica por incumplimiento y/o voluntario.

h) Clasificación del caso: Caso sospechosos, caso probable y caso confirmado: Por laboratorio, por clínica y por nexo epidemiológico. 


\section{Principales problemas de Salud Pública en México}

i) Situación del animal agresor: Conocido, desconocido, desaparecido, muerto (fecha y causa de muerte), vivo, vacunado, no vacunado, se desconoce (Fecha de vacunación, nombre dirección y teléfono del propietario) estado al momento de la agresión ( con signos de rabia, sin signos de rabia y se desconoce).

j) Vigilancia del animal agresor: Días observados, lugar de retención y observación del animal agresor (casa, clínica veterinaria y centro de zoonosis), estado actual del animal (vivo, muerto y enfermo) confirmación del caso de rabia en el animal agresor (si, no, pendiente y no se realizó y fecha de confirmación del caso) anotar con que prueba de laboratorio se confirmó el caso en humano (IFD, prueba biológica, titulación de anticuerpos, inmunohistoquímica, otra).

k) Acciones de Vigilancia Epidemiológica: Se realizó notificación inmediata, si, no y no se sabe, se realizó cerco epidemiológico, se realizó estudio de contactos, se establecieron y/o intensificaron acciones del 1er nivel de prevención (trípticos, volantes carteles informativos, pláticas etc. y actividades de protección específica en los especímenes susceptibles de vacunación.

1) Se capacito al personal de salud y/o a los comités de salud ejidales.

m) Se realizaron campañas de eliminación de perros callejeros ${ }^{23}$.

Uso de vacunas y sueros para el manejo de los pacientes

El uso de vacunas y sueros dependen de las acciones procedimentales ante la exposición al virus rábico. Las vacunas y sueros (inmunoglobulinas), con las que cuenta México son múltiples, por lo que a continuación las presentamos, al igual que su esquema de vacunación, como sus vías de aplicación, dosis, indicaciones y contraindicaciones, entre otros (Cuadros 3, 4 y 5) 3,7,11,24,28. 


\section{Rabia}

Cuadro 3. Inmunoglobulinas utilizadas para la rabia.

\begin{tabular}{|l|l|l|l|l|}
\hline \multicolumn{1}{|c|}{ Origen } & \multicolumn{1}{|c|}{ Producto } & \multicolumn{1}{|c|}{ Marca } & \multicolumn{1}{c|}{ Productor } & \multicolumn{1}{c|}{ Dosificación } \\
\hline Humano & Inmunoglobulina & Berirab & Behrin & 20 U.I./Kg \\
\hline Humano & Inmunoglobulina & Rabuyman berna & Berna & 20 U.I./Kg \\
\hline Humano & Inmunoglobulina & Imonogam rabies & Merieux & 20 U.I./Kg \\
\hline Equino & Globulina & $\begin{array}{l}\text { Suero antirrábico } \\
\text { hiperinmune }\end{array}$ & G.g.b y r. & 40 U.I./Kg \\
\hline Equino & Globulina & $\begin{array}{l}\text { Suero antirrábico } \\
\text { berna }\end{array}$ & Berna & 40 U.I./Kg \\
\hline
\end{tabular}

Retomado de: SSA. Manual para la Vigilancia Epidemiológica de la Rabia.

Cuadro 4. Esquema de vacunación de acuerdo al biológico disponible.

\begin{tabular}{|l|l|l|}
\hline \multicolumn{1}{|c|}{ Vacuna tipo } & \multicolumn{1}{c|}{ Vía de aplicación } & \multicolumn{1}{c|}{ Región anatómica } \\
\hline C.R.L. fuenzalida & Subcutánea & $\begin{array}{l}\text { Periumbilical } \\
\text { Interescapulovertebral }\end{array}$ \\
\hline $\begin{array}{l}\text { CELS. Diploides } \\
\text { CELS. Vero }\end{array}$ & Intramuscular & $\begin{array}{l}\text { Deltoidea } \\
\text { En niños pequeños cara anterolateral } \\
\text { P.C.E.C }\end{array}$ \\
\hline
\end{tabular}

Retomado de: SSA. Manual para la Vigilancia Epidemiológica de la Rabia.

Cuadro 5. Manejo del esquema de inmunización.

\begin{tabular}{|l|l|c|c|c|l|l|}
\hline Substrato & $\begin{array}{c}\text { Marca y } \\
\text { productor }\end{array}$ & $\begin{array}{c}\text { Dosis } \\
\text { humana }\end{array}$ & Tratamiento & $\begin{array}{l}\text { Núm } \\
\text { Dosis }\end{array}$ & $\begin{array}{c}\text { Contra } \\
\text { indicaciones }\end{array}$ & \multicolumn{1}{|c|}{$\begin{array}{c}\text { Reacciones } \\
\text { secundarias }\end{array}$} \\
\hline $\begin{array}{l}\text { Cerebro } \\
\text { de ratón } \\
\text { lactante }\end{array}$ & $\begin{array}{l}\text { Fuenzalida } \\
\text { GGB y R }\end{array}$ & $1 \mathrm{ml}$ & 14 dosis & 4 dosis & $\begin{array}{l}\text { Sensibilidad } \\
\text { previa al tejido } \\
\text { nervioso }\end{array}$ & $\begin{array}{l}\text { Fiebre, cefalea, } \\
\text { Guillain-Barre, } \\
\text { encefalitis }\end{array}$ \\
\hline $\begin{array}{l}\text { Fibroblastos } \\
\text { de embrión } \\
\text { de pollo }\end{array}$ & $\begin{array}{l}\text { Rabippur } \\
\text { Behring }\end{array}$ & $1 \mathrm{ml}$ & 5 dosis & 3 dosis & $\begin{array}{l}\text { En pos } \\
\text { exposición } \\
\text { ninguna. En } \\
\text { pre exposición } \\
\text { en personas } \\
\text { enfermas o } \\
\text { convalecientes }\end{array}$ & $\begin{array}{l}\text { Locales: dolor, eritema } \\
\text { y tumefacción (5\%) } \\
\text { Casos aislados: } \\
\text { linfadenopatía dolor } \\
\text { de cabeza, letargia, } \\
\text { fiebre leve, reacción } \\
\text { alérgica cutánea }\end{array}$ \\
\hline
\end{tabular}


Cuadro 5. Manejo del esquema de inmunización (continuación).

\begin{tabular}{|l|l|c|c|c|c|l|}
\hline Substrato & $\begin{array}{l}\text { Marca y } \\
\text { productor }\end{array}$ & $\begin{array}{c}\text { Dosis } \\
\text { humana }\end{array}$ & Tratamiento & $\begin{array}{l}\text { Núm } \\
\text { Dosis }\end{array}$ & $\begin{array}{c}\text { Contra } \\
\text { indicaciones }\end{array}$ & \multicolumn{1}{|c|}{$\begin{array}{l}\text { Reacciones } \\
\text { secundarias }\end{array}$} \\
\hline $\begin{array}{l}\text { Células } \\
\text { diploides } \\
\text { humanas }\end{array}$ & $\begin{array}{l}\text { Rabivac } \\
\text { Behring }\end{array}$ & $1 \mathrm{ml}$ & 5 dosis & 3 dosis & $\begin{array}{l}\text { En pos } \\
\text { exposición } \\
\text { ninguna. En } \\
\text { pre exposición } \\
\text { en personas } \\
\text { enfermas o } \\
\text { convalecientes }\end{array}$ & $\begin{array}{l}\text { Locales: dolor, eritema } \\
\text { y tumefacción (5\%) } \\
\text { Casos aislados: } \\
\text { linfadenopatía dolor } \\
\text { de cabeza, letargia } \\
\text { fiebre leve, reacción } \\
\text { alérgica cutánea }\end{array}$ \\
\hline $\begin{array}{l}\text { Células } \\
\text { vero }\end{array}$ & $\begin{array}{l}\text { Verorab } \\
\text { Merieux }\end{array}$ & $0.5 \mathrm{ml}$ & 5 dosis & 3 dosis & --- & $\begin{array}{l}\text { Locales: dolor, eritema, } \\
\text { induración, prurito. } \\
\text { Generales: cefalea, } \\
\text { fiebre leve }\end{array}$ \\
\hline $\begin{array}{l}\text { Embrión de } \\
\text { pato }\end{array}$ & $\begin{array}{l}\text { Lyssavac } \\
\text { Berna }\end{array}$ & $1 \mathrm{ml}$ & 5 dosis & 3 dosis & $\begin{array}{l}\text { Sensibilidad a } \\
\text { proteínas de } \\
\text { ave }\end{array}$ & $\begin{array}{l}\text { Locales raras :dolor, } \\
\text { eritema, induración }\end{array}$ \\
\hline $\begin{array}{l}\text { Células } \\
\text { diploides } \\
\text { humanas }\end{array}$ & $\begin{array}{l}\text { Vacuna de } \\
\text { la rabia } \\
\text { inactivada }\end{array}$ & $1 \mathrm{ml}$ & 5 dosis & 3 dosis & --- & $\begin{array}{l}\text { Locales:(menos } \\
\text { de 10\%) eritema, } \\
\text { induración. } \\
\text { Generales(1\%) fiebre, } \\
\text { ligera(38ㄷ) astenia } \\
\text { ligera }\end{array}$ \\
\hline
\end{tabular}

Retomado de: Programa de Acción de Rabia 2001.

\section{Medidas de prevención}

Las medidas de prevención de primer nivel, van encaminadas a la Vigilancia Epidemiológica, promoción de la salud, la que incluye hábitos de cuidado y posesión de animales, esterilización de las hembras, orquiectomía bilateral, para limitar el incremento de la población canina y felina; trampeo y captura de murciélagos con redes, en refugio y corral; la atención médica y antirrábica de personas agredidas con el afán de evitar que se presente la enfermedad; control de la rabia canina, la que incluye su prevención; y limitar el control de la rabia canina. ${ }^{6,13,24,29}$

La prevención secundaria implica dos factores a realizar, el diagnóstico temprano y el tratamiento oportuno, para tales efectos se debe de limpiar exhaustivamente la herida; 


\section{Rabia}

dar tratamiento profiláctico y pos exposición; identificar el animal agresor, verificar si este tiene la vacuna, captúralo y vigilarlo por 10 días, y enviar muestras al laboratorio en casos necesarios, para confirmar caso de rabia (muestras del animal agresor y del humano).

La limpieza de la herida y la inmunización según las recomendaciones de la OMS tan pronto como sea posible tras un contacto sospechoso con un animal permite prevenir la aparición de la rabia en prácticamente el 100\% de las exposiciones. El tratamiento recomendado para prevenir la rabia depende del tipo de contacto:

- Tipo I: persona con piel intacta que haya tocado o alimentado animales sospechosos.

- Tipo II: persona con piel no intacta que haya sido lamida por animal sospechoso o contacto que haya producido pequeños arañazos, pero sin pérdida de sangre.

- Tipo III: persona que haya sufrido una o más mordeduras o arañazos, lametones en piel no intacta u otros contactos que interrumpan la continuidad de la piel, o que haya estado expuesta a murciélagos.

El tratamiento profiláctico de la rabia tras la exposición incluye la limpieza y desinfección de la herida o punto de contacto, seguida de la inmunización antirrábica lo antes posible en caso de exposición de tipo II o III. En caso de contacto de tipo III y en personas con sistema inmunitario debilitado deben administrarse inmunoglobulinas (anticuerpos) antirrábicas.

El tratamiento pos exposición debe comenzar inmediatamente y sólo debe detenerse si el animal es un perro o un gato que siga estando sano al cabo de 10 días. Los animales sacrificados o que hayan muerto deben ser sometidos a pruebas de detección del virus, y los resultados deben enviarse a los servicios veterinarios y de Salud Pública competentes para que la situación en la zona esté bien documentada ${ }^{6,12,16,24}$

El control de la rabia urbana requiere reducción rápida de animales susceptibles, mediante vacunación periódica (anual) de perros y gatos, además del control y eliminación de animales vagabundos ${ }^{11,18,24}$.

Para la rabia silvestre, inmunización de poblaciones afectadas y control de densidad de población ${ }^{18,28}$. 


\section{Principales problemas de Salud Pública en México}

Las normas de transporte internacional de animales obligan en países indemnes a prohibir la introducción de perros y gatos que provengan de áreas infectadas o establecer una cuarentena larga o exigir certificado de vacunación ${ }^{20}$.

Los animales sospechosos de padecer rabia han de ser sacrificados y sometidos a diagnóstico de laboratorio, excepto los pertenecientes a la especie canina que deben ser puestos en observación durante 14 días; si en ese periodo el animal muriese o desarrollase sintomatología debe ser sometido a pruebas diagnósticas ${ }^{16,20}$.

La prevención terciaria, incluye todas aquellas que se llevan a cabo durante el periodo de exposición, cuando la enfermedad ya se ha manifestado claramente, se basa principalmente en el tratamiento de la enfermedad y en la reducción de las complicaciones. (Considerada una enfermedad $100 \%$ letal). ${ }^{9.11}$

Por todo lo expuesto en éste capítulo, a pesar de que la rabia es una zoonosis, el médico general debe ejecutar las acciones de control y Vigilancia Epidemiológica de este padecimiento sobre todo en zonas rurales que es en donde aún se siguen reportando casos, propiciando un ambiente de capacitación a la población en riesgo.

\section{Referencias}

1. Secretaría de Salud. Norma Oficial Mexicana NOM-011-SSA2-1993, para la prevención y control de la rabia. Disponible en http://www.salud.gob.mx/unidades/cdi/ nom/011ssa23.html

2. Carrada Bravo T. Rabia. Visión nueva de un mal milenario. Rev Mex Patología Clínica. 2004; 51(3):153-166.

3. Secretaría de Salud. Manual para la vigilancia epidemiológica de la rabia, SSA. Disponible en http://.dgepi.salud.gob.mx/infoepi/manuales/Man-Rabia/ Manrabhtm $\{19082010032254 . p m$.

4. Boletín Epidemiológico/OPS, Vol. 26, No. 1 Marzo 2005? Revista Panamericana de la Salud Pública. Disponible en: [online].2209,vol25,no.3pp260269.ISSN1680.5348,http:// www.scielosp.org/scielo.php?script=sci_artextt

5. Romero Cabello, R. Microbiología y parasitología humana. 3a ed. Buenos Aires: Panamericana; 2007. p. 146. 


\section{Rabia}

6. Ministerio de Salud. Norma técnica para la prevención y control de rabia humana en Perú. Perú: Dirección General de Salud a las Personas, Dirección de Atención Integral de la Salud; 2008.

7. Domínguez OJ. Comportamiento epidemiológico de la rabia en México. México: Merial; 2004.

8. Ministerio de Salud. Manual de normas y procedimientos de vigilancia y control de enfermedades de notificación obligatoria. Revisión Nacional 2007. República de Argentina: Ministerio de Salud; 2007.

9. Boletín Epidemiológico 32(17), semana 17-26 de abril al 2 de mayo del 2015. Disponible en: www.gobiernofederal.gob.mx y www.cenave.gob.mx

10. Vigilancia epidemiológica de la rabia en las Américas. Centro Panamericano de Fiebre Aftosa-OPS/Informes Semanales N 52, 1999.

11. Secretaría de Salud. Programa de acción de rabia, SSA 207-2012 rabia y otras zoonosis. México: SSA; 2008.

12. Vigilancia Epidemiológica de la Rabia en las Américas Centro Panamericano de Fiebre Aftosa-OPS/Informes Semanales N 56, 2004.

13. Prieto Y, García A, Sánchez E, Medina A, Oviedo de Vale M. Factores de riesgo asociados a la ocurrencia de rabia humana en el municipio de Maracaibo del estado Zulia, Venezuela. Revista Científica (Maracaibo). 2006; XVI(2):165-175.

14. Secretaría de Salud. Guía para la atención médica antirrábica de la persona expuesta al virus de la rabia. Programa de zoonosis del CENAPRECE. 2a ed. Octubre 2010. Disponible en: www.gobiernofederal.gob .mx

15. Monroy Gómez AC. Epidemiología espacial de los casos de rabia paralítica en especies de importancia económica notificados del 2011 al 2014 en México [Tesis]. México: Facultad de Medicina Veterinaria y Zootecnia, UNAM; 2016.

16. Jackson AC. Actualización sobre la patogénesis de la rabia. Rev Pan-Amaz Saude. 2010; 1(1):167-172. Disponible en: http://scielo.iec.gov.br/pdf/rpas/v1n1/es_ v1n1a23.pdf

17. www.who.int./rabies/rabnet. Who Expert Consultation on rabies. 2004: Geneva Switzerland; 2005. 


\section{Principales problemas de Salud Pública en México}

18. Schneider M.C, Belotto A, Adé MP, Leanes LF, Correa E, Tamayo H, Medina G, Rodrigues MJ. Situación epidemiológica de la rabia humana en América Latina en 2004. Boletín Epidemiológico. 2005; 26(1): 2-4.

19. Evento de vigilancia: rabia. Primer semestre de 2007. INS-Subdirección de Vigilancia y Control. p. 4-23.

20. Secretaría de Salud. Modificación a la Norma Oficial Mexicana NOM-011-SSA2-1993, para la prevención y control de la rabia. Publicada el 25 de enero de 1995.

21. OPS. Vigilancia Epidemiológica de la Rabia en las Américas. Instituto Panamericano de Protección de Alimentos y Zoonosis-OPS. XXV(1-12), 15 de julio; 1995.

22. Velázquez Reyes VR, Flores Ávila MG, Gómez Pedroso B. Tratamiento de heridas por mordedura de perro en región cráneo facial. Revista Odontológica Mexicana. 2013; 17(4):247-265.

23. Sevillano Fernández O. Rabia: actualización de conocimientos y gestiones de las actividades Sanitarias. Madrid: Centro de Vigilancia Sanitaria Veterinaria; 2010.

24. Llamas López L, Orozco Plascencia E. Rabia: infección viral del sistema nervioso central. Revista Mexicana de Neurociencia. 2009; 10(3):212-219.

25. Benenson AS (ed.). Manual para el control de las enfermedades transmisibles. 17a ed. Washington: OPS; 1997.

26. Organización Panamericana de la salud. Guía actualizada de la OMS de profilaxis antirrábica pre y post- exposición en humanos. Disponible en: https://www.minsalud. gov.co/sites/rid/Lists/BibliotecaDigital/RIDE/INEC/INTOR/guia-oms-de-profilaxisantirrabica-pre-y-post-exposicion-en-humanos.pdf

27. López Ramos F. Epidemiología. Enfermedades transmisibles y crónicas degenerativas. 2a ed. México: Manual Moderno; 2010.

28. Secretaría de Salud. Guía para la atención médica y antirrábica de la persona expuesta al virus de la rabia. México: SSA; 2010.

29. Organización Mundial de la Salud. Rabia Nota descriptiva Nº 99 marzo de 2016. Disponible en: http://www.who.int/mediacentre/factsheets/fs099/es/

30. Secretaría de Salud. Programa de acción de rabia, 2001-2006. p. 13-36. Disponible en http://www.salud.gob.mx/unidades/cdi/documentos/rabia.pdf 


\title{
21. Trastorno por déficit de atención e hiperactividad
}

\author{
Dr. Noé Contreras González \\ José Luis Espinoza Herrera
}

\section{Introducción}

La atención es una de las muchas funciones cerebrales superiores que nos permite percibir un objeto, un proceso o una idea, así como estar al tanto de los detalles en la ejecución de una tarea. Junto con el estar despierto, la atención es la base y guía de todas las demás funciones cerebrales superiores ${ }^{1}$.

El Trastorno por Déficit de Atención e Hiperactividad (TDAH) es uno de los trastornos persistentes del neurodesarrollo en la infancia. Se estima a través de diversos criterios que su prevalencia es de 3-6\% en población escolar y 3-4\% en población adulta. En niños por lo regular se presenta en menores de 7-8 años según la revisión del DSM-IV aunque en la siguiente edición (DSM-V) se amplió a menores de 12 años. Es más frecuente en los varones con una proporción de 8:12.

Es un trastorno caracterizado por un patrón persistente de inatención, hiperactividad e impulsividad que conlleva al sujeto a tener problemas en 2 o más situaciones (ej. casa, escuela, trabajo, etc.). Los sujetos con este trastorno suelen no poner atención a detalles o cometer errores por descuido; suelen tener dificultades para mantener la atención en actividades cotidianas, ya que las actividades que exigen un esfuerzo mental sostenido son percibidas en estos pacientes como desagradables. Los sujetos también se distraen con facilidad ante estímulos irrelevantes (ruidos o hechos simples de la vida diaria). Suelen ser olvidadizos. Los déficits de atención pueden expresarse por cambios frecuentes en la conversación, no suelen escuchar a los demás, no atienden las conversaciones y no siguen los detalles o normas de juegos o actividades. La hiperactividad puede manifestarse estando inquieto o retorciéndose en el asiento, o por el estar realizando actividades como 


\section{Principales problemas de Salud Pública en México}

correr, saltar, hablar en exceso, mover las extremidades inquietamente, etc.; son ruidosos, impacientes, no siguen las reglas. La impulsividad se puede denotar por los accidentes que sufra o el deseo por realizar cosas peligrosas ${ }^{3}$.

Es muy común que el TDAH coexista con otras entidades: conducta oposicionista, dificultad específica del aprendizaje, trastornos de ansiedad, trastornos del afecto, trastornos de conducta. Algunos niños con trastornos de conducta terminan por presentar conductas antisociales y abuso del alcohol y de sustancias en la adolescencia; suelen presentar trastornos de lenguaje en edad preescolar, dificultades específicas en el aprendizaje en edad escolar y trastornos afectivos y de ansiedad en la adolescencia ${ }^{3}$.

\section{Concepto}

El TDAH es una patología neuropsiquiátrica, con una elevada prevalencia en la infancia y en la adultez, que se conforma de una triada característica que es la persistencia de inatención (déficit de atención), sobreactividad e impulsividad. No aparece necesariamente asociado a un trastorno del desarrollo, esquizofrenia u trastornos psíquicos ni otro trastorno mental (trastorno del estado de ánimo, de ansiedad, disociativo o de personalidad) ${ }^{4}$.

\section{Clasificación}

La mayor parte de los individuos tienen síntomas tanto de desatención como de hiperactividad-impulsividad, en algunos predomina uno u otro de estos patrones. El subtipo para un diagnóstico actual debe estar en función del patrón sintomático predominante durante los últimos 6 meses. Si se mantienen síntomas clínicamente significativos, pero ya no se cumplen los criterios de ninguno de los subtipos, el diagnóstico apropiado es el de trastorno por déficit de atención con hiperactividad, en remisión parcial. Cuando los síntomas de un sujeto no cumplen actualmente todos los criterios del trastorno y no queda claro si tales criterios se cumplían con anterioridad, debe diagnosticarse un trastorno por déficit de atención con hiperactividad no especificado. ${ }^{3}$

En la actualidad existen 2 clasificaciones de los trastornos mentales más utilizadas la Clasificación internacional de Enfermedades en su décima edición (CIE-10) y la clasificación de la Asociación Psiquiátrica Americana (APA) en el Manual de Diagnóstico y Estadístico de los Trastornos Mentales, cuarta edición texto revisado (DSM-IV-TR); según el manual 


\section{Trastorno por déficit de atención}

diagnóstico y estadístico de los trastornos mentales cuarta edición (DSM-IV); y el manual diagnóstico y estadístico de los trastornos mentales quinta edición (DSM-V) se clasifica al TDAH de la siguiente manera (Cuadro 1$)^{2}$ :

Cuadro 1. Clasificación del TDAH, según DSMIV y DSM V.

\begin{tabular}{|c|l|l|}
\hline Manual & \multicolumn{1}{|c|}{ Tipos } & \multicolumn{1}{c|}{ Descripción } \\
\hline & $\begin{array}{l}\text { TDAH } \\
\text { predominantemente } \\
\text { inatento (TDAH-I) }\end{array}$ & $\begin{array}{l}\text { Se cumplen 6 o más criterios de inatención pero } \\
\text { menos de 6 de hiperactividad-impulsividad. (si } \\
\text { se satisface el Criterio A1, pero no el Criterio A2 } \\
\text { durante los últimos 6 meses) }\end{array}$ \\
\cline { 2 - 3 } DSM-IV & $\begin{array}{l}\text { TDAH } \\
\text { predominantemente } \\
\text { hiperactivo-impulsivo } \\
\text { (TDAH-HI) }\end{array}$ & $\begin{array}{l}\text { Se cumplen 6 o más criterios de hiperactividad- } \\
\text { impulsividad pero menos de 6 de inatención. (si } \\
\text { se satisface el Criterio A2, pero no el Criterio A1 } \\
\text { durante los últimos 6 meses) }\end{array}$ \\
\cline { 2 - 4 } & $\begin{array}{l}\text { Combinado (TDAH-C) } \\
\text { Se cumplen más de 6 criterios de inatención } \\
\text { y más de 6 criterios de hiperactividad- } \\
\text { impulsividad. (si se satisfacen los Criterios A1 y } \\
\text { A2 durante los últimos 6 meses) }\end{array}$ \\
\hline \multirow{2}{*}{ DSM-V } & $\begin{array}{l}\text { TDAH sin } \\
\text { hiperactividad } \\
\text { significativa (TDAH-R) }\end{array}$ & $\begin{array}{l}\text { Personas con deterioros debidos a un TDAH sin } \\
\text { problemas significativos de hiperactividad. }\end{array}$ \\
\hline
\end{tabular}

\section{Epidemiología}

Cada año, en educación primaria y secundaria, en el país desertan más de 2 millones de estudiantes, muchos de los cuales presentan el TDAH. Según el Instituto Nacional de Estadística, Geografía e Informática (INEGI), anualmente desertan unos 250 mil estudiantes a nivel de primaria y unos 900 mil reprueban sus materias. A nivel de secundaria deserta casi medio millón y reprueba más de un millón. Lo cual se traduce como una pérdida de 2 millones 650 mil estudiantes a nivel básico (primaria y secundaria). Las razones son diversas pero la mayoría se debe a que estos estudiantes padecen el TDAH.

En México la mayoría de los que sufren de tal trastorno no son diagnosticados. Y este trastorno condiciona a padecer serios problemas sociales, económicos y académicos; ocasionando en el individuo baja autoestima, alteraciones en sus relaciones 


\section{Principales problemas de Salud Pública en México}

interpersonales, ya que estos individuos son rechazados de los círculos sociales y son subestimados (Cuadro 2$)^{8}$.

Cuadro 2. Priorización de Hanlon para el TDAH.

\begin{tabular}{|c|l|c|}
\hline $\begin{array}{c}\text { Escala de } \\
\text { Hanlon }\end{array}$ & \multicolumn{1}{|c|}{ Descripción } & Puntuación \\
\hline Magnitud & $\begin{array}{l}\text { El TDAH, en México; en niños de 5-14 años afecto entre } \\
\text { 643, 614 y 1,073,193 de un total de 21,463,861 en el 2005, } \\
\text { siendo predominante en varones }\end{array}$ & 10 \\
\hline Severidad & $\begin{array}{l}\text { Tiene una prevalencia de 3-6\% en niños de edad escolar } \\
\text { y de 3-4\% en adultos }\end{array}$ & 10 \\
\hline \multirow{2}{*}{ Eficacia } & $\begin{array}{l}\text { Si es eficaz pero debido a la etiología (que aún es incierta) } \\
\text { con predominio de predisposición hereditaria, al igual } \\
\text { que los factores ambientales, puede no ser tan eficaces } \\
\text { para combatir este problema6,7. }\end{array}$ & 1 \\
\hline \multirow{2}{*}{ Factibilidad } & Pertinencia, aceptabilidad y legalidad. & Si \\
\cline { 2 - 4 } & Factibilidad económica y recursos. & No \\
\hline
\end{tabular}

\section{Causalidad}

Es un trastorno multifactorial, principalmente de carácter genético, aunque también intervienen aspectos ambientales y emocionales; debe tomarse en cuenta de que ningún factor por si solo explica el trastorno ${ }^{6,7,8,9}$ :

- Genéticos: que algún familiar presente TDAH (1/3 de las personas que padecen TDAH tienen algún familiar con el mismo trastorno); si el individuo tiene TDAH, es muy probable que sus hermanos lo padezcan; no en todos los hermanos se manifiesta de la misma manera (uno puede predominar la hiperactividad y otro puede tener un predominio de inatención) ${ }^{6}$.

- Prenatales: Se han asociado factores como tabaquismo, alcoholismo con embriaguez, estrés materno, enfermedades febriles, amenaza de aborto en el primer trimestre de la gestación, así como amenaza de parto prematuro para la aparición de TDAH en el hijo. 


\section{Trastorno por déficit de atención}

- Neurobioquímicos: presencia de problemas químicos a nivel cerebral. Deficiencia en los niveles de neurotransmisores dopamina y noradrenalina ${ }^{6}$.

- Neuroanatómicos y fisiológicos: daños en corteza de la parte anterior del frontal, núcleos basales del cerebro y cerebelo ${ }^{6}$.

- Psicosociales: familias donde persiste el estrés psicológico, pérdida del equilibrio familiar u otros que ocasionen ansiedad en el individuo, contribuirán a tener o no el TDAH; temperamento del niño o adolescente y exigencias sociales; el nivel socioeconómico no parece influir en el TDAH; también contribuyen las técnicas de educación inapropiadas (faltas de reglas en los diversos ámbitos, limites inconscientes o falta de acuerdos padrehijo $)^{6}$.

- Aspectos nutricionales: Se ha relacionado la alimentación baja en ácidos grasos omega, tanto en la madre durante el embarazo como en la alimentación de los niños con la aparición del TDAH ${ }^{8}$.

Entre los factores de riesgo que influyen en la capacidad para padecer TDAH se encuentran: los factores genéticos, tener algún familiar de primera línea que presente el TDAH, este trastorno se debe a alteraciones en los receptores a2A de noradrenalina; alteraciones en receptores D1, D2 y D4 dopaminérgicos; factores traumáticos craneoencefálicos con lesión en la corteza de asociación superior cortical (corteza prefrontal, parietal o temporal); factores prenatales, en casos como que la madre consumiera alcohol durante la gestación, u otras sustancias como nicotina, drogas, que la gestante padeciera hipertensión arterial, o estrés materno durante el embarazo, así como que al nacimiento el recién nacido tuviera bajo peso; también influyen los factores familiares como los métodos de crianza y educación hacia los hijos; infecciones como las encefalitis o meningoencefalitis; y la exposición a sustancias neurotóxicas (como el plomo) $)^{10,11,12}$.

\section{Fisiopatología}

La atención es la red neuronal jerárquica que realiza un conjunto de operaciones corticales y es indispensable para los procesos cognitivos, siendo necesaria para las siguientes funciones: 


\section{Principales problemas de Salud Pública en México}

- Regularización de las entradas de información y su procesamiento cognitivo final.

- Focaliza selectivamente la conciencia.

- Resuelve la competencia entre estímulos para su procesamiento en paralelo.

- Recluta-activa zonas cerebrales para temporizar las respuestas apropiadas.

- Facilita la percepción, la memoria y el aprendizaje $e^{1,13}$.

\section{Sistemas que participan en la atención}

Dentro de ellos, la corteza de la parte más anterior del frontal posee tres funciones atencionales: dirección de la atención, atención selectiva y atención sostenida. El hemisferio izquierdo realiza el control unilateral, mientras que el hemisferio derecho, con control bilateral, regula la alerta cortical manteniendo su estado ${ }^{13,14,15}$.

Los más recientes avances en neurobiología han demostrado la relación entre el TDAH con y las cortezas de asociación superior corticales; la corteza de asociación parietal, la cual es importante para la orientación de los recursos de la atención y espacio; y en la corteza de asociación temporal analiza las características visuales para la identificación de objetos y lugares; la corteza de la parte más anterior del frontal es fundamental para la atención basada en la relevancia, también es importante para la regulación del comportamiento y las emociones, inhibiendo los instintos impulsivos. En los seres humanos la corteza prefrontal derecha es importante para regular las distracciones, el lenguaje, la toma de decisiones, la conducta inapropiada y las respuestas emocionales. En estudios de imagen se ha demostrado que los pacientes con TDAH que estas regiones tienen baja actividad con conexiones débiles a otras partes del cerebro ${ }^{13,14}$.

La corteza de la parte más anterior del frontal está especializada por regiones: las porciones dorsales y laterales regulan la atención y las respuestas motoras, a través de conexiones de la corteza sensorial, motora, ganglios basales y el cerebelo; la porción ventral y medial regula la emoción a través de la amígdala, el hipotálamo, el núcleo accumbens septi y núcleos del tronco cerebral; la porción derecha inferior de esta corteza regula el comportamiento, el daño en esta región debilita la capacidad de detener el movimiento continuo, induciendo la hiperactividad y la impulsividad ${ }^{13,14}$. 


\section{Trastorno por déficit de atención}

La corteza de la parte más anterior del frontal regula la atención y la conducta a través de redes de conexión entre las células piramidales, estas redes al excitarse guían las acciones para almacenar metas y reglas, siendo dependientes del entorno neurobioquímico (por neurotransmisores como la noradrenalina, catecolaminas o dopamina). La noradrenalina y la dopamina son liberados en la corteza de la parte más anterior del frontal de acuerdo a nuestro estado de alerta (poca liberación durante la fatiga o aburrimiento; y aumento de la liberación en estados de estrés). Las óptimas concentraciones de noradrenalina y dopamina se liberan durante el estado de alerta o cuando el individuo está interesado sobre algo $15,16,17$.

La disfunción en los niños con TDAH se localiza en el lóbulo frontal, concretamente en tres áreas: dorsolateral, orbitofrontal y en el cíngulo. En estas áreas se localizan funciones ejecutivas tan importantes como la atención sostenida, la atención selectiva, el control inhibitorio, la flexibilidad cognitiva y la memoria de trabajo, entre otras funciones básicas que van a ayudar al niño a madurar para encarar, de forma eficaz, los distintos aprendizajes para encarar su ciclo vital ${ }^{18}$.

Los efectos benéficos de la noradrenalina ocurren en el receptor postsináptico a2A (existen 3 receptores para la noradrenalina: A, B y C, siendo de mayor concentración el A en la corteza prefrontal), sobre las espinas dendríticas de las células piramidales de la corteza prefrontal, la estimulación de estos receptores inicia el cierre de los canales iónicos, favoreciendo la conexión de entradas de señales en la célula. Los efectos benéficos de la dopamina se produce en los receptores D1, que actúan debilitando entradas irrelevantes en las células piramidales. También puede alterar la función de la corteza prefrontal a través de los receptores D2 y D4; el receptor D2 al ser sobre estimulado afecta la memoria de trabajo; y el D4 es un importante supresor del ácido G-aminobutírico que contienen las neuronas inhibitorias, a través de la reducción mediada por Gi de la vía de AMPc; el TADH se asocia también al polimorfismo 7 del receptor D4, que debilita la eficacia del receptor D4, causando una insuficiencia inhibición del GABBA y por ende un insuficiente disparo a las células piramidales de la corteza prefrontal ${ }^{15,16,17}$.

Algunos estudios de ligamento genético han demostrado que estas vías pueden alterarse en algunas familias con TDAH como la enzima que sintetiza la noradrenalina (Dopamina b-hidroxilasa) disminuyendo las capacidades de la corteza prefrontal. Otras alteraciones en los genes implicadas en la señalización de las catecolaminas son: los receptores DA D1 


\section{Principales problemas de Salud Pública en México}

y D5, la DA y NA transportadores, el receptor D4, el-receptor A2a y DA b-hidroxilasa, la enzima necesaria para la síntesis de NA $\mathrm{N}^{15,16,17}$.

Estudios farmacológicos indican que las catecolaminas en la corteza prefrontal son muy relevantes para producir TDAH. El bloqueo del receptor para noradrenalina a2A con yohimbina produce características similares al TDAH (hiperactividad locomotora, impulsividad y mala memoria de trabajo) $)^{15,16,17}$.

\section{Cuadro clínico}

Las manifestaciones de los síntomas y signos son variables según la clasificación, y se van a manifestar en función de la edad del paciente y el estado de la evolución del TDAH, puede haber baja tolerancia a la frustración, arrebatos emocionales, autoritarismo, testarudez, insistencia excesiva y frecuente en que se satisfagan sus peticiones, labilidad emocional, desmoralización, disforia, rechazo por parte de compañeros y baja autoestima. Con frecuencia, el rendimiento académico está afectado y devaluado, lo que conduce típicamente a conflictos con la familia y el profesorado, percibiéndose como pereza, escaso sentimiento de responsabilidad y comportamiento oposicionista ${ }^{2,3,4,19}$.

En cuanto a su desempeño académico pueden alcanzar notas inferiores al resto de sus compañeros y en el trabajo rendimientos laborales inferiores. Su coeficiente intelectual suele ser menor a los demás individuos de su edad. En su forma grave, el trastorno es muy perturbador, afectando la adaptación social, familiar y escolar ${ }^{3,4,19,20}$.

En estos pacientes suele haber trastornos del estado de ánimo, trastornos de ansiedad, trastornos del aprendizaje y trastornos de la comunicación ${ }^{4,10,20}$.

En la historia clínica puede existir antecedentes de maltrato o abandono infantil, adopción o acogida, exposición a sustancias neurotóxicas (como el plomo), infecciones (encefalitis), o que durante el embarazo la madre consumiera fármacos, bajo peso al nacer y retraso mental ${ }^{3,4,19}$.

\section{Complicaciones}

Las complicaciones en los pacientes con TDAH se relacionan con la disfunción afectiva, cognitiva y social ${ }^{21,22,23}$. 


\section{Trastorno por déficit de atención}

- Dificultades en las relaciones interpersonales. Los niños con TDAH son rechazados por sus compañeros por sus conductas molestas, antisociales y agresivas; por sus comportamientos egoístas y prepotentes. En el noviazgo llegan a tener varias parejas, agravando los conflictos.

- Pobre funcionamiento académico. Por sus dificultades cognitivas, el niño con TDAH va teniendo retraso en la trayectoria escolar.

- Abandono escolar. Por sus dificultades en el aprendizaje, es frecuente que no termine la educación primaria o abandone la educación secundaria.

- Propensión a las adicciones. La baja autoestima de niños, adolescentes y adultos con TDAH los hace presa fácil de las adicciones. El abuso de drogas es dos veces más frecuente en esta población.

- Trabajos menos remunerados. Debido a su falta de orden y dificultades en la conclusión de tareas, es frecuente que anden de un trabajo a otro y su remuneración sea baja.

- Disfunción psicosocial. La cooperación social es el área más afectada; implica el seguimiento de reglas y respuestas adecuadas con los pares y adultos.

- Delincuencia organizada. La baja autoestima, las dificultades económicas y la poca tolerancia a la frustración llevan a las personas con TDAH a caer fácilmente en la delincuencia organizada.

- Disfunción marital y parental. Sus comportamientos y falta de autocrítica lleva a los pacientes con TDAH a tener disfunción afectiva importante con sus parejas y familiares. Los padres de niños con TDAH experimentan altos niveles de estrés, frecuentes enfrentamientos de pareja y limitaciones en su vida social.

- Insatisfacción con la vida. Los patrones de conducta y sus consecuencias llevan a una insatisfacción con la vida en los pacientes de TDAH.

- El paciente con TDAH no es consciente que tiene un problema, por lo tanto, no es capaz de busca ayuda. 


\section{Principales problemas de Salud Pública en México}

\section{Diagnóstico}

El trastorno por déficit de atención/hiperactividad (TDAH) tiene características definidas de inatención, sobreactividad e impulsividad; siendo el más frecuente de los trastornos del neurodesarrollo iniciados en la infancia diagnosticados en atención primaria. ${ }^{20}$.

La prevalencia del TDAH en niños es del 4-12\%; dos terceras partes continuaran con sintomatología en la edad adulta: un $15 \%$ será bien diagnosticado y un $50 \%$ lo hará en remisión parcial ${ }^{4}$.

El diagnóstico clínico se basa en los criterios de diagnóstico publicados por manuales y clasificaciones internacionales: Los síntomas frecuentemente coexisten con otros emocionales, de comportamiento y problemas de aprendizaje, incluyendo el trastorno negativista desafiante, trastorno de conducta, depresión, ansiedad y cambios en el estado del ánimo ${ }^{2,4,20}$.

A. (1) o (2):

\section{Criterios para el diagnóstico de TDAH}

(1) seis (o más) de los siguientes síntomas de desatención han persistido por lo menos durante 6 meses con una intensidad que es desadaptativa e incoherente en relación con el nivel de desarrollo:

\section{Desatención}

(a) a menudo no presta atención suficiente a los detalles o incurre en errores por descuido en las tareas escolares, en el trabajo o en otras actividades

(b) a menudo tiene dificultades para mantener la atención en tareas o en actividades lúdicas

(c) a menudo parece no escuchar cuando se le habla directamente

(d) a menudo no sigue instrucciones y no finaliza tareas escolares, encargos, $\mathrm{u}$ obligaciones en el centro de trabajo (no se debe a comportamiento negativista o a incapacidad para comprender instrucciones)

(e) a menudo tiene dificultades para organizar tareas y actividades

(f) a menudo evita, le disgusta o es renuente en cuanto a dedicarse a tareas que requieren un esfuerzo mental sostenido (como trabajos escolares o domésticos)

(g) a menudo extravía objetos necesarios para tareas o actividades (p. ej., juguetes, ejercicios escolares, lápices, libros o herramientas) 


\section{Trastorno por déficit de atención}

(h) a menudo se distrae fácilmente por estímulos irrelevantes

(i) a menudo es descuidado en las actividades diarias

(2) seis (o más) de los siguientes síntomas de hiperactividad-impulsividad han persistido por lo menos durante 6 meses con una intensidad que es desadaptativa e incoherente en relación con el nivel de desarrollo:

\section{Hiperactividad}

(a) a menudo mueve en exceso manos o pies, o se remueve en su asiento

(b) a menudo abandona su asiento en la clase o en otras situaciones en que se espera que permanezca sentado

(c) a menudo corre o salta excesivamente en situaciones en que es inapropiado hacerlo (en adolescentes o adultos puede limitarse a sentimientos subjetivos de inquietud)

(d) a menudo tiene dificultades para jugar o dedicarse tranquilamente a actividades de ocio

(e) a menudo «está en marcha» o suele actuar como si tuviera un motor

(f) a menudo habla en exceso

\section{Impulsividad}

(g) a menudo precipita respuestas antes de haber sido completadas las preguntas

(h) a menudo tiene dificultades para guardar turno

(i) a menudo interrumpe o se inmiscuye en las actividades de otros (p. ej., se entromete en conversaciones o juegos).

B. Algunos síntomas de hiperactividad-impulsividad o desatención que causaban alteraciones estaban presentes antes de los 7 años de edad.

C. Algunas alteraciones provocadas por los síntomas se presentan en dos o más ambientes (p. ej., en la escuela [o en el trabajo] y en casa).

D. Deben existir pruebas claras de un deterioro clínicamente significativo de la actividad social, académica o laboral.

E. Los síntomas no aparecen exclusivamente en el transcurso de un trastorno generalizado del desarrollo, esquizofrenia u otro trastorno psicótico, y no se explican mejor por la presencia de otro trastorno mental (p. ej., trastorno del estado de ánimo, trastorno de ansiedad, trastorno disociativo o un trastorno de la personalidad). 


\section{Criterios para el diagnóstico de F91.8 trastorno disocial}

A. Un patrón repetitivo y persistente de comportamiento en el que se violan los derechos básicos de otras personas o normas sociales importantes propias de la edad, manifestándose por la presencia de tres (o más) de los siguientes criterios durante los últimos 12 meses y por lo menos de un criterio durante los últimos 6 meses:

Agresión a personas y animales

(1) a menudo fanfarronea, amenaza o intimida a otros

(2) a menudo inicia peleas físicas

(3) ha utilizado un arma que puede causar daño físico grave a otras personas

(p. ej., bate, ladrillo, botella rota, navaja, pistola)

(4) ha manifestado crueldad física con personas

(5) ha manifestado crueldad física con animales

(6) ha robado enfrentándose a la víctima (p. ej., ataque con violencia, arrebatar bolsos, extorsión, robo a mano armada)

(7) ha forzado a alguien a una actividad sexual

Destrucción de la propiedad

(8) ha provocado deliberadamente incendios con la intención de causar daños graves

(9) ha destruido deliberadamente propiedades de otras personas (distinto de provocar incendios)

Fraudulencia o robo

(10) ha violentado el hogar, la casa o el automóvil de otra persona

(11) a menudo miente para obtener bienes o favores o para evitar obligaciones (esto es, «tima» a otros)

(12) ha robado objetos de cierto valor sin enfrentamiento con la víctima (p. ej., robos en tiendas, pero sin allanamientos o destrozos; falsificaciones)

\section{Violaciones graves de normas}

(13) a menudo permanece fuera de casa de noche a pesar de las prohibiciones paternas, iniciando este comportamiento antes de los 13 años de edad

(14) se ha escapado de casa durante la noche por lo menos dos veces, viviendo en la casa de sus padres o en un hogar sustitutivo (o sólo una vez sin regresar durante un largo período de tiempo)

(15) suele hacer novillos en la escuela, iniciando esta práctica antes de los 13 años de edad

B. El trastorno disocial provoca deterioro clínicamente significativo de la actividad social, académica o laboral. 


\section{Trastorno por déficit de atención}

B. El trastorno disocial provoca deterioro clínicamente significativo de la actividad social, académica o laboral.

C. Si el individuo tiene 18 años o más, no cumple criterios de trastorno antisocial de la personalidad.

Especificar el tipo en función de la edad de inicio:

Tipo de inicio infantil: se inicia por lo menos una de las características criterio de trastorno disocial antes de los 10 años de edad

Tipo de inicio adolescente: ausencia de cualquier característica criterio de trastorno disocial antes de los 10 años de edad

Especificar la gravedad:

Leve: pocos o ningún problema de comportamiento exceden de los requeridos para establecer el diagnóstico y los problemas de comportamiento sólo causan daños mínimos a otros

Moderado: el número de problemas de comportamiento y su efecto sobre otras personas son intermedios entre «leves» $\mathrm{y}$ «graves»

Grave: varios problemas de comportamiento exceden de los requeridos para establecer el diagnóstico o los problemas de comportamiento causan daños considerables a otros.

\section{Criterios para el diagnóstico de F91.3 trastorno negativista desafiante}

A. Un patrón de comportamiento negativista, hostil y desafiante que dura por lo menos 6 meses, estando presentes cuatro (o más) de los siguientes comportamientos:

(1) a menudo se encoleriza e incurre en pataletas

(2) a menudo discute con adultos

(3) a menudo desafía activamente a los adultos o rehúsa cumplir sus demandas

(4) a menudo molesta deliberadamente a otras personas

(5) a menudo acusa a otros de sus errores o mal comportamiento

(6) a menudo es susceptible o fácilmente molestado por otros

(7) a menudo es colérico y resentido

(8) a menudo es rencoroso o vengativo

Nota. Considerar que se cumple un criterio sólo si el comportamiento se presenta con más frecuencia de la observada típicamente en sujetos de edad y nivel de desarrollo comparables.

B. El trastorno de conducta provoca deterioro clínicamente significativo en la actividad social, académica o laboral. 


\section{Principales problemas de Salud Pública en México}

C. Los comportamientos en cuestión no aparecen exclusivamente en el transcurso de un trastorno psicótico o de un trastorno del estado de ánimo.

D. No se cumplen los criterios de trastorno disocial, y, si el sujeto tiene 18 años o más, tampoco los de trastorno antisocial de la personalidad.

Retomado de: Pichot P, López J, Aliño I, Valdés Miyar M. Trastornos de inicio en la infancia, la niñez o la adolescencia. Asociación Psiquiátrica Americana; 199533.

Se ha propuesto que para realizar una evaluación precisa del TDAH en adultos es necesario poder responder a cuatro preguntas esenciales ${ }^{18,19,25,26}$.

La primera es acerca de que si el paciente tuvo presencia de los síntomas de TDAH en la infancia y si tuvo problemas en diferentes ámbitos.

1. La segunda se basa en recalcar la relación entre los síntomas y los problemas en diferentes ámbitos que llego a tener (se requiere información del paciente y de un familiar directo).

2. La tercera se enfoca en la relación entre los síntomas y otro trastorno psiquiátrico.

3. La cuarta requiere la comprobación de presencia de otros trastornos comórbidos con el TDAH.

Como datos de comorbilidad se sabe que el TDAH se encuentra en un $33 \%$ sola, un $40 \%$ con un trastorno negativista desafiante, un $11 \%$ con presencia de tics, un $14 \%$ con trastornos de la conducta, un $4 \%$ con trastornos de ánimo y un $34 \%$ con trastornos de ansiedad ${ }^{3}$.

La evaluación en adultos requiere realizar una Historia Clínica enfocada en los datos del desarrollo psicoinfantil. Se deben valorar los síntomas actuales y pasados, también de los trastornos comórbidos. En los antecedentes no patológicos se debe enfocar hacia el consumo de sustancias tóxicas, relaciones interpersonales. En los antecedentes patológicos eventos traumáticos principalmente (accidentes de tránsito, infracciones de tránsito, problemas legales y dificultades en el rendimiento académico o laboral) $)^{4,18,19,23,25}$.

La evaluación del paciente con TDAH, también se realiza mediante la siguiente encuesta del Manual Diagnóstico y Estadístico de los Trastornos Mentales Cuarta Edición (DSM-IV)3. 


\section{Trastorno por déficit de atención}

\section{TDAH}

Nombre Edad Género

Marque una equis $(X)$ cada una de las opciones, según corresponda.

\section{EVALUACIÓN DE LA ATENCIÓN}

\begin{tabular}{|l|l|}
\hline & Afirmativo / Negativo \\
\hline No presenta suficiente atención a los detalles & \\
\hline $\begin{array}{l}\text { Tiene dificultades para mantener la atención en tareas o } \\
\text { actividades }\end{array}$ & \\
\hline Parece no escuchar & \\
\hline $\begin{array}{l}\text { No sigue instrucciones y no finaliza tareas escolares, } \\
\text { encargos u obligaciones }\end{array}$ & \\
\hline Tiene dificultades para organizar tareas y actividades & \\
\hline $\begin{array}{l}\text { Evita o es renuente para dedicarse a tareas que requieren un } \\
\text { esfuerzo mental sostenido }\end{array}$ & \\
\hline Extravía objetos necesarios para tareas o actividades & \\
\hline Se distrae fácilmente por estímulos irrelevantes & \\
\hline Es descuidado en las actividades diarias & \\
\hline
\end{tabular}

EVALUACIÓN DE LA IMPULSIVIDAD

\begin{tabular}{|l|l|}
\hline $\begin{array}{l}\text { Precipita respuestas antes de haber sido completadas las } \\
\text { preguntas }\end{array}$ & Afirmativo / Negativo \\
\hline Tiene dificultades para guardar su turno & \\
\hline Interrumpe o se inmiscuye en actividades de otros & \\
\hline
\end{tabular}




\section{Principales problemas de Salud Pública en México}

\section{Evaluación de la hiperactividad}

\begin{tabular}{|l|l|}
\hline & Afirmativo / Negativo \\
\hline Mueve en exceso manos y pies, o se mueve en su asiento & \\
\hline $\begin{array}{l}\text { Abandona su asiento en situaciones en que se espera que } \\
\text { permanezca sentado }\end{array}$ & \\
\hline $\begin{array}{l}\text { Corre o salta excesivamente en situaciones en que es } \\
\text { inapropiado hacerlo }\end{array}$ & \\
\hline $\begin{array}{l}\text { Tiene dificultades para jugar o dedicarse tranquilamente a } \\
\text { actividades de ocio }\end{array}$ & \\
\hline "Está en marcha" o suele actuar como si tuviera un motor & \\
\hline Habla en exceso & \\
\hline
\end{tabular}

Retomado de: APA. DSM-IV. 2000.

\section{Laboratorio y gabinete}

Para los estudios de laboratorio y gabinete, se han realizado estudios de resonancia magnética funcional (RMf), la tomografía por emisión simple de fotón único (SPECT) y la tomografía por emisión de positrones (PET), mediante mediciones del flujo cerebral o del metabolismo de la glucosa. Los estudios anatómicos cerebrales de niños con TDAH han demostrado una lenificación en el desarrollo cerebral, y el volumen global del cerebro de estos niños es inferior al normal ${ }^{4,11,25}$.

Los estudios de resonancia magnética craneal en pacientes con TDAH muestran una disminución global del volumen cerebral, pareciendo una alteración no progresiva, originado por factores genéticos tempranos en el desarrollo y factores ambientales. También presentan una disminución del volumen estructural de la corteza prefrontal (CPF) derecha, el núcleo estriado, especialmente el núcleo caudado, y se ha detectado una menor actividad eléctrica en esas zonas, un menor flujo sanguíneo y una alteración en la disponibilidad de dopamina y noradrenalina. Sin embargo, en un número considerable de casos no se detecta ningún tipo de alteración en pacientes con TDAH. 


\section{Trastorno por déficit de atención}

Una de las regiones más prometedoras en el TDAH tiene relación con el cerebelo y sus conexiones con los circuitos corticoestriado y talamocortical, que elige, inicia y desarrolla complejas respuestas motoras y cognitivas. En este sentido, se han observado alteraciones estructurales en lóbulos VIII-X del cerebelo en niños con TDAH ${ }^{10,26,27,28}$.

\section{Terapéutica}

El manejo terapéutico del paciente con TDAH es multidisciplinario y debe ser individualizado a cada paciente, con adecuada comunicación entre los participantes: el médico, el psicólogo, el neuropsicólogo, los maestros, los padres y el paciente. El manejo se realiza a tres niveles: el paciente, la familia y el colegio. Comprende los siguientes aspectos:

\section{A) Medidas Generales}

- Alimentación: El paciente con TDAH requiere de una alimentación equilibrada, con proteínas y ácidos grasos omega ${ }^{8}$.

- Terapia cognitivo-conductual: Consta de varias estrategias mediante las cuales el individuo aprende a reflexionar sobre sus pensamientos y sus conductas para resolver situaciones angustiantes y detectar, de una manera más favorable, la forma de reaccionar ante ellas y producir una respuesta más aceptada. La finalidad de este tipo de tratamiento psicológico, es conseguir que el niño sea capaz de alcanzar por sí mismo una razonable autonomía, tanto en la regulación de su conducta como en los hábitos de su vida cotidiana ${ }^{5}$.

- Intervención neuropsicológica: Entrenamiento de las funciones ejecutivas para el desarrollo del niño. Las sesiones deben ser breves, variadas, que estimulen diversas vías sensoriales, de complejidad creciente, registrar resultados y retroalimentar, en un ambiente propicio ${ }^{18}$.

\section{B) Tratamiento Farmacológico}

Los fármacos psicoestimulantes (metilfenidato y dexanfetamina) son la primera opción para el manejo del TDAH en adultos. De segunda elección se tiene a la atomoxetina seguida por otros no estimulantes como son el bupropión, la guanfacina, el modafinilo o antidepresivos tricíclicos ${ }^{29,30,31}$. 
El metilfenidato es un estimulante leve del sistema nervioso central usado más comúnmente en el tratamiento de TDAH y en la narcolepsia, con una elevada tasa de eficacia y seguridad. Es un derivado de la piperidina, con una relación estructural similar a la anfetamina. Entre sus efectos predominan los mentales sobre los motores. Se absorbe con facilidad después de la administración oral, alcanza concentraciones plasmáticas en 2 horas. Es un medicamento racémico compuesto de los enantiómeros D-treo y L-treo (el enantiómero D-treo es el activo); tiene una semivida de 4-6 horas. Su principal metabolito urinario es el ácido ratalinico. Su mecanismo de acción se basa en el bloqueo de la recaptura de dopamina y noradrenalina, en las neuronas adrenérgicas centrales alterando el transporte de dopamina o proteínas portadoras; también actúa en el tronco cerebral y la corteza cerebral aumentando la actividad simpaticomimética en el SNC. Se debe administrar a dosis de 5 y $10 \mathrm{mg}$ cada 8 horas; la dosis daría total no debe exceder los $60 \mathrm{mg}$, casi todos los niños con TDAH requieren de 2 a 3 dosis diarias. La biodisponibilidad oral absoluta en niños es de $22 \pm 8 \%$ para el enantiómero D y $5 \pm 3 \%$ del enantiómero L. Tiene una unión a proteínas plasmáticas del 10-33\%. Es metabolizado activamente en el hígado y excretado en un $78-97 \%$ por vía renal y un $1-3 \%$ por vía fecal. La intoxicación con metilfenidato se presenta por vómitos, agitaciones, temblores, hiperreflexia, contracciones musculares, convulsiones, euforia, confusión, alucinaciones, delirio, diaforesis, sofocación, cefalea, hiperpirexia, taquicardia, palpitaciones, arritmias cardiacas, hipertensión, midriasis y sequedad de mucosas. $\mathrm{Su} \mathrm{LD}_{50}=90 \mathrm{mg} / \mathrm{kg}^{6,32,33}$.

La atomoxetina es la primera droga no estimulante aprobada para el tratamiento de TDAH solo o en combinación con el tratamiento conductual; es comercializada como sal de hidroclórica de atomoxetina. Se clasifica como un inhibidor de la receptación de la noradrenalina, y está aprobado su uso en niños, adolescentes y adultos. Tiene menos potencial de abuso de estimulantes, está comprobado que controla los síntomas asociados por TDAH en adultos y niños hasta por $24 \mathrm{~h}$, pero su efecto terapéutico se alcanza hasta pasadas 3-4 semanas. Su mecanismo de acción aún es incierto, pero se cree que tiene una inhibición selectiva hacia los receptores del trasportador de norepinefrina. Se absorbe rápidamente después de su administración oral, con una biodisponibilidad del 63\% al 94\%. Su absorción no se afecta con las comidas. Su volumen de distribución es de $0.85 \% \mathrm{~L} / \mathrm{kg}$. Se une a un $98 \%$ de proteínas plasmáticas, principalmente albúmina. La atomoxetina es metabolizada principalmente por la CYP2D6 a 4 hidroxiatomoxetina. Tiene una vida media de 5 horas. La intoxicación con atomoxetina ocasiona los siguientes síntomas: somnolencia, agitación, hiperactividad, comportamiento anormal y síntomas gastrointestinales. Se administra a dosis de $1.2 \mathrm{mg} / \mathrm{kg}$, día en una sola dosis diaria ${ }^{6,33,34}$. 


\section{Trastorno por déficit de atención}

\section{C) Información sobre el Problema}

- Asesoramiento a los padres: El asesoramiento familiar debe centrarse en el entendimiento del padecimiento, el autocontrol y la expresión afectiva. Ayudar a los padres a desarrollar técnicas de solución de problemas, de reestructuración cognitiva y de relajación. Lo anterior favorecerá la aplicación de técnicas de disciplina y una adecuada comunicación con sus hijos con TDAH ${ }^{12,22}$.

- Colaboración con el colegio: La orientación psicopedagógica en la escuela es necesaria para una intervención eficaz en el ámbito académico. Debe tener en cuenta las características del colegio y su profesorado.

El trastorno por déficit de atención/hiperactividad (TDAH) tiene una fuerte carga hereditaria, pero también es el resultado de la interacción de factores ambientales y la susceptibilidad de múltiples genes que contribuyen al efecto genético total. Por lo tanto, el ambiente psicosocial desempeña un papel modulador fundamental sobre la predisposición biológica al TDAH, influyendo en la forma en la que la actividad, la impulsividad y la desatención son comprendidas y manejadas por la familia, la escuela o la sociedad ${ }^{6,33}$.

\section{Medidas de prevención}

Dado que el TDAH es de origen multifactorial, su prevención debe hacerse con medidas generales, como las siguientes $6,8,9,21,23$ :

- Consejo genético: es deseable que los miembros de la pareja no padezcan TDAH y no tengan familiares con TDAH.

- Control prenatal adecuado: atención médica de la madre durante el embarazo, evitando sustancias tóxicas que afecten al bebé; utilizando una nutrición adecuada.

- Atención adecuada del parto.

- Nutrición adecuada del niño para un desarrollo adecuado, donde no falten proteínas y ácidos grasos omega.

- Evitar padecimientos que afecten el desarrollo neurológico del niño: meningoencefalitis, traumatismo craneoencefálico, uso de drogas. 


\section{Principales problemas de Salud Pública en México}

- Propiciar la colaboración de los padres, entre sí, para el apoyo del desarrollo de los hijos, tomando conciencia de la importancia de esta labor.

- Diagnóstico temprano y tratamiento oportuno del TDAH para evitar complicaciones.

\section{Referencias}

1. Ozaki TJ. Frontal-to-parietal top-down causal streams along the dorsal attention network exclusively mediate voluntary orienting of attention. PLoS ONE. 2011; 6: $1-5$.

2. Fernández-Perrone A, Fernández-Mayoralas D, Fernández-Jaén A. Trastorno por déficit de atención/hiperactividad: del tipo inatento al tipo restrictivo. Rev Neurol. 2013; 56(Supl 1):S77-S84.

3. Pichot P, López J, Aliño I, Valdés Miyar M. Trastornos de inicio en la infancia, la niñez o la adolescencia. En: Asociación Psiquiátrica Americana. Manual diagnóstico y estadístico de los trastornos mentales. 4a ed. España: Masson; 1995. p. 39-128.

4. Ramos-Quiroga JA, Picado M, Mallorquí-Bagué M, Vilarroya O, Palomar G, Richarte $\mathrm{V}$, et al. Neuroanatomía del trastorno por déficit de atención/hiperactividad en el adulto: hallazgos de neuroimagen estructural y funcional. Rev Neurol. 2013; 56(Supl 1):S93-S106.

5. Elcirculoazul.com [internet]. México. Puente Colín L. 28 de abril, 2009, 16:36. Disponible en: http:/elcirculoazul.zoomblog.com/archivo/2009/04/28/tdah-Trastorno-por-deficitde-atencion.html

6. Sánchez-Mora C, Ribasés M, Mulas F Soutullo C, Sans A, Pàmias M, et al. Bases genéticas del trastorno por déficit de atención/hiperactividad. Rev Neurol. 2012; 55(10): 609-618.

7. Vásquez J, Cárdenas EM, Feria M, Benjet C, Palacios L, Peña F. Guía clínica para el trastorno por déficit de atención e hiperactividad. México: Instituto Nacional de Psiquiatría Ramón de la Fuente Muñiz; 2010.

8. Quintero J, Rodríguez-Quiróz J, Correas-Lauffer J, Pérez-Templado J. Aspectos nutricionales en el trastorno por déficit de atención/hiperactividad. Rev Neurol. 2009; 49(6):307-312. 


\section{Trastorno por déficit de atención}

9. Pineda DA, Puerta IC, Merchán V, Arango CP, Galvis AY, Velázquez B, et al. Factores perinatales asociados con la aparición del trastorno por déficit de atención en niños de la comunidad colombiana "paisa". Rev Neurol. 2003; 36(7):609-613.

10. Lajornada.com [internet]. México: Avilez K. Enero 2014. Disponible en: http://www. jornada.unam.mx/2004/01/12/045n1soc.php?origen=

11. Cardo E, Servera M. Trastorno por déficit de atención/hiperactividad: estado de la cuestión y futuras líneas de investigación. Rev Neurol. 2008; 46(6):365-372.

12. Miranda-Casas A, Grau-Sevilla D, Marco-Taberner R, Roselló B. Estilos de disciplina en familias con hijos con trastorno por déficit de atención/hiperactividad: influencia en la evolución del trastorno. Rev Neurol. 2007; 44(Supl 2):S23-S25.

13. Valdizán JR. Funciones cognitivas y redes neuronales del cerebro social. Rev Neurol. 2008; 46(Supl 1):S65-S68.

14. Rodríguez-Jiménez R, Cubillo A, Jiménez-Arriero M, Ponce G, Aragüés-Figuero M, Palomo T. Disfunciones ejecutivas en adultos con trastorno por déficit de atención e hiperactividad. Rev Neurol. 2006; 43(11):678-684.

15. Arnsten AFT. Toward a new understanding of attention-deficit hyperactivity disorder pathophysiology: an important role for prefrontal cortex dysfunction. CNS Drugs. 2009; 23(Suppl. 1):33-41.

16. Brennan AR, Arnsten AFT. Neuronal mechanisms underlying attention deficit hyperactivity disorder: the influence of arousal on prefrontal cortical function. NY Acad Sci. 2008; 1129:236-245.

17. Rubia K, Alegría A, Brinson H. Anomalías cerebrales en el trastorno por déficit de atención/hiperactividad: una revisión. Rev Neurol. 2014; 58(Supl 1):S3-S18.

18. Abad-Mas L, Ruiz-Andrés R, Moreno-Madrid F, Herrero R, Suay E. Intervención psicopedagógica en el trastorno por déficit de atención/hiperactividad. Rev Neurol. 2013; 57(Supl 1):S193-S203.

19. Ramos-Quiroga J, Chalita P, Vidal R, Bosch R, Palomar P, Prats L, et al. Diagnóstico y tratamiento del trastorno por déficit de atención/hiperactividad en adultos. Rev Neurol. 2012; 54(Supl 1):S105-S115. 


\section{Principales problemas de Salud Pública en México}

20. Cardo E, Servera M, Vidal C, de Azua B, Redondo M, Riutort L. Influencia de los diferentes criterios diagnósticos y la cultura en la prevalencia del trastorno por déficit de atención/hiperactividad. Rev Neurol. 2011; 52(Supl 1):S109-S117.

21. Pardos A, Fernández-Jaén A, Fernández-Mayoralas DM. Habilidades sociales en el trastorno por déficit de atención/hiperactividad. Rev Neurol. 2009; 48(Supl2):S107-S111.

22. Miranda Casas A, Presentación Herrero J, Colomer-Diago C, Roselló B. Satisfacción con la vida de niños con trastorno por déficit de atención/hiperactividad: estudio de posibles factores de riesgo y de protección. Rev Reurol. 2011; 52(Supl 1):S119.S126.

23. Roselló B, García-Castellar R, Tárraga-Mínges R, Mulas F. El papel de los padres en el desarrollo y aprendizaje de los niños con trastorno por déficit de atención con hiperactividad. Rev Neurol. 3002; 36(Supl 1):S79-S84.

24. Vaquerizo-Madrid J. Evaluación clínica del trastorno por déficit de atención/ hiperactividad, modelo de entrevista y controversias. Rev Neurol. 2008; 46(Supl 1): S37-S41.

25. Puentes J, Barceló E, Pineda D. Características conductuales y neuropsicológicas de niños de ambos sexos, de 6 a 11 años, con trastorno por déficit de atención/ hiperactividad. Rev Neurol. 2008; 47:175-84.

26. Cardo E, Casanovas S, Banda G, Servera M. Signos neurológicos blandos: ¿tienen alguna utilidad en la evaluación y diagnóstico del trastorno por déficit de atención/ hiperactividad? Rev Neurol. 2008; 46(Supl 1):S51-S54.

27. Escobar Mendoza E, Schmidt Vacaflores G, Sardinas Castellón S. Alteraciones electroencefalografícas y trastorno por déficit de atención. Rev Soc Bol Ped. 2011; 50(1):3-6.

28. Madera-Carrillo H, González-Garrido AA, Gómez-Velázquez FR, Enríquez-de Rivera D. Análisis cuantitativo del electroencefalograma para confirmar trastorno funcional frontal en niños con trastorno por déficit de atención con hiperactividad. Gac Méd Méx. 2007; 145(5):391-400.

29. Montañés-Rada F, Gangoso-Fermoso A, Martínez-Granero M. Fármacos para el trastorno por déficit de atención/hiperactividad. Rev Neurol. 2009; 48(9):469-481.

30. Loro-López M, Quintero J, García-Campos N, Jiménez-Gómez B, Pando F, VarelaCasal $\mathrm{P}$, et al. Actualización en el tratamiento del trastorno por déficit de atención/ hiperactividad. Rev Neurol. 2009; 49(5):257-264. 


\section{Trastorno por déficit de atención}

31. Mulas F, Gandía R, Roca P, Abad L. Actualización farmacológica en el trastorno por déficit de atención/hiperactividad: modelos de intervención y nuevos fármacos. Rev Neurol. 2012; 54(Supl 3):S41-S53.

32. Mardomingo-Sanz MJ. Uso clínico de metilfenidato 30:70 de liberación modificada en el tratamiento del trastorno por déficit de atención/hiperactividad. Rev Neurol. 2012; 55(6):359-369.

33. Laurence L, Bruton S, Lazo JL, Parker K. Las bases farmacológicas de la terapéutica. 10a ed. México: McGraw-Hill; 2007. p. 259-263.

34. Velázquez-Tirado JD, Peña JA. Evidencia actual sobre la atomoxetina. Alternativa terapéutica para el trastorno por déficit de atención e hiperactividad. Rev Neurol. 2005; 41(8):493-500. 



\section{Obesidad y los problemas de malnutrición}

Dra. María Luisa Ponce López

Mtra. Xochitl Ponce Martínez Alma Rosa Silva Barrios

\section{Introducción}

Los conceptos de transición nutricional y de la doble carga de malnutrición fueron introducidos en los últimos 20 años para describir el efecto de los cambios alimentarios producidos por el crecimiento económico, tecnológico que se ha vivido en los países en vías de desarrollo. La carga doble de la malnutrición se refiere a la presencia simultánea de desnutrición y sobrenutrición en una población

La malnutrición incluye fenómenos de subnutrición y sobrenutrición. La subnutrición se manifiesta en padecimientos por falta en el aporte de vitaminas y nutrimentos inorgánicos principalmente, hierro, zinc, vitamina D, vitamina B12, manifestándose en padecimientos como anemia, crecimiento ponderal inadecuado, emaciación, retraso en el desarrollo cognitivo entre otros. La sobrenutrición se expresa en enfermedades como la obesidad, diabetes mellitus tipo 2, Hipertensión Arterial Sistémica (HAS), dislipidemias, enfermedades metabólicas, estos padecimientos son provocados por el consumo excesivo de alimentos con alta densidad energética y pobre en nutrimentos, es decir alimentos con pobre calidad nutricional.

La carga doble de malnutrición es característica de los países en vías de desarrollo y poblaciones marginadas, debido al crecimiento acelerado de la población, urbanización acelerada, escasez de recursos, infraestructura inadecuada, acceso limitado a servicios básicos de salud y desigualdad social. Así las políticas alimentarias y sociales deben ir encaminadas a combatir la carga doble de malnutrición.

El presente capítulo pretende documentar los cambios alimentarios en México producidos por el crecimiento económico, la facilidad en la accesibilidad y disponibilidad tecnológica y alimentaria así como los efectos en el estado de nutrición de la población. 


\section{Principales problemas de Salud Pública en México}

\section{Concepto}

El origen etimológico de la palabra "malnutrición" proviene del latin malus (malo) y nutrire (nutrir), es decir un estado de nutrición incorrecto, fuera de los márgenes saludables debido a una alimentación inadecuada, ya sea por la subnutrición, es decir la deficiencia o carencia de uno o más nutrimentos o sobrenutrición, exceso de uno o más nutrimentos En términos generales la obesidad es una enfermedad metabólica caracterizada por el incremento del peso corporal asociado a un desequilibrio en las proporciones de los diferentes componentes del organismo, en la que aumenta fundamentalmente la masa grasa con anormal distribución corporal, se considera hoy en día una enfermedad crónica originada por muchas causas y con numerosas complicaciones ${ }^{2}$.

\section{Clasificación}

Los esfuerzos para clasificar la desnutrición o al estado en el que existe un balance insuficiente de uno o más nutrimentos y que manifieste un cuadro clínico característico, comenzaron con los trabajos realizados por un grupo de investigadores mexicanos en los años 50's liderados por el Dr. Federico Gómez ${ }^{3}$, quienes clasificaron la desnutrición en primero, segundo y tercer grado, de acuerdo al peso para la edad. En los años 70's se clasificó a la desnutrición en tres dominios, el primero se basa en aquellos individuos que no logran alcanzar la talla para la edad con un peso adecuado para su talla sin embargo se han ido adaptando, es decir que existe un retraso en el crecimiento conocido como desnutrición crónica. El segundo, consistió en una delgadez excesiva o emaciación y se le denominó desnutrición aguda con un peso disminuido para su talla, el tercero, derivado de los trabajos de los mexicanos reside en un peso para la edad deficiente, situación frecuente en menores de dos años.

Fue hasta el año 2000 que se estableció el uso del Índice de Masa Corporal (IMC) para la edad como parámetro para clasificar el estado de nutrición en la población ${ }^{4}$. Al respecto, la Organización Mundial de la Salud (OMS) ha propuesto una clasificación del grado de nutrición de acuerdo al índice ponderal como criterio ${ }^{5,6,7}$.

- Bajo peso $:<18,5$ :

○ Delgadez severa: $<16 \mathrm{~kg} / \mathrm{m}^{2}$ 


\section{Obesidad y los problemas de mal nutrición}

○ Delgadez moderada: $16-16,99 \mathrm{~kg} / \mathrm{m}^{2}$

○ Delgadez leve : $17-18,49 \mathrm{~kg} / \mathrm{m}^{2}$

- Normopeso: IMC 18,5 - 24,9 kg/m²

- Sobrepeso: IMC $25-29 \mathrm{~kg} / \mathrm{m}^{2}$ :

- Obesidad grado I con IMC $30-34 \mathrm{~kg} / \mathrm{m}^{2}$

- Obesidad grado II con IMC $35-39,9$ kg/m²

○ Obesidad grado III con IMC $>=40 \mathrm{~kg} / \mathrm{m}^{2}$

- Obesidad de tipo IV (extrema) con IMC >50

Según la Norma Oficial Mexicana NOM-008-SSA3-2010, para el tratamiento integral del sobrepeso y la obesidad ${ }^{5}$, considera los siguientes criterios para población mexicana:

- Estatura baja, a la clasificación que se hace como resultado de la medición de estatura menor a 1.50 metros en la mujer adulta y menor de 1.60 metros para el hombre adulto.

- Sobrepeso, al estado caracterizado por la existencia de un IMC igual o mayor a $25 \mathrm{~kg} /$ $\mathrm{m}^{2}$ y menor a $29.9 \mathrm{~kg} / \mathrm{m}^{2}$ y en las personas adultas de estatura baja, igual o mayor a 23 $\mathrm{kg} / \mathrm{m}^{2}$ y menor a $25 \mathrm{~kg} / \mathrm{m}^{2}$.

- Obesidad, a la enfermedad caracterizada por el exceso de tejido adiposo en el organismo, la cual se determina cuando en las personas adultas existe un IMC igual o mayor a 30 $\mathrm{kg} / \mathrm{m}^{2}$ y en las personas adultas de estatura baja igual o mayor a $25 \mathrm{~kg} / \mathrm{m}^{2}$.

- En menores de 19 años, el sobrepeso se determina cuando el IMC se encuentra desde la percentil 85 y por debajo de la 95, de las tablas de edad y sexo de la OMS.

- En menores de 19 años, la obesidad se determina cuando el IMC se encuentra desde la percentil 95 en adelante, de las tablas de IMC para edad y sexo de la OMS. 


\section{Principales problemas de Salud Pública en México}

En la edad pediátrica, la OMS (OMS), establece los criterios de obesidad de alto riesgo, sobre peso de alto riesgo u obeso, sobre peso o en riesgo y peso saludable (Cuadro 1$)^{8}$.

Cuadro 1. Criterios para clasificar el peso en edad pediátrica.

\begin{tabular}{|l|l|}
\hline \multicolumn{1}{|c|}{ Tipo de peso } & \multicolumn{1}{c|}{ Criterios } \\
\hline Obeso de alto riesgo & $\bullet$ Índice de masa corporal $\geq$ Pc 95 \\
\hline & $\bullet$ Índice de masa corporal $\geq$ Pc 95; o \\
& $\bullet$ Índice de masa corporal $\geq$ Pc 85; y uno de los siguientes: \\
& $\circ$ Historia familiar positiva \\
& $\circ$ Hirsutismo \\
Sobrepeso de alto & $\circ$ Amenorrea secundaria u oligomenorrea \\
riesgo u obeso & $\circ$ Aumento brusco de peso \\
& $\circ$ Preocupación por el peso \\
& $\circ$ Características de otra patología o síndrome \\
& $\circ$ Presión arterial elevada \\
\hline Sobre peso o en riesgo & $\bullet$ Índice de masa corporal $\geq$ al percentil 75 y < al percentil 95 \\
\hline Peso saludable & $\bullet \quad$ Índice de masa corporal < al percentil 75 \\
\hline
\end{tabular}

Retomado de: OMS, 2006.

La OMS propone también el uso del puntaje Z, que permite evaluar y seguir antropométricamente en forma más precisa tanto a niños que están dentro del rango de normalidad como a los que estén por fuera de los mismos parámetros. Permite valorar en forma numérica cuánto se alejan de los valores normales de la media de la normalidad poblacional y monitorear su evolución en forma más precisa (Cuadro 2).

Cuadro 2. Puntaje Z para evaluar estado nutricional en niños.

\begin{tabular}{|l|l|}
\hline \multicolumn{1}{|c|}{ Estado nutricional } & \multicolumn{1}{c|}{ Parámetros observados } \\
\hline Normal & entre $<1$ y 1 DE \\
\hline Bajo peso & entre $<1$ y 2 DS \\
\hline Emaciado & $<2$ DS \\
\hline Sobrepeso & entre $>1$ y 2 DS \\
\hline Obesidad & $>2$ DS \\
\hline
\end{tabular}

Retomado de: http://www.who.int/childgrowth 


\section{Obesidad y los problemas de mal nutrición}

También la obesidad se puede clasificar según la distribución de la grasa, en obesidad androide, ginecoide y homogénea:

- Obesidad androide: También conocida como obesidad abdominal, se presentan en un mayor número de casos en varones que en mujeres. Se caracteriza por el acúmulo de grasa por encima de la cintura. Se trata de un factor predisponente para enfermedades como: hipertensión arterial, enfermedades cardiovasculares, colelitiasis, hiperinsulinismo y diabetes mellitus.

- Obesidad ginecoide: Con mayor frecuencia en mujeres que en varones. Caracterizada por la acumulación de grasa en el bajo vientre, caderas y muslos ${ }^{5,9}$.

- Obesidad de distribución homogénea: es aquella en la que el exceso de grasa no predomina en ninguna zona del cuerpo.

De acuerdo a los consensos de expertos los sujetos se los clasifica en función del porcentaje grasa corporal, cuando este está por encima del $25 \%$ en los varones y del $33 \%$ en las mujeres los podemos catalogar como personas obesas. Los valores comprendidos entre el 21 y el 25\% en los varones y entre el 31 y el 33\% en las mujeres se consideran límites.

\section{Epidemiología}

El sobrepeso y la obesidad son actualmente uno de los principales problemas de Salud Pública. Sin embargo, las enfermedades por carencia de nutrimentos también están presentes.

$>$ Transición epidemiológica

$\mathrm{Al}$ respecto, la teoría de la transición epidemiológica fue descrita por Abdel Omran ${ }^{10}$. En donde el autor describió el complejo cambio de los patrones de morbi-mortalidad en los países del norte de Europa, la interacción entre dichos patrones y sus determinantes demográficas, económicas, sociológicas y sus consecuencias. Durante la transición epidemiológica se observa que las muertes por enfermedades infecciosas son desplazadas por muertes debido a enfermedades crónicas, este fenómeno tardó siglos en dichos países. Durante ese tiempo, la población y la esperanza de vida aumentaron y se presentaron cambios industriales. Las zonas rurales eran mayoritarias en comparación a las zonas urbanas. 


\section{Principales problemas de Salud Pública en México}

\section{Transición demográfica}

También, México ha experimentado un cambio demográfico, de acuerdo a los datos del Instituto Nacional de Estadística y Geografía (INEGI), en los años 50's el 42.6 \% de la población mexicana residía en zonas urbanas, en cambio en el año 2010 esta cifra aumentó a $76.8 \%$. Los cambios epidemiológicos también se han visto afectados; en los años 30's las personas morían principalmente a causa de enfermedades transmisibles como, parásitos e infecciones en el aparato digestivo o respiratorio. En el 2010 las principales causas de defunción en México fueron las enfermedades isquémicas del corazón, diabetes mellitus y tumores malignos ${ }^{11}$. Además, una de las características de México es la diferencia epidemiológica entre regiones del país, zonas urbanas y rurales y niveles socioeconómicos. La explicación de estas diferencias es la polarización epidemiológica y nutricional en las diferentes poblaciones, además que los Servicios de Salud atraviesan por un cambio en la atención, ya que anteriormente ésta iba dirigida a tratar enfermedades agudas y actualmente va orientada a prevenir obesidad y sus enfermedades asociadas ${ }^{12}$.

\section{Transición nutricional}

La sobrenutrición como problema de Salud Pública tomó interés hasta hace pocos años. El Dr. Barry Popkin introdujo el término de transición nutricional en $1994{ }^{13}$ como fenómeno asociado a cambios alimentarios de una dieta tradicional a una occidental es decir a un aumento en el consumo de proteínas, grasas y azúcares refinados junto con la reducción de hidratos de carbono complejos y fibra ${ }^{14}$. Junto con este fenómeno de cambios en la alimentación ha habido una reducción en la actividad física, ya que la población utiliza de forma más frecuente aparatos tecnológicos que impiden la realización de actividad física. Como el cambio de equipos para trabajar con vehículos motorizados, o bien sustituir el desplazamiento de un lugar a otro a pie, por transporte automovilístico. Ambos cambios, alimentarios y de actividad, han contribuido al incremento en la prevalencia de sobrepeso y obesidad, alimentarios y de actividad, han contribuido al incremento en la prevalencia de sobrepeso y obesidad. La alta prevalencia de subnutrición ha cambiado en conjunto con la transición demográfica y epidemiológica, con alto porcentaje de sobrepeso, obesidad y sus enfermedades asociadas (diabetes mellitus tipo 2, hipertensión arterial y dislipidemias) en la población, así el interés por las enfermedades infecciosas han perdido importancia. 


\section{Obesidad y los problemas de mal nutrición}

No obstante, las encuestas de salud dejan ver que los problemas de desnutrición aún se presentan en la población, así las etapas clásicas de la transición epidemiológica no corresponden a lo que se observa actualmente en los países en desarrollo, en donde coexisten los problemas y enfermedades por desnutrición y sobrenutrición ${ }^{15}$.

En México se ha experimentado en los últimos años un aumento en el consumo de alimentos procesados, con contenido elevado en grasa, azúcar y sal. Mayor consumo de comida rápida y alimentos preparados fuera de casa y de bebidas azucaradas.

Se ha observado una disminución en el consumo de frutas y verduras, leche, carnes en paralelo a un aumento de hidratos de carbono simples, bebidas azucaradas y productos con mayor contenido en grasa. También se ha observado una mayor exposición de publicidad de alimentos industrializados y mejor acceso a aparatos que facilitan los trabajos y las tareas cotidianas disminuyendo el gasto energético ${ }^{16}$.

Además se observan diferencias en el consumo de nutrimentos en los diferentes sectores de la población en México; mayor consumo de grasas totales, grasas saturadas, colesterol junto con menor consumo de fibra y frutas y verduras en zonas urbanas que en áreas rurales ${ }^{17}$.

$>$ Carga doble de malnutrición en México

La carga doble de malnutrición que se observa en nuestro país tiene las siguientes características:

- La anemia, la emaciación y el sobrepeso continúan siendo problemas de Salud Pública en niños preescolares y escolares.

- La más alta prevalencia de desnutrición, crecimiento lineal es la baja talla.

- La anemia por deficiencia de hierro continúa siendo un problema de Salud Pública en las embarazadas.

- Existe un incremento acelerado de sobrepeso y obesidad en todos los sectores de la población incrementándose cada vez más en edades tempranas. 


\section{Principales problemas de Salud Pública en México}

Las enfermedades del corazón, la diabetes mellitus y enfermedades crónicas no transmisibles han ido en aumento, mientras que las enfermedades por infecciones han disminuido, reapareciendo otras nuevamente.

\section{Magnitud del problema}

De acuerdo a los datos de la última Encuesta Nacional de Salud en México (ENSANUT-2012) $11^{16}$, el $2.8 \%$ de la población menor de cinco años presentó bajo peso, $1.6 \%$ emaciación y $13.6 \%$ de talla baja. El retraso en el crecimiento o baja talla refleja los efectos negativos acumulados en un periodo de tiempo largo de la mala nutrición en este sector de la población. A pesar que ha habido una disminución desde el año 1988 al 2012 de la desnutrición aguda en niños menores de cinco años, este problema de nutrición sigue aún presente en nuestro país. Debe de recordarse que la desnutrición aguda incrementa el riesgo de padecer enfermedades infecciosas. Por otro lado, la prevalencia de sobrepeso y obesidad en menores de cinco años ha registrado un ascenso a lo largo de 1988 a 2012 (de $7.8 \%$ a 9.7\%, respectivamente). En cuanto a la deficiencia de hierro la ENSANUT-2012 mostró una prevalencia de anemia en niños de 1 a 4 años de edad de $23.3 \%$ y en niños de 5 a 11 años de $10.1 \%$. Además la mayor prevalencia se observó en zonas rurales en comparación a las urbanas ( $25.2 \%$ vs. $22.6 \%$ en preescolares y $11.7 \%$ vs $9.7 \%$ en escolares), lo anterior puede ser explicado a menor disponibilidad y acceso de alimentos con hierro biodisponible y mayor consumo de fitatos en la dieta. En las embarazadas se registró una prevalencia de anemia del $17.9 \%$. De acuerdo a la OMS la anemia deja de ser un problema de Salud Pública cuando la prevalencia es menor del $5 \%{ }^{14,18}$, por lo que en nuestro país aún este padecimiento continúa siendo un problema que debe de ser prioritario en la agenda nacional.

En cuanto al sobrepeso y la obesidad, las cifras en México son alarmantes; la prevalencia de sobrepeso y obesidad en población pre-escolar (menores de cinco años) registró un ligero ascenso entre 1988 y 2012, pasando de 7.8\% a 9.7\%. De acuerdo a los datos de la ENSANUT-2012, la prevalencia combinada de sobrepeso y obesidad en niños y niñas en edad escolar fue de $34.4 \%$ (sobrepeso: $19.8 \%$ y obesidad: $14.6 \%$ ). En este mismo grupo de edad, las niñas presentaron una prevalencia combinada de $32 \%$, (sobrepeso: $20.2 \%$ y obesidad: $11.8 \%$ ), mientras que los niños mostraron una prevalencia de sobrepeso de $19.5 \%$ y $17.4 \%$ de obesidad, la prevalencia combinada fue de $36.9 \%$. En la población adolescente, los datos de la ENSANUT-2012 revelan que la prevalencia nacional combinada de 


\section{Obesidad y los problemas de mal nutrición}

sobrepeso y obesidad fue de $35 \%$ en ambos sexos; en las adolescentes fue de $35.8 \%$ y $34.1 \%$ en los adolescentes. La proporción de adolescente con sobrepeso fue mayor en las mujeres (23.7\%) que en los hombres (19.6\%). Lo contrario se observa en la prevalencia de obesidad; el porcentaje de adolescentes de sexo masculino con obesidad fue de $14.5 \%$ y en el sexo femenino de 12.1\%. Los datos de la ENSANUT-2012 registraron una prevalencia combinada de sobrepeso y obesidad en las mujeres mayores de 20 años del 73 \% y en los hombres de $69.4 \%$. Al igual que en las otras poblaciones mexicanas de menor edad, se observa un incremento de sobrepeso y obesidad en los últimos seis años en la población femenina, en el 2006 se registró una prevalencia de $71.9 \%$. La obesidad se ha convertido en la enfermedad metabólica más prevalente en los países desarrollados ${ }^{19}$.

En los adultos mexicanos se observa una prevalencia de obesidad abdominal del $64.5 \%$ en hombres y $82.8 \%$ en mujeres. La prevalencia de obesidad abdominal más alta se registró en el grupo de 50 a 59 años en mujeres (93.9\%) y en hombres en el grupo de 60 a 69 años (78.3\%).

Los datos de la ENSANUT-2012 muestran que la prevalencia nacional de obesidad en cuanto a área de residencia fue de $34 \%$ en las zonas urbanas y del $26.5 \%$ en zonas rurales.

México ocupa el segundo lugar de los países con mayor índice de obesidad en su población con $30 \%$ de la población con esta enfermedad, superado sólo por Estados Unidos, con $33.8 \%$. Los países con menor índice de obesidad son Japón y Corea, con $4 \%$. Además la obesidad infantil es actualmente un problema de salud en México. Existen más de 4 millones de niños con sobrepeso y obesidad. Se sabe que 1 de cada 5 niños tiene problemas de sobrepeso. México ocupa el cuarto lugar en obesidad infantil sólo superado por Grecia, Italia y Estados Unidos. Es importante tratar esta entidad ya que un niño con sobrepeso $\mathrm{u}$ obesidad tiene mayor riesgo de serlo en la vida adulta, lo que puede traducirse a disminución en la calidad de vida y aumento del ausentismo laboral, lo que conlleva a empobrecimiento en las familias.

Un estudio realizado por el Dr. Barquera ${ }^{20}$ reportó una prevalencia del 6.2\% de coexistencia de obesidad central materna con hijos desnutridos, siendo mayor en áreas rurales, la región sur del país y entre familias indígenas $(14.5,12.5$ y $23.9 \%$ respectivamente). 


\section{Principales problemas de Salud Pública en México}

\section{Causalidad}

Las causas de la malnutrición y de la obesidad son multifactoriales, entre ellas se encuentran la urbanización o vivir en zonas rurales, la capacidad para la distribución de los alimentos y su adquisición, por parte de los pacientes, determinados por los aspectos culturales, sociales, económicos, psicológicos y biológicos.

\section{Factores contribuyentes a la malnutrición}

De acuerdo a la OMS, la desnutrición y la obesidad son dos de los diez factores de riesgo de enfermedades en el mundo. La aparición de estas dos condiciones de malnutrición en los países con bajos recursos es un fenómeno cuyos factores de riesgo son: la urbanización acelerada, la desigualdad social, económica, de acceso a los Servicios de Salud entre las poblaciones ${ }^{21}$. De acuerdo a las proyecciones de las Naciones Unidas, en el año 2030 cerca de 4.9 billones de personas (o el 60\% de la población mundial) vivirán en zonas urbanas ${ }^{22}$.

La expansión de las zonas urbanas tiene cuatro grandes consecuencias para la seguridad alimentaria:

1. Las demandas de espacios para vivir o para la industria compromete a la tierra para la producción agrícola, así estos espacios para la agricultura se pierden.

2. Aumento de la importación y distribución de los alimentos hacia las ciudades, lo que se traduce a mayor tráfico de camiones de carga en las ciudades, mayor contaminación ambiental, construcción de calles y avenidas sin planeación e ineficientes.

3. Modificación en la adquisición y consumo de alimentos. El costo de los alimentos en zonas urbanas es 30\% mayor que en zonas rurales, así los habitantes de las ciudades pagan más por la obtención de sus alimentos y tienen menos tiempo para preparar sus alimentos, lo que provoca mayor demanda de alimentos de la calle, obtenidos de establecimientos sin infraestructura adecuada, oferta de alimentos poco higiénicos, procesados, con alta densidad energética y pobre en micronutrimentos.

4. La disminución del apoyo al campo ha hecho que disminuya el trabajo agrícola, así las personas que realizaban estas labores han tenido que inmigrar a las ciudades. Estas 


\section{Obesidad y los problemas de mal nutrición}

personas generalmente se establecen en área perturbanas con acceso limitado o nulo a agua potable, calles, electricidad, mercados y servicios básicos de salud. Estas personas tienen menor posibilidad de acceder a refrigeradores $\mathrm{u}$ otros aparatos para preparar los alimentos. Lo anterior se traduce a que las personas de zonas urbanas pobres enfrenten un costo adicional a la obtención diaria de sus alimentos en tiempo.

El crecimiento acelerado de estas zonas hace que no exista una planeación en la infraestructura de sanidad y Servicios de Salud, así el progreso en mejorar el sistema de agua y sanidad ha sido lenta, el desarrollo de los sistemas de Salud Pública débil al igual que los programas sociales para reducir la desnutrición. A la par, el incremento acelerado en la urbanización ha provocado que exista una mayor proporción de personas con bajos recursos que viven en estas zonas, con deficiencia en las condiciones de sanidad y Servicios de Salud, mayor desigualdad social, y mayor acceso a los medios de comunicación. Todos estos factores han contribuido a que existan cambios en los patrones alimentarios y de estilos de vida lo que contribuye al aumento acelerado en la prevalencia de sobrepeso, obesidad y sus enfermedades asociadas en conjunto con padecimientos por falta de vitaminas y nutrimentos inorgánicos, como por ejemplo la anemia o niños con baja talla.

Factores que favorecen el sobrepeso y obesidad.

Existen varios factores que influyen en la ganancia de grasa corporal, entre ellos se encuentra: la predisposición genética en un $5 \%$, los factores ambientales y conductuales, el envejecimiento, y los embarazos en un $95 \%$. Sin embargo la principal causa del incremento acelerado en los últimos años del sobrepeso y la obesidad se encuentra asociado al estilo de vida, principalmente a un exceso en el consumo de energía acompañado de sedentarismo. Este exceso de energía se acumula en el cuerpo en el tejido adiposo. Ambos factores, dietéticos y la actividad física, tienen una gran influencia en la ecuación del equilibrio energético, y se consideran los factores que con mayor facilidad pueden modificarse. De hecho, los datos asociados al incremento en la prevalencia de sobrepeso y obesidad en el mundo se ven acompañado de un incremento en el consumo de ácidos grasos saturados, trans, azúcares y una disminución en el consumo de verduras, frutas y fibra, en conjunto con un mayor uso de vehículos y disminución de la actividad física.

a) Causas prenatales, perinatales y genéticas: Son muchos los factores relacionados con la obesidad; aunque más del 90\% de las causas están relacionadas con la ingesta calórica. 


\section{Principales problemas de Salud Pública en México}

Cada vez se da más importancia a los factores genéticos y factores de programación intrauterina como condicionantes de este fenómeno ${ }^{23,24,25}$. La obesidad materna, ganancia de peso materno durante el embarazo por sobrealimentación, la presentación de diabetes gestacional y otras patologías asociadas condicionan mayor ganancia de peso del niño al momento del nacimiento relacionada con el fenómeno de hiperinsulinismo, hiperleptilemia, alteraciones en el metabolismo de la glucosa y de los ácidos grasos ${ }^{23}$. En la obesidad, en etapas tempranas de la vida, es importante diferenciar la obesidad ocasionada por anormalidades genéticas de aquellas formas comunes. En algunos casos mutaciones en un solo gen, pueden tener un efecto importante sobre el índice de masa corporal (IMC); de la misma forma, se ha demostrado en las madres con mayores índices de masa corporal en el embarazo y/o antecedente de haber presentado síndrome de ovario poliquístico, pareciera existir mayor predisposición para hijos obesos y/o con síndrome metabólico en la vida posnatal ${ }^{20,23}$.

b) Historial familiar: Los niños adoptan los hábitos de sus padres. Así, un niño de padres con sobrepeso, que consuman alimentos con alto contenido de calorías y sean poco activos, probablemente llegará a tener sobrepeso también. Por otra parte, si la familia adopta hábitos saludables respecto a la alimentación y el ejercicio, disminuirán las probabilidades de que el niño llegue a tener sobrepeso u obesidad. La obesidad tiende a ser parte de la familia; y eso no es sólo por la genética, los miembros de la familia tienden a tener hábitos alimenticios similares, de estilo de vida y de actividades. Si uno o dos de los padres son obesos, el riesgo de que una persona sea obesa es más grande, pero en parte también se debe a que los hábitos culturales alimentarios y sedentarios contribuyen a repetir los patrones de obesidad de padres a hijos ${ }^{26}$.

c) Factores psicológicos: Por otro lado los factores psicológicos también han sido objeto de estudio en el paciente con obesidad. También hay estudios que identifican comportamientos compulsivos y ansiosos en el patrón de alimentación de los niños y adultos obesos. Inclusive algunos estudios han reportado abuso sexual durante la infancia en pacientes que presentan obesidad en la edad adulta ${ }^{27,28}$, entre otros factores, y divorcios entre los padres, duelos psicológicos, aislamiento, estigmatización. Es importante indagar en los aspectos psicológicos que puedan ser sustrato de una conducta alimentaria anómala y encauzar estas observaciones para que el grupo multidisciplinario llegue a la identificación y tratamiento de los mismos. 


\section{Obesidad y los problemas de mal nutrición}

d) Edad: A medida que uno envejece, tiende a perder masa muscular, especialmente si hace menos ejercicio. La pérdida de masa muscular puede disminuir la velocidad en la que el cuerpo quema calorías. Si la persona no reduce el consumo de calorías a medida que envejece, puede aumentar de peso. El aumento de peso en mujeres de edad madura se debe principalmente al envejecimiento y al estilo de vida, pero la menopausia también interviene. Muchas mujeres aumentan kilos durante la menopausia y tienen más grasa alrededor de la cintura que la que tenían antes.

e) Trastornos alimentarios relacionados con el sueño: Se ha demostrado en investigaciones que la falta de sueño aumenta el riesgo de obesidad. Por ejemplo, un estudio realizado en adolescentes demostró que las probabilidades de volverse obeso aumentaban con cada hora de sueño perdido. La falta de sueño también aumenta el riesgo de obesidad en otros grupos de edad. Las personas que duermen menos horas también parecen preferir los alimentos que contienen más calorías y hidratos de carbono (alimentos dulces, salados y ricos en fécula), con lo cual pueden comer en exceso, aumentar de peso y volverse obesas. El sueño mantiene un equilibrio saludable de la hormona que estimula el apetito (la grelina) y de la que nos hace sentir saciedad (la leptina). Cuando usted no duerme lo suficiente, la concentración de grelina aumenta y la de leptina disminuye. Entonces siente más apetito que cuando se ha descansado bien. El sueño también afecta la forma en que el organismo reacciona a la insulina, la hormona que controla la concentración de glucosa en la sangre, los períodos reducidos de sueño están asociados con una menor tolerancia a la glucosa y una mayor concentración de cortisol en sangre. La tolerancia a la glucosa es un término que describe el modo en que el organismo controla la disponibilidad de la glucosa presente en la sangre para los tejidos y el cerebro. En períodos de ayuno, el elevado nivel de glucosa y de insulina de la sangre indica que la administración de glucosa realizada por el cuerpo es inadecuada. Existen pruebas que demuestran que la baja tolerancia a la glucosa es un factor de riesgo para la diabetes de tipo 2. Los estudios sugieren que la restricción de sueño a largo plazo (menos de 6,5 horas por noche) puede reducir la tolerancia a la glucosa en un $40 \%$. Hay también que tener en cuenta que cuantas menos horas se duerme, más tiempo hay para comer y beber. Existen estudios que demuestran que éste es un factor que contribuye a los aspectos obesogénicos de la reducción del número de horas de sueño. La falta de sueño provoca una concentración de glucosa en la sangre más alta que la normal, con lo cual puede aumentar el riesgo de sufrir diabetes $29,30,31,32,33$. 


\section{Principales problemas de Salud Pública en México}

f) Condiciones sociales y económicos: Ciertas condiciones sociales y económicas pueden ligarse con la obesidad, por ejemplo, la falta de acceso a áreas seguras para hacer ejercicio, el haber aprendido maneras poco saludables para cocinar y comer, el no contar con suficiente dinero para comprar frutas y vegetales frescos, o alimentos que no han sido procesados, empaquetados con alta densidad calórica, la falta de oportunidades para adopción de estilos de vida saludables ${ }^{24}$.

g) Otros aspectos causales de la obesidad: Como se evidencia, la etiología de la obesidad es multifactorial y nunca se dará solución o tratamiento si hacemos el enfoque en una sola ruta: siempre existen factores ambientales que modifican condiciones genéticas para expresar o reprimir la presentación de obesidad, y siempre el adecuado soporte psicológico del paciente y su familia permitirá el mantenimiento en peso saludable a través de la modificación de hábitos y solución de alteraciones comportamentales si las hubiere Aunque es relevante señalar que el diagnóstico de la obesidad en más de un $90-95 \%$ corresponde a factores relacionados con los estilos de vida alimentarios y sedentarismo los cuales son exógenos y de alguna manera influyen también en la expresión genética.

Es importante evaluar la posibilidad de alteraciones genéticas, los genes de una persona pueden afectar la cantidad de grasa que se almacena y cómo ésta se distribuye. La genética también juega un papel importante en cómo el cuerpo convierte eficientemente los alimentos en energía y en cómo el cuerpo degrada calorías durante el ejercicio aunque esta predisposición se da en un 3-5\% aproximadamente. Otras causas endógenas son las endocrinológicas o medicamentosas que la condicionen también. Por lo tanto, se obliga la exclusión de diagnósticos diferenciales mediante la realización de una buena historia clínica que arroje datos donde se pueden diferenciar los tipos de obesidad según sus causas, que pueden ser obesidad endógena y la obesidad exógena (Cuadros 3 y 4$)$.

Cuadro 3. Factores que favorecen la obesidad primaria o exógena de causa no delimitada.

Incremento de las actividades sedentarias: hábito de ver televisión, videojuegos

Disponibilidad de comidas rápidas, industrializadas alto contenido energético
Pequeño para edad gestacional y rápida recuperación o productos macrosómicos

Mutaciones en péptidos orexígenos y anorexígenos 


\section{Obesidad y los problemas de mal nutrición}

Cuadro 4. Factores que favorecen la obesidad primaria o exógena de causa no delimitada.

\begin{tabular}{|l|l|}
\hline $\begin{array}{l}\text { Multifactorial, susceptibilidad } \\
\text { multigenética. Obesidad familiar }\end{array}$ & Factores psicológicos y familiares \\
\hline Soledad, aislamiento social & Factores perinatales \\
\hline Nivel educativo & Urbanización \\
\hline
\end{tabular}

Retomado de: Prevención de la obesidad infantil. En: Recomendaciones PrevInfad/ PAPPS.

Cuadro 5. Factores que favorecen la obesidad secundaria o endógena de causa conocida.

\begin{tabular}{|l|l|}
\hline Trastornos psicológicos: bulimia reactiva. & $\begin{array}{l}\text { Administración de glucocorticoides, } \\
\text { valproato sódico, algunos psicotrópicos. }\end{array}$ \\
\hline Síndromes dismórficos & Secuelas posinfección \\
\hline $\begin{array}{l}\text { Lesiones del SNC: retraso mental, } \\
\text { traumatismos, tumores, espina bífida. }\end{array}$ & $\begin{array}{l}\text { Enfermedades de las glándulas } \\
\text { endocrinas: hipotiroidismo, } \\
\text { hiperinsulinismo, hipopituitarismo, } \\
\text { hipercorticismo (síndrome y enfermedad } \\
\text { de Cushing), síndrome de Stein-Leventhal, } \\
\text { insulinoma. }\end{array}$ \\
\hline Lesiones del hipotálamica & Genética \\
\hline
\end{tabular}

Retomado de: Aranceta J. Definición, clasificación y epidemiología de la obesidad en distintas etapas de la vida. ${ }^{30}$

\section{Fisiopatología}

Se resumen algunos de los muchos posibles mecanismos fisiopatológicos involucrados en el desarrollo y mantenimiento de la obesidad ${ }^{26,34}$, entre estos debe mencionarse el descubrimiento de la leptina en el año 1994, gracias al cual se ha dilucidado muchos otros mecanismos hormonales que participan en la regulación del hambre y consumo de alimentos, así como en los patrones de almacenamiento en el tejido adiposo y en el desarrollo de resistencia a la insulina. Desde el descubrimiento de la leptina, han sido estudiados, otros mediadores como la ghrelina, orexinas, PYY 3-36, colecistoquinina, adiponectina y las adipoquinas que son mediadores producidos por el tejido adiposo; se piensa que su acción se modifica con muchas enfermedades relacionadas con la obesidad. La leptina y ghrelina son consideradas complementarias en su influencia sobre el hambre y saciedad, la ghrelina producida por el estómago, modula el control del apetito a corto plazo (para comer cuando el estómago está vacío y para parar con el estómago está lleno). La leptina es producida por 
Principales problemas de Salud Pública en México

el tejido adiposo para señalizar las reservas de grasa almacenadas en el organismo y mediar el control del hambre a largo plazo (para comer más cuando las reservas de grasa están bajas y menos al de las reservas de grasa son altas). Algunos individuos obesos parecen ser resistentes a la leptina, esta resistencia explica en parte porqué la administración de leptina no ha mostrado ser eficiente en suprimir el hambre en la mayoría de los sujetos obesos. Mientras que la ghrelina y la leptina son producidas periféricamente, su control del apetito y saciedad es a través de sus acciones sobre sistema nervioso central. En particular, estas y otras hormonas con este mecanismo neuroregulador, actúan sobre el hipotálamo central en la regulación del consumo de alimentos y el gasto de energía, hay varios círculos dentro del hipotálamo, que contribuyen con este rol de integración del apetito, hambre y saciedad, siendo la vía de la melanocortina la mejor comprendida ${ }^{34}$. El circuito comienza en el núcleo arcuato del hipotálamo, que tiene salidas al hipotálamo lateral (HL) y ventromedial (HVM), los centros del hambre y la saciedad en el cerebro respectivamente ${ }^{35}$. El núcleo arcuato contiene dos grupos distintos de neuronas ${ }^{36}$. El primer grupo coexpresa neuropéptido Y (NPY) y el péptido relacionado agouti (AgRP) y recibe señales estimulatorias del hipotálamo lateral y señales inhibitorias del hipotálamo ventromedial. El segundo grupo coexpresa proopiomelanocortina (POMC) y transcritos regulados por cocaína y anfetamina (CART) y recibe señales estimulatorias del hipotálamo ventromedial y señales inhibitorias del hipotálamo lateral. Consecuentemente, las neuronas NPY/AgRP estimulan el hambre e inhiben la saciedad, mientras que las neuronas POMC/CART, estimula la saciedad e inhiben el hambre. Ambos grupos de neuronas del núcleo arcuato son reguladas en parte por la leptina. La leptina inhibe el grupo NPY/AgRP, mientras que estimula el grupo POMC/CART. Por lo tanto una deficiencia en la señalización por leptina, vía deficiencia de leptina o resistencia a la leptina, conduce a una sobrealimentación y puede dar cuenta por algunas formas de obesidad genética y adquirida ${ }^{37}$.

Otro elemento importante es el papel de los adipocitos en la obesidad ya que es el reflejo del aumento de los depósitos de grasa, tanto subcutáneo como visceral. Los obesos tienen adipocitos aumentados de tamaño, o hipertróficos, que pueden considerarse la anatomía patológica de la obesidad. Los numerosos productos elaborados y secretados por los adipocitos desempeñan un papel relevante en las consecuencias patógenas de la obesidad. El control de los procesos de síntesis, almacenamiento y depósito de la grasa es un componente importante del sistema controlado. La insulina interviene de forma clave en la activación de la lipogénesis en los adipocitos. También inhibe la lipólisis y participa en la diferenciación de los adipocitos. La diferenciación de los adipocitos es un proceso en 


\section{Obesidad y los problemas de mal nutrición}

múltiples pasos que requiere varios factores, además de la insulina. Uno de los primeros pasos implica la interacción de los ácidos grasos con el receptor activado por el proliferador de peroxisomas (PPAR-gamma [peroxisome proliferator-activated-gamma]). Este PPARgamma forma un heterodímero con el receptor de retinoide $X(R X R)$ para iniciar el proceso de diferenciación de los adipocitos. La activación del proceso aumenta la diferenciación de los adipocitos, y la inhibición de RXR inhibe este proceso. Una publicación clínica sugiere que los defectos del gen de PPAR-gamma pueden estar relacionados con la obesidad ${ }^{35}$. Por otro lado la insulina es también esencial para el desarrollo de la obesidad. Desempeña un papel clave en la lipogénesis y en la inhibición de la lipólisis. El empleo de insulina, o de fármacos que aumentan su secreción, para tratar la diabetes provoca más aumento de la grasa corporal que otras modalidades de tratamiento de la diabetes. A la inversa, en formas experimentales de obesidad, la destrucción de las células beta lentifica o frena el desarrollo de obesidad. De forma similar la ausencia de insulina, como la que se observa en la diabetes tipo 1, se acompaña de un peso corporal normal ${ }^{36,38}$.

Otros factores etiológicos de la obesidad se muestran en datos recientes que indican que la población de microorganismos residentes en el intestino, conocida como microbiota intestinal, puede influir sobre la absorción de nutrientes y el almacenamiento de energía. Se ha demostrado que la composición macrobiótica difiere tanto entre ratones como entre humanos obesos y magros, lo que deja entrever que la modulación de la composición microbiótica intestinal ofrece una nueva vía para el tratamiento de la obesidad y el sobrepeso.

El rol de las bacterias que colonizan el tracto digestivo en el desarrollo de la obesidad ha comenzado a ser recientemente objeto de investigación, las bacterias participan en la digestión (especialmente de ácidos grasos y polisacáridos) Los números máximos de microorganismos se hallan en el colon humano, donde se han registrado más de $10^{39}$ microorganismos/g de contenido (peso en fresco ${ }^{40}$ y alteraciones en la proporción esto pueden explicar por qué ciertas personas son más propensas a ganar peso que otras.

En el tracto digestivo humano, las bacterias generalmente son miembros del filo de los bacteroides o de los firmicutes (grampositivos), Bacteroidetes (gramnegativos), Actinobacterias (grampositivas) y Proteobacterias (gramnegativas) ${ }^{39,40}$. En la gente obesa, existe una abundancia relativa de firmicutes (los cuales causan una absorción de energía relativamente alta), lo cual es restaurado por la pérdida de peso. A partir de estos resultados no se puede concluir aún si este desbalance es la causa de la obesidad o es un efecto ${ }^{32,39}$. 


\section{Principales problemas de Salud Pública en México}

\section{Cuadro clínico}

Es vital realizar una extensa historia clínica dirigida a elementos específicos para el buen diagnóstico de esta patología, en la que se resaltan los siguientes aspectos:

$\diamond \quad$ Curso de la gestación: complicaciones maternas y fetales.

$\diamond \quad$ Ganancia total de peso de la madre y/o presentación de diabetes gestacional. Peso y talla al nacer. Se prestará especial atención a los niños pequeños para edad gestacional o macrosómicos por los fenómenos de programación intrauterina ${ }^{41}$.

- Historia familiar de obesidad, y/o síndrome metabólico, síndrome de ovario poliquístico, cáncer, litiasis vesicular, cirrosis hepática, etc.

- Hábitos saludables: ejercicio, patrón de sueño, grado de actividad metabólica.

- Lactancia materna e inicio de la ablactación.

- Relaciones familiares y sociales.

- Hábitos de riesgo: sedentarismo, tiempo dedicado a televisión y videojuegos.

- Alimentación y dieta diaria.

- Padecimiento actual: inicio, tiempo y evolución del sobrepeso y obesidad, posibles causas, tratamientos.

- Examen físico completo:

$\diamond$ Signos vitales: Frecuencia cardíaca, tensión arterial, temperatura, frecuencia respiratoria.

$\diamond \quad$ Peso, talla alta, índice de masa corporal, circunferencia de la cintura, relación cintura/ talla, relación cintura cadera, pliegues cutáneos para cálculo de porcentaje de grasa, velocidad de crecimiento normal o acelerada. 


\section{Obesidad y los problemas de mal nutrición}

$\diamond \quad$ Presencia de acantosis nigricans, verrugas vulgares en cuello, estrías cutáneas.

$\diamond \quad$ Tiromegalia.

$\diamond \quad$ Tipo de distribución de grasa.

$\diamond \quad$ Características fenotípicas o antropométricas especiales.

$\diamond \quad$ Estado de desarrollo puberal.

Revisión por aparatos y sistemas

$\diamond \quad$ Historia de estreñimiento, piel seca, caída del cabello o algún dato de disfunción endocrina.

$\diamond \quad$ Irregularidades menstruales, acné, hiperandrogenismo.

$\diamond \quad$ Tiempo en el que se ha dado la ganancia ponderal

$\checkmark \quad$ Perfil metabólico: química sanguínea, biometría hemática, general de orina, relación glucosa insulina, perfil tiroideo, detección de síndrome genéticos, cortisoluria de 24 horas, transaminasas, proteína $\mathrm{C}$ reactiva, ecocardiografía de hígado y vías biliares, electrocardiograma.

Con estos elementos realizar un diagnóstico de riesgos, un diagnóstico clínico y comorbilidades asociadas. Una vez realizada la historia clínica y con las herramientas antropométricas se evaluará la posibilidad de diagnósticos diferenciales y si no los hubiere, la de compromiso metabólico, cardiovascular u otra complicación secundaria a la obesidad: se solicitarán los estudios confirmatorios y se iniciará el manejo interdisciplinario, enfatizando al paciente y su familia la necesidad del compromiso y modificación de hábitos para todo el grupo con el fin de garantizar el éxito y prevención de complicaciones o reversión de las mismas si ya las hubiere.

Los signos y síntomas más comunes para la obesidad son: exceso de peso, incremento de la grasa corporal, signos y síntomas de otros procesos patológicos asociados a la obesidad, vida sedentaria, problemas psicológicos como depresión, baja autoestima, etc. 


\section{Principales problemas de Salud Pública en México}

\section{Complicaciones}

Históricamente, la desnutrición o subnutrición se ha asociado a prevalencias elevadas de enfermedades infecciosas, retraso en el crecimiento, deficiencia de masa muscular y tejido adiposo, muertes perinatales; padecimientos causadas por deficiencia en el consumo de energía y nutrimentos esenciales (vitaminas, minerales y proteínas, principalmente).

Otro de los problemas asociados a la subnutrición es la interacción de nutrimentos e infección, la cual es sinérgica como antagónica. El estrés de la infección causa el deterioro del estado de nutrición, esta es la dimensión sinérgica, mientras que el deterioro del estado de subnutrición intensifica la propensión, gravedad y duración de las enfermedades infecciosas. En el sentido antagónico, existen algunos casos en los cuales la subnutrición intensifica la resistencia a las infecciones, como es el caso del hierro. La mayoría de los parásitos intracelulares, protozoarios y helmínticos hematófagos tienen necesidades específicas de hierro, buscan tejidos y células ricas de este mineral para satisfacer estas necesidades. Se ha descrito que la carencia de hierro reduce la virulencia de ciertas infecciones causado por patógenos dependientes de hierro.

La carencia de hierro o anemia tiene consecuencias importantes sobre el desarrollo cognitivo y físico en los niños y en el desempeño físico y la productividad laboral de los adultos. La causa más frecuente de anemia en México es la dieta deficiente alimentos con contenido elevado en hierro biodisponible junto con un alto contenido de fitatos. Las condiciones fisiológicas del embarazo condicionan el aumento en los requerimientos de hierro. La prevalencia de anemia es un indicador del estado de salud poblacional.

Existe una asociación entre eventos metabólicos adversos e infecciones, los cuales inducen la pérdida de los depósitos de energía, tejido corporal, vitaminas y nutrimentos inorgánicos. La liberación de hormonas y citosinas pro-inflamatorias a partir de células inmunitarias circulantes y tisulares, es la primera reacción de las infecciones, manifestándose en fiebre, activación de mecanismos inflamatorios y cambios en el metabolismo celular. Durante las infecciones se produce glucosa a partir de aminoácidos del tejido muscular, además existe una pérdida urinaria de grandes cantidades de nitrógeno, zinc y vitamina A, lo que se traduce a la deficiencia de vitaminas y nutrimentos inorgánicos. El proceso inflamatorio deteriora de forma directa el crecimiento y la función celular. Se ha demostrado que la inflamación interfiere con la utilización de micronutrientes hematínicos, contribuyendo 


\section{Obesidad y los problemas de mal nutrición}

al deterioro de la producción de eritrocitos. La desnutrición tiene efectos adversos en el rendimiento escolar e intelectual, en el desarrollo de capacidades, en el rendimiento e ingreso laboral en los adultos, lo que repercute en el desarrollo económico y social del país.

El retraso en el crecimiento fetal y el bajo peso al nacer se asocian a mayor riesgo en la vida adulta de cardiopatía coronaria, diabetes mellitus de tipo 2 y alteración de la tolerancia a la glucosa. El Dr. David Barker ${ }^{41}$ afirma que este riesgo se asocia a "consecuencias de plasticidad durante el desarrollo, el fenómeno por el cual uno de los genotipos puede dar lugar a una gama de estados fisiológicos o morfológicos diferentes en respuesta a condiciones ambientales diferentes durante el desarrollo", fenómeno que también se ha descrito como programación fetal.

La escasez nutrimental en la vida intrauterina seguida de una dieta excesiva de nutrimentos en la vida posterior hace que las respuestas programadas afecten la salud metabólica, con mayor riesgo de desarrollar enfermedades crónicas no transmisibles. Esta es una problemática que los países con recursos deficientes deben afrontar, ya que en estos lugares la nutrición materna es precaria, y las consecuencias que esto conlleva en el desarrollo de estos países es preocupante.

En la otra forma de malnutrición esta la obesidad, la cual se mencionó es una enfermedad crónica con repercusiones negativas para la salud y existe una asociación clara y directa entre el grado de obesidad y la morbilidad y mortalidad. De hecho, está vinculada al 60\% de las defunciones debidas a enfermedades no trasmisibles primeras causas de mortalidad, morbilidad y discapacidad en nuestro país.

La obesidad es un factor de riesgo para desarrollar diabetes tipo 2 y otras complicaciones derivadas de un porcentaje excesivo de masa grasa, como son las enfermedades cardiacas, la hipertensión y problemas del aparato locomotor, además estas complicaciones derivadas del sobrepeso y la obesidad implican costos elevados en su atención.

Lejos de ser solo un problema estético o psicológico, la obesidad ha demostrado serias implicaciones metabólicas y cardiovasculares patentes desde la infancia y con severas complicaciones en la adultez, causas de muerte prematura o años de vida perdidos por discapacidad debida a la complicación de las comorbilidades de esta enfermedad. Entre estas está el síndrome metabólico (también conocido como síndrome $X$, síndrome 


\section{Principales problemas de Salud Pública en México}

plurimetabólico, síndrome de insulinorresistencia, síndrome de Reaven a la conjunción de varias enfermedades o factores de riesgo en un mismo individuo que aumentan su probabilidad de padecer una enfermedad cardiovascular o diabetes mellitus ${ }^{42,43}$, la detección complicaciones metabólicas o del síndrome metabólico desde etapas tempranas en su aparición, de tal manera que su diagnóstico y tratamiento se convierte en el pilar en la prevención de mortalidad a mediano plazo $^{44,45,46}$.

El síndrome metabólico es la más importante complicación de la obesidad en el niño, adolescente y en la actualidad, por ser el predictor fundamental de las complicaciones, en la vida adulta ${ }^{44,47}$.

La morbilidad asociada a la hipertrofia de los adipocitos y la excreción de ácidos grasos libres y sustancias proinflamatorias; citosinas y citoquinas se puede dividir en varios grupos de enfermedades como son la diabetes mellitus, cardiopatía, hipertensión, patología de la vesícula biliar, y algunas formas de cáncer ${ }^{48,49}$. En la siguiente tabla se resumen las principales complicaciones descritas con relación a la obesidad (Cuadro 6).

La obesidad siempre se caracteriza por un incremento del depósito de grasas debido a una alteración en el balance entre ingreso energético y consumo, en el que el ingreso siempre es mayor que el consumo, dando como resultado el acúmulo del exceso de energía en forma de grasas. Esto indica que una persona puede desarrollar un cuadro de obesidad por disminución del gasto energético, es decir, descenso en la energía que se consume, la presencia conjunta de los dos hechos mencionados y el aumento de la ingesta de energía. El gasto energético que tiene una persona depende del:

Gasto energético basal: Es decir, la cantidad de energía que requiere el cuerpo en estado de reposo, ayuno de 12 horas y condiciones ambientales neutras Termogénesis: gasto energético debido a los diferentes estímulos ambientales (calor, frío, etc.).

Gasto energético: que condiciona la actividad física: Se trata del consumo de energía causado por las actividades diarias y ejercicio que realiza el individuo.

Para saber ante qué tipo de obesidad nos encontramos tenemos que dividir el perímetro de la cintura por el perímetro de la cadera. En la mujer, cuando es superior a 0,9 y en el varón cuando es superior a 1 , se considera obesidad de tipo androide. Obesidad relacionada 


\section{Obesidad y los problemas de mal nutrición}

con la resistencia a la insulina y precursora de enfermedades cardiometabólicas, primeras causas de morbilidad y mortalidad en nuestro país ${ }^{4,8}$.

Cuadro 6. Complicaciones sistémicas de la obesidad.

Sistema osteomuscular

- Deslizamientos epifisiarios

- Genu valgo, tibia vara

- Espondilolistesis

- Escoliosis

- Osteoartritis

- Pie plano

Piel y anexos

- Acantosis nigricans

- Estrías

- Mayor predisposición intertrigo candidiásico

- Queratosis pilaris

Sistema nervioso central

- Pseudotumor cerebral

- Hipertensión intracraneal

Cáncer

- Esófago, mama, endometrio, colon y recto, páncreas, riñón, tiroides, vesícula biliar.

Pulmonar

- Intolerancia al ejercicio

- Apnea obstructiva del sueño

- Asma

Cardiovascular

- Hipertensión arterial

- Dislipidemias

- Coagulopatía

- Inflamación crónica

- Disfunción endotelial
Alteraciones endocrinológicas

- Resistencia a la insulina

- Intolerancia a la glucosa

- Diabetes mellitus tipo 2

- Síndrome de ovario poliquístico

- Hiperandrogenismo

- Pubertad temprana

- Irregularidades menstruales

- Hipotiroidismo

Sistema cardiovascular

- Hipertensión arterial

- Hipertensión pulmonar (relacionada con apnea obstructiva)

- Lesión endotelial - incremento formación de placa ateromatosa

- Síndrome metabólico

Renal

- Glomeruloesclerosis

Gastrointestinal

- Litiasis vesicular

- Reflujo gastroesofágico

- Esteatosis hepática

Psicosocial

- Desórdenes alimenticios

- Baja auto-estima

- Desorden de imagen corporal

- Aislamiento social y estigmatización

- Depresión

Retomado de: National Health and Medical Research Council. Clinical practice guidelines for the management of overweight and obesity in adults. Australia: NHMRC; $2003^{50}$. 


\section{Principales problemas de Salud Pública en México}

La International Obesity Task Force (IOTF) ${ }^{51}$, la $\mathrm{OMS}^{52}$ y las sociedades científicas, entre ellas la Sociedad Española para el Estudio de la Obesidad (SEEDO) ${ }^{5,53}$ en el Consenso 1996 y en el Consenso 2000, aceptan como criterio para la definición de obesidad valores para el índice de masa corporal (IMC) (peso en kilogramos dividido por el cuadrado de la altura en metros) y adoptado por la Norma Oficial Mexicana NOM-008-SSA3-2010, para el tratamiento integral del sobrepeso y la obesidad (ver el apartado de Clasificación) ${ }^{7}$.

Es importante que desde la consulta se traten de establecer las condiciones clínicas y paraclínicas que midan el riesgo y una vez establecido el diagnóstico se refiera a la consulta de endocrinología.

Se han tratado de identificar los factores predictores del síndrome metabólico y se observa, en la actualidad, especial interés por la correlación de la circunferencia de la cintura en relación con la talla. Se demuestra que valores superiores a 0,48 en niñas y 0,50 en niños están correlacionados con sobrepeso y pueden ser predictores de dislipidemia, hipertensión y diabetes, por lo cual es otro punto antropométrico para tener en cuenta como parte de la evaluación del niño obeso ${ }^{54,55,56}$ y para el adulto, circunferencia cintura en mujer mayor de $80 \mathrm{~cm}$ y en hombre mayor de $90 \mathrm{~cm}$ se asocia con población en riesgo, en población mexicana de acuerdo a los estándares de la Secretaría de Salud en nuestro país.

\section{Diagnóstico}

Dada la importancia de la obesidad como factor que determina el síndrome metabólico, a continuación de describen los criterios diagnósticos para el mismo, propuestos por los expertos en adultos y en niños:

\section{a) Criterios de clasificación para el Síndrome metabólico en el adulto:}

- Definición ATP III ${ }^{56}$

El diagnóstico del síndrome metabólico es realizado cuando 3 o más de los siguientes factores de riesgo están presentes:

1. Circunferencia abdominal $>102 \mathrm{~cm}$ ( $>40$ in) en hombres y $>88 \mathrm{~cm}$ ( $>35$ in) en mujeres. 


\section{Obesidad y los problemas de mal nutrición}

2. Triglicéridos séricos $>/=150 \mathrm{mg} / \mathrm{dL}(>/=1.7 \mathrm{mmol} / \mathrm{L})$.

3. Presión arterial $>/=130 / 85 \mathrm{~mm} \mathrm{Hg}$.

4. HDL Colesterol $<40 \mathrm{mg} / \mathrm{dL}(<1.0 \mathrm{mmol} / \mathrm{L})$ en hombres y $<50 \mathrm{mg} / \mathrm{dL}(<1.3 \mathrm{mmol} / \mathrm{L})$ en mujeres.

5. Glucosa de ayunas 110 a $126 \mathrm{mg} / \mathrm{dL}(6.1$ a $7.0 \mathrm{mmol} / \mathrm{L})(100 \mathrm{mg} / \mathrm{dL}$ [>/=5.6 mmol/L] también puede ser apropiado).

- Definición de la OMS52

Diabetes, IFP, IGT o resistencia a la insulina y al menos 2 de los siguientes criterios:

1. Relación cintura-cadera $>0,90$ en hombres o $>0,85$ en mujeres.

2. Triglicéridos séricos $>/=1,7 \mathrm{mmol} / 1$ o HDL colesterol $<0,9 \mathrm{mmol} / 1$ en hombres $\mathrm{y}<1,0$ $\mathrm{mmol} / \mathrm{l}$ en mujeres.

3. Presión arterial $>/=140 / 90 \mathrm{~mm} \mathrm{Hg}$.

4. Excreción de albúmina urinaria $>20 \mathrm{ug} / \mathrm{min}$ o relación albúmina - creatinina $>/=30$ $\mathrm{mg} / \mathrm{g}$.

IFG; Glucosa de ayunas alterada.

IGT; Tolerancia a la glucosa alterada.

- Nueva definición de la Federación Internacional de Diabetes (IDF) ${ }^{57}$

De acuerdo a la nueva definición de la IDF, para que una persona tenga síndrome metabólico debe tener: obesidad central (definido como circunferencia de cintura $>/=$ $94 \mathrm{~cm}$ para hombres caucásicos $\mathrm{y}>/=80 \mathrm{~cm}$ para mujeres caucásicas, con valores étnicos específicos para otros grupos). 


\section{Principales problemas de Salud Pública en México}

Más de dos de los siguientes 4 factores:

1. Nivel de triglicéridos (TG) elevados: $>/=150 \mathrm{mg} / \mathrm{dL}(1,7 \mathrm{mmol} / \mathrm{L})$, o tratamiento específico para esta anormalidad lipídica.

2. Colesterol HDL reducido: $<40 \mathrm{mg} / \mathrm{dL}(1,03 \mathrm{mmol} / \mathrm{L})$ en hombres y $<50 \mathrm{mg} / \mathrm{dL}(1,29$ $\mathrm{mmol} / \mathrm{L}$ )en mujeres, o tratamiento específico para esta anormalidad lipídica.

3. Tensión arterial (TA) elevada: TA sistólica $>/=130$ o TA diastólica $>/=85 \mathrm{~mm} \mathrm{Hg}, \mathrm{o}$ tratamiento de hipertensión previamente diagnosticada.

4. Glucosa plasmática en ayunas elevada $>/=100 \mathrm{mg} / \mathrm{dL}(5,6 \mathrm{mmol} / \mathrm{L})$, o diabetes tipo 2 previamente diagnosticada. Si la glucosa en ayunas es $>5,6 \mathrm{mmol} / \mathrm{L}$ o $100 \mathrm{mg} / \mathrm{dL}$, la prueba de tolerancia oral a la glucosa (PTOG) es fuertemente recomendada pero no es necesaria para definir la presencia del síndrome.

\section{b) Criterios de Síndrome metabólico en los niños.}

- Definición ATP III ${ }^{56}$

Se define como la presencia de tres o más de los siguientes componentes:

1) Obesidad central (circunferencia cintura $\geq$ al percentil 90 en mujeres y hombres).

2) Concentraciones elevadas de triglicéridos ( $\geq 110 \mathrm{mg} / \mathrm{dl})$.

3) Niveles de C-HDL bajos ( $\leq 40 \mathrm{mg} / \mathrm{dl}$ en hombres y mujeres).

4) Presión arterial elevada sistólica o diastólica $\geq$ al percentil 90 para la edad, género y altura).

5) Niveles de glucosa de ayuno elevados ( $\geq 100 \mathrm{mg} / \mathrm{dl})$.

- La definición IFD, en el Cuadro 7 


\section{Obesidad y los problemas de mal nutrición}

Cuadro 7. Criterios de Síndrome metabólico en niños de acuerdo a la Federación Internacional de Diabetes mellitus (IFD) ${ }^{57,58}$.

\begin{tabular}{|c|c|c|}
\hline Obesidad central & 10-15 años & $\geq 16$ años \\
\hline Datos somatométricos & $\begin{array}{l}\text { Circunferencia de cintura: } \\
\text { >Percentil } 90 \text { para la edad y } \\
\text { sexo } \\
2 \text { o más componentes }\end{array}$ & $\begin{array}{l}\text { Circunferencia de cintura: } \\
>90 \mathrm{~cm} \text { (masculino) } \\
>80 \mathrm{~cm} \text { (femenino) } \\
2 \text { o más componentes }\end{array}$ \\
\hline $\begin{array}{l}\text { Presión arterial sistólica } \\
\text { (PAS) y diastólica } \\
\text { (PAD) (mm Hg) }\end{array}$ & $\begin{array}{l}\text { > Percentil } 90 \text { para la edad y } \\
\text { sexo }\end{array}$ & $\geq 130 \mathrm{y} / \mathrm{o} \geq 85.2$ \\
\hline HDL-colesterol (mg/dl) & $<40(<$ percentil 5$)$ & $<40 \mathrm{mg} / \mathrm{dl}$ \\
\hline Triglicéridos (mg/dl) & $\begin{array}{l}\text { > Percentil } 90 \text { nacional para la } \\
\text { edad y sexo }\end{array}$ & $\geq 150$ \\
\hline Glicemia (mg/dl) & $\begin{array}{l}\geq 100 \text { o con diagnóstico de } \\
\text { diabetes tipo } 2\end{array}$ & $\begin{array}{l}\geq 100 \text { o con diagnóstico de } \\
\text { Diabetes Mellitus tipo } 2\end{array}$ \\
\hline
\end{tabular}

La identificación temprana en niños y adultos de los criterios de Síndrome metabólico puede ser útil para predecir futuras enfermedades cardiovasculares y la diabetes mellitus tipo 2, o bien retrasar su aparición y llevar un buen control.

\section{Terapéutica}

El reconocimiento de la desnutrición primaria como problemas de Salud Pública no tiene más de siete décadas. Con la descripción clínica del Kwashiorkor por Williams, en la década de los 30's, se sabe que la subnutrición o desnutrición se atiende con el suministro adecuado de energía, proteínas en la dieta y micronutrimentos específicos dependiendo de la gravedad del daño orgánico y en caso de desnutrición secundaria identificar la causa que está provocando la desnutrición y atenderla en forma multidisciplinaria.

En el caso del tratamiento ideal de la obesidad es la prevención. Habría que dar prioridad a las medidas de Salud Pública, como el desarrollo de campañas informativas en cuanto a alimentación en general, y sobre hábitos alimentarios saludables en particular, y promover $\mathrm{y}$ facilitar el desarrollo de ejercicio físico a distintos niveles de actividad ${ }^{59}$. 


\section{Principales problemas de Salud Pública en México}

Podemos inferir el papel preponderante del médico en la identificación y manejo inicial de la obesidad, tanto en la prevención de complicaciones a corto, mediano y largo plazo, como en la creación de hábitos saludables, benéficos para el paciente y su núcleo familiar.

Adoptar nuevos hábitos que puedan influir en el mantenimiento de un peso corporal adecuado, aquellos pacientes que sufran sobrepeso evitar evolucionen a la obesidad y evitar las comorbilidades. Esto ayudará a realizar un diagnóstico precoz en una fase preclínica con sobrepeso y cuando estén presentes las comorbilidades atender los daños evitando las complicaciones futuras.

Tratar la enfermedad obesidad y reducir las comorbilidades, o revertirlas actuando en forma simultánea, en la disminución de peso y en el mejoramiento del perfil bioquímico. El tratamiento no farmacológico, farmacológico y quirúrgico si en su caso fuera necesario como en el caso de la obesidad mórbida y comorbilidades en donde haya daño a órgano blanco o pongan en peligro su vida, serán abordados simultáneamente, en cualquier ámbito del tratamiento. Cada caso debe ser individualizado y de ahí proponer un esquema de tratamiento multidisciplinario.

En primera instancia el tratamiento estará encaminado a cumplir un objetivo cuyo tratamiento es reducir la grasa corporal induciendo, obviamente, un balance energético negativo. La reducción de la ingesta debe diseñarse individualmente de forma que permita las actividades normales. Un déficit de $500 \mathrm{kcal}$ diarias puede hacer perder alrededor de 500 a $1000 \mathrm{mg}$ por semana a obesos adultos ${ }^{59}$. La combinación de ejercicio físico y restricción calórica es más efectiva que cualquiera de ambos por separado. Aunque la adición de ejercicio a la dieta incrementa poco la pérdida de peso en las primeras fases, parece que es el componente del tratamiento que más promueve el mantenimiento de la reducción de peso en el tiempo ${ }^{60,61}$. La modificación de la conducta desempeña un papel importante en el tratamiento de la obesidad, con ella se pretende ayudar al obeso a cambiar su actitud frente a la comida y sus hábitos alimentarios y de actividad física, así como combatir las consecuencias que se producen después de una trasgresión dietética ${ }^{60,61}$. El apoyo psicológico o psiquiátrico puede ser necesario cuando existan alteraciones importantes de la personalidad o cuadros ansioso-depresivos relevantes o falta de adherencia al tratamiento.

Los fármacos son otra de las armas terapéuticas para el tratamiento de la obesidad. Desafortunadamente, aunque casi todos los obesos pierden peso de forma relativamente 


\section{Obesidad y los problemas de mal nutrición}

rápida a corto plazo, es raro que esta pérdida se mantenga en el tiempo, la inmensa mayoría van ganando peso lentamente pero inexorablemente, hasta recuperar el de la situación previa al tratamiento, pero el éxito del tratamiento farmacológico es mantener este por abajo del peso inicial y el logro del cambio de estilo de vida durante el tiempo que se consumió el fármaco. Existen potentes factores no bien comprendidos que tienden a inducir la recuperación del peso perdido, de todas formas el principal problema no es el peso corporal en sí mismo, si no la morbilidad asociada a las complicaciones metabólicas y éstas pueden mejorar sustancialmente, incluso tras una pérdida moderada de peso ${ }^{61}$. Por ello no es preciso ponerse como objetivo alcanzar el peso deseable o normal porque es poco realista a largo plazo. Combinando dieta y ejercicio con tratamientos conductuales pueden conseguirse pérdidas del 5\% al 10\% del peso durante un período de 4 a 6 meses $^{60}$.

El tratamiento farmacológico debe utilizarse como apoyo del dietético y del ejercicio, pero no debe utilizarse nunca como único tratamiento, requiere una estricta indicación y supervisión médica. La posibilidad de su prescripción puede considerarse en obesos con un IMC de $30 \mathrm{~kg} / \mathrm{m}^{2}$ o más, en los que haya fallado la dieta, el ejercicio y los cambios conductuales, o en aquéllos con un IMC de 27 o más si se asocian factores importantes de morbilidad como diabetes, hipertensión, dislipidemias, etc., a pesar de otros tratamientos. Los fármacos que son y han sido utilizados en el tratamiento de la obesidad se clasifican en los siguientes grupos atendiendo a su mecanismo de acción: fármacos anorexigénicos y serotoninérgicos que actúan como estimulantes del sistema nervioso central con supresión del hambre o actúan estimulando la saciedad, en los sistemas noradrenérgicos y dopaminérgicos centrales, otros los que disminuyen la absorción de nutrientes, los que aumentan el gasto energético y aquellos medicamentos basados en hormonas intestinales que se utilizan para tratar la diabetes, como los agonistas del receptor de GLP1, pero que también han demostrado reducir el peso corporal, la pérdida de peso asociada a la utilización de estos fármacos es superior en los individuos no diabéticos. Los investigadores han estado trabajando para entender de qué modo en éstos fármacos hay que añadir numerosas sustancias que en la actualidad están en investigación en diferentes fases clínicas ${ }^{62,63}$.

El tratamiento quirúrgico, como las técnicas restrictivas y/o las malabsortivas, pueden producir pérdidas de peso a largo plazo, pero debe reservarse sólo a pacientes seleccionados que cumplan una serie de condiciones y con un IMC de 35-40 o superior, si tienen complicaciones de riesgo asociadas a la obesidad; y naturalmente, que hayan fracasado reiteradamente los tratamientos no quirúrgicos ${ }^{7}$. 
Principales problemas de Salud Pública en México

Sin embargo la piedra angular del tratamiento son los cambios en el estilo de vida en los diferentes de los ciclos de vida ${ }^{60}$.

\section{Medidas de prevención}

Prevención primaria, es decir educar al paciente en cuanto como actuar sobre a los factores de riesgo modificables que intervienen en esta patología y a la familia. Desde etapas tempranas como el embarazo, con el control adecuado del índice de masa corporal y los niveles adecuados de la glucemia.

La etapa infantil fomentando la lactancia materna exclusiva de cuatro a seis meses y la introducción de alimentación complementaria adecuada con un correcto esquema de ablactación, deben tomarse en cantidades adecuadas que aumentarán gradualmente a medida que el niño crezca, con una alimentación variada evitando en lo posible los alimentos de alta densidad calórica como alimentos complementarios ricos en grasas, azúcar y sal y bajo índice glucémico, procurando una alimentación saludable durante los diferentes ciclos de la vida, fomentando la actividad física en forma cotidiana como un estilo de vida permanente lo cual repercutirá en una buena calidad de vida en la edad adulta y en la vejez.

Dado que una de las principales causas de la obesidad es el estilo de vida, es importante capacitar a los profesionales de la salud que promuevan cambios conductuales en la población, además que los gobiernos y las comunidades deben promover cambios en el entorno para facilitar el estilo de vida saludable. Entre los temas que deben ser incluidos en los programas gubernamentales de nutrición están la promoción de mayor ingesta de frutas y verduras, implementar medidas reguladoras para mejorar la alimentación en las escuelas y centro de trabajo. Además de crear y mejorar espacios recreativos y de esparcimiento al aire libre, facilitar el acceso y uso de transporte público para garantizar el gasto energético por actividad física. La piedra angular del tratamiento de la obesidad y los problemas de malnutrición es la prevención primaria sin embargo cuando la enfermedad está ya instalada, más sus comorbilidades, es importante desarrollar programas y estrategias de intervención para disminuir la morbilidad y mortalidad en nuestro país asociada a la obesidad. Los objetivos de la prevención serán:

La prevención durante el embarazo cuidando la alimentación, el peso y los niveles de glicemia de la madre y un adecuado control prenatal. La prevención primordial dirigida 


\section{Obesidad y los problemas de mal nutrición}

a mantener un IMC normal durante la niñez, la adolescencia y vida adulta, la prevención primaria que consiste en evitar que los niños con sobrepeso se vuelvan obesos, la prevención secundaria que consiste en tratar que los niños obesos; reducir los componentes del síndrome metabólico y diferentes comorbilidades, dar marcha atrás a las complicaciones y prevención terciaria tratar el daño a órgano blanco y rehabilitación física y psicológica.

\section{Referencias}

1. Shamah T, Amaya MA, Cuevas L. Desnutrición y obesidad: doble carga en México. UNAM. Revista Digital Universitaria. 2015; 16(5): 1-14.

2. Solomons NH. La malnutrición en los países en vías de desarrollo: un cambio de apariencia. Ann Nestlé [Esp]. 2009; 67:74-86.

3. Gómez F, Ramos GR, Cravioto MJ. Studies on malnutrition in children. Bol Med Hosp Infant Mex. 1951; 8(5):593-608.

4. Cole TJ, Bellizzi MC, Flegal KM, Dietz WH. Establishing a standard definition for child overweight and obesity worldwide: international survey. BMJ. 2000; 320:1240-1243.

5. Salas-Salvadó J, Rubio MA, Barbany M, Moreno B, Grupo Colaborativo de la SEEDO. Consenso SEEDO 2007 para la evaluación del sobrepeso y la obesidad y el establecimiento de criterios de intervención Terapéutica. Med Clin (Barc). 2007; 128(5): 184-196.

6. WHO. Report of a WHO consultation on obesity. Report series. Ginebra: World Health Organization; 2000.

7. Secretaría de Salud. Norma Oficial Mexicana NOM-008-SSA3-2010, para el tratamiento integral del sobrepeso y la obesidad. DOF: 04/08/2010.

8. Tanner JM, Whitehouse RH. WHO multicentre growth reference study group. The WHO child growth standards, length/height-for-age, weightfor- age, weight-for length, weight for height, body mass index-for-age, Methods and development. Genève: World Health Organization; 2006.

9. Bray G, Bouchard C, James WPT. Definitions and proponed current classifications of obesity. Handbook of obesity. New York: Marcel Dekker; 1998. p. 31-40.

10. Abdel R. Omran. The epidemiologic transition: a theory of the epidemiology of population change. the milbank memorial fund quarterly. 1971; 49(4),Part 1: 509-538. 


\section{Principales problemas de Salud Pública en México}

11. Instituto Nacional de Estadística y Geografía. Estadísticas de Mortalidad. México: INEGI; 2011.

12. Barquera S, Campos I, Rojas R, Rivera J. Obesidad en México: epidemiología y políticas de salud para su control y prevención. Gaceta Médica de México. 2010; 146:397-407

13. Popkin BM. The nutrition transition in low- income countries: an emerging crisis. Nutr Rev. 1994; 52:285-298.

14. Drewnowski A, Popkin BM. The nutrition transition: new trends in the global diet. Nutr Rev. 1997; 55:31-43

15. Rivera JA, Barquera S, Campirano F, Campos I, Safdie M, Tovar V. Epidemiological and nutritional transition in México: rapid increase of non-communicable chronic diseases and obesity. Public Health Nutrition. 2002; 5(1A),113-122.

16 Ponce X, Rodríguez S, Mundo V, Shamah T, Barquera S, González de Cossío T. Dietary quality indices vary with sociodemographic variables and anthropometric status among Mexican adults: a cross-sectional study. Results from the 2006. National Health and Nutrition Survey. Public Health Nutr. 2013; 14:1-12.

17. Gutiérrez JP, Rivera-Dommarco J, Shamah-Levy T, Villalpando-Hernández S, Franco A, Cuevas-Nasu L, Romero-Martínez M, Hernández-Ávila M. Encuesta Nacional de Salud y Nutrición 2012. Resultados Nacionales. Cuernavaca, México: Instituto Nacional de Salud Pública (MX); 2012.

18. WHO. Iron deficiency anemia: assessment, prevention, and control. A guide for programme managers. Geneva: World Health Organization; 2001.

19. Atlantis E, Barnes EH, Fiatarone Singh MA. Efficacy of exercise for treating overweight in children and adolescents: a systematic review. Int J Obes. 2006; 30:1027-1040.

20. Barquera S, Peterson K, Must A, Rogers BL, Flores M, Houser R, Monterrubio E, RiveraDommarco JA. Coexistence of maternal central adiposity and child stunting in México. International Journal of Obesity. 2007; 31:601-607.

21. Popkin B. What is unique about the experience in lower- and middle- income lessindustrialised countries compared with the very-high-income industrialised countries? The shift in stages of the nutrition transition in the developing world differs from past experiences! Public Health Nutrition. 2002; 5(1A):205-214. 


\section{Obesidad y los problemas de mal nutrición}

22. Aragrande M, Argenti O. Studying food supply and distribution systems to cities in developing countries and countries in transition methodological and operational guide (revised version). DT/36-01E. Food and Agriculture Organization of the United Nations Rome; 2001.

23. Boney CM, Verma A, Tucker R, Vohr BR. Metabolic syndrome in childhood: association with birth weight, maternal obesity, and gestational diabetes mellitus. Pediatrics. 2005; 115:e290-e296.

24. Nathanielsz P, Poston L, Taylor P. In utero exposure to maternal obesity and diabetes: animal models that identify and characterize implications for future health. Clin Perinatol. 2007; (34):515-526.

25. Whitaker RC, Wright JA, Pepe MS, et al. Predicting obesity in young adulthood from childhood and parental obesity. N Engl J Med. 1997; 337:869-873.

26. Caterson ID, Gill TP. Obesity: epidemiology and possible prevention. Best Pract Res Clin Endocrinol. 2002; 16:595-610.

27. Noll J, Zeller M, Trickett P, Putnam F. Obesity risk for female victims of childhood sexual abuse: a prospective study. Pediatrics 2007; 120:e61-e67.

28. Kiess W, Bluher S, Kapellen T, Garten A. Physiology of obesity in childhood and adolescence. Current Paediatrics. 2006; 16:123-131.

29. Vetrugno R, Manconi M, Ferini-Strambi L, Provini F, Plazzi G, Montagna P. Nocturnal eating: Sleep eating disorder or night eating syndrome. A videopolysomnographic study. Sleep 2006; 29:949-954.

30. Winkelman JW. Sleep-related eating disorder and night eating. Syndrome: Sleep disorders, eating disorders, or both? Sleep. 2006; 29:876-877.

31. Spiegel K, et al. Sleep loss: a novel risk factor for insulin resistance and type 2 diabetes. Journal of Applied Physiology. 2005; 99:2008-2019.

32. Knutson KL, et al. The metabolic consequences of sleep deprivation. Sleep Medicine Reviews. 2007; 11(3):159-162.

33. Van Cauter E, et al. Impact of sleep and sleep loss on neuroendocrine and metabolic function. Hormone Research. 2007; 67:2-9.

34. Flier JS. Obesity wars: molecular progress confronts an expanding epidemic. Cell. 2004; 116(2): 337-350. 


\section{Principales problemas de Salud Pública en México}

35. Eckburg PB, Bik EM, Bernstein CN, et al. Diversity of the human intestinal microbial flora. Science. 2005; 308: 1635-1638.

36. Suau A, Bonnet R, Sutren M, et al. Direct analysis of genes encoding $16 \mathrm{~S}$ rRNA from complex communities reveals many novel molecular species within the human gut. Appl Environ Microbiol. 1999; 65:4799-4807.

37. Trayhurn P. Endrocrine and signalling role of adipose tissue: new perspectives of fat. Acta Physiol Scand. 2005; 184(4):285-293.

38. Ezquerra EA, Castellano JM, Barrero AA. Obesidad, síndrome metabólico y diabetes: implicaciones cardiovasculares y actuación terapéutica. Rev Esp Cardiol. 2008; 61(7): 752-764.

39. Tannock GW. The intestinal microflora. In: Fuller R, Perdigon G (eds.). Gut flora. Nutrition, immunity and health. Oxford: Blackwell Press; 2003. p. 1-23.

40. Ley RE, Turnbaugh PJ, Klein S, Gordon JI . Microbial ecology: human gut microbes associated with obesity. Nature. 2006; (7122):1022-1023.

41. Barker DJ. Adult consequences of fetal growth restriction. Clin Obstet Gynecol. 2006; 49:270-283.

42 Reaven GM. Banting lecture 1988: role of insulin resistance in human disease. Diabetes. 1988; 37:1595-1607.

43. Liese AD, Mayer-Davis EJ, Haffner SM. Development of the multiple metabolic syndrome: an epidemiologic perspective. Epidemiol Rev. 1998; 20:157-172.

44. Barlow SE. Expert committee recommendations regarding the prevention, assessment, and treatment of child and adolescent overweight and obesity: summary report. Pediatrics. 2007; 120:164-192.

45. Castañeda-González L, Camberos-Solís R, Bacardí- Gascón M, Jiménez-Cruz A. Longterm randomized clinical trials of pharmacological treatmentof obesity: systematic review. Colomb Med. 2010; 41:17-25.

46. Jeffery RW, Wing RR, Sherwood NE, Tate DF. Physical activity and weight loss: does prescribing higher physical activity goals improve outcome? Am J Clin Nutr. 2003; 78:684-689.

47. Cole TJ, Flegal KM, Nicholls D, Jackson AA. Body mass index to define thinness in children and adolescent: International survey. BJM. 2007; 335:166-167. 


\section{Obesidad y los problemas de mal nutrición}

48. Jones DB, Provost DA, DeMaria EJ, Smith CD, Morgenstern L, Schirmer B. Optimal management of the morbidly obese patient. SAGES appropriateness conference statement. Surg Endosc. 2004; 18:1029-1030.

49. Speiser P, Rudolf M, Anhalt H, et al. Consensus statement:childhood obesity. J Clin Endocrinol Metab. 2005; 90:1871-1887.

50. National Health and Medical Research Council. Clinical practice guidelines for the management of overweight and obesity in adults. Australia: NHMRC; 2003.

51. The International Obesity Taskforce (IOTF) is the advocacy arm of the International Association for the Study of Obesity; 2005.

52. World Health Organization. Definition, diagnosis and classification of diabetes mellitus and its complications. Report of a WHO consultation. Geneve: WHO; 1999.

53. Sociedad Española para el Estudio de la Obesidad (SEEDO). Consenso español 1995 para la evaluación de la obesidad y para la realización de estudios epidemiológicos. Med Clin (Barc). 1996; 107:782-787.

54. Kiess W, Bluher S, Kapellen T, Garten A. Physiology of obesity in childhood and adolescence. Current Paediatrics. 2006; 16:123-131.

55. Mendivil C, Sierra E. Avances en obesidad. Rev Fac Med Univ Nac Colomb. 2004; 52(4):270-286.

56. Executive Summary of The Third Report of The National Cholesterol Education Program (NCEP) Expert Panel on Detection, Evaluation, And Treatment of High Blood Cholesterol In Adults (Adult Treatment Panel III). JAMA. 2001; 285:24862482.

57. The IDF consensus worldwide definition of the metabolic syndrome. International Diabetes Federation, 2005. Disponible en: www.idf.org/webdata/docs/IDF_ Metasyndrome_definition.pdf

58. Alberti KGM.M, Zimmet PZ, Shaw JE. The metabolic syndrome: a new world-wide definition from the International Diabetes Federation consensus. Lancet. 2005; 366:10591062.

59. Barlow SE. Expert Committee recommendations regarding the prevention, assessment, and treatment of child and adolescent overweight and obesity: summary report. Pediatrics. 2007; 120:164-192. 


\section{Principales problemas de Salud Pública en México}

60. Jeffery RW, Wing RR, Sherwood NE, Tate DF. Physical activity and weight loss: does prescribing higher physical activity goals improve outcome? Am J Clin Nutr. 2003; 78:684-689

61. Atlantis E, Barnes EH, Fiatarone Singh MA. Efficacy of exercise for treating overweight in children and adolescents: a systematic review. Int J Obes. 2006; 30:1027.

62. Castañeda-González L, Camberos-Solís R, Bacardí- Gascón M, Jiménez-Cruz A. Longterm randomized clinical trials of pharmacological treatment of obesity: systematic review. Colomb Med. 2010; 41:17-25.

63. Vilsboll T, Christensen M, Junker AE, Knop FK, Gluud LL. Effects of glucagon-like peptide-1 receptor agonists on weight loss: systematic review and meta-analyses of randomised controlled trials. BMJ. 2012 Jan 10; 344:d7771. 


\section{Atender al padeciente: una}

propuesta conceptual para la conformación de un modelo de atención médica a enfermedades crónicas

Dr. Marco Antonio Cardoso Gómez Mtro. Alejandro Zarco Villavicencio Mtra. Irma Araceli Aburto López Mtra. Gloria Marina Moreno Baena Mtra. Irma Cortés Escárcega

\section{Introducción}

La transición epidemiológica y demográfica actual se caracteriza, entre otras cosas, por el envejecimiento de la población y el incremento de las enfermedades crónico-degenerativas como causas de morbi-mortalidad. Lo anterior demanda un modelo de atención médica diferente al creado para atender enfermedades agudas e infecto-contagiosas, en las que el individuo enfermo puede recuperar su salud en un tiempo relativamente corto, no así en las enfermedades crónico-degenerativas, en las que el individuo enfermo las "padece" por tiempo prolongado, con grandes repercusiones en su vida familiar, laboral y social. Proponemos utilizar el término "paciente" para los individuos con enfermedad aguda o infecto-contagiosa y "padeciente" para aquellos con padecimientos crónico-degenerativos.

\section{Transición epidemiológica y demográfica}

En el ámbito nacional, la mejora de las condiciones socioeconómicas, la consolidación del Sistema Nacional de Salud y la política de implementación de programas prioritarios de salud para la resolución de los problemas que aquejan a los mexicanos, han permitido que los indicadores de morbilidad y mortalidad sean diferentes a los que existían a mediados del siglo pasado, e que en la actualidad nos encontramos en la llamada 


\section{Principales problemas de Salud Pública en México}

transición epidemiológica y demográfica caracterizada por: 1.- La disminución de la mortalidad general, 2.- La tendencia secular descendente de la mortalidad infantil, debido a la presencia de enfermedades infectocontagiosas, en particular la influenza, neumonía y afecciones gastrointestinales, 3.- La subsistencia de enfermedades infectocontagiosas como causas de morbilidad, 4.- El aumento de la esperanza de vida al nacer, la disminución de la tasa de fecundidad y el envejecimiento de la población, lo que conlleva a otras necesidades de atención médica, como son las enfermedades crónico-degenerativas, neoplásicas y accidentes.

La transición demográfica es un proceso que en México se ha caracterizado por una desaceleración del crecimiento de la población manifestada por la disminución de la fecundidad, cuya tasa ha pasado de 5.7 en los años 1976 a 2.0 en el año 2011, con una disminución de la mortalidad general que pasó de 13.5/1000 habitantes en el año 1955 a 5.05/1000 habitantes en 2009. Según cifras oficiales en el año 1930 la esperanza de vida para las mujeres era de 35 años y para los varones de 33; para el año de 2010 la esperanza de vida es de 78 y 73 años respectivamente.(Kuri-Morales 2011).

Con respecto a la transición epidemiológica, en México en el año 1950 predominaban las enfermedades diarreicas, las neumonías, las enfermedades prevenibles por vacunación como principales causas de muerte, en el año 2009 las principales cusas de mortalidad son la diabetes, las cardiopatías, las neoplasias malignas y sólo aparece un rubro de enfermedades infecciosas entre las primeras 10 causas de muerte: el de la neumonía e influenza. (Kuri-Morales 2011).

En México, por ejemplo, en el año 1922 el 11.8\% de las defunciones correspondió a enfermedades crónico-degenerativas, para 1992 éstas llegaron al 55\% (es a partir de la década de los años 70 cuando este incremento se hace más notable) ${ }^{1}$. Dada su magnitud y trascendencia, es menester puntualizar que esta repercusión va más allá del ámbito biológico del individuo y que afecta su ambiente familiar, social y laboral ${ }^{2}$, provocando la aparición de comorbilidad, lo que dificulta de manera importante el manejo de la enfermedad inicial y sus complicaciones ${ }^{3,4,5}$.

En su mayoría, las enfermedades infectocontagiosas son agudas, de corta duración y se resuelven en menos de dos semanas, siempre y cuando se efectúe un diagnóstico y manejo adecuado, lo que permite la curación del enfermo. En cambio, cuando las personas sufren 
alguna enfermedad crónico-degenerativa, solo se logra controlar su padecimiento, lo que permite limitar la evolución de complicaciones y de incapacidades, sin embargo, no podemos decir que en estos casos existe curación.

El modelo de atención médica creado y utilizado para tratar las enfermedades transmisibles, no resulta efectivo para las enfermedades crónico-degenerativas, ya que a través del tiempo, se ha tratado a los pacientes erradicando al agente etiológico y específico que ocasionó su enfermedad, sin considerar los factores condicionantes y determinantes del proceso saludenfermedad. Además, la creciente tecnología ha beneficiado la atención médica, ya que actualmente aporta innumerables recursos para el diagnóstico y el manejo de los pacientes. Sin embargo, junto con estos cambios, el personal de salud se "acerca" cada vez menos a los enfermos, pues el médico tratante ofrece una asistencia corporal y escucha, distante, al enfermo sobre cómo se siente.

Actualmente, no se cuenta con los recursos, la infraestructura, ni un modelo de atención médico-científico acorde a las necesidades de resolución del proceso salud-enfermedad ya que, para que los Servicios de Salud sean eficaces y eficientes en la atención de las enfermedades crónico-degenerativas, se demanda la participación de múltiples profesionales del área de la salud tales como: médicos, enfermeras, psicólogos, trabajadoras sociales, tanatólogos, nutriólogos, terapistas físicos y ocupacionales, etc., además de esfuerzos intersectoriales e interinstitucionales.

En relación a la diabetes mellitus, por ejemplo, Arredondo (2011) menciona que esta enfermedad es un problema de salud que requiere un abordaje integral, ya que su tendencia al incremento no ha sido impactada con los esfuerzos desarrollados y recursos económicos asignados para su resolución.

Al respecto, la Organización Mundial de la Salud $(2003)^{6}$, declara que los equipos de atención sanitaria están fracasando en lo que se refiere a la prestación de apoyo al comportamiento de los pacientes, tarea para la cual no han sido entrenados, y que los sistemas de salud no permiten que los profesionales sanitarios respalden los cambios de comportamiento de los pacientes, función para la cual no han sido diseñados.

Las escuelas y facultades de medicina, encargadas de formar los recursos humanos para la atención médica, la mayoría de ellas, de prestigio reconocido, se fundaron a mediados 


\section{Principales problemas de Salud Pública en México}

del siglo pasado, por lo que sus planes de estudio están diseñados para preparar médicos con un enfoque curativo, capacitados para el manejo de enfermedades agudas en su mayoría, y no con un enfoque integral, que se requiere para la atención y prevención de las enfermedades crónicas. Es importante resaltar que el modelo de atención para el proceso salud-enfermedad debe incluir la prevención antes que la curación, sin demeritar esta última, así como favorecer el manejo integral y el seguimiento continuo de quien padece la enfermedad, con la participación del equipo de salud, además de considerar el entorno familiar y ambiental.

\section{Modelo de atención de la enfermedad}

Las enfermedades infecto-contagiosas se tratan considerando al agente patógeno que ataca a un individuo sano, este agente causa al individuo una alteración llamada enfermedad, la cual se manifiesta a través de una serie de síntomas y signos que son percibidos por el individuo, quien acude con el médico en busca de ayuda para recuperar su salud. El médico, mediante el interrogatorio, la exploración física y, en los casos que ameriten exámenes de laboratorio clínico e imagenología, obtiene una serie de datos, algunos objetivos y otros subjetivos, que le permiten identificar, en la mayor parte de los casos, la enfermedad que presenta el paciente.

Para las enfermedades infecto-contagiosas, una vez hecho el diagnóstico, el médico procede a elaborar el manejo general de ésta en el que se incluye el tratamiento medicamentoso así como otras acciones encaminadas a favorecer la curación del enfermo, como el reposo, la dieta y evitar cambios bruscos de temperatura, entre otras. De esta manera, el paciente recibe indicaciones precisas sobre cómo debe tomar los medicamentos, así como las recomendaciones y restricciones pertinentes, con lo que se espera que el paciente recupere su estado de salud previo.

En cambio, las enfermedades crónico-degenerativas, para los profesionales del modelo médico dominante, es decir, la medicina científica, se conciben como incurables, por lo tanto, la finalidad del tratamiento es disminuir, más que eliminar los signos y síntomas de los pacientes, así como prevenir las complicaciones futuras ${ }^{7}$. Por ejemplo, la Norma Oficial Mexicana NOM-015-SSA2-2010, para la prevención, tratamiento y control de la diabetes mellitus $^{8}$, en el numeral 11.1, refiere que “...el tratamiento de la diabetes tiene como propósito aliviar los síntomas, mantener el control metabólico, prevenir las complicaciones 
agudas y crónicas, mejorar la calidad de vida y reducir la mortalidad por esta enfermedad o por sus complicaciones".

Para tal efecto, la medicina científica ubica la causalidad de la enfermedad en los procesos biológicos, para lo cual se apoya en la anatomía, la patología, la fisiopatología, la microbiología, la endocrinología, la nutrición y, más recientemente, en la biología molecular, y así explica la enfermedad, a partir de las variables biológicas medibles, con base en datos derivados del examen de la estructura o función corporal detectados ${ }^{9}$. Este tipo de abordaje médico se realiza mediante procedimientos altamente especializados, como son los bioquímicos, los radiológicos, los inmunológicos o los microscópicos ${ }^{10}$.

Con fundamento en esta perspectiva de entendimiento de la enfermedad y de los resultados de los exámenes, estos terapeutas traducen el conjunto de síntomas de los enfermos a signos $\mathrm{y}$, posteriormente, sitúan su equivalente en algún órgano o sistema alterado del cuerpo para entonces definir los procesos corporales afectados. Por consiguiente, el tratamiento está dirigido hacia la modificación o restauración del daño celular o sistémico detectado ${ }^{11}$, utilizando para esto, medicamentos y cambios en el estilo de vida, tales como dieta y ejercicio ${ }^{12,13}$.

Esta forma de comprender, explicar y tratar las enfermedades crónicas, en general, es equivalente a la forma como se tratan las enfermedades infectocontagiosas. Por lo que, el tratamiento se centra casi de manera absoluta en el aspecto biológico y, al parecer, es en esta forma de actuar en donde se encuentra una limitante para el control de las enfermedades crónicas. Dado el afán de encontrar el mal aún sin haber estudiado bien al paciente, y basándose casi exclusivamente en los estudios de laboratorio y gabinete, cada vez más precisos, cada vez más sofisticados, se olvida al individuo que está enfermo, alejándose de él, y antes de conocerlo como ser humano, se le atiende como una máquina descompuesta que requiere diagnóstico preciso; lo que lleva a la deshumanización del actuar médico, tanto, que en los Estados Unidos ya no se habla de la relación médico/paciente, sino de la interacción health care provider/health care consumer "proveedor de la salud/consumidor de la salud"; esto ha promovido que la medicina se convierta en un acto de comercio, con todas su tristísimas consecuencias.

Los médicos, sólo se percatan de una mínima parte de los problemas que enfrentan las personas, ya que al observar exclusivamente la fase de crisis de la enfermedad, la 
Principales problemas de Salud Pública en México

exacerbación de los síntomas o las complicaciones de la misma, desconocen lo que les ocurre a los enfermos en su vida diaria ${ }^{14}$. En consecuencia, como proceso que tiene una tendencia positiva, y dado que el modelo biomédico dominante ha sido insuficiente para controlarlas, las enfermedades crónicas demandan la creación de un modelo de atención consecuente con sus propias características.

\section{Enfermedad vs. padecimiento}

Un modelo de atención implica varios elementos estructurales, uno de ellos es el conceptual, por lo que, es fundamental hacer una reflexión acerca de algunos conceptos sobre los que se diseña el plan de tratamiento. En inglés, suele utilizarse la palabra "disease" para referirse a enfermedad e "illness" para referirse a padecimiento. La distinción no responde a excentricidades académicas, sino que se pretende hacer alusión a dos condiciones distintas de vivir una enfermedad.

Aunque suelen utilizarse ambos términos como sinónimos, la enfermedad es connotada según el ámbito disciplinar donde se le utilice. Por ejemplo, taxonómicamente es un concepto convencional, en el que un grupo de expertos se pone de acuerdo para designar a un grupo de casos; para los patólogos es un concepto biológico; para los fisiólogos representa disfunción; para los sociólogos y etólogos implica adaptación; para los fisiopatólogos es un concepto explicativo; para la historia natural significa proceso; para quienes se ocupan de la supervivencia es un pronóstico; para los terapeutas es un concepto decisional; para un clínico es un artificio didáctico y operativo descrito en los libros, que puede diferir o no de lo que ocurre en el sujeto enfermo, dependiendo no solo de las lesiones anatómicas, sino también de las respuestas del sujeto a la agresión ${ }^{15}$. Asimismo, para Canguilhem ${ }^{16}$, la enfermedad no solo es desequilibrio o desarmonía, también es -y puede ser principalmenteesfuerzo de la naturaleza en el hombre para obtener un nuevo equilibrio. La enfermedad es una reacción generalizada con intenciones de curación. El organismo desarrolla una enfermedad para curarse ${ }^{17}$.

En contraste, el padecimiento es lo que efectivamente tiene la persona, de modo que puede estar formado por varias enfermedades simultáneas, por un solo fragmento de la enfermedad o no corresponder a enfermedad alguna ${ }^{15}$. Con este término se pretende dirigir la atención hacia la forma en que la persona vive esa condición denominada enfermedad, es decir, las condiciones, además de las biológicas, como son las psicológicas, sociales, económicas y culturales. 
El padecimiento está constituido por varios elementos como son: a) Las ideas de la persona sobre la salud, las experiencias, conocimientos, creencias, suposiciones, esperanzas, miedos y actitudes respecto a la enfermedad en general o referentes a la enfermedad que tiene o imagina, y b) Las experiencias, conocimientos y actitudes de y ante la medicina y los médicos, la manera como la persona siente y vive sus redes de apoyo psicosocial y afectivo, la religiosidad, las reflexiones, certezas o suposiciones de la persona sobre el costo en dinero de la enfermedad y su tratamiento.

Seguin ${ }^{18}$, menciona que el padecimiento generalmente se origina en el cuerpo de las personas, por la percepción e interpretación personal de los síntomas y signos de la enfermedad y por la manera como se vivencia la incapacidad del cuerpo para cumplir con lo que la persona espera de él. Éste es un padecer sin enfermedad propiamente dicha. El padecimiento como pérdida de armonía, se produce en la conciencia, en el plano de la información y en el cuerpo sólo se muestra.

La preocupación, que generalmente es la expresión de miedos o temores referidos a varios asuntos (impotencia, sufrimiento, inutilidad, marginación social, desprecio y, aún, la muerte) es una de las maneras más frecuentes en que la persona siente su padecer. A esto, podemos agregar la desesperación, la vergüenza, el disgusto por molestar a los familiares, el sentimiento de minusvalía o inferioridad, etc.

Conrad, citado por Mercado ${ }^{11}$, menciona aspectos de la experiencia del padecimiento: la incertidumbre, la carrera del enfermo, el estigma, el trabajo biográfico y la reconstrucción del yo, el manejo del tratamiento, los conocimientos, la concienciación, el intercambio y las relaciones familiares.

Con todo lo anteriormente expuesto, se entiende que existen diferencias importantes entre enfermedad y padecimiento, la enfermedad se refiere al concepto construido por la biomedicina que alude a las anormalidades en la estructura o la función de los órganos y sistemas, así como a los estados patológicos, sean o no reconocidos culturalmente ${ }^{19}$. El padecimiento, en cambio, es lo que el paciente efectivamente experimenta, e incluye no solo sus síntomas, sino todos sus acompañantes, ya sean físicos, psicológicos o sociales ${ }^{15}$. Es aquel fenómeno subjetivo, cambiante, en el que el sujeto enfermo o los miembros de su red social más cercana perciben, interpretan y responden a las manifestaciones y efectos de la enfermedad, a través de sentimientos, estados emocionales, sensaciones corporales, 
Principales problemas de Salud Pública en México

cambios en la apariencia física, alteraciones en los sentidos, etc,, todo esto en un marco de estructuras, relaciones y significados sociales que lo determinan y moldean. Cada sujeto enfermo tiene experiencias particulares con su padecimiento y percibe cambios cualitativos y cuantitativos en su ámbito corporal, laboral, social y emocional, que se modifican con el tiempo ${ }^{19}$. El padecimiento es inherente a la enfermedad y se ampara fundamentalmente en su dimensión subjetiva, es decir, trata de explicar cómo la persona vive con su enfermedad ${ }^{20}$.

\section{Paciente vs. padeciente}

Con base en las diferencias entre enfermedad y padecimiento, es pertinente reflexionar sobre el término paciente y su uso. La palabra paciente viene del latín pati/patior (sufrir), y hace referencia a quien padece una enfermedad. Para comprender su manejo, conviene conocer algunas acepciones que tiene este término.

De acuerdo con Lifshitz ${ }^{15,21}$, paciente es el que padece, por lo tanto es un padeciente, y esto es interesante, porque el paciente puede no tener síntomas y estar invadido por un cáncer en varios órganos del cuerpo. Cuando se usa el término paciente se hace referencia a alguien que tiene paciencia, o a una persona enferma que está en tratamiento para curarse o que se somete a una revisión médica. Aceptar que se puede enfermar y admitir que requiere ayuda médica convierte a una persona en un paciente. Una vez que se ha iniciado esta relación entre el médico y la persona que padece, ésta se ha convertido en paciente; tal conversión no es de índole biológica, sino social, y legitima su nuevo papel dentro de la sociedad, con el que adquiere derechos, así como obligaciones. El mismo autor enfatiza que el paciente no es necesariamente un enfermo, sino quien entra en contacto con un Sistema de Salud, de manera que puede haber pacientes sanos, en los que la medicina moderna aspira intervenir antes de convertirse en pacientes enfermos Lifshitz ${ }^{15,21}$.

Cuando a alguien se le denomina paciente se espera de él disciplina y obediencia, entre otras características; no se le concede la oportunidad de opinar sobre el tratamiento que recibirá, ni de manifestar sus intereses prioritarios, solamente debe conducirse conforme a la prescripción del médico ${ }^{22}$. Además, debe soportar el autoritarismo con el que, en ocasiones se conducen algunos médicos. Esto ha colocado al individuo enfermo en una relación de subordinación con respecto al médico que lo atiende, dada la secular soberbia de algunos colegas, a partir de que la sociedad ha ponderado el valor de la profesión ${ }^{23}$, 
postura egocentrista de algunos médicos y otros miembros del personal de salud que utilizan sus conocimientos para sentirse superiores y dueños del paciente ${ }^{24}$.

Esta relación entre el médico y el paciente ha sido muy cuestionada, sin embargo, conviene hacer una distinción, dado que se justifica ante una enfermedad aguda. La palabra paciente surge para conceptualizar a alguien que presenta una enfermedad aguda o infecto-contagiosa y, en consecuencia, se le demanda una participación peculiar acorde a su condición, por ejemplo, el médico, después de escuchar a la persona y determinar que los signos y síntomas que manifiesta corresponden a una apendicitis, debe asumir la responsabilidad y actuar en consecuencia a esta enfermedad aguda. Él sabe que si no se realiza una cirugía, la persona puede morir, por lo tanto, y con la autoridad que le otorga un título profesional, da indicaciones sobre cómo se debe proceder, informa a la persona y le pide su consentimiento, posteriormente se le prepara para la intervención, lo que incluye despojarlo de su ropa y colocarle una bata, canalizar una vena, afeitar la zona (en caso necesario), realizar, en ocasiones, procedimientos como enemas, colocación de sondas, vendajes, así como administrar medicamentos por vía oral o parenteral.

En estas circunstancias, además de sumar la presencia de dolor agudo, condición que por sí misma conduce a la persona a realizar lo que se le pide con la esperanza de eliminarlo, lo más conveniente para el enfermo es confiar en el médico y realizar lo que se le indica con disciplina y obediencia, es decir, se debe conducir como paciente, ya que de no hacerlo podría perder la vida. Esta situación genera una relación de autoridad-subordinado, que de no establecerse así, la persona con apendicitis resultaría perjudicada.

Otra condición importante es la convalecencia, en la que el plan de tratamiento regularmente requiere entre 7 y 10 días. Después de este período, la persona puede volver a su vida cotidiana, con lo cual la relación autoritaria médico-paciente se desvanece. También ésta es la forma de tratar enfermedades infecto-contagiosas como la gripe o la infección estomacal, entre otras. Al parecer, cuando el médico se encuentra ante enfermedades agudas o infectocontagiosas, debe asumir la responsabilidad y conducirse con autoridad, y la persona que presenta alguna de estas enfermedades debe conducirse como paciente, es decir, debe actuar conforme la prescripción médica.

Sin embargo, aun cuando quien tiene una enfermedad crónico degenerativa vive una condición distinta, el tratamiento se le prescribe de forma similar al de las enfermedades 
agudas o infecto-contagiosas. Cuando una persona acude al médico para recibir orientación sobre cómo atender las manifestaciones corporales que le impiden desarrollar sus actividades cotidianas, la atención del galeno se centra en clasificar dichas manifestaciones e identificarlas con un tipo de enfermedad, lo que significa que es el profesional quien designa la enfermedad y determina la condición de enfermo de la persona que le consultó.

El uso del término paciente para quienes padecen una enfermedad crónico-degenerativa ha conducido a los médicos a suponer que se les debe obediencia por la autoridad conferida por un título profesional. Por tal motivo, dichos profesionales confían el éxito de su participación en la disciplina y obediencia del paciente ${ }^{25}$, de manera que el éxito del tratamiento se entiende como la obediencia que tienen los enfermos a la prescripción médica, para lo cual se aducen razones de tipo científico, técnico, administrativo o de autoridad y al no cumplimiento se le da una connotación de 'desviación', por lo cual, la explicación del fracaso del tratamiento se busca en los propios pacientes ${ }^{19}$.

De modo que, por no cumplir con el régimen médico, al enfermo crónico-degenerativo se le señala como el único perpetrador de su propia enfermedad. Se le califica como desobediente, negligente, necio, irracional, entre otros epítetos ${ }^{11,26}$, es decir, se concibe como que prefiere, por ignorancia o por necedad, continuar con sus hábitos alimenticios y su estilo de vida a cambio de padecer, por ejemplo, ceguera o amputaciones, entre otras complicaciones, como en la diabetes, es decir, que si no obedece las indicaciones pagará muy caro las consecuencias ${ }^{24}$.

Estas nociones implican que el paciente es pasivo, que es el destinatario conformista de los consejos de expertos, en consecuencia, se le concibe como lo opuesto a un colaborador activo durante el proceso de tratamiento. Al respecto, Mercado indica que la persona con diabetes es vista como un 'paciente pasivo', como el objeto sufriente de un curador activo o como el portador de un rol de enfermo el cual debe cumplir de acuerdo a lo estipulado ${ }^{11}$. En esta misma línea de pensamiento, Zola ${ }^{27}$ advierte, que al ver a una persona con una enfermedad crónica como paciente, se asume tácitamente que se trata de alguien débil, dependiente, indefenso e incapaz de atenderse o tomar decisiones sobre su situación.

La atención médica, mediante esta concepción del enfermo crónico-degenerativo, no considera que la persona esté inmersa en un mundo social que le demanda realizar diversas actividades, muchas de las cuales le parecen más apremiantes que su propia salud. Por 
ejemplo, cuando no se tiene un trabajo que permita una remuneración económica estable, se debe ocupar de obtener ingresos que le permitan subsistir ${ }^{11}$.

La atención médica, entre otros aspectos, también soslaya el hogar, espacio donde se sufren las consecuencias de las enfermedades crónico-degenerativas y las dificultades para vivir con los tratamientos prescritos. No considerar el hogar como parte del tratamiento ha influido en la falta de control de la enfermedad porque ahí es donde se enfrentan los obstáculos para conseguir insumos necesarios para el tratamiento. Es ahí donde se ponen de manifiesto los esfuerzos para hacer los cambios necesarios, de tal suerte que es en el hogar, donde se presentan, en su más cruda realidad y sin cortapisas, los efectos de las complicaciones o las limitaciones ocasionadas por las mismas ${ }^{28}$. La atención médica elude todo aquello que inquieta, molesta, hace sufrir al paciente ${ }^{29} \mathrm{y}$ lo hace acudir al médico, es decir, soslaya su padecer. Según expresa Jinich ${ }^{30}$, la visión de muchos pacientes y de algunos médicos acerca del padecer es reducida. La realidad es más compleja, pues puede haber una enfermedad sin presencia de síntomas y síntomas sin que exista enfermedad.

Si se produce daño anátomo-patológico, hay enfermedad, aunque no necesariamente se traduce en padecer si el individuo no experimenta los signos y síntomas de la misma. Puede ser que aparezcan dichos datos clínicos, pero el paciente no les conceda importancia, de manera que no los "padezca". Lo anterior obedece a que los síntomas se someten a un proceso de valoración del individuo, que depende de numerosos factores como sus experiencias previas, su educación, su cultura, sus ideas acerca de la salud, la enfermedad y la medicina, entre otros.

Estar enfermo marca un alto en el camino de la persona. Pasar de ser un individuo sano a uno enfermo se califica de manera negativa, aunque en realidad enfermarse es algo inherente a la vida. La manera en que cada individuo percibe la salud y la enfermedad es variada y compleja, pues cada persona vive estas experiencias de manera diferente ${ }^{21}$. La enfermedad y la salud son conceptos internos de cada cultura, son el objeto de representaciones sociales en donde el cuerpo es sólo uno de los aspectos ${ }^{31}$.

Quien padece alguna enfermedad se preocupa y experimenta un sinfín de emociones, como malestar, enojo, agobio, tristeza, desconcierto, ansiedad y vulnerabilidad ${ }^{21}$. La enfermedad para el paciente no es una alteración anatómica o fisiológica, la siente como un castigo de los dioses, venganza de enemigos, maldición inexplicable, intromisión intolerante 


\section{Principales problemas de Salud Pública en México}

en sus planes, la enfermedad se percibe como peligro, al darse cuenta el individuo de la fragilidad y temporalidad de su existencia. La enfermedad significa interrumpir los estudios, el trabajo, los proyectos, es señal de debilidad, es súbita inferioridad frente a los demás, es dolor, vergüenza, humillación, motivo para reclamar atención, afecto, lástima, recompensa, admiración; es también desquite, medio de purificación y símbolo de superioridad espiritual ${ }^{30}$.

Landis, citado por Apostolo ${ }^{32}$, considera que vivir con una enfermedad crónica es un estado de inseguridad constante, el reto de adaptarse a ella es una experiencia vivida que requiere de múltiples adaptaciones, en donde el estado de incertidumbre es una experiencia profunda y personal.

Omitir el padecimiento en una enfermedad crónica ha propiciado que, al no contextualizarse los tratamientos ofrecidos, en lugar de coadyuvar a la persona en el control de su enfermedad, regularmente se le genera un problema más grave. Por ejemplo, cuando el médico, sin considerar el padecimiento prescribe un plan estricto para el cambio alimentario a su "paciente", quien tiene obesidad o diabetes, lo envía a que tenga problemas con su familia ya que no considera sus valores ni costumbres alimentarias ${ }^{22}$.

La dificultad para aceptar esta condición lleva al portador de la enfermedad a vivir un eterno dilema, aceptarse como diabético exige percibirse como alguien que aprendió a vivir con la incomodidad, la molestia y el dolor generado por la restricción de hábitos, por el control impuesto por el tratamiento sobre uno de los impulsos más básicos del ser humano, que es el de alimentarse ${ }^{33}$.

Por ejemplo, en reuniones familiares, tales como el festejo de Navidad o de Año Nuevo, los cuestionamientos que prevalecen en la mayoría de las familias mexicanas, para la organización de dichas festividades son los siguientes:

A quién invitar y

$>$ Qué se les ofrecerá de comer.

Las respuestas suelen ser: en primer término invitar a la familia, y en segundo lugar, con respecto al ágape, se ofrece una gran variedad de guisos o platillos, pero todos comparten 
23. Atender al padeciente: una propuesta conceptual para la conformación de un modelo de atención médica a enfermedades crónicas

la característica de contener grasas e hidratos de carbono, elementos que la dieta de quien padece diabetes debe contener en cantidades reguladas ${ }^{13,34,35,36}$.

Es así como, en una festividad de este tipo, la persona con diabetes se ve ante una disyuntiva: elegir entre su salud, siguiendo la prescripción médica, o la convivencia con su familia, con todas sus implicaciones afectivas y emotivas. Méndez ${ }^{37}$ y López-Amador ${ }^{38}$, concuerdan en que los diabéticos tienen la necesidad de mantener solidaridad con la familia para poder sobrellevar la enfermedad. Tomando como referencia la cultura mexicana se puede anticipar que, en esa ocasión, elige la convivencia familiar a costa de su salud, debido a que: 1) regularmente no se presentan estímulos del orden biológico, como un dolor intenso, que lo obligue a atender su salud de manera inmediata, 2) después de todo, los efectos de la diabetes son a mediano y largo plazo, 3) el enfermo prefiere la convivencia familiar porque son sus prácticas cotidianas, las que a su vez son producto de creencias, valores y conductas transmitidas socialmente, las cuales no son fáciles de cambiar.

El siguiente episodio, extraído de una entrevista en profundidad, es un ejemplo representativo de lo antes expuesto:

Pedro, padeciente diabético, oriundo de Guadalajara, es profesor de secundaria e imparte la materia de Biología. Su edad es de cuarenta años. Tiene tez morena y pelo negro rizado. Su estatura es de $1.75 \mathrm{~m}$, es robusto, pesa $97 \mathrm{Kg}$ y tiene un abdomen bastante prominente. Es alegre, activo y frecuentemente muestra disposición a lo que se le solicita. Está casado y tiene dos hijas, de 15 y 13 años, y dos hijos, de 9 y 7 años. Él informa ser muy dichoso con su familia y su trabajo le ha proporcionado grandes satisfacciones. Conforme a su opinión, está contento con la vida. No obstante estas condiciones, también tiene diabetes.

Al inicio de su tratamiento se mostró bastante cooperador, cuando acudió al programa DUPAM presentó $280 \mathrm{mg} / \mathrm{dl}$ de glucosa en sangre. Después de dos meses de atención logró controlar su nivel de glucosa en $120 \mathrm{mg} / \mathrm{dl}$, permaneciendo así por espacio de tres meses. El tratamiento médico consistió en la prescripción de hipoglucemiantes orales, de dieta baja en grasas e hidratos de carbono y de ejercicio físico.

El tratamiento odontológico consistió en saneamiento básico, eliminación de caries en tres piezas, dos molares y un premolar. El tratamiento psicológico consistió en entrenamiento en autocontrol para facilitar y establecer la práctica de la prescripción médica y para apoyar 


\section{Principales problemas de Salud Pública en México}

y establecer el aseo bucal. También se le entrenó en el manejo de la relajación muscular para controlar el estrés y se realizó una resignificación cognoscitiva con la finalidad de cambiarle la concepción de que la diabetes es una "desgracia", para que, en contraparte, la concibiera como una oportunidad para superarse en la vida.

Al parecer, basándose en los análisis de sangre, este tratamiento había logrado su objetivo: el control de la glucosa en sangre dentro de los niveles aceptables para un enfermo con diabetes. Sin embargo, después de dos meses de control del problema y tres meses de estabilización, cinco en total, Pedro comenzó a asistir irregularmente. Conforme avanzaban los días, se mostraba cada vez más enfadado. Dejó de seguir las prescripciones y en consecuencia, se elevó su nivel de glucosa.

En una ocasión salió bastante molesto del consultorio médico, por lo que se le invitó a conversar. Pedro, un tanto irritado por la insistencia en platicar, respondió abruptamente el porqué de su molestia y el porqué de su descuido:

- Si el médico cree que voy a hacer lo que me indica está loco, está como "operado del cerebro".

- Se le preguntó: ¿Ha habido algún malentendido con el médico?

- No.

- ¿Lo ha tratado de alguna manera que le moleste o le incomode?

- No, de ninguna manera.

- ¿No confía en la capacidad del médico o en el tratamiento que le ha estado prescribiendo?

- No. No es eso. No tengo queja en ese sentido. Lo que pasa es que el médico quiere que yo tenga problemas con mi familia y eso no lo voy a aceptar.

Se le preguntó el por qué. Se le pidió que explicara más ampliamente en qué se fundamentaba para suponer eso y contestó lo siguiente:

- Usted sabe que soy de Guadalajara. Allá mi padre nos enseñó que un domingo sin "carnitas", sin "chicharrón", sin "barbacoa," conviviendo con la familia, no es domingo. Mi padre nos 
23. Atender al padeciente: una propuesta conceptual para la conformación de un modelo de atención médica a enfermedades crónicas

enseñó a ser así y yo estoy muy contento con esas enseñanzas. Nos permitió ser una familia unida. Me permitió disfrutar de la compañia de mis padres y hermanos. Ahora recuerdo lo feliz que fui allá. Acá, con mi familia yo trato de seguir las enseñanzas de mi padre. Un domingo en familia sin "carnitas", sin "chicharrón", sin "barbacoa", no es domingo. Nos acostumbramos desde siempre, con mi esposa, que el domingo es para la familia y sin comer lo que nos gusta, pues no se la pasa uno igual. Es tan bonito ver a mi familia convivir los domingos, oír sus risas, tan contentos todos unidos, saboreando la comida. Sin embargo, con el tratamiento que me dan aquí, pues simplemente hasta mi familia sale afectada. Y para evitarles eso tengo que hacer cosas como: no comer con ellos, separarme e irme a comer a otro lugar de la casa. Me separo porque es tan feo tener enfrente lo que le gusta a uno y no podérselo comer, pero es peor pedirles también a ellos que se sacrifiquen. Si cambio mis costumbres, eso me va a llevar a la desintegración de mi familia. Y ya lo pensé bien, como no me queda más que elegir entre mi salud o vivir contento con mi familia los años que me restan, pues prefiero a mi familia y vivir feliz con ellos como lo fui cuando pequeño, allá en Guadalajara.

Lo anterior refleja que el tratamiento médico, al no atender el padecimiento, choca con los intereses de la persona con diabetes, es decir, del padeciente, que en esos momentos son el convivir con su familia de acuerdo a las costumbres mexicanas establecidas. Por supuesto que el padeciente debe cambiar su estilo alimentario, pero eso no se hace con buena voluntad ni por prescripción ${ }^{33,39}$, los cuales, si bien son elementos fundamentales, no son suficientes. El tratamiento para el control de la diabetes, y para las enfermedades crónicas en general, también debe atender las necesidades del padeciente y, para esto, se requiere que el médico se involucre e indague sobre sus características y las de su familia: ingreso económico, hábitos y costumbres, roles, escolaridad, adicciones, redes de apoyo, además debe apoyarse en otros profesionales que atiendan estos aspectos, para así diseñar el plan de abordaje integral tanto para el padecimiento como para la enfermedad de la persona.

Ahora bien, la propuesta de atender el padecimiento no es nueva, por siglos, la naturaleza y el origen de las enfermedades fueron desconocidos, y en las diferentes culturas se atribuyeron diversas enfermedades a fenómenos externos, como el "mal aire", o "miasmas", así como a influencias sobrenaturales, "embrujo", "maldiciones", al demonio o a castigos divinos por pecados cometidos aún por los antecesores del enfermo. En consecuencia, el médico, sintiéndose impotente para contrarrestar muchas de esas influencias, se dedicaba a atender el sufrir del enfermo, a escuchar su queja, a consolar su desvalimiento, a comprender lo 


\section{Principales problemas de Salud Pública en México}

que sentía, a tratarlo como padeciente, como alguien que sufre por su enfermedad aunque no la comprenda. No hay que olvidar que desde el principio de los tiempos, el primer médico fue un ser humano que se dolió del dolor de otro ser humano y trató de aliviar no solo su dolor sino su padecer.

El término paciente tradicionalmente se ha utilizado para denominar a alguien que presenta una enfermedad aguda o infecto-contagiosa. El médico tratante espera de esa persona un comportamiento de colaboración entendido como obediencia, disciplina y paciencia, características que facilitan la curación de la enfermedad. En este contexto se da una relación autoridad-subordinado. Es decir, el médico tratante asume la responsabilidad del tratamiento y el enfermo debe asumir las indicaciones. Esta relación ha salvado a muchas personas de perecer ante una enfermedad aguda o infecto-contagiosa.

El término paciente también es utilizado para referirse a una persona que tiene una enfermedad crónico-degenerativa, sin embargo en este ámbito:

1. Las enfermedades agudas y las crónicas son entidades diferentes, no sólo por su duración, sino por su repercusión en la vida del enfermo.

2. El abordaje de la enfermedad aguda y la enfermedad crónica debe ser diferente.

3. En el manejo de la enfermedad crónica, el médico debe considerar las condiciones individuales del paciente y su entorno familiar y social: costumbres, hábitos, creencias, roles, redes de apoyo, ingreso económico, etc.

4. Es recomendable hacer el abordaje del padecimiento a través de equipos multidisciplinarios: médico, psicólogo, enfermera, trabajador social, etc.

Los equipos multidisciplinarios de profesionales de la salud facilitan esta tarea y logran muy buenos resultados. Quizá la enfermedad no logre curarse, pero la percepción de la persona enferma (padeciente) y su familia seguramente cambiará y el padecimiento será más fácil de sobrellevar.

Proponemos usar el término paciente para aquellos individuos con enfermedades agudas e infecto-contagiosas, y el de padeciente para los individuos que presentan enfermedades 
23. Atender al padeciente: una propuesta conceptual para la conformación de un modelo de atención médica a enfermedades crónicas

crónico-degenerativas, con el fin de enfatizar esta condición particular en la que el enfermo sufre, experimenta, soporta, es decir "padece" la enfermedad con todas sus repercusiones físicas, psicológicas y sociales que se van presentando durante el curso de la misma, lo que hace la diferencia fundamental entre estar enfermo y sentirse enfermo (ref editorial).

Este cambio conceptual pretende que los profesionales del equipo de salud intervengan de manera oportuna en el desarrollo del padecimiento, con el fin de retrasar, modificar e incluso evitar las repercusiones de éste en la vida del enfermo, y así optimar el plan de tratamiento para el control de las enfermedades crónico-degenerativas.

\section{Referencias}

1. Moreno AL. Epidemiología y diabetes. Rev Fac Med UNAM. 2001; 44(1):35-37.

2. De los Ríos CJ, Sánchez CJ. Calidad de vida en pacientes con diabetes melitus tipo 2. Rev Med IMSS. 2004; 42(2):109-116.

3. Omran AR. The epidemiologic transition: a theory of the epidemiology of population change. Milbank Q. 2005 Dec; 83(4):731-757.

4. Ham-Chande R. El envejecimiento: una nueva dimensión de la salud en México. Salud Pub Mex. 1996; 38:409-418.

5. Olaiz G, Rivera J, Shamah T, et al. Encuesta Nacional de Salud y Nutrición 2006. México México: Instituto Nacional de Salud Pública Secretaría de Salud; 2006.

6. Organización Mundial de la Salud. Aherence to long-term therapies. Evidence for action. 2003. Disponible en http://who.int/chronic_conditions/en/1_7_2003_prsp.pdf

7. Menéndez E. Hacia una práctica médica alternativa. Hegemonía y autoatención (gestión) en salud. México: CIESAS; 1984.

8. Secretaría de Salud. Norma Oficial Mexicana NOM-015-SSA2-2010, para la prevención, tratamiento y control de la diabetes. Disponible en: http://www.ssa.gob.mx

9. Engel G. The need for a new medical model: a challenge for biomedicine. Science. 1997; 196(4286):129-136.

10. Fabrega H. The study of disease in relation to culture. Behavioral Science. 1972; 17(2): 183-203. 


\section{Principales problemas de Salud Pública en México}

11. Mercado MF. Entre el infierno y la gloria. La experiencia de la enfermedad crónica en un barrio urbano. México: Universidad de Guadalajara; 1996.

12. Alpizar SM. Guía para el manejo integral del paciente diabético. México: Manual Moderno; 2001.

13. Oviedo MM, Espinosa LF, et al. Guía clínica para el diagnóstico y tratamiento de la diabetes melitus tipo 2. Rev Med IMSS. 2003; 41(supl):S27-S46.

14. Strauss A. Preface to qualitative research on illness. Soc Sci Med. 1990; 30(11):V-VI.

15. Lifshitz GA. ¿Padecimiento o enfermedad?. Med Int Mex. 2008; 24(5):327-328.

16. Canguilhem G. Lo normal y lo patológico. México: Siglo XXI; 1981.

17. Rodríguez OI. Ensayo sobre el dolor humano. México: FES Zaragoza, UNAM; 2000.

18. Seguin CA. La enfermedad, el enfermo y el médico. Madrid: Ediciones Pirámide; 1982.

19. Mercado-Martínez F, Robles SL, Ramos HI, Moreno LN, Alcántara HE. La perspectiva de los sujetos enfermos. Reflexiones sobre el pasado, presente y futuro de la experiencia del padecimiento crónico. Cad Saúde Publica. 1999; 15(1):179-186.

20. Hueso MC. El padecimiento ante la enfermedad. Un enfoque desde la teoría de la representación social. Index Enferm. 2006; 15(55). Disponible en: http://dx.doi. org/10.4321/51132-12962006000300011.

21. Burr C, Piño A, Quiroz LA, Martín-Lunas E. Guía para el paciente participativo. México: Fundación Pfizer; 2011.

22. Cardoso GMA. La cultura como configurador de estilos alimentarios antagónicos al tratamiento médico para la diabetes. Cultura, dieta y diabetes. Cuicuilco. 2006; 13(37): 129-147.

23. LIfshitz GA. Prólogo en Burr C. y cols. Guía para el paciente participativo. México: Fundación Pfizer; 2011.

24. García VM. Páginas de Salud Pública. Salud Pub Mex. 1998; 40(1):105-107.

25. Mercado MF. El manejo del tratamiento médico en el marco de la vida diaria. Relaciones. 1998; 19(74):137-164.

26. Cardoso GMA. La obesidad y el matrimonio como patrones culturales antagónicos al tratamiento médico institucional para el control de la diabetes en Ixhuatlancillo, 
Veracruz. En: Serrano C, et al. Estudios de Antropología Biológica UNAM/IIA-INAHAMAB. 2000; 12:583-598.

27. Zola IK. Bringing our bodies and ourselves back in: reflections on past, present and future Medical Sociology. J Health Soc Behav. 1991; 32:1-16.

28. Corbin J, Strauss A. A nursing model for the chronic illness management. Based upon de trajectory framework. New York Springer; 1992.

29. Martínez A. En: Jinich H. El paciente y su médico. Universidad Nacional Autónoma de México. México: JGH Editores; 1998.

30. Jinich H. El paciente y su médico. Universidad Nacional Autónoma de México. México: JGH Editores; 1998.

31. Rapaport J. Salud y enfermedad. Diccionario de acción humanitaria y cooperación al desarrollo. Universidad del País Vasco. Disponible en: http://dicc.hegoa.efaber.net

32. Apostolo JLA, Viveiros CSC, et al. La incertidumbre en la enfermedad y la motivación para el tratamiento en diabéticos tipo 2. Rev Latino-am Enfermagem. 2007; 15(4). Disponible en www.eerp.usp.br/rlae

33. Péres DS, Santos MA, et al. Dificultades de los pacientes diabéticos para el control de la enfermedad: sentimientos y comportamientos. Rev Latino-am Enfermagem. 2007; 15(6). Disponible en www.eerp.usp.br/rlae

34. Beaser RS, Hill JV. Manual Joslin para la diabetes. USA: Simon \& Schuster Aguilar 1995.

35. Durán GL, Bravo FP, Hernández RM, Becerra AJ. El diabético optimista. Manual para diabéticos, familiares y profesionales de la salud. México: Trillas; 1997.

36. Murillo MJ. Vivir con diabetes, Guía para pacientes, sus familiares y educadores. Madrid; Neo Person; 2000.

37. Méndez LDM, Gómez LVM, et al. Disfunción familiar y control del paciente diabético tipo 2. Rev Med IMSS. 2004; 42(4):281-284.

38. López-Amador KH, Ocampo-Barro P. Creencias sobre su enfermedad, hábitos de alimentación, actividad física y tratamiento en un grupo de diabéticos mexicanos. Arch Med Fam. 2007; 9(2):80-86.

39. Boudieu P. Sociología y cultura. México: CONACULTA-Grijalvo; 1990. 


\section{Principales problemas de salud pública en México}

\section{Irma Araceli Aburto López \\ Juana Freyre Galicia \\ editoras}

El presente libro es una labor colectiva de docentes, pensado y escrito con la finalidad de apoyar los estudios de licenciatura en las disciplinas del área de la salud.

Se trata de un texto de apoyo académico acorde a la avanzada visión educativa de la FES Zaragoza que rompe con una educación disciplinaria propia del modelo flexneriano, y que es hoy un referente de la educación médica en nuestro país. En correspondencia con esta visión, el libro integra distintas disciplinas alrededor de problemas de salud pública en nuestro país facilitando el aprendizaje del estudiante.

Su estructura tiene como eje algunos de los principales problemas de Salud Pública en México, mismos que van siendo abordados uno a uno, desde los accidentes y lesiones hasta la obesidad y problemas de mal nutrición, pasando por grandes problemas como el cáncer, la escabiosis, la cirrosis, la epilepsia y otros tantos que tienen como común denominador: ser problemas frecuentes y trascendentes a los que se enfrentarán el médico, la enfermera, el psicólogo y otros profesionales de la salud.

Finalmente, podemos afirmar que este libro es un reto para el estudiante, pues de su lectura se desprende la necesidad de profundizar en diversas áreas en las que cada capítulo ofrece una generosa y actualizada bibliografía.
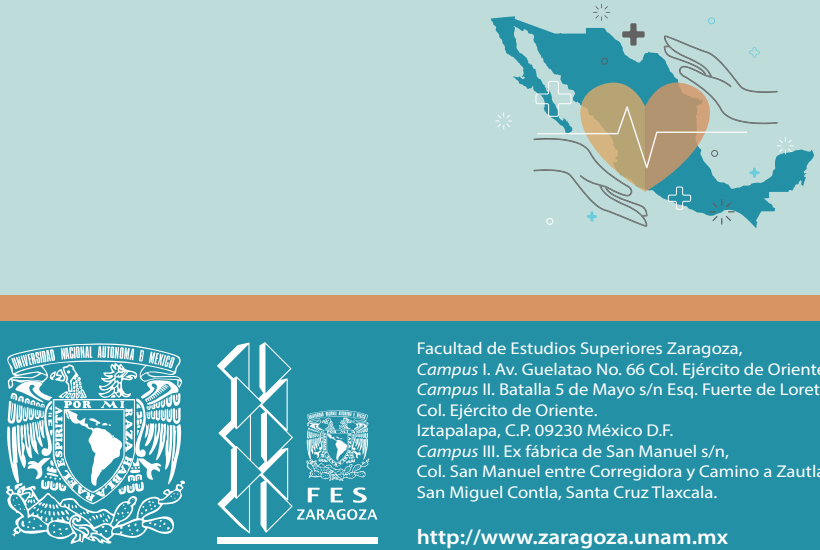

Facultad de Estudios Superiores Zaragoza, Campus I. Av. Guelatao No. 66 Col. Ejército de Oriente, Campus II. Batalla 5 de Mayo s/n Esq. Fuerte de Loreto.

Col. Ejército de Oriente.
Iztapalapa, C.P. 09230 México D.F.

Campus III. Ex fábrica de San Manuel s/n,

Col. San Manuel entre Corregidora y Camino a Zautla,

San Miguel Contla, Santa Cruz Tlaxcala.

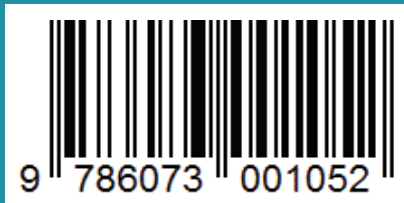

http://www.zaragoza.unam.mx 